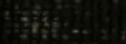




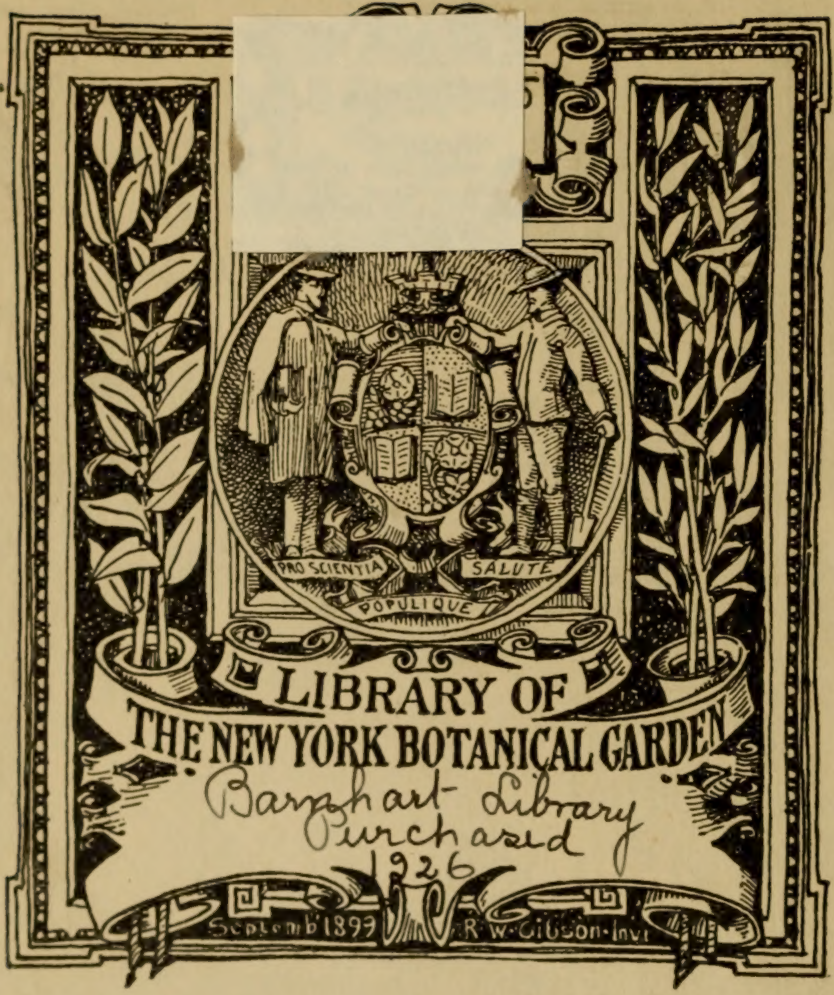




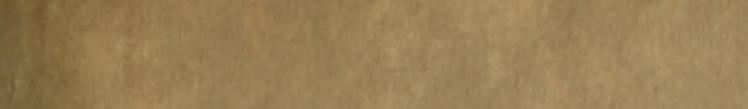

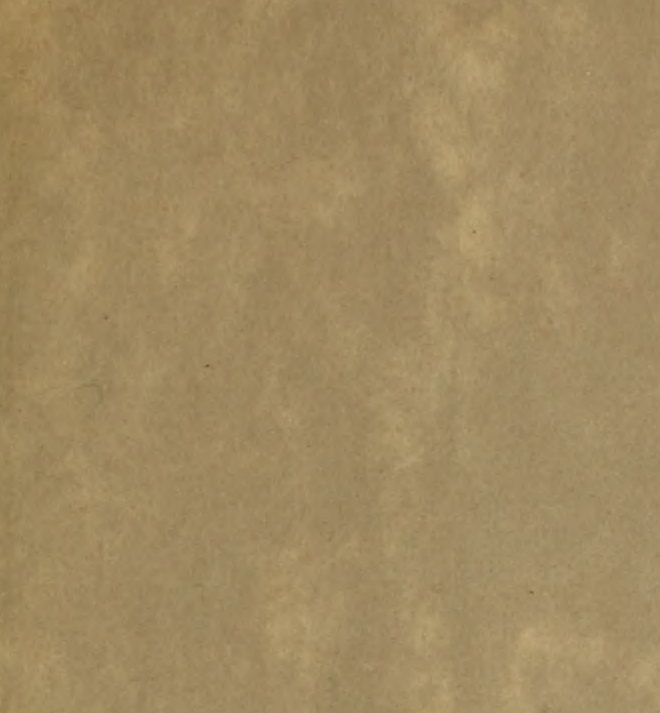


, 


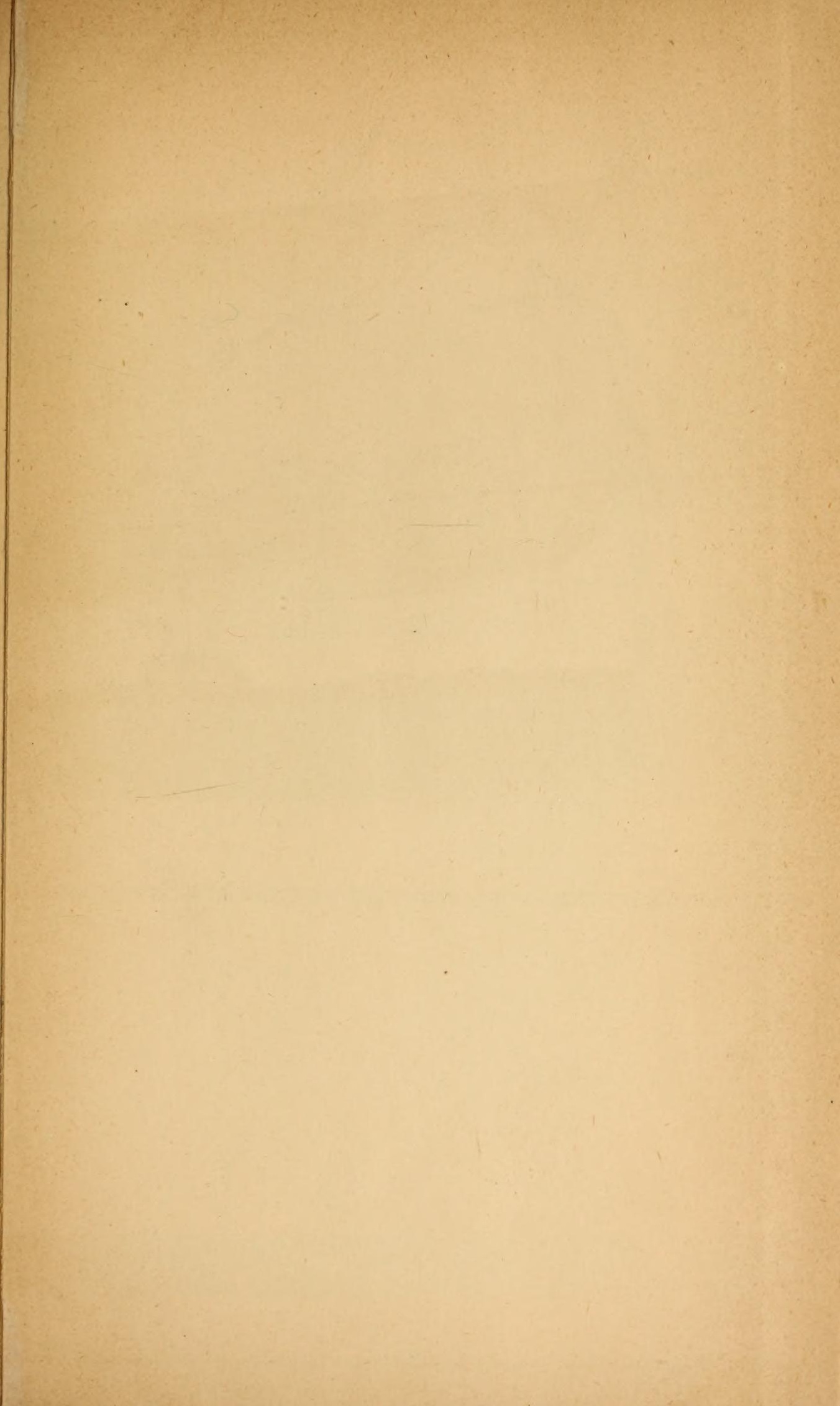




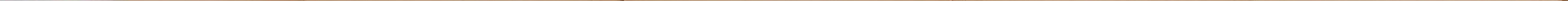




\title{
REPORT
}

ON THE

\section{GEOLOGY AND RESOURCES}

OF THE

\author{
REGION IN THE VICINITY OF
}

THE FORTY-NINTH PARALLEL,

FROM THE LAKE OF THE WOODS TO THE ROCKY MOUNTAINS.

WITH

LISTS OF PLANTS AND ANIMALS COLLECTED, AND NOTES

ON THE FOSSILS.

BY

GLORGE MERCER DAWSON, Assoc. R.S.M., F.G.S., GEOLOGIST AND BOTANIST TO THE COMMISSION,

ADDRESSED TO

MAJOR D. R. CAMERON, R.A., H.M. BOUNDART COMMISSIONFR.

MONTREAL :

DAWSON BROTHERS, ST. JAMES STREET.

LONDON : SAMPSON, LOW \& CO. I NEW YORK: B. WESTERMANN \& CO. 1875. 
QE 185
.038 
To MAJOR D. R. CAMERON, R. A.

\section{H. M. North American Boundary Commissioner :-}

Sir,-I have the honour to present herewith, my final Report of work in connection with H. M. North American Boundary Commission. In undertaking single-handed the care of Natural History work in connection with the Boundary Commission, it was obvious that in attempting too much it might happen that nothing should be well done. I therefore decided to give the first place to geology; and in that field to endeavour to work out as far as possible the structure of the country, and to make illustrative collections of rocks and fossils, rather than to amass large local collections, at the expense of general information. Such time as could be spared from the geological investigations, has been devoted to collection and work in other departments; and in this Report the results are presented, elaborated in so far as the time at my disposal would allow, and supplemented also by several valuable notices of the collections in special departments, by gentlemen whose names are elsewhere stated.

The field work, in extent, has directly covered a region, stretching from the Lake of the Woods on the east, to the Rocky Mountains on the west, and lying in the vicinity of the forty-ninth parallel, which here forms the International Boundary. In time it has extended over two seasons, those of 1873-74. Owing to the vastness of the region covered by the operations of the survey, much of the period actually spent in the field has been necessarily employed in more or less arduous, and often almost continuous travel.

To yourself I am under great obligations for the facilities readily granted for work in the department entrusted to me, and for the interest. you have taken in its progress. To all the officers of the Commission I 
must tender my most cordial acknowledgments for their general co-operation, and it should be mentioned specially that to the indefatigable assistance of Drs. Burgess and Millman-first and second Medical officers to the Commission respectively-are due many of the most interesting plants enumerated in Appendix F.

In arranging the information accumulated for publication, I have discarded the form of diary or journal often adopted, and by so doing have been able not only to group the facts under certain general headings but by avoiding repetition and useless details, very materially to condense the matter. At the same time, in the arrangement adopted, it has become necessary sometimes to pass more than once over the same region, in treating of different formations, or classes of facts.

The main geological result arrived at is the examination and description of a section over 800 miles in length, across the central region of the continent, on a parallel of latitude which has heretofore been greologically touched upon at a few points only, and in the vicinity of which a space of over 300 miles in longititude has-till the operations of the present expedition-remained even geographically unknown.

In working up the geological material, I have found it necessary to make myself familiar with the geological literature, not only of the interior region of British America, but with that of the western portion of the United States to the south, where extensive and accurate geological surveys have been carried on. It has been my aim to make the region near the boundary line as much as possible a link of connection between the more or less isolated previous surveys, and to collect by quotation or reference, the facts bearing on it from either side. In this way it has been attempted to make the forty-ninth parallel a geological base-line with which future investigations may be connected. The matter contained in the special preliminary report on the Lignite Tertiary formation, published last year, has in this final report been included, in so far as necessary to complete the general section on the line. 
The topography of the general map is in the main from that lately published by the Department of the Interior, which is based on that of Captain Palliser, but includes also the work of the Commission Survey.

- In laying down the boundaries of formations north of the localities which I have myself visited, use has been made of the geological maps of Dr. Hector and Prof. Hind, and also of facts from Prof. Bell's Report, printed in the Geological Surrey Memoirs for 1873-74. In the map of the Lake of the Woods, Prof. Bell's Reports have again been consulted; but for the regions I was unable to examine, Dr. Bigsby's map-elsewhere referred to-has been the chief authority. For the topography of the region near Lac Plat, I am indebted to Mr. A. L. Russell. The remaining uncoloured sketches and diagrams, with the exception of Plate xvI, are copied from pen-and-ink sketches of my own, by the photo-engraving process of Mrr. D. C. Dallas, Grey's Inn Road, London.

I am indebted to Principal Dawson for notes on fossil plants collected; to Prof. Cope for a report on the vertebrate fossils, and to Mr. S. H. Scudder for a description of a part of the collection of insects : Also to Dr. P. P. Carpenter for the determination of the Unionida; to Prof. Macoun for his examination of the grasses, carices, \&e; to Mr. G. Barnston for a list of the mosses. Dr. Hooker has also kindly undertaken the determination of a number of critical and difficult flowering plants.

Dr. Elliot Coues, who accompanied the United States contingent of the Boundary Survey, as naturalist, is, I believe, preparing elaborate reports on the zoology of the region.

Sapper Thomas Duckworth, detailed as taxidermist and collector, and working under my direction for two years, proved rery useful and zealous in his department.

Your obedient servant,

\section{GEORGE M. DAWSON}

McGill College, Montreal, July 19, 1875. 



\title{
CONTENTS.
}

\author{
CHA P TER I. \\ PHYSICAL GEOGRAPHY AND GENERAL GEOLOGY.
}

General Physical Geography.-Interior region of the Continent-Eastern boundary-Western boundary-Slope of the region-First prairie level-Second prairie level-Third prairie level-Transverse watersheds-Description of the southern transverse watershed-The northern transverse watershed-Areas drained by different river systems-Area of the plains. General Outuins of THE GEOLogr.-General nature of the region-Silurian series-Devonian series_Possible existence of Carboniferous rocks-Permian and TriassicJurassic_Cretaceous formation-Lignite Tertiary formation-Authorities on the Geology of the region $-\ldots+\ldots+-\ldots$

\section{CH A P T E R I I}

\section{GEOLOGY OF THE LAKE OF THE WOODS. LAURENTIAN AND HURONIAN.}

Position and Geography of the Lake-Clear-water Lake-Sand-hill Lake-Whitefish Lake-Lac Plat-Former Geological Explorers-Laurentian Formation -Vicinity of the North-West Angle-Flag Island to Rainy River-Bigsby Island-Middle Island-North Island-Shebashca-AREA OF MUCH-ALTERED Huronian.-Introsive Granitic Mass of North-West Angle-Its formNorthern branch-Southern branch-Included area of altered rocksHuronian Rocks-Angle Inlet to KA-KA-KE-WABEC-Quartzite-Conglomerate belt-Schistose rocks-Second Conglomerate belt-Second Schistose beltKa-Ka-Ke-wabec Granite-Heronian Rocks Ka-Ka-Ke-Wabec to Rat Portage -Schistose belt-Conglomerate of Lacrosse Island-Extensive Schistose belt with some conglomerates-Junction of the Laurentian and Huronian at Rat Portage-General Distribution and 'Attitudes of the Rocks-Main directions of flexure-Comparison with other localities-CHARACTER AND Age of the so-called Huronian Rocks-Nature of the Conglomerates-Metamorphism-Dykes and veins-Minerals of eConomic value - - - p. 22

\section{CH A P T E I I I.}

\section{STRLCTLPE OF THE ROCKY MOUNTAINS IN THE VICINITY OF} THE FORTY-NINTH PARALLEL.

General Featcres.-Intersection of the Mountains and Forty-ninth ParallelGeneral Geological Structure-Rocks in the vicinity of Waterton Laki - Series A.-Series B.-Series C.-Rocks in the Kootanie Pass-Subdivisions of Series C.-East Fork-Rocks west of East Fork-The Waturshed-West Fork-Rocks exposed in Mt. Yarrell-Rocks Near thE Bous- 
Dart Montuent-Series H.-Section of Series F. and G.-Eastern Front op the Watershed Range, Mt. Wilson and Chief Mountain-Revisw of this Section-Comparison of the Rooks with those of other Localitise-Rocks described to the North-Rocks described to the South-Limestones like those of Series B. and D.-Underlying beds-Upper red beds-General conclusions-Period of elevation of the Mountains - - - - - p. 56

\section{CH A P T E I V.}

\section{CRETACEOUS AND TERTIARY ROCKS OF THE VICINITY OF THE FOR'TY-NINTH PARALLEL-PEMBINA ESCARPMEMT TO WOOD MOUNTAIN.}

Cretaceots Rocks.-Pemlina Escarpment-Niobrara group-Fossils of the Boyne River-Pembina Mountain group-Rocks near the Boundary-line-Sections in Pembina River-Sections in Long River-Thickness of beds exposed-Lithological character-Lignite Tertary Rocks oN the Souris Rrvgr-Driftcovered region-La Roche Percée-Section on Short Creek-Sections west of Short Creek-Sections near Wood End-Gap IN THE SEction on this Boundary-line-Lignite Tertiary Rocks of Great Valley, and Praamid Cresk-Sections on Great Valley-Sections on Pyramid Creek-Lranite Tertiary Rocks of Porcupine Creek-Eighteen-foot lignite bed-Lignite Tentary Rocks on tue Traders' Road - - - - - - - - p.78

\section{CH A P T E R V.}

\section{CRETACEOUS AND TERTIARY ROCKS OF THE VICINITY OF THE FORTY-NINTH PARALLEL-WOOD MOUNTAIN TO THE ROCKY MOUNTAINS.}

Lignite Tertiary Rocks near Wood Mountain-Sections in Bad Lands South of Wood Mountain-Nature of Bad Lands-Divisions of Section-Fossil plants-Vertebrate fossils-Sections WeBt of THE BAD LANDs to Whitg Mud Rrver-Cretaceous No. 4-Fossils-White Mud River-Cretaceous Nos. $4 \& 5$-Relations of beds, White Mud River and Bad Lands-Secrions Wrst of Wood Mountain Setrlemsent to Whrte Mud River-Bay of Cretaceous Rock8-Tertiary Plateau-Cretaceous No. 4, with fossils-WhiTe Mud Rrver тo Mrrk Rrvkn-Cretaceous plain-Tertiary Plateau-East Fork of Milk River-Section near West Fork of Milk River-Age of Beds exposedCretaceous plain-Milk River Valley-Sections in Milk River ValleyUpper arenaceous clays, \&c.-Sandstone Zone-Lower arenaceous clays, \&c. Mile River to the West Butre-Sections North of East Butte-Nature and height of the Buttes-East Butte-Igneous rocks of the Buttes-Middle Butte-West Butte-West Butre to the Rocky Mountaing-Synclinal west of West Butte-First Branch Milk River-Vertebrate fossils-Second Branch Milk River-Fresh Water deposit\&-St. Mary River-Disturbance of Bed8-Coal Bed-Marine Fossiliferous Beds-Exposures nearest the Mountains—South Fork of Belly River _ . . . . . . . - p. 102

\section{CH A P T E R V I.}

GENERAL ARIANGEMENT AND FXTENT OF THE CRETACEOUS AND LIGNITE TERTIARY FORMATIONS.

Curtaceors No, 1.-Trpical series-Representatives westward-Dr. Hector's Group E-Ligniteg in Lower Cretaceous Rocks-Lignite from Rainy River.-CRsTACEov No. 2.-Typical series-Representatives westward-Beds of this age 
on the Saskatchewan-Dr. Hector's Group D.-Cretucsoos No. 3.-Typical series-Representatives westward-Representatives in Manitoba-CretacEous No. 4.-Typical series-Pembina Mountain Group-Representatives on the Line westward-Effect of this Formation on the country-Modifying effect of Drift-Saline springs-Prof. Hind's Section-Dr. Hector's Group B. and C.-Cretacrous No. 5.-Typical series-Representatives on the LineProf. Hind's Section-Distribution of Cretaceods Subdivisions-Lignite TerTIARY Formation--Relations of beds on the Line-Eastern limit of the Formation-Western Representatives-Persistent zone of SandstonesResemblance of western series to Judith River beds-Tertiary beds observed by Dr. Hector - - - - - - - - - - - - - p. 136

\section{CHAPTER VII.}

CONDITIONS OF DEPOSIT CRETACEOUS AND TERTIARY. BURNING OF LIGNITE BEDS.-COMPOSITION AND ECONOMIC VALUE OF LIGNITES AND IRONSTONES.

Conditions mplied by Creteceous and Tertiary deposits-Period of shallow waterExtent and nature of submergence during Niobrara period-Detrital beds of Fort Pierre group-Closing period of shallow waters-Extensive land areas during Lignite Tertiary-Conditions of formation of lignites.-Combustion of LIGNITE BEDs-Appearances indicating this action-Effects produced on surrounding beds-Area over which similar phenomena have been observedQuestion whether such fires are spontaneous-Extent to which lignites have been destroyed-Composition and Economic Vatur of lignrtes and Iron oresAnalyses of lignites-Nature of lignites-Classes of lignites representedVariability of water content-Lignites as fuels-Import of the St. Mary River coal-Other similar fuels near the mountains-Area of lignite-bearing formation-Ironstones of the Lignite Tertiary - Ironstones of the CretaceousProbability of their future economic importance $-{ }_{-}-{ }_{-}-$p. 159

\section{CHAPTER VIII。}

AGE OF THE LIGNITE-BEARING FORMATION AND POSITION OF THE LINE SEPARATING THE CRETACEOUS AND TERTIARY.

AgB of the Lignite Formation-Nature of the question-Physical break between Cretaceous and Tertiary of Europe-No physical break in Interior Continental region-Unity of the Lignite formation-Tertiary age of Eastern representatives not directly questioned-Summary of facts and opinions bearing on the age of Lignite formation-Stratigraphical-Invertebrate fossils-Fossil plants-Vertebrate remains-Character of Junction Cretaceous No. 5 and Lignite formation-Contemporaneous deposit of No. 5 over the entire area.-Rivww of тHE Evidencs-Plants-Fresh-water molluscsMarine molluses-Vertebrates-General conclusions - - . - - p. 183

\section{CHAPTER IX.}

\section{GLACIAL PHENOMENA AND SLPERFICIAL DEPOSITS.}

Glaciation and Sepfrficial Deposits, Lake of the Woons-The lake-basin-Depth of the lake-Direction of glacial striation-Superposed striation in different directions-Special instances of glaciation-Pre-glacial age of outfall of lake-Distribution of boulders-Upper Silurian limestone boulders, with fossils-N. E. limit of limestone drift-Methods of accounting for limestone 
drift-Drift Platead of Eastern Manitoba axd Northern Minnesota-Kames and Eskers-N. W. limit of red drift-Height and contour of the plateauSections on Roseau River-General Features of Glacial Phenomena E. of RED RIVER-Elevation and slope of the Laurentian axis-Confluent glacier covering the Laurentian region-Former southern'outfall of Lake of the Woods-Drift Deposits of the Siecond Prairie Plateau, and Turtle Mountain -Surface of the plateau-Terraces of Pembina Escarpment-Sections on Long River-Numerical analysis of constituents of the drift-Turtle Mountain-Boulder covered region-Marain and EAstern Refion of the Third PlateaU-The Missouri Coteau-Ancient river valleys-Erratics of the Coteau-Quartzite drift _..... $\ldots \ldots \ldots \ldots+\ldots$ p. 203

\section{CH A P T E X.}

\section{GI.ACIAL PHENOMENA AND SUPERFICIAL DEPOSITS-(Continued.)}

Margin and Eastern Region of the Third Plateau (Continued)-Drift deposits near Wood Mountain-Northern Extension of the Coteau-Southern extension of the Coteau-General aspect of the Coteau-Methods of accounting for the formation of the Coteau-Drift Deposits of the Thimd Plateau west of Wood Mountain-Boulder-clay of East Fork of Milk River, \&e.-Composition of the Drift near Milk River-The Three Buttes-Western limit of Laurentian drift-Glacial Action in the Rocky Mountains-Former glacier of Waterton Lake-Terraces in the mouth of the S. Kootanie Pass-Origin of gold-Moraines and lakes-Cirques-General Composition of the DriftThe Red RIver VALLeY-Its character and inclination-Alluvial depositsSections from borings at Winnipeg and Fargo-Yellow marl deposits-Connection of deposits of Red River Valley and Missouri Country-Pre-Guacial ASPECT OF THE Country-Former southern flow of Red River-First stage in depression-Correlation of levels of plateaus and terraces-Depth of submergence when greatest, and action at this time-Emergence of the continent-Difficulties met with in explaining the phenomena-Post-GLaciaL Phenomena-Possible existence of a pluvial period-Great river valliesAlternative vallies-Valley of the Red River-The formation of coulees.

CH A P TER XI.

\section{CAPABILITIES OF THE REGION WITH REFERENCE TO SETTLEMENT.}

Region in the vicinity of tie Lake of the Woods-Areas capable of cultivationBarren region-Vegetation of the lake-REGION BETWEEN THE LAKE OF THE WoOds AND RED RIVER PraIRIs-Country in the vicinity of the Government Road-Country bordering on the Reed and Roseau Rivers-Height of Land Muskeg-Thi Red River Prairis-Soil, and nature of the surface-Measure of agricultural capacity-Wood-Climate-Progress of the spring here and at other points in the Fertile Belt-Rainfall-Water supply-Countrx of tife Second Prairie Steppe-Pembina Escarpment-Western margin of the great plains-Turtle Mountain-Timber-Country in the vicinity of the Sourik River-Meteorological cycle-Country or the Thind Prairis StrappePlateau of the Tertiary-Eastern limit of buffalo-Big Camp of half-breeds Fertile Belt at the base of the mountains-Timber of the mountainsClimate of the Third Steppe - - - - - - - - - p. 269 


\section{CHAPTER XII.}

\section{CAPABILITIES OF THE REGION WITH REFERENCE TO SETTLEMENT.-(Continued.)}

Causes Deterrent to Setrlement and Agriccltere.-Future of the North-west-Climate-Wintering of stock-Difficulty of access-INROADS OF THE GRASSHOPPER -Origin of the insect-Its range-The young and winged swarms-Its flight-Years when it has appeared in Manitoba-Means of prevention-THE SupPly or Wood in the NoRth-WEst-The plains never entirely woodedCauses tending to destruction of forest-Causes of treelessness of prairieDryness of soil and atmosphere-Causes of drought-Causes of greater rainfall on wooded areas-Facts tending to show progressive desiccation in the west-Similar drought brought on elsewhere by destruction of forest -Amelioration of climate by planting forest-Treeless area of the continent - Normal area of country which should be in forest-Successful growth of trees in the west-Scheme for the planting and preservation of trees, p. 301.

\section{APPENDIX.}

(A) - Note on the Plants, collerterl by Mr. G. M. Dawson, from the Liymite Tertiary Deposits, near the Forty-ninth Parallel _ _ _ _ _ _ _ . - 327

(B)-Report on the Vertebrate Fossils from the Fort Union Group of Milk River - - 333

(C)-Lake of the Woods-Table showing the nature and distances of the dykes and veins observed - - . - . - . - . . . . . - - 339

(D)-Notice of the Butterflies and Orthoptera, collected by Mr. G. M. Dauson, as Naturalist of the B. N. A. Boundary Commission . . . . . - - 341

(E)-Land and Fresh-water Molluses, collected during the summers of 18\%3-\%4, in the vicinity of the Forty-ninth Parallel-Lake of the Woods to the Rocky Mountains.

(F) - List of Plants collected during the summers of 18\%3-74, in the vicinity of the Fortyninth Parallel-Lake of the Woods to the Rocky Mountains - - - - 351 



\title{
BRITISH NORTH AMERICAN BOUNDARY COMMISSION.
}

\section{REPORT ON GEOLOGY, BOTANY, \&c.}

\section{CHAPTER I.}

\begin{abstract}
PHYSICAL GEOGRAPHY AND GENERAL GEOLOGY.
\end{abstract}

\begin{abstract}
Geveral Physical Geography. - Interior region of the Continent-Eastern boundary - Western boundary-Slope of the region-First prairie level-Second prairie level-Third prairie level-Transverse watersheds-Description of the southern transverse watershed-The northern transverse watershed-Areas drained by different river systems-Area of the plains. GENeral OUTLINE OF T'HE GEOLOGY.-General nature of the region-Silurian series-Devonian series-Possible existence of Carboniferous rocks-Permian and TriassicJurassic-Cretaceous formation-Lignite 'Tertiary formation-Authorities on the Geology of the region.
\end{abstract}

\section{General Physical Geography.}

1. The great region of plain and prairie which occupies the whole of the central part of the United States and British America, where it crosses the forty-ninth parallel, is included in longitude between the 96 th and 114th meridians. It narrows rapidly northward, chiefly by the encrochment on it of its eastern border, and is limited to the north by the skirt of the coniferous forest, which nearly follows the line of the North Saskatchewan River. This great inland plain has an area in British America, between the forty-ninth and fifty-fourth parallels, of about 295,000 square miles.

2. Its eastern boundary is the slope of the old crystalline nucleus of the continent, which extends north of the River St. Lawrence and the Great Lakes, from Labrador to the Lake of the Wroods, and, then turning suddenly at an angle of about sixty degrees to its former general direction, runs with a north-north-west course to the Arctic Ocean, where it is described as appearing along the coast-line for some four hundred miles. The crystalline and highly metamorphic rocks forming this axis, are mostly referable to the Laurentian formation; but, no doubt, includo 
throughout their whole extent patches of the newer Huronian series, as they have been found to do where carefully examined north of the St. Lawrence, and also in the Lake of the Woods district as fully shown in another part of this report. The Huronian rocks are included with the Laurentian in their flexures, and to a great extent also partake in their metamorphism, and even appear in some places to have rested at first almost conformably upon them. This eastern barrier resembles more a rocky plateau, than a mountain region; there is no well-defined height of land, and the watershed follows a very sinuous direction among the innumerable lakes, small and great, which cover a large part of its surface. Northward from the Lake of the Woods, it divides the water's flowing into Hudson's Bay, from those draining directly into the Arctic Ocean, with one important exception. The Nelson Rirer, carrying the accumulated waters of the Saskatchewan River, the Red River of the North, and innumerable smaller streams, breaks through the Laurentian barrier at the north end of Lake Winnipeg, and empties into Hudson's Bay at York Factory. Through the same gap the Churchill or English River, a not inconsiderable stream, also parses. The geological circumstances which have allowed the drainage of the plains to find this easy exit, and the age and character of the vallies of the Nelson and Churchill Rivers, are interesting questions still arvaiting solution.

3. The Rocky Mountains on the west, rise abruptly from the elerated plain at their base, presenting often to the east almost perpendicular walls of rock. They are composed, not of a single upheared ridge, but of a number of more or less nearly parallel ranges, which have a general direction a little west of north, and a breadth of over sixty miles, extending from the margin of the great plains to the vallies of the Columbia and Kootanie Rivers. In the vicinity of the forty-ninth parallel, the geological continuity of the country is as sharply broken by the line of their eastern base, as its physical character; and we pass suddenly from the little altered or disturbed strata of Cretaceous and Tertiary age, to scarped mountain sides of palæozoic rocks, metamorphosed and crumpled in a violent manner. Southward, the mountains have not the same abrupt character on their eastern slope ; and to the north, after having culminated between the fifty-first and fifty-second parallels, the ranges not only become more diffuse, but decrease rapidly in height, till on the border of the Arctic Ocean they are represented by comparatirely low hills. In intimate connection with this change in the character of the mountains 


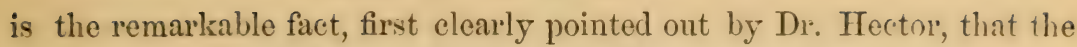
rivers flowing into Hudson's Bay and the Arctic Ocean have their sources further back among the mountains as we proceed northward. Near the Boundary-line, the tributaries of the Missouri and South Suskatchewan, rise in the abrupt eastern vallies of the first range. The Kananaskis River, one hundred miles to the north, rises in the first longitudinal valley, or at the foot of the second range; Bow River from the third range; the North Saskatchewan from the fourth range; the Athabasca from the fifth, and the Peace River still further to the west.

4. The interior region of the continent, slopes gradually eastward from the elerated plains lying at the base of the Rocky Mountains, to the foot of the Laurentian highlands; and though the inclination is more abrupt on approaching the mountains, it is not so much so as to attract special attention. Between the fifty-fourth and forty-ninth degrees of latitude, however, along two lines which are in a general way parallel, and hold a north-west and south-east course across the plains, rery remarkable step-like rises occur. These escarpments form the eastern boundaries of the two higher prairie plateaus, and the most eastern of them orerlooks the lowest prairie level, or that of the Red Rirer Valley, from the west. The three prairie steppes thus defined differ much in age and character; they hare been impressed on the soft formations of the plains by the action of sub-xrial denudation, of the sea, and of former great lakes, and though the precise mode of their formation is more fully discussed elsewhere, they deserve notice here, as being among the great . primary features of the country.

5. The actual increase of elevation accounted for in the two escarpments, however, is but slight compared with that due to the uniform eastward slope of the plains. The direction of their greatest inclination is towards the north-east, and a line drawn from the intersection of the forty-ninth parallel and the mountains, to a point on the first prairie level north of Lake Winnipeg, will be found to cross the oscarpments nearly at right angles, and to have an average slope of 5.38 feet to the mile. From the same initial point, in a due east line to the lowest part of the ralley of the Red River-a distance of 750 miles-the plains have an average slope of 4.48 feet per mile.

6. The first or lowest prairie level, is that of which the southern part lies along the Red River, and which northward embraces Lake Wimipeg and associated lakes, and the flat land surrounding them. A great part of its eastern border is conterminous with that of Lake Winnipeg, and 
formed by the rocky fiont of the Laurentian; but east of the Red River it is bounded by the high-lying drift terraces surrounding the Lake of the Woods, and forming a part of the drift plateau of northern Minnesota. To the west, it is limited by the more or less abrupt edge of the second prairie level, forming an escarpment, which, though very regular in some places, has been broken through by the broad valleys of the Assineboine and other rivers. The escarpment, where it crosses the Line, is known as Pembina Mountain, and is continued northward by the Riding, Duck, Porcupine, and Basquia Hills. The arerage height above the sea, of this lowest level of the interior continental region is about 800 feet; the lowest part being that surrounding the Winnipeg group of lakes, which have an elevation of about 700 feet. From this it slopes up southward, and attains its greatest elevation-960 feet-at its termination far south in Mimnesota. The edges of this prairie level are also, notwithstanding its apparent horizontality, considerably more elevated than its cectral line which is followed by the Red River. Its width on the forty-ninth parallel is only fifty-two miles; its area, north of that line, may be estimated at 55,600 square miles, of which the great system of lakes in its northern part-including Lakes Winnipeg, Manitoba, Winnipegosis, Cedar and St. Martin's-occupies 13,900 miles. A great part of this prairie level is wooded more or less densely, and much of the low-lying land near the great lakes appears to be swampy and liable to flood. The southern part, extending from the boundary line nearly to the south end of Lake Wimipeg; inclucles the prairie of the Red River Valley, with an area of about 6,900 square miles; one of the most fertile regions, and, at the same time, the most accessible portion of the North-west.

7. The superficial deposits of this stage are chiefly those of a great lake which occupied its area after the glacial submergence. This part of the interior of the continent being the last to emerge from the Arctic waters, and having been covered for a long time afterward by a sea of firesh water, held back either by drift deposits, or by rocky barriers, which have subsequently been cut through, and which must have united all the lakes now found in the region into one sheet of water, which extended with narrower dimensions about two hundred miles south of the Boundary line.

The Red and Assineboine Rivers and their tributaries have not yet cut rery deeply into its alluvial deposits, and its surface is level and little furrowed by denudation.

8. The second steppe of the plains, is bounded to the east as aiready 
indicated, and to the west by the Missouri Cotean, or edge of the third prairie level. It has a width on the forty-ninth parallel of two hundred and fifty miles, and on the fifty-fourth of probably about two hundred, though it cannot there be so strictly defined. Its total area is about 105,000 square miles, and includes the whole eastern portion of the great plains properly so-called, with an approximate area of 71,300 square miles. These occupy its southern and western portions, and are continuous westward with those of the third prairie steppe. To the south, the boundaries of this region appear to become more indefinite, and in the southern part of Dakota, the three primary levels of the country so well marked north of the Line, are probably scarcely separable. The rivers have acted on this region for a much longer time than on the last, and are now found flowing with uniform currents in wide ditch-like rallies excarated in the soft material of the plains, and often depressed from one-hundred to threehundred feet below the general surface. In these, the comparatively insignificant streams wander from side to side, in tortuous channels, which they only leave in times of flood. The surface of this prairie steppe is also more diversified than the last, being broken into gentle swells and undulations, partly, no doubt, by the action of denudation, and partly also as will appear, from the original unequal deposition by currents and ice, of the drift material which here constitutes the superficial formation. The arerage altitude of this region may be taken at $1,600 \mathrm{fect}$, and the character of its soil and its adaptability for agriculture, differ much in its different portions.

9. The third or highest prairie steppe, may be said to have a general normal altitude of about 3,000 feet, though its eastern edge is sometimes little over 2,000 feet, and it attains an elevation of 4,200 feet at the foot of the Rocky Mountains. Its area, including the high land lying along the base of the mountains, is about 134,400 square miles, and of this by far the greater part, or about 114,000 square miles, appears to be almost entirely devoid of forest; the wooded region being confined to a small area of its northern extension near the North Saskatchewan River and its tributaries. Its breadth on the forty-ninth parallel is four hundred and sixty-five miles, and its eastern boundary is well marked, being the broken hilly country known as the Coteau de Missouri or Great Coteau, which crosses the Boundary near the 10 th meridian, and thence runs north-westward nearly to the Elbow of the South Saskatchewan. It is then-according to Palliser-continued to the north by a range of high lands, of which the Eagle Hills west of Fort Carleton constitute a part. 
Ilere, howerer, it becomes broken and undefined. The Thickwood Hills near the Elbow of the North Saskatchewan, and the Red Deer Hills, probably form outlying portions of this plateau, and the high ground west of the Saskatchewan, near Fort Pitt, may be its eastern limit in that region.

10. This portion of the great plains was the first to emerge from the waters of the Tertiary, and from those of the glacial submergence, and its surface may have been subject to denudation through a great part of the two later periods of the Tertiary, as well as in post-glacial times. Those portions of it which still remain but little modified, form tablelitnds, the surfaces of which, from the horizontality of the underlying Lignite Tertiary strata, may be in many places nearly the same as those of the last deposited beds. It bears some evidence, howerer, of having been subsequently levelled by marine action. The immense denudation which has taken place by rain and rivers, is evidenced by the size and depth of the vallies of rivers and streams, both of pre-glacial and postglacial age, the great ravines and gullies which have been cut, and are still extending themselves among the soft sandstones and clays of these newer formations, and the isolated plateaus and buttes, which now stand far out on plains of lower level, seamed with newer systems of coulées and gorges. Deposits belonging to the glacial period, and transported boulders and gravel, are found on this highest steppe, but are not spread with the same uniformity as on the lower levels, and a great part of the surface is hased almost immediately on Cretaceous or Lignite Tertiary berk, and varies in the character of its regetation and appearance accordingly. The nature of the soil and prospective agricultural value of this great regrion ale too varied to allow of generalization; embracing as it dues, land along the foot of the mountains of unsurpassed fertility, and also the northern extension of the Great American Desert, with its surface of sun-baked clay or sand, scarcely supporting a thin growth of Cactus and Stipa.

11. Though thus so remarkably simple and definite in its grand features, the interior region of the continent shows many irregularities and exceptions in defail. The second steppe has some elerations on its surface as high as the erlege of the third platean, and that part surrounding

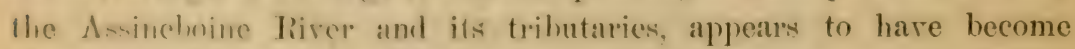
almo:mally depesied, making some portions of the eastern edge of this pratrie level. which overlonk Manitoha Take, more to resemble outlyers than intergat parts of it. The third steple, thongh so irregulan in many 
of its details, shows evidence in the closely corresponding heights of the portions now remaining of its original surface, of previous uniformity. The apparent indefiniteness of the three prairie levels and other features of the country to the north, no doubt, arises in great part, from the deficiency of our knowledge of that portion of the region, and it is highly probable that subsequent investigation will show the second and third steppes to be well marked in the elevated district between the Saskatchewan and Mackenzie Rivers.

12. The central portion of British North America, may therefore be regarded as a great shallow trough, of which the western edge is formed by the Rocky Mountain watershed, the eastern by that of the Laurentian axis, but of which the western portion of the floor is now more elevated than its eastern rim. The age of the former of these bounding watersheds, with that of the greater part of the mountains themselves, probably does not go much further back than early Tertiary times. The latter is a part of the oldest watershed and axis of the continent. There are, however, two other and transverse watersheds in the area in question, which, though apparently not marked by any great geological breaks, are of great importance geographically. Of these the southern, with a gencral course of east and west, follows a sinuous line, and several times crosses the Boundary on the forty-ninth parallel. It separates the water's of the Red River and Saskatchewan, which find their way through Winnipeg Lake to Hudson's Bay, from those of the Mississippi and Missouri and their various tributaries. Commencing with an elevation of about 1,600 feet, in that region of swamp and lake in northern Minnesota which feeds the variously destined head-waters of the Winnipeg, St. Lawrence, Mississippi and Red Rivers; it dips southward between the tributaries of the latter two streams, and passes between Lake Traverse and Big Stone Lake, about two hundred miles south of the Line, with an eleration of only 960 feet. Thence, pursuing a general north-westward course along the high-lands formed by the southern extensions of Pembina escarpment and the Missouri Cotean, it finally becomes identified with the latter, and crosses the Boundary-line near its intersection with the 104th meridian, three hundred miles west of Red River, and continues with the same course toward the Elbow of the South Saskatchewan. The tributaries of the Souris River here lie along the north-eastern base of the Coteau, while those of the Missouri cut deeply into the soft Lignite formation of its south-western side. Between these river systems it lies as a helt of country withont determinate direction of drainage or syatems of river 
vallies, but consisting of broken tumultuous hills of drift material. It has a width of orer twenty miles on the forty-ninth parallel, and a height of about 2,200 feet, and is very definite; but widens when followed to the north-west, and becomes more diffuse, and where crossed by the old Trader's Road to Woody Mountain, the tributaries of the Souris River are found rising within it, and the line of watershed leaving it and falling back somewhat further to the south, so that at Woody Mountain settlement in longitude $106^{\circ} 30^{\prime}$, the primary watershed lies only from fifteen to twenty miles north of the forty-ninth parallel. It is necessary to inecify the primary watershed, as it would appear that most of the small streams now ruming northward in this region, are intercepted by the mounds and ridges of drift material, and caught in saline lakes and pouds. Many of them may, however, still find their way to the Saskatchewan in seasons of flood.

13. The watershed near Woody Mountain is a narrow flat-topped plateau composed of Lignite Tertiary strata, irregular in outline, but with a general east and west course, and furrowed on either side by the vallies of streams which ramify in it, and which, were denudation advanced a little further, might inosculate. The height of the water-shed is here about 3,200 feet. Fifty miles west of Woody Mountain, and twentyfive north of the line, where the watershed was again crossed, it preserves most of the characters just indicated, but has been still more extensively reduced by denudation, and has a height of only about 3,000 feet. West of this point it trends northward, and is again found in the Cyprés Hills, forty miles north of the Line in longitude $110^{\circ} 30^{\prime}$, where it still appears to follow a rilge of Lignite Tertiary deposits, now but a scanty remnant of that once extensive formation, as the streams on either side soon debouch on plains of Cretaceous strata, from which the Tertiary has been removed by their action. West of the Cyprés Hills the watershed again trends southward and crosses the line about thirty miles from the base of the Rocky Mountains for the last time. It here separates the waters of the St. Mary, a tributary of the Belly River, from those of one of the upper branches of the Milk River, and is scarcely indicated by any physical feature, though so important hydrographically. The valley of the tributary of the Milk River and that of the St. Mary River, are deep, and the stroams are found crossing the Isine nearly parallel in a northcantwarl direction, the Milk Liver subsepuently bending eastward and sumthwand, and recressing the Line twenty miles east of the Sweet-grass 1lills. The lower part of the watershed region between them is 
undulating with some small lakes and swamps, while the hills are flat-topped and dry, and in some places coalesce to form a high-level plateau.

14. This southern transverse watershed is throughout characterized by diffuseness, and is indeterminate in direction. It has, in all probability, been outlined at first by some very gentle flexure of the strata on a large scale, produced during the eleration of the Cretaceous and Tertiary beds to their present position; but has been subsequently shaped by the denudation of these soft formations on all sides. Such an elevation would very likely be accompanied by corresponding parallel depressions, like it, slight in amount but extensive in area, which would indieate the valleys of the Saskatchewan and Missouri. The eastern extension of the northern of these synclinals might also account for the passage of the Nelson and Churchill Rivers through the otherwise continuous barrier of metamorphic rocks there.

15. The Tertiary plain of the third prairie steppe must first have been scored by rivers flowing from west to east, and then by their numerous branches flowing to the north and south to the precursors of the Saskatchewan and Missouri. By these the strata have been gradually cut down and back, till an extensive table-land separated the valleys of the two streams. Waste still continuing, has reduced this in many places to a mere dividing ridge, or has almost altogether remored it. The quantity of material carried away has been vast, and by far the greater part of this denudation appears to have been accomplished before the glacial period.

16. Of the second great transverse watershed but little is known. It separates the waters of the Saskatchewan system of rivers from those which pass directly into the Aretic Ocean by the Mackenzie River. Where crossed by the canoe route at Methy Portage, near its eastern junction with the Laurentian, Sir J. Richardson gives it an elevation of 1,560 feet. According to Dr. Hector's observations, its western end would appear to have an altitude of about 2,400 feet. The intermediate portion is probably less elevated than either of the extremities.

17. Of the area as at first defined, extending from the Rocky Mountains to the base of the Laurentian country, and lying between the fifty-fourth and forty-ninth parallels, the great Saskatchewan River and its tributaries drains by far the largest part, an area of about 139,000 square miles. The Red River and its great tributary the Assincboine, drain 70,500 square miles; the vallies of numerous small streams flow- 
ing into the Winnipeg group of lakes, including the area of the lakes themselves, corer 52,800 square miles. The head waters of the Missouri, and especially of its tributary the Milk River, drain a considerable area to the south, embracing about 22,800 square miles; while the Athabasca and North Pembina Rivers, flowing into the Mackenzie, drain an area of only about 10,000 square miles in the north-western corner of the region.

18. The total area of prairie country within the same limits, including that of all three prairie levels, may be estimated at 192,900 square miles. Though much of this vast region is not absolutely treeless like its southwestern part, its aggregate tree-clad area is quite insignificant as compared with that of its open plains. North of the fifty-fourth parallel, the area of the prairie region is inconsiderable, and has not yet been so well defined as to render any estimate possible.

\section{General Outline of the Geology.}

19. After the Huronian period, the geography of which cannot yet be dufined, the succeeding formations of the western prairio region seem to have accumulated on a great submarine plateau, stretching westward from the base of the Laurentian and Huronian range, and probably continuous with an ocean occupying the present position of the Pacific. The region now occupied by the western mountain ranges, was at different times outlined by areas of shoals and sand-banks, but true marine limestones were formed over it at several epochs. At least as early as the close of the Cretaceous period, the elevation of mountain ranges appears to have begun; and from this time, the formations accumulating between them and the Laurentian and palacozoic barriers to the east, were those of a great interior continental basin. These waters, at first in free communication with the sea to the south and north, were soon, by the gradually increasing elevation of the continent, eut off from it more or less completely; and, after a period of transition, became a great freshwater lake or series of lakes. At the close of the Lignite Tertiary formation-gencrally attributed to the Eocene period-the elevation of the Rocky Jountain ranges was resumed with renewed vigour, and in lakes of constantly decreasing size, the sands and clays of the later Tertiaries were deposited. These include, in erreat abundance, the remains of the numerous land animals which inhabited the then extensive area of the continent; but are not yet known to oecur north of the fortyninth parallel. The Cretaceous and Tertiary rocks lying along the base 
of the mountains followed them in their elevation, and thus, at a very late stage in the history of the continent, the great region of the plains acquired its eastward slope. In the vicinity of the forty-ninth parallel, these rocks have been raised almost horizontally to a height of orer 4,000 feet abore the sea; to the south their eleration is even greater, while northward the platean which they form falls gradually. It is interesting to observe that while the Cretaceous and Tertiary beds of the interior, have thus been raised en masse by the slow exercise of immense force, their broken remnants on the west coast have scarcely been elevated above the level of the Pacific.

20. The details of the Laurentian and Huronian rocks receiving more extended notice in subsequent pages, these need not be mentioned in this preliminary sketch. On their western flanks, and resting directly on their contorted and denuded edges, limestones of Lower Silurian age appear. They have been deposited tranquilly around the Laurentian shores, and in general still rest almost horizontally upon them, though they hare been described as occurring much disturbed at one locality on the southern shore of Lake Winnipeg. Upper Silurian rocks are not certainly known to exist in place, though limestones of this age probably remain concealed by drift and alluvial deposits, and may even at one time have overlapped a great part of the Laurentian plateau, and hare been continuous with those which appear to underlie the whole flat margin of Hudson's Bay on the north-restern side of the same Laurentian region. The best known exposure of the Lower Silurian limestones is near the Stone Fort, on the Red River, twenty miles south of Lake Winnipeg. It was examined as long ago as 1848 by Dr. Oren, then engaged in a Geological Surrey of the Northern Territories of the United States. He concisely describes the limestone as "of a light buff colour, sometimes mottled, spotted, or banded, with light brown," and in his report gives the most extensive list of the fossils yet made, and figures some of them. The list includes serenteen forms, but-unless some mistakes in the reference of these has occurred-shows a rather mixed fauna, but one which, according to Dr. Owen, agrees with that of the lower beds of the Ulyer Magnesian limestone of Wisconsin, and may therefore be taken as representing the Trenton.

Dr. Hector also gives a short list of fossils collected at the same place, in his report.

The limestone is highly magnesian, and afforded Dr. Shumarl, who 
has made analyses of two samples, 40.5 and 17.8 per cent. respectively of magnesic carbonate.*

Prof. Hind has also recognised limestones of the Trenton, Birdseye and Chazy divisions of the Lower Silurian, and the operations of the Canadian Geological Survey lately extended to this region, will no doubt, soon show the true relations of these beds, with their nearest representatives in Minnesota and the neighbouring states, where the arrangement is as follows in descending order: $\dagger$

Hudson R. Maquoketa Shales.

Trenton. (Galena Limestone,- (buff and blueish magnesian limestone, ) 180 feet.

Chazy. (Trenton Limestone, - (flaggy limestone, with shale,) $\quad 160$ "

Calciferous. Lower Magnesian Limestone,_-(light buff, some beds sand,) about 200 "

St. Croix Sandstone, - (massive white or buff coloured, shale at base,J over

Potsdam. Potsdam Sandstone,-(hard sandstones, often red,) at least

500 6

400 “

22. Fragments, known by their mineralogical character and the fossils which they contain, to have belonged to these Silurian limestones of the first prairie level, have been strewn broadcast over the plains almost to the Rocky Mountains, by glacial agency during the period of the drift.

23. They also, without doubt, underlie the greater part of the interior continental area, though completely covered by rocks of later date; and they are known to occur again in some parts of the Rocky Mountains, but considerably modified in appearance and thickness. Their eastern line of outcrop follows the Laurentian, to the north, occupying a broad belt of country to the head waters of the Mackenzie, where they appear to be orerlapped by Devonian strata. Other smaller areas of Silurian, however, appear further north along the same line of strike, and limestones probably referable to this age, again expand widely on the shore of the Arctic Ocean.

24. Limestones very similar in appearance to those of Silurian age, but known to be Devonian by their included fossils, occur on Manitoba and St. Martin's Lakes, and elsewhere along the western border of the the northern part of the first prairie level. Prof. Hind has defined by observations in several localities a belt of these rocks at least fifty miles in width. He describes them as in intimate connection with the brine springs of that district, the waters of which yicld an excellent quality of salt on concentration. From the continuation of such saline springs to 
the southward, he has deduced the direction of the outcrop of the formation, where, from the thick covering of drift and alluvium, no natural exposures exist. While this method of tracing the limit of the Devonian beds, probably affords as near an approximation to the fact as can at present be made, it must be remembered that where so great a thickness of unconsolidated drift and alluvium intervenes, and where formations even of Cretaceous age may overlap these older rocks, saline waters, even though emanating strictly fiom a single series of beds, may travel far in the porous layers of the superficial formations before reaching the surface.

25. The Devonian rocks already mentioned as occurring on the head waters of the Mackenzie near Methy Portage appear, from Sir J. Richardson's observations, to occupy a wide belt of country from that place to the Arctic Sea. Their eastern edges rest against the border of the Laurentian region, and the underlying Silurian appears only in isolated localities. The rocks consist of limestones and shales highly charged with bituminous matter. He obtained from them specimens of Productu, Spirifer, Orthis resembling O. resupinata, Terebratula reticularis, and a Pleurotomaria which Mr. Woodward considered Devonian.* Also a Pteropod "apparently Tentaculites fissurella of Hall, a Chonetes, the Strophomena setigera of Hall, and Avicula lavis of the same author," a Strombodes (Cystiphyllum?) and Favosites, like F. polymorpha. Prof. Meek, who has had the advantage of studying a collection of fossils from the Valley of the Mackenzie, made by Major R. Kennicott and some of the Hudson's Bay Compariy's servants, has described and figured a number of species, some of them for the first time, in a paper contributed to the Chicago Academy of Sciences. $\dagger$ He refers the beds from which they were obtained, and which are the same as those already doscribed by Sir J. Richardson, and are very extensively developed, to the horizon of the Hamilton rocks and Genesee Slates.

Prof. Meek gives the following list of forms from this very interesting area of the Devonian:-

Cyathophyllum arcticum, Meek; Cystiphyllum Americanum var arcticum, Meek; Aulophyllum? Richardsoni, Meek; Zaphrentis recta, Meek; Zaphrentis Macfarlanei, Meek; Śmithia Verrilli, Meek; Combophyllum multiradiatum, Meek; Palcocyclus Kirbyi, Meek; Favosites polymorpha, Goldfuss; Alveolites vallorum, Meek ; Lingula minuta, Meek; Strophomena demissa, Conrad; Strophomena (Strophodonta) sub-demissa, 
Hall; Orthis Macfarlanei, Meek; Orthis Iowensis? Hall. Producta dissimilis? Hall. Two other imperfectly characterized species of Producta. Chonetes pusilla, Hall; Rhynchonella castanea, Meek; Pentamerus borealis, Meek; Atrypa aspera, Schlotheim; Atrypa reticularis, Linn.; Cyrtina Billingsi, Meek; Cyptina Hamiltonensis, Hall ; Cyrtına panda, Meek; Spirifer Kennicotti, Meek; Spirifer compactus, Meek ; Spirifer (Martinia) sublineatus, Meek; Spirifer (Martinia) Richurdsoni, Meek; Spirifer (Mrartinia) Meristoides, Meek; Spirifer (Martinia) Franlilinii, Meek; Rensseleria laris, Meek; a Pleurotomaria; and Gyroceras Logani, Meek.

26. A more extended exploration of the Devonian rocks of the North-west is much to be desired. Their prospective value as a saltbearing group is great, not only in the sonthern part, but far to the north on the Mackenzie River, where Richardson deseribes very copious brine springs. Their northern extension is also everywhere associated with bituminous deposits, from Methy Portage to the Arctic Ocean. Sir J. Richardson especially mentions certain localities on the Athabasca Rircr, near the position of a former trading establishment, now known as La vieux Fort de la Riviére Rouge, "a copious spring of mineral pitch issues from a crevice in a cliff composed of sand and bitumen. It lies a few hundred yards back from the rirer in the middle of a thick wood." Of another locality he writes: "The whole country for many miles is so full of bitumen, that it flows readily into a pit dug a few feet below the surface," * and similar references abound in his Journal. Where bitumen exists in such abundance on the surface, there is every probalility that flowing oil wells might be obtained without going to any great depth, the bitumen being generally but the inspissated residue of lighter oils beneath.

The bituminous limestones and shales have, as already stated, been referred, by Prof. Meek, to the Hamilton and Genesee epochs. The "Black Slate" of the Western and Southern States, has been shown to be the equivalent there, of the latter. It "holds exactly the same position with relation to the Ifamilton beds as the clear water and Athabasca shales" of the Mackenzie River regiont and is very frequently connected with oil and brine springs. This being the case, it is highly probable that the same formation in the intermediate region south of Methy Portage and in Manitoha, where it is to a great extent covered by Cretaceous rocks, would, if properly explored, be found to yield mineral oil as well as salt. 
27. The possible existence in the vicinity of the settlements of the Red River Valley, of beds referable to the period during which the deposits of coal in most parts of the world were produced, is a question of considerable interest, and has already attracted some attention. No exposures of Carboniferous rocks are known, and considering the low angles at which the Silurian and Deronian beds rest, and how close the area supposed to be occupied by the latter lies along the eastern edge of the Cretaceous, it is probable that the margin of the Carboniferous series is altogether concealed. Prof. Hind made a special search for the outcrop of these rocks along the base of the high-lands west of Maritoba Lake, which appears to be the most likely locality for their occurence; but unsuccessfully * It would no doubt be possible, by boring in judiciously selected localities, west of the escarpment of the Cretaceous, in the Riding, Duck and Porcupine Hills, to penetrate that formation, and discorer rocks of Carboniferous age; which may probably exist there at no very great depth. We know something of the Carboniferous formation of the interior continental region, howerer, from its derelopment on the upper waters of the Mississippi, and it would appear that the search for any coal beds of economic value west of Iowa, is almost hopeless. The character of the rocks, as compared with those producing valuable coal beds further to the east, changes completely; the thick shales and sandstones of the latter region, being represented by limestones accumulated in deep water. It is true that seams of coal are known as far west as Nebraska, but they do not exceed a ferw inches. in thickness, and seem to lie on the rery margin of the coal-bearing basins of the east. This estimate of the valuelessness of the rocks of Carboniferous age which underlie the great plains, is confirmed by an examination of their representatives yet further west. Where again emerging to view along the slopes of the Rocky Mountains, they are not known either in the United States or in British America, to show any sign of reverting to their eastern coal-bearing character. This being the case, it would appear that the western prairie regions must depend for their supply of fossil fuel on the coals and lignites of the Cretacerus and Tertiary formations, there so extensively dereloped.

28. Rocks of Permian or Triassic age are unknown in the interior region of British North America, with the probable exception of some beds of the Rocky Mountains, the equivalents of which south of the forty-

*Prof. Hind figures a specimen of Producta, which Mr. Billings considered to be of Carboniferous type. It appears to have been derived from a boulder found near Fort Garry. - Rep. p. 187. 
ninth parallel have been referred to these periods. They must either have been remored by denudation, along the eastern margin of the area, previous to the Cretaceous period, or may never have been deposited there; as an elevation of the oceanic plateau to a sufficient height to allow the formation of coarse sedimentary beds on its western margin, would probably lay the eastern bordering region dry for a great breadth.

29. The Jurassic period, also, has left few records in the rocks of the North-west. It is hardly probable that strata of this age come to the surface in any part of the great interior continental valley north of the Line, though Richardson, when with Sir J. Franklin in 1826, obtained some fossils which Mr. Sowerby referred to the "Oxford Oolite and Cornbrash."* As they came from the limestone beds of the Mackenzie, however, and if placed in the Jurassic series, would appear necessarily to carry with them the bituminous shales now conclusively proved to be Devonian, there is no doubt some error in the reference. Prof. Meek writes, apparently with regard to the same fossils; "from one of these beds Sir John Franklin collected in 1825 some fossils referred to Spirifer acutus, and several Terebratalœ, resembling T. resupinata,"-_ Spirifer acutus, howerer, being a Carboniferous species, and Terebratula resupinata a Liassic form, it is evident there is some error in these identifications." $\dagger$ Rocks known to be Jurassic by their fossils, are however, found in the Rocky Mountain region of Montana, and their equivalents-though not yielding fossils-appear among the highest rocks seen in the vicinity of the South Kootanie Pass, and will probably be found above the carboniferous limestone much further north in the range.

30. The Cretaceous rocks, corresponding in age with the great chalk formations of Europe, though very different from them in mineral character; are those which spread over by far the greatest surface. Except in a few localities, and those chiefly in proximity to the Rocky Mountain region of uplift, they are still almost as perfectly horizontal as when originally deposited. The eastern edge of this formation partly orerlaps the underlying Silurian and Deronian beds, and runs nearly parallel with the base of the Laurentian range at a distance of about one hundred and thirty miles, from the fifty-third to the fiftieth parallel of latitude. Southward it trends to the east, and probably crosses the fortyninth parallel east of Red River; while in south-western Minnesota Cretaceous rocks repose directly in some places on granites, which are no 
doubt Laurentian. The general course of the eastern onterep) is consequently about north-north-east; and it is marked, broadly, by a series of cscarpments and elevations, including-from south to north-Pembina, Riding, Duck, Poreupine and Basquia Mountains. All these ajplear to be composed for the most part, if not entirely, of Cretacous rocks, though the extreme elge of the formation may often stretch beyond them. These so-called "Mountains" are, more correctly speaking-as already shown-salient points of the edge of the second plateau, and the generally horizontal position of the berls thus suddenly cut off to the east, attests the immense denudation which must have taken place in comparatively modern times.

31. North of the Basquia Mountain, from the very scanty information we at present possess, the edge of the Cretaceous would apjear to run westward and cross the Saskatchewan Rirer near Fort à la Corne, where at Cole's Falls a dark-coloured shale which has been referred to the lowest member of the series, occurs. It may very probably be nearly conterminous with the elge of the second plateau, which, according to Mr. Selwyn, crosses the river forty-five miles below the Fort. The western border of the Cretaceous seems in some places to follow clocely along the base of the Rocky Mountain Range, but many circumstances arise to complicate the question in that region, and it will only be after the accumulation of much more information than is at present in our possession, that the line can be laid down with any accuracy. In some parts of the range, Cretaceous rocks have been incluted among the mountains themselres, and considerably altered; but the greater part of the newer strata, which must have covered the palrozoic rocks of this region when the uplift first took place, have leen remored by denudation.

32. The Cretaceous rocks thus defined in breadth, north of the Boundary-line, have heen noted by Prof. Hind, Dr. Hector; Mr. Selwyn and Prof. Bell, in many localities on the second prairie lerel, some of which are more particularly referred to in the sequel; and are known to extend in a broal zone from the North Saskatchewan to the Mexican fronticr. and southward. In the western Territories of the Tnited States, the stratigraphical sequence and palæontology of the Gretaceous beds, have heen carefully studied by Dr. Hayden, Professols Cope, Newherry, Marsh, Lesquereux, Leidy and others. South of the forty-ninth parallel, howerer, the Cretareous itself is to a great extent comcealed by represits of Tertiary age, which, though they have been aremumbated at different. periods, from the generally undisturbed nature of the country, are rarely 
found to rest on the Cretaceous in other than a conformable position. North of the Line, the only one of these later formations yet recognized is the lowest or Lignite Tertiary.

32. Ou knowledge of the Cretaceous beds beyond the North Saskatchewan, is as yet very limited, and depends almost entirely on the observations of Sir J. Richardson, aided by chance notes of other cxplorers not profesised geologists. It is likely, however, that a trough or series of more or less isolated basins of lignite and coal-bearing strata, follows near the eastern base of the mountains the whole way to the Aretic Sea. A part of these beds is known to represent the Lignite Tertiary of the south; but judging from their association elsewhere, they will probably be found to rest on Cretaceous rocks throughout. Indeed, from the fragmentary nature of the information concerning this great norther'n region, and the unsettled questions with regard to the age of the coal series of the analogous region near the mountains and south of the North Saskatchewan, it is impossible to decide whether some of the coals and lignites described, may not belong to the Cretaceous formation itself. The existence of Cretaceous beds has, however, only been determiner with certainty at a single locality, on the Bear Lake River, neal its junction with the Mackenzie. Sir J. Richardson here discorered an Almmonite among saudstones and shales which he states renemble those of the coal measures. Prof. Meek has detected fragments of an Ammonite and Inoceramus in Mr. Kennicott's collection from the same place, * and had formerly described two species of Ammonites from that neighbourhood, submitted to him by Prof. Hind, as A. Barnstoni and A. Billingsi. +

33. The suldivision of the Cretaceous, as it occurs in Manitoba and the North-west Territories will require diseussion after the systematic description of the localities in which it has been examined. From its (close general resemblance however, to that which has been studied in the western part of the United States, it will be useful to have the Upper Misompi seretion of Meek and Hayden, which has now become typical, as a standard of comparison.

The formation is there comprosed as follows in descending order :

- Trans. Chicagn Acad. Sci., vol, I., p. 72.

$\dagger$ Repurt Assineboine and Yaskatchewan Exjedition, p. 184. 


\section{Later Cretaceous.-}

No. 5. Fox Hill BeDs.-Grey, fermginons and yellowish sandstones and arenaceous clays. Marine shells. 500 feet.

"4. Fort Pierre Group.-Dark grey and blueish plastic clays. Marine shells, gypsum and fish remains ......................... 700 "

\section{Earlier Cretaceous.-}

No. 3. Niobrara Group.-Calcarenus marls. Marine shells, fish remains, Foraminifera, dic...........

"2. Fort Benton Group-Dark grey laminated clays,

“ 1. Dakota Group.-Yellowish, reddish, and whitish sandstones, and clay, with occasional lignites. Marine and some fresh-water shells, and Angiospermous leaves ..................... 400

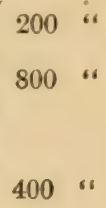

Giving, as an approximate thickness of the formation in that region, 2,600 feet.

34. The Lignite Tertiary rocks north of the line are not bounded by any great physical features of the country, but adhere closely to the upper members of the Cretaceous, and behave as an upper member of that formation might be expected to do. Though no doubt originally deposited in extensive basin-like depressions of the Cretaceous strata, these are now generally found forming slightly elevated plateaus. Denudation must have acted on these rocks on a rast scale, but they still cover an immense area, and contain the greatest stores of mineral fuel known to occur in the vicinity of the forty-ninth parallel. The line of their eastern edge crosses the parallel near the 102nd meridian, and thence appears to pursue a north-restward course, remaining for some distance nearly parallel with the elge of the third plateau. Beyond the Elbow of the South Saskatchewan, though the same physical feature continues to the north, it is not known what relation it may bear to the outcrop of this formation, nor has its northern limit heen accertained. Between the North and South branches of the Saskatchewan River there is a great tract of country, the geological features of which are still very imperfectly known, but where it is highly probable, outlyers, if not direct extensions of this Lignite formation will be met with. To the west, it appears to extend, at least in some places, nearly to the base of the Rocky Mountains.

35. A thick mantle of sands and clays, referable to the glacial period, and to former great lakes, covers almost the entire surface of the plains. A geologist may often travel a hundred miles without once 
being able to observe a section of the underlying Cretaceous or Tertiary rocks, and but for their great uniformity and simplicity of structure, it would be a rery difficult task to unravel the geology of so vast a region. The very monotony of the plains is, howerer, to a great extent, a corollary of the attitude of the strata beneath them, and of their unconsolidated and homogreneous character.

36. In the foregoing brief summary of the Physical Geography and (icology of the interior region of British America, I have availed myself fireely of the various sources of information on that subject, some of which have been alrealy acknowledged. Though there are many works bearing more or less directly on the general nature and aspect of the country, the geological bibliography is as yet quite small, and the knowlerlge of some districts has not been extended since the date of the first observations, made many years agro. The principal authorities on this regrion, exclusire of those relating entirely to its Arctic portion, are as follows:-

Sir J. Richardson, in his "Journal of a Boat Voyage through Rupert's Lame," 18.51. Also in "Topographical and Geological Appendix to Franklin's Second Jomriey to the Aretic Sea," and various papers in the Jomrual of the freological Society of London. His personal observations were chiefly contined to the Canoe Route, from Lake Superior to the mouth of the Mackenzic, and to the regions lying near the coast of the Polar Sea.

Dr. Bigstry, in two paper's published in the Journal of the Geological Suciety, 1851 and 1852, grives much information on the Lake of the Wouls region, as more fully mentioned in mother part of this report.

Mr. Islister, in the Journal of the Geological Society for 1855, gives a concise account of the general geology of the north-western regions of Americal, as then knowri, and a geological map chiefly based on that of Richardson.

Prof. H. Y. Hind, in his various reports of the "Assineboine and Saskattheran Exploring Expedition," organized by the Canadian Government in $1857-58$, furnishes much information, both as to the geology and greneral character of the country traversed.

Dr. Heclor, geologist to the exploring expedition sent out by the Imperial forermment under Capt. Palliser, traversed an immense extent of eomutry during the years $1857-58-59$. To him the first really trust-

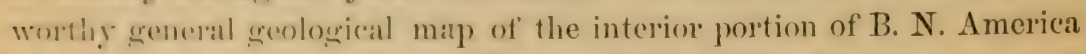
is due; and he hats besides alcemmulated and published a great mass of 
geological observations, the significance of many of which appears as the country is more thoroughly explored. II is report is pullished, together with the other results of the expedition, ly the British Gorernment, as a Blue Book, bearing date 1863. He has also contributed a paper to the Geological Society's Journal on the subject. (Vol. xvii.)

Dr. D. D. Orcen, in his "Geology of Wisconsin, Iowa and Minnesota" (1852), touches incidentally on the Silurian limestones of Red River.

Prof. Keating, in 1823, made some cursory observations on the same limestones, and on the rocks of Lake of the Woods.

Prof. F. B. Meek, in a paper entitled "Sketch of the Geology and Palaontology of the Valley of the Mackenzie River," published in the first rolume of the transactions of the Chicago Academy of Sciences (1868), describes a number of fossils collected by Mr. Kennicott, and reviews the geology of the region.

Prof. Heer, in his work, "Flora Fossilis Arctica," gives three plates, and descriptions, of fossil plants from the Mackenzie River.

$M r$. Selwyn, director of the Geological Survey of Canada, in the Report of Progress, for 1873-74, gives the results of a preliminary examination of the North Saskatchewan region. Prof. Bell, in the same volume, reports on the country in the vicinity of the South Saskatchewan and Qu' Appelle River's. 


\title{
CHAPTER II.
}

\section{GEOLOGY OF THE LAKE OF THE WOODS. LAURENTIAN AND HURONIAN.}

\begin{abstract}
Position and Grography of the Lake-Clear-water Lake-Sand-hill LakeWhite-fish Lake-Lac Plat-Former Geological Explorers-LaUrenttan Fon:ustion - Vicinity of the North-West Angle-Flag Island to Rainy River -Bigsby Island--Middle Island-North Island-Shebashea-ARFA or Me'Haltered Huronian.--Intrusive Granitic Mass of North-Wrst Angle -Its form-Northern branch-Southern branch-Included area of altered Tocks-HURONIAN ROCKS-ANGLe INLET TO KA-KA-KE-WABEC-QuartziteConglomerate belt-Schistose rocks - Second Conglomerate belt-Second Schistose belt-KA-Ka-KR-WABEC GrantTE-Huronian Rocks KA-KA-KE WABEC To RAT PORTAGE - Schistose belt-Conglomerate of Lacrosse IslandExtensive Schistose belt with some conglomerates-JUNCTION OF THE LAUrrmtian and Huronian at Rat Portage-General Distribution and AtTitudes of THE Rocks-Main directions of flexure-Comparison with other localities-Character and AGE of the so-Called Huronian Rocks Nature of the conglomerates-Metamorphism-Dykes and veins-MINERALS OF ECONOMIC VALUE.
\end{abstract}

\section{Position and Geography the Lake of the Woods.}

37. The Lake of the Woods is over seventy miles in extreme length, and from its exceedingly irregular form has a very extended coast line. It belongs to that system of inland waters which includes the Great Lakes to the east, and is continued in the north and west by Lakes Winnipeg, Athabasca, Great Slave and Great Bear Lakes; all of which lie along the southern and western margin of the great metamorphic nucleus of the continent, where its crystalline rocks sink below those of Silurian and Devonian age. This lake, in its geographical and geological relations, thus differs from those which cover so great a part of the surface of the erystalline metamorphic series itself, and which appear to occupy shallow rock basins in it.

38. The water supply of the lake is derived chiefly from the northward and eastward by the Rainy River, a magnificent stream, draining the western slope of the watershed which divides the waters flowing to the Lake of the Woods, from those falling eastward into Lake Superior. The tributary streams from the country lying west of the lake, though comparatively numerous, are unimportant; as the low ridge which separates these from those passing westward into the Red River, lies very near 
the lake. The lake discharges its waters by the Winnipeg River at Rat Portage, and there begins the descent of about three hundred feet to Winnipeg Lake, by a fine cascade and rapid.

39. The northern part of the lake is studded with innumerable islands, comparatively few of which are marked on any map. Some are several miles in length, other's of very small size, but they are invariably composed of solid rock, and seldom have more than a rery scanty covering of soil. The shores of this part of the lake are also rocky and bold, and the water clear and deep, giving rise to its common name of Clear-uater Lake. It communicates by several narrow passages through a maze of islands, with the southern portion, which is totally different in character. Here, islands are comparatively rare, and the lake forms a broad sea-like expanse, which is easily thrown into violent agitation by the winds, rendering canoe navigation somewhat precarious. The shores are for the most part low and swampy, in some places corered with a dense growth of tamarac, but often bordered by low sand-hills, and stretching out behind them in great reedy Muskegs.* The water is comparatively shallow and somewhat turbid. To this part of the lake the name Lake of the Woods is generally applied, but it is more properly called Lake of the Sand-hills. A third great division of this system of waters lies between the eastern bays of Clear-water Lake and Lake of the Sand-hills. It communicates with the former by narrow channels, and from the latter is entered across a rocky division known as Turtle Portage. This part of the lake is designated White-fish Lake, and has never, so far as I can learn, been properly examined or surveyed. Lac Plat, situated to the west of Clear-water Lake, may, though much smaller than the other's, be counted a fourth division. It is, I believe, entered in one place withont unloading canoes, and also by several easy portages. It would appear to be shallow, merging into swamp westward, and is the great rice ground of the Indians. The North-west Angle Inlet, is a narrow arm running westward from near the junction of Sand-hill and Clear-water Lakes. On it is situated the eastern terminus of the road from Winnipeg, and in connection with this there is a Gorernment station for immigrants. There is also a Post of the Hudson's Bay Company, several traders' houses, and usually a large camp of Indians. At Rainy River is another Government post, known as Hungry Hall, and between this place and the North-west Angle a steamer now plies regularly, forming

* A Chippewa word generally adopted to designate the wide grassy swamps of this region. 
a link in the through route from Lake Superior to Manitoba. The mouth of Rainy River is also, and has been from time immemorial, a favourite (amping place of the natives. At liat Portage there is a small Hudson's Bay Post, surrounded by a stockade, and trading with Indians hunting over a great area of country.

\section{Former Geological Explorers.}

40. The geology of the Lake of the Woods was first discussed by Dr. J. J. Bigrsby, in a paper which appeared in the seventh volume of the Jommal of the Geological Society (1852), and gave the results of an examination male, I believe, in 1823, during a visit to the lake in his capacity as Medical Officer to the Boundary Commission Survey of that date. This paper grives a remarkably clear general account of the geology of the region, and I must express my obligation to it for several fitcts incorporated in the general map appended to this report. Prof: Keating, associated with Major Long, in a United States Gorermment expedition to the sources of the St. Peter River and neighbouring country, passed through the Lake of the Woods by the Canoe lioute in 1823, and gives a few notes on the lithologrical character of the rocks observed. Prof. Hind mentions some facts bearing on the geology, in his Reports (1857 and 1858). Prof. Bell, of the Canadian Geological Survey, in his Report for 1872, gives a short account of the rocks secn cluring a canoe voyage from Rat Portage to North-west Angle, and some conclusions on the general geology.*

\section{Detail of Observations on Geology.-Laurentian. $\dagger$}

41. On approaching the Lake of the Wools from the west, by the road from Wimipere, the first rock in place is seen about three miles east of Birch Creck fiovermment Station, and comsists of Laurentian granitoid gneiss. About eleren miles east of the same place, and on the eastern margin of the Caribon Mukeg, a large surfice of a similar rock is exposed, and is seen to be traversed by veiris of red felspar. A mile further east, amother good sories of exposmes occurs, the rock being a greyish gneiss, the lamination of which has a strike of $\mathrm{N} .60^{\circ} \mathrm{E}$. It is intersected by many reins of red felspar rumning in all directions. About fourteen miles

\footnotetext{
n. To Mr. A. L. Russell I am indebted for much information concerning the part of the lake which I was unable personally to visit; also for an opportunity of examining specimens collected by him in Lae Plat, and assistance in bringing the map up to date by the addition of the results of recent surveys.

+ The bearings given throughout this chapter are magnetic. The variation at the North-West Angle being $11^{\circ} 17^{\prime}$ East, according to observations by Capt. Anderson, R. E., in October, 1872.
} 
east of Birch Creek, a well stratified and thinly bedded gneiss rock is exhibited, haring in some layer's a green colour firom hornblende or epidote. Its strike is $\mathrm{X} .50^{\circ} \mathrm{F}$. Other exposures of similar rocks, with a general aceordance of strike, were seen between the last mentioned place and the North-west Angle.

42. Near the upper part of the North-west Angle Inlet, rock exposures are extremely rare; but this region is also apparently underlaid by Laurentian. A few hundred yards northward from the Reference Monument, and in the midst of a dense wool, a low rounded mass of dark gneissic rock rises above the general level. It holds apparently both hornblende and mica, which are arranged in thin and regular laminae, and is nearly rertical with a strike of $\mathrm{X} .70^{\circ} \mathrm{E}$. On the opposite sicle of the inlet, in the entrance to a reedy creek, a few yards of a compact greyish-black micaceous rock appears nearly at the water level. Its attitude is not clear, but it is trarersed by two quartz-felspar veins, each about eighteen inches wide, with a course of $\mathrm{S} .75^{\circ} \mathrm{E}$.

43. The rocks in the ricinity of the North-west Angle Inlet are thrown into some confusion by the presence of a great granitic and syenitic intrusive mass, more fully noticed on a subsequent page. South of this intrusive mass on the west shore of the lake, the first rock clearly Laurentian, occurs about fire miles southrard from the entrance of the Inlet, and about. a mile from the southern end of the granitic peninsula, known as Flag Island. The rock might here undoubtedly be called a granite, and in some parts is quite coarsely crystalline, with large and prominent felspar crystals. The whole, howerer, shows a foliated structure, and other remains of stratitication parallel to the direction of this, are to be seen in places. The general line of strike thus indicated, is nearly east and west, turning sometimes a little north of east.

44. This rock is traversed by dykes and reins in many places, and - one instance of curiously complicated intersection of these was olserved. The oldest intrusion is a vein of red felspar, but a few inches thick, and running about north-east. This is divided by a dyke three or four feet wide, of greenish diorite, which includes fragments of the much-altered gncissic rocks, and gives off some direrging branches. A this. seam of rery dark homblendic diorite of still later age, cuts across both these, and is in turn intersected by an irrecrular rein of red granite. Lastly; a morement parallel to the direction of the largest diorite dyke, and subsequent to all the others, is indicated by a rack-mark, along which the granite rein has been slipped. (Plate I.) 
45. The gneiss above described, extends along the shore sonthward for about a mile and a half, and then sinks below the level of the water, and for about fifty miles, following the coast-line,-which treads westward and forms two deep bays,- - no rock is seen in place; the shore consisting of sand and wide-stretching grassy swamps. The rock next appears forming the north-eastern point of the southern promontory of the lake, which is about eighteen miles due south of the last mentioned exposure. It is very possibly a much altered gneiss, but assumes the appearance of a finegrained granite, very compact, and pinkish-grey in colour. It is much broken up by intrusive diorite dykes of large size, which have a general direction of from N. $20^{\circ}$ E. to N. $40^{\circ}$ E. These are very compact, darkgreen, with irregular grains of iron pyrites; and show large isolated greenish-white blotches which give the rock a roughly porphyritic aspect, and are composed of felspar crystals, which have undergone fracture in several directions since their formation. A small rocky islet, about a mile and a half north-east from the point, is composed of a similar material ; it was covered, when visited, with nests full of young cormorants (Graculus dilophus). Both these diorites essentially resemble that composing an island near the first exposure of Laurentian rocks south of the Angle Inlet.

46. Four miles eastward, the north-eastern point of the southern promontory is found to consist of rock in place, which extends for more than a mile along the shore. It consists of thinly stratified gneiss and hornblende schist, much broken up by small faults, and twisted, but showing a general dip of from N. $50^{\circ}$ E. to N. $70^{\circ}$ E., at angles of $50^{\circ}$ and upward.

47. From this point to the vicinity of Rainy River no rock appears. Near the mouth of the river, limestone has been reported to exist, but I did not find this rock except as scattered boulders, in which form it is common along the whole southern border of the lake.

48. A fow miles north of Rainy River, the Laurentian rocks again rise above the level of the drift, as hornblende schists, associated with thinbedded gneiss. Where first met with, their strike is N. $85^{\circ} \mathrm{W}$., and the dip southward at a high angle. At two points a little further north, the strikes were found to be N. $73^{\circ} \mathrm{W}$. and N. $78^{\circ} \mathrm{W}$. respectively. The hornblende schists are generally composed of black hornblende and white felspar, and are fine grained and thinly bedded. In some places, however, the hornblende changes to a rather light green. The rocks are traversed by numerous sinuous red felspar veins, and in minor cracks show streaks of 


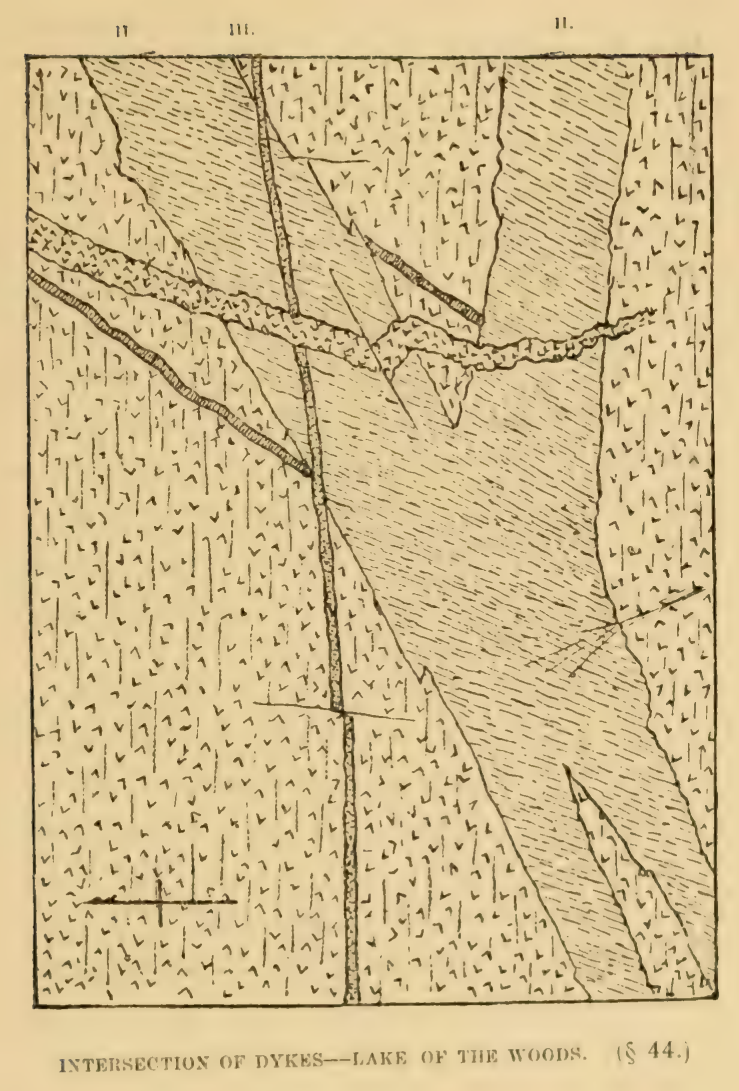



epidote. A small island off Windy Point is of gneiss, with a strike of N. $51^{\circ} \mathrm{W}$. and a high dip to the south.

49. Making a traverse of three miles to Bigsby Island-which lies to the north, and is the most southern island of the chain which stretches across the eastern bay of Sand-hill Lake-the rock is found to be a granitoid gneiss with a strike of $\mathrm{N} .70^{\circ} \mathrm{W}$. It probably belongs to a stratum considerably underlying the last described beds, on the mainland. The south-eastern point of the island shows grey and hornblendic gneiss striking N. $50^{\circ} \mathrm{W}$. The eastern point is formed of grey granitoid gneiss, only showing in a few places sufficient traces of stratification to allow the strike-which is N. $65^{\circ} \mathrm{W}$.-to be observed. In several places in this vicinity there are large irregular segregation veins composed of red orthoclase felspar and white quartz. The felspar crystals, have as usual, formed first, and their crystallization is very bold; one of them beautifully cut and polished in section by glacial action, measuring seventeen inches in length. The quartz has filled irregular pockets remaining among the felspar crystals. Two miles north, and still on the same island, a point was observed where granitoid gneiss of the usual type, reddish-grey in colour, and also holding veins of felspar, was cut by a large dyke of very compact dark-green diorite. The northern portion of this island is entirely composed of grey granitoid gneiss, in some places scarcely distinguishable from granite, and of which the strike and dip is indeterminate. At the extreme northern point, it forms low gently rounded knolls which rise slightly above the surface of the drift.

50. Middle Island, opposite the north end of Bigsby Island and for about two miles northward, is composed of thinly bedded and often ribbon-like gneiss and mica schist, with some greenish layers like those intercalated in the strata last described on the mainland. The attitudes at three points, beginning at that furthest south, were found to be respectively: $\operatorname{dip}$ N. $53^{\circ}$ E. $<68^{\circ}-$ S. $60^{\circ}$ W. $<35^{\circ}-$ S. $65^{\circ}$ W. $<38^{\circ}-$ indicating a well marked synclinal fold. The beds where they dip north-eastward on the south side of this synclinal, are probably the return of those last seen on the mainland, and must overlie the granitoid gneiss of Bigsby Island. It can hardly be supposed, however, that the phenomenon is a simple anticlinal in which all the beds from Windy Point to this locality are included, as the distance is at least eight miles, and the angles of inclination high. It is more probable that a series of sharp flexures having an approximate east and west direction, are superimposed on a long gentle swell of the strata parallel to them, and 
the higher part of which has been entirely removed by denudation. North of the last mentioned locality, grey granitoid gneiss agrain constitutes the shore, and is traversed as usual by many felspar reins, some of them of large size and having an approximate east and west course, and underlie to the north. Northward, about two miles from the northern point of the island, hornblende schist appears with a dip of S. $39^{\circ} \mathrm{W} .<55^{\circ}$. This is immediately succeeded by granite, being a portion of the great intrusive mass of North Island, and forming also the northern part of this island with the exception of about halt a mile along the north-eastern shore; where the eastern end of a small auticlinal of mrey gneisi overlaps the edge of the intrusive rock. The gneiss, besides red felspar veins, is intersected by several of dark green diorite having an east and west course. The granite in the northeru part of the island asserts itself by giving the country a much higher and bolder appearance, and is evidently intrusire, as it holds detached fragments of clearly stratified gneiss near its junction with that rock. It is homogeneous, of red and greyish-red tints and fine grain ; and is traversed by occasional felspar veins, some of which were found to have a course of $\mathrm{N}$. $30^{\circ} \mathrm{W}$.

51. Opposite the north end of Middle Island, North Island is composed of grey gneiss, dip N. $37^{\circ} \mathrm{W} .<30^{\circ}$, and probably connected with that just noticed. This is immediately followed to the north by pink finegrained granite, enclosing large unaltered masses of the gneiss. The remainder of the island is formed of similar granite rock of grey, greyishred, and red tints, and very compact.

52. The junction of this great mass of intrusive granite with the rocks to the northward, is concealed below the water's of the strait which separates North Island from the mainlaind, and which is from three quarters of a mile to a mile in width. The rock where next seen is a blackish hornblendic schist, dipping N. $68^{\circ} \mathrm{W} .<40^{\circ}$, or away from the granite, and including red felspar veins more or less nearly conformable with the strike, which are probably commected with the eruptive mass.

53. The shore from this point runs morth-westwat for about eight miles, and is decply indented with bays of rery irregular outline, and fringed with high rocky islands. The rock, with the exception of two or three granitic masices of 'omparatively small size, is hornblende schist and gneiss, and with a few exceptions, has a general south-westerly dip, and nearly coincides in its strike with the greneral line of the coast. In a deep bay, a short distance west of the last mentioned locality, and separated from it by a boss of red granite holding gneissic fragments; black and 
greenish hormblende schist recurs. It dips north at an angle of $55^{\circ}$, and a few hundred yards further northward become rertical. Near the bottom of the bay the rock is still hornblende schist, rertical, and greenish in colour, with an approximate strike of $\mathrm{X} .55^{\circ} \mathrm{W}$.; showing a great thickness of these hornblendic rocks. A mile and a half westward in the line of strike the same schist appears, with a nearly east and west strike, and is immediately succeeded to the south by intrusive granite, possibly an extension of the last mass. This is followed by grey gneiss, strike, N. $83^{\circ} \mathrm{E}$. Rather over a mile north-trest of this the prevailing rock is again a hornblendic schist, which appears to be partly micaceous in places, and has a dip S. $18^{\circ} \mathrm{W}$. < $50^{\circ}$. This rock, in following the shore, is immediately succeeded by wellmarked gneiss, which appear's to le stratigraphically inferior to any rock seen since leaving North Island. It constitutes the shore and islands for at least two miles. Its colour is usually grey, and in one locality it showed a direction of strike $\mathrm{N} .45^{\circ} \mathrm{W}$., and a dip at high angles to the southward. In some places it is granitoid, and so massive as to give no well-defined direction of strike or dip. Near the point where this compact gneiss disappears, the shore begins to trend rapidly to the north, sweeping round the end of the promontory dividing Sand-hill and Clear-water Lakes. This change is closely followed by the strata, which show a simultaneous tendency to alter their strike toward the same direction. The rock again changes to a hornblendic schist, with a dip of S. $40^{\circ} \mathrm{W} .<60$. This rock is probably the representative of the thick series of hornblendic schists mentioned as occurring in the first bay west of North Island. It becomes micaceous westward, and includes some gneiss bands; and constitutes the shore for about two miles, having in two places where observations were made, dip S. $60^{\circ} \mathrm{W} .<50^{\circ}$, and S. $45^{\circ} \mathrm{W} .<60$.

54. Westward from this place, the rocks assume a quite difierent appearance, and belong, as I believe, to an area of much-altered Huronian which lies to the south of the great North-west Angle intrusive mass. The actual junction between the two formations at this point is concealed by water, but they show a remarkal,le appearance of conformity, the next rock seen, heing a soft greenish slate, with a dip of $\$ .60^{\circ} \mathrm{W} .<45^{\circ}$. It is worthy of notice that similar apparently conformalle junctions of Laurentian and so-(alled IIuronian rocks have been noticed by P'rof. Bell, as occurring on the Albany River at Martin's Falls, and also in the neighhourhood of White River.* 


\section{Area of Much-altered IIuronian Rocks lying South of the Intrusive Granitic Mass of the North-west Angle.}

55. This detached area of Huronian is comparatively small ; its greatest diameter, which lies nearly east and west, may be stated as about eight miles, and its width at about four. So far as could be ascertained by an examination of the islands which fill this narrow part of the lake, the northern and western edges of the area are bounded by intrusive rock, and the eastern passes in the manner already described into the Laurentian; but, as the southern edge is only defined by the margin of the belt of islands, and the falling away of the rock surface below the waters of the lake, it may possibly extend much further in this direction. Indeed, considering the close manner in which the form of the lake accommodates itself to the areas occupied by the softer rock formations, it is not improbable that much of the southern part of its basin may have been excavated in Huronian rocks softer than those now treated of, which have assumed an altered character from their proximity to the granitic mass.

56. The rock first found on leaving those of the Laurentian series, and belonging to the eastern end of the area now in question, is a dull-green soft hornblendic slate, separating into rather thin laminæ, often brownish in colour along the division planes, and where weathered. It includes, in some places, more or less lenticular masses of grey rock resembling gneiss in appearance, which may have been intruded parallel to the stratification planes, but is more probably bedded, and formed of material differently affected by metamorphism. A short distance west of this, the rocks assume a vertical attitude, with a strike of about N. $80^{\circ} \mathrm{E}$. Quartzites of greyish colours preponderate, and are associated with a rock resembling diorite, but which may possibly be a much altered sediment. The quartzite shows many joints running in all directions, and in some places is so cut up by them as to render it difficult to break off a clean-faced specimen. The joints are sometimes slickensided and generally rusty. West of this, at about six miles east of the northern end of Flag Island, the strata dip N. $27^{\circ} \mathrm{E}$., $<70^{\circ}$, the rock being a soft, very finely laminated micaceous schist of a grey colour; the mica in which is black. It is intersected in one place by a well defined dyke of diorite, not of great width, but with a fixed direction of S. $40^{\circ}$ E. For about a mile south-west of this, the rock, where seen, is a thinly bedded grey gneiss, imperfectly crystallized. It was found to have at three points where observations were taken, the following attitudes:-N. $8^{\circ}$ 
W. $<60^{\circ}-\mathrm{N} .13^{\circ} \mathrm{W} .<45^{\circ}$, and N. $5^{\circ}$ E. $<58^{\circ}$. It forms with the rocks still further west, a series with a nearly east and west strike, and northerly dip, toward the intrusive mass.

57. South of the last mentioned locality, on the southern side of the belt of islands, the rock, which must considerably underlie those just spoken of, is a hardened chloritic slate of dark-green colour, including thin belts of gneiss-like material, which although parallel to the strike, may be intrusive. These rocks have a dip N. $12^{\circ}$ E. $<60^{\circ}$, and formhigh bold islands. They are very probably the return on the southern side of a synclinal of those Huronian beds of similar appearance, which were first described, and which, about four miles to the north-east were found dipping south-westward off the flanks of the Laurentian.

58. Three and a half miles east of the north end of Flag Island, rocks, overlying the last, consist of dark micaceous schists, dip N. $10^{\circ} \mathrm{W} .<$ $45^{\circ}$. In the islands to the west, the schist is replaced by hard darkgreen altered rocks, which probably hold a somewhat higher place in the series. The islands to the north, are composed of light-coloured granitic rocks, the line of junction between which and the green rocks, is everywhere covered by water. These green rocks generally yield only an approximate dip or direction, but were found to give in two places N. $12^{\circ}$ W. $<45^{\circ}$, and N. $5^{\circ}$ W. $<60^{\circ}$. Near the western extremity of the Huronian area, they compose a large island lying immediately east of Flag Island; and on crossing a passage three quarters of à mile wide to the latter, the rock changes to compact pinkish intrusive granite (\$64). A little tongue of much altered and contorted green rock, occupies the eastern shore of Flag Island for a few hundred yards, and seems to be the outlying end of a minor synclinal fold, the greater part of which has been removed by denudation. A similar outlyer of the same rock rises above the lake as a small water-washed islet, in the southern part of the bay south of Flag Island, and may extend westward under the low shore of the bay.

59. The general character of the rocks of this area of much-altered Huronian, is quite different from that of the typical Laurentian of other parts of the lake. They are softer, and more schistose and slaty, and give a different appearance to the country, and a more ragged and broken character to the shore. Dark green shades are prevalent, the most prominent mineral constituent of many of these altered rocks being green hornblende, generally crypto-crystalline, and often occurring with scarcely a trace of felspar. From the evidence of other rocks surrounding the 
sranitic onthu'st, these must have suffered intense metamorphism, and hat this been superimposed on that which is seen to effect the Laurentian rockis in general, they would have assumed a very different aspect from that they now have. They differ, howerer, from the altered IIuronian on the north side of the granite, in the absence, so far as observed, of rocks clearly representing altered conglomerates, so common there.

\section{Intrusive Granitic Mass of the North-west Angle and Vicinity.}

60. This intrusion may be considered as roughly separating the Huronian series of the northern part of the lake, from the Laurentian of the south ; but cuts off the area of much altered IIuronian rocks, just described, from the rest. Its general form, so far as I have been able to define it, is that of the letter $\mathbf{Y}$, the bifureation taking place westward, and the northern branch passing almost directly up the North-west Angle Inlet, while the southern curves southward toward Flag Island. In the fork of the $\mathbf{Y}$ an area of sedimentary rocks is caught up, which appears, like those lying to the south and north, to be highly altered Huronian, but may also include some beds of the Laurentian.

61. The multitude of large and small islands separated by narrow and tortuous channels, which fill the lake opposite the North-west Angle Inlet, are due to the superior hardness of this mass, and its surrounding altered rocks; and it very probably, as suggested by Dr. Bigsby, runs eastward and constitutes the backbone of the promontory, which so constricts this part of the lake. Its most western visible extension is seen at McKay's Island, a rounded half-submerged hill, which stands boldly out from the low swampy ground of the northern shore of the Inlet, some seven miles east of the government landing, and about eight miles from the Lamentian rock already described as existing at the Reference Monument not far from that place. The granite is moderately coarse, and grerish-ped in colour. It has scattered through it irregular masses of greyish fine-crained hornblendic rock, which is softer and weathers away into hollows, and probably represents included fragments of surrounding strata. Many secrecation reins of coarse-grained reddish felspar with quartz, occur, with a general course nearly east and west. They run very straight in some places. but do not exceed a foot in width. Fastwand from McKay's Island, on the north shore of the Inlet, several points show a granite similar to that there represented, grey in colour, and often holding segregations of red felspar and quartz. 
62. Bucketé Island, on the south side of the Inlet where it widens to the lake, is also composed of granite, belonging to the same mass, but red in colour. Here are also many segregated veins and bunches of felspar and quartz. Sereral of the veins were found to have a direction of $\mathrm{N} .40^{\circ}$ E. The felspar is pale pink, the quartz scarcely milley, and there are occasional plates of white mica; the veins thus showing all the minerals of the matrix. The quartz penetrates the felspar much more than is usual in such aggregations. Two and a half miles east and a little north, of Bucketé Island, granite belonging to the northern branch of the mass is again seen, but considerably reduced in brearlth, and bounded on each side by highly altered Huronian.

63. The Southern branch is seen furthest south, about a mile southwest of Flag Island, in close conjunction with the Latuentian gneiss alleady described, and is there reddish grey and compact. It continues in a gereral north-eastward direction for alout three miles, forming in its course nearly the entire mass of Flag Island, and then runs eastward for a mile or two, and finally again takes a north-east course and passes into the main mass. The southern part of Flag Island is composed of greenish-grey and pinkish-grey syenitic granite, of rather coarse grain and somewhat peculiar aspect. The felspar is greyish and pinkish, the quartz nearly transparent and colomrless, and the mica and hornblende black. This rock is traversed by many veins and lenticular masses of compact, greenish-grey rock of dioritic aspect, fine-grained and siliceous. It is probably an imperfect granite, hut much resembles the gneisise masses already described as occurring between the layers of greenish much-altered Huronian rocks. (\$56). Some of these veins run nearly in straight lines, with a general course of north-east and south-west, and though presenting much the appearance of stratified lacks which had resisted the metamorphism converting the surromeling rocks into granite; are evillently intrusive dykes, and contain loroken fiagments of the containing rock. The granite here also shows small, irregular pockets and veins of vitreous quartz.

64. The northern part of Flag Island is composed of a compouct pink granite. About a mile north-west, a similar red granite is again serent, and beyond this the rock becomes syenitic, (rhanging first to at red syenite, and then to a grey rock, which might be callod a syenitic diorite.

65. The main body of the intrusive mass, where crossed about eleven

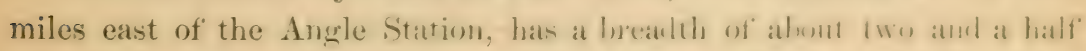
miles. Its northern edge, in this place is composed of a pinkish mante, 
rory deficient in quartz, and the mica of which is black and forms irregular secremations in the predominating felspar. It is traversed by several systeme of irregular folspar, and quartz-felspar veins. Going southward it changes to a syenitic granite, showing perfect felspar crystals in a base of black hornblende, the latter sometimes so much in excess, as to give the rock a very dark colour. Here also many masses of altered sedimentary rockis are included. Still further south, red syenite of a granitic appearance occurs, and is traversed by felspar and quartz-felspar veins. In one place a grey diorite dyke running N. $30^{\circ}$ E. was observed, which from its afpearance and course may possibly belong to the same series as those seen in the southern part of Flag Island.

66. Along its southern olge, and where almost in contact with the alterei sedimentary rocks, the intrusive mass seems to assume a still more basic character and darker colour; being represented by blackish diorite of gneisic aspect, and grey syenitic diorite. In one place the sedimentary rocks were observed in close proximity to the granite. The dip was fouml to be N. $25^{\circ} \mathrm{W}$., or directly toward the intrusion, at an angle of $45^{\circ}$, the rock being a hard altered slate, somewhat resembling the green altered rocks seen further south, but so much changed as to simulate a cleavable diorite.

\section{Isolated Area of Huronian Rocks.}

67. The area of altered rocks, which lies between the two western branches of the intrusive mass, is not separated by a great width of the latter, from the rockis of similar character to the north; and as these have also similar directions and dijs, the two may well be considered in connection. The most eastern portion of this area examined, is composed of a hard grey rock of gueissic appearance, but consisting: mainly of quartz and hornblende, and in some plasces passing to a distinct quartzite. It is then not so highly metamorphosed as to obliterate the forms of the grains of samb, which are rather fine, and contain amoner them many hornblencle crystals similar in size. This rock is arrersed by many granite dykes, and by quartz-felspar veins, which ate newer than, and intersect them. It is probable that rocks ledomging to this area ocerpy the greater part of the large bay between Bn.licé and Flage Islands. An island in this hay, not far north-west of Flang l-land, is formed of the grey hornblende or mica schist, dipping 1. 20 II. 4. It. It is interseccted by many red felspar veins 2 to 3 feet Wite, and all:o hy small seams of vitreous quartz; both of which nearly 
follow the strike. Numerous crack-lines are also observable on weathered surfaces, and run N. $10^{\circ} \mathrm{W}$. Another island near this is composed of a similar micaceous rock, which has a dip of $\mathrm{N} .40^{\circ} \mathrm{W} .<60^{\circ}$. Along the north-west shore of Flag. Island are numerous small rocky islets, and half submerged rocks, some of which are composed of black hornblencle rock with large and numerous red felspar reins, while others are of red and greyish granite. It is quite possible that in this part of the region, some beds belonging to the Laurentian series, may have been brought up in connection with the disturbances due to the intrusion of the granite, and appear here with those, the true analogy of which is with the Huronian rocks to the north.

\section{Huronian Rocks North of the Intrusive Mass, to Ka-ka-ke-uabec.}

68. North of the granite mass, and reposing on its edge just east of Bucketé Island, a grey, gneiss-like, finely stratified rock appears, dipping about north-north-west at angles of from $25^{\circ}$ to $30^{\circ}$, and holding-as is usual with the rocks in proximity to the granite--many reddish veins, chiefly composed of orthoclase felspar. At a distance of two and a half miles eastward from this, and nearly in its line of strike, a similar rock occurs, and is again seen to abut directly on the granite. Its dip near the latter is $\mathrm{N} 20^{\circ} \mathrm{W} .<45^{\circ}$, and it continues in a direction at right angles to its strike for nearly three-quarters of a mile, at which distance it was found to have a dip N. $5^{\circ} \mathrm{W} .<35^{\circ}$. It is eut by many red felspar veins, and one dark hornblende dyke with nearly east and west course was observed. The rock, though close-grained and quite gneissic in aspect, and of a grey colour, is here evidently a much altered conglomerate of the kind abundant further north, which has been called greenstone conglomerate. On weathered surfaces the original fragments are still quite discernible, forming lenticular areas of coarser texture and lighter colour than the uniformly grey matrix.

69. Orerlying this, and forming the islands opposite the southern border of the Small Promontory - which extends from the north shore of the Inlet about four miles east of Mr.Kay's Island-and also seen on the promontory itself, is an important series of quartzites. With the possible exception of those lying south of the granite ( $\$ 56)$ thene are the most extensive on the lake. It is quite proballe, indeed, that the beds represented in both localities may he the same, and that the granite has merely separated them. The southern part of the quartzite, in this place, is shattered and traversed ly many rusty joints, but neasly white 
on freshly firctured surfaces. It has a strike of $\mathrm{N}$. $76^{\circ}$ F., with a dip at an angle of $55^{\circ}$ northward. The part on the mainland, north of this, is a very fine-grained homogeneous grey rock, of which the constituent particles are barely visible, and which includes small crystals of pyrites. It is somewhat disturberl, but may be stated to hare an average dip of $\mathrm{N} .35^{\circ} \mathrm{W} .<80^{\circ}$. This quartzite belt occupies a width of about one third of' a mile, and unless unknown complications affect the strata, must have a thickness of at least 1,500 feet.

70. Five and a half miles west of this point, and in immediate juxtaprition to the northern edge of the granite mass, a quartzite, so little altered that it might almost be called a sandstone, mexpectedly appears. It is fine grained, and grey in colour, and is penetrated by a dyke of graunlite with quartz seams, and small included (rystals of molybdenite. It has a dip of S. $37^{\circ} \mathrm{E} .<63^{\circ}$, or toward the granite, but this is no douht local, and due to folding connected with the extrusion of that mass. It probahly represents the same band of quartzite as that last descruled, and if so, the northern edge of the granite runs obliquely to the strata to such an extent as to cover or remove the whole of the western extensión of the underlying conglomerate series.

71. In describing the details of rocks of the remaining portion of the lake; the oider of those beds seen along the shore of the mainland between the North-west Angle, and Rat Portage, will be followed. That part of the coast-line is laid down with sufficient accuracy on the map to enahle points to be fixed with some degree of certainty. In discussing ear.h well marked series of beds, it will then be traced eastward as far as my olservations extended. The accompanying general section (Scet. 3) will be fimul of use in following the descriptions, but must be accepted ar only accurate in a general way, as subordinate intercalations of slates and shales, occurring among preponderating greenstone and connlomerate beds, have not been indicaterl. Incled, where the rocks have suffered great metamorphism, as in the neighbourhood of the rarious smanitic masces, it is exceedingly difficult to lay down precise houndaries; and such arearacy could only be the result of long and patient tracing out of well marked beds as datum lines.

7:. The rock immediately suceeding the last described quartzite in the small l'romontory, is a dark-green crystalline hornblendic material, with lamine of "hlorite. It might be an eruptive rock, but rather seems to belong to the verios of greyish and blackish schists next in order, which. males orcrluoled among the much altered rocks a fow miles 
eastward, has no representative there, and must run out in that direction.

73. North of this, and forming the eastern point of the Small Promontory, hard greenish and blackish hornblendic spotted rocks appear. They have a strike of $\mathbf{N} .67^{\circ} \mathrm{E}$, and are rertical. Small ramifying epiclotic: reins occur, cutting through them in all directions. Rocks similar in appearance, also spotted, and much altered, are again seen on the strike of these, in the bay to the south-west of the Small Promontory. They have a dip of $\mathrm{N} .53^{\circ} \mathrm{W} .<50^{\circ}$, and probably belong to the same series, which appears to be one of rather fine-grained, but much altered conglomerates. These stand in place of the rast thickness of conglomerate rockis occurring to the east. The eastern part of the conglomerate belt apparently absorbs the slate band last referred to, and by its great increase in thickness deflects northward the next slate band, in its eastern extension.

74. At a distance of a little over five miles from the Small Promontory, the conglomerate belt corer's a brealth of two and a half miles, the angle of dip throughout being rery high. Where crosised firm south to north in that region, the component beds present the following litholocical characters and attitudes.-Hard gneissic altered rock, strike N. $80^{2}$ F. Hard altered conglomerate with some quartzite, strike N. $79^{\circ}$ E. The two last speries of rock are rery frequently associated, and in some locali. ties, one eren seem - to pasis into the other. Hard dark-grey rock, which resembles a quartzite. but has minute hornblende and mica crystals dereloped in it, and shows the forms of original peblyles diftering from the matrix in being felspathic. A little further north, grey highly altered conglomerate of gneisic appearance. This continues for some distance, and then changes to less altered conglomerate with much siliceous matter in its composition, and grey in colour. Strike N. $60^{\circ}$ E., with a dip at a high angle to the south. This rock constitules the northern edge of the conglomerate belt now in question.

75. The eastern end of the next belt, which is of highly altered slate, runs into the first lay north of the Small Promontory. It is not of great width, and appears to narrow eastward, where it bends northward to pass round the convexily due to the thickening of the conglomerate belt just described. The castern portion is a soft thin-berlded hornblendic schist, composerl chicfly of blarek hornblemle and white quartz, with but little felspar. It includer a few (onmparet srey lenticular masses, which may have originally been pebbles, and seen to assimilate it to the conglomerate. At the place examined, it hal the some. 
what abnormal dip of S. $25^{\circ} \mathrm{W}$., and was nearly vertical. Abont six miles westward, what I believe to be the same bed, appears as a soft fine-grained micaceous sehist, brownish in colour and thinly cleavable. Dip S. $30^{\circ}$ E. $<45^{\circ}$.

76. The next band, which is composed of eonglomerates and similar hard rocks, neems to be the canse of the point immediately north of the Small Promontory, and distant about a mile and a half from it. This belt ruus north-westward for some time pretty nearly parallel to the main shore, forming an interrupted chain of large and bold islands. At the point just mentioned, the rock is greenish and spotted, dip S. $23^{\circ}$ E. $<60^{\circ}$. Half a mile further westward a hard greenish-black hornblendic rock occur's, which, though it may be a contemporaneous diorite, shows spots which are apparently remains of pebbles. The hornblende crystals are minutely acicular. Half a mile still further west a similar rock is seen, but silica now so much preponderates that it might be called a hornblendic quartzite. Three miles westward from the point, the rock is a true "greenstone conglomerate," much disturbed, and showing a local strike of $\mathbf{N}$. $10^{\circ}$ E. Six and a half miles northward and westward from the same place, the rock is again a typical greenstone conglomerate, hard and considerably altered and contorted, but with a general strike of N. $43^{\circ} \mathrm{W}$. In one place a polished and glaciated horizontal section, shows what appears to be the nose of a compressed synclinal fold; a thin layer of conglomorate imbedded in compact greenish altered rock, being bent round at a very acute angle. The inner side is quite rough and irregular in outline, as though representing the former upper surface of the brecciated material. A mile further north-westward, the rock is a hard, spotted, highly altered conglomerate, or greenstone. For about two miles, still in the same direction, greenstone conglomerate continues, with fragments larger or smaller, and often weathering rough superficially. At the extreme northern edgo of the belt, the rock is hard, green, altered, contorted, and of spotted appearance, but gires an approximate strike of N. $57^{\circ} \mathrm{E}$.

77. North of the belt just described, an extensive series of schistose rocks is found forming the north-western shore of the lake for a long distance. Many of these are softer and less altered than any yet describod, but are locally hardened by the occurrence of several minor masses of intrusire rock. The rocks belonging to this series, probably form the shores of the greater part of the second large bay north of the Small Promontory, though they were not actually observed there. Five miles north-westward 
from the promontory, they are represented on a small island off the main shore, by a soft, oreen, chloritic schist with a strike of $\mathrm{X}$. $70^{\circ} \mathrm{F}$. and reltical. About a mile further mestward, and opposite the month of the third large bay, the rock is a thinly laminated soft mica-schist, silvery on the faces, with a dip of S. $58^{\circ}$ E. $<70^{\circ}$. The same bed, a short distance further on, forms the high rock called Picture-rock Point; and is there seen perfectly vertical, with its line of strike parallel to that of the shore. A large island lying behind the point, and within the mouth of the lay, shows much-altered greyish-green rock, abutting against an importunt granitic mass, which gires off other minor dykes nearly parallel to its own direction. The altered rock, has a dip of N. $42^{\circ} \mathrm{W} .<70^{\circ}$, and the granite appears pretty nearly to follow its strike. The granite has a rather deep red colour, from its felspar, which is largely in excess. It is also hornblendic, the homblende being black, and forming crypto-("rystalline agropegations in the felspar. In its general appearance it much resemuliess some parts of the intrusive granite of the North-west Angle.

78. Picture-rock Point, is so named from the remains of Indian derices marked upon the broad flat surface of the slate in rerl paint. A mile noithwest from it, the same thin-bedded bright slate, still forms the slore, the direction of the strike and that of the coast-line nearly coinciding. Two miles from the same point, and still nearly on the same geological horizon, is a fincly laminated greenish-grey talcose schist, lying very straight and eren, rertical, and with a strike of $\mathrm{N} .58^{\circ}$ E. Three and a quarter miles from Picture Point, and still following the shore, the rock is a grey alterod slate, rerticerl, and with a strike of $\mathrm{N} .55^{\circ} \mathrm{E}$. Beyond this, for a short distance, greenstone is seen, but it is not very clear whether it is intrusive, or contemporaneous. A mile beyond the last locality, a rather massire quartzite comes out on the shore, dipping S. 2:3 E. at an angle of $55^{\circ}$ in one place, but generally nearly vertical. It apparently umelerlies the schists and slates just described, but no rock precisely resembling it was seen in any other part of the lake. It is rery jure, translucent, light greenish-grey, with oceasional thin fibres of chloritic matter. It wrather's a dead white, and is trarersed in the bed by innumerable joints and sedum Beyond this the slates leecome considerably altered, from proximity to intrusive masses and dykes, which are alunt on the same horizon as lhore described in Picture Print Bay, and may continue behind the line of the conast to this place. The reck is here, leowever, a rather impertiont grmulte, grey in colour, with rounded white felspar crystals, and small cubical crystals of iron pyrites. It resembles the intrusive mass of Ka-ka-ke- 
wabec lying to the northward. A short distance further westward, on an island, a clyke of similar material, also grey, and with pyrites crystals, and a large excess of whitish felspar, occurs. It traverses a hard green altered rock, with a course of $\mathrm{N} .63^{\circ} \mathrm{E}$., and probably follows the strike. Two miles westward from the first appearance of the intrusive rock, it is again seen, and is a whitish granite, with rather large black mica crystals. It cuts through a soft dark-green chloritic slate, with a strike of $\mathrm{N}$. $77^{\circ}$ E., which the intrusion follows, though irregular and lenticular.

79. Further north, and apparently underlying the last, is a hard closegrained slate, with rather irregular cleavage, and a strike of $\mathrm{N} .75^{\circ} \mathrm{E}$. Beyond this, the rock continues to be highly altered, and of a darker green colour, the strike being somewhat obscure, but generally nearly east and west. A mile and a quarter south of the southern end of Ka-ka-ke-wabec, the rock is hard, green-grey, felspathic, and rather coarse-grained, with scales of talc. Strike N. $80^{\circ}$ E. Next this, on the north, is a belt of thin-bedded and finely cleavable slate, greenish-grey in colour, and chloritic or talcose. It dips N. $5^{\circ} \mathrm{W} .<80^{\circ}$, a position which appears to indicate the northern side of an anticlinal, the axis of which must run nearly east and west. This is further confirmed, by the reappearance of a rock precisely similar to that last described. Beyond this, to the north, is a hard much-iltered greenstone conglomerate, with a strike of $\mathrm{N} .72^{\circ}$ E., and on edgre. The thickness of this bed is not clearly shown, but it cannot be very great, as it is immediately succeeded by a much altered rock, probalbly not a conglomerate, in which a good deal of pale-green hornblende is dereloped, and which has a nearly vertical attitude with a strike of $\mathrm{N} .55^{\circ} \mathrm{E}$. The narrow belt of conglomerate was not noticed on the south side of the anticlinal, but my observations tend to prove that these rocks are only locally constant.

\section{Intrusive Mass of Ka-ka-ke-wabec Island.}

80. The continuity of the strata is here interrupted by the important intrusive mass of Ka-ka-ke-wabee Island. The southern point of the island is high and cliff-like, and forms the eastern side of the narrow and picturesque passage separating it from the main shore. The rock is there a granite, quite similar to that last described, and with small cubical crystals of pyrites. It continues to occur northward, on the west shore of Ka-kit-ke-walere, for nearly a mile; but changes its aspect somewhat, lecoming in some places a greyish-red hornblendic granite, and inclucting large masses of highly altered siliceous slates, the stratification of 
which is quite obliterated, and which indeed often resemble diorite from the coarseness of their crystallization. This zone of intrusire rocks, may run eastward a long way, and probably forms the nucleus of the chain of large islands which here extend across the lake, but are not correctly represented on the maps. This supposition is confirmed by the circumstance that the northern shores of these islands are composed of soft and fissile rocks, which could hardly have held their ground unless so supported.

\section{Huronian Rocks from Ka-ka-ke-wabec to Rat Portage.}

81. The north end of Ka-ka-ke-wabec Island, is composed of rough green chloritic rock, not showing any appearance of excessive alteration, and forming the southern margin of another extensire belt of schistose strata. The comparatively small distance to which these rocks are altered, northward from the intrusire mass, would almost lead to the conclusion that they have been brought into contact with it by a fault, nearly following its norther'n edge. The next rock observed, which occupies a position somewhat inferior to the last, is a chloritic slate, of rusty appearance, caused by the weathering of dolomite, with which it is minutely interleaved. A short distance north of this, near the main shore, is a soft thinly bedeled talcose schist of a grey-green colour, almost nacreous in places, and inclucling particles of dolomite. It has a strike of $\mathrm{N} .88^{\circ} \mathrm{E}$., and is rertical. A mile and a half west, and nearly on the same strike, a similar thin-bedded talcose schist appear's, again showing traces of dolomite, and on edge. North of this, and about a mile north of the eastern end of Ka-ka-ke-wabec, is a somewhat micaceous schist, with greenish-white felspar, like all the rocks in this part of the lake, vertical. Strike N. $85^{\circ}$ W. Near the horizon of these schists, and about a mile south of Lacrosse Island, is a whitish thin-bedded talcose slate of rather remarkable aspect. Strike N. $82^{\circ}$ W. Passing northward from this toward the south end of Lacrosse Island, the rocks, so far as could be ascertained from an examination of the islands, were:-Thin fine-bedded chloritic schist, including lenticular masses composed of dolomite and quartz, round which the layers of rock bend-vertical, strike N. 77 $\mathrm{E}$. The rocks here bear the appearance of having been intersected, while still nearly horizontal, by jointage planes at right angles to the stratitication, and cutting it neatly; which, now that the beds have been folded through an angle of $90^{\circ}$, produce on weathering, in some places, almost perfectly horizontal areas. These are as smooth as though subjected to the action 
of glacier ice, but that they have not been produced in this way, is evident, as a rounded and glaciated surface may sometimes be seen peeling off under the action of the weather, and exposing the subjacent plane.

82. Here a fragment of dolomitic limestone, 2 feet 6 .inches in greatest diameter, was found, being the only limestone boulder observed in the whole northern part of the lake. It did not appear to have travelled far, and differs much in character from those subsequently to be mentioned as occuring in the southern part of the lake; being hard, coarsely crystalline, highly magnesian, and weathering to a deep-brown colour. It much resembles the dolomites found in the Bastern Townships of Quebec in association with the altered rocks there; and such limestones may very probably orcur inter-bedded with the dolomitic schists already described, but in parts of the series, which from their more readily decomposable nature, are generally concealed by water or orergrown by woods.

83. North of this on a small island, a rough greenish schist appears, spotted where weathered, and having a strike of $\mathrm{N} .75^{\circ} \mathrm{E}$. It is in contact to the north with a thinly cleavable nacreous schist, minutely undulating and of white and reddish colours. Another small island nearly on the same line of strike shows a rough, green, and rather hard chloritic schist; $\operatorname{dip}$ N. $5^{\circ}$ E. $<55^{\circ}$.

84. Lacrosse Island, so-called on Dr. Bigsby's map, * and deriving its name from the fact that some parts of it are level and open, and have been used by the Indians at one time, for this, their farourite game, lies about nine miles south of Rat Portage. Its extreme south-western point is composed for at least 100 feet of dark-coloured diorite, rather fine-grained, and with little segregations of epidote where in contact with the slates; but coarser and porphyritic at some distance from them. The line of junction with the stratified rocks is vertical, and runs very straight, with a course of S. $25^{\circ}$ E. North of this, for nearly half a mile, the western shore is composed of very thinly cleavable schists, whitish and greenish in tint, and though regularly bedded, minutely undulated throughout; strike N. $58^{\circ}$ F., dip northward $<88^{\circ}$. The shore for about a mile, is then occupied by greenstone conglomerate and associated rocks, forming a belt, with a brealth of about half a mile across the strike, which was observed to be N. $46^{\circ} \mathrm{F}$. at the southern, and N. $78^{\circ} \mathrm{F}$., at the northern edge. The rocks are hard and compact, and though breaking with a 
rough surface, the fracture passes indifferently through pebbles and matrix, as do also the jointage planes of the rock. It is only on a weathered surface that the structure is plainly apparent. This belt of conglomerate was not observed westward, in the vicinity of the main shore of the lake, and if it does not thin out altogether before reaching that place, is probably but feebly represented. It is possible, however, from the attitude of the strata to the north and south of this mass on Lacrosse Island, that it may be brought up on the ridge of an anticlinal, the axis of which dips away westward. The rock succeeding this northward, and forming the northern part of the island, is a whitish, somewhat nacreous schist; which, if the last supposition is correct, must represent that forming the southern part.

85. The band of slates lying north of the Lacrosse Island conglomerate, was seen also in sereral places along the main shore, and neighbouring islands lying to the north-west. The southern part seems to consist mainly of soft green and greenish chloritic schists, which are peculiar in weathering rough, and showing pitted surfaces. These schists were found to have in one place on the mainland, a strike of $\mathrm{N} .43^{\circ}$ E., vertical, or with a high dip north-westward. They are succeeded to the north by whitish and greenish thin-bedded silvery schists, and the most northern part of the belt there examined, consists of chloritic, but rather hard, green schists, with small intercalations of dolomite. The same belt, where crossed a few miles eastward, amoug the islands north of Lacrosse Island, appears to be much more altered, wherever exposed to view. It is probable, howerer, that as this is an open reach of the lake, the greater part of the softer beds has been remored. Immediately beyond the north end of Lacrosse Island, a small island shows hard whitish schistose rock, with some greenstone conglomerate. Strike about N. $48^{\circ}$ E. vertical. Many parallel crack-marks appear, having a course of $\mathrm{N}$. $80^{\circ} \mathrm{E}$ Half a mile further north, a second island shows hard green altered rock, with a probable strike of $\mathrm{N}$. $35^{\circ} \mathrm{E}$. Still further north, and near where the dolomitic zone seen on the mainland should pass, according to the strike, a hard green altered rock appears.

86. This schistose belt is defined northward, on the mainland, by a bed of conglomerate which comes to the shore at the end of the large point, which, a mile or two north of Lacrosse Island, constricts the width of the lake to about two miles. It resembles a breccia, the fragments being of all shapes, and rarying much in size. They are mostly of quartzite, and imbedded in a greenish chloritic base. It dips $\mathrm{N} .17^{\circ} \mathrm{W}$, at a high 
angle. This rock was not observed on the east side of the lake, but may very possibly be represented there.

87. North of this, another extensive belt of slate rocks crosses the lake, but the strata in this region are not regular, and it is difficult to correlate the beds except in a general way. The first rock observed beyond the conglomerate, on the west side, was a close-grained grey schist, with a strike of $\mathrm{N} .55^{\circ}$ E. A mile beyoud the conglomerate, similar schistose rocks were observed, and again vertical. Rough, green, and rather soft chloritic schists then appear, and are the predominant rocks till within about half a mile of the north-west end of the lake. On the eastern side of the lake, near where the strike of the last-mentioned greenstone would bring it to the shore, and probably in immediate proximity to its continuation, is a hard green altered rock, with epidote and quartzose segregations, and no determinate dip or direction. North of this, thinly laminated green chloritic slates occur. Among these, on an island about three miles southward from the Hudson's Bay establishment at Rat Portage, a rein a foot or two in width was observed to pass, apparently conforming with their strike. The vein-stone was white, but had the appearance on the surface of being stained by the decomposition of some ore of copper. It was, however, too boisterous to land with the canoe at the time. Northward, similar rocks continue, but become harder. A mile from the Hudson's Bay Post, they were observed to have an east and west strike and to be quite vertical. About half a mile south of the Post, there is a somewhat extensive belt of greenstone-like rocks, which, though conglomeritic in places, do not show that character persistently, but appear to graluate into compact homogeneous diorite. This belt seems to cross the lake just south of its extreme northern shore, and to strike into the western side, immediately south of the entrance to Rat Portage proper. There its rocks occupy a breadth of perhaps half a mile, and are separated from the Laurentian by a belt of slaty rocks of about the same width. On this sicle they appear as compact diorite, but show cleavage planes, and resemble the sometimes conglomeritic greenstone of the west shore.

\section{Geology of the Vicinity of Rat Portage. Junction of the Huronian and Laurentian.}

88. The Winnipeg River, on leaving the Lake of the Woods, falls into an elongated basin, which lies transwerse to its general direction and stretches westward nearly parallel with the shore of the lake for some 
distance. The river and lake are only separated by a comparatively narrow riclge of rock, through which there are three gaps. The furthest west, or Rat Portage proper, does not carry any water; the second or middle galp, is that of the Rat Portage Rapids; the third or east one, near the Hudson's Bay Fort, that of the Rat Portage Fall. (Plate 2.)

89. A band of slaty rocks, with an arerage width of about half a mile, separates the greenstone-like series last described, from the Laurentian. Its lowest beds were seen just north of the greenstone, two and a quarter miles westward from the Hudson's Bay Post, and at the entrance of the channel, which leads to Rat Portage proper. The rock is a very finegrained micaceo-hornblendic schist of a dark colour, and quite hard; vertical, with a strike of $\mathrm{N} .65^{\circ} \mathrm{E}$. Entering the river-like inlet, which leads northward and then westward to the Portage path, similar rocks are seen, but rather darker and more hornblendic. They appear to have a high northerly dip. The portage, from the waters of the lake to those of the river, at this place is not more than 150 yards long. The southern end of the path passes orer Huronian rocks, which may be described as considerably altered slates, chiefly hornblendic, greenish-black in colour, crypto-crystalline, and silky in lustre. At the water's edge,-where they are worn smooth by the feet of the voyageurs of old time,-they were found to be rertical, with a strike of $\mathrm{N}$. $75^{\circ} \mathrm{E}$. About half-way across the Portage, and at its highest part, the rocks $\operatorname{lip}$ N. $17^{\circ} \mathrm{W} .<48^{\circ}$, and are then immediately succeeded by Laurentian grieiss, which is granitoid, and of a light pinkish-grey colour; $\operatorname{dip}$ N. $30^{\circ} \mathrm{W} .<89^{\circ}$. The junction is so close that one may actually lay the hand upon it, and the separating line is remarkably straight and eren. Followed about one hundred yards westward, it was found to preserve the course of $\mathrm{S} .67^{\circ} \mathrm{W}$, or nearly that of the strike of both series of rocks. The gneiss at this distance, has a strike of $\mathrm{N} .72^{\circ} \mathrm{E}$., and the green slate, just across the line of junction, and only a few yards remored, $\mathrm{N} .73^{\circ} \mathrm{E}$.

90. About a mile eastward from the entrance to the portage, the lake finds one of its exits by a passage at right angles to its shore, down which the water flows orer a fine series of rapids. At an island opposite this opening, the same greenish hornblendic schist occurs, finc-grained, and sometimes almost chloritic in aspect, as before. A long portage on the eastern side of the rapids leads to the Winnipeg Rirer, and a considerable breadth of rery hard coarse-grained green diorite is exposed, which hat not the a-pect of any of the altererl rocks seen in the vicinity of the lake. It has all the character of a mass intrucled along the line of 
junction of the gneiss and green slates, though its actual contact with either was not seen.

91. A mile still further eastward, at the extreme north-eastern corner of the lake, the Winnipeg River, may be said to begin, in a bold cascade, which falls northward, across the junction of the Laurentian and Huronian series, through a narrow passage between rocky cliffs. At the fall, the rock is quite similar to that seen at Rat Portage proper, being a fine-grained, hornblendic slate, much hardened and of greenish colour; dip N. $10^{\circ} \mathrm{W} .<45^{\circ}$. Just below the fall, the red grieiss again suddenly appears with a dip N. $18^{\circ} \mathrm{E} .<78^{\circ}$. The line of junction of the formations obtained by protracting that at the fall, to that at Rat Portage proper, coincides remarkably with that already obtained by observation on a more limited scale at the latter place, and follows the summit of the ridge which separates the river from the lake. A rock quite similar to the eruptive greenstone seen at the rapids, is again visible at the entrance to the gorge of the fall. If it really belongs to this mass, it must toward the eastern end depart somewhat from the actual line of junction, and may possibly attain this position by following the strike of the slates.

92. Notwithstanding the close accordance of the strike of both series of rocks, and the direction of the line of junction, the evidence appears to be nearly conclusive, that the two formations are here brought together by a fault, with an extensive downthrow southward. If they are thus in contact merely by sharp folding, the relative position must be reversed, as the dips would carry the slate series below the gneiss; and it is difficult to imagine such extensive flexures taking place without imparting a yet more highly altered aspect to the schists than that which they now have. The straightness of the line, and the sharp separation by it of the two kinds of rock, also points in the same direction.

93. The change in aspect of the country to the north and south of this great fault, is very sudden and striking. Southward, the shores of Clearwater Lake are generally characterized,-where not caused to assume unusual boldness by hardening eruptive rocks,-by low, gently-rounded rocky hills, which in their natural state bear a good growth of trees. These hills, even when they have been burned over, retain a sufficiency of soil to cause the re-appearance within a year or two of a dense uudergrowth, giving them a uniformly green aspect from a distance. North of the fault, the Lamentian rocks form a succession of boldly rounded and tumultuous hills, showing a great surface of bare rock, which may never have been corered by trees, but which more probably has had forest and 


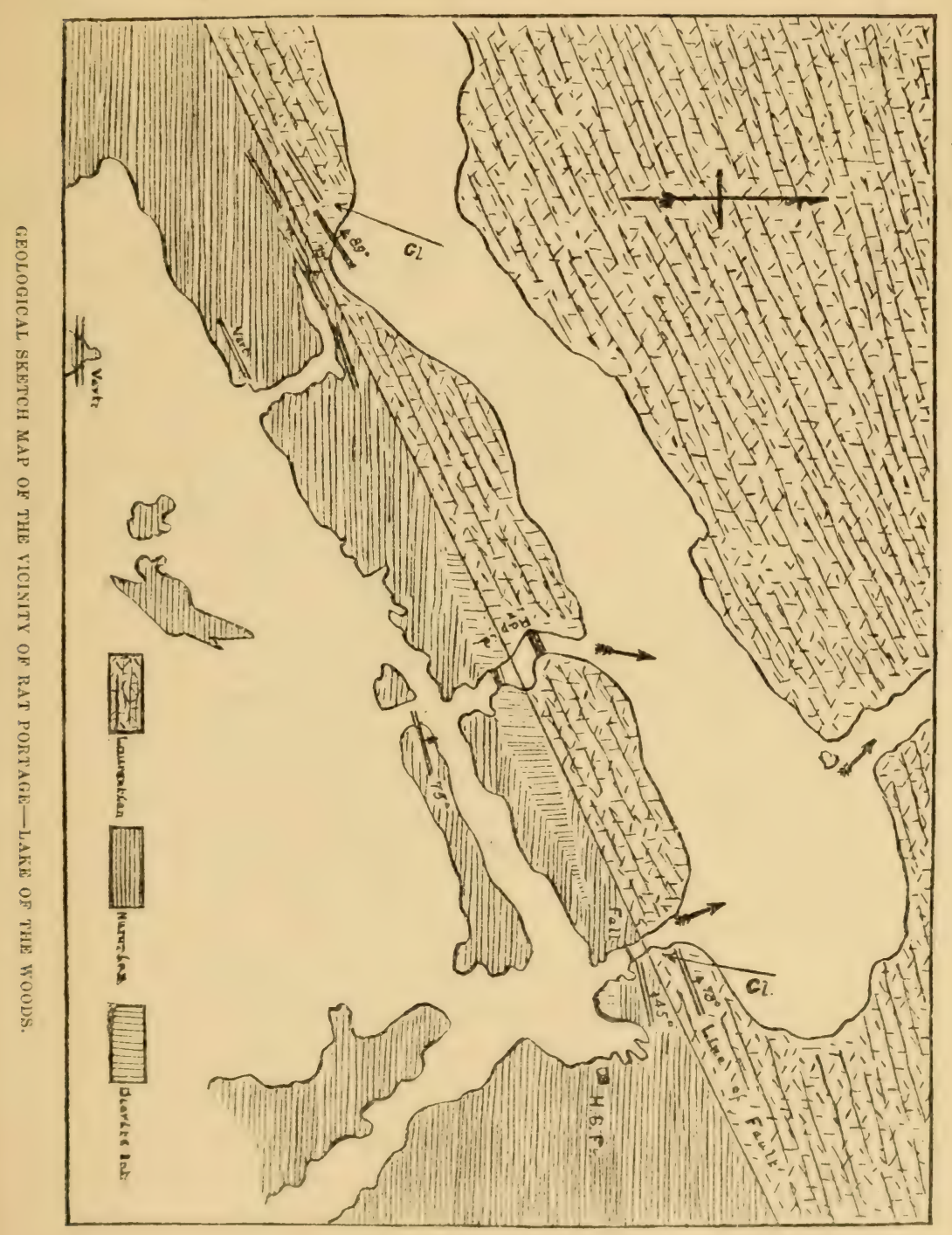



what peaty soil supported it removed at once by fire. These hills also appear of light whitish and pinkish colours, even from a distance, and contrast remarkably with the sombre aspect of the slates to the south.

\section{General Distribution and Attitudes of the Rocks.}

94. From the evidence of the foregoing detailed observations, and that which I have been able to collect from other sources, I am inclined to believe that almost the entire southern division of the Lake of the Woods, known as Sand-hill Lake, corers rocks of Laurentian age, with the possible exception of the extreme south-western part, where Upper Silurian limestone may exist. The eridence concerning this formation will be more fully stated in reviewing the drift deposits. The isolated area of Huronian, south of the North-west Angle granite, may howerer, as already mentioned, extend further southward than supposed. From Dr. Bigsby's map, the extreme eastern arm of this part of the lake, south of Turtle Portage, appears to be much complicated, and may also probably include some beds of the green slate series.

95. The general direction of strike of the Laurentian wherever it appear's on the west side of the lake, is nearly east and west. Toward the extreme south of the lake, the few knolls which rise above the surface, show a tendency to north and south strikes, and vertical attitudes. North of Rainy Rirer, these rocks run generally east and west, or' east-south-east and west-north-west. Similar directions characterize the rocks of Bigsby Island, while those of the northern islands, and shore of the district of Shebashca, show bearings from a few degrees north of west, to north-west and south-east. The Laurentian rocks at the North-west Angle, and west of it on the road to Winnipeg, have general north-east by southwest, or east-north-east by west-south-west bearings.

96. The Huronian rocks, though conforming to easterly and westerly directions in the ricinity of the granitic masses of the Angle, when followed northward, are found to take a north-north-east direction and nearly vertical attitude, which they retain in a general way as fur as Rat Portage, with the important exception of the rocks in the vicinity of Ka-ka-ke-wabec, which, for a consilerable breadth, run nearly east and west. The rocks for some distance southward from Rat Portage, also show a tendency to turn. north-east and east-north-east. The forces acting at right angles to these directions have been very great, and the rocks of this series are almost everywhere on edge; and though probably repeated several times, the evidence of synclinal and anticlinal folds has 
been almost obliterated. The conglomerate beds, however, north of the great granitic mass, have a general dip northward at comparatively low angles, for some distance; the southerly dip at their contact with the granite, shown in the general section, being quite local. A well-marked synclinal axis appears to lie immediately north of the Small Promontory, and to have a direction of east-north-east. There is also some evidence to show the existence of an anticlinal axis, which would strike the main shore about a mile south of Ka-ka-ke-wabec, and have a nearly east and west course. From the attitudes of the rocks, and from the recurrence to the north of Lacrosse Island, of slate beds characterized by small quantities of dolomite, and resembling those seen north of Ka-ka-ke-wabec, it is further probable, that another anticlinal axis runs north-east through the former. Besides these, howerer, there must be many folds not to be discorered without a minute topographical and geological study of the whole lake; and it is even possible that orerturned folds may occur without their existence being suspected.

97. Two great series of movements seem to have conspired to give form to the rocks of this region, both of which appear to have been posthuronian in date. The first of these apparently produced folds which were not of a very abrupt character, but involved great breadths of strata; and which run in a general course a few clegrees north of west. The great masses of intrusive granite are probably closely connected with this series of disturbances, and are nearly parallel to the axes of the folds. These granites intersect indifferently rocks of Laurentian and Huronian age, and are consequently post-eozoic. The Huronian rocks of the ricinity of the North-west Angle, are-as already fully stated-much altered by these granitic outbursts; and by the superior hardness due to this alteration, and possibly also the support of the granitic masses with which they are in contact, they have been able successfully to resist the subsequent violent north-north-east and north-east folding; - flexure in these directions at the same time affecting the softer remaining portion of the Huronian, and bringing them up to a vertical position. These hardened rocks consequently now show comparatively moderate dips, and east and west strikes dependent on the previous disturbance. This arrangement will be clearly seen on an inspection of the smaller section, (Sect. 2) the nearly rertical rocks at the northern end of which, are the first of those which extend with similar attitudes to Rat Portage.

98. The chain of large islands stretching northward from near Rainy River, though composerl of Laurentian locks only, is nearly parallel to 
the folds of the Huronian rocks in Clear-water Lake; and is probably due to an uplift of hard lower gneiss rocks by action at the second period, subsequent to that which has here been the chief agent in folding the Laurentian strata of this part of the lake.

99. Flexures corresponding pretty closely to those above inclicated, are found affecting Lamentian and Huronian rocks at very distant localities. Sir W. E. Logan, in speaking of the Laurentian of the Ottawa region, says:- " The arrangement presented by the outcrop appears to depend on two sets of undulations, the axis of the one running in bearings approaching north and south, and of the other in bearings nearly east and west, the latter apparently related to the oldest system of dykes. The north and south undulations appear to be the more important and more numerous of the two, giving to the lines of outcrop in that direction the greater number of repetitions and the longer stretches. For about twentyfire miles from the Ottawa and North Rivers, the bearing of these axis is about N. $10^{\circ}$ E."* Mr. Henry G. Vennor, in discussing the general relations of the Laurentian in the County of Hastings and ricinity, in Ontario, remarks :- - The geographical distribution of these rocks shows a series of north-east and south-west undulations, throwing the upper division into long narrow troughs in these directions. These undulations are crosised at irregular intervals by geological elevations which separate the ends of the troughs, and by depressions which unite their sides." $\dagger$ The latter, on reference to his map of the district, are seen to hare north-westerly courses. The rocks of supposed Huronian age which are now being found by the Geological Surrey among those of Laurentian date, in widely separated localities, also run in belts with general north-east and southwest bearings. It would thus appear, that the disturbances affecting the Laurentian and Huronian formations have not only been very violent, but rery uniform in their action over a great extent of country, and indeed to have operated on an almost continental scale.

100. The granitic mass of the North-west Angle and vicinity, which, as already mentioned, is of post-huronian age, if it runs eastward through the promontory separating Clear-water and Sand-hill Lakes, as suggested by Dr. Bigsby; probably closely follows its northern edge; as in treating of this part of the border of the lake, Dr. Bigsby mentions several districts of tire or six miles in length each, showing a rock resembling syenite. This term might well be used in describing large areas of the mass where 
I have seen it. It may probably in this case cut the eastern shore of Clear-water Iake at Red-cliff Bay, where the same authority indicates the existence of a considerable bread th of syenitic-greenstone and granite. The direction thus indicated for the extension of the intrusive granite, appear's to be further confirmed by the exceedingly even contour of the shore as shown on the map, a feature which in other parts of the lake is found to arise from a parallel band of hard altered, or igneous rock; and which, in this case, has maintained itself against the prevalent direction of glaciation. It would also agree with the general course of the mass where last seen to the eastward, and with that of the fold in the sedimentary rocks, which it appears to follow. The granite resembles in appearance that described as cutting through typical Huronian and Laurentian rocks on Lake Huron.*

101. Though the complicated structure of the rocks in the ricinity of the Lake of the Woods, renders it impossible to give a detailed section of the formations there exhibited; an approximate idea of their arrangement may be obtained. The Laurentian formation appears to be represented, first, by a great thickness of granitoid and thick-bedded gneiss, generally pinkish or reddish in tint, and characterized by orthoclase felspar. This passes upward into thin-bedded gneisses, and highly crystalline micaceous and hornblendic schists, often more or less epidotic. The Huronian rocks are much more variable in character, but the lowest beds appear to be those represented south of the North-west Angle granite, and are, for the most part, hard green rocks with little trace of stratification, but hold some well stratified micaceous and chloritic schists, and also the imperfectly characterized gneiss already referred to. (\$56-57.) On these rests a very great thickness of massive beds, characterized by the predominance of conglomerates, but also including quartzites, and compact dioritic rocks. Above these is an extensive series of schistose and slaty beds, generally more or less nacreous, and chloritic or talcose; but often hornblendic and micaceous. They include al-o some conglomerate, quartzite, and diorite beds; but how often these recur, or on what horizons, it is as yet impossible to say.

\section{Lithological Character and Age of the so-called Huronian.}

102. The rockis spoken of throughout as Huronian, show considerable rescmblance to the typical series of that age, as described on Lakies Huron and Superior, hut differ markedly in some points. They 
also resemble those of the Quebec group, as dereloped in the Province of Quebec, but do not, so far as known, hold serpentines in the region now in question.

103. The conglomerates hare been already fully described as to their distribution; they must occur at several different horizons among the slaty rocks, but corer the greatest breadth at the narrow part of the lake north of the Angle Inlet. The particular series there shown must be of immense thickness, and appears to grow thicker when followed eastward. A similar tendency to increase in importance eastward, was observed with other belts of these rocks, in difterent parts of the lake, and agrees with their general inconstant character.

104. Perhaps the most usual form of the conglomerate is that which may appropriately be designated Slate Conglomerate. The whole rock is of a green colour, varying between the tint of epidote and that of the lighter shades of homblende, and possibly in some instances due to a derelopment of both minerals, though, generally I think to the latter. Where a good weathered surface is exposed, the rock is seen to consist of numerous fragments of irregular shape, which in appearance resemble the harder parts of the associated slate rocks. These are imbedded in a matrix composed of similar compact green material, and joints-which are frequent in some localities-cut erenly through both. On a freshly broken surface no clear distinction appears between the fragments and the enclosing material, and the rock only difier's from the more compact altered schists and slates in its rougher surface of fracture, and a somewhat spotted appearance.

105. Another form of the conglomerate, which has been called by Dr. Bigsby and others Greenstone C'onglomerate, appears to consist of roughly fractured pieces of somewhat crystalline diorite, the whole enclosed in a dioritic jaste, similar in colour. The fragments in this species are often larger, and the rock they compose is very compact. A third varjety consists largely of quartzite and quartzose rocks, angular fragments of which are found imbedded in a greenish mass, or sometimes in a base also apparently of quurtzite and of grey and greyish-green colours.

106. The whole of these rocks appear to he uncertain in their extension, ard one is sometimes found replacing another seemingly in the same strike. They are associated generally with compact dark-coloured dioritic beds, which do not show any fragmentary apjearance, but which are not so (orarse in texture as the well characterized intrusive diorites. The quartzites also show a tendency throughout this region to run with 
the conglomerates. The comglomerate rocks, have as a whole much the aspect of volcanic breccias, such as those found in association with the oleler silurian series in Wales and Cumberland; and voleanic action would appear to olier the most reasonable explanation of their origin and distribution. Their association with the greenstone-like beds, would also then be explicable, as the ejection of rock fragments and lapilli, would probably be accompanied by the outflow of molten rock in the same neighbourhood; or many of these layer's may have originally been ash-beds formed of the finer cletritus from rolcunic vents. 'The material of these, having been at one time in a state of fusion, would have the chemical composition of hornblende, pyroxene, felspar, \&c., and would yield more readily to a subsequent metamorphism than the surrounding beds of detritus formed by sulwerial weathering and transported by water, and firom which a great part of the basic constituents had been removed. These rocks and the conglomerates, which have been united under the darkgreen colour in the appended general section because of their association, would in this case be properly classed together from their similar origin.

107. A point of difference between the rocks of this series, and those of some parts of the typical Huronian of the localities already mentioned, is the entire absence of fragments of the underlying granitic and gneissic beds in the conglomerates and breccias. Fragments of their reddish felspars do not even occur among the quartzites, nor are rocks of reddish tints, such as might arise from their disentegration found. This is a remarkable fact, and might seem to indicate that the Laurentian had not suffered much metamorphism before the formation of these rocks, and consequently that they are older than the true Huronian. The appearance of conformity with the Laurentian, of the rocks of this and other similar, but widely separated areas; and their resemblance to some rocks described as Laurentian in Hastings County, and elsewhere, would appear to point in the same direction.*

108. The absence of altered Laurentian rocks in the composition of this series may, however, be sujposed to show that their formation took place at a period subsequent to that of the typical Huronian, but before the violent disturbances which brought large areas of Laurentian again under the influence of demudation; and that their material was almost wholly de-

\footnotetext{
- ASue on the latter point, Geol. Canada., p. 31. Report of Progress Geol. Surv. Canada. 1866, p. 91, et seq., and foot nuto to p. 93 ; also $1866-60$, p, 143, et seg.
} 
rived from the degredation of comparatively unaltered Huronian rockis. From the oceurrence of nacreous schists, and other points of resemblance to the rocks of the Quebec group, the latter supposition may probably prove to be the correct one, and these rocks be classed as nearer in age to the Quebec group than the true Huronian. MLr. Selwyn, in treating of similar rocks explored by him north-west of Lake Superior", writes: "As rexards the age of these so-called Huronian rocks, the evidence is not of the most satisfuctory kind. While stratigraphically they rest directly upon highly crystalline and typical Laurentian gneisses, mineralogically they resemble as closely the chloritic, epidotic: and dioritic strata of the altered Quebec group, as they do those which on the shores of Lalies Huron and Superior are referred to the Huronian series." * All that can be definitely said with regard to the age of these rocks in the region of the Lake of the Woods, taken by itielf, is that they are newer than the typical Laurentian, there largely dereloped, and older than the little altered and nearly horizontal Lower Silurian limestones of Fort Garry and Lake Winnipeg.

109. Numerous localities present opportunity for the study of the nature of metamorphism experienced by the rocks of the green slate serics, when approaching intrusive masses. The chloritic, talcose, and nacreous slates, are observed, when nearing such a centre of alteration. to become harder and less finely fissile, and to assume green and grey-grreen colour's from the formation of erypto-crystalline hornblende, and possibly also of epidote. They next become still harder and more compact, changing to a green altered rock, characterized by hornblende, and in which the original bedding can sometimes scarcely be distinguished. Where inmediately in contact with the eruptive rock, this is generally still further changed to a grey soft gneiss, by the appearance of mica in place of the homblende. The conglomerates generally show a temlency to pass from hard green altered rock, to rocks of a roughly gneisic character, which still exhibit remains of the component fragments on firatured surfaces.

110. A table showing the character and directions of all the dykes and intrusive masses is appended. The granitoid gneises and intrusire granites are universally cut by veins of red orthoclate felspar: an-redated with white quartz. These appear to be true segregation reins finmed ly at

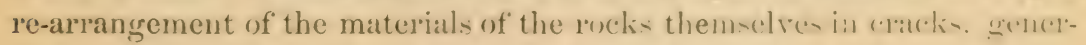


ally irregular, and with no very determinate direction. They are also common among hormblendic and altered rocks surrounding the intrusive masses; and the latter, in such places, are probably not far below the surface, and have supplied the materials filling the veins. They have been seen to cut across granitic dykes, which are probably outlying spurs of the main masses. The granite and granitoid rocks of the southern part of the lake were also observed to be penetrated by the very large coarse-grained diorite dykes already described. These were not sufficiently well exposed to warrant any very definite statements concerning them, but appeared to have general east and west courses, and may very probably be among the oldest of the intrusions. Other diorite dykes, very hard and compact, cut both the granitic outbursts, and altered Laurentian rocks, with a general bearing of northeast and south-west. These are specially frequent in the vicinity of Flag Island.

\section{Occurrence of Minerals of Economic Value.}

111. Minerals of economic importance, though carefully looked for throughout the district, were not observed to occur in any quantity. The existence of a vein with at least traces of copper, has been already mentioned, and I have been shown specimens of copper pyrites from several parts of the lake which I had not time to visit, which give ground for believing that workable and valuable deposits of this ore may yet be found. Small quantities of molybdenite were observed in connection with the altered rocks in one place. Slaty rocks, though abundant, do not assume the character of true roofing-slate in any part of this region which I have visited. It is not always possible to ascertain how much of the cleavage of the rocks is due to bedding, and how much to true superinduced slaty-eleavage. The Huronian rocks are so closely pressed togrether, that the two seem often to coincide; and I did not observe any clear instance of slaty structure forming a consiclerable angle with the belding. Of soatp-stone, though not actually observed in place, I have seen specimens from localities in the south-eastern part of Clear-water Iake. Small quantities of magnetic iron sand are found along the shores of the sonthern part of Sand-hill Lake, but this mineral is known to be disseminated in small crystals through many parts of the Laurentian.

112. Rockis of similar age and character to those here called IIuronian, and which oreupy the whole of Clear-water Lake, are known to be metal- 
liferous in other regions, and more especially in the country north and west of Lake Superior. They are there found to yield silver and gold in paying quantities, and also contain copper and iron ores, and it is no improballe that systematic investigation of the rocks of the Lake of the Woods may lead to similar discoveries. The examination and definition of these bands of newer rocks among the Laurentian, therefore becomes important in view of future mineral discoreries, as well as interesting in a purely geological point of view. 


\title{
CHAPTER III.
}

\section{STRUCTULE OF THE ROCKY MOUNTAINS IN THE VICINITY OF THE FORTY-NINTH PARALLEL.}

\begin{abstract}
General Features, - Intersection of the Mountains and Forty-ninth Parallel General Geological Structure-Rocks IN THE VICINITY OF WATERTON LAKE - Series A.--Series Bo-Series C.-Rocks in the Kootanie Pass-Subdivisions of Series C.-East Fork-Rocks west of East Fork-The Watershed-West Fork-Rocks exposed in Mt. Yarrell-RockS NEAR THE Boundary Munument - Series H. - Section of Series F. and G. - Eastern Front of the Watershed Range, Mt. Wilson and Chief Mountain-Review of THE SEction-COMPaRison OF THE RockS WITH THOSE OF OTHER LOCALITIES -Rocks described to the North-Rocks described to the South-Limestones like those of Series B. and D.-Underlying beds-Upper red beds-General conclusions-Period of elevation of the Mountains.
\end{abstract}

\section{General Features.}

113. The eastern ranges of the Rocky Mountains in the vicinity of the forty-ninth parallel, have not heretofore been geologically examined. The explorers of the Wester'm Territories of the United States, have not yet penetrated so far to the north in this region; and Dr. Hector's observations do not extend southward in the range, beyond about latitude $50^{\circ} 30^{\prime}$. Lieutenant Blackiston, originally attached to Captain Palliser's expedition, crossed the momtains by the South Kootanie, or Boumdary Pass, and gives a map and profile of it in his Report to the Imperial Government, * but has not furnished any geological notes.

114. The eastern ranges, where the forty-ninth parallel intersects them, seem to be retreating north-westward, in a step-like manner, or en échelon; the line formed by the base of the mountains as a whole, not coinciding in direction with that of the component ridges. A similar structure appears to occur firequently both to the south and north of the region now in question. Chief, or Chicf"s Mountain, which on Palliser's map is placed on the Boundary-line, was found to be about four miles to the south of it. The Line, however: strikes into the hills and abrupt ridges surrounding its base; and then crossing the narrow valley of the South Fork of the Belly River, passes over the Mt. Wilson Range, of 
Blackiston, and next intersects Waterton or Chief Mountain Lake, which lies at the foot of the principal range. The Line thus runs for about fourteen miles through an outlying mountainous country, which, by a detour of a few miles to the north, may be entirely avoided, and waggons brought to the north end of Waterton Lake without difficulty.

115. The general structure of the main, or water-shed range, is rery simple, and so far as I have been able to examine it, appear's to be very constant; though often complicated by smaller superposed flexures and faults, which from the very clearness with which they are shown, in the sides of the bare rocky peaks, are apt at times to lead to confusion. The width of the range is about twenty miles, and the height of its highest summits in this latitude is not over about 10,000 feet. The rocks of the eastern and western borders are found to dip inward toward the water-shed line, and generally do not lie at very high angles; while the central mountains frequently show rocks not far from horizontal, or affected by local and irregular dips, and often exhibit some of the highest beds of the series. When these latter beds appear in the central region, they may form a part of the general synclinal of the range; but when older rocks are found, they are probably separated by faulting from those of the edges, as appears to be the case in the South Kootanie Pass. In the outer ridges of the range, the highest peaks usually occur, and the attitude of the rocks determines to a great extent the forms of the mountains, which generally have their steep sides facing outward, and resemble wares curling over to break to the east and west, their inner sides sloping more gently along the dip of the beds. (Sect. 4.)

\section{Rocks in the Vicinity of Waterton Lake.}

116. Disregarding for the present the eastern outlying ranges, I shall descrile the rocks seen in the ricinity of Waterton or Chief Mountain Lake, which include the lowest observed in any part of the region. The lower beds are brought up by an inregular anticlinal fold, which crosses the lake near its northern end, with a north-west and south-east direction. They consist of a series of impure dolomites, and an overlying limestone, which I did not elsewhere find exposed, but which are here well shown on both siles of the lake.

117. The dolomites, which for convenience of reference I shall call Series $A$. present a very remarkable appearance in the bare mountain sides firm the peculiarity of the tints as:umed by them on weathering, which are for the most part hright reddish, and yellowish browns; and 
alternate in broad belts, according with the stratification. The bedding is very regular, and is marked, besides the alternation of tint, by the erosion of some softer layers composed of thin flaggy beds, which alternate with massive compact layers kereral feet in thickness. The fracture of the more massive portions is conchoidal, with a dim lustre, and the colours of fieshly broken surfaces are much less marked than those of the exterior, and vary from light grey, to dull purplish and fleshcolour, some beds being a pale pink.

118. The structure of the rock is generally very close and fine, and from the preponderance of sedimentary matter, it frequently more resembles a metamorphosed mud-rock, than a true dolomite. It does not effervesce in cold dilute acid, but on heating gently, a brisk action commences; and when the whole of the magnesian and calcareous matter has been removed, a coherent, though brittle mass, remains. This, when examined microscopically, is found to consist of very fine and uniform argillaceous and silicious particles. The exposed surfaces are generally decomposed to a depth of a few lines. Small grains of iron pyrites are sometimes included in the rock, but no organic forms of any kind were discovered.

119. Of these rocks, at least seven hundred feet in thickness is exposed; they are well shown at the Cascade on the western shore of the lake, but to the south soon dip out of sight, and overlying beds come down to the water level. The southern end of Waterton Lake, I was, however, unable to examine in any detail, from the precipitous and impassible nature of the mountains surrounding it, and the impossibility, in the short time at our disposal, of making a servicable boat or raft.

120. Resting directly on these peculiar dolomites, is a very massire bed of limestone, also dolomitic, which forms a prominent feature from the chalky-white aspect of its weathered surfaces. It may be designated by the letter B., and has a probable thickness of about two hundred feet, and includes at least one well-marked band of coarse magnesian grit. The limestone on firesh fracture is of a pale-grey colour, and has a highly metamorphic aspect. It is very close-grained and compact, and breaks with a splintery fracture, the original planes of deposition being almost entirely lost. Some layers are exceedingly cherty, the siliceous matter being at times aggregated into well-defined nodules, but more usually disiseminated, and forming an irregular skeleton, which gives to somo weathered surfaces of the limestone an excecdingly rough 
appearance. With acid, the rock hardly efferveses in the cold, but on gentle heating is rapidly dissolved, leaving a comparatively small amount of residue, which, under the microscope, appears not to be of a detrital nature, but to have the form of minute concretions produced during the metamorphism of the rock, by the re-arrangement of the silica. There does not appear to be any unconformity between this limestone series and that of the underlying impure dolomites, of which it may be considered an upward extension. It indicates, howerer, a well-marked change in the character of the deposit; depending on the exclusion of the fine detrital matter forming so large a part of the previous beds,- - a change brought about, perhaps, by the deepening of the sea. The limestone, where it crosses the lake folded into the anticlinal already mentioned, from its superior hardness, forms a projecting point from either side, and a transverse reef which almost divides the sheet of water into two.

121. Series C. overlying the last, is well exposed in the bare sides of the mountains on both shores of the northern end of Waterton Lake. On the east side, a great portion of the western front of Mt. Wilson is composed of it, while to the west, a mountain rising about 4,000 feet above the lake, is almost entirely formed of these beds, which have there been subjected to violent flexure. (Sects. $6 \& 8$ ). As a whole, this division of the section may be described as consisting of hard quartzites, sandstones, slates and shales; and its most remarkable feature is the rapid alternation of beds differing in colour and texture. Various shades of green, purplish-brown, red, and white, are the most prevalent tints.

122. In the almost vertical western side of Mt. Wilson, about two thousand feet of these beds is seen. They lie directly on the last mentioned white limestone, and if any unconformity exists it was not observed. Here two pretty thick bands of magnesian grit appear among the other rocks of the series, and may be distinctly traced along the mountain side for some distance. At one end of the section a considerable thickness of red beds occur's, as the highest in Series C., and in some places these are seen to underlie directly the limestone of Series D., next in order, while in others they are wanting, and D. rests on the lower green slates and sandstones, showing a well marked unconformity. (Sect. 6.) The mountain on the western side of the valley of the lake, shows but a single band of the magnesian sandstone, which is very irregular in its thickness. The red beds are only clearly seen in a few places, and faults may exist which complicate the structure more than is 
apparent. There seems, however, to be above the red band, a considerable thickness of slaty rocks, which are altogether wanting in the last section.

\section{Rocks in the Kootanie Pass.}

123. The beds of Series C. are, however, best displayed in the sides of the South Kootanie Pass,-which enters the mountains three and a half miles north of Waterton Lake,-and were there separated for convenience of reference into five subdivisions. The rocks at the entrance to the pass have a general south-westerly dip. The lowest seen were in the bed of the brook, and must be well down in the series. They consist of hard greenish slates and compact thin-bedded quartzites, much resembling those underlying the magnesian sandstone, in the last mentioned locality. In the mountain on the north side these were seen to be overlaid by reddish, greenish, and bluish-grey sandstones, with some slaty beds, all considerably altered; but which form a talus, and are not very well exposed. These were designated subdivision 1.

124. About midway up the mountain, a massive bed of magnesian sandstone or grit, appears, and constitutes subdivision 2 . It must be about fifty feet in thickness, and great blocks of it which have broken off from time to time, are now strewn round the foot of the slope, and encumber the pass. It no doubt corresponds with one of the similar beds already described as occurring near Waterton Lake, and lithologically, also bears a close resemblance to that intercalated in Series B. It is composed of large well-rounded grains of transparent quartz, with occasional darker particles-the whole imbedded in an opaque white calcareous and magnesian matrix, which rapidly turns brown on exposure to the weather.

125. Next in the series, and forming the summit of this mountain, is a considerable thickness of red, greenish, and bluish-grey sandstones and slates; which, by their alternation give the cliffs a curious banded appearance. They resemble those of subdivision 1 , and may be named suldivision 3.

126. A series of bright-red beds appears on the slope of the mountain on the south side, overlying the last; they constitute subdivision 4 , and represent those already noticed as oceuring in Mt. Wilson and elsewhere. In following the trail along the north side of the valley, they come down almost to the level of the brook, about one and a quarter mile from the entrance of the pass. Their thickness at this place must be about two 
hundred feet, and from their exceelingly bright colour, they constitute wherever they occur, an excellent reference horizon, and may often be detected eren at a great distance. They are hard, red, thin-bedded sandstones, with frequent thin intercalations of red argillaceous material, and one or two beds of small thickness, composed of pale-greenish, shaly quartzite. A fifth subdivision which intervenes in some places between the red beds and the base of the limestone above, is not well seen in this part of the valley.

127. Five miles westward in the pass, the valley forks, one branch taking a north-westward direction, the other running west-south-west. The trail also divides here; one track, which does not appear to be much used, taking the former, while the other takes the latter direction, and in doing so, follows the main stream of the brook. The north-western valley was not examined in detail, but the mountains surrounding it afforded from a distance, a fine general section of the rocks fiom Series C. upward.

128. In following the main valley, after crossing the brook, the trail for about half a mile runs parallel with the axis of a gentle anticlinal which has an east and west course, and passes eventually into the mountanious point which separates the two vallies. In the bed of the brook, and well down among the variegated sandstones and quartzites of subdivisions 1 or 3 of Series C., is an extensive exposure of diorite. It appears to be intercalated between the beds, but is probably intrusive, as it was not elsewhere seen. Over twenty feet in thickness is exposed. The rock is so traversed by fissures as to render it almost impossible to break off a clean-faced specimen, and is dark coloured and compact. Some large fragments found in the brook, which appear to have been derrved from the same bed, show remarkable stellar aggregations, several inches in diameter, of pale green felspar crystals. Below the diorite, and in the bed of the brook, an extensive series of banded red and green sandstones and quartzites, with occasional white quartzite layers, appears. The beds are not inclined at high angles, or much disturbed, but are somewhat corrugated on a small scale. A species of slate conglomerate* is also not uncommon, though not generally occurring in beds more than a few feet in thickness. The rock so designated, is generally a greenish or white quartzite, enclosing small irregular fragments of

* Though the name slate conglomerate best describes the constitution of this rock, it differs much in appearance, and probably also in origin, from the Hurouian slate conglomerates. (8 104.) 
green, or red, close-grained slaty rock. These slate conglomerates are not uncommon at sereral horizons in Series (., and fragments of them have been recognised among the drift deposits far out on the plains.

129. The crest of a remarkably bold peak on the north-west side of the pass, at this place, is composed of thick limestone beds, forming Series $D$. of the general section. They weather light-brown, and fawn-colour on exposure, and are found to enter largely into the composition of all the mountains of this region. When, as in this instance, they form the summits of a peak or ridge, disintegration proceeding most rapidly along vertical lines of fracture, produces extremely picturesque and rugged outlines. When, however, merely exposed in the side of a mountain, and still corered by other beds, they form steep terraced slopes or perpendicular cliffs quite different in aspect. The upper beds, are generally more frequently divided by horizontal planes than the lower. The entire thickness of the series must be about one thousand feet.

130. About four miles beyond the division of the valley, or East Fork of the trail, a thick bed of contemporaneous trap appears on the tops of . the mountains on the north-west side, overlying the limestone. This bed, which is designated in the series by the letter E., must here be over fifty feet thick, though any very precise estimate could not firom its position be obtained. Great blocks of the trap have fallen into the valley below, and increase the difficulty of the trail. The rock is a dark-coloured and very compact diorite, but has numerous amygdaloidal cavities. Series F. and $G$. occur overlying the trap in this part of the pass, but were not here examined.

131. A deep transverse valley, filled in some places with fine spruce woods, lies along the eastern base of the actual ridge of the water-shed, and from the brook flowing in it, to the summit of the water-shed, an ascent of 1,022 feet is made by the trail ; which here becomes exceedingly steep and hardly practicable for heavily laden pack animals. The rocks of the water-shed ridge apparently belong, in this place, entirely to Series C., but other beds may also be represented, as the exposures are not very good. From the evidence, I have been induced to indicate a fault on the reneral section, as separating these from the last described westerlydipping becls of the valley, though their relation was not actually observed.

132. The height of the water-shed where crossed by the trail, as indicated by the mean of three closely corresponding readings, taken on as many difterent days, and compared with Mr. Fish's nearly simul- 
taneous observations at the West Butte, was 6,673 feet.* Lieutenant Blackiston, in 1858, made the height 6,030 f'eet, by a single observation in unsettled weather. The trail descends on the west side of the watershed ridge very rapidly, and at the distance of three quarters of a mile, crosses a little brook which lies 1,325 feet lower than its summit, and 300 feet below the stream last crossed on the east side. It next passes for about two miles along the face of a very steep hill-side, when a descent is again made to a piece of flat ground in the bottom of the valley, covered with a scattered growth of young pines. ( $P$. contorta, var. latifolia Eng.) This place may be called the West Fork, as a second valley as large as that of the pass, here comes in from the south-east. The rocks in the hillside last mentioned, dip generally north-westward; they appear to belong to the same series as those of the watershed ridge, and to be included, at least for the most part,-in division C. The lower part of the hill is composed principally of greenish slaty-rocks and sandstones, while at the higher levels, red sandstones preponderate, and are seen to be overlaid just north of the West Fork, by a remnant of the great limestone D.

133. Westward from the West Fork, the Valley of the Pass was examined for about four miles. It is here hemmed in by two immense mountain masses, which were at once recognised as Mts. Yarrell, and Kirby and Spence, of Lieut. Blackiston. The rocks in these have a general easterly and north-easterly dip, and appear to be unconnected with those of the central region last described, and probably separated from them by a fault. About a mile from the Forks, in the north side of the Pass-which as before offer's the best section-a great series of reddish sandstones, often in quite massive layers, is found. The tint is most pronounced in the upper layers, the lower becoming interstratified with thin beds of yellow-weathering magnesian limestone, often concretionary, which finally preponderate in giving colour to the strata. These rocks represent Series F. and G., elsewhere more fully noticed. Below them, and forming a prominent feature, is the trap bed E. It retains its character as before described, but in Mt. Yarrell, is much more important, and must be at least 100 feet in thickness. The great limestone D., is here also shown, underlying the trap; and is well situated for examination, as the whole of the beds come down in succession on the trail. It is not so highly magnesian as the limestone B., and generally

*The observations were as follows:-Aug. 15th, 11.25 A.M., 6,682; Aug. 16th, 11.20 A.M., 6,678; Aug. 20th, 10.20 A.M., 6,659. 
efferverces freely without the application of heat. - It is hard and metamorphic, but close-grained, and not crystalline. The colour of freshly fractured surfaces is generally bluish, and varies from a dark shade to a pale bluish-grey; some layers, have, however, a yellowish tinge. Weathered surfaces are pale-brown, fawn, or buff-coloured, and show an irregularity of structure which is not apparent on fracture, but seems to arise from the unequal resistence to the weather of parts more or less largely impregnated with magnesia; the differentiation being produced by some sort of segregative action. The more highly magnesian layers are at times arranged in planes parallel to those of deposition, but also, not infrequently, quite irrespective of it.

134. Below the limestone the lowest beds here seen oc'ur. They are composed of the variegated sandstones and slates of Series C. The former are grenerally reddish and greenish, the latter grey and green, but there are also many bands of white quartzite of small thickness. No marked unconformity between this series and the limestone is here observable, but subdivision 4 was not recognized, and it would seem that the limestone here rests on No. 1 or 3 . The sandstones and slates also seem to be much more metamorphosed than any of the rocks higher in the series, and are beautifully plicated on a small scale.

135. I was unable to observe the rocks further west than this point, which is about five miles from the Flathead River. The mountains were here, however, decreasing in altitude, and the watershed range was nearly passed through.

\section{Rocks near the Boundary Monument.}

136. In the valley which runs south-eastward from the West Fork, and leads almost directly toward the Boundary Monument on the watershed, the rocks exposed in the hill-sides are chiefly red, or reddish sandstones, generally rather thin-bedded, but sometimes massire. They belong for the most part to the upper red Series G. Series H., composed of flaggy fawn-coloured beds, which are no doubt magnesian limestone or sandstone, forms the soft-outlined and crumbling summits of some of the mountains on the south-rest side. These rocks-the highest observed in the mountain region-were not closely examined, though a greater or less thickness of them was frequently seen resting on Series G., and differing from it markedly in colour, it was always at a great height above the valleys.

137. The spot known as Camp Akamina, the eastern terminal 
station of the old North-west Boundary Commission, is situated at the head of the valley just described. It has an elevation of about 6,000 feet above the sea, and is a sheltered hollow characterized by thick spruce woods of fine growth. The Boundary Cairn is placed on the watershed about a mile from the camp, and though built thirteen years ago was found in perfect preservation. It is important as marking not only the forty-ninth parallel or boundary between British North America and the United States, but as lying at the adjacent angles of British Columbia and the as yet unorganized North-west Territory.

138. Near Camp Akamina the rocks are red sandstones, but are not well shown or regular in position. In a mountain-side between the camp and the Boundary Monument, however, a very good section is exposed ; and here the structure of series F. and G. of the general section was best seen, and orer six hundred feet in thickness examined. The section may be taken as embracing the lower beds of Series G., and the whole of Series F. The highest beds examined consist almost entirely of flaggy duil-red compact sandstones, which are frequently ripple-marked. Above them about two hundred feet of similar reddish beds was visible in distant hill-sides, and these again were orerlaid by the upper fawn-coloured Series H. In descending, these begin to alternate with beds of grey and fawn-coloured sandstones, the latter magnesian, and whitish on fresh fracture. Lower in the section, while red and reddish-purple sandstones still continue, whitish and fawn-coloured limestones,-frequently concretionary, -are intercalated, and become thicker and more frequent toward the base. The lowest rock seen in Series F. is a dark purplish sandstone, and not far below it is the trap designated in the general section by the letter E. Many of the sedimentary beds throughout the entire section are ripple-marked, and rain-pitting and sun-cracks are not infrequent. At sereral different levels, too, the surfaces of sandstone beds show impressions caused by salt crystals, subsequently dissolved out. Some of these are as much as half an inch in diameter, and exhibit distinctly the peculiar hopper-shaped forms characteristic of sodic chloride. The conditions of formation indicated by the rocks are those of a shallow, land-locked, salt lagoon or lake; which was, perhaps, sometimes in communication with the open sea. No traces of fossils could be found.

139. The division made between Series $F$. and $G$., and that between $G$. and $\mathrm{H}$., are probably not of great importance. No unconformity obtains, and the same conditions keem to have prevailed throughout ; the deposition of reddish sandstone, alternating with that of pale dolomitic sand- 
stone, and magnesian limestone. It is one of convenience only, and founded on the different colours of the zones as they appear in the mountain sides.

140. The trap E. is still important at this place, but is not so thick as in the Mt. Yarrell sections. It is dark-purplish in colour, and full of irregular amygdaloidal cavities, which are lined with green chloritic matter, and generally filled with white calcite. It overlies the great limestone, as before.

\section{Eastern Front of the Water-shed Range, Mt. Wilson and Chief Mountain.}

141. Northward from the entrance of the South Kootanie Pass, along the eastern side of the mountains, for at least twenty-five miles north of the Line, the rocks exposed are similar to those already described. All the beds of the eastern ridges appear to dip westward, or west-northwestward, toward the axis of the chain ; and are broken off abruptly to the east, forming steep cliffy fronts toward the plains. The lower and outur ranges consist almost entirely of the variegated Series C., of which the red beds are often visible at a great distance. Many of the higher mountains are capped by the limestones of Series D., and where gaps in the eastern wall allow the inner ranges to be seen, they frequently show the upper fawn-coloured, and red beds, with gentle dips forming steep, but straight-edged ridges. Section 5 represents the geological structure, and general contour of the mountains to the north, as seen from a hill about six miles north of the entrance to the South Kootanie Pass. The most distant mountain of which the geological structure is indicated, was estimated to be about fifteen miles from the point of view. The more distant peaks shown on the horizon were but dimly visible, and must lie from fifty to one hundred miles northward. They appear to be of great height.

142. The outlying or counterfort range, which is situated on the east side of Waterton Lake, has a breadth from west to east of seven miles. It may be designated the Wilson Range; that name having been applied to a part of it by Lieut. Blackiston. Its western side has been already partly described in connection with Waterton Lake. As viewed from the north, its fiont is chiefly composed of the rocks of Series C., of which subdivision 4 , the red band, is conspicuous in many places. The central and higher parts of the range are of limestone belonging to Series D. Rocks diflering from the rest, and apparently brought up by a 
fault, occur at the north-eastern corner of the range. They were not closely examined, but may belong to Series B.

143. Chief, or more properly Chief's Mountain, which projects still further to the eastward, is one of the most remarkable mountain masses of this region. It is nearly isolated from the rest, though surrounded by rugged foot-hills, which are covered with dense woods and wind-fall, rendering it almost unapproachable. As seen from the eastward, it resembles the base of a broken column, and its outline was quite distinguishable from that of the remainder of the mountains, even from the Sweet Grass Hills, a distance of one hundred miles. On three sides, the central mass of the mountain is precipitous, and its bare rocky cliffs are of great height. To the west, it appears to slope more gradually, and its summit is cleft with deep ravines. It seems to owe its remarkable form to the peculiar weathering of the limestones of Series D., of which the perpendicular portion is composed. The rocks of the foot-hills are softer, and no doubt belong to Series C. Chief Mountain resembles in its structure the peak called Castle Mountain by Dr. Hector, each being formed of a huge quadrangular block of nearly horizontal limestone beds.

\section{Review of the Section.}

144. The total thickness of the beds seen in this part of the Rocky Mountains must be about 4,500 feet, though this can only be regarded as an approximation; as owing to the short time at my disposal, few of the beds were actually measured. The entire series arranged as a continuous section in descending order, is as follows:-

H. Fawn-coloured flaggy beds, seen only at a distance, but probably composed of magnesian sandstones and limestones. 100 feet.

G. Beds characterized by a predominent red colour, and chiefly red sandstone, but including some thin greyish beds, and magnesian sandstones, the whole generally thin-bedded, though sometimes rather massive. Ripple-marks, \&c., Weathers to a steep rocky talus, where exposed in the mountain sides; and passes gradually down into the next series. 300 feet.

F. Fawn-coloured flaggy beds of magnesian sandstone and limestone. Some red sandstones occur throughout, but are especially abundant toward the top. Apparently a continuation upward of the limestone D., and only separated from it by the trap overflow. 200 feet. 
E. Amygdaloidal trap ; dark coloured and hard. 50 to 100 feet.

D. Compact bluish limestone, somewhat magnesian, and weathering brownish. This forms some of the boldest crags and peaks of the mountains, and apparently rests unconformably on Series C. 1,000 feet.

C. Sandstones, quartzites and slaty rocks, of various tints, but chiefly reddish and greenish-grey; the individual beds seldom of great thickness, and the colour and texture of approximate beds rapidly alternating. In this series occur's a band of bright-red rocks, of inconstant thickness, also two or more zones of coarse magnesian grit. 2,000 feet or more.

B. Limestone, palc-grey, cherty and highly magnesian; hard, muchaltered and weathering white. It includes at least one band of coarse magnesian grit like that found in the last series, which weathers brown. 200 feet.

A. Impure dolomites and fine dolomitic quartzites; dark purplish and grey, but weathering bright brown of various shades. 700 feet or more.

145. The trap E. is remarkable for its continuity over an extensive area without any great variation in thickness or character. It is represented along the eastern side of the mountains for probably at least twenty-five miles, holding always the same position in the series. It occur's also in the Boundary Mountain, and in Mt. Yar':ell almost at the extreme western margin of the range. In a bold peak standing in the angle between the two branches of the pass at the East Fork, what appears to be a thin bed of a similar trap occurs among the limestones of Series D. It can there be traced for a long distance on the cliffs, but was not elsewhere observed.

146. No granitic or gneissic rocks were found in this part of the mountains; and, as elsewhere shown, they even disappear as constituents of the drift before the foot-hills are reached in this latitude. These rocks are not known to oceur in any part of the eastern range of the mountains north of the forty-ninth parallel. Southward, they appear in some places as the basal rocks of the series, and in Colorado are quite extensively exposed, and hold in association with them the ores of the precious metals. In some ciases these rocks are observed to be clearly overlapped by the Potsilam sandstone; and if not the equivalent of the Laurentian of the east, are at least Eozoic. 
147. The difference in character of the country on the east and west sides of the first range of the mountains, which on the forty-ninth parallel constitutes the water-shed, is rery striking. Standing on one of the higher summits, glimpses of the treeless prairie can be seen between the eastern bordering mountains. The undulations of the grassy foot-hills are, firom the elevation, completely lost; and the plain appears to differ only in colour from the sea. Looking westward, even where the view is most extensive, it is one of tumultuous peaks and ridges, pine-clad or bare and rocky, to the horizon; and these are only the first of those which in almost unbroken series extend to the Pacific Coast, a distance of four hundred miles.

\section{Comparison of the Rocks seen in the Vicinity of the Forty-ninth Parallel, with those of other Localities.}

148. Sir J. Richardson has described the Rocky Mountains, where he met with them on the Mackenzie River, as being in great part composed of Carboniferous limestone. Dr. Hector is, so far as I know, the only other geologist who has examined their eastern ranges in British America. He had the opportunity of traversing them in sereral places, and has noted the occurrence of limestones of Carboniferous age, in many localities. In the eastern range, where cut by the Bow River, he describes a "deep blue limestone, which weather's to a light blue colour, and is traversed by veins of calcspar. The surfaces of these beds are very rough, and masses of chert are left protruding by the action of the weather." They were found to contain fragments of Encrinite stems; also, Producta and Spirifer; and are consequently of Carboniferous or Devonian age. They are said, in this locality, to be associated with earthy shales.* Near the same place-in Castle Mountain-limestone beds oceur, which would appear from the description, to have been estimated at about 2,000 feet in thickness. They overlie quartzites and quartzite-conglomerates, though not directly. $\dagger$ Somewhat further west, at the head of the Vermilion River, a similar limestone is again found, with fossils like those last mentioned. Certain hill-sides are also described as consisting of "horizontal strata of blue slate rock, closely banded with red stripes" + whick may be supposed to represent Series C.

149. On the upper water's of the North Saskatchewan, Carboniferous

*Palliser Exploration of British North America, 1863, pp. 99-100. † Ibid., p. $102 \quad$ † Ibid., p. 104. 
limestones full of Encrinites and corals, are mentioned;* and near Old Bow Fort, cream-coloured limestone, with cherty nodules and obscure Encrinite stems, blue crystalline limestone and compact earthy limestone, with Cyathophyllum and Favosites were found associated. $†$

150. In Roche Miette Mountain, near Jasper House, Dr. Hector obtained the following interesting section: $-\ddagger$

Hard, compact blue limestone and shale, with nodules of iron pyrites....................... 2,000 feet.

Fissile shales, almost black................ 300 "

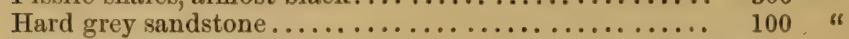

Shales, toward the upper part with green and red blotches, the lower part rust-coloured......... 500 " "

Cherty limestone and coarse sandstone, obscured by timber

This shows a moderately close resemblance with the membciis of the Boundary section from D. to B., inclusive.

151. At the nor ${ }^{2} \mathrm{~h}$ end of Pipe-stone Pass, a dark-blue limestone, containing Atrypa reticularis, and therefore characterized as Devonian, occurs. $\S$

152. Near the Upper Columbia Lake, on the west side of the main range of the mountains, Carboniferous limestone is found lying unconformably on slaty rocks, a very interesting fact when taken in conjunction with the supposed unconformity of Series D. and C., on the Line. Dr. Hector clescribes the "cherty Carboniferous limestone" as "resting on slate, both dipping to the north-east, but the latter at a very high angle," || and in another place recurs to the observation as proving the unconformity of the limestone on the underlying series.

153. In summing up his observations, Dr. Hector considers the eastern range to be mainly composed of thick-bedded limestones. $\mathrm{He}$ writes:- "These limestones are of dark and light-blue colour, crystalline, compact or cherty, with fossils that are either of Carboniferous or Devonian age, the principal of which are Spirifer, Orthis, Chonetes, Conularia, Lonsdalia, Cyathophyllum, Lithostrotion, \&e. Along with them are softer beds of grity, sindy shale, generally of a dull red or purple colour." *** "In the second range we have the same limestones and shales repeated as in the first, but at the base I observed traces of a magnesian limestone of a buff colour, containing Atrypa reticularis, a true Devonian fonsil." $+\dagger$ "On the Kicking-horse River, in the third range, we have the

\footnotetext{
+ Ibld., p. 146. Exploration of British North America, p. 113.
\$I Ibid., p. 150.

- Juurn. Geol. Soc., vol. Xvii., p. $43 . \quad$ ** Expluration of British North America, Ibid., p. 154 i† Journ. Geol. Soc., vol, vii., p 443.
} 
mountains again formed of blue limestone, along with a compact blue schist with red bands, giving a curious striped aspect to the rocks." *

154. Dr. Hector is not very clear as to the separation of the supposed Devonian and Carboniferous limestones, and they may indeed, very probably belong to a single series. Prof. Meek, in describing fossils from limestones occurring in the mountains south of the Boundary-line, which from the general facies, he beliered to be Carboniferous; mentions the fact that the forms, without exception, belong to genera, which are common both to that formation and the Devonian, and of which a small number are represented also in the Silurian. $\dagger$

155. Dr. Peale, in his report to Dr. Hayden $\ddagger$ describes, at Spring Canon, Montana, about two hundred miles south of the Line, an interesting section which is clearly comparable with Series D, F, G, and H. It may be summarized as follows :-

\section{Cretaceous- Jurassic- \\ Red, purple, and grey sandstones, with brown limestone.. 200 feet. \\ Brown and yellowish limestones, with sandstones and thin quartzites........................... 449 "6}

\section{Triassic-}

Red and purple sandstones, sometimes calcareous, with one thin limestone near the top.............. 68 "

Carboniferous-

Limestone, the upper layers arenaceous............435

Allowing for the distance by which the two regions are separated, the agreement is sufficiently close. We have first, a limestone comparable with D. The trap E. of the Boundary section, is probably intercalated among the beds here included in the Carboniferous, and separates the representatives of the lower compact limestone, from those of the upper flaggy and arenaceous beds; which, in the Boundary section, are designated Series F. Next, a great ascending series of limostones associated with reddish arenaceous beds.

156. The beds classed-as Triassic, in the above section, are so-named merely from their analogy with those of that period in other regrions. Dr. Hayden, elsewhere, states his belief, that the Triassic and Devonian series are wanting in Montana, $\$$ and that below the lignite-bearing formation, follow in descending order, the Cretaceous, Jurasicic, Carboniferous, and a great thickness of lower strata, probably Silurian, which rest unconformably on granitic and gneissic rocks. 
157. The great series of limestones attributed to the Carboniferous period, are also found to repose unconformably on the rocks beneath them. They lie in some places directly on the gneissic rocks, while in other localities, 1,500 feet to 2,000 feet of Silurian strata intervene.* The entire thickness of the Carboniferous rocks is estimated at from 1,000 to 2,000 feet. $\dagger$

158. Other limestones, supposed to be Lower Silurian, are also described in this regrion, and said to have a " much older look than those of the Carboniferous." They are also "more compact, and contain a greater per centage of silica, are full of cavities lined with crystals of quartz, and weather into much more rugged forms." + In another locality, limestones belonging to the two series are found almost in contact, and "although there is no positive non-conformity between the Carboniferous and Silurian, yet there appears to be a well defined physical line of separation. The Silurian limestones are more massive, brittle, cherty, and have an ancient look, while the Carboniferous beds are more pure limestone, and with thin, well defined layers." \$

159. On the Gallatin River the thickness of the various formations is estimated as follows:-Jurassic, 1,200 feet; Carboniferous, 2,500 to 3,000 ; Silurian, 800 to $1,000 . \|$ Near the junction of the Gallatin and Missouri, a section shows "about 2,000 feet of metamorphosed slates, clays, and quartzites of all textures and colour's, but mostly thinly laminated," which Dr. Hayden has no doubt belong to the Potsdam group. Compact, grey limestones, also of Silurian age, are developed in this locality, and overlying the whole series the Carboniferous limestone is found. The general resemblance of this section to that represented by Series C. and D. on the Boundary, is at once apparent.

160. At Jackass Creek, and near Gallatin City, sections more or less closely comparable with those on the Boundary-line are also met with,** but many of the beds entering into the composition of the mountains in Montana, seem to be somewhat local and variable in their appearance.

161. In the mountains at the head waters of the Powder River, five hundred miles south-easterly from the Boundary sections, the Carboniferous limestone, acrain occurs, as a compact, cherty, yellowish-white rock, with few fossils, but enough to indicate its age. It there rests directly on an irregular surface of quartzites and sandstones attributed to the

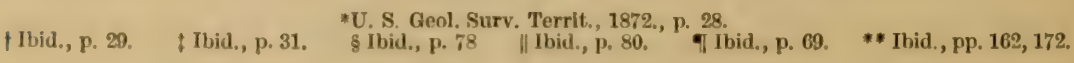


Potsdam.* Near the Snake River, on the western side of the water-shed, we again find as a conspicuous feature, a "blue, cherty Carboniferous limestone," overlaid by siliceous rocks. $\dagger$ In the Black Hills of Dakota, yellowish Carboniferous limestones appear, and rest on grey and ferruginous Potsdam sandstones, holding characteristic organic remains. The latter formation was here discovered for the first time, west of the Missouri River, by Dr. Hayden, in 1857.+

162. The rocks representing the Carboniferous formation, in the Rocky Mountain region, would therefore appear to be wide-spread, and to be represented in great part by massive limestones, which are remarkably constant in their lithological character.

163. A section examined by Dr. Hayden, in the Uinta Range, in Utah, is interesting as a standard of comparison with those on the fortyninth parallel. Here, red beds, supposed to be Triassic, and from 150 to 200 feet in thickness, are first met with, and pass downward into grey sandstones, quartzites and indurated arenaceous clays; then, alternate beds of thin grey limestone and sandstones; and flnally, a massive limestone, about 1,000 feet in thickness, holding Carboniferous fossils. Next, dull purplish sandstones, with a series of thin layers of slate and clay, graulually passing down into brittle reddish and grey quartzites, and being more compact and massive. In this whole series, from the red beds above, to the lowest quartzites, no unconformity is apparent; the junction between the base of the limestone and the underlying sandstone becoming clear and regular. The total thickness of the beds exposed is estimated at 10,000 feet, of which 8,000 feet, is composed of the lower sandstones and quartzites. Of these last, Dr. Hayden believes the upper beds to be Silurian, and to pass gradually downward without any break in time, to rocks of Huronian age; the lower purplish quartzites being compared with those underlying the Cretaceous and Carboniferous rocks in Dakota, which are supposed to belong to that period. $\S$

164. The general similarity of this with the Boundary - section is apparent, and the resemblance of the rocks underlying the great limestone in the two localities is particularly interesting. The lowest impure dolomites of Series A. might rery well be called purplish quartzites on a superficial examination, and would be such but for the presence of a proportion of calcaren-magnesian matter. The magnesian limestone B.

* Geological Rejort Yellowstone and Missouri Expedition. 1s69., p. 70. 
appears to be wanting in the Uinta section, but its introduction would be in correspondence with the increaserl quantity of calcareous matter in the other rocks.

165. Red beds overlying the Carboniferous limestone are frequently found in the western territories. Some of them, from their fossils, are certainly Jurassic, while other's are Triassic, or perhaps Permian. They have been already more than once referred to. Near the head waters of the Cheyenne River, in some localities, between the Carboniferous limestone and the supposed Jurassic red beds, they attain a considerable thickness, and hold gypsum,* the accumulation of which implies conditions similar to those causing the briny lakes, shown to have existed after the deposition of the great limestone in the Boundary sections. Near the head of Wind River, the Carboniferous rocks are followed in ascending order by 150 feet of arenaceous beds, and greyish, ash-coloured sandy clays; then by a great series of reddish, purplish, yellowish, and grey beds, sandstones, flaggy 'limestones and marls. Ripple-marked surfaces are common, and organic remains prove the rocks to be Jurassic. $\dagger$

166. Of the mountains about the sources of the Missouri, the Big Horn, and Wind River ranges, Dr. Hayden writes:- "A series of arenaceous beds, which we have called the red arenaceous deposits, or Triassic, form one of the most conspicuous features of the geology along the flanks of both sides of the principal ranges of mountains, and are almost always present." They are "sometimes called saliferous or gypsum-bearing beds, from the fact that they contain both salt and gypsum, the latter mineral oftentimes in great quantity." A portion of these red beds is beliered to be Triassic, but above them lies a series of marls, or arenaceous marls, of light or ashen grey colour, with Jurassic fossils.t

167. Though the absence of fossils in the rocks of the mountains near the forty-ninth parallel, wherever I have examined them, precludes the fixing of their horizons by palieontological evidence, it seems possible to correlate them lithologically and stratigraphically with similar beds in other and better known regions of the west. This means of correlation appears to be a pretty reliable one, from the great genoral constancy in succession and character of the stratified rocks of the interior and western part of the continent.

168. On comparing the sections, it would hardly seem to admit of

- Geological Report Yellowstone and Missouri Expedition., p. 76. ; U. S. Geol. Surv. Territ. 1857-59., pp. 112-113. 
doubt, that the great limestone series D. represents that attributed to the Carboniferous by Dr. Hector, to the north, and by Dr. Hayden and others to the south. Abore it, we have the redidish and fawn-coloured beds of F., G. and H. Of the former, the lower part probably belongs to the Carboniferous limestone beneath, being only separated from it by the trap E. The two latter may represent in part what has elsewhere been called Triassic, but, in all probability, are for the most part of Jurassic age.

169. Below the Carboniferous limestone, a break in the continuity of the series obtains in the Boundary sections, and Series C. and B. resemble most closely the rocks which to the south have been called Silurian. The limestone B., in its rough, metamorphic, and cherty character, closely resembles some of the Silurian rocks of the southern region, but does not lie so near the base of the carboniferous limestone as is often the case there.

170. The rocks of Series A., as already mentioned, may represent those which Dr. Hayden has compared with the Huronian. This comparison, however, appears to rest on but slender evidence, and to be merely of the nature of a suggestion. The similarity of the impure dolomites of Series A. with those largely developed in the Upper Copperbearing rocks of Lake Superior, however, is so remarkable as to deserve mention, though it be hardly safe to use lithological character as a criterion of age at so great a distance.

171. With regard to the question of the age of elevation of the mountains, I have been able to obtain but little information in the region examined, and that chiefly of a negative kind. Cretaceous and Lignite Tertiary rocks have, however, shared in the resulting disturbance. Mr. Clarence King has deduced from his observations on the fortieth parallel, three great periods of uplift. The first, he refers to the Jurassic period; the second to the close of the Lignite Tertiary, and the third is supposed to have been simultaneous with the great volcanic outbursts of the posttertiary. Evidence of elevation at the first of these periods, does not appear to have been very generally found; and that it cannot have been very great, or such as to form a complete barrier between the eastern and western regions, the similarity of the marine mollusca of the lowest lignite beds of the mountains, with those of the rocks of the west coast, appears to show.*

172. Other evidence, however, goes to prove that some morement took 
place prior to the period of elevation above named the second. Dr. Hector describes a hill of Carboniferous limestone, which appears to have been an island at the time of the deposition of the surrounding Cretaceous or early Tertiary rocks, and to have been subsequently pushed up to a greater elevation.* Dr. Peale believes that the Bridger Range, in Montana, was elevated probably at the close of the Cretaceous, while other neighbouring mountains were not formed till the close of the Eocene; and Dr. Hayden is also of opinion that a gentle elevation had commenced before the close of the Cretaceous.t

173. The great period of elevation, however, was that bringing to a close the formation of the Lignite Tertiary, and intervening between it and the later rocks assigned to the Miocene and Pliocene. Dr. Hayden has accumulated in the course of his surveys an immense number of facts proving the violence and universality of this dislocation. He believes the series, up to the summit of the Lignite Tertiary, to have passed completely over the present position of the mountains, and writes: "From the Silurian to the upper Lignite group inclusive, a thickness of 10,000 to 15,000 feet extended, in an unbroken, horizontal mass, over nearly or quite the entire area of Montana, and probably much more widely." §

174. The evidence concerning the periods in the formation of the mountains, however, is as yet by no means complete; and it is certain that elevatory movements antedating all these above mentioned, have taken place. Disregarding those which had effected the Eozoic rocks previous to the deposit of the next oldest sediments known in the west; we find at least one break in the series at the base of the Carboniferous, and in different localities the Potsdam, Carboniferous limestone, Triassic, and Cretaceous are found resting on the denuded edges of Eozoic rocks, which must at these periods have formed coast lines.

175. The comparatively small total thickness of the beds representing a great part of the Palaozoic series, in the west, is remarkable, especially when taken in connection with the relatively great deposits of the Cretaceous and later ages. This, and the absence of coal deposits, even in the Carboniferous series, would tend to show that the area of dry land during the Palrozoic must have been quite small.

* Exploration of British North America., p. 115.

\& On the Perich of Flevation

\& U.S. Geol. Surv. Territ. 1872. p. 83. Qeological Report Yellowstone and Missouri Expedition., p. 5. Also, for the Black Hills and Laramie Mountains, U. S. Geol Surv. Territ, 1857-59., p. 70. 
The recurrence of magnesian rocks at so many different horizons is also noteworthy.

176. The sudden nature of the break between the nearly horizontal strata of the plains, and the crumpled rocks of the mountains, is a remarkable feature on the forty-ninth parallel. A similar peculiarity of structure has, however, been observed in other and distant parts of the range. Near the head waters of the Powder River, the Cretaceous and Tertiary beds, beyond ten to fifteen miles from the mountains, are not flexed.*

* Geological Report, Yellowstone and Missouri Expedition, p. 66. Compare also Mr. Marvin's Sections. U. S. Geol. Surv. Territ., 1873. 


\title{
C H A P E R I V.
}

\section{CRETACEOUS AND TERTIARY ROCKS OF THE VICINITY OF THE FORTY-NINTH PARALLEL-PEMBINA ESCARPMENT TO WOOD MOUNTAIN.}

\begin{abstract}
Cretaceous Rocks. - Pembina Escarpment--Niobrara group-Fossils of the Boyne River-Pembina Mountain group-Rocks near the Boundary-line-Sections in Pembina River--Sections in Long River-Thickness of beds exposed-Lithological character-Lignite Tertiary Rocks on the Souris River-Driftcovered region-La Roche Percée-Section on Short Creek-Sections west of Short Creek-Sections near Wood End-GAP IN THE SECTION ON THE Boundary-line-Ligntte Tertiary. Rocks'of Great Valley and Pyamid CreEk-Sections on Great Valley-Sections on Pyramid Creek-Lignite Tertiary Rocks on Porcupine Creek-Eighteen-foot lignite bed-Lignite Tertiary Rocks on the Traders' Road.
\end{abstract}

\section{Cretaceous Rocks of Pembina Escarpment, Pembina River, and Long River.}

177. On leaving the Lake of the Woods, and proceeding westward, the face of the country is found to be thickly covered with drift and alluvial deposits. The Silurian limestones, which probably exist at no very great depth, are not observed, and the first rocks seen are those of the Cretaceous formation, along the base of the escarpment known as Pembina Mountain, which bounds the Red River Valley to the west. From this point westward to the base of the Rocky Mountains, no rocks older than the Cretaceous are found. The beds of this series are seldom well exposed in the eastern part of the prairie region lying north of the forty-ninth parahlel, and the information acquired concerning them by the few previous explorers has, in consequence, been fragmentary and inconclusive, though great areas of country have been traversed.

178. About twenty-five miles north of the Line, where the Boyne River cuts through the Pembina Escarpment, beds occur clearly referable to the 3r(d or Niobrara division of Meek and Hayden's Upper Missouri section. (\$33.) Though unable to visit this very interesting locality, I have receiverl specimens of the rocks, through the kindness of Mr. A. L. Russell, which exactly resemble those coming from the Niobrara division in Nebraska, both lithologically and in the nature of the included organic remains, 
179. The rock is a cream-coloured, or nearly white limestone, breaking easily along horizontal planes, parallel to the surfaces of the shells of Ostrea and Inoceramus, of which it is in great part composed. The Inocerami are too fragmentary to admit of specific identification, and have served as supports for the oysters, which still, in many instances, alhere to them. The oysters, apparently, all belong to a single species, and are identical with the Ostrea congesta of Conrad, so characteristic of the Niobrara limestones further south.

180. These larger shells are imbedded in a soft, whitish, earthy matrix, which is found, when microscopically examined, to consist almost entirely of the more or less perfect remains of Foraminifera, Coccoliths and allied organisms; together with the small irregular prisms arising from the disintegration of Inocerami. The Foraminifera represented are : Textularia gibbosa D'Orb. Var. globulosa Ehr. Textularia agglutinans Var. pygmoea D'Orb. Planorbulina globulosa Ehr. Planorbulina farcta Var. ariminensis D'Orb. Globigerince referable to $G$. cretacea, also occur though not abundantly. All these I have also identified in specimens of the Niobrara limestone from Eau qui Court in Nebraska. The first named species was found by Ehrenberg in the Brighton and Gravesend chaik, being one of the commonest forms in the latter. It also occurs in the Meudon chalk of France, and is still living in the Mediterranean and elsewhere, at depths of from fifty to one hundred fathoms. The second textularine form is closely allied to, if not identical with, one found in the English chalk, and is common at the present day in the North Atlantic and elsewhere; becoming, howerer, rare and small at great depths, and apparently most at home at a depth of about ninety fathoms in the latitude of England. Planorbulina globulosa is common in the modern ocean, and in the North Atlantic is best developed from the shore-line down to fifty or seventy fathoms. The specimens from Manitoba resemble those from the greater depths in being considerably flattened. The second rotaline form is abundant in the English chalk, in that of Möen, Denmark, and doubtless elsewhere ; and is also found in Tertiary and recent deposits. (Plate XVII., Fig. 2, in Appendix.)

181. The general facies of the foraminiferal fauna of these Cretaceous rocks of Manitrba, as well as those of like age in Nebraska, singularly resembles that of the English chalk. Both abound in textularine and rotaline forms of similar types; the more abundant in 
both, being the form with globose chambers, and each having its rarer analogue, with chambers flatiened and more delicate.*

182. The finer part of the softer portions of the rock, is composed almost entirely of the extremely minute bodies, which are included under the general names-Coccoliths and Rhabdoliths. These are now known to belong to minute pelagic vegetable organisms. Coccoliths are abundant in most modern oceanic deposits, and have long been known to occur in the chalk of England and elsewhere, but do not appear to have been previously observed in the Cretaceous rocks of America. The allied Rhabdoliths were discovered by Dr. O. Schmidt in 1872, in the Adriatic Sea; but I do not know that they have heretofore been found in the fossil state. These very minute bodies are well preserved in the limestone from Boyne River, and run through the same set of forms as those described by Dr. Schmidt. $\dagger$ (Plate XVII., Fig. 1.)

183. The limestone, where it occurs on the Boyne River, appears to be interleaved with beds of soft clay; but the accounts $I$ have received, are not sufficiently precise to enable any definite conclusions as to its thickness or extent, to be arrived at. Its occurrence at this one locality, enables the outcrop of the Niobrara Division-or highest bed of the Lower Cretaceous series-to be defined at a point nearly four-hundred miles further north than it has previously been known, and fixes the position of a well-marked horizon in the Cretaceous rocks of the Northwest. $\ddagger$

184. In the immediate vicinity of the forty-ninth parallel, no rocks referable to the Niobrara division are found along the escarpment of Pembina Mountain, and their outcrop is no doubt concealed by the great thickness of sandy and alluvial deposits piled against its base. The beds here seen in place appear to belong to the 4 th or Fort Pierre group of Meek and Hayden, which, in their Missouri sections, immediately orerlies the last, and forms the base of the closely associated group of Later Cretaceous deposits. From the scarcity of fossils in the great thickness of beds exposed in the Pembina kiscarpment, and the want of information as to the nature of the Cretacoous beds intervening between these exposures and those of the tributaries of the Missouri, caused by the thick

- The microscopic ormanisms from this rock are described, and their relations more fully discussed, in the Canadian Naturalist., vol. vii., p. 252 ir relations more fully discussed, : Specimens since obtained by the Canadian Geological Survey, west of Lake Winnipegosis, seem to belong to the same division, and enables its uutcrop to be traced still further to the north. See Report of Progress, 1874-75.

The rocks of the Niobrara division in Nebraska, are found to yield the best quicklime of any in the State, though Carboniferous limestones also occur there. 
mantle of drift, it is impossible at present to fix this group as exactly contemporary with that defined by Meek and Hayden. I shall therefore refer to it in this Report merely as the Pembina Mountain Group; a name to which it may well be entitled, from the numerous good exposures which occur in the ravines of that escarpment, and which expresses its intimate connection with this great feature of the physical geography of the plains.

185. In the valley by which the Commission Trail ascends Pembina Mouritain, ten miles north of the Boundary-line, and not far from the wooded projection known as Point Allard; rocks of this division were met with for the first time, in a bare hill-side, which is too gently sloping and crumbled by the weather to yield a good section. The rock is a rather dark greenish-grey clay-shale, in which no organic remains appear. It holds at least one, and probably several, layers of clay ironstone an inch or two in thickness, dark brown fragments of which strew the face of the bank. The exposure must represent at least 30 feet of the strata, which appear to be quite horizontal. The ironstone is very poor, the iron in a sample examined amounting to only $19 \cdot 14$ per cent. It is almost wholly in combination with carbonic acid, and is associated with much clayey matter, like that of the surrounding beds.

186. Seven miles further west, on the second prairie plateau, of which Pembina Mountain forms the front; the Calf Mountain, so called, though only about thirty feet in height, forms a somewhat prominent feature on the plain. It appears to be an outlyer of a gently sloping ridge which runs northward from it, and may be due to the surface contour of the drift, but more probably indicates the line of outcrop of a bed of the Pembina Mountain group somewhat more resisting than the rest.

187. Where the forty-ninth parallel cuts the base of the Pembina Escarpment, rocks of this series are well shown in the almost precipitous banks of a small stream. Some feet of the upper part of the section consist of drift material, in which fragments of the underlying shale are mingled with gneiss and granite boulders. Bekow this, about forty feet of Cretaceous clay-shale are exposed, much resembling that already described, and of the same dark greenish-grey colour when freshly broken, but weathering to a lighter shade. It crumbles into little rectangular fragments by the action of the frost and weather, and the bank, even where freshly exposed, is penetrated in all dircetions by cracks with rusty surfaces. Several large lenticular septarian nodules occur in the 
section; one of them was found to be as much as six feet long, with a thickness of about two feet in the middle. The general substance of the concretions is nearly black in colour, and hard; and is composed of argillaceous matter, cemented together with calcic carbonate, and not highly ferruginous. The veins which traverse them in all directions, are composed of white and amber-coloured calcite. In certain layers of the section, well formed selenite crystals are found in great abundance. They are often several inches in length and quite transparent, and sometimes form radiating groups. Some parts of the clay-shale yield also to careful search numerous fragmentary remains of small teleostian fishes, consisting of detached scales, and bones, chiefly from the vertebral column. (Plate 18.) These organic remains are of an inconspicuous brown colour, and little altered; and from the crumbling nature of the matrix are very difficult to preserve as specimens.

188. Pembina River, where it debouches from the escarpment at St. Joseph's-a small settlement of half-breeds, a few miles south of the Line-does not show any good sections of the Cretaceous formation, its high banks being composed of drift material. I was unable to trace the rumours of the occurence of gold, coal, and other valuable minerals, in this locality, to any authentic source.* That fragments of lignite, or even traces of gold, should exist in the drift deposits of any part of this region, is not impossible; but it is more probable that the reports concerning the latter, have arisen from the discovery of iron pyrites in the Cretaceous clays.

189. The course of the Pembina River, west of the escarpment, will be seen on reference to the map. Where crossed by the Commission Trail, nearly twenty miles west of the edge of the escarpment, and about ten north of the Line, sections of the Cretaceous rocks are again found. The river, though not more than thirty or forty feet in width, here flows in an immense valley, about a mile wide, and three hundred feet in depth. The banks of the valley are remarkably abrupt and steep, and in any formation composed of harder, or less uniformly soft rocks than those of this part of the Cretaceous, would no doubt afford numerous and fine exposures. As it is, comparatively few sections are to be found, and these in the form, merely, of steep, weathered banks, in which the original stratification is not apparent till they hare been scarped down with the pick and shovel.

- Rumours prevalent at least since 1852. See Dr. D. D. Owen's Report on Wisconsin, Iowa and Minמescta. 
190. The most promising bank in this locality yielded, when thus treated, the following section:-

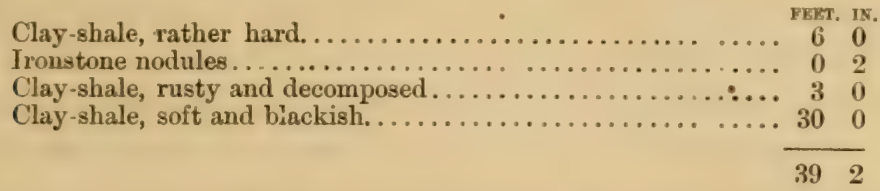

The lower shale is so soft as to merit rather the appellation of hardened clay. It is blackish in colour, from the admixture of a small quantity of carbonaceous matter, and also holds minute selenite crystals and fracmentary fish remains; the latter quite comparable with those alrearly described, in form and state of preservation. Above this is a bel of soft decomposed clay-slate, rusty in colour, and holding much selenite in small stellar groups, which are generally arranged in fissures and partings of the rock. They have been developed, no doubt, by the decomposition of iron pyrites in the bed, subsequent to its deposition, and under the influence of percolating waters.

191. The ironstone, though nodular, forms a nearly continuous sheet in some places of about two inches in arerage thickness. It is grey within and rather compact, though weathering brown and becoming soft externally: A sample examined was found to contain but $21 \cdot 78$ per cent. of metallic iron.

192. The upper portion of the section consists of harder clay-shale, which is, howerer, when freshly exposed and full of moisture, comparatirely soft, and shows little tendency to break along its deposition planes. When dried and weathered it becomes harder, and splits easily into rather thin leaves. Its colour when in the bank is sombre olive-grey, but on the surface a pale whitish-grey. It contains no fossils, unless certain hranching rusty lines, or small tubes, with which some layers penetrated in every direction, may represent fucoidal remains.

193. The lower part of this stratum is probably sixty feet abore the level of the Pembina River, and though not actually seen at a higher level in the bank at this place, it occurs at a greater elevation in other sections. Its crumbled remains also exist at a higher level near this place, and form the subsoil of the prairie wherever the surface has becn disturberl sufficiently to bring it to riew, for some distance west of the Pembina Valley. As the beds appear to be perfectly borizontal, this stratum would have a thickness, measuring upward from its batse in the section just given, of at least 240 feet. 
194. South and east of this locality, where the Boundary-line crosses the Pembina Valley, it is still more gorge-like and abrupt, and shows several sections of the Pembina Mountain beds. One of those must be over 100 feet in height, and though the softer fish-bearing shales probably occur at its base, they appear to be completely covered by the falling down of dubris from the crumbling upper beds. No nodules or bands of ironstone appear. Sereral of the ravines cutting deep into the prairie west of the river valley, and south of the Line, show more or less perfect sections of the same hard upper clay-shales.

195. About forty miles west from the foot of Pembina Mountain, expostures of beds belonging to the same group again occur in the banks of the ralley of Long River and in neighbouring coules. A cliff on the west side of Long River, some miles north of the Line, shows a considerable thickness of shale near the water level, underlying a great accumulation of drift. It is also seen at intervals for ten or twelve miles south along the river valley. It appears, as usual, to be quite horizontal, and as it is found at various levels from that of the bed of the river to the general surface of the prairie, it must still have a thickness of fully one hundred feet. The clay-shales here present exactly the physical characteristics of those of the upper part of the Pembina River sections, and also resemble them in the paucity of their organic remains. The curious rusty markings, which may be the remains of small amnelid burrows, or of fucoids, are still very common; and also other obscure rusty impressions more nearly parallel to the deposition surfaces. The mould of a small fragment of Inoceramus, which showed the prismatic structure of the shell, was found; also the flattened impression of a small naticoid shell, and other for'ms resembling broken portions of a ribbed cephalopod.

196. Obscure markings, like these, indicating the former positions of calcareous fossils, are frequently found in some layers of this clay-shale both here and at Pembina Mountain. The fossils themselves, have, no doult, been removed by the action of sulphuric acid, formed by the decomposition by surface waters of iron pyrites, contained in these little consolidated beds. The acid so produced, has attacked the calcic carbonate, converting it into the sulphate, and this has been redistributed and deposited in the fissures and more porous layers of the beds as sclenite. The clay, at the time of this action, must have been so soft as to (lose in on the cavities formed by the abstraction of the shells.

197. From this point, for over 350 miles westward, I have found no exposures of Cretaceous rocks in the ricinity of the forty-ninth parallel. 
For about 150 miles, the country is so thickly covered with drift deposits, that none of the streams cut through them to the underlaying strata; or, if the great valley of the Souris does so, they are concealed by its gently sloping and grassy banks. When the rocks underlying the drift are again seen, near La Roche Percée, they belong to the overlying Lignite Tertiary series.

198. The section seen at the crossing-place of the Pembina River, and given above, is the most instructive, as showing the line of junction of two portions of this division of the Cretaceous; of these, the harder beds, highest in the section, form the substratum of the plains for a belt at least forty miles wide, and extending westward from the front of Pembina Mountain. The lower beds characterized by their different lithological character, and the comparative abundance of fish remains; not only form the base of the Pembina River section, but are extensively developed along the front and foot of Pembina Mountain.

199. Microscopically examined, the clay-shales of the lower series are seen to consist of fine argillaceous matter, with some siliceous grains, not much rounded by attrition. No minute organisms are visible, and the rock does not effervesce when treated with an acid; proving the entire absence of calcareous matter. The upper and harder clay-shales from Pembina River and Long River, show almost exactly the same characters. Siliceous particles are more abundant, but of smaller size, and more uniform; and no effervescence is caused by acid. Both rocks contain small quantities of bituminous or carbonaceous matter. When heated they blacken, and that of the lower division sometimes even sustains a small flame for a moment. When the carbonaceous matter is removed by urging the heat, a hard mass, with much the texture of biscuit porcelain, and of white, or very light dun-colour remains. Some layers of these fine Cretaceous clay-shales would yield excellent material for the manufacture of pottery.

200. These rocks, though so barren palwontologically; are of interest from the great area which they must underlie, and the very great rarity of their exposures. The upper portion of the Pembina Mountain series, must have a thickness of at least 300 feet, and taking into consideration the gentle westerly dip which the Cretaceous rockis probahly possess throughout all this region, and which timally carres them moler the Tertiary, it may be much more. Of the lower portion, it is impossible to speak with certainty, but it is probable that a thickness exceeding 100 feet was seen in the various sections examined. It is not pretender that the 
division into two parts above indicated, is so distinct as to be of much stratigraphical importance, or of a nature to be constant over great areas. It expresses merely the composition of the series at the Pembina Mountain localities.

\section{Lignite Tertiary Rocks on the Souris River.}

201. In proceeding westward across the drift-covered region above referred to, the upper beds of the Cretaceous are passed over. The Lignite Tertiary rocks next appear, and are first seen in the valley of the Souris River at a point 250 miles west of the Red River, and about four miles east of the tributary from the south known as Short Creek. These beds may underlie the prairie some distance east of this point, but the banks of the Souris Valley near this place show a remarkable change, presenting numerous exposures of the Lignite Tertiary to the west, while eastward they are gently sloping and grassed from top to bottom. This change probably coincides with the eastern edge of the Tertiary basin. The line of junction runs north-westward, and from the contour of the surface of the country, and other considerations, I have been led to indicate it on the map as crossing the Boundary-line near the 230 mile point.

202. From the point where the Lignite Tertiary beds are first seen, exposures oceur at frequent intervals in the banks of the Souris Valley, westward, to the position occupied in the summer of 1873 by Wood End Depot Camp, a distance of about twelve miles by the Line, and considerably more by the river.

203. The hard sandstones of the base of the Lignite Tertiary, fringe the Souris Valley near the mouth of Short Creek, and give it a picturesque alppearance. These are not, however, the very lowest beds of the formation, as some miles east of this point, and underlying the sandstones, whitish and purplish clays, and arenaceous-clays occur; and in one place, a small bed of lignite was found.*

2utin 201. On the south side of the Souris Valley, and a short distance to the rast of the valley of Short Creek, the Roche Percée group of rocks is situated. This locality has already been described by Dr. Hector and Calptain Palliser, who made a branch expedition to it from the north, in

\footnotetext{
2. The sections and details of exposures of the Lignite Tertiary rocks of this part of the Souris River, nuel 11 - I waril to the $39: 3$ mile puint, were published in a separate form, as a part of the Report of Progress

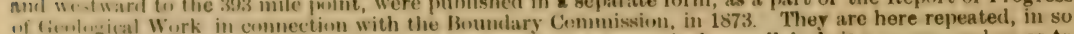
of timlecical Work in connection with the Boundary Commission, in 1873 . They are here repeated, in so fullow the general order of doscription, from east to west,
} 


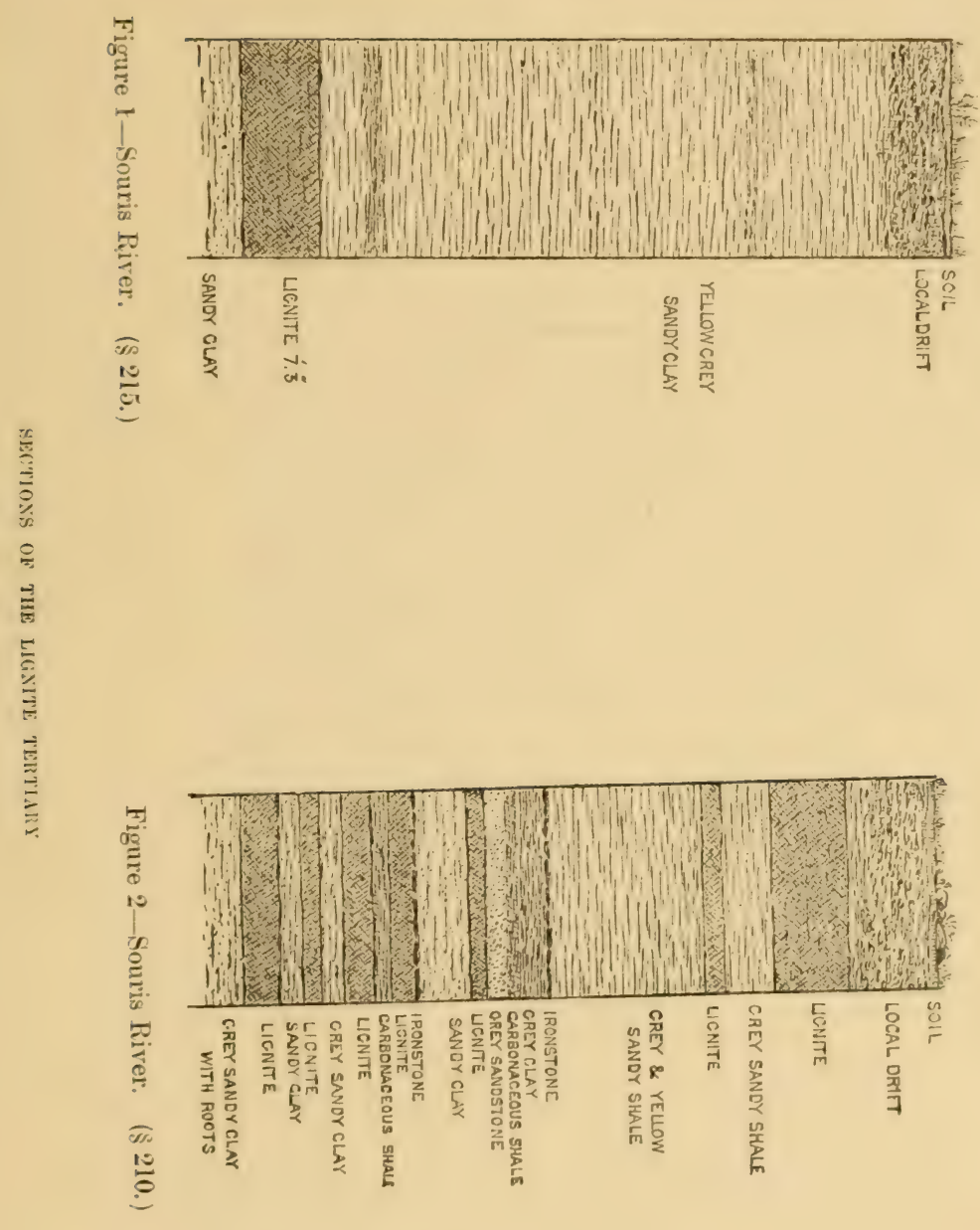



August, 1857, being induced to do so by the reports of Indians and halfbreeds.* These remarkable rocks, which have long been objects of superstition to the Indians inhabiting the surrounding country, owe their curious forms to the weathering away of a soft grey sandstone firom below a bed of similar rock which weathers yellow, and is rendered durable by an abundant calcareous cement. Both the upper and lower sandstones show false-bedded structure in great perfection; though that in the upper hard portion, is on a smaller scale, owing to the thinner divisional planes of the rock. The capping sandstone is not harlened in a perfectly uniform manner, but in belts several yards in width, lying parallel in a north-west and south-east direction, and separated by spaces more easy of disintegration. There is also a system of cross-jointing nearly at right angles to this main direction.

205. This combination of structures has given rise, under the long continued action of the weather, to the remarkably castellated, fantastic and picturesque rock scenery of this part of the Souris Valley. The hard belts form tongues projecting diagonally from the grass-covered bank, and the erosion of the underlying soft sandstone, parallel to the cross joints, has, in several places, produced window-like openings through them. The soft rock bear's in many places, rude Indian carvings, representing various animals and birds, strings of beads, \&c.

206. Short Creek, already mentioned as an affluent from the south, shows many sections of the lignite strata. The banks of the stream have assumed the most picturesque forms from successive landslips, and are often quite red in colour from the alteration of the clays by the burning of lignites. One of the most perfect sections is on the left bank, near the crossing place of the Commission Trail, and extends from the level of the prairie almost to the water of the stream. [Plate t, Fig. 2.]

1. Soil

2. Yellowish coherent sand, grey externally, and holding some much broken Unio-like shells at its base........ $12 \quad 6$

3. Grey clay ................................ 210

4. Yellowish and greyish thin-bedded sands and sandy clays, with several very thin ironstone layers, weathering orange-red externally ..................... 6

5 . Grey clay..................................... 24

6. Similar to No. 4, with decryed fragments of gasteropodous shells. ................................ 120

7. Also similar to No. 4, but with a great number of thin ironstone sheets........................ 30

8. Hard yellowisk sandy clay, a few inches at the top carbonaceous............................... 10

- Exploration of British North America, pp. 49 and 225. 


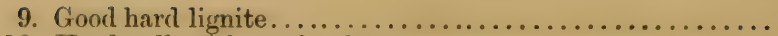

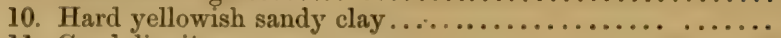

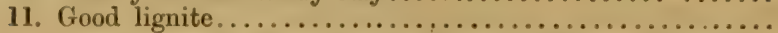

12. Greyish sand and sandy clay, showing lines of stratification-in some places soft and incoherent, in others with large concretions, and sometimes forming a nearly solid sandstone .................................

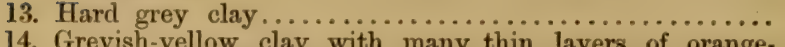

14. Greyish-yellow clay with many thin layers of orange-

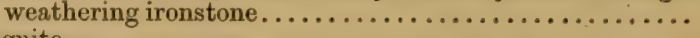

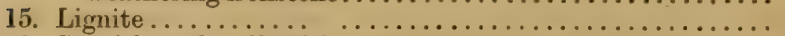

16. Greyish and yellowish hard sand and sandy clay......... Section concealed by slope of detritus, about............

\section{$\begin{array}{lll}9 & 0\end{array}$ \\ 20 \\ 30 \\ 26

Small spherical ferruginous nodules, resembling bullets, occur in considerable number at the foot of the bank. They have a calcareous cement, and are derived from one or other of the sandy layers. This exposure is remarkable for the very gentle graduation of one bed into the next, making it almost impossible to draw lines between them in a measured section.

207. Sections more or less perfect are exhibited in many places in the Souris Valley, a mile or two west of the entrance into it, from the south, of Short Creek; and more especially on the north side of the valley. They show a great similarity, though not absolutely the same in any two places. One of the most perfect exposures seen was in the face of a bank from sixty to seventy feet high, and consisted of sand, sandy clays, and hard fine clays, very regularly and perfectly stratified, and coloured in various shades of yellow-grey, grey, and light drab. At two different levels harder sandstone layers of small thickness were seen, and also three distinct beds of lignite. The lowest is a hard compact lignite resembling cannel coal in aspect, and two feet three inches thick. A few feet above this a second seam, eighteen inches thick, occurs, and still higher in the series, and about half-way up the bank, a third, of the same thickness. At the top of the bank some large nearly spherical sandstone nodules rest, and have evidently been derived from a superior bed which has been removed by denudation. The clays, and arenaceous clays, at several different levels include remains of mollusea, but these are very fragmentary, having been crushed by the compression of the containing material. A species of Unio is abundant, and remains of gasteropoda also occur, though rarely, and in poor preservation.

208. On the opprosite side of the Souris Valley-which is here of considerable width-and not far from the last mentionod section, soft sandstone beds, capped by a harder layer also of sandstone, weather into 
table-like forms. These beds are doubtless the representatives of those which, a few miles eastward, produce the Roche Percée.

209. Six miles north from Wood End Depot, on the bend of the river, the following section occurs :-

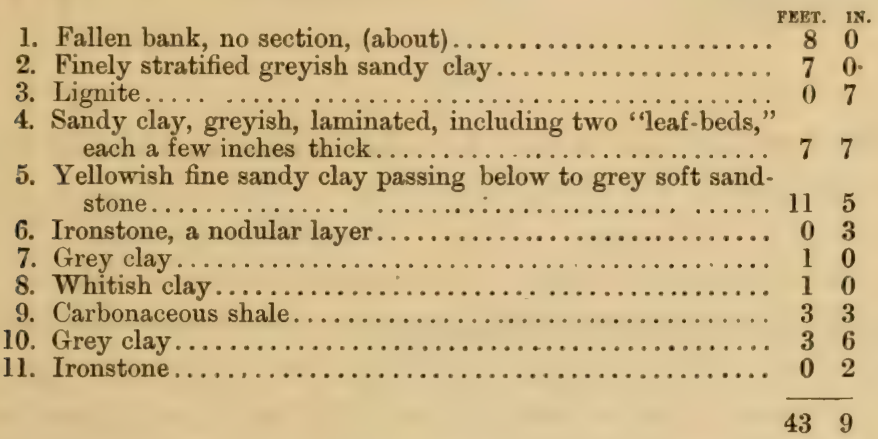

The beds appear to be perfectly horizontal. Those of sand and arenaceous clay, though having the appearance of well characterized layers at a little distance, and giving the banks a ribboned aspect, are found, on closer examination, to pass almost imperceptibly into each other. This peculiarity is often to be observed in almost all localities where these rocks are found. The so-called "leaf-beds" are of a greyishpurple tint, and contain many impresssions of flag-like parallel-veined leaves, which, though distinct enough when freshly taken from the bank, it is impossible to preserve on account of the crumbling nature of the matrix. The ironstone, though generally forming extensive sheets, is nodular in structure, and varies a good deal in thickness. It weathers a bright brownish-red, is hard, compact, and rery heavy, and on fresh fracture is bluish to yellowish-grey.

210. A short distance south of this locality, the bank shows the following section very perfectly :-(Plate 3, Fig. 2.)

Prairie sod.

YEET. IN.

1. Mixed shale and drift.................... 70

2. Lignite $\ldots \ldots \ldots \ldots \ldots \ldots \ldots \ldots \ldots \ldots \ldots \ldots . \ldots \ldots$

3. Greyish sandy shale (about) .................. 4 0

4. Lignite .............................. 16

5. Greyish and yellowish well-stratified fine sandy and shaly

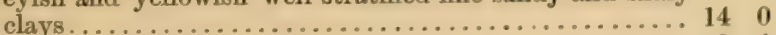

6. Ironstone (nodular)................................ 0

7. Greyish and whitish clay.................... 20

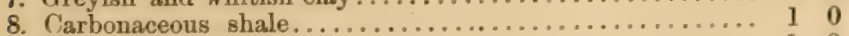

9. Grey soft sandstone....................... 18

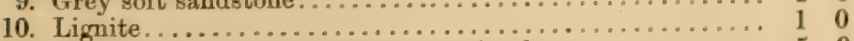

11. Grey and yellowish laminated sandy clay ........... 50

12. Ironstone (nodular) ......................... 0 


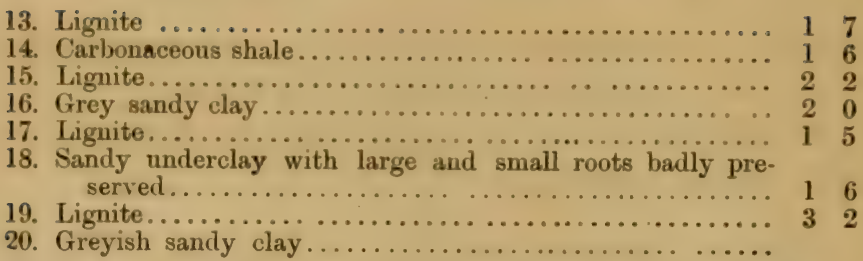

The lower lignite beds are of excellent quality, firm and compact, and in some places show spots of fossil resin. The structure of the component wood is also in many instances very plainly apparent. The upper lignite lying immediately below the surface, is soft and decomposed where exposed, being in many places penetrated by roots from above. It might, however, prove equally compact with the lower beds where undisturbed. Layer 18, is one of the few instances in which lignite was observed to lie upon an erident underclay with roots. The ironstones are specially good and compact in this section. Owing to the wearing away of the softer strata a large quantity of this material strews the surface of the hillside.

211. This section does not seem to correspond at all with the last, though situated only a few hundred yards from it; and if no fault or break in the strata interrenes-and there is no appearance of any suchthe horizontal uncertainty of the deposit must be very great. Fragments of a vesicular material, resembling scoriaceous lava, are abundant in this locality. The substance is produced by the combustion of the lignite beds, a phenomenon which receives attention on a subsequent page.

212. Nearly three miles southward from the last mentioned locality, in following up the valley, another very good section occurs on the east side of the stream, where in one of its many devious windings, it has undermined the bank. This section is specially interesting, as affording one of the best localities for the collection of shells of Mollusca characteristic of the formation. The section is as below, measurements being estimated :

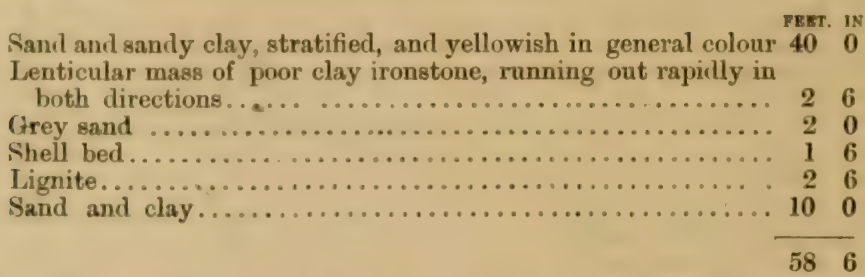

213. The shell bed, is of hard grey sandy clay, and in some places is 


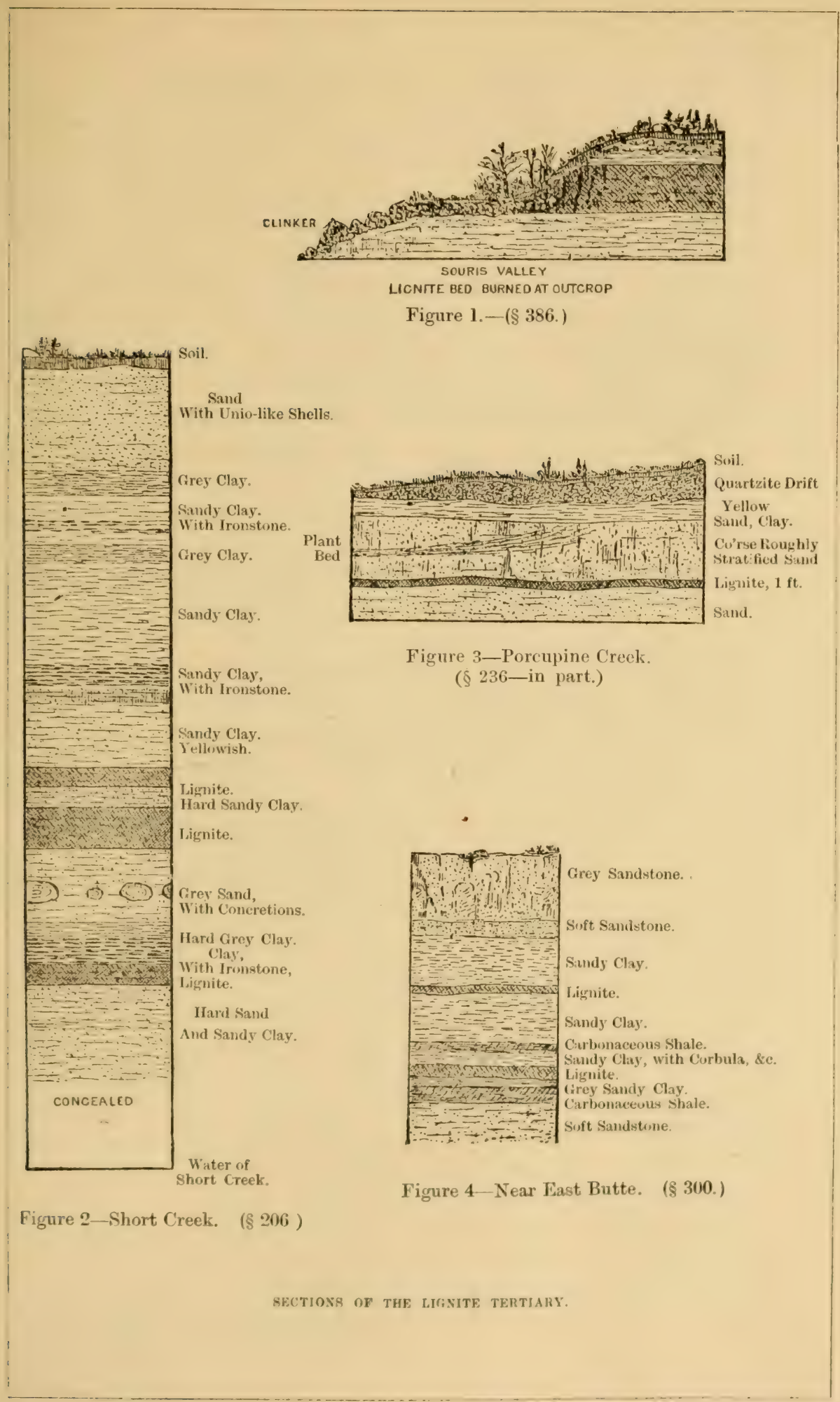



very full of shells, which are also less crushed and in a better state of preserration than is usual in this formation. The most common Mollusc is Melaniu Nebrascensis M. \& H., which occur's in all stages of growth, and several varietal forms. There is also a second species of this genus, or of Goniobasis; fragments of Unio and Paludina; and a few examples of Corbula (Potamomya) mactriformis M. \& H. The latter must be considered a brackish-water type, but with this exception, no brackish or salt water forms are found in these sections of the Souris Valley. The Mollusca exactly resemble those of the Fort Union or Great Lignite Group of the Missouri, and fix with certainty the stratigraphical position of the beds here represented.

214. In the water of the stream, at this place, are several large spheroidal sandstone concretions which have a tendency to split into layer's parallel to their flattened surfaces-one of them measuring four or five feet in diameter. These do not appear in the bank, but possibly may have been washell out of the lower part of the section, which was not so clearly shown.

215. South of the last section, and about one mile nearly due north of the position occupied by Wood End Depot, an exposure, showing the most valuable dignite bed I hare seen in the Souris Valley, is situated. The beds are arranged thus:-(Plate 3, Fig. 1.)

1. Drift material, (about) $\ldots \ldots \ldots \ldots \ldots \ldots \ldots \ldots \ldots \ldots . .8 \%$

2. Yellowish and grey stratified sandy clays, obscured in most

3. places by slips of the bank. ............... $52 \quad 0$

4. Grey soft arenaceous-clay .................... 1 or more.

216. The bottom of the lignite is about twenty-five feet abore the level of the river below, and this part of the section, though apparently consisting of yellowish sandy clays like those overlying it, is obscure. The lignite is continuously visible for at least two hundred feet along the face of the bank, and seems to preserve uniformity of character and thickness. Fxternally it is often crumbling, and mixed with clay which has penetrated its joints from above; but where freshly exposed, it is hard and compact. It is quite black on freshly fractured surfaces, but has a brown streak, and in many places the structure of the original wood is still quite discernible. Some surfaces are strewn with fragments of mineral charcoal like that found in many true coals. Other specimens are apparently structureless, and resemble cannel coal in appearance, though not in composition. The upper beds of arenaceous clay yield a few poorly preserved shells (Paludina, \&c.) 
217. On the opposite side of the river valley, near this place, the upper part of the bank shows a grood rection of arenaceous clay, below which, and some fifteen or twenty feet below the prairie level, is a seam of lignite of good quality, fortr feet in thickness. This lignite bed would seem to occupy a position stratigraphically superior to the last.

218. Somewhat further up the stream, and on the same side of the valley, about sixty feet below the prairie level, and sixteen feet above the river, a bed of lignite occurs, of which the upper three feet only are visible. The bank above it is not well exposed, but appears to consist of sandy clays. The lignite is of good quality, but much weathered at the out-crop. It may very probably represent the continuation of that of the last section.

219. The whole of these deposits, though in some places showing a dip amounting to a few degrees in one direction or other, appear to have no determinate direction of inclination, but over large areas to be as nearly as possible horizontal.

\section{Gap in the Section on the Boundary-line.}

220. West of Wood End, the Souris Valley runs north-westward along the base of the Coteau, diverging rapidly from the Boundary-line. It loses, at the same time, its abrupt character, and no sections either of Tertiary or Cretaceous rocks occur on it for a long distance. In following the forty-ninth parallel, the escarpment of the third great prairic level is overcome, and it is not till after having passed through the broken Coteau belt, and reached the Great Valley, that exposures of the underlying rocks are again found. This valley is the most eastern great channel of erosion which crosses the Line southward, towards the Missouri, and in it the beds of the Lignite Tertiary are exhibited on a grand scale. On the Boundary-line, thus, a space of eighty-two miles from the 263 to the 345 mile point, is completely shrouded by drift deposits. There is every reason to believe, however, that the Lignite Tertiary beds stretch uninterruptedly between the two localities, and an exposure of these rocks, some distance north of the Line, helps to sustain this view.

221. This small exposure of the Lignite Tertiary was discovered at a locality on the meridian of the 307 mile point, but nearly twenty miles north of the Line; where the Trader's load to Wood Mountain, in going westward, crosses the Souris for the second time. Of the rocks at this place a very small rection is seen, but sufficient to correlate them with 
those to the east and west. At the water's edge, about eighteen inches of a bed of lignite appears, the bottom of the bed being concealed. It is overlaid by several feet of greyish sandy clay, of rather fine texture. The lignite exactly resembles those deseribed as occurring at Wood End, and in some places shows spots of amber.

222. Retween Wood End and Wood Mountain-(Long. $103^{\circ} 10^{\prime}$ to $106^{\circ} 30^{\prime}$ ) - the country was examined on two lines; the first nearly coinciding with the forty-ninth parallel, the second following the Traders' Road above mentioned, and at its furthest northerly point being thirtyeight miles from the Line. In describing the geology of this region, the general plan of taking localities in succession westward, will be in so far departed from as to allow the description of these in the immediate vicinity of the Line, before mention of those further to the north.

\section{Lignite Tertiary Rocks of the Great Valley, and Pyramid Creek.}

223. In the gorge already referred to as the Great Valley, the beds exposed are at an elevation of about seven hundred feet greater than that of those last seen on the Souris, near Wood End; and probably at least six hundred feet above those of the northern locality (\$221.) Their exact relation to either of these stratigraphically, it is, however, impossible to determine. The lowest beds seen are curiously banded clays and shales; clay beds charged with plant remains and carbonaceous matter, and having quite a purple tint when viewed from a little distance, alternating with clays nearly white, and yellowish sandstones. Above these is a sandstone layer which though of no great thickness, has in several places produced remarkable conical mounds by acting as a protecting capping for the softer strata below, the latter forming slopes or nearly perpendicular steps, according to their relative hardness, which, taken together with the distinctive colouring of the beds, gives a very striking aspect to the scenery. Plate 6, which is accurately copied from a photograph, gives an idea of the peculiar weathering of these berls. Above the sandstone capping of this lower part of the section, is a great deposit of sandy clays and concretionary sandstones, among which three beds of lignite of various thicknesses are intercalated. The beds are almost horizontal, but undulate at low angles, and the valley of the stream appears to occupy, in the main, the centre of a shallow synclinal fold.

224. The upper part of the section in this valley consists of at least 100 , and probably 150 feet of clays and argillaceous fine sands of greyish 
and yellowish-grey colours, and well stratified. They contain thin leafheds at sereral different levels, which are prominent from their greypurple tint; but though containing very many dicotyledonous and flas-like leaves, from their soft and crumbling nature, they do not yield determinable specimens.

225. This pirt of the section also includes at least three lignite beds. The highest of these is about 140 feet above the base of the section, and three feet or more in thickness. It would appear to be of fair quality, though much decomposed and quite crumbling at the out-crop, from the action of the weather. The next is about 120 feet above the same datum, and can be traced a very considerable distance along the face of the bank. It is five feet in thickness, but includes, where examined, several thin layers of carbonaceous shale; and, though of good quality in places, does not appear to have the same uniformity in the rarious layer's that is generally found in the coals of this region. The lowest lignite is some seventy-five feet above the base of the section, and is only a few inches in thickness.

226. The complete section may be thus represented:-

1. TEET. IN.

1. Upper part, yellowish sands and clays, lignites, \&c. . . . 1500

2. Hard grey and yellowish, somewhat false-bedded sandstone, forming a "capping rock" to beds below (about) 30

3. Greenish-yellow, thinly bedded fine sand ........... 150

4. Soft yellowish sandy clay ................... 24

5. Greyish and yellowish hard bedded clay............. 2

6. Blackish thin-bedded clay or shale with plant remains... 50

7. Greyish thin-bedded clay, becoming darker toward the top (plant remains) graduating into next bed........... $10 \quad 0$

8. Hard, pale-brown, compact clay, with very few plant re-

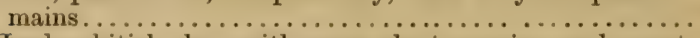

9. Hard, whitish clay, with some plant remains, and a scattered layer of heavy ironstone balls about a foot from

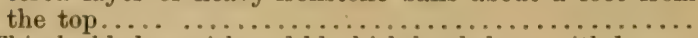

10. Thin-bedded greyish and blackish hard elays, with leaves, and some small groups of selenite crystals...........

11. Fine-bedded clay filled with leaves and plant remains, hard and rusty in the upper portion............. I 8

12. Grey hard sand, with charcoal-like fragments in some

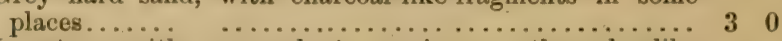

13. Ironstone with many plant remains, mostly sedge-like blades............................. 0 . 3

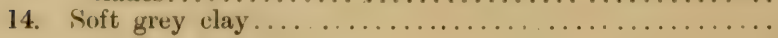

227. In certain parts of the upper portion of this section, the remains of Mollusca occur in some abundance, but in a very bad state of preservation. By diligent search, howerer, some specimens of Melania Nebrascensis were obtained; and also of a peculiar angular Paludina of 
the type of Paludina (Vivipara) trochiformis, M. \& H. No shells, other than those of purely fresh waters, were found.

228. The lower part of the section forms a group well distinguished by its colour and the perfection of its stratification from the upper, and often endures, protected by its hard sandstone (No. 2), when the more crumbling upper division has been removed. The plant remains, though occurring more or less throughout the whole section, are best preserved in the lower purplish layers. They consist chiefly of leaves of dicotyledonous trees, which appear to have fallen when mature, in the course of nature, and with the change of the seasons, and floated without violence to the great lake in the fine silty deposits of which they have been preserved. Populus, Cinnamomum, Quercus, and other forms, are represented. Leares and small branches of coniferous trees, referable to Sequoia Langsdorfii, and Gilyptostrobus Europeus, are particularly abundant at this place. Details concerning the fossil plants of the Lignite Tertiary, will however, be found on a subsequent page.

229. Many of the crumbling hill-tops in this valley have a brick-red colour resembling that seen in parts of the Souris Valley, and due, as there, to the combustion in situ of the deposits of lignite. The slag or clinker produced by this action is also found here, though it was not observed actually in place.

230. The next stream crosses the Line at the 351 mile point; it also flows through a deep valley of erosion, and may be called Pyramid Creek, from a remarkable pyramidal hill formed of the usual clays and sands, capped by a portion of a layer of hard grey sandstone, the cement of which is calcareous. It has a tendency to break into large quadrangular maswes along intersecting jointage planes, and shows conspicuous falsebedded structure. Below this is a thickness of about fifty feet of rather incoherent fine yellowish sand sometimes argillaceous. This, producing a sloping bank, is not very well seen, but constitutes about one-third of the thickness of the beds exposed in this valley. The middle third consists of soft crumbling sandstone or compact sand without any apparent cementing matter, and of which the constituent particles are rather coarse; contrasting strikingly in this respect with the overlying material. It shows evidence of having been deposited by water in rather rapid motion, through its entire thickness, but the false-bedding is very definitely cut off at many different horizons by perfectly horizontal planes, alove which it again commences. The weather acting on these beds causes the hill sides composed of them to assume a well-marked 
terraced appearance, on a small scale, each horizontal break producing a terrace level. The sandstone contains here and there a few poorlypreserved shells, among which can be recognized two species of Melania, fragments of Paludina and of Unio. In one place a layer of ironstone, about three inches thick, is seen to r'un for some distance. The most notable feature, however, of this part of the section is the remarkable concretionary character of some layers of the sandstone. The concretions are hard, and of all shapes and sizes. They are generally spherical or spheroidal, and two or more of them are often confluent, forming dumb-belllike masses or more or less continuous sheets of a lumpy character. Many are long and root-like, and project in a singular way from the bank.

231. The lower third of the section in this valley is-as seems often to be the case with the lower layers of these rocks,-much more clearly defined, and divided into thinner beds in which dark colours predominate. Altogether the section here much resembles that seen in the last great valley; the lower beds of this probably correspond with the purplish leaf-beds there, and the great thickness of sands and sandstones above, correspond in a general way; though in this place they differ in the absence, so far as could be ascertained, of beds of lignite. The layers of hardened sandstone must also in this case occupy different horizons in the two sections, but this is not to be wondered at, when the extremely local, and indeed often nodular character of the induration is considered, and the fact that it merely depends upon the introduction of a small proportion of calcareous cement among the particles already compacted by pressure.

232. The whole section in Pyramid Valley may be represented thus:

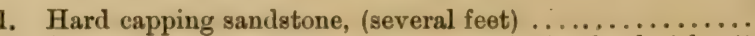

2. Soft yellowish sandy beds, forming a sloping bank, (about) $50 \quad 0$

3. Soft sandstone, grey, false-bedded, (about). ..........5 50

4. Stratified sandy clay ...................... 30

5. Purplish plant beds with thin layers of lignite, and much selenite in thin sheets, isolated crystals and stellar groups .................................... $3 \quad 0$

6. Lignite, with many spots of amber.............. 1

7. Purplish bed, with a few plants ..................... 20

8. Grey slightly coherent sand, with nodules of arenaceous selenite crystals .......................... 40

9. Purplish bed, with obscure remains of leaves. .......... 1

10. Incoherent arenaceous clay and sand ................. 70

11. Purplish-grey arenaceous clay, with obscure plant remains and some fossil wood ......................... 30

12. Brownish clay with ferruginous layers............... 6

13. Lignite ...................................... 10

14. Brown earthy bed ............................. 0

15. Grey somewhat coherent coarse sand, with argillaceous matter ................................ 120

About.................. $144 \quad 0$ 
The rocks show no well marked dip, but appear to undulate slightly at very low angles.

233. The occurrence of gypsum as selenite was observed, here and elsewhere, to be nearly always in association with plant-beds, and generally with those holding many half-obliterated vegetable remains, and of a purplish shade. This association is not accidental, but brought about by the action of the included vegetable matter, which when still undergoing decomposition, would facilitate the deposition of iron pyrites by the deoxidation of iron compounds in presence of organic sulphur compounds. The porous character of the plant-beds, at a subsequent period, would allow the passage of surface waters containing oxygen; leading to the decomposition of the pyrites, the formation of sulphuric acid, and by its action on the clays, of selenite or calcic sulphate.

234. A few miles west of Pyramid Creek several hills are capped with heavy and hard sandstone beds, a feature quite exceptional in a country so gently undulating. These do not appear to be perfectly horizontal, but have a slight dip to the west. They may be equivalent to the capping sandstone of the Pyramid Hill, but more probably are yet higher in the series.

Ten miles west of Pyramid Valley, in the upper part of the valley of another stream, yellowish and grey stratified sandy clays, are again seen, but are not perfectly exposed.

With the exception of this exposure, the underlying rocks are nowhere clearly visible in the vicinity of the Line from Pyramid Valley to Porcupine Creek, a distance of about thirty-five miles. One very considerable stream is crossed about midway, but its valley is wide, and with gently sloping banks. Highlands appear to the north, and maty possibly show sections of strata overlying those seen in the banks of the streams, but I was unable to reach them, the ground, especially in the vieinity of these highlands, being covered with snow, and the time at my disposal limited.

\section{Lignite Tertiary Rocks of Porcupine Creek.}

235. In Porcupine Creek and the tributary vallies, many partial sections occur. Lignite is seen in three places near the Line, and just above the level of the brook in each instance. The expostres seem to belong to the same bed, and if so, nearly a mile of its horizontal extent 
can be traced. The lignite and associated beds undulate slightly in all the sections, the former decreasing from four feet in thickness in the most northern bank, to one foot in that furthest south. The overlying rocks consist of yellowish and grey sands and clays, well stratified, and much resembling those forming the upper part of the section in the Great Valley. (Plate IV., Fig. 3.)

236. The best exhibition of these strata was obtained in a bank about forty feet in height, on removing the decomposed material from the surface. The section was carefully measured as follows:-

1. Soil.

RRET. IN

2. Quartzite drift, several feet.

3. Soft greenish sandy clay, 2 feet or more.

4. Soft blackish clay ........................ 16

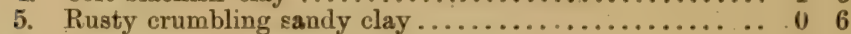

6. Grey clay, with some plant remains.............. 90

7. Grey clay, with well preserved dicotyledonous leaves.... 18

8. Impure ironstone in concretions ................ 0

9. Yellowish sand and sandy clay, with obscure plant remains ........................ 90

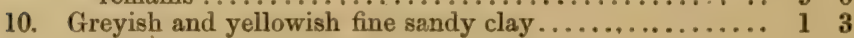

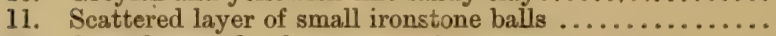

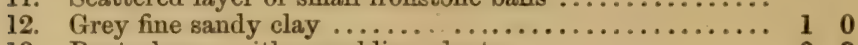

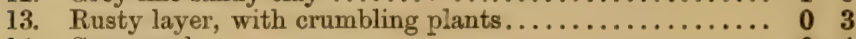

14. Grey sand ......................... 04

15. Detached masses of lignite showing the form of flattened tree trunks, about ............................ 04

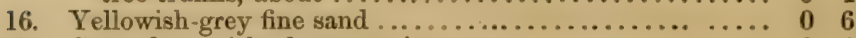

17. Grey clay, with plant remains................ 04

18. Lignite, not of best quality. The grain and form of component wood generally clearly perceptible. Bed undulating slightly. 3 to 4 feet.

19. Soft grey arenaceous clay, 1 to 2 feet.

About......................... $\overline{31 \quad 0}$

237. The vegetable remains imbedded in the rocks overlying the lignite, are mostly those of deciduors trees, and in certain beds are very perfectly pieserved. Lignite from this section was used for camp fires, in the absence of wood, but did not burn very freely, as it was taken damp from the bed, and piled on tiw ground without any provision for draught from below.

238. The most interesting and important section, however, in this region, is that which occurs in a valizy joining that of Poreupine Creek from the west, exhibiting a bed of lignite eighteen feet in thickness, and yielding 'also some of the mos perfect and interesting remains of plants. The bank in which this outerep is situated is over half-a-mile outh of the Line. The beds are arranged thus:-(Plate V.) 


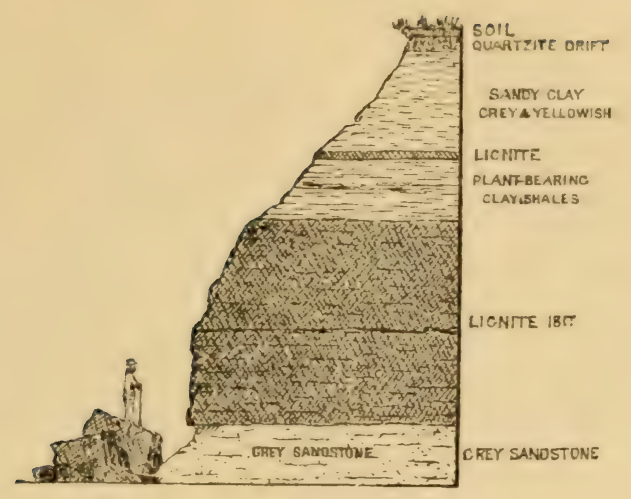

Figure 1-Porcupine Creek. (§ 238.)

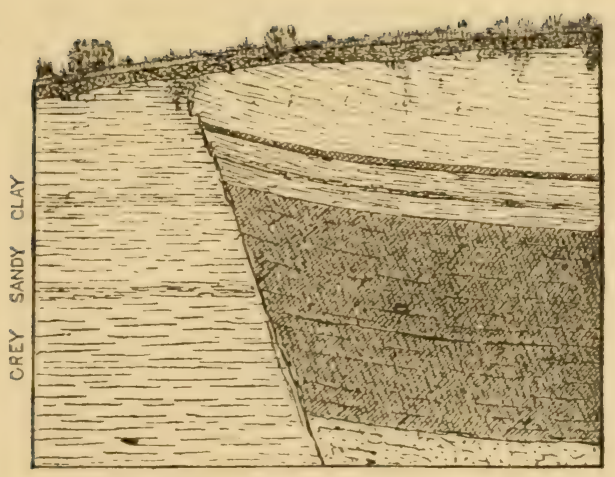

Figure 2-Porcupine Creak. (s:40.)

SECTIONS OF THE LIGNITE TERTIARY. 



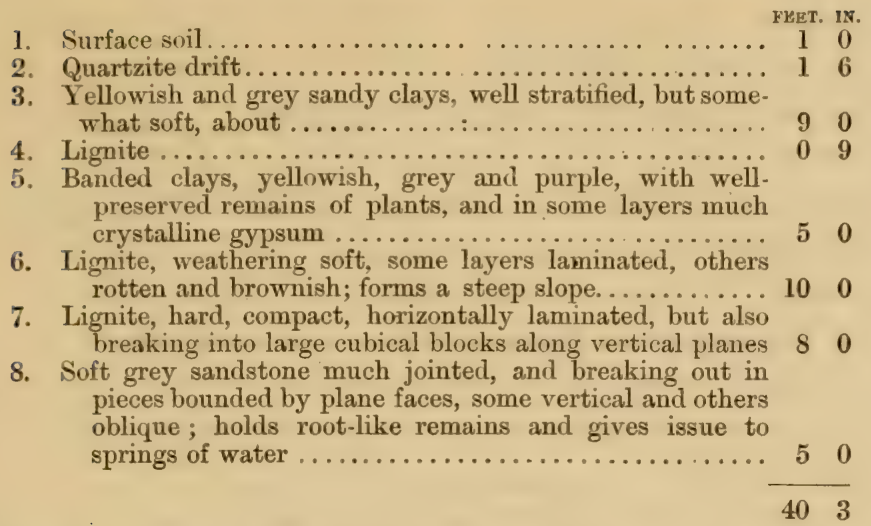

Though undulating a little, the strata have no true dip, and are as nearly as possible horizontal on the large scale.

239. The lower part of the lignite bed is very compact and tough under the pick, and holds in some layers many drops of amber. The jointage planes form a conspicuous feature, and were not noticed in anything like the same perfection, in other lignite beds examined. They cause the coal to break off in large cubical pieces which lie in the stream at its base. Some of them show thin seams of white gypsum, and in one case a thin film of iron pyrites was detected, being the first appearance of this mineral in connection with these lignite deposits.

240. This section also exhibits the first instance of dislocation, observed to effect the Lignite Tertiary formation. The eighteen-foot lignite and associated strata, are seen to have been brought to their present position by a downthrow fault, on the other side of which their place is taken by underlying sandy clays. (Plate V., Fig. 3.)

241. The southern side of the valley, opposite this great lignite bed, is broken down, and forms a gentle thoigh irregular slope, which is encumbered by many large, strangely shaped and coloured blocks of stone, much harder than any rocks ocenring in the neighbourhood, and in pieces larger than the erratics found in the region. They proved on inspection to consist of masses of beds such as those associated with the lignite, but indurated by its combustion, which has also caused the interruption in the erlece of the ralley. About a fourth of a mile east on the same valley the great lignite is again exposed, and apparently in much the same development and association.

242. The plants in layer 5 , are in a beautiful state of preservation, and when the clay is first split open, show every vein-mark in perfection, not 
only in the larger and coarser leaves but in delicate ferns, which are here unusually common. The matrix is, however, unfortunately very soft ; it crumbles easily, and tends to crack on drying. A considerable number of specimens of fossil plants from the vicinity of Porcupine Creek, have been preserved, though all in a more or less shattered condition. They are in the main identical with those of the Fort Union group, and include Glyptostrobus Europeus, Seguoia Langsdorffi, Thuja interrupta, Onoclea sensibilis, and one other species of ferr ; and examples of the leaves of many deciduous trees. For the identification of these fossils, and the notes on them which appear in a subsequent chapter, I am indebted to Principal Dawson.

No molluscous remains were found in any of the Poreupine Creek sections.

\section{Lignite Tertiary Rocks on the Traders' Road to Wood Mountain.}

243. The furthest west of the sections in the vicinity of Porcupine Creek-that in which the eighteen-foot lignite occurs-is situated near the 393 mile point on the Line, and lies about thirty miles south-east of the trading settlement of half-breeds known as Montagne de Bois, Wood, or Woody Mountain. The point above indicated was the terminal one of the geological work of the season of 1873. Reverting now to Wood End, on the Souris River, the exposures of Lignite Tertiary rocks on the Traders' Roal to Wood Mountain-which rums nearly parallel with, but to the north of the Boundary-line-require a brief notice.

244. The section first met with is that already described as filling a gap in the sequence on the Line (\$221.) Westward for about ninety miles, no beds underlying the drift and surface deposits are seen in the vicinity of the Traders' Road. Beyond this point, however, for the remainder of the way to Wood Mountain-about thirty miles-many more or less perfect exposures of the rocks of the Lignite Tertiary occur.

245. The road here follows along the northern slope of the watershed plateau, or occasionally crosses over one of its projecting spurs. The whole regrion appears to be formed of rocks of Tertiary age, against which the drift deposits of the northern extension of the Coteau, elsewhere more fully described, are found to lie.

246. The north-eastem exposure of this series is formed in a steep woorled hill, which forms the salient angle between two of the broad flatbottomed vallies, so common in this region. The section consists of alter- 
nations of sand and arenaceous clay of light-grey and drab colours, the different layers not well defined. No hard sandstone layers crop out, and the whole of the beds are of a very soft and unconsolidated nature. A seam of impure lignite, two feet in thickness, occurs. It is soft, brown in colour, and holds much sandy matter. Selenite crystals are abundant, and some thin layers of ironstone are also found. The whole appears to be quite horizontal, and the thickness more or less perfctiy displayed, must be over 150 feet.

247. The remainder of the sections from this point to Wood Mountain do not present any features of much interest, and resemble pretty closely that just described. Yellowish-grey, greyish, whitish, and drab, soft arenaceous clays, and sandstones, appear with unvarying monotony in all the scarped banks of the vallies, which here ramify in every direction. No fossils, except the badly preserved remains of plants, were found, nor were lignites of any importance observed, though some of the men on a hunting excursion, some miles south of the road, brought back samples of a fair quality. 


\title{
CHAPTER V .
}

\section{CRETACEOUS AND TERTIARY ROCKS OF THE VICINITY OF THE FORTY-NINTH PARALLEL-WOOD MOUNTAIN TO THE ROCKY MOUNTAINS.}

\begin{abstract}
Lignite Tertiary Rocks near Wood Mountain-Sections in Bád Lands South of Woud Mountain - Nature of Bad Lands-Divisions of Section-Fossil plants-Vertebrate fossils-SECTIONS WEST of THE BAD LANDS TO WHITE Mud River-Cretaceous No. 4-Fossils-White Mud River-Cretaceous Nos. 4 \& 5. - Relations of beds, White Mud River and Bad Lands-Sections West of Wood Mountain Settlement to White Mud River-Bay of Cretaceous Rocks-Tertiary Plateau-Cretaceous No. 4. with fossíls-W HITR Mud River to Mrlk River-Cretaceous plain-Tertiary Plateau-East Fork of Milk River-Section near West Fork of Milk River-Age of Beds exposed -Cretaceous plain-Milk River Valley -Sections in Milk River ValleyUpper arenaceous clays, \&c. - Sandstone Zone-Lower arenaceous clays, \&c.Milik River to the West BUTtE-Sections North of East Butte-Nature and height of the Buttes-East Butte-Igneous rocks of the Buttes-Middle Butte-West Butte-West Butre to the Rocky Mountains-Synclinal west of West Butte-First Branch Milk River-Vertebrate fossils-Second Branch Milk River-Fresh Water deposits - St. Mary River-Disturbance of BedsCoal Bed-Marine Fossiliferous Beds-Exposures nearest the MountainsSouth Fork of Belly River.
\end{abstract}

\section{Rocks near Wood Mountain.*}

248. In the immediate neighbourhood of the half-breed settlement of Wood Mountain, no good exposures were observed. Where rocks were seen, they were generally hard greyish sandstones, which protrude here and there in the sides of the hills, and banks of vallies, the softer intervening beds being concealed. These sandstones no doubt belong to the Lignite Tertiary, and probably occur at several different horizons. They have much to do with the definite shape of the watershed plateau, which but for them would probably have been but a diffuse ridge.

249. South-west of Wood Mountain, on the trail used by the halfbroeds of that place in going to Fort N. J. Turney-a trading post south of the Line-ravines cut in the southern edge of the water-shed plateau show occasional sections of the Lignite Tertiary rocks. . At nineteen miles from Wood Mountain, by odometer, the edge of the plateau is

- The name Woxd, or Woody Mountain, is sometimes used to designnte the whole, or an indefinite part, of the Tertiary watershed platem. It is here restrictod to the half-lireed settlement und its immediate vicinity. 
reached, and a few miles further on, the trail crosses the junction of the Tertiary and Cretaceous, and passes out on a lower level plain based on the latter formation. Near this place, an exposure shows several seams of lignite, one of which appeared to be of good quality and considerable thickness, though not sufficiently well exposed for measurement. This bed turns out from the bank in which it occurs, a copious spring of cold water, with a very slight ferruginous taste. The associated beds are thick arenaceous clays of purplish-brown colour; soft, and containing some selenite in crystals.

\section{Sections in the Bad Lands South of Wood Mountain.}

250. The most instructive section, however, in the Wood Mountain region, lies twenty miles south of the settlement of that name, on the forty-ninth parallel near the 425 mile point from Red River; here beds undoubtedly belonging to the Lignite Tertiary formation,-which, east of this locality, has covered so great an area of country,-are found clearly superposed on indubitable Cretaceous rocks. The exposures are numerous, and are produced by the streams flowing from the southern escarpment of the water-shed plateau, above referred to, which has here been gashed by their action into most rugged Bad Lands.

251. This term has attached to it in the western regions of America, a peculiar significance, and is applied to the rugged and desolate country formed where the soft, clayey Tertiary formations are undergoing rapid waste. Steep irregular hills of clay, on which scarcely a trace of vegetation exists, are found, separated by deep, nearly perpendicularsided, and often well nigh impassable vallies; or, when denudation has advanced to a further stage - and 'especially when some more resisting stratum forms a natural base to the clayey beds-an arid flat, paved with the washed-down clays, almost as hard as stone when dry, is produced, and supports irregular cones and buttes of clay, the remnants of a former high-level plateau. Denudation in these regions, proceeds with extreme rapidity during the short period of each year, in which the soil is saturated with water. The term first and typically applied to the newer White River Tertiaries of Nebraska, has been extended to cover country of similar nature in the Lignite Tertiary regions of the Upper Missouri, and other Tertiary areas of the west. In the Bad Lands, south of Wood Mountain, the hills assume the form of broken plateaus; degenerating gradually in to conical peaks, when a harder layer of sandstone, or material indurated by the combustion of 
lignite beds, forms a resistant capping. Where no such protection is atforded, rounded mud-lumps are produced from the homogeneous arenaceous clays. Waste proceeds entirely by the power of falling rain, and the sliding town of the half-liquid clays in the period of the melting snow in spring. The clay hills are consequently furrowed from top to base, by innumerable runnels converging into larger furrows below. The small streams rapidly cutting back among these hills, have formed many narrow steep-walled gullies, while the larger brooks have produced wide flat-bottomed vallies at a lower level, in which the streams pursue a very serpentine course. Denudation is even here, however, still going on, as from the frequent change in the channel of the stream, it is constantly encroaching on the banks of the main valley, undercutting them and causing landslips. The method of the immense denudation of Tertiary beds, which is proved to have taken place over the area of the western plains, is explained by the degradation still going on in this way along their present borders.

252. The general section at this place, which though not exposed as a whole at any one spor, is remarkably clear; is naturally divided into four parts.

Taking first the highest bed seen, the order is as follows (Plate VII., Fig. 2.) :-

a. Yellowish sand and arenaceous clay, sometimes indurated in certain layers and forming a soft sandstone. It forms the flat plateau-like tops of the highest hills seen. About 50 feet.

$\beta$. Clays and arenaceous-clays, with a general purplish-grey colour when viewed from a distance. About 150 feet.

$\gamma$. Yellowish and rusty sands, in some places approaching arenaceous clays, often nodular. About 80 feet.

8. Greyish-black clays, rather hard and very homogeneous, breaking into small angular fragments on weathering, and forming earthy banks. About 40 feet seen.

The whole of the beds appear to be conformable, and disregarding minor irregularities, are quite horizontal to the eye.

25:3 The clays and arenaceous clays of the upper part of Division $\beta$. are very regularly bedded, and include a lignite-bearing zone. Three linnite beds, of from one to two feet each in thickness, were observed, but they are separated from each other by rather wide clay partings, and are not pure or of good quality. A bed rich in the remains of plants, immediately overlies the upper lignite. It is composed of a very fine, 


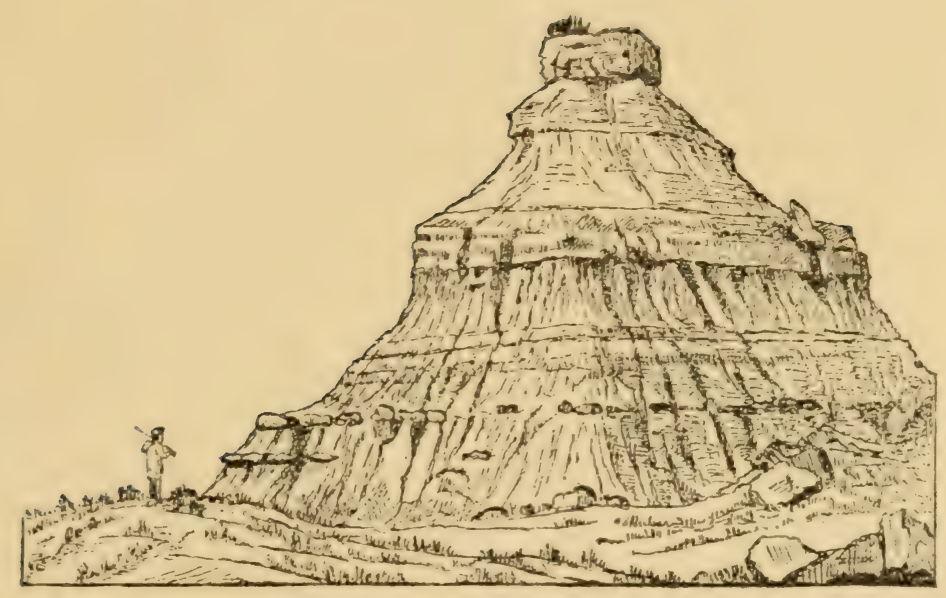

Great Valley-Weathering of Lignite Tertiary beds. (\$223.) 

and nearly white indurated clay, in which the most delicate structures are perfectly preserved. From its soft and crumbling character, it is almost impossible to obtain or keep good specimens; but, in the fragments which were preserved, a few very interesting plants appear. Of these, some are characteristic of the Fort Union group, and identical with those of Porcupine Creek. The association of remains is that of a freshwater pond or lake, and a fine new species of Lemna occur's abundantly.

254. In the lower portion of this division, the beds are more sombre in tint, and little differentiated by colour, which elsewhere often renders the stratification apparent. They contain some layers of sand and sandstone, which show much false-bedding and current structure, and sometimes terminate suddenly with abrupt undulations. In some places, sufficient calcareous cement has been introduced among the grains to form hard sandstones, but their thickness is never great, nor do they extend far. Much ironstone occurs in thin nodular layers, and some selenite. About one-third from the base of this division a bed was found, in which curious fruits have been preserved, referable to a new species of Esculus. (Plate XVI., Figs. 8 and 9.)

255. The most interesting feature of this part of the section, however, is the occurrence of the remains of vertebrate animals. They are found exclusively in the lower portion of this division, and most of them below the fruit-bed just mentioned. They are generally closely connected with the ironstone layers, and are often themselves impregnated with that substance. They are also, unfortunately, apt to be attached to the ironstone nodules, or incorporated with them, and traversed by crack-lines, in such a way as to render it difficult to obtain good specimens. A more prolonged search among these hills, than I was able to make, would, however, no doubt result in the discovery of localities where the remains are more abundant and in better preservation.

256. Professor Cope has kindly examined the vertebrate fossils obtained in connection with the expedition. Those from this place include fragments of sererel, species of turtles, scales of a gar-pike, and broken bones of dinosaurian reptiles. Of the turtles, two are new species, to which Professor Cope has given the names-Plastomenus rostatus, and $P$. coalescens-and there are portions of species of Trionyx and Compsemys. The gar-pike belongs to the genus Clastes, and of the dinosaurian remains, though mostly too fragmentary for determination, a caudal vertebra resembles that of Hadrosaurus.

257. Division $\gamma \cdot$, the lower series of yellow sands and arenaceous 
clays, is a much better defined member of the section than Division $a$. It is exposed chiefly in the banks of the smaller ravines, but also in the upper parts of those of the main brooks. The nodules which it contains are large and irregular, but often approach more or less closely to a spherical form. They are arranged in horizontal lines in the exposures. No fossils were found in this part of the section.

258. The line of separation between divisions $\gamma$. and $\delta$., is quite well-marked by the change in colour. The latter shows scarcely a trace of stratification lines. I was very anxious to obtain fossils from it, but succeeded only in collecting a few small fragments. They, however, indicate purely marine conditions; and one of them is referable to the genus Leda or Yoldia. The identification of the horizon of this bed does not, howerever, depend on such slight grounds as these, as it was afterwards traced westward, and found to be continuous with well-marked fossiliferous Cretaceous rocks.

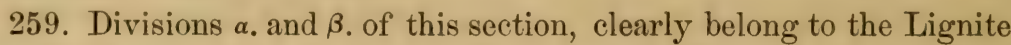
Tertiary. They probably represent, however, merely the lower layers, and differ somewhat in lithological character and arrangement, from those seen at Porcupine Creek, thirty miles east of this place, and at other localities still further eastward. These beds, no doubt, belong to a lower part of the series than is exposed in any of the sections examined between this locality and the Missouri Coteau, and are probably also older than any of those found in the Souris Valley. The beds described as occurring on the trail south of Wood Mountain, (\$249) belong to about the same horizon, and it is probable that those seen in some places on the Traders' Road, may not be much higher up in the series. It would appear that the conditions most favourable to the formation of deposits of lignite, did not oceur frequently or continue long in the earlier stages of the formation in this locality.

260. Division $\delta$. being certainly Cretaceous, it only remains to classify division $\gamma$., which is so markedly different in character from the beds above and below it. This bed, I believe, represents group No. 5, of the Cresaceous; or the Fox Hill group of Meek and Hayden. It was frequently observed at other places further west, and its relations will be more fully discussed in the sequel.

261. The Lignite beds oceurring in division $\beta$., have been burned away over great areas in this region. Numerous red-topped hills are seen, the capping being composed of indurated clays and sandstones, often with much the colour and appearance of red brick. The tops of 

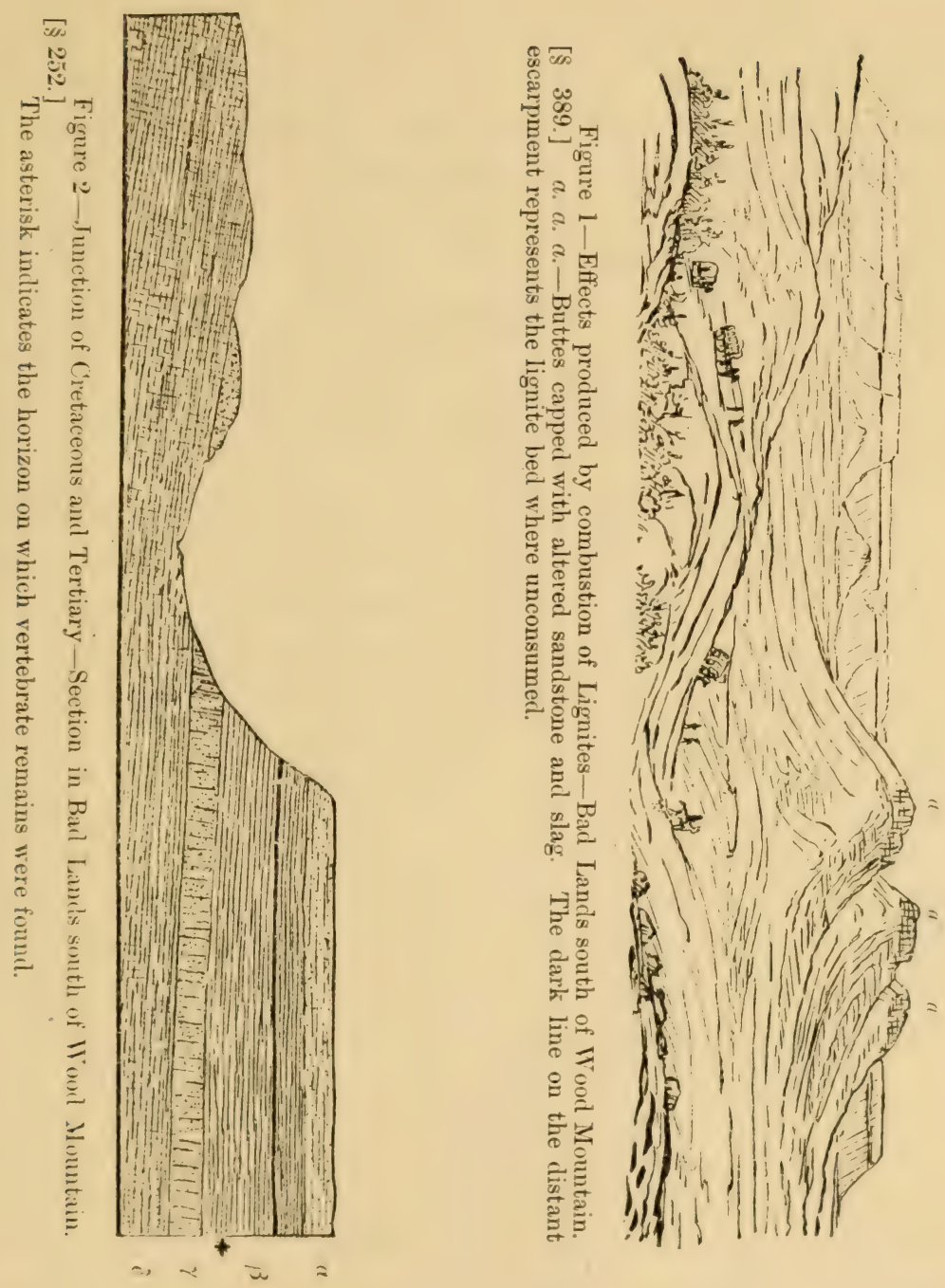

these hills are all nearly on the same plane, and this, if traced back into some of the larger hills and edges of the plateau, exactly coincides with the zone there still containing the lignite. The beds, as there exposed, howerer, seem hardly of sufficient thickness or importance to cause an alteration of the strata so extensive as has taken place. It is possible, from the irregular nature of these deposits, that over the areas destroyed by combustion, the lignite has been thicker and of better quality, and that the fire may have been unable to extend itself into the thinner portions of the bed, where it is separated by clay partings and covered by such a great thickness of other deposits. The combustion must have taken place ages ago, as isolated red-topped buttes now only remain to mark what must have been the level of the plain at that time. (Plate VII., Fig. 1.)

It will frequently be necessary to refer to this typical section, in discussing the Cretaceous and Tertiary rocks further west.

\section{Cretaceous and Tertiary Rocks South of Wood Mountain Plateau, and between the Bad Lands and White Mud River.}

262. On proceeding westward along the Line from the sections above described, one passes over Cretaceous beds, while the southern edge of the Wood Mountain water-shed plateau-which is here coextensive with the edge of the Tertiary-follows a more or less nearly parallel direction at a distance of ten to fifteen miles to the north.

263. The sombre Cretaceous clays of divisision $\delta$., may be traced almost continuously for a distance of about ten miles. Lower beds are, however, exposed, from the igeneral slight easterly dip of the rocks; which is proved by the fact that the sombre clays, though first seen in the bottoms of the vallies, soon form the whole substance of the hills. They attain this position much more rapidly than the slight westward slope of the surface of the country at this place, will account for. About ten miles westward, near the crossing of the forty-ninth parallel and trail to Fort N. J. Turney, where the Wood Mountain Astronomical Station was established, good exposures of these rocks are again found in the banks of the valley of a large brook. On careful examination they were found to contain fossils, and specimens of Baculites compressus, B. ovatus, and other forms characteristic of Meek and Hayden's 4th, or Fort Pierre group, were obtained. This horizon is also indicated by their position relatively to the Tertiary, and their lithological character.

264. The rock is a soft clay-shale, which though fine, and regularly stratified, from its homogenious character hardly shows traces of its 
bedding. It crumbles down into earthy banks, which, however, in some places, exhibit prominent nodular bands of ironstone, and in connection with these the foswils are, for the most part preserved. They are usually completely imbedded in the ironstone and filled with it, though the concretions must have been formed some time after the deposit of the clay, as the larger shells are frequently crushed. The Baculites still retain to a great extent, their original nacreous lustre and play of colour. The ironstone nodules are often septarian, and from the rapid removal of the clays by denulation, their fragments strew the surface in abundance. selenite is diffused in small quantity through all parts of the beds.

265. Taking into account the difference of level between this locality and that of the section in the Bad Lands, the clays here seen must be at least 200 feet below the base of division $\gamma$. The sombre Cretaceous clays of these localities resemble a good deal in lithological character the beds of the Pembina Mountain group, and they also hold the same relation to the overlying Lignite Tertiary series, as that assigned to those deposits. They differ chiefly in being less consolidated and darker in colour, and in forming when weathered a crumbling bank of earthy appearance, rather than one of somewhat sharp-angled shaly fragments. The scarcity of fossils in the Pembina Mountain sections, prevents any instructive palæontological comparison of these beds with them. It must be remembered too, that probably at least several hundred feet of the upper part of the Pembina Mountain group, was no seen on the eastern margin of the basin, and it is this very part of the series which must be represented here. Taking into account, however, the great distance separating the exposures on the eastern and western margins of the region covered by Tertiary, the lithological and structural resemblance of the deposits is quite as close as could be looked for, even in an area characterized by such wide-spread similar conditions, as the interior plateau of the continent.

266. Westward from these sections, the continuity of the Cretaceous clays in the vicinity of the Boundary-line, is indicated by occassional small exposures, and at a distance of thirteen miles, a tolerably good exhibition of the rocks again occurs. They are now found to resemble very closely the clay-shales of the upper part of the Pembina Mountain series, and to differ to a corresponding extent from those last described. They are firmer in texture, and lighter in colour, and are traversed in all directions by rusty-faced cracks. The peculiar small rusty fucoidal markings, already more than once referred to, 
are also abundant, though other fossils are extremely scarce. A few impressions resembling fish scales, but very obscure, were found; also a single specimen of Baculites compressus, being a cast of the interior of the shell in soft iromstone, with the impressions of two gasteropodous shells, which had fallen into its outer chamber. One of the latter is of naticoid type, with a short spire, and few volutions rapidly increasing in size. Not a trace of the calcareous substance of any of these fossils remains; and the clay-shale shows in many places, obscure impressions, which apparently mark the former positions of other calcareous fossils, as in the shales of the Pembina Mountain series. 'The fact that two shells of different species, were caught up in the body-chamber of the single Baculite, which owed its preservation to an ironstone concretion, taken in connection with the indications just mentioned, would tend to show that organic remains were originally somewhat abundant, but that they have been removed by chemical action in the way already noticed.

267. Selenite in small crystals abounds, and is generally found filling the lines of fissure. Well-marked white bands indicate the the stratification lines in some places. They are occasionally several inches in thickness, and have evidently been bleached subsequently to the deposition of the clays, by the percolation of water charged with sulphuric acid, produced by the decomposition of pyrites, along the more permeable layers.

268. Where the Line crosses White Mud River; * or, Frenchman's Creek, numerous and very fine exposures of the Cretaceous rocks occur. The stream flows in the bottom of a great trough, cut out of the soft Cretaceous strata, orer three hundred feet deep, and in some places fully three miles wide. Many ravines enter this valley from the sides, and numerous land-slips have brought down the upper beds to various levels in its banks, and hare produced a rugged mass of conical hills and ridges. The tops of the banks on both sides of the valley are formed of yellowish ferruginous sands, referable to division $\gamma$, of the Bad Land section. They are, in many places, hardened into layer's of sandstone, and are nowhere very soft. Land-slips have confused the section, but they can be traced in their original position as far up and dowr the valley as can be seen. I could find no fossils in these beds, though sixty to seventy feet of them must be visible in some places.

* There are probably half-a-dozen streams of this name in different parts of the North West. The best known is that at the south end of Manitoba Lake, with which this must not be confounded. 
269. Below these are sombre Cretaceous clays of division $\delta$, and they extend downward to the water level of the river; showing a thickness of 273 feet, the base not being seen. The portion of these clay-slates most nearly resembling those last described, and those of the Pembina Mountain series, lies immediatcly below the yellow sands; below this, to the bottom of the valley, they show rather the crumbling earthy character and more sombre colour of the Bad Lands and Wood Mountain Astronomical Station exposures. This would tend to prove that rocks like those of the upper part of the typical Pembina Mountain series, are not confined to any particular horizon in the western representatives of that group. About 100 feet below the base of the yellow sands, a bed characterized by the great abundance of the remains of a fine species of Ostrea, occurs. It is referable to Ostrea patina of Meek and Hayden; and fragments of a thick Inoceramus appear in the same stratum. The Ostreas, for the most part, are quite perfect, and have been intombed where they grew, the valves being still attached. They are fiequently roughened externally, and crusted with selenite crystals, produced apparently by the action of acidulous waters on the shell itself.

270. A short distance below this Ostrea bed, is a zone containing many large septarian ironstone nodules. In some places, a horizontal surface of this bed has been exposed, forming an arid wind-blown expanse of crumbled fragments of the shale, which here and there supports an Artemisia, and from which the nodular masses stand up at intervals, as they have been exposed by weathering. The concretions are often as much as twelve or fifteen feet in diameter, and lenticular in for'm, but are generally broken into fragments by the action of the frost. They hold remains of Ammonites and Baculites, the former at times two feet in diameter, and reforable to $A$. placenta, a form, like Ostrea patina, characteristic of the 4th group of the Missouri River section. The fossils are unfortunately intersected by the cracks which traverse the mass of the nodules, in such a way as to render their preservation very difficult. Some of them retain their nacreous lustre in all its original perfection. Bleached bands like those alrealy described, occur in many parts of these clays.

271. The beds here appear to be perfectly horizontal, and the increased elevation of the general surface of the country will more than suffice to account for the reappearance of the yellow sandy deposits last seen in the Band Landr-without supposing the existence of any gentle 
anticlinal between the two localities. Our camp, situated a short way down the eastern slope of the White Mud Valley, and consequently somewhat below the general level of the prairie, was 445 feet above the Wood Mountain Astronomical Station, nineteen miles east, by comparison of seven barometric readings at each place. The base of the yellow sands being about 30 feet below the camp, is 409 feet above the Astronomical Station; and as the base of the same stratum (division $\gamma$.) in the Bad Land section was found to be about 170 feet above the Astronomical Station, a difference of 239 feet between the same horizon in the Bad Lands and at White Mud River, would remain in favour of the latter. The distance being about thirty miles, gives an eastward slope of about eight feet in the mile.

\section{Cretaceous and Tertiary Rocks-Wood Mountain Settlement to the Crossing Place on White Mud River.}

272. The main trail going west from Wood Mountain settlement, passes for some distance along the northern edge of the water-shed plateau, and then going over it where it turns north-westward, crosses the valley of the White Mud River, sixteen miles north of the fortyninth parallel, and twenty-three miles north-west of the exposures last described. Between Wood Mountain and the White Mud River the water-shed plateau is formed, as before, of the lower beds of the Lignite Tertiary, and projects like the prominent parts of a cameo, while the lower ground, and the deeper portions of the valleys of the streams, are formed of the underlying Cretaceous clays. On the trail, near Wood Mountain, small exposures of the Tertiary rocks frequently appear. About thirty-four miles west of that place, sections of characteristic sombre Cretaceous clay-shale occur, and a deep bay of these lower rocks, penetrates the edge of the Tertiary plateau from the north. in this vicinity. On ascending the plateau forming the west side of this bay, Lignite Tertiary rocks are again seen at intervals, to within about fifteen miles of White Mud River, when the road descends the western edge of the plateau, and again passes over the Cretaceous clays.

273. A reference to the accompanying geological map will render the arrangement of the formations in this region clear. In the absence of other information for the district north-west of Wood Mountain, I would have followed Dr. Hector in provisionally indicating the border of the Tertiary as running from the Cypress to the Thunder Brecding Hills. The occurrence of a bay of Cretaceous rocks on the north side of the 
Tertiary plateau, however, throws doubt on Dr. Hector's supposition of the continuity of the edge of th: Tertiary between the two last mentioned localities. Judgring from anoiogy, there is reason to believe that the bay of Cretaceous rocks must extend continuously from the north side of the plateau to the South Saskatc'.'ewan River. The strata are as nearly as possible horizontal, and throughout this region it is found that a valley once cut down through the harder Tertiary rocks to the Cretaceous, does not in the lower part of its course again pass over the former. Dr. Hector did not reach the northern edge of the Tertiary between the Cypress and Thunder Breeding Hills, and it is by no means certain that there is a continuous escarpment uniting them, as shown on the map.

274. Twelve miles east of the White Mud River, in the banks of a deep coulée tributary to it, good exposures of the Cretaceous rocks occur, and yield in great abundance the characteristic fossils of Meek and Hayden's 4th group. Baculites compressus is the most common form, and is associated with several species of Inoceramus and other molluses. Specimens of Avicula (Pteria) linguiformis M. and Acteon concinnus, M. $\& H$., are included in the collection, and are especially interesting, as having been previously recognised by Prof. Hind, in localities further to the north,-the former at the elbow of the South Saskatchewan, the latter at Two Creeks on the Assineboine.

275. The fossils resemble very closely, both in their general appearance and mode of preservation, those brought by Dr. Hayden's expeditions from the Upper Missouri. They are included in nodules of ferruginous limestone, which, like the enclosing clays, are of dark-grey colour. The concretions only occur in certain beds of the clay, and are generally more or less septarian in character, the cracks being filled with ambercoloured calcite. In other parts of the section, beds with large ironstone concretions occur, which usually have the same septarian character, but were not observed to contain many fossils. Selenite crystals abound in the clays, and a fibrous mineral, which may best be called a ferro-calcite, occurs in discontinuous layers parallel to the stratification; one of which was observed to be nearly a foot in thickness. This substance was also found in connection with the sombre clays of the Wood Mountain Astronomical Station exposures, and with those of the Bad Lands. (\$258-263.) It is minutely prismatic, the prisms in some cases, radiating from a centre, but more usually nearly parallel, and at right angles to the beds. It is pearly-grey within, but weathers yellowish-grey, and in that state much resembles, at first sight, silicified wood. 
276. The valley of the White Mud River, where crossed on this northern route, is very broad, but the banks are much reduced in height, as compared with those on the Line, and are not of the same precipitous character. The bottom of the valley is flat, and the soil being based on the Cretaceous clays without the intermediation of drift material, is barren in the extreme, and supports a scattered growth of Artemisia, and some salt-loving plants. The Cretaceous clays are seen in the banks, but are not well exposed.

\section{Cretaceous and Tertiary Rocks, from White Mud River to Milk River.}

277. On the western side of White Mud River, hilly ground occur's, in which some of the lowest Tertiary beds may be represented; but, which I am inclined to believe, is due entirely to accumulation of drift. The banks of the two branches of Cottonwood Coulée, next met with, do not appear to yield any exposures, but the country, from its character and elevation is, no doubt, based on the dark Cretaceous clay-shales, to about the 505 mile point, where the prairie which has been gradually becoming more undulating and hilly, makes a very definite rise, and forms a plateau, which extends along the Line, to the 534 mile point.

278. This plateau like that near Wood Mountain, is found to be composed of Tertiary beds, but is not so well defined. Its surface is always undulating and often quite hilly, large quantities of drift having apparently, been piled upon it. The underlying rocks are seldom seen, and its age might have remained a doubtful question, but for the sections occurring along its abrupt western front. On coming to this edge, a great area of barren and arid prairie, at a lower level, and based on Cretaceous No. 4, is seen stretching westward toward the Milk River. The Three Buttes or, Sweet Grass Hills, the Bear's Paw, and Little Rocky Mountains, are also here seen for the first time, at a great distance, rising above the level horizon. The exposures are not very clear or extensive, but indicate the existence near the foot of the escarpment, of a considerable thickness of greyish and brownish arenaceous clays, forming rather massive beds. Some distance above these, a well-marked red zone occurs, and can be traced at various points along the edge of the escarpment, as far as the eye can reach. It is due to the combustion, in situ, of one or more lignite beds; portions of which were found in one place, unaffected by the fire, but not sufficiently well exposed to enable measurements to be taken, or any estimate of their quality formed. The metamorphism produced, has been very extensive, and rocks are found 
in all stages, from those simply reddened, to others completely porcelainized, or fused into lava-like material. Some of the baked sandstones still retain obscure impressious of plants. Overlying the red beds are whitish and yellowish arenaceous clays, of such light tints, as to appear, from a distance almost like chalk.

The thickness of heds included between the highest and lowest exposures seen here, m. be from two to three hundred feet, and so far as comparison can be made, the section shows a remarkable general agreement with that of divisions $a$. and $\beta$. of the Bad Lands, 115 miles eastward.

279. The valley of the East Fork of Milk River, where it crosses the Line, is wide and trough-like, with scarped banks about forty foet in height. The cliffs are composed entirely of drift deposits, and it maintains this character as far up and down as I have been able to examine it. Many fragments of Cretaceous fossils, and large masses of fossiliferous ironstone, are found in the bed of the stream, and in the clay banks; and so large a proportion of the drift is formed of the redistributed matter of the Cretaceous clay-shales, that it seems probable that they exist here at no very great depth. Baculites grandis is among the fossils, and was not elsewhere observed; there are also a few species which are probably derived from the lower beds of the Tertiary.

280. A most interesting section occurs in a deep valley about six miles west of East Fork. Exactly on the Boundary-line the banks show good exposures of the Cretaceous shales, more closely resembling in their lithological character those seen in the upper part of the Pembina Mountain sections, than those of the same beds as occurring in the vicinity of Wood Mountain. The rock is almost, or quite horizontal, is pretty hard, and well stratified, and includes white bands like those already referred to. On following the valley about a mile northward, these clay-shales seem to bend suddenly upward, and give place to a series of rocks, which appear to underlie them, and which differ from them altogether in character, and include massive layers of sandstone and thick arenaceous clays.

- 281. A section was measured across the up-turned edges of these beds, which is given below, the measurements being reduced, so as to represent the actual thickness of the strata. The section-supposing no reversal to have taken place-is in descending order :- 
1. Sombre Cretaceous clay-shales, Divicion 4 MRar. IN.

2. Grey and yellow arenaceous clays, with some remains of Ustrea in the lower layers (about) .............. 200

3. Greyish-white arenaceous clay, with iwregular sheets of ironstone.............................. 86

4. Carbonaceous shale........................ I 0

5. Grey arenaceous clay ....................... 26

6. Black carbonaceous shale..................... 20

7. Dark shales, with carbonaceous bands............. 126

8. Carbonaceous shale, with poorly preserved plant remains 16

9. Grey arenaceous clay ..................... 300

10. Brown shale, with indistinct impressions of plants, a few inches

11. Grey arenaceous clay $\ldots \ldots \ldots \ldots \ldots \ldots \ldots \ldots \ldots \ldots \ldots \ldots$

12. Laminated carbonaceous shale, with spots of amber, and impressions of plants.................... 20

13. Grey and yellow arenaceous clay............... 200

14. Yellowish arenaceous clay ...................... 110

15. Grey arenaceous clay ..................... 90

16. Soft beds-probably yellowish arenaceous clays, but not well exposed............................ 35

17. Grey sandstone, weathering yellow, and with many

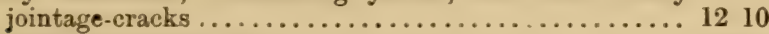

18. Greyish arenaceous clay.................... 4511

19. Hard sandstone, breaking into large rectangular fragments, and weathering into pot-holes............ 40

20. Soft arenaceous clays.................... 1210

21. Fine-grained grey-yellow sandstone, with dendritic mark-

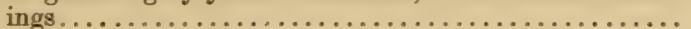

22. Grey and yellowish arenaceous clay, with some thin sheets

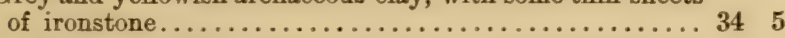

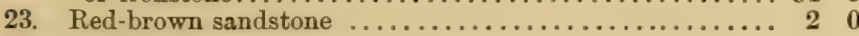

24. Soft grey sandstone........................ 6

25. Nodular brown sandstone ....................... 0

26. Soft beds, with some thin sandstone layers. .......... 240

27. Nodular red-brown sandstone (about) ............... 30

28. Greyish and yellowish arenaceous clays, well stratified, and with small fragments of some lamellibranchiate shell at the base ........................ 88

29. Greyish and yellowish arenaceous clays, well stratified..121 10

30. Sandstone.................................. 30

31. Brownish arenaceous clays, crumbling and rotten where

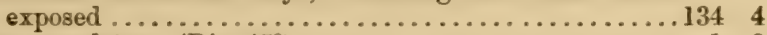

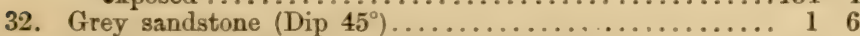

33. Yellowish sandstone, thin-bedded and flaggy ......... 340

34. Purplish and brownish clays, with evident stratification lines............................... 47

35. Impure ironstone...................... 10

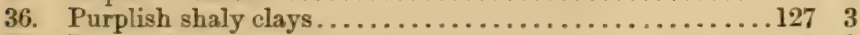

37. Impure ironstone........................ 10

38. Crumbling earthy-clays............................ 6

The beds below these are not exposed sufficiently well to enable the section to be measured. From blocks of sandstone strewing the banks, however, it is probable that one or more layers of this rock occur not far below the base, as here given.

282. When this section was examined, I had no doubt that the whole 
of the heds included in it were truly lower than the dark Cretaceous clayshales of No. 4, though noting the similarity of the series here exposed, with its light-coloured arenaceous clays, ironstones, and carbonaceous shales, to the beds of the Tertiary. Having afterwards examined the sections of the lower part of the Tertiary in Milk River, with which these are eren more closely comparable, and finding there a species of Ostrea which appear's to be indistinguishable from that represented by the few fragments obtained from bed No. 2, I find it still more difficult to feel assured in referring these beds to a position inferior to No. 4 of the Cretaceous. Had they occurred apart from well-marked Cretaceous rocks, they would probably have been referred, without doubt, to the Lignite Tertiary; in the absence of characteristic organic remains.

283. To explain the present position of these beds, under the supposition that their age is Tertiary, it is necessary to suppose either an extensive overturn; or that they have been thrown down by a reversed fault, with an angle of only about $30^{\circ}$, nearly coinciding with the stratification, and carried beneath the edges of the undisturbed Cretaceous clays. Either of these alternative circumstances is difficult to account for in a country so little disturbed, and where the strata are, as a rule, almost perfectly horizontal. If, howerer, the beds are truly Cretaceous, it still remains uncertain whether they should be considered as forming an important intercalation in No. 4, or whether they lie entirely below that division. The latter is the more probable supposition, as where the rocks of No. 4 are turned up against the flanks of the Buttes, further west, in such a manner as to reveal a great part of their thickess; though some thin layers of sandstone occur, nothing is found comparable with this series.

284. The sandstones of these beds differ a little in aspect from most sandstones occurring in sections clearly referable to the Tertiary, being somewhat more uniform in their bedding, thinner leaved, and more equally hardened throughout. The carbonaceous shales of beds 6 , and 12 , are thinly cleavable, and might, in some places, be called impure lignite. One of the beds contains drops of amber, similar to those found in connection with many of the lignite beds elsewhere; and plant remains are abundant, but too poorly preserved for recognition. It is evident that where these carbonaceous shales were found, all the conditions which might lead to the accumulation of important beds of lignite oltained, and that such beds as these might be found, if followed, to widen out, or coalesce with carch other within a short distance. The 
occurence of amber shows that coniferous wood, which composes so large a part of the clearly Tertiary lignites, was here going to decar If then it be granted that these beds are lower Cretaceous, the possibility of the occurrence; of beds of fossil fuel in the rocks of that age, in this region, would be established.

285. The strike of these beds is N. $27^{\circ}$ E., (mag.) and their dip, south-eastward, at angles varying from $45^{\circ}$ to about $30^{\circ}$. The tilting of strata to such angles as these-eren if the existence of no more violent flexure be suspected-is in itself a circumstance sufficiently remarkable, in a country where, for hundreds of miles, the rocks are found with inclinations no greater than can be accounted for by original irregularities of deposit. The nearest disturbed region is that in the neighbourhood of the Buttes, and the upturning is there in immediate connection with the extrusion of igneous matter.

286. The valley of the West Fork of Milk River, though showing some scarped banks, does not penetrate below the drift.

287. Two and a half miles beyond.West Fork, exposures of sombre Cretaceons clay-shales of the usual character were again met with, and the barren plain is based on these rocks for about twenty miles westward. Immediately west of the West Fork, a well-marked plateau runs up nearly to the Boundary-line, from the south, and no doubt marks the overlap of Tertiary rocks, which are again met with in full force in the high ground around Milk River. On approaching this stream, a line of small lakes* and swamps, is found along the eastern base of a plateau, which runs north-westward, and on the Line has a breadth of six miles, east of the river. Near the edge of the plateau the clay plain shows extensive superficial deposits of loose sands, which have probably been derived from the disintegration of the soft sandstones of division $\gamma$, equivalent to the Fox Hill group.

288. The valley of the Milk River is one of the most important features met with on the line of the forty-ninth parallel, and offers continuous and magnificent sections of beds referable to the Lignite Tertiary series. The country on both sides of it, is seamed with tributary ravines and gorges, the banks of which are often nearly perpendicular, and which ramify in all directions. Where the Line crosses the river valley; it is utterly impassable for waggons or carts, and near this place the Great Dry Coulée branches off, which, according to Palliser's map, runs to Lake 
Peekopee. The appearance of the valley of the river itself is strange and desolate.

289. The banks rise nearly three hundred feet above the level of the stream, and are more than a mile apart. They are almost bare of vegetation, and marked by bands of differant coloured clays and sandstones in a nearly horizontal position, as far as the eye can reach. The descent into the valley cannot be made on horseback, but by taking advantage of the well-worn buffalo tracks, which are found leading down almost every coulée and ravine. The river itself is comparatively insignificant, and winds in broad curves from side to side of the valley, and is fringed by a growth of large poplar trees, and by willows. The bottom of the valley is marked out into three distinct levels, differing much in appearance, though only by a few feet in height. Over the first of these the river must constantly pass in flood. It shows in many places a luxuriant growth of grass, and supports most of the timber. The second level, which the river can seldom if ever touch, is characterized by the abundant growth of Artemisia of several different species. A third level, which forms a kind of low terrace at the foot of the cliffs, and must be twenty to thirty feet above the stream, consists of hard, parched clay, the washings of the banks, and nourishes only the greasewood, and a few other thick-leaved drought-loving plants.

290. The sections in the banks are undisturbed and regular. The beds are divided into an upper and lower series, by a zone of sandstones, which is about two-thirds up the bank near the Line, but about eight miles north-westward up the valley, is found forming the very summit of the cliff; which here, from the better support afforded by such hard rocks as compared with the clays and arenaceous clay's of the rest of the formation, assunes a bolder and more rugged aspect, and a greater height than elsewhere. Fourteen miles south-eastward of the crossing of the Line, the same sandstone zone is again seen, but now only about one-third up the bank, indicating a general inclination of the beds in a south-easterly direction,- - which may not be exactly that of the full dip, - of about ten feet to a mile.

291. The sandstones, though often well and evenly bedded, are not regularly hardened, but have a nodular character; and though in some localities indurated throughout their entire thickness, in other places not far removed, they may show only certain hard layers of comparatively small thickness, separated by heds of unconsolidated sand. They appear, however, to be rery constant in extent, and do not differ 
materially in thickness at the sereral localities where they were examined. They are slightly ferruginous, with prevailing light yellow tints, and are often more or less affected by false-bedding. Below the sandstones occur clays, sands, and arenaceous clays, generally well stratified, and individual beds of which may often be traced a long way up or down the valley. The colours are usually light, but there are some zones of darker carbonaceous clays, and in a few places impure lignites of no great thickness were observed. These appeared to be less persistent than most of the other beds, and generally to thin out and disappear when followed far in either direction. From their appearance, and mode of occurrence, these lignites may well have originated from the drifting together of wood or peaty matter, and differ considerably from the pure and definite beds which characterize the Lignite Tertiary further east, and which appear to be formed of trees which have grown on the spot.

292. Above the sandstone zone is a great thickness of sands and arenaceous clays, forming more massive beds, in which the stratification is less perfectly marked. The general tints are pale greenishgrey, greyish, and light buff.

293. No fossils were found in this upper series or in the sandstones. In the beds below the sandstones organic remains are also singularly rare, but are not altogether absent. In a part of the section not far below the base of the sandstone zone, is a layer with large arenaceous concretions, which contain in some places abundance of fossils.

Among these are Melania Nebrascensis, one or more species of Paludina, a Helix, several species of Corbula, and a Sphorium, which is almost certainly S. formosum, described by Meek and Hayden, from the Fort Union beds, and is identical with one afterwards found 110 miles further west, and within thirty miles of the base of the Rocky Mountains. A few rolled fragments of bone are also included in the bed, and some traces of fossil plants. Lower down in the section valves of Ostrea are found, sparingly scattered through the deposit, and not very far from the base a layer containing shells of Unio in a poor state of preservation was observed. Near the latter were found fragments of the bones of a large rerteh:ate. They were scattered, and not in a very good state of preservation, and had evidently been strewn about after the death of the animal, and before their envelopment by the sediment. These, with the other vertebrate remains, were submitted to Prof. Cope, 
who pronounces them to be portions of the sacrum and long-bones of a Dinosaurian.

294. A section of the upper beds and sandstones; observed in a ravine on the east side of the Great Dry Coulée, near the Line, showed the following succession of beds :-

1. Light jellowish slopes and higher grounds, but of which a few feet at

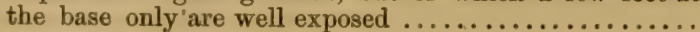

2. Grey sand

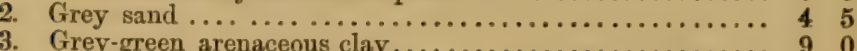

arenaceous clay........................ 9

4. Arenaceous clay (rusty, irregular layer)........... $2 \quad 3$

5. Highly ferruginous layer. A few inches.

6 Grey arenaceous clay, rather conspicuously banded ..... 1710

7. Grey soft sandstone ...................... 14

8. Sandstones, hard and soft, brownish, yellowish and grey; often concretionary, generally well stratified, but sometimes false-bedded, forming cliffs in the gorge, and weathering out into overhanging ledges, and horizontally fluted walls

About $90 \quad 0$

295. The most complete section of the beds below the sandstone zone was obtained about eight miles north-westward from the intersection of the valley with the Line, and on the north-east side of the valley. It may overlap the last by a few feet, or a few feet may be omitted; but, allowing for this slight uncertainty, it forms a continuation downward of the base of the former section.

1. SEET. IN.

2. Red-brown concretionary sandstone, with large flattened

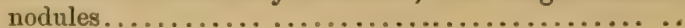

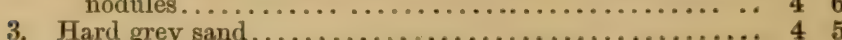

4. Reddish nodular sandstone ..................... 20

5. Whitish arenaceous clays, with some selenite in the lower

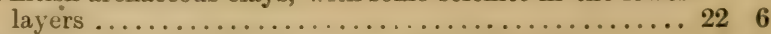

6. Greyish and yellowish arenaceous clays (banded)........ 134

7. Yellow-grey arenaceous clay................. 11. 0

8. Greyish arenaceous clay in which stratification is scarcely

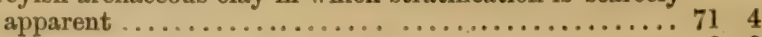

9. Yellowish sandstone, thin bedded.................... 20

10. Grey arenaceous clay ....................... 45

11. Purplish shale........................... 16

12. Grey arenaceous clay ....................... 5 6

13. Brown shale, with imperfectly preserved plant remains.. $\quad 0 \quad 6$

14. Grey arenaceous clay ..................... 148

15. Purplish shale, with some thin layers of impure lignite.. 810

16. Purplish-brown shale....................... 10

17. Greyish arenaceous clay ................... 7

18. Grey arenaceous clay, upper part shaly........... 11

19. Yellowish arenaceous clay ................... 4.5

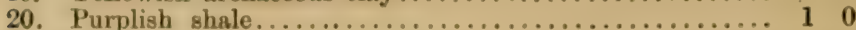

21. Yellowish arenaceous clay ..................... 811

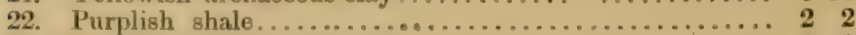

23. Greyish arenaceous clay .................... 6 
24. Sandstone, a few inches.

25. Greyish arenaceous clay .................. 46

26. Yellowish arenaceous clay (lowest bed in which remains of molluses were found at this place. Ostrea)...... $4 \quad 5$

27. Nodurlarly hardened sandstone................ 10

28. Yellowish arenaceous clay ....................... 31

Concealed in slope to river, about.............. $30 \quad 0$

About.................... $\overline{28410}$

296. The thickness of beds displayed in the above sections, when combined, is about 375 feet, and the bottom of the river valley, is probably not very far above the base of the Lignite Tertiary formation. It will be obserred that the genus Ostrea, is here for the first time mentioned as occurring in these beds; further west it becomes one of the most usual forms. The conditions of deposit implied by the beds on the Milk River, are those of an estuary, or shallow sea margin, where, while oysters and corbulas were living, the remains of fiesh-water shelis and land regetation were being carried, and mingled with them. The salinity of the water just indicated at Wood End, must have been here, however, well pronounced; a fact according with the observations of Dr. Hayden and other observers to the south.

297. The superposition of these beds on the Cretaceous clays of group 4, is not clear in this locality, as no junction of the two formations was observed. Their lithological character, might almost seem to render it probable, that they represent the same series as that supposed to come up from below the Cretaceous clays between the East and West Forks of Milk River. The beds here examined, however, can be traced almost continuously westward to the country round the Three Buttes, and are there found clearly resting on Upper Cretaceous rocks, recognizable not only by their mineralogical similarity to those already described, but by their fossils.

298. Eight miles south of the Line, where the Commission Trail crosses the ralley of Milk River, the banks are somewhat lower and less rugged, but exhibit the same rocks with very similar appearance and arrangement.

\section{Cretaceous and Tertiary Rocks from Milk River to the West Butte.}

299. In the coulées and gorges which intersect the prairie on the west side of the Milk River, exposures of rocks similar to those described in the main valley occur, the beds continuing to maintain a nearly horizontal attitude. Eighteen miles west of the crossing place of the 
river, the same beds were again observed, and beyond this point small exposures very frequently oceur, and show yellowish nodular sindstones, and arenaceous clays, precisely resembling those of the Milk River.

300. Some miles further west, near the 620 mile point on the Line, a very interesting section was observed on the eastern side of a small coulee, where the flood-water haul cut away the bank. (Plate IV., Fig. 4.) The upper layer is of massive grey sandstone, about eight feet in thickness, and immediately below it a softer led filled with Ostrea shells occurs. Below this, about six feet of arenaceous clay, with a few shells of Ostrea, and then an irregular and impure lignite about a foot thick, which is underlaid by about seven feet of arenaceous clay similar to that above it, but more perfectly stratified. Next, a carbonaceous shale, overlying a grey arenaceous clay filled with the remains of small molluscs, the most abundant of which appears to be identical with Corbula undifera of Meek; a second species, probably referrable to $C$. mactriformis, is also sparingly represented. Below the shell-bed is another seam of impure lignite, which is slightly thicker than the upper, and holds in some places rather large drops of amber or fossil resin. Below this lignite, is a bed of grey arenaceous clay, underlying which is a foot or two of carbonaceous shale, which rests on a grey, soft sandstone, constituting the base of the section as here exposed.

301. The beds in this section are exceptionally rich in the remains of Mollusca, and the form referred to Corbula undifera, constitutes about half the substance of the bed which it characterizes, occurring in all stages of growth. The proportion of carbonaceous beds and lignites, is also greater in this section than in the corresponding beds exposed in the valley of Milk River. The conditions of deposit implied, are those of shallow water, perhaps estuarine, but of distinctly saline character. The section is situated about fourteen miles north-eastward from the most eastern of the Three Buttes, and the beds are horizontal. In a second locality, nor far removed, is a fossiliferous bed containing a few specimens of Corbula undifera, mingled with Goniobasis insculpta, Meek, fragments of Ostrea, and a species of Dostia or Neritina, not yet specifically determined, but probably either $N$. patelliformis or $N$. Bellatula; forms deseribed by Prof. Meek from Colville in Utah.

302. On approaching the East Butte to within ten or twelve miles, the hitherto horizontal beds are found to assume a gentle dip away from it, or on this sille, to the northward. In the vallies of the streams which seam the flanks of the hills, and furrow the surface of the prairie around 
them, numerous more or less extensive exposures of the rocks of the Lignite Tertiary, occur. As might be anticipated from the nature of the deposit, as it has been already noticed on the Souris River and elsewhere, few of the beds are found to have any great horizontal constancy; but, from their general similarity, any very detailed account of the various exposures would be but repetition. Clays, and arenaceous clays, with intercalated sands and sandstones, and in some places nodules and thin sheets of ironstone; in various modifications of thickness and arrangement, build up the formation.

303. The isolated mountains, called by the Half-breed hunters, Montagnes du Foin de Senteur, are known to traders of the Missouri Region, as the "Sweet Grass Hills." They are roughly indicated on most good maps of the west, and are there found under the geographical appellation of the "Three Buttes." As indicated by the latter name, there are three distinct mountain masses. A line passing from the peak of the eastern, through the central mass of the western Butte, would have a direction of about N. $80^{\circ}$ W., the Central Butte lying between them, but some miles to the south. The highest summits are those of the eastern and western Buttes, which are about twenty miles apart, and rise nearly 3,000 feet above the level of the plains at their base. The height of the summit of the East Butte, as ascertained by the aneroid barometer, and taking the mean of two readings separated by about an hour, is 6,200 feet. That of the West Butte was found to be 2,746 feet above the Depôt Camp at its base, by comparison with nearly simultaneous readings there; and taking the height of the latter locality as 3,737 feet, the height of the West Butte above the sea, would be 6,483 feet.

304. The central masses of the Buttes, are composed of eruptive trappean rock, and around them, the previously horizontal beds of the plains have been tilted up, those immediately surrounding the igneous masses, resting at very high angles. The western Butte is the most important, and forms quite a little mountain region, having numerous peaks and ridges, with round or blunted tops, and deep, almost precipitous vallies. The eastern Butte is next in importance, and consists of four main peaks, arranged nearly as the angles of a square. The north-western of these is the most prominent and conical; the southwestern is round-topped and connected with the north-western by a ridge, and not far below it in height. The north-eastern and south-eastern summits are nearly equal in elevation, but considerably less than the other's. The central Butte was not ascended, but appear's to be considerably 
smaller than the others. It ha: conical form, as viewed from almost every direction, and its slopes must form an angle of nearly $45^{\circ}$ with the horizon. Like the Fast and West Buttes, it is surrounded by grassy foot-hills, which are specially prominent on its northern slope.

305. Dykes of eruptive material, traverse the sedimentary rocks surrounding the Buttes, in some places, and appear generally to have a direction radiant from their higher peaks. In a valley about ten miles north of the summit of the East Butte, one of these is well exposed. By the wearing away of the softer surrounding beds, it stands up like a massive partly-ruined wall, the resemblance being increased by the fact, that the rock has been broken up by the weather, into quadrangular blocks. Its observed course is N. $70^{\circ}$ E. (mag.) The rock would probably be included under the name Kersanton, of Von Cotta's classification, and is a mica-trap of dark greenish-grey colour, and not very hard; in which small tabular crystals of brown mica are thickly disseminated. It has probably been originally of the same nature as the acidic central masses of the Buttes, but has become more basic by the incorporation of portions of the surrounding sedimentary rock; and has acquired a different mineralogical character, from this circumstance, and its more rapid cooling. The clays and sandstones on either side, are nearly horizontal, except immediately in contact with the dyke, where they are bent and contorted, and much altered. Some dark carbonaceous shales, especially, are so much hardened, as to bear a close resemblance to those usually found associated with coal beds in the Carboniferous formation. valves of Ostrea, are abundant in some of the surrounding beds, and specimens of Corbula undifera were also recognised.

306. On ascending the East Butte, the harder beds are found constituting more or less continuous ridges, round the central masses, while the softer intervening strata are not usually well exposed. The total thickness of the beds seen is not very great, as the ground rises almost equally with the increasing dip. There are, no doubt, also many small dislocations which complicate the section. The sedimentary rocks, in some places, rise to within about one thousand feet of the summit, and are then found much hardened and altered, and dipping very steeply away from it. They are here also traversed, like the igneous rock itself, by many small seams of crystalline quartz, in which a careful examination failed to detect a trace of any metallic mineral. As some of these veins appeared, however, to be not without promise, I afterwards panned 
out a quantity of gravel in one of the small brooks, but without being able to detect the presence of any raluable metal; a small quantity of magnetic iron and garnet sand from the northern drift, being the only result.

307. Nearest the trappean mass, and lowest in the series on the East Butte, occur beds of hardened sandstone, not of great thickness; on these rests a considerable thickness of hard, blackish, fissile shale, in which no characteristic fossils were found, but which from the sections afterwards examined near the West Butte, are no doubt referable to the fourth division of the Cretaceous, and represent the sombre clays, and clayshales, so frequently observed further east. Above this, is a rather extensive sandstone formation, much of which is regularly bedded, but which in some places is nodular, and gives rise in the vallies which cut through it to castellatel, step-like, and fluted rocks of picturesque appearance. Next in order are the clays, sandstones and arenaceous clays, characterised by Ostrea, \&c., already described as constituting the substratum of the plain.

308. The igneous material, composing the higher peaks and central masses of the mountains, though very hard and compact, is seldom seen actually in situ, the solid rock being concealed under a great depth of its own fragments. These are very irregular in form, but generally angular, and bounded by plane faces; they vary in size from a few inches to about two feet in greatest diameter, and render the upper slopes utterly barren. The rock is rery uniform in appearance and composition. It is usually a Rhyolitic Trachyte-porphyry; but, by the introduction of a small quantity of hornblende, sometimes passes, without otherwise much changing its appearance, into a material: which may be called a Sanidinetrachyte. The matrix is pale greenish-grey, porcellanous, but not perfectly homogeneous, and encloses crystals of sanidine felspar, which vary from those barely visible, to others which attain an average size of about 3 millimètres. Quartz is present as a constituent in small quantity, forming minute granular aggregations; and specks, of pyrites are generally to be :een. The hornblende, when it occurs, is found generally in very small crystals between those of the sanidine, but sometimes forms bunches an inch or two in diameter, which appear as darker spots on the surface of the rock.

.309 The highest peak of the West Butte, is at its eastern side, and is a large blunt-topped mountain, which to the east presents perpendicular rocky cliffs. West and north of this summit, several important 
peaks and ridges rise, and enclose a rugged, pine-clad, and rocky area of some extent. The foot-hills of the western Butte are also on a larger seale than those of the others, and an examination of their rocks served to explain much formerly in doubt. The sedimentary rocks are here, as at the east Butte, found to dip away from the central igneous intrusion on all sides; but a considerable mass of stratified rock, has here been, as it were, caught up by the eruptive material, and occupies the depressed central portion of the group of mountains. A great part of these beds dip south-eastward at a rather high angle; they have been very considerably altered, and consist now of slaty shales, and hard, thin-bedded sandstones, in which I was unable to find any fossils by which their age might be made certain. I have little doubt, however, that they are Cretaceous. The trappean nucleus of this Butte is indistinguishable, lithologically, from that of the East Butte, formerly described, and forms shattered and rubbly hill-tops, in the same way.

310. The clearest sections of the rocks surrounding this Butte, were met with on its western side, (Plate VIII., Fig. 2.) where a considerable brook issues from the central valley. The shaly-clays of division 4 of the Cretaceous, are here seen with a gentle westerly dip, somewhat indura!ed, and in places, baked into rather hard black clay-shale, corresponding exactly-with that previously found surrounding the East Butte. Their thickness, as developed here, may be roughly estimated at about 800 feet, though the nature of the sections did not allow of precise measurements. They are not here found to be characterized by the same abundance of septarian nodules, as in localities east of Milk River; a few such, however, occur, and minor arenaceous layers are also intercalated, and sometimes found to persist a considerable distance horizontally, though generally quite local and lenticular. In one of these masses a number of fossils were found, which though not in a very good state of preservation, are very interesting. They include one or two species of Inoceramus, several gasternpods resembling Fusus, fragments of an Ammorite, and a portion of a Belemnitella, probably B. Bulbosa, M. \& H.

Some fish scales; found with the other fossils here, are specifically irlentical with some of those occurring in certain beds at Pembina Kscarpment, 600 miles distant, (Plate XVIII., Fig. 1.) and were not observed in any intermediate locality.

311. Underlying these clay-shales of No. 4, in some places, are rather massive sandstones, tilted at high angles against the flanks of the eruptive rock. They represent the sandstone beds found occupying a 


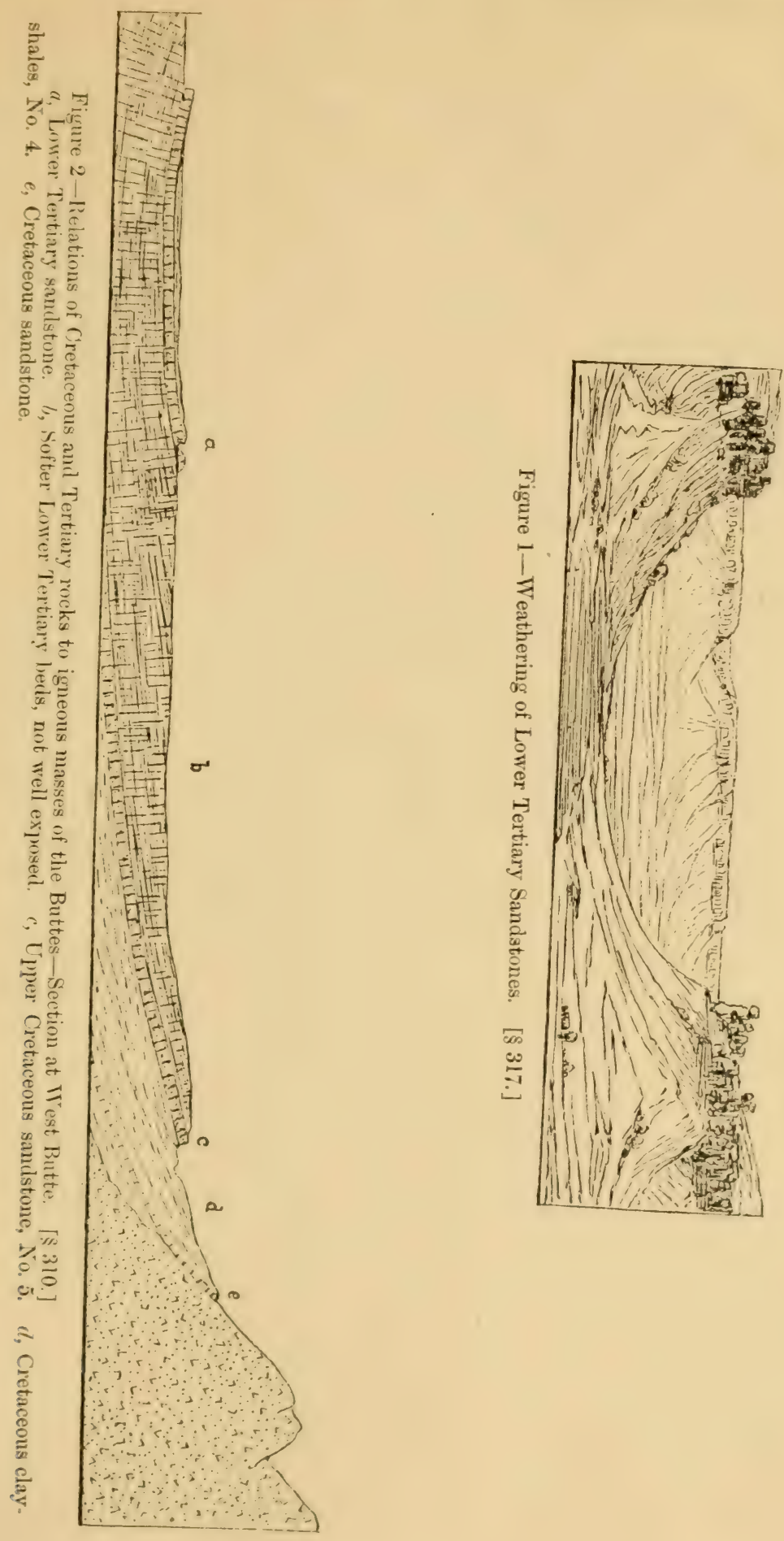



similar position on the East Butte, and probably indicate the base of division 4, and the top of the next lowest division of the Cretaceous. They might very well represent the sandstones which apparently underlie the dark clay-shales near the East Fork of Milk River. Overlying No. 4, are massire sandstione beds, yellow in colour, and though in this place much more uniformly indurated, than those seen in the same relative position further east, no doubt represent the Upper Cretaceous sandstones of Division $\gamma$., of the Bad Land sections. These sandstones, from their superior hardness, generally form a prominent ridge, at a little distance from the base of the Butte; some layers are flaggy and thin-bedded, but they did not appear to contain any fossils. On the west flank of the Butte, they dip away at an angle of about $12^{\circ}$, and a thickness of over forty feet is exposed.

312. The exhibition of the lower rocks at the Buttes, enables the relative position of those forming the surface of the country-and traced almost continuously from Milk River to this point-which might otherwise hare been a doubtful question, to be definitely ascertained. They are found to overlie the upper. Cretaceous beds, and to be related to them precisely as the lowest beds of the Lignite Tertiary are, in the Bad Lands south of Wood Mountain. The character of the Cretaceous beds is little changed, though the tendency of No. 4 seems to be, to become somewhat coarser in this direction. The Lignite Tertiary rocks have, howerer, changed very materially, and especially in becoming more distinctly marine, and perhaps also less lignitiferous.

313. With regarl to the age of the igneous masses, here so unexpectedly found, all that the sections prove, is that they are later than the Lignite Tertiary rocks, which are elerated by them and traversed by their dykes. They are probably protrusions quite local in character, and not broadly based on similar rocks. This is indicated not only by the comparatively very slight metamorphism which the surrounding beds have sustained, but by the very rapid increase of the dip on approaching the masses, and the short distance which the disturbance consequent on their protrusion is found to extend. They have not, howerer, at all the character of modern rolcanic cones, and I did not see any rocks in connection with them which had even probably cooled at the surface. If of the nature of volcanoes they are very ancient ones, of which the cores, or stumps, now only remain, and from about which the whole of the ejected material has been removed. The denudation affecting the rocks tilted up round the Buttes has been very great, 
and from analogy with other circumstances, elsewhere more fully discussed, must have taken place to a great extent before the glacial era. They have, indeed, the appearance of having been subjected to a very long course of erosion in later Tertiary times, and may probably date from that period of disturbance closing the 'Lignite Tertiary period, of which very extensive traces are found elsewhere in this western region.

314. The quaquaversal dip of the sedimentary rocks round the central igneous masses of the Buttes, suggests a resemblance to Von Buch's craters of elevation. This, though rather an exceptional mode of mountain formation elsewhere, would appear from the observations of Dr. IIayden and others, to be common in the west. Bear Peak, near the Black Hills, may be taken as an instance; and there the features represented in the Buttes appear to be almost exactly paralleled. Dr. Hayden thus writes of the locality: "This peak is an isolated protrusion of basaltic rock, very compact, rising to a height of 1,500 feet above the prairie around, and separated from the Black Hills by an intervening space of seven or eight miles. All round the peak the disturbed beds form annular ridges, receding from the central point like the waves of the sea." * The central mass is elsewhere described as consisting of "porphyritic trappean rock." Near Fort Benton,-which is only about eighty miles south of the Buttes,-Ceruptive rocks of post-cretaceous age appear to be frequently met with, and their contemporaniety with such masses as those of these mountains seems not unlikely. In the Report ust quoted, Dr. Hayden says: "We have near the Arrow Creek a bed of erupted material thrust between Cretaceous rocks, which presents a vertical wall of 150 to 200 feet at one point, and then suddenly ceases. These small centres of effusion of melted rock seem to corer the whole region." $\dagger$

315 . In the very valuable coloured map accompanying the same report, the geology of the country surrounding the Buttes, or Sweet Grass Hills, is conjecturally indicated, and reproduced without question in Hitcheock and Blake's map, published in 1872. The annular' structure there extended to these mountains from analogy, proves to be justified by the fact; but whereas in conformity with the structure of similar mountain masses to the kouth, rocks of Carboniferous, Triassic, and Jurassic ages, are represented as forming wide zones round the central protrusions, in a country based on the overlying Cretaceous rocks, I 
could find no rocks older than those of the Upper Cretaceous in connection with the mountains, and the plain appears to be based entirely on the Lignite Tertiary beds.

Cretaceous and Tertiary Rocks from the West Butte to the Eastern base of the Rocky Mountains.

316. Westward from the West Butte, the beds are found to assume a gentle synclinal form, and exposures are not infrequent in the steep banks of coulées. About six miles from the base of the West Butte, a zone of sandstone appears, which must hold a position considerably above the base of the Lignite Tertiary, as the beds are still dipping westward at low angles. Two miles further west, the same sandstones are again seen, but now with a gentle eastward dip. The eastern and western outcrops of the sandstone form the low escarpments of a plateau, due to its superior hardness, which occupies the trough of the synclinal. (Plate VIII., Fig. 2.) This synclinal arrangement is not, however, persistent, nor of great structural importance, as, in proceeding westward, sandstones which appear to occupy the same horizon in the Tertiary, are soon again found nearly horizontal.

317. In a system of ravines south of the Line, about twenty miles west of the base of the Butte, these sandstones are again well exposed, and have an estimated thickness of over thirty feet. In these valleys they occur not much below the general level of the prairie, and forming the upper parts of the banks, give them a most picturesque and remarkable appearance. The lower layers of the sandstone are generally very regularly bedded, and some of them are exceedingly fine and thin, and show worm-tracks and other obscure markings. The upper beds are more massive and have a nodular character, which causes them to weather out into the castellated forms, resembling in some places those of the Roche Percée. (Plate VIII., Fig. 1.) Underlying the sandstones are less permeable clays, or arenaceous clays, of light colours, of which I did not succeed in finding good exposures, but which turn out numerous small springs of a highly saline character. The beds appear to be quite horizontal in this locality.

318. Near this place, and about ten miles south of the Boundaryline, a bold escarpment occurs, facing southward, toward a great stretch of lower country. Its outline is that of any section of the bank in the last described valley, its abrupt edge being produced by the sandstone zone in the same way. From the rapid falling away of the surface of 
the country to the south, it must also nearly mark the line which in this place bounds the southern margin of Tertiary.

319. Two branches of the Milk River cross the Line with northeasterly courses between the Buttes and the Rocky Mountains, and after uniting to form the main stream of the Milk River, flow eastward, north of the Buttes, and recross the forty-ninth parallel, with a south-easterly course, as has been already mentioned. The Line crosses the first of these tributaries, at the 696 mile point, and though the stream flows in a deep valley, the banks do not show anything but drift. Six miles west, however, a bend of the river again approaches the Line from the south, and it here exhibits very interesting sections of rocks probably belonging to the base of the Lignite Tertiary.

320. The best exposures are found in a group of small hills, which assumes in miniature, the appearance of the Bad Lands, and stands like an island of older rocks among the drift deposits, which lap around its base. It is an outlyer of a plateau, which, with irregular edge, runs northward with a little easting, where it crosses the Line. The beds are horizontal, and are exposed for a thickness of about sixty feet. The lower portion of the section is of pale greenish-grey clays, while above, the greenish colour is not so marked, and there are somewhat massive sandstones. In some places the latter are almost conglomerates, and hold many small pebbles, the majority of which are of greenish shale. They also include fragments of reptilian bones and large Unio shells. Small nodules occur abundantly in some layers of the lower greenish clays of a tint similar to the matrix. The bones are found in considerable abundance in all parts of the section, but are much crushed and fissured. When imbedded in the bank, they are purplish-black in colour, but on weathering, assume whitish and rusty tints. It is very difficult to dig the bones out of the bank itself, from the great hardness of the dry clay relatively to that of the fossils, and where washed out by the rains, they are found only as broken fragments, difficult to reconstruct. From specimens obtained here, however, in the course of a few hour's, Prof. Cope finds, besides many broken bones of dinosaurs, new species of Cionodon and Compsemys, which he has called C. stenopsis and C. agmius, respectively.

321. The greenish clay beds are doubtless formed of the disintegrated material of beds of green shale, similar to those represented by the pebbles in the conglomerates. A microscopic examination of the clay did not reveal any recognisable fragments of green mineral or rock, the 
colour apparently residing in the very fine argillaceous matter, through which a few large partly rounded grains of transparent quartz are scattered. The bones, in the manner of their preservation, much resemble those of division $\beta$. of the Bad Lands south of Wood Mountain, which these beds may possibly represent. The lithological character, howerer, has changed considerably, as compared with any of the more eastern exposures of the Tertiary, though connecting links are supplied by the sections on the main stream of the Milk River, and in the vicinity of the Buttes. Sandstones are now more important, and coarser in texture, and the clays and argillaceous sands have assumed more definitely than ever before, the greenish tint abore referred to.

322. It is a curious coincidence that near this place, also, green slaty shale begins to be an abundant constituent of the drift. It does not appear to be derived from the degradation of the Tertiary rocks, as the matrix of their conglomerates is generally harder than the enclosed shale, but must come directly from the slopes of the Rocky Mountains, and increases in abundance on approaching them. It would thus appear probable that even in early Tertiary times some part at least of the mountains was sufficiently elevated to allow a distribution of fragmental material similar to that afterwards taking place on a larger scale in the glacial period.

323. About fourteen miles further west, the Second Branch of Milk River is met with, and in its valley, for several miles, beds resembling those last described are exposed and are still apparently quite horizontal. The best sections-which are near the river level-probably show beds somewhat lower in the series than those last described, which the higher parts of the banks on both sides of the valley more closely resemble. About forty f:et above the level of the stream, a thin band of nodular and ferruginous limestone was found to be highly fossiliferous. The rock is dark bluish-black internally, but weathers reddish-brown. Fraggments from the same, or a precisely similar band, were previously found detached in the valley of the First Branch of Milk River, twenty miles eastward. The fossils are entirely those of fresh-water, and include specimens of Paludina, Limnce, Planorbis, Spharium, and a Bulinus or Physa. The Planorbis is almost certainly that called $P$. subumbilicatus by Meek, from the Tertiary of Fort Clarke, (Valvata subumbilicata of Smithsonian Check List?) though I have not had an opportunity of comparing it with authentic specimens. It also, however, appears to be indistinguishable from small specimens of Planorbis parvus of Say, now 
so common over the North American continent. The Sphoerium is specifically the same with that previously found on the Milk River 110 miles further east, and referred to S. formosum M. \& H. The Paludina remains of are very fragmentary, but there are forms indistinguishable from specimens of $P$. Trochiformis and $P$. Conradii.

324. The oceurrence of fresh-water forms so far west, while the general tendency of the lower beds of the Tertiary is to become more distinctly marine westward, would either tend to show that there were important exceptions to this rule, or that the beds here represented are high up in the series. The occurrence of abundant Dinosaurian remains in the section described in paragraph 320 , would seem to tell against the latter conclusion, and it would appear that the question must remain for the present an undecided one.

325. Fifteen miles further west, is the St. Mary River, a tributary of the Belly River. Its banks show good exposures for several miles, and here the disturbance connected with the elevation of the Rocky Mountains is first found to begin. The sudden nature of the break separating the nearly horizontal beds of the country further east, from the region of sharp and frequent flexures now entered upon, is a matter of surprise, as is also the very limited width of the belt of country much affected by the disturbance, the St. Mary River, on the Line, being only about twelve miles from the bare sides of the outlying range of Chief Mountain.

326. The lowest rocks seen in the part of the river examined, were sandstones of greyish and yellowish tints, regularly bedded, and quite hard, with some surfaces showing ripple-marks and worm-tracks. They have a south-westerly dip at an angle of $20^{\circ}$, and are present in considerable thickness. About half a mile south of these lower beds, and overlying the upper layers of the same sandstone zone, a bed of fuel, with all the mineralogical characters of true bituminous coal, was found.* It has a thickness of about eighteen inches only, and occurs just at the level of the water in the river, by which it is partly covered. It breaks with a clean fracture into cuboidal fragments with bright faces, and is indistinguishable in appearance from many coals of the true Carboniferous formation. Below the coal is a foot or two of dark carbonaceous shale, somewhat indurated, and holding imperfect remains of plants. A similar shale, but only a few inches in thickness, rests upon the coal, and is

* I am indebted to Mr. W. A, Ashe, of the Survey party, for first calling my attention to this deposit. 
followed in ascending order by a hard shell-bed eighteen inches to two feet thick, dark-coloured from included carbonaceous matter, but in the main composed of shells of Ostrea and Cyrena. Above this is a considerable thickness of flaggy and ripple-marked sandstones, greyish and brownish-grey, with a dip of $\mathrm{S} .28^{\circ} \mathrm{W} .<35^{\circ}$. The ripple-marks indicate a current with a direction of $\mathrm{S} .14^{\circ} \mathrm{W}$. (mag.)

327. A few hundred yards south-east of the last exposure, sandstones similar to those overlying the coal are found well shown in a steep bank. (Plate IX., Fig. 2.) They are sharply folded into an anticlinal form, and are orerlaid by a considerable thickness of greenish-grey clay beds. The latter are charged with small flat masses of calcite, formed apparently in fissures, but now scattered orer the surface of the claybank, giring it a remarkable appearance. A shell-bed rery similar to that found in connection with the coal, but probably not identical with it, as it wants the carbonaceous colouring matter, also appears here. It probably underlies the sandstone, but though large blocks of it are strewn about, it is not very well exposed. The rocks are so abruptly folded that they appear in some places to be slightly orerturned; and in the absence of large or continuous sections, the precise relations of the beds cannot be traced.

328. About two miles northward on the same river, it cuts through high banks which exhibit similar rocks. It here seems to follow still more closely the line of fracture of the country, the beds on the east side being not far from horizontal, while those on the west are much disturbed, the lithological character and general appearance of both series being, howerer, much alike. No coal-beds, or beds containing fossils were seen here.

329. Four miles west of the St. Mary River, a hard fossiliferous bed comes to the surface, forming the crest of a ridge. It dips west-southwest, at an angle of $20^{\circ}$. Where exposed, it is an almost solicl maks of fossil shells, forming a rough limestone. The same mollus('s are represented here as in the other sections in the locality of St. Mary River, the most abundant being a species each of C'yrena and Ostrea. The former is probably C. occidentalis, M. \& H., and in some of its forms is scarcely distinguishable from $C$. corlata, Morris, a shell of the English Eocene.* The Ostrea is a large shell, trigonal, and very massive, but not yet specifically determined.

* Figured in Journ. Geological Society, Vol. X. Meek, compares C. occidentalis with this species. 
330. A short distance further west, a bed of hard sandstone appears, again forming the crest of a ridge, which can be traced for miles in a north-westward course. The strike of the sandstone itself, as shown by the stratification lines, is N. $41^{\circ} \mathrm{W}$., (mag.) with a south-westerly dip at high angles. The persistence of this bed in the line of its strike seems to show that, though the strata are so much disturbed, the folding has taken place very regularly, parallel to a single direction. The sandstone evidently underlies the shell bed last referred to, and must be some hundreds of feet below it. It is yellowish, and not so much indurated as that seen in the bed of the river, some layers being still quite soft. In this bed was found enclosed, a trunk of silicified wood, the first actually observed in situ, though fragments are abundant in the drift several hundred miles eastward.

331. The whole of the exposures seen in the vicinity of the St. Mary River, evidently belong to one series of beds; but with so much disturbance and folding, it is probable that in some places, beds both much lower and higher than those observed, must occur at the surface. Those seen do not precisely resemble any part of either the Cretaceous or Tertiary rocks previously examined. They belong, however, without doubt, to the latter series, and are probably near its base. The gradual change which is found to effect the Lignite Tertiary, as followed westward, has here reached its extreme. The occurrence of a true coal, differing altogether from the lignites previously found to cover so great an area of these western marine represcntatives of the Lignite Tertiary, raises questions of much importance, which are more fully discussed in the sequel.

332. Nearer the base of the mountains, few exposures of the rocks of the plains were seen, and these singularly deficient in fossils or other means of correlating them with their eastern representatives. From what I could see, however, I am of opinion that in the immediate vicinity of the forty-ninth parallel, rocks representing the Lignite Tertiary, come almost to the base of the bare rocky cliffs of the Mountains. I did not find any beds certainly Cretaceous, but it is highly probahle that they are brought to the surface in many places, and cover larger or smaller areas.

333. About eight miles north of the entrance to the Kootanie Pass, sandstones similar to those seen on the St. Mary River, and clays charged in precisely the same way with flakes of calcite, were found within about two miles of actual exposures of the palsezoic rocks of the mountains. 

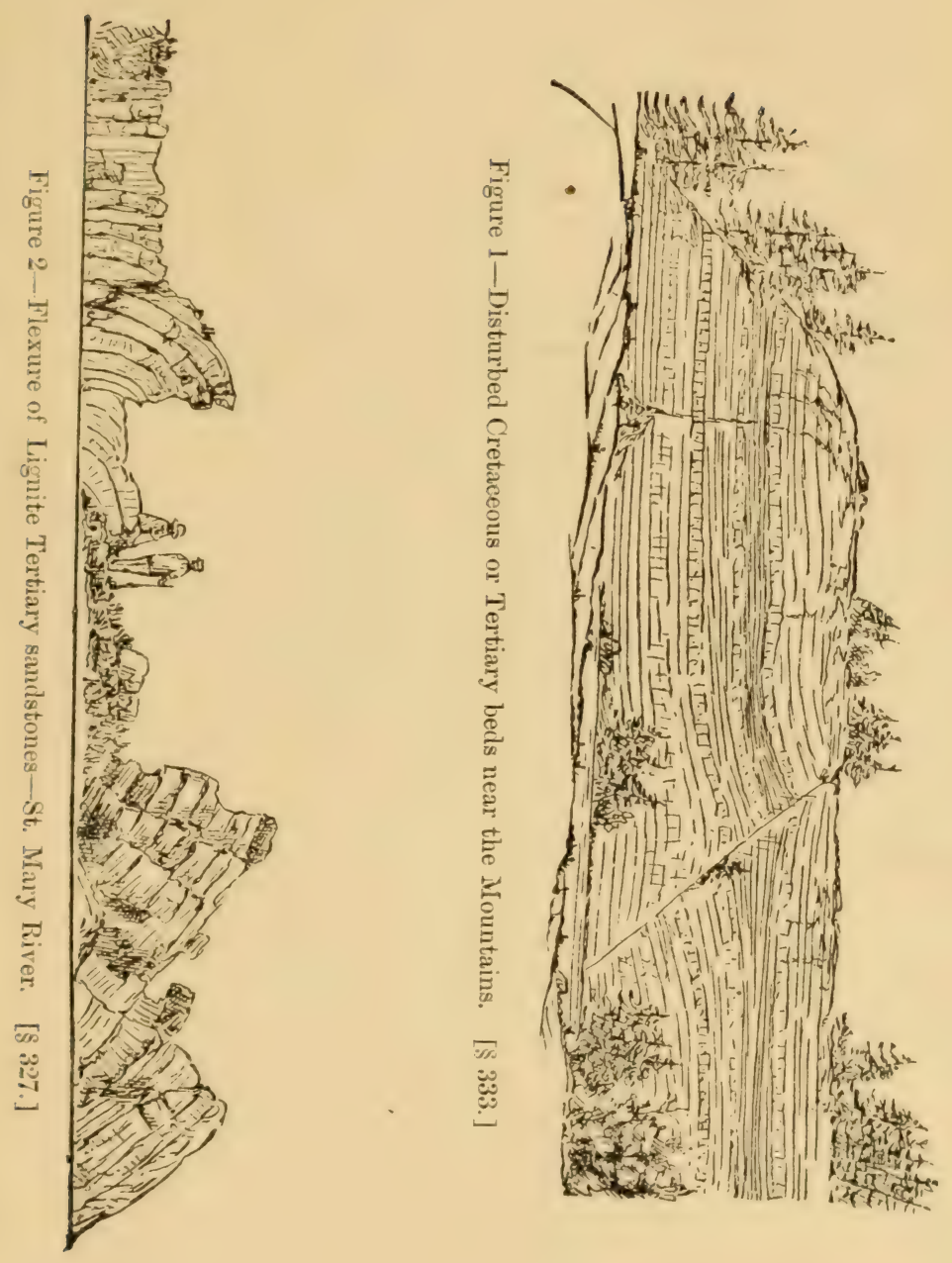

Fire miles east of the entrance of the pass, and north of the Mount Wilson Range, exposures of thin-bedded clays and argillaceous sandstones, with occasional beds of hard flaggy sandstone, were seen. The whole are of varioue shades of light grey, and though curiously folded and faulted, not much altered. Some surfaces of the sandstone are strewn with small carbonaceous fragments, but no recognizable fussils were found. (Plate IX., Fig. 1.)

334. The South Fork of the Belly River-which rises between the Mount Wilson and Chief Mountain ranges, and flows northward out upon the plain-where its valley is contracted among the mountains, in some places lies between high banks, which though in most cases composed of drift, in one locality, about four miles north of the Line, showed a section of beds probably Tertiary. The beds are thin sandstones and clays, like the last, and dip northward at an angle of about $15^{\circ}$. These beds here actually lie in a retired valley among the older rocks of the mountains. Further down the same stream, large fragments of lignite, exactly resembling that of the eastern Tertiary rocks, were found. As drift at this elevation is altogether derived from the mountains, and not so far travelled as that of the lower levels, it is almost certain that in this valley there exist some beds of Tertiary lignite. 


\section{CHAPER VI.}

\section{GENERAL ARRANGEMENT AND EXTENT OF THE CRETACEOUS AND LIGNITE TERTIARY FORMATIONS.}

Cretaceous No. 1.--Typical series-Representatives westward-Dr. Hector's Group E-Lignites in Lower Cretaceous Rocks-Lignite from Rainy River.-CrETACEOUS No. 2.-Typical series-Representatives westward-Beds of this age on the Saskatchewan-Dr. Hector's Group D.-Cretackocs No. 3.-Typical series-Representatives westward-Representatives in Manitoba.-CRETACEous No. 4.-Typical series-Pembina Mountain Group-Representatives on the Line westward-Effect of this Formation on the country-Modifying effect of Drift-Saline springs-Prof. Hind's Section-Dr. Hector's Groups B and C.-Cretaceous No. 5.-Typical series-Representatives on the Line - Prof. Hind's Seotion.-Distribution of Cretaceous Subdivisions-LigNite Tertiary Formation. - Relation of beds on the Line-Eastern limit of the Formation-Western Representatives-Persistent zone of SandstonesResemblance of western series to Judith River beds-Tertiary Beds observed by Dr. Hector.

\section{Cretaceous No. 1.-Dakota Group.}

335. The beds representing the Dakota, or lowest Cretaceous division, in the typical Missouri River sections, are described as being "yellowish, reddish, and occasionally white sandstones, with, at places, alternations of various coloured clays, and beds and seams of impure lignite; also silicified wood, and great number's of leaves of the higher types of dicotyledonous trees," with "casts of shells referable to the genera Pharella, Axincea, Mactra, and Cyprina," * and Unio Nebrascensis. This description refers to the eastern outcrop of the formation, and where the Cretaceous rocks are agrain exposed beyond the western margin of the Tertiary basin, and along the base of the Rocky Mountains, the whole Dakota group appears to be represented by a series of alternating clays and sandstones. Dr. Hayden says of the western representatives of this group:- "Along the margins of the mountain elevations, I have never been able to discover a single specimen of organic remains that would establish the age of the rocks. I only know that there is a series of beds of remarkable persistency, all along the margin of the mountain ranges, holding a position between well-defined Cretaceous No. 2 and Jurassic beds, and in my previous reports, I have called them transition

\footnotetext{
* Geological Report Yellowstone and Missouri Expedition.
} 
beds, or No. 1. They consist of a series of layers of yellow and grey, more or less fine-grained sandstones and pudding-stones, with some intercalated layers of arenaceous clays. In almost all cases there is associated with these beds a thin series of carbonaceous clays, which sometimes become impure coal, and contain masses of silicified wood, \&c." Also, "on the eastern slope of the Big Horn Mountains, I observed this same series of beds in the summer of 1859 , holding a position between Cretaceous No. 2, and the Jurassic marls, with a considerable thickness of earthy lignite," and large quantities of petrified wood.* Fresh water shells of the genera Unio, Planorbis, and probably Paludina, have been found in association with Ostrea, in beds apparently belonging to this part of the formation in the Black Hills region. It preserves a very similar character as far south as Colorado, and there appears to have been somewhat definitely correlated with the lowest Cretaceous of the eastern Missouri, by the discovery of certain plant remains. $\dagger$ The conditions implied throughout, are those of deposits forming in shallow, salt, or brackish waters, with neighbouring extensive land surfaces, and a marked tendency toward the accumulation of carbonaceous beds or lignites.

336. To this division of the Cretaceous, Dr. Hector is inclined to refer the group which in his general section he has designated by the letter E., $\ddagger$ and which is characterized by great deposits of lignite. The proriso, howerer, is made, that the region which he had examined did not afford sufficiently clear evidence, to render it certain that under the same title, he had not included some Tertiary rocks as well as Cretaceous. The rocks of Series E., are thus described: "Sandstone, coarse and friable, or argillaceous and concretionary, indurated shales and soft limestones, ironstone nodules, beds of lignite 3 to 10 feet. Silicified wood, Taxites and sedge-like stems in the sandstones." §

337. It is highly probable that some at least of the coal and lignite bearing beds, described by Dr. Hector, are really Cretaceous, in view of some of the fossils which he has found associated with them. I The question might indeed be considered as definitely settled in that sense, but for the remarkable mingling of Cretaceous fossils with those of the Lignite Tertiary, in the far west; a subject more fully noticed on a subsequent page. If then, it be admitted that a part of the carboniferous beds belong to the Cretaceous properly so-called, it would appear that they

- U. 8. Geol. Surv. Territ., 1857-59., p. 113 113. U. S. Geol. Surv. Territ, 1873. Vol. 'XVII., of the Journal of the Geological Society, differs. I have adopted that of the former. §xploration of Bricish North America, p. 22\%. I, See especially Foot Note to p. 233, Op. cit. 
must represent one or other of its lower divisions, as from the lithological character of the two Upper Cretaceous groups, preserved with great uniformity, in the varions localities south of the Line, and also in the most widely separated exposures on the forty-rinth parallel, it seems highly improbable that in a comparatively short distance to the northward, they should so change their character as to become coal-bearing. The known tendency of the Dakota group, would then certainly point to it as being the one represented. At the same time, I cannot resist the conclusion, that Dr. Hector was right in supposing that some Tertiary beds are included in his division E., and it may even turn out that a large proportion, or the whole, of this group, really belongs to the base of the Lignite Tertiary. The subject is one not only of geological interest, but of great practical importance, for should it be found, that there are two distinct carboniferous horizons in the rocks of the North-west; the area over which valuable deposits of fuel are to be expected, would-as pointed out by $\mathrm{Mr}$. Selwyn-be very largely increased.

338. The beds referred by Dr. Hector to division E., appear to be extensively developed on the upper parts of nearly all the rivers flowing eastward from the base of the mourtains, including the Red Deer River, North and South Branches of the Saskatchewan, Athabaska, and North Pembina Rivers. Their furthest eastward appearance on the North Sas. katchewan, is stated to be about fifty miles below Edmonton. Mr. Selwyn who has examined the coal-bearing rocks of this river in 1873 , inclines to the view that they are truly Cretaceous, and draws attention in this connection to the fact, that the coal series of Vancouver Island is now known to oceur in the lower part of that formation.*

339. Rocks of the Dakota period have not been recognised in Manitoba, or in any locality along the eastern out-crop of the Cretaceous in British America. In the vicinity of the Line they are concealed below the alluvial lands of the Red River Valley, and if natural exposures are to be looked for at all in this region, it must be in some part of the high lands marking the escarpement of the Cretaceous west of the great system of lakes. That the occurrence and nature of these beds may not be an unimportant question, is shown by their character in Nebraska, where they contain lignites, which though not of very good quality, or great thickness, have been more or less used economically, on account of the great scarcity of finel in that treeless region. These beds, associated

* Report of Progress. Geol. Surv. Canada, 1873-74. p. 50. 
with carbonaceous clays, are mentioned as occurring in numerous localities, and one of them-which appears, however, to be in transition beds between this and the next overlying division-is even stated to have been "worked to a considerable extent," and used by blacksmiths with some success.* Similar beds are now also known to occur in Cretaceous rocks in south-western Minnesota, though not as yet found of a quality sufficiently good for use as fuel. $\dagger$

340. Through the kindness of Mr. A. L. Russell, I have received a sample of lignite from a locality near Fort Francis, on the Rainy River, east of the Lake of the Woods. An analysis of the lignitewill be found in a subsequent chapter. It is said to be found below the water level, in several small streams, and though no geologist has visited the locality, it appears to occur in too great quantity to be accounted for as far travelled drift. It may prove that in this locality we have a Lower Cretaceous outlier similar to those of Minnesota, but here probably resting on the Laurentian.

341. The possibility of the discovery of such fuels as these, in the Province of Manitoba, might not seem worthy of much attention; but there is no reason why in a series such as this, good and raluable deposits may not exist in some localities; a probability greatly heightened if the lignites of the base of the Rocky Mountains, are found to appertain to rocks of similar age. In any event, in the representatives of the Dakota series in Manitoba, there appears to be a possibility that workable lignite beds may exist, and should this prove to be the case, they would offer the nearest and most accessible source of fuel, to the settlements of the Red River Valley.

\section{Cretaceous No. 2.-Fort Benton Group.}

342. The Fort Benton Group, or second division of the typical Cretaceous series, is so closely associated with the last, that further investigation may probably render it advisable to unite the two under one name. This is especially the case in many of the more western

* U.S. Geol. Surv. Territ., 1867. p. 48.

† Prof. N. H. Winchell. Second Annual Report Geol. Surv. Minn., 1874

Prof. Winchell's conclusions on the Cretaceous coals (so called) of Minnesota, are interesting as bearing on a country situated in many respects almost exactly as Manitoba. He writes :-

1. The rocks that have been explored for coal on the Cottonwood aud Redwood Rivers, belong to the Cretaceous system, and do not promise to be productive of coal in valuable quantities. 2. The coal here taken out is of an inferior grade, though varying from cannel coal to charcoal. 3. As the rocks of the Cretacenus perind are believed to have existeri throughout the most of the State, the only probable exception being in the south-western portion, including half-a-dozen counties, such coal is likely to occur in a great many places. 4. The "Float" coal which has so often attracted the attention of the people, is derived, so far as yet known, from the disruption of the Cretaceous rocks by the glaciers of the ice period. It is scattered through the drift, and is met with in wells and other excavations, and may be often picked up along the beds of streams. 
must represent one or other of its lower divisions, as from the lithological character of the two Upper Cretaceous groups, preserved with great uniformity, in the varions localities south of the Line, and also in the most widely separated exposures on the forty-rinth parallel, it seems highly improbable that in a comparatively short distance to the northward, they should so change their character as to become coal-bearing. The known tendency of the Dakota group, would then certainly point to it as being the one represented. At the same time, I cannot resist the conclusion, that Dr. Hector was right in supposing that some Tertiary beds are included in his division E., and it may even turn out that a large proportion, or the whole, of this group, really belongs to the base of the Lignite Tertiary. The subject is one not only of geological interest, but of great practical importance, for should it be found, that there are two distinct carboniferous horizons in the rocks of the North-west; the area over which valuable deposits of fiuel are to be expected, would-as pointed out by Mr. Selwyn-be very largely increased.

338. The beds referred by Dr. Hector to division E., appear to be extensively developed on the upper parts of nearly all the rivers flowing eastward from the base of the mourtains, including the Red Deer River, North and South Branches of the Saskatchewan, Athabaska, and North Pembina Rivers. Their furthest eastward appearance on the North Sas. katchewan, is stated to be about fifty miles below Edmonton. Mr. Selwyn who has examined the coal-bearing rocks of this river in 1873 , inclines to the view that they are truly Cretaceous, and draws attention in this connection to the fact, that the coal series of Vancouver Island is now known to oceur in the lower part of that formation.*

339. Rocks of the Dakota period have not been recognised in Manitoba, or in any locality along the eastern out-crop of the Cretaceous in British America. In the vicinity of the Line they are concealed below the alluvial lands of the Red River Valley, and if natural exposures are to be looked for at all in this region, it must be in some part of the high lands marking the escarpement of the Cretaceous west of the great system of lakes. That the occurrence and nature of these beds may not be an mimportant question, is shown by their character in Nebraska, where they contain lignites, which though not of very good quality, or great thickness, have heen more or less used economically, on account of the great scarcity of finel in that treeless region. These beds, associated

- Repurt of Progress. Geol. Surv. Canada, 1873-74. p. 50. 
with carbonaceous clays, are mentioned as occurring in numerous localities, and one of them-which appears, however, to be in transition beds between this and the next overlying division-is even stated to have been "worked to a considerable extent," and used by blacksmiths with some success.* Similar beds are now also known to occur in Cretaceous rocks in south-western Minnesota, though not as yet found of a quality sufficiently good for use as fuel. $\dagger$

340. Through the kindness of Mr. A. L. Russell, I have received a sample of lignite from a locality near Fort Francis, on the Rainy River, east of the Lake of the Woods. An analysis of the lignite will be found in a subsequent chapter. It is said to be found below the water level, in several small streams, and though no geologist has visited the locality, it appears to occur in too great quantity to be accounted for as far travelled drift. It may prove that in this locality we have a Lower Cretaceous outlier similar to those of Minnesota, but here probably resting on the Laurentian.

341. The possibility of the discovery of such fuels as these, in the Province of Manitoba, might not seem worthy of much attention; but there is no reason why in a series such as this, good and valuable deposits may not exist in some localities; a probability greatly heightened if the lignites of the base of the Rocky Mountains, are found to appertain to rocks of similar age. In any event, in the representatives of the Dakota series in Manitoba, there appears to be a possibility that workable lignite beds may exist, and should this prove to be the case, they would offer the nearest and most accessible source of fuel, to the settlements of the Red River Valley.

\section{Cretaceous No. 2.-Fort Benton Group.}

342. The Fort Benton Group, or second division of the typical Cretaceous series, is so closely associated with the last, that further investigation may probably render it advisable to unite the two under one name. This is especially the case in many of the more western

* U.S. Geol. Surv, Territ., 1867. p. 48.

† Prof. N. H, Winchell. Second Annual Report Geol. Surv, Minn, 1874.

Prof. Winchell's conclusions on the Cretaceous coals (so called) of Minnesota, are interesting as bearing on a country situated in many respects almost exactly as Manitoba.' He writes :-

1. The rocks that have been explored for coal on the Cottonwood aud Redwood Rivers, belong to the Cretaceous system, and do not promise to be productive of coal in valuable quantities. 2. The coal here taken out is of an inferior grade, though varying from cannel coal to charcoal. 3. As the rocks of the Cretaceous period are believed t, have existed throughout the most of the state, the only probable exception being in the south-western portion, including half-a-dozen counties, such coal is likely to occur in a great many places. 4. The "Float" coal which has so often attracted the attention of the people, is derived, so far as yet known, from the disruption of the Cretaceous rocks by the glaciers of the ice period. It is scattered through the drift, and is met with in wells and other excavations, and may be often picked up along the beds of streams. 
localities, south of the Blacke IIills, and along the base of the Rocky Mountains. In Nebraska, this division is described as consisting of "dark grey laminated clays, with lighter coloured arenaceous partings, and layers and beds of sandstone. Towards the upper part, near its connection with the Niobrara Division above it, it sometimes includes intercalated layers of grey limestone, in all respects similar to the lower portions of the overlying rock; while at some other places, its upper portion passes into a dark shale."* Further west it is very extensively developed near Fort Benton on the Missouri, from which it takes its name. The beds here "assume the form of black plastic laminated clay, with numerous calcareous concretions." $\dagger$ The western edge of this division in Colorado, shows shaly beds, which, though generally argillaceous, are occasionally quite arenaceous, and sometimes more or less calcareons; the total thickness varying from 200 to 400 feet. $\ddagger$

343. In the eastern region of British North America, this portion. of the formation seems to have been pretty clearly recognized, on the Saskatchewan, near Fort à la Corne, by Prof. Hind, who says:"On the North Branch of the Saskatchewan, and a few miles above the Grand Forks, huge masses of a dark coloured, almost black shale, with sharp well-preserved edges, jut out of the banks, and are exposed whenever portions of the face of the clay cliffs fall into the river. Their appearance is such as to justify the expectation, that rock in position, from which they originated, is close at hand. Some specimens which I procured and sent to Mr. Meek, contain, according to that gentleman, fish scales, sharks' teeth and Inoceramus, which renders it almost certain that the masses were detached from rocks belonging to formation 2, or 3 , of the vertical section." Cretaceous No. 2 is also stated to have been recognized from specimens found on the Assineboine River, 250 miles west of Fort Garry; $\|$ but, as the locality thus described must be near Fort Ellice, where the exposures are few, and Dr. Hector, who has examined them, found fossils characteristic of the 4th group only; it is probable that some mistake has arisen, either in the localization of the specimens, or from their obscurity.

344. Dr. Hector, though he does not expressly state that he consider's his firoup D., as representing the Fort Benton, or 2nd group of Meek and Hayden's section, implies as much by placing it between beds

\footnotetext{
- Geolugical Report Yellowstone and Missouri Expedition. t U.S. Geol.Surv. Territ., 1873. p. 101.

5 Report Assinchuhe aml Saskatchewan Fxplorimer Expedition, 1859 || Prof. Meek, in Geological Report Yellowstone and Missouri Expedition. p. 16 
which he correlates with groups 1, and 2. Group D. is described as consisting of "sandstone orerlying marly clays, banded with thin seams of ironstone, thin beds of limestone, stiff dark blue clay, and arenaceous shales, with Ostrea cortex, O. vellicata, O. anomiaformis, Cytherea, Mytilus, Cardium, Venus, Natica, \&c., and stems and roots of silicified trees."* Rocks of this series, he believes, underlie a considerable area of the third great prairie plateau, and are mentioned as occurring on the lower part of the Red Deer River, at the Hand Hills, at the Elbow of Battle River, above Fort Pitt on the North Saskatchewan, on the Bow, and Belly Rivers, and also to the west and north of Edmonton. The relations of this group with those above and below it, do not seem, however, to have been very clearly made out, and Dr. Hector appears to remain in some doubt, as to its position and distribution. $\dagger$ Ostrea vellicata, and $O$. anomiaeformis, are shells characteristic of the Cretaceous formation, in its development near the Mexican frontier, and while their occurrence probably places beyond dothbt, the Cretaceous age of some of the beds here referred to, it is probable that others, especially in the more southern localities, may belong to the marine base of the Tertiary; the rocks of which, in some places near the forty-ninth parallel, answer closely to their description.

\section{Cretaceous No. 3.-Niobrara Group.}

345. The occurrence of rocks of the Niobrara, or 3rd division of the Cretaceous, in the escarpment of Pembina Mountain, near the Boyne River, has been already noticed. (p. 78.) The specimens, so far as they go, exactly resemble those of this member in the typical section in Nebraska, which Dr. Hayden thus describes:- "Lead-grey calcareous marl, weathering to a yellowish and whitish chalky appearance above, containing large scales and other remains of fishes, and numerous fragments of Ostrea conjesta attached to fragments of Inoceramus, passing down into light-yellowish and whitish limestone" and blending with the next lowest group. "At the Black Hills this rock sometimes presents its normal appearance, but generally there, as well as along the Rocky Mountains further west, is scarcely distinguishable lithologically from the formation below." $\ddagger$ In Colorado, according to Mr. Marvine, No. 3 still retains to some extent its calcareous character, and consists in great part of impure limestones, often highly fossiliferous. $\S$

* Exploration of British North America, p. 227.

; Geological Report Yellowstone and Missouri Expedition, p. 14

\$ U. S. Geol. Surv. Territ., 1873. p. 102. 
346. With this division Dr. Hector correlates group C, of his general section, composed of dark clays, with septarian nodules. These beds, however, I have, I believe, clearly identified as forming an integral part of Meek and IFayden's 4th group, as displayed in the vicinity of the Line, a conclusion also warranted by the fossils obtained by Dr. Hector in them. If this is the case, none of the beds described by Dr. Hector ('an be cited as representing No. 3, unless, indeed, a part of those included under D., may belong here. The rocks which appear to come up from below No. 4, near the East Fork of Milk River, already fully described; (\$ 280) from their position might represent the Niobrara group, and it is worthy of remark, that in their lithological character they pretty closely resemble Dr. Hector's group D. Limestone beds, or even rocks containing many calcareous fossils, are, however, altogether wanting, and the occurrence of richly carbonaceous clays so close below the base of No. 4, is somewhat anomalous. A similarity also suggests itself between these beds and those described by Dr. Hayden,* as directly underlying the Judith River fresh and brackish-water deposits. These Dr. Hayden provisionally classes with Cretaceous No. 1, and has observed in another locality, to pass beneath No. 4; which appear's to prove that in this particular region, Nos. $2 \& 3$, are unrepresented. The lithological resemblance is moderately close.

\section{Cretaceous No. 4. Fort Pierre Group.}

347. This group appear's to occupy a very great extent of country in the region north of the forty-ninth parallel The junction of this part of the formation with that next below it, is pretty definite, and there is not the same palsontological and lithological blending, that occurs between the three members below it. At its base, occurs the first real break in the typical Cretaceous series of the interior of the continent; and here the line reparating the upper and lower portions of the Cretaceous has been placed. In the Nebraska section, this division is represented by a great thickness of " fine, grey, and dark-coloured clays, in moderately distinct layers, but never presenting a laminated or slaty structure, like the Fort Benton group. When wet the clays are soft and plastic, but on drying they often crack and "rumble so as to obliterate the marks of deposition in vertical exposures." $\dagger$ Towand the base, there occurs in this division, in some places, a local bed of from ten to thirty feet in thick- 
ness, of fine unctuous clay, with much carbonaceous matter, and containing also crystals of pyrites and selenite, and impressions of fish scales. The western outcrops of No. 4 on the upper Missouri, and along the Rocky Mountains, as far south at least as Colorado, appear to maintain, to a great extent, the character which it presents in the east.

348. The beds which I have included in the Pembina Mountain group, appear to belong to this part of the series. Their character has already been fully described. They extend; in all probability, on the forty-ninth parallel, from the escarpment of Pembina Mountain, nearly to the edge of the Lignite Tertiary formation, on the 102nd meridian. In the great searcity of organic remains, they resemble the typical series as dereloped in the original locality near Fort Pierre, * and from the obscurity of their stratigraphical relations in the Pembina Mountain region, their position might still remain a doubtful question, but for their precise lithological resemblance to beds, north, and west of this place, the horizon of which can be defined by palæontological evidence, and superposition. The only part of the Pembina Mountain series, in which septarian nodules form a striking feature, is that shown at the foot of the escarpment, and near the base of the sections there exposed.

349. Where these rocks are again brought to riew south of the Wood Mountain Tertiary plateau, their general appearance is somewhat different from that of those of the Pembina Mountain sections. They are, as a whole, more crumbling and earthy, but extensive layers in them still so closely resemble the eastern rocks, as to be lithologically indistinguishable from them. These harder layers do not appear to be confined to any particular horizon, but occur in different localities, sometimes near the top, sometimes nearer the base. The septarian nodules are now found at sereral different levels in the section, characterizing narrow zones, and it is almost exclusively in connection with them that fossils are preserved, the intermediate beds being nearly as barren as the clay-shales of Pembina Mountain, but always clearly distinguishable from the overlying Tertiary rocks.

350. After passing over a great plain based on Tertiary rocks, the 4th group again appears upturned around the flanks of the Buttes, and still preserving-though now within a hundred miles of the base of the Rocky Mountains-its old characters, the only real change being the introduction of a few arenaceous layers, small in thickness and extent, but

* Geological Report Yellowstone and Missouri Expedition, p. 40. 
sufficient to vindicate the character maintained through the whole of the Cretaceous period by the Rocky mountain region - that of deposit by more rapidly moving waters. West of this place, the beds of the Fort Pierre group are not seen in the vicinity of the Boundary-line, though I am of opinion, from the rapid southward slope of the country toward the Missouri Valley, that these beds of the Cretaceous must again come to the surfuce not far south of the forty-ninth parallel. The Missouri, it would seem, flows for the upper part of its course in a trough excavated in Cretaceous beds, of which the southern part of the Lignite Tertiary, met with on the forty-ninth parallel, forms the northern edge.

351. The character impressed on the face of the country, whenever the beds of No. 4 immediately underlie the surface, is unfavourable in the highest degree. Without the intermixture of foreign material, the debris of these rocks seems scarcely capalle of supporting vegetation. Their fine unctnous character prevents any drainage from below, and the plains based on them, alternate with the keason, from the condition of soft tenaceous mud, to that of hard white sun-cracked clay. I have frequently noticed spots poached up by the buffaloes in their spring. migration, consolidated hy the heat and drought of summer to such an extent, that the passage of twenty or thirty loaded waggons will not suffice to form a level trail. These clays appear also to want the chemical ingredients of a good soil. Calcareous matter is generally almost entirely absent, and from the small quantity of organic remains, and the refactory nature of the shales under the blow-pipe, phosphates and alkalies are probably deficient, the felspar being, to a great extent, kaolinizcd. The saline waters of springs issuing from these clays, impregnate the soil of the low grounds and vallies, and produce conditions farourable to the growth of Sulicornea, Obione, Sarcobatus, \&c., while the higher plains are the most perfect deserts met with on the forty-ninth parallel, and are often almost destitute of vegetation; or, sparingly covered with Cactus and Stipa.

352. Dr. Hayden, in treating of this group, writes:- "This formation is the most inportant one in the Cretaceous system of the Northwest, not only in regard to its thickness and its geographical distribution, but also in its influence on the agricultural capabilities of the country." "In summing up the extent of country underlaid by this great formation, we find that south of the Lignite Basin, it occupies an area of two hundred miles in length, and one hundred in width; or, twenty thousand Aquare miles. North of the Great Lignite Basin, 
oommencing at its first appearance near Milk River, we find it corering an area of two hundred miles in length, and sixty in breadth; or, about twelre thousand square miles. I have been thus particular in estimating its approximate limits and extent of surface, on account of its influence on the future destiny of that region. Wherever this deposit prevails, it renders the country more completely sterile than any other geological formation I have seen in the North-west. We see from the above estimate that it renders barren, orer thirty thousand square miles of the valley of the Missouri." * The contrast between the country resting on this formation, and that based on the Lignite Tertiary, is rery striking, and even in regions where the vegetation is stunted from the want of sufficient moisture, and where the dry uplands of the Tertiary would seem, at first sight, less favourable than the low-lying plains of No. 4; the former can support a short thick growth of nutritious grasses, where the latter has the character abore described. In tracing the outlines of the various formations in a country where exposures are usually so rare and small, this difference of character in the aspect of its surface, is soon remarked as a valuable aid.

353. These remarks, however, only apply in their entirety to the region south of the great transverse watershed, which approximately follows the forty-ninth parallel; and to the higher ground toward the base of the mountains. Wherever the causes which have produced the thick drift deposits of the plains, have operated in their full intensity, the influence of the underlying beds on the soil, has been greatly modified by the addition of transported material. This modifying action has perhaps nowhere been more effectual, than over the areas covered by No. 4, which, from its comparatively yielding character, has been cut away into hollows and buried under great depths of travelled material. The improvement thus effected on the country is especially notable between Pembina Escarpment, and the Missouri Coteau. I cannot speak from personal knowledge of the country south-west of the upper parts of the Red River Valley, but it is probable that the drift agencies have here, to a certain extent, orer-ridden the low barrier of the water-shed. Further west, and south of the Tertiary plateaus of Wood Mountain, and the Cypress Hills, the barriers to the north-eastern drift appear to have been nearly complete.

354. As already mentioned, the waters of springs flowing from all 
parts of No. 4 are impregnated with salts-probably in the main sodic and magnesic sulphates-and are often also charged with sulphuretted hydrogen. Springs of this class were specially noted in the Pembina Mountain region, and where the disturbed beds of this division are upturned at the Buttes. In the latter locality some springs were found from which sulphuretted hydrogen was given off so freely, and so little mingled with other galses, that it might be ignited on the surface of the water.

355. Prof. Inind, in 1858, recognised this division of the Cretaceous in several widely separated localities, and obtained fossils from it which were examined by Prof. Meek, and aided in fixing the position of the beds. The most interesting sections described by Prof. Hind, are those on the Souris River, a short distance above its junction with the Assineboin, and about thirty miles north of the east end of Turtle Mountain, or near the present western boundary of Manitoba. Several of the fossils obtained were specifically new. The following list is given: Anomia Flemingi, Inoceramus Canadensis, Leda Hindi, Natica obliquata, Avellana concinna and Ammonites.* The two latter were obtained at the Two Creeks on the Assineboine, sixty miles west-north-west of the Souris River exposures. Both these localities are interesting, as lying at no great distance north of the Line, and opposite a part of it where no sections appear. The other localities for this division, mentioned by Prof. Hind, are: Big Cut Arm Creek, and Scissors Creek, on the Qu' Appelle River; also the South Saskatchewan near the Elbow, where Avicula linguiformis was found; also midway up the escarpment of the second prairie steppe, at Riding Mountain.

356. Dr. Hector, in his report considers his group B., to represent No. 4. He describes it as consisting of "Indurated olive-coloured shales, with bands and fissures filled with clay ironstone. This formation he first met with at Long River, the rocks of which are elsewhere described in this report (\$195) and are identical with those of the upper part of the Pembina Mountain series, as developed on the Pembina River. Dr. Hector, a few days afterward, examined the exposures near Forked Creek on the Assineboine, from which some of Prof. Hind's fossils were obtained, and there found the rocks to be exactly similar. Leda Hindi wats also found, and in addition Ostrea luyubris, scales of ctenoid fishes, annelide tubes, and plant remains. (iroup B., is also supposed to occur south of the (2u'Appelle River, and on the North Saskatchewan for a con-

- Inseribed and figured in Report Assinehoin and Saskutchewan Exploring Expedition. Toronto, 1859; and Narrative of the Canadian Red River Exploring Expedition. London, 1860. 
siderable distance above the Eagle Hills. The beds examined in the localities referred to by both Hind and Hector, and those of Pembina Mountain, would seem to belong to the upper part of the th group, for Prof. Meek in writing of the fossils states that they are of species which occur in No. 5, as well as No. 4, but mere commonly in the latter, which, with the lithological character of the matrix "leaves little room to doubt" that the beds represent No. 4 .

357. Division C., of Dr. Hector's section, correlated by him with No. 3 of the Nebraska series, may now, I believe, also be certainly incluled in No 4. It is described as consisting of "dark purple and brown laminated clays, with ironstone septaria, and sometimes crystals of selenite."* These beds were found at Fort Ellice, on the Assineboine; at the elbow of the South Saskatchewan, in relation with the escarpment of the third prairie plateau; at the base of the Cypress Mountains on their northern side, at the Eagle Hills, and on the North Saskatchewan at Fort Pitt. From the South Saskatchewan locality, Baculites compressus Inoceramus (I. Crepsii of Roemer and Conrad ?) Pholadomya occidentalis Morton, Cardium, Exogyra, Astarte Texana, and Cytherea were obtained, and are in themselves sufficient to mark the horizon with some certainty.

358. I have described similar rocks, certainly referable to No. 4, about fifty miles southward of the Cypress Mountain locality, referred to in the last paragraph; and a considerable stretch of country south of these hills appears to be based on this member of the formation. One hundred and twenty miles southward of the locality on the south Saskatchewan, and south of the Lignite Tertiary plateau, sombre ('retaceous clays, with large septarian nodules, exactly resembling those described by Dr. Hector, and containing some of the same fossils, are found, and are known to belong to division 4 , not only by the fossils. but by their stratigraphical relation. These rocks were also found, as already stated, to contain thick bands, indistinguishable from the harder clay-shales of Long River and Pembina Mountain.

\section{Cretaceous No. 5.-Fox Hill Group.}

359. The Fox Hill group, is the highest of the Cretaceons series of the west, and is thus described in the Nebraska section :- "This formation is generally more arenaceous than the Ft. Pierre group, and also differs in presenting a more yellowish or ferruginous tinge. Towards 
the base it consists of sandy clays, but as we ascend to the higher beds we find the arenaceous matter increasing, so that at some places the whole passes into a samdstone. It is not separated by any strongly defined line of demarcation from the formation below, the change from the fine clays of the latter to the more sandy material abore, being very gradual."'* Nor does the transition appear to be marked by any great change in life, as indeed this division might almost as well be considered the closing epoch of the last, but for the lithological break, and the persistency of these upper sandstones over great areas. In the Black Hills region, and along the base of the mountains, they are well dereloped, with similar lithological character.

360. Though this division must border the eastern edge of the Lignite Tertiary, its rocks are not there exposed in the vicinity of the fortyninth parallel. The first beds distinctly referable to it, were met with in the Bad Lands south of Wood Mountain, and in the general section there dewignated by the letter $\gamma$. Their outerop is again seen on the White Mud River, and they must follow continuously along the southern base of the Tertiary plateau, though seldom exposed. They were not seen at the junction of the Cretaceous and Tertiary, east of Milk River, but their position was marked by sand-hills. On the flanks of the Buttes, they are again brought to the surface, and consist of rather hard sandstone, with some softer and more argillaceous beds near the base. Judging from the few localities where they were observed, the extent of their induration appears to increase westward, being greater in the White Mud River sections than the Bad Lands, and still more pronounced near the Buttes.

361. Prof. Hind notes the occurrence of these rocks in two places only, hoth situated on the northern edge of the Wood Mountain Tertiary plateau. The first is at the junction of the Eyebrow Hill stream, on the Qu'Appelle, where ferruginous clays, and hard greenish sandstones, with some veins of selenite, appear. The second locality is the Elbow of the South Saskatchewan, $\dagger$ where the rocks consist of greenish, and yellowishgrey sandstonos, with some clays, and large imbelded concretions. The forsils obtained from these were submitted to Prof. Meek, and by him stated to be characteristic of group 5 ; the following species being represented: Scaphites Conradi, Nautilus Deckyi, Avicula linguiformis, Avicula

* Ceological Report Yellowstone and Missourl Expedition, p. 22.

+ This is probably also the lueality described by Prof. Bell. Report Progress Geol. Surv. Canada, p. 75. $1873-74$ 
Nebrascana, and Rostellaria Americana. As localities of this group, Dr. Hector mentions doubtfully the Elbow of Battle River, and the lower part of the section at the Roche Percée. The latter may now be included certainly in the Lignite Tertiary. The former is not fully described, and no fossils appear to have been obtained from it.

\section{Distribution of Cretaceous Subdivisions.}

362. Taking into account, the whole of the information accessible on the Cretacéous formation in the interior region of British North America, and the general contour and character of the country; the limits of some of its members, and the area they cover, may be laid down with an approach to accuracy. The western boundary of No. 4 crosses the forty-ninth parallel, between the 170 and 240 mile points west of Red River, and probably nearer the latter than the former. Thence it runs west-north-westward, and passing north of the Lignite Tertiary beds discovered by Prof. Bell near Dirt Hills, becomes nearly identified with the edge of the Missouri Coteau, before reaching that part of it called the Thunder Breeding Hills on Palliser's map. Thence, after dipping southward into one or two deep bays, it reaches the Cypress Hills. A narrow neck of these Cretaceous rocks, may thence possibly pass round the western escarpement of these hills, and unite with the wide area covered by them to the south, where they stretch from long. $109^{\circ}$ to about long. $110^{\circ} 20^{\prime}$ on the Line. The strip of this formation northward of the Cypress Hills, is, according to Dr. Hector's map, * quite narrow ; and northward from the Thunder Breeding Hills he has laid down the western edge of the rocks which I identify with No. 4, as nearly following the edge of the third prairie plateau,- - previously described,-to the North Saskatchewan. South of the Wood Mountain portion of the Tertiary plateau, the rociks of this series, and of No. 5 , have a breadth of about eighty miles on the forty-ninth parallel, and stretch northward in the form of bays and inlets into the Tertiary. Round the whole of the northern edge of the Missouri Coteau, the rocks of No. 5, probably cover but a narrow strip of ground, between the boundary indicated for No. 4 and the Tertiary to the south; with, howerer, the exception of the locality near the Elbow of the South Saskatchewan, where they appear to be more important, and to underlie a considerable area.

363. Eastward from the edge of the third platean, rocks of the age 
of the Fort Pierre group, probably occupy nearly the whole area of the secoml platean, south of the North Saskatchewan, and between it and the Boundary-line. Fastward, they terminate in the escarpment overlooking Manitoba Lake, and the low lands of the Red River Valley. It is possible, however, that future explrations may bring to light, over this great area, many places where the beds of No. 5 have been preserved, from their superior hardness, especially in such high-lands as the Touchwood Hills, and parts of the so-called 'mountains' of the eastern escarpment. Outlyers of the Lignite Tertiary may even yet be found.

364. The rocks of the earlier Cretaceous do not seem immediately to underlic any great area on the eastern edge of the formation, but to occur merely along the base of the high-lands formed by No. 4. In the ricinity of the forty-ninth parallel, they are completely hidden by alluvial deposits. If it be supposed that No. 4 is shown nearly to its base, in Pembina Fiscarpment, on the Line; allowing the two lower divisions the same thickness assigned to them by Meek and Hayden in Nebraska, and taking the general slope of the prairie surface toward Red River, as representing that of the denuded edges of the rocks below, - suppositions, none of which are probably far from the truth-then, rocks of the 3rd Group, with a thickness of 200 feet, would have their eastern limit about twenty miles from the base of the escarpment, while those of the two lowest groups, would pass below the bed of the Red River, with a thickness of about 1,000 feet. This would allow them to alut directly on the older Silurian or Laurentian rocks of the east. Rockis apparently belonging to this formation, as proved by boring, umlerlie the allurial and glacial drift deposits of the Red River Valley, at Morehearl, 180 miles to the south; and are also now known to overlap Laurentian and Silurian rocks in south-western Minnesota.* While it is proluahle that they exist below the Red River prairie on the Line, at least as fur east as the river, and very likely to the eastern palæozoic boundiry of the valley; it is hardly probable that they do so in such fince at alove indicated. The basin of older rocks containing those of the ('retacens, probably shoals rapidly eastward, and would cause these marrinal beds (1) be thinner than those of the Nebraska section. It is alsi) probable, that their eastern edges may have a pronounced westward (lip, whelh would cause them to run out more rapidly. As a proof of the

- Prof. N. H. Winchell, Second Annual Report Geol. Surv. Minn., 1874. 
CRETACEOUS AND TERTIARY-GENERAL ARRANGEMENT.

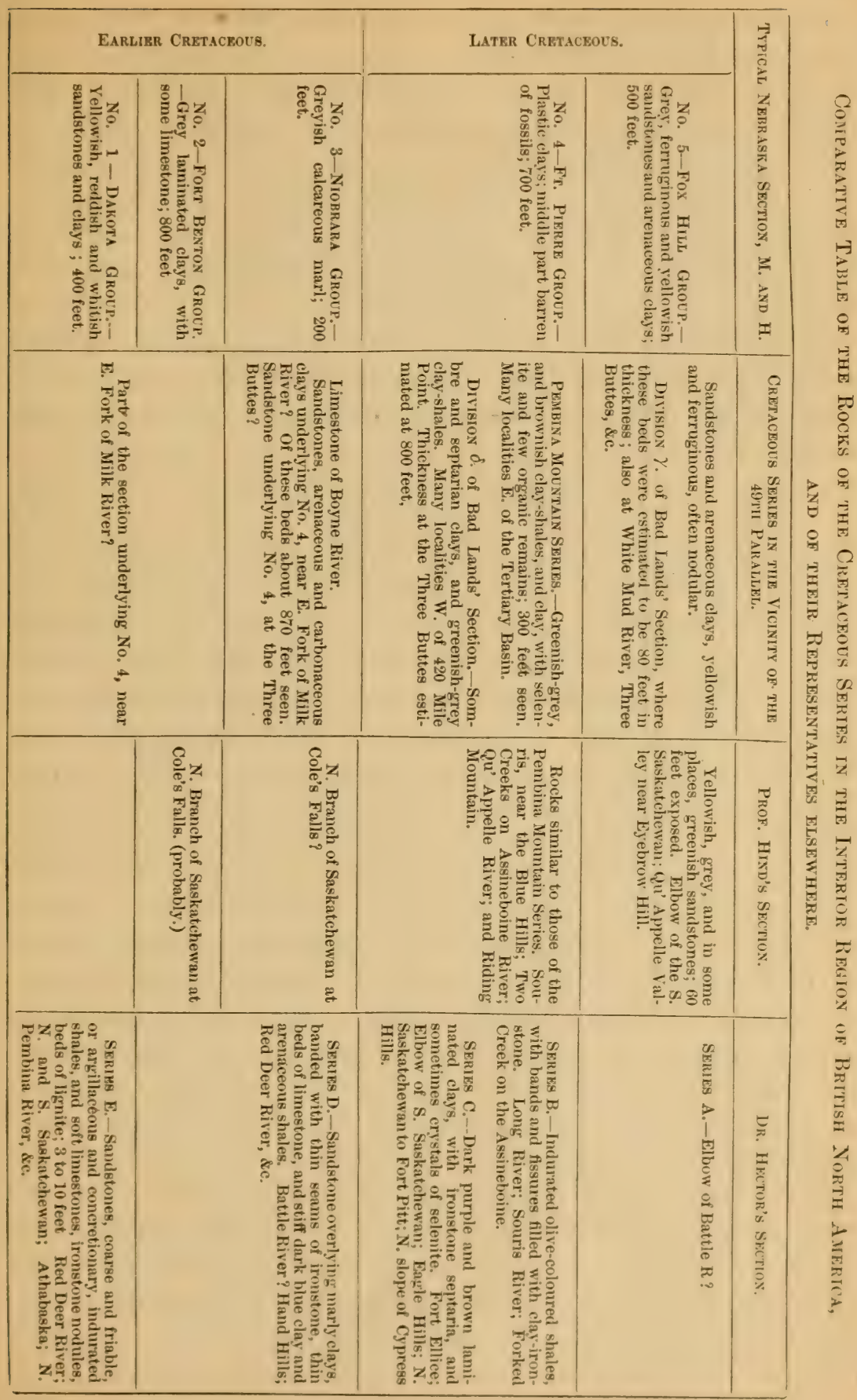


general horizontality of the Cretaceous rocks, however, it is worthy of notice, that the difference of elevativa between the station at the foot of Pembina Fiscarpment,-where No. 4 is reen,--and the point where the Cretaceous rocks are known to be orerlapped by the Tertiary, 200 miles westward, is about 750 feet; 700 feet being the thickness assigned to No. 4, in Nebraska. This would allow the beds to be almost perfectly horizontal, as No. 5 is only about eighty feet thick, when seen near Wood Momtain, and the base of No. 4 is not exposed at the first mentioned locality.

The possibility of the discovery of lignites in the lower Cretaceous, has been already adverted to, and the extent of this portion of the formation, may perhaps become a question of some importance in this regard.

\section{Lignite Tertiary Formation.}

365. The highest beds of the Lignite Tertiary series, in the vicinity of the forty-ninth parallel, are probably those which occur about Porcupine and Pyramid Creeks, and the Great Valley, and high lands south of the Missouri Cotean; and I am inclined to believe that if there is any difference of horizon among the beds of these localities, those of the first mentioned may somewhat overlie the others. At the same time, in a region where local dips due to original irregularity of deposition, so much surpass in amount those due to any general inclination of the beds; and where individual strata have so little constancy, and good exposures occur with comparative rarity, it is impossible to arrive at any very precise knowledge of the equivalency of the beds of different localities. The creeks above mentioned cross the Line at the 385,352 , and 345 mile points respectively, and have been proved by the explorations of Lieutenant (ireene of the U. S. Northern Boundary Survey, to be tributaries of the (2uaking $A s h$, an affluent of the Missouri. In connection with this part of the section, numerous and important beds of lignite occur, in ansociation with greyish, yellowish, and purplish arenaceous clays, sands, and little consolidated sandstones, and bands of ironstone. The deposit shows no trace of marine or brackish-water conditions, and wherever remains of molluses are found they are those of fresh water. The lignites appear to prove the frequent elevation of parts of the area above the surfite of the water, and the general prevalence of plant remains in the intervening sands and clays, show that at no time were land surfaces far removed. 
366. The upper beds of the Souris River sections, in the vicinity of Wood End Depôt, though probably occupying a position inferior to those of the localities above mentioned, cannot be separated from them by any determinate character. They show perhaps a somewhat more regular deposition, and a more rapid alternation of conditions, but are little, if at all, more indurated. The lower beds of the Souris River sections, including the nodular sandstone of the Roche Percée series, are in great part arenaceous, which, together with the frequency with which some of the molluses have sustained fracture of their shells during life, would indicate disturbed waters. Nothing of the nature of a conglomerate, howerer, occurs, nor can the sandstones often be considered coarse. In beds overlying the Roche Percée sandstones, the only remains indicative of brackish-water,-being shells of Corbula,-were found; and these were in association with preponderating numbers of purely fresh-water forms.

367. In my Preliminary Report on the Lignite Tertiary, the following remarks, bearing on the position of its eastern limit on the Boundary, were made:-The Souris Valley, for about four miles east of the Roche Percée, continues to show numerous sections of the usual clays and sands, and hardened sandstone beds, - the latter in one place nearly three miles east from Roche Percée,-forming a group almost equally picturesque with it. Rather hard beds of sand and sandy clay are seen in several places to underlie the sandstones, and one of these was found to be filled with well-preserved specimens of a peculiar Paludina. About a mile further east, the valley changes its character considerably; the banks formerly scarped and clayey, are replaced by regular grassy slopes, and, though followed for a distance of ten or fifteen miles beyond this point, yielded no further sections. This change I am at present disposed, in the absence of more certain data, to consider as indicating the passage from the Lower Tertiary beds to the Cretaceous. The eastern edge of the outcrop of the harder beds connected with the Roche Percée, also appears to be indicated by a slight, though pretty well defined step in the level of the prairie, which may be considered as the first gentle rise of the Missouri Coteau, and runs about south-eastward to the Boundary-line, which it crosses near the 240 mile point. The spring, known among the Half-breeds as Peter's Spring, lies at the foot of this step, not far north of the Line, and is probably connected with the junction of the more permeable sandstone beds with the underlying impervious clays. It is possible that lignite coals of importance may 
exist on a lower horizon than this, and in beds showing a more decided approximation to marine deposition, and cretaceous forms of life; in which case their out-crop would ocecur still further to the east. It is not, however, very probable that this is the case, as the inve.tigations of Hayden and others south of the Line seem to show that in the eastern region the deposition of lignite did not commence till the conditions of the Cretaceous formation had distinctly passed away.

368. I am now aware of the existence of a lignite bed a few inches in thickness in clay beds underlying the Rocine Percée sandstone, in a tributary of the Souris River, and this, taken in connection with the position of the presumed representatives of these sandstones in the western development of the formation, would seem to show that some thickness of Tertiary beds may underlie them. This would place the outcrop of the eastern edge of the formation at least several miles further eastward than above stated; as shown in the map accompanying this Report. North-westward from its intersection with the forty-ninth parallel, the position of the line of junction laid down on the map, is not founded on direct observation, the country being thickly covered with drift, but includes all known exposures of the Tertiary-joining with Prof. Bell's observations northward-and is probably not in any part of its course far from the truth.

369. The palxontological resemblance of the portion of the Lignite Tertiary above described, with the typical Fort Union beds, is exact. Their lithological similarity, though less to be depended on, is not less striking; but the rocks of the forty-ninth parallel, when compared with the sections on the Missouri River, appear to show a general tendency of the beds, northward, to include more carbonaceous matter. The lignites are more frequently found, are generally thicker, and almost always more compact and purer than those of the eastern extension of the Tertiary to the south. The identity of the rocks on the Line, however, from the Roche Percée westward to Wood Mountain, with the eastern fresh-water extension of the southern Lignite Tertiary, generally known as the Fort Union Tertiary, does not admit of doubt, and to whatever horizon the one is finally adjudicated, the other must follow.

370. In continuing a review of the formation westward, the sections in the Bad Lands south of Wood Mountain next require mention. Here the Lignite Tertiary is found with a somewhat different appearance; and westward from this point it gradually changes, till in the region arvund the Buttes, it has assumed an appearance so entirely different 
from that of its eastern development, that were sections from the two localitios directly compared, it would be difficult to prove their equivalency. The beds best exposed in the Bad Lands, it is true, are at the very base of the formation, and lower than any seen east of this place; still their difference, when compared with those of the Souris, is not very striking, and chiefly obtains with the lowest beds of division $\beta$., which are more massive, and homogeneous, while the upper part of this division, with its lignites, corresponds closely enough with the lignite-bearing beds near Wood End. In some of the lower beds of $\beta$., a pale greenish grey tint, not previously observed, appears; and the introduction of reptilian bones is a new feature, none having been found east of this place. No molluscous fossils were found in the beds of this locality.

371. On the Milk River, where the next great series of exposures of this formation occurs, its character has undergone a further change. The pale greenish shade is now more pronounced, and characteristic of a greater thickness of the beds; and while well marked fresh-water molluses abound, they are mixed for the first time with the remains of Ostrea, a marine genus. Lignites still occur, though not abundantly, and reptilian bones are found in certain layers. Midway in the section, is an important band of sandstones, which may be placed, conjecturally, on the horizon of those of the Roche Percée and division $a$. of the Bad Lands. The change from salt to fresh water conditions, which, in the eastern regions seems synchronous with the change from Cretaceous to Tertiary, here begins to fail us as a test.

372. In the vicinity of the Buttes, or Sweet Grass Hills, while lignites and carbonaceous clays still occur, the beds are characterized by the presence of Ostrea shells in great numbers, with one or more species of molluscs identical with those of the Bitter Creek coal series of Wyoming, and a Dostia (Neritina) apparently indistinguishable from those of Coalville in Utah. Near the first and second branches of the Milk River, where the formation is again well exposed, there is a remarkable reversion to fresh water conditions, quite at variance with its general tendency to become more strictly marine westward. Dinosaurian and other reptilian remains, however, still occur in connection with Unio, near the First Branch, and on the Second Branch the bone-bearing beds appear to overlie a considerable thickness of strata holding Limnoea, Paludina, Planorbis, and Sphorium-some of which are identical with those of the welldefined eastern Fort Union beds. Greenish-grey, arenaceous clays, now constitute a large part of the sections, coarse sandstones occur fre- 
quently, and a fiew beds of conglomerate are noted. No lignites were, however, observed in this part of the fimuation.

373. Where next met with, on the St. Mary River, the beds of the formation represented, are probably considerably below thowe of the last localities. They still have much the same general character; and greenish, arenaceous clays are conspicuous. They are more consolidated, howerer; the coal found here differ's considerably from the lignites of any of the eastern localities, and the mollusca, though probably estuarine, are decidedly salt-water forms. No reptilian remains were found in this neighbourhood.

374. It would thus appear, that though the general tendency of the Lignite. Tertiary, is toward salt-water conditions westward, and those of fresh-water lakes to the east, that there are important exceptions; and that, while brackish-water forms spread eastward in the lower beds, as far as the Roche Percée, fresh-water species are scattered westward, nearly to the base of the mountains, and sometimes occur in great abundance. A zone of sandstones appears to be of very constant occurrence in the formation. It appear's on the Souris River, forming the Roche Percée. In the Bad Lands it is about 150 feet above the Cretaceous rocks. In the ralley of the Milk River, about 200 feet above the base of the section, and in the region surrounding the Buttes, at several miles from the base of the mountains, and therefore, probably several hundred feet up in the Tertiary. The correlation of the sandstones of any one of these western localities, with those of the Roche Percée, might be open to great doubt; but from their occurrence so persistently, at a horizon in the formation, approximately the same, I think that they may be considered as reprerenting the Roche Percée, series with some degree of certainty. In the Missouri Regiom, south of the Line, the Lignite formation is assigned a thickness of about 2,000 feet. I have not met with any locality near the forty-ninth parallel, where it might be even approximately determined; but, assuming the horizontality of the beds, the rise in the general surface of the country would give it, in several places, a thickness of at least 1,000 feet.

From the Souris River, westward, the Lignite Tertiary nearly always occupies high ground, and frequently forms a well-marked plateau, resting on the clays of Cretaceous No. 4.

375. Though I have not yet had an opportunity of comparing the fossils, obtained in the western marine and brackish-water beds of the Tertiary on the forty-ninth parallel, with those from the Judith 
River beds of the Missouri, I have little doubt of the identity of the formations. The age of these Judith River beds has long been an unsettled question, and they have only lately been included by some geologists, with the remainder of the Lignite Tertiary, and called Cretaceous. Dr. Hayden was only prevented from calling them Fort Union Tertiary * by the occurrence of certain vertebrate remains-the meaning of which is now better understood. The lithological resemblance between these beds of the Line, and those of the Judith River, is close.

376. Prof. Hind did not recognize the Lignite Tertiary formation in any part of the North-west trarersed by him, while in connection with the Assineboine and Saskatchewan Exploring Expedition. Dr. Hector, while in some doubt whether to attach the beds seen by him near the Roche Percée to the top of the Cretaceous, or to the Lignite basin of the Missouri, appears to regard the latter conclusion with most favour; and his supposition is now borne out by their fuller examination. He also considers Eocene Tertiary to be represented, in the upper beds of the Cypress Hills, and colours them as marine Tertiary in his map and section published in the Geological Society's Journal. The following fossils were obtained in this locality: Modiola,? sp. Ostrea Veleniana, Unio, Carlium,? sp. "The existence of Tertiary strata, ascertained to be so by their organic remains, has only been proved at one point west of the $\mathrm{Cy}$ press Hills, where Mr. Sullivan obtained Ostrea Veleniana, associated with a Modiola, and a few other fossils which Mr. Etheridge, who has named all the Neozoic fossils brought home, has been unable to identify. The beds from which the fossils were obtained, consisted of friable sandstones, with argillaceous and calcareous concretions, the bedding heary and irregular, and often passing into incoherent pebble conglomerate. Judging alone from the mineralogical resemblance, these beds were recognized orer a considerable area, but always forming high ground in the neig!. bourhood of the Missouri Coteau, south-east from the mouth of Belly River." †

377. These remarks are interesting, as bearing on a locality not forty miles north of the magnificent exposures of partly marine Tertiary, in the banks of Milk River near the Line, and indeed, if the fossils mentioned as obtained by Mr. Sullivan, were collected while on his branch expedition to the south, + they may have been derived from some of the 
sections which I have examined. I cannot doubt that these marine Tertiary beds are a part of the series so extensively developed on the Milk River and in the region of the Buttes. The Cypress Hills, like the plateau of Wood Mountain, and other Tertiary plateaus near the Line, is characterized by comparative fertility, and supports a good growth of grass, while surrounded by barren plains of Cretaceous No. 4. Captain Palliser writes :- "In the midst of the arid plains traversed by the South Saskatchewan, there are isolated patches of table-land, upon the surface of which the regetation becomes luxurient, and pasture of fair quality may be found." * The Hand Hills are mentioned as an example of this peculiar feature, which so strongly suggests the repetition of the superposition of 'Tertiary rocks like those of Wood Mountain, on the Cretaceous. The rocks of the Hand Hills, above referred to, are classed by Dr. Hector in his group D., and consist of sandstones and banded clays, which much resemble in their lithological character those of the Lignite Tertiary. Though it may be hazardous to generalize in so vast a country, where our knowledge is as yet so scanty, I cannot help believing that some partperhaps a great part—of the third prairie plateau, marked in Dr. Hector's map as Lower Cretaceous, may yet be found to be the equivalent of the marine and estuarine base of the Tertiary.

* Exploration of British North America, p. 11. 


\title{
CHAPTER VII.
}

\author{
CONDITIONS OF DEPOSIT CRETACEOUS AND TERTIARY. \\ BURNING OF LIGNITE BEDS.-COMPOSITION AND ECONOMIC \\ VALUE OF LIGNITES AND IRONSTONES.
}

\begin{abstract}
Conditions implied by Cretaceots and Tertiary deposits-Period of shallow water-Extent and nature of submergence during Niobrara period-Detrital beds of Fort Pierre group-Closing period of shallow waters-Extensive land areas during Lignite Tertiary-Conditions of formation of lignites.-ComBUSTION OF LIGNITE BEDS - Appearances indicating this action - Effects produced on surrounding beds-Area over which similar phenomena have been observed-Question whether such fires are spontaneous-Extent to which lignites have been destroyed.-Composition aNd Economic VALUE or LIGNITES AND IRON ORES-Analyses of lignites-Nature of lignites-Classes of lignites represented - Variability of water content-Lignites as fuels Import of the St. Mary River coal-Other similar fuels near the mountainsArea of lignite-bearing formation-Ironstones of the Lignite Tertiary-Ironstones of the Cretaceous-Probability of their future economic importance.
\end{abstract}

\section{Conditions implied by the Cretaceous and Tertiary Deposits.-Nature and Origin of their Material.}

378. The question of the origin of the material composing the Cretaceous and Tertiary rocks of the interior continental region, is one of considerable interest. The general aspect of the beds of the first and second divisions of the formation, is that of shallow-water deposits. They consist largely of sands, and coarse detrital materials, and, from the frequent occurrence of land-plants, and the occasional preservation of freshwater mollusc's, in both their eastern and western developments, argue the neighbourhood of considerable areas of dry land. The third, or Niobrara division, in the eastern portion of the area, consists in great part of the calcureous remains of molluses, foraminifera, ete, and resembles the accumulation of a somewhat deep sea, from which cold arctic currents were excluded, and into which very little detrital matter was being carried. A general depression of the present surface of the continent, to the extent of about 1,500 feet, would gire a depth of 700 to 800 feet, above the horizon of the Niobrara deposits; and would be amply sufficient to satisfy the conditions indicated by their animal remains. A depression of this extent, would howerer, almost submerge the Laurentian barrier to the north and east, and would suffice in its present condition to open broad avenues 
through it, to the waters and currents of the Northern Sea. Before the Cretaceous period, however, the Laurentian axis had probably acquired its full height from local elevatory action, while its actual summit must have been much higher than at present, as it had not then suffered the extensive denudation of Tertiary time, and of the glacial period. It would, therefore, stand sufficiently above the water, with such a degree of continental submergence as that indicated, to form an efficient barrier to the north-east, and yet not present a sufficient surface of its own to sub-aerial denudation, to supply, under ordinary circumstances, much detrital matter to the surrounding seas. Even at this time, the region of the future Rocky Mountains, must have been marked out by shallows and banks, and perhaps also by small areas of dry land, for the calcareous deposits do not retain the character of their eastern derelopments, to their western borders, but are to a great extent replaced by arenaceous and other mechanical sediments; while still containing a sufficient number of the characteristic fossils of the Niobrara division to prove their age.

379. Between this division of the Cretaceous, and the next in order of time-that known as the Fort Pierre group to the South, and represented by the Pembina Mountain group in Manitoba, and also extensively westward, to the north and south of the Line-there exists an evident break, which is not alone marked by a palreontological change, but by the sudden substitution of fine homogeneous argillaceous sediments, with scarcely a trace of ('alcareous matter, for those consisting almost entirely of the calcareous remains of marine life. The surface of the Niobrara deposits, has also been noticed, in some places, to have suffered erosion before the deposition of the first beds of the next group. I am not aware that proof exists of the elevation of any part of the area, to such an extent as to permit sub-aerial denudation, and it is probable, that the surface of these soft calcareous beds, was furrowed by the action of rather strong marine currents; which now, from some change in the physical geography of the period, gained access to the region. Whether this change was brought about by the opening of an easy communication from the waters of the northern to the southern ocean, between the Rocky Mountain region and the Laurentian land, by the submergence of some barrier till that time existing, it is impossible to say with any degree of certainty. This would, however, seem to ofter the most tenable solution, and it is further probalble, that this change was caused by a general movement of depresion which brought rocks decayed by sub-acrial weathering, under the action of the sea, and served to supply ready-made material. In any 
case, the deposits of this division resemble, in their fineness and homo geniety both in time and extension, sediment borue far br marine currents and deposited in a sea of some depth, rather than that formed from the denudation of neighbouring land. In the Rocky Mountain region, however, these deposits still show the existence of somewhat shallower water conditions, and though generally maintaining somewhat the aspect of these eastern representatives, contain much coarser matter.

380. In the closing period of the Cretaceous, represented by its fifth division, we have continualiy shoaling waters, and the introduction for a comparatively limited interval, of deposits, for the most part, coarse and arenaceous, and aimost destitute of organic remains. This shoaling of the area, may have been produced not so much by any general eleration of the continent, as by the increasing thickness of the Cretaceous deposits themselves, which may now have amounted in some places to orer 2,000 feet. If this was the case the banks and shoals of the region now marked by the ranges of the Rocky Mountains, need not have been raised up into extensive land areas, but would retain the character so long maintained by that area, and now again assumed by the interior continental region generally. The distribution of this arenaceous material was probably due to aretic currents, no doubt, then as now forming a part of the general oceanic circulation. These, like those still flowing down the eastern coast of America, would be urged westward by the rotation of the earth, and passing over the extensive shallow water area of the continental plateau, would find-if not a continous sea-wide straits and openings through the Rocky Mountain region, and fall thence into the deeper basin of the Pacific. Professor Newberry, from the indications furnished by a comparison of the floras, concludes that relative differences of temperature, similar to those now obtaining, existed during the Cretaceous and Tertiary periods, between the interior continental region, and the west coast.* If the former region was influenced in the manner above supposed, by the arctic currents, while the shores of the latter were bathed in warmer waters flowing from the south, as at the present day, this may easily be accounted for.

381. It would thus appear, that the Cretaceous opened with a period of considerable land surface, shallow waters, and current-driven sandbanks, which also extended to the Mississippi region, described by Prof. Hilgard; and probably to the Cretaceous coast-deposits of New Jersey. 
This seems next to have been followed in the interior continental region, by a gradual subsidence, during which the second division was formed. The cessation of subsidence- or possibly even a slight movement of elevation-and the advent of a prolonged period of comparative tranquility, with certain other favouring circumstances, gave rise to the Niobrara limestone formation. The indications next favour the belief of a second subsidence, admitting marine currents and bringing on important changes in physical geography. During this period, according to Meek and Hayden, a part of the clays and green-sands of Now Jersey, were formed on the Atlantic coast; and in the Mississippi region, according to Hilgard, the Rotten-limestone group was deposited. The fact that calcareous beds were being formed in the southern portion of the interior continental trough, while such purely argillaceous deposits were produced in the northern; would also tend to verify the supposition of the entrance of sediment-bearing waters from the north. Closing the Cretaceous, properly so-called, the fifth division shows the resumption of shoal water and sand-bank orer the entire northern portion of the interior, a change probably at least aided by elevation. But that the decreased depth was perhaps mainly due to the filling up of the northern portion of the basin, seems to be indicated by the fact, that limestones and marlites still continued to be deposited in the Mississippi region.

382. The early Cretaceous period, from the evidence chiefly of the plants of the Dakota group, must have had a temperate climate. During the succeeding ages, the heat was no doubt becoming greater, for though there is no complete suecession of land plants, we find a well-marked maximum of temperature, as stated by Prof. Lesqereux, in the early period of the Lignite Tertiary, and from that time the change was back again to a climate resembling that of the Dakota group, if not even cooler.

383. Prof: N. II. Winchell, in his last published report, announces the discovery of extensive beds of granite decomposed in place, and kaolin-like materal, covering the oldest rocks of south-western Minnesota, wherever they have been protected by overlapping Cretaceous beds from the scouring of the drift period.* This throws much light on the origin of the fine clayey, and coarser sandy deposits of the Cretaceous, and shows that the rocks of the Laurentian axis must have been much decomposed by sul-acrial action prior to the opening of the Cretaceous period, and that these soft materials brought under the action of the wares during 
the succeeding periods of depression, could supply a great quantity of ready formed detritus.

384. The earlier beds included in the Lignite Tertiary series, while showing a continued progression of the physical changes operating during the later Cretaceous periods, evidence the elevation of much dry land; and though these deposits are supposed to have passed entirely across the present Rocky Mountain region in some places, * still, about this time a pretty continuous barrier of land must have been formed there. The northern current still passed along a narrow trough on the eastern margin of this land, and piled up local and irregular sandbanks, while numerous molluses of shallow and brackish-water types, assisted in the formation of the deposits. At the same time, or very shortly afterward, further to the east, much finer sediments were being laid down with considerable regularity; and only in the very lowest layers of these do we find salt or brackish-water species of shells. The source of the vast quantity of fine argilo-arenaceous material of the Lignite Tertiary,much of which must have been depositsd in land-locked basins,-is a question of very great difficulty, unless, indeed, we may suppose that some parts of the Cretaceous series were already undergoing denudation by rain and rivers. If the Rocky Mountain region became an actual land barrier about the beginning of the Tertiary, the later Cretaceous deposits of the west coast, should present a more coarsely detrital aspect than those of the western part of the interior of the continent, while those of the earlier Tertiary, should be relatively finer in the first locality. For, during the former period, the shallow banks and bars would supply material to the south-western drift, while during the latter, they would prevent the access of other sediment than that derived firom their own waste.

385. It is unnecessary here to recapitulate, in giving an account of the lithological character of the beds of the Lignite Tertiary, which are fully described in connection with the various sections on preceding pages. In some parts of the formation, however, the lignite beds themselves constitute a not unimportant part of the thickness of the strata. In one of the Souris River sections, in a total thickness exposed of 57 feet, the lignite amounts to 17 feet, and is disposed in seven distinct beds, separated by clays and sands. The lignites themselves comparatively seldom show intercalations of shale or detrital matter, and their ash is found, as a rule, to consist of very tine whitish, to pale yellowish or reddish, earthy

* Dr. Hayden. Geological Report Yellowstune and Missouri Expedition, p. 5. U. S. Geol. Surv. Territ., 1867-69, p. 70, dic. 
matter, without coarse grains, and not more in amount than may have been contained in the substance of the original vegetable materials. Though some of the lignites may have been formed from accumulations of drift-wood in shallow water, it is difficult to understand how such collection could go on for long pe:iods, without the contemporaneous deposit of sandy or muddy matters, which would have been suspended in waters moving with sufficient force to convey the wood. It would also appear difficult under this theory, to explain the regular and even superposition of the sandy and clayey beds, which overlie the lignites, and the fact that these do not send extensions downward into them, as they must have done if formed above a tangled mass of trunks and branches of trees. It secms likely, therefore,- - though layers like true root-beds were only observed in one or two instances to underlie the lignites-that at least the majority of these beds were produced by the growth and partial decay of trees, and also perhaps of peaty matter from swamp mosses, in the positions which they now occupy. Their method of formation would, therefore, agree with that already proved for coals of the true Carboniferous formation. This is rendered more probable by the circumstance that lignite beds are sometimes immediately covered by beds holding leaves of trees, ferns, and grasses, a fact which has been noted by Dr. Hayden and others with regard to those further south, and which is also found to obtain with coal beds of the Carboniferous period. Some of the more impure beds, indeed, seem still to show evidence of having been formed from accumulations resembling those of a peat-bog, in which occasional logs of wood have been enclosed. A great part of such a bed is soft and structureless, but it holds irregular masses of hard jet-like material, with conchoidal fracture, and evident remains of woody structure. As already stated, also, some of the more impure lignites seen in the further western portion of the formation, seem compatible with the explanation of formation from drift-wood.

\section{Combustion of Lignite Beds.}

386. In connection with the Lignite Tertiary, the phenomena of the combustion of lignite beds orer great areas, and the metamorphosis of rocks, and features impressed on the country by it, is a subject of interest and importance. In no part of the world does this destruction of mineral fucls seem to have occurred on so rast a scale, as in the central plateau of this continent. The appearances produced by this action were met with in the vicinity of the forty-ninth parallel, at the very eastern 
edge of the Lignite Tertiary, and were also found in almost all the localities in which lignite occurred. The products of the combustion were first noticed as fragments of rock indistinguishable in appearance from modern lavas, and scorias, strewing certain banks, and in the beds of streams. The connection between these traces, and the combustion of the lignites was, however, soon established, and beds actually found which had been burned but a short way in from the outcrop. The bank of the Souris River,-as stated in the Preliminary Report already referred to-in one place shows an amphitheatrical depression a few feet below the general prairie level, in front of which a great quantity of lignite clinker, often in large masses, was strewn down the slope toward the river. A bed of lignite six feet thick, elsewhere well exposed and overlaid by about five feet of clay and drift, was here completely burned away, (Plate IV., Fig. 1.) By reference to the detailed accounts of the various localities, many similar instances will be found.

387. The effects produced on the lignites and associated beds, as derived from the examination of numerous widely separated localities, admit of classification and general statement. The lignites themselves appear to be invariably consumed in their entire thickness, and their immediate horizon is represented by a layer of ashy clinker, or of a material resembling scoriaceous lava, and vesicular in structure. The fused masses are always dark coloured, generally blackish or dark grey, but sometimes opaque bluish or brownish-black. This clinker bed is doubtless composed of the ash of the lignite itself, and any intercalated shaly layers, or portions of carbonaceous clays associated with it; the particles of which have been brought more intimately in contact with the burning material. The fusion may also be aided by the alkalies and alkaline earths of the lignite ash, which differs in composition from the surrounding clays.

388. The alteration extends much further above the position of the lignite bed than below it. The surrounding layers are very generally of the nature of fire-clays, and contain little or no iron, and a smal proportion of undecomposed felspar, or other fusible mineral, and are consequently very refractory. Those immediately above the lignite, are frequently altered to hard jaspery, or porcelain-like rock, breaking with sharp conchoidal fracture, sub-translucent, and of greyish-blue and dull greenish tints. In this substance, impressions of the stems and leaves of plants are, however, sometimes recognisable The porcelainized beds are generally traversed in all directions by rusty fissures, 
but on fresh fracture show the original stratification of the rock by bands slightly differing in tint. Their hardness is about 6.5 , and splinters are fusible on the edges, before the blow-pipe, with greater or less difficulty. In their fusibility they range from $4 \cdot 5$ to 6 of Van Kobell's scale, and when fused they form translucent beads. The thickness of the beds thus greatly altered is generally not more than a few inches. In the Bad Lands section a very fine white clay, containing numerous impressions: of plants, rests immediately on a lignite, which at a short distance, was found to be completely consumed, the representative of the white clay, being apparently a hard porcelain-like material of this kind, of pale bluish-grey colour, and waxy lustre.

389. Other clays and clay-shales not so closely in contact with the lignites, are generally hardened into whiteish and cream-coloured rocks, resembling tiles or biscuit porcelain ; and in these the impression of plants are often preserved with great beauty. I was not, however, so fortunate as to find any locality in which large collections of plants in this favourable state of preservation could be obtained. The clays, or shaly-clays, seldom hold enough iron to give them a red hue when metamorphosed. The) sandstones and coarser arenaceous clays, are not usually much indurated or otherwise altered, except in colour; but generally contain sufficient iron to cause a moderately striking red colouration, and some beds are very deeply tinted. Such sandstones are among the most prominent marks of the combustion, and were observed in a great number of localities. In the Bad Land region, several isolated buttes capped with intensely red sandstone, which had a remarkable prismatic structure, were seen. The structure resembled, on a small scale, the columnar appearance of basalt, the sandstone being divided by joints into vertical prisms, and breaking along these nearly at right-angles to its original bedding. The rock here precisely resembles ordinary red brick, and gives out a faint-ringing sound when struck. Such localities, Mr. Allen, who has studied similar metamorphism in Dakota and Montana, believes to indicate former vents by which the pent-up gases arising from the fire have found exit. (Plate VII., Fig. 1.)

390. The effect of the combustion of the lignites over large regions, though to indurate the surrounding beds, is evidently from its observed relations with great denudation, more destructive than conservative. The strata appear to be cracked and fissured in such a way by the action, as to allow the entrance of surface waters to their mass, and accelerate their removal, 
391. Similar combustion of lignite in situ, has been observed to occur at various places, over an immense area. South of the Line, Lewis and Clarke have noted the phenomenon in the account of their journey up the Missouri, and numerous references to it will be found in Dr. IIayden's various reports. Mr. J. A. Allen, in his interesting paper already referred to, $*$ has collected a great deal of information on this subject, and added the result of his own observations. As an example of the great areas over which it may extend, he mentions the Bad Lands of the Little Missouri, where, "with a breadth of twenty to thirty miles, these appearances are said to be continuous for fully two hundred miles. Throughout this vast area, all the ridges and buttes are capped, or banded with the reddened and indurated shales." He is in error, however, in supposing that the phenomena do not occur north of the forty-ninth parallel, for, according to the accounts of various traveller's, they extend even to the shores of the Arctic Sea.

392. The earliest notice of appearances referable to this cause appear's, however, in Sir Alexander Mackenzie's account of his voyage up the Peace River in 1793 , where he refers to certain "chasms in the earth, which emitted heat and smoke, which diffused a strong, sulphurous stench." A lignite bed on the Mackenzie River, near Bear River, was also observed to be on fire by Sir Alexander Mackenzie in his first voyage of discorery in 1792. Sir J. Richardson, in 1848, found it still burning, and emitting smoke and flame, visible by night. "Some portions of the clay were semi-vitrified, and so hard as to receive no impression from a file." Sir J. Richardson also noted "bituminous shale" to be on fire, in 1826, near Cape Bathurst on the Aretic Sea. "The clay's which had been exposed to the heat were baked and ritrified, so that the spot resembled an old brickfield." He also had information from Chief Factor Alexander Stewart, "that beds of coal are on fire on the Smoking River, which is a southern affluent of the Peace River, snd crosses the fiftyseventh parallel of latitude." "There are coal becls on fire also near Dunvegan, on the main stream of the Peace River." $\dagger$ Dr. Hector, in his report, mentions several localities where lignites have been thus destroyed. Near Fort Edmonton, the appearances seem to be particularly striking. Of a locality on the Red Deer Piver, lat. $52^{\circ} 19^{\prime} 25^{\prime \prime}$, long. $113^{\circ} 3^{\prime}$, he writes:- "It was found to be as the Indians had asserted, and far along the banks of the Red Deer River, where the coal appeared,

- Proc Boston Society of Natural History, vol. XVt.

$\uparrow$ Journal of a Boat Voyage through Rupert's Land, vol, 1., Pp. 189, 191, 271, 195. 
the spontaneous fire was in activity. The Indians say that as long as they can remember this has been the case."*

393. This combustion, though often spoken of as spontaneous, camnot, I think, be proved to be so. In cases of the spontaneous combustion of bituminous coal, which sometimes occur when large masses of it are piled together, the production of the degree of heat necessary for its initiation, is traceable to the decomposition of pyrites, under the combined action of air and moisture. In my Report of Progress for 1873, I have writter: "Such fires may either be caused by the ignition of the beds by prairie fires, or fires of Indians' or Trader's' camps; or by the spontaneous combustion of the lignite, when undergoing decomposition at the outcrop. The latter, however, seems improbable, as iron pyrites, the usual cause of such spontaneous combustion, is almost entirely absent from the lignites, which I have examined chemically." To this I can now only add, that a further examination of the lignites, over a more extended area, confirms the almost total absence of visible pyrites, and the very small quantities of iron found in the ashes, would alone serve to prove its non-existence in any quantity. The only clear case of the occurrence of pyrites, is in the lower part of the 18-foot bed on Poreupine Creek, where small dises of the material, about the thickness of ordinary paper, were found in the vertical joints. Mr. Marvine also, in speaking of the lignites of the same formation in a more southern region, remarks that the sulpher seldom reaches one per cent., and is often nominally absent. $\dagger$ Though it is chemically possible, that spontaneous combustion might arise, under certain circumstances, in the carbonaceous matter of the soft, crumbled outcrops of the lignites themselves; it is obvious that such places would offer the most favourable opportunities for the ignition of the beds by prairie fires. These, even when burning over very scantily grassed regions, possess sufficient heat to ignite the bois des vaches, or dried buffialo excrement, with which the surface is strewn,-a much less combustible fuel. Mr. Allen says that several instances are well known of the lignite beds having taken fire from the burning of the prairie grass by the Indians. It would therefore seem that the aid of spontaneous combustion need hardly be invoked. $\ddagger$

394. The destruction by this agency, over great areas, of lignite beds

\footnotetext{
Exploration of British North America, p. 88. † U. S. Geol. Surv. Territ., 1873., p. 110.

- It shwuld be to the spontaneoux combustion of lignite slack, at Carbon and Coalville respectively. U. S. Geol. Surv. Territ., 1872, pp. $368,449$.
} 
which might have been of value to the future population of the Northwest, is a matter of certainty. It would seem, however, that the combustion does not affect beds unless their edges have been laid bare to the weather by denudation; and the proportion thus exposed, in a country in which the strata are so nearly horizontal, must be small. The whole of the lignites, too, lying below the natural drainage level of the country must remain unaffected, and the fire would also seem unable to penetrate very far into a bed, unless it lies so near the surface as to be able to open communication with it, for the escape of its products of combustion, and to obtain a supply of oxygen. The face of the exposure, crumbling down on the ruins of the bed, must soon stop all access of air in that direction; though from the almost complete conservation of the heat of a combustion thus taking place in the mass of the formation, a very limited supply of air would be sufficient to maintain the necessary temperature.

395. The only place in which the combustion was still found to be in progress near the forty-ninth parallel, was in a locality on the Souris River, and then it was only evidenced by the issue of a little smoke of a tarry empyrumatic odour. Other localities, from the immense amount of denudation which has taken place subsequent to the destruction of the lignite, show eridence that the fires have been extinct from a very remote period; though as a rule, in the region which I have examined, the products of combustion appear to be pretty closely confined to the localities in which this can be proved to have taken place. Mr. Allen, however, has found "this igneous material in a water-worn state, occurring in the drift which covers the general surface of the country, often many miles from the nearest seat of metamorphic action, as well as in the terraces that border the larger streams," * and concludes that the combustion must have begun before the close of the drift period-a very important fact.

\section{Composition and Economic Value of the Lignites and Iron Ores.}

396. The following are proximate analyses of lignites from various localities in the vicinity of the forty-ninth parallel, and of the coal from St. Mary River. The greater part of these were published in the Report of Progress for the year 1873, already referred to :-

397. Souris Valley. (\$207.) Lowest lignite, two feet three inches thick. Conchoidal fracture with rather dull surfaces, and resembling cannel coal, ash reddish-white. 
Water

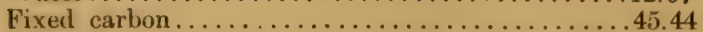

Volatile combustible matter...............39.74

By rapid coking.

Ash

38.90

$\overline{100.00}$

398. Souris Valley. (§ 210) Layer 19. A weathered specimen separating into laminre horizontally. Clay from orerlying bed filling fissures. Ash yellow-brown.

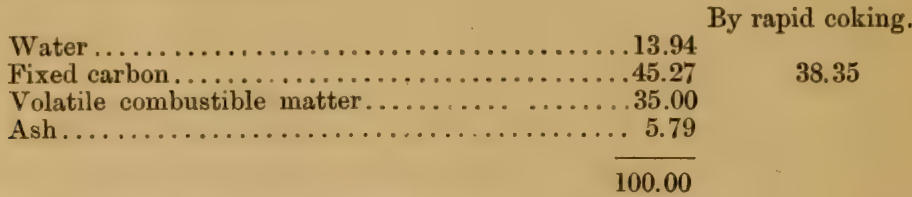

399. Souris Valley. (\$ 210) Layer 17. Weathered specimen. Black, compact, with shining faces. Ash yellowish.

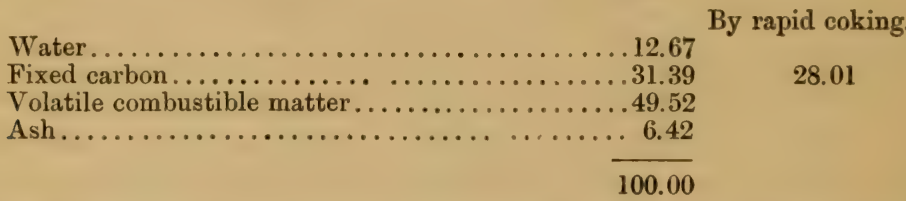

400. Souris Valley. (§ 210.) Layer 10. Lustre dull, separating along horizontal planes. Ash light yellowish.

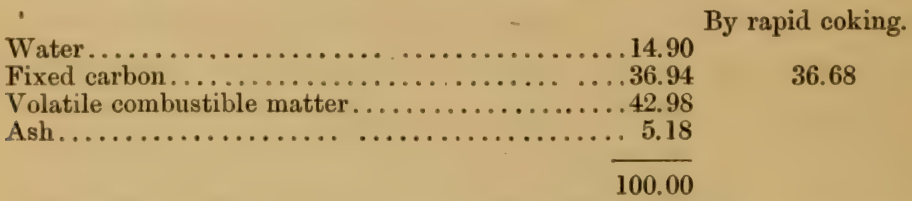

401. Souris Valley. (\$210.) Layer 2. A weathered specimen, soft and.crumbling. Ash greyish-white.

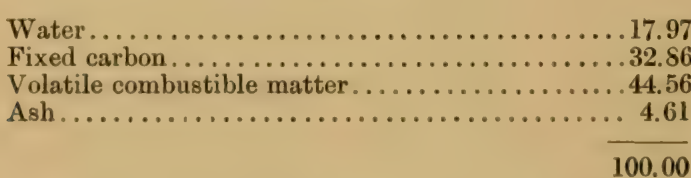

By rapid coking.

30.10

402. Souris Valley. (§218.) Black compact lignite with much woody structure apparent. Ash yellow.

Water................................ 14.73

Fixed carbon.........................42.48

Volatile combustible matter..................... 39.99

Ash .............................. 2.80

100.00
By rapid coking.

34.07 
403. Souris Valley. (\$ 215.) 7 foot seam. Hard, compact, black lignite, breaking with pseudo-conchoidal fracture, and showing traces of structure of wood. Ash yellowish-white, light.

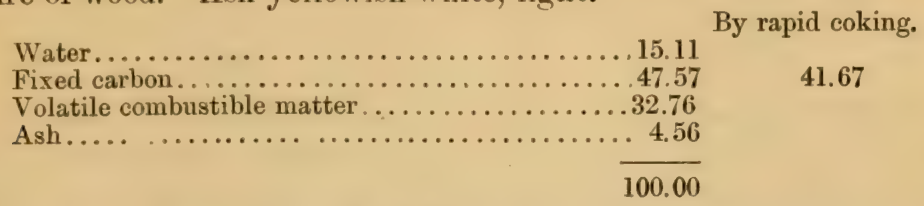

404. Souris River, $62 \mathrm{~m}$. W. of Wood End. (\$ 221.) Laminated, and breaking up along horizontal planes on drying. Many small drops of amber or fossil resin. The wood composing the bed has apparently been much decomposed. Ash reddish.

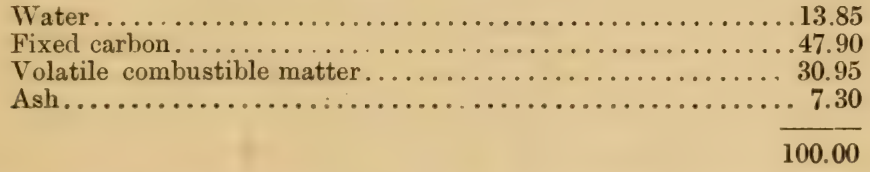

405. Great Valley. (\$225.) Lowest Lignite. Weathered specimen, crumbling. Ash grey.

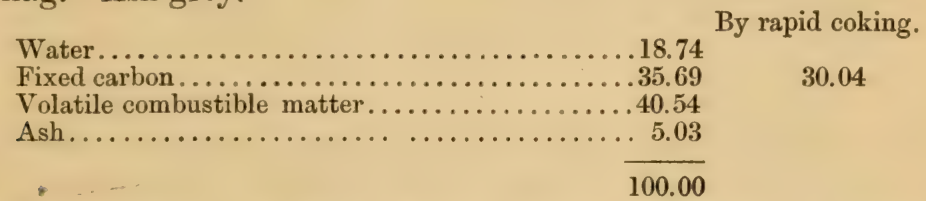

406. Great Valley. (§225.) Middle Lignite. Weathered specimen. Soft, breaking into layers along deposition surfaces. Largely composed of comminuted charcoal-like fragments.

\begin{tabular}{|c|c|}
\hline \multicolumn{2}{|r|}{ By rapid coking. } \\
\hline 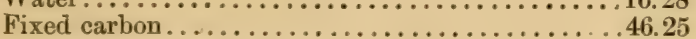 & 29,18 \\
\hline Volatile combustible matter...................... 19 & \\
\hline Ash.............................. 4.28 & \\
\hline 0 & \\
\hline
\end{tabular}

407. Great Valley. (\$ 225.) Upper Lignite. Outcrop specimen. Crumbling. Tends to break into layers parallel to deposition planes.

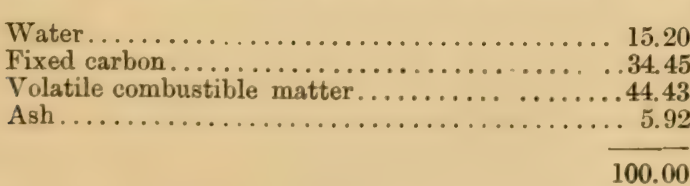

By rapid coking.

27.61

408. Great Valley. Section on the forty-ninth parallel. Bed four feet thick. Out-crop specimen. Brownish. Fracture almost conchoidal. Ash yellowish-white. 


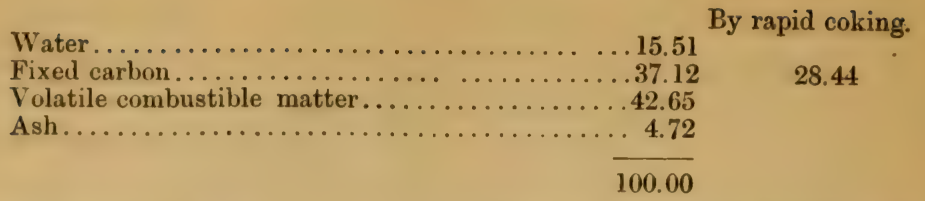

409. Porcupiue Creek. (\$238.) Lower part of 18 foot seam. Tough, compact lignite, separating into horizontal layer's. Much amber in small spots, a good deal of woody structure apparent, and some mineral charcoal. Ash light-grey.

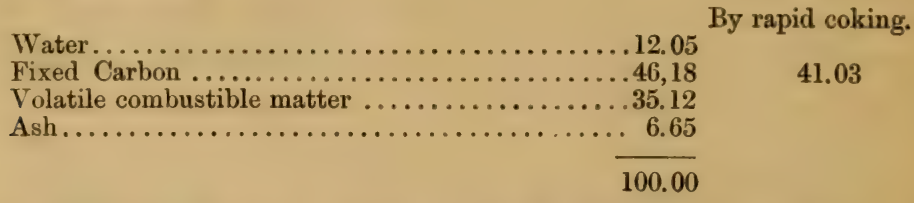

410. Porcupine Creek. (\$238.) Upper part of 18 foot seam. Outcrop specimen, crumbling. Ash white.

\begin{tabular}{|c|c|}
\hline \multirow{4}{*}{$\begin{array}{l}\text { Water } \ldots \ldots \ldots \ldots \ldots \ldots \ldots \\
\text { Fixed Carbon................... } \\
\text { Volatile combustible matter } \\
\text { Ash ................... }\end{array}$} & \multirow{2}{*}{ By rapid coaking. } \\
\hline & \\
\hline & .34 .32 \\
\hline & $\begin{array}{r}37.51 \\
11.30\end{array}$ \\
\hline & 100.00 \\
\hline
\end{tabular}

411. St. Mary River- (\$326.)-Bituminons Coal. Bed about eighteen inches thick. A strong coal not atfected by weather. Traces of horizontal lamination, often showing more or less mineral charcoal. Cleat in two directions nearly at right angles, with smooth shining faces, and often very thin films of calcite in the cracks. Certain parts show slight traces of pyrites. Forms a perfect coke when rapidly heated, with the evolution of a quantity of rich illuminating gas. When slowly heated, in powder, a weak coke is formed which may be crushed between the fingers. Ash reddish grey.

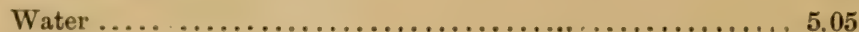

Fixed carbon...................................64.65

Volatile combustible matter.........................25.30

Ash ............................................. 5.00

$\overline{100.00}$

412. Rainy River. ( $(340)$ Compact Lignite, with woody structure plainly apparent. Ash yellowish-grey.

Water

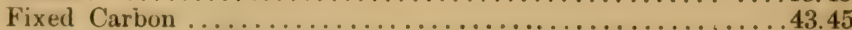

Volatile combustible matter......................... 33.70

Ash. 
413. The lignite from Rainy River, to which the last analysis refers, is noticed in the paragraph indicated above. The specimen received was a small one; and not having visited the locality, I cannot speak confidently as to the mode of its occurrence. In its appearance and composition it resembles many of the lignites of the Tertiary, but if in situ, it may more probably be found to belong to an outlyer of Lower Cretaceous rocks. In any case, it is far removed from the regions to which the other analyses refer, and does not at present require further consideration.

414. The mineral fuels met with in the neighbourhood of the Line, fall naturally into two distinct categories. The first, including all except one, must be called lignites; the second, represented by a single example only, is a true bituminous coal. The first class includes not only, therefore, the great majority of the fuels met with in the vicinity of the fortynith parallel, but also almost all known in the interior region of the continent, both north and south of this line. They are emphatically lignites or broun coals, and though they may be designated by the name lignite coal, insomuch as they come under the generic class of coals, they certainly cannot properly be named by the latter word alone, as by it an entirely different kind of material is generally understood. The vast area, and great importance of these beds of fuel, should not be allowed to weigh in changing the name which would without any hesitation be applied to them, were their occurrence on a more limited scale. The word lignite has attached to it a definite mineralogical significance, and must be employed when it is desired to define the position of these fuels in the scale of combustible materials. Lignites are found in connection with many of the later geological formations, and differ from true coals in containing a larger percentage of water, hygroscopic and combined, a greater proportion of hydrogen, oxygen and nitrogen, and less carbon. They also invariably give a brown streak or powder, yield easily a brown solution with caustic potash, and sometimes even to water, and, according to Frémy, may also be distinguished from coal and peat by their complete solubility in nitric acid and hypochlorites. The better kind of Tertiary lignites of the region now in question, differ from many foreign fuels of the same class, in their small percentage of ash, but show for the most part distinct evidence of having been produced from wood, and would therefere even be classed as lignites under the most restricted meaning of that term. The wood, from its microscopic structure, has been coniferous, and may have belonged to the same species of Thuya, Sequoia, etc., represented by leaves in the associated clays. 
415. The lignites of the forty-ninth parallel appear to admit of classification under three leading types.

First-Compact, homogeneous lignite, without very erident traces of deposition planes. The woody structure often plainly apparent. Disintegration proceeding irregularly, or with reference to the structure of the wood. Generally tough under the pick. This is the typical, and most abundant variety, and includes many of the most promising beds.

RESULTS OF ASSAYS OF LIGNITES, WATER BEING ESTIMATED AT AN AVERAGE OF 12 PER CENT.

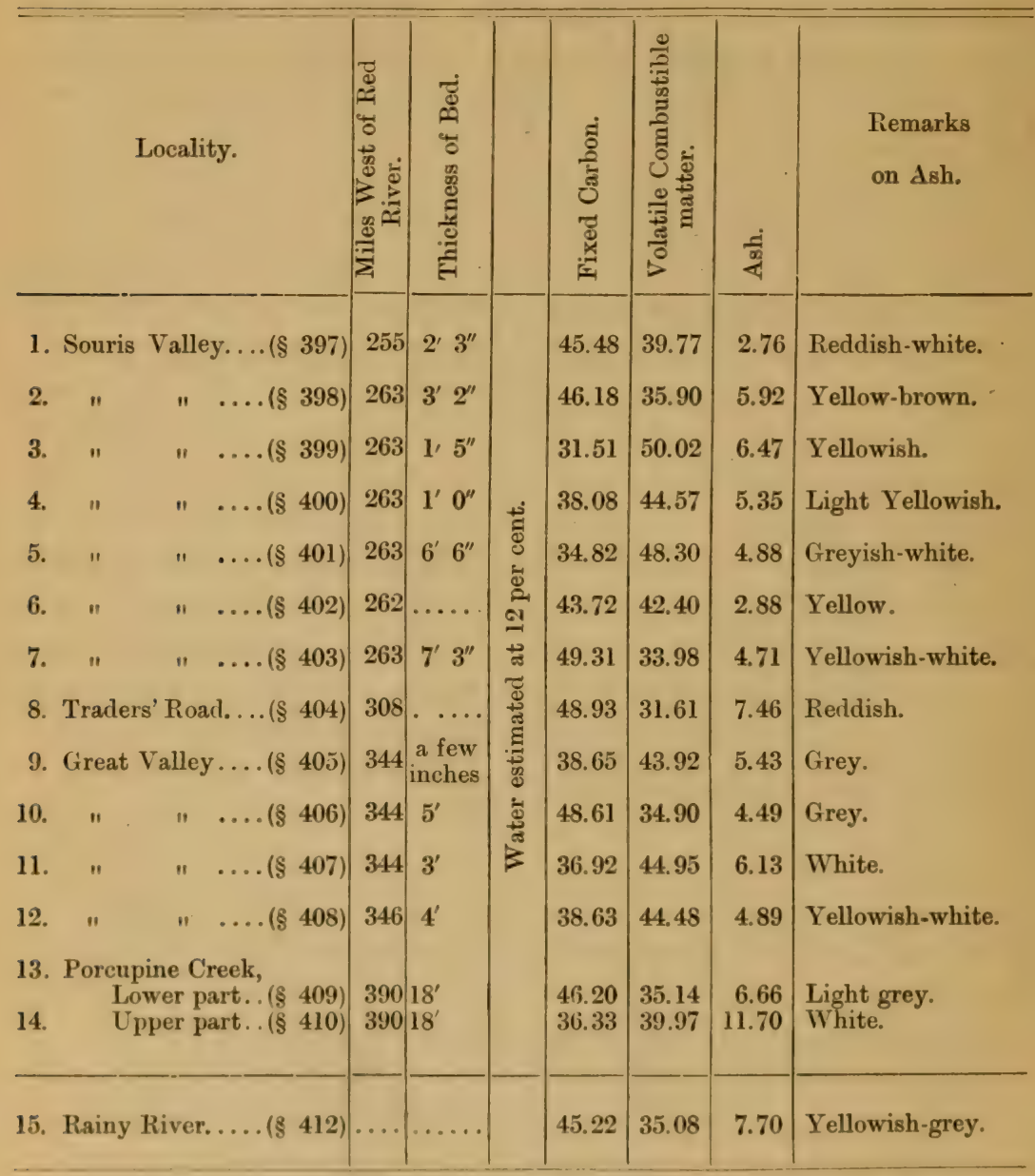

Second.-Lignite more or less distinctly horizontally laminated, showing little apparent woody structure, but sometimes a not inconsider- 
able quantity of mineral charcoal. Not very tough under the pick, and on weathering, breaking up along the planes. This form, is probably also in almost all cases composed of wool; but the material has undergone more thorough decay before the deposit of the next highest beds.

Third.-Soft and friable; often with much mineral charcoal, but frequently brownish, and containing harder masses in some places. This variety, no doubt, often results from the thorough decomposition by the weather, of either of the others; and beds with this appearance would probably change their character for the better, more or less completely, if penetrated beyond the outerop. There appear, however, to be some beds of this nature throughout; and these have been formed from peaty accumulations, with little wood. This class it is, which is most apt to contain much ash, and the beds under it, sometimes do not show clear lines of junction with the enclosing clays, but graduate into them.

416. In the assays above given, it has not been thought necessary to restrict the examination to those beds which are of workable thickness, as a generál comparison of the various seams, thick or thin, is of more value in giving an idea of the average quality of the lignites of the formation now known, and those which future exploration may bring to light, in the same region. The analyses, therefore, include a selection from the various sections; and several beds of good quality and thickness, with many of an inferior character, are unrepresented.

417. Though giving the actual amount of hygroscopic and combined water, as found by analysis, it must be premised that it depends entirely on the conditions to which the lignites have previously been subjected; and that, by prolonged exposure to dry air, it might have been in many cases very considerably reduced. It has, therefore, been thought advisable, in another place to reduce the results of all analyses to correspond to a certain percentage of moisture, that they may be better compared with each other, and with foreign lignites. The water content has been taken in the table, at 12 per cent., which has been adopted as the probable practical limit of dessication by dry air, under ordinary circumstances, of most of the samples. The lignites, it will be observed, are on the whole uniform in composition, and contain an average of over $40 \mathrm{per}$ cent. of fixed carbon when the water is estimated at 12 per cent. They thus fall somewhat behind the lignites found in the ricinity of the Union Pacific Railway; but it must be remembered that these only represent those seams which have been selected as workable from their good quality, and thickness; and also that many of them 
belong to the extreme western part of the interior continental region, and to the better class of lignites found in the vicinity of the Rocky Mountains, which are but slenderly represented in my collections. None of the lignites yield a proper eoke. They merely shrink somewhat in size during the expulsion of the volatile combustible matter, and turn out of the crucible in a dry incoherent powder. The volatile matter is, as might be expected, comparatively poor in luminous gases, and the lignites would, consequently, be of little use in the manufacture of illuminating gas.

418. The ash is generally of pale colours; grey and white, passing into yellowish-white, being the prevailing shades. One or two only yield a deeply-coloured ash, which is then brick-red. It is small in amount in most of the specimens, and does not usually appear of a nature to form troublesome clinker. The lignites when burning yield a peculiar empyrumatic odour, but no smell of sulphur; and indeed, as might be foreseen from the nature of the ash, the quantity of sulphur present is very small.

419. The proximate analyses give, in a general way, the means of estimating the value of the lignites as fuels, but there are many other considerations which require attention. The ash is not greater, and in many cases less, than that contained in most ordinary coals; and cannot therefore be supposed to detract specially from the quality of the lignites. The amount of water present is, however, the most serious drawback, as it not only counts as so much incombustibie material, being already fully oxidized, but absorbs and renders latent a considerable quantity of heat, which is necessary to convert it into the form of steam. Thus not only the total thermal effect of the fuel suffers, but the pyrometric intensity is reduced, which is a matter of special importance in metallurgical operations, and in the use of a fuel for raising steam, when the space allotted to the combustion is limited. Besides the quantity of oxygen present in these fuels, already in combination with hydrogen to form water; there is an additional quantity,-not inconsiderable in amount and probably in the form of various bituminous compounds with carbon and hydrogen, - which, as soon as combustion begins, combines also with the latter to form water. The weight of this oxygen, and the hydrogen necessary for its saturation, must thus also be deducted, together with the nitrogen, which is usually present in greater quantity than in truo coals. We have then remaining, a propor- 
tion of carbon and hydrogen which may be counted on for the useful production of heat, considerably less than that found in the same way for most true coals, but much in excess of that for wool or peat.

420. By taking into account all these circumstances, with others of less importance, and applying the knowledge to the examination of the results of ultimate analyses of fuels, rery exact estimates of their capabilities may be formed. Of the lignites of the interior region of this continent, unfortunately, but few reliable ultimate analyses are to be found, and of these only two apply to those of British North America. I had hoped to have added such analyses of some of the more important lignites of the forty-ninth parallel to this Report, but the time at my disposal has not sufficed. The analyses referred to are from specimens collected by Dr. Hector, and are as follows * :-

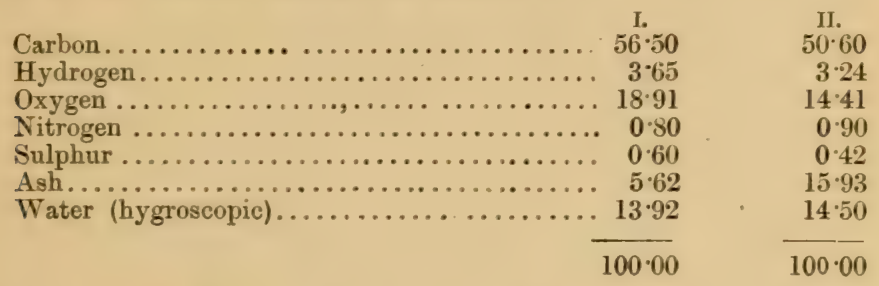

No, I. from the Souris River near La Roche Percée. No. II. firom a six-foot seam occurring near Fort Edmonton, on the north Salskatchewan. The calorific power of these two lignites as compared with that of pure carbon taken at 100 , is 59 and 53 per cent. respectively. $\dagger$

421. One of the most important practical difficulties which has arisen in connection with the use of the lignites of the Wustern States, has been the cracking up of the material, on parting with its water, and its speedy reduction to fragments when exposed to the weather. It has there been found preferable to use the lignites as soon as pussible, after their extraction from the mine, even at the expense of an adritional quantity of heat, lost in evaporating hygroscopic water. As the lignites do not form a coherent coke, this cannot be remedied, as it might be with most bituminous coals; lignite charcoals might, however, be produced; and though in most cases, these are found to be rather firiable, many of the compact western lignites would probably give a good result. The lignites are, however, now extensively employed for locomotive engines, and other steam-raising purposes, and though not directly

* Hector. Journ. Genl. Soc., vol. xvir., pp. 409, 421. The analyses made by Mr. Charles Tonkey in Dr. Percy's laboratory. Royal school of Mines.

$\uparrow$ As calculated by Mr. Raymond. Quoted by Mr. Marvine in U. 8. Geol. Surv. Territ., 1873, p. 114. 
applicable to most metallurgical procesies, might be used in tho form of charcoal, or perhaps more profitahly in gas furnaces after the pattern of those of Mr. Siemens; and, as settlement spreals westward, and these fuels are more in demand, many new methods will no doubt be found for their application. When they exist in the vicinity of land capable of agricultural settlement, they will be of great value, not only for domestic uses, but for the manufacture of bricks, tiles, and pottery, for whicis many of the enclosing clay and sand beds are very suitable.

422. The St. Mary Rirer coal, though unimportant in itself, from the thinness of the bed, is yet of great interest, as showing that there is a region toward the base of the mountains on the forty-ninth parallel, where fuel, better in quality than any heretofore found in the interior coutinential region, may be looked for. It is highly probable that important seams of similar coal exist even near the Line; and I have heard of the occurrence of similar beds on the Belly River to the north. Some traders, indeed, brought a sample of coal to one of the Depôt Camps on the Line, which, being handed to the blacksmith, was, before I returned to the place entirely consumed; it being found well suited to smithy work, and thus differing from the lignites. I was unable to risit the locality from which this specimen came, but was informed that it lay about fifty miles northward, at the junction of the Waterton and St. Mary Rivers, that the bed lay nearly flat, and that what appeared to be the same seam was found on both rivers, being about five feet thick on the former, and six on the 'atter. It would seem that the conditions of deposit, or mar terials forming these coals and higher class lignites in the vicinity of the mountains, must have differed from those of the lignites further east. Metamorphism accompanying and caused ly the folding of the formation, would probahly convert a lignite:into an ancisiacice, without allowing it to pass through the intermediate condition of a bituminous coal ; and the bed list referred to, and other's of somewhat similar quality elsewhere, are found in a nearly horizontal position.

423. Four analyses of fuels obtained by the Rev. L. Taylor, and examined hy Prof. Haancl, of Victoria Collewre, Colurge, have a very direct bearing on the question of the nature of the coals which may be expected to oceur along the hase of the mountains. The analyses appeared in the the Toronto (ilobe in Fohruary, 1874, and their results may be thus summarized :- 


\begin{tabular}{l|c|c|c|c|c}
\hline & Sl. gr. & $\begin{array}{c}\text { Moisture given } \\
\text { off at } 212^{\circ} \mathrm{F} .\end{array}$ & Volatile Matter. & Flxed Carbon. & Ash. \\
\cline { 2 - 3 } I .......... & 1.375 & 11.88 & 28.66 & 57.25 & 2.21 \\
II.......... & 1.375 & 11.41 & 29.07 & 56.94 & 2.58 \\
III......... & 1.340 & 6.69 & 33.70 & 53.25 & 6.36 \\
IV ........... & 1.337 & 6.89 & 33.57 & 50.90 & 8.64 \\
\hline
\end{tabular}

No. I. from the North Pembina River 100 miles north-west from Fort Edmonton. No. II. from near Belly Rirer. No. III. from Belly River. No. IV. from the Saskatchewan Rirer near Fort Edmonton. Prof. Haanel thus describes the specimens:- "I. and II. are bituminous coals, of a bright lustre, irregular fracture, showing, to judge from the small specimens sent, no distinct lamination; of a high specific gravity, comparatively free from sulphur, and giving out little tarry matter upon coking. No. III. and IV. are also bituminous, of a less specific gravity, lustre dull, distinct lamination; fracture at right angles to lamination, irregular with bright surfaces. Parallel to the place of lamination the slabs separated are dull ; gires out considerable tarry matter upon coking." It is stated that the two first do not form a coherent coke, and it is to be inferred from what Prof. Haanel says, that the others do. Nos. III. and IV. much resemble the St. Mary River coal in composition, and come from the ricinity of the coal bed described to me as occurring at the junction of that stream with Waterton River.

424. In the Report of Progress of the Geological Survey of Canada for 1873-74, a number of interesting analysis of fuels from the interior region of British North America are given. Seren of these, by Mr. Christian Hoffmann, refer to specimens collected by Prof. Bell near Dirt Hills,* and south of that place; not far from the north-eastern border of the lignite formation near the 106th meridian. The quantity of water in these lignites when thoroughly air-dried, as shown by the analysis, raries from 12.26 to $19 \cdot 33$ per cent. They exactly correspond in other respects with those of about the same longititude on the Line. The second series of analysis, by Dr. B. J. Harrington, are of fuels collected by Mr. Selwry, Director of the Survey, on the North Saskatchewan, between Rocky Mountain House and Edmonton; there, though Prof. Harrington classes

\footnotetext{
* This name seems to be rather loosely applied to different parts of the north-eastern edge of the Coteau, the point so called in the accompluying geological map, is not that reforred to by Pruf. Eell, which is further to the west and north.
} 
them all as brown coals, are of a far superior quality, some of them approaching the St. Mary River (')al, and equalling the best Tertiary fuels of the Western States. The water found in the various specimens is as follows:-7.82, 11.81, 10.90, 12.93, 7.50, 11.09 per cent. Some of these are stated to crack and fall to pieces on exposure, while others are little affected, and are considered suitable for transportation to a distance.

425. On reviewing the whole of the analysis of these fuels, and referring them to their localitles on the map, it will appear that lignites which contain, when thoroughly air-dried, above twelve per cent. of water, occupy the eastern part of the area covered by the Lignite Tertiary, while beyond about the 113th meridian, many, if not most, of the fuels met with contain less than that amount of moisture, and pass by en: $y$ gradations, in some instances to coals indistinguishable from those of the Carboniferous formation. These two regions are not, howerer, mutually exclusive, for west of the line above indicated, lignites of the former class are often found, and also, apparently, fuels representing all intermediate stages. This mixture of the two classes in the extreme west would sug= gest either the presence of two distinct coal-bearing formations, or two different horizons of the same series of rocks. From the apparently complete gradation in the quality of the fuels, and analogy with the better known regions to the south, the latter would appear at present the more probable explanation. In the Western States, this arrangement is exactly paralleled, and the poorer lignites of the Fort Union Beds, are represented in the far west by those of good quality and comparatively small percentage of water in Colorado, Utah, \&c.

426. The total area of the western part of the prairie region between the forty-ninth and fifty-fourth parailels, now known by more or less connected lines of observation, to be underlaid by the lignite and coal-bearing formation, or formations, does not fall short of 80,000 square miles; and should future inręstigation result in affixing some of the fuels to the Lower Cretaceous, it must be very much greater. The importance of these great deposits of fuel, in a country naturally so destitute of wood over great areas, cannot be exaggerated. In Colorado the thick and workable lignite beds seem to oceur only at the very hase of the Lignite Tertiary formation, and though this may also be the case in the vicinity of the mountains further north, it does not hold with the eastern portion of the formation, on the forty-ninth parallel, where lignites are equally characteristic and ahundant at all horizons exposed. 
Where the very base of the Lignite Tertiary is seen in the Bad Lands section, and further west near the 534 mile point, there appears, as already mentioned-to be a very persistent lignitiferous zone, but there is no appearance of any fuel of better quality like those of the extreme west. It, therefore, cannot be supposed that the improved appearance of the St. Mary seam, and others, is due merely to their occupation of a lower horizon than elsewhere exposed, irrespective of westward change in the character of the beds.

427. The ironstones of the Lignite Tertiary formation, to which frequent reference has been made, though occurring very often in the same sections and in close proximity to the lignites, have not been observed in any part of the area examied to occur in considerable thickness. They generally appear in nodular sheets, or scattered nodules, following certain horizons in the clays and argillaceous sands, and are found in greater or less abundance in nearly all the sections examined. Externally, they weather to various shades of chocolate-brown and reddish-brown, but are hard and compact in structure, and within preserve their original bluishgrey, or yellowish grey colour.

428. The subjoined partial analyses of specimens collected in 1873 , were published in the "Report of Progress" for that year. I regret that the time at my disposal prevents the execution of more complete analyses, or the examination of many other specimens subsequently obtained.

\section{Clay Ironstone. Souris Valley- $(\$ 209$.}

Protoxide of iron .................................49.00

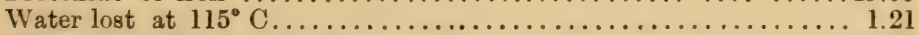

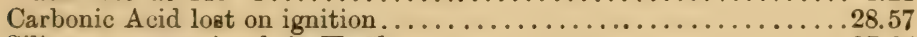

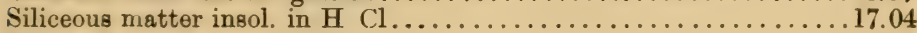

Sulphuric Acid.................................. 0.26

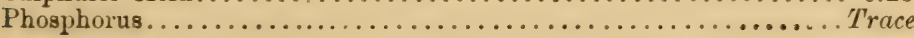

Metallic iron per cent., in raw ore...................

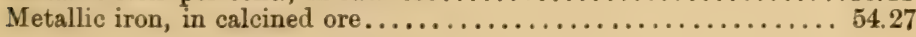

\section{Clay Ironstone-Great Valley.}

Protoxide of iron... ............................ 46.72

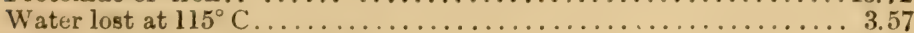

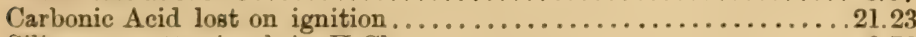

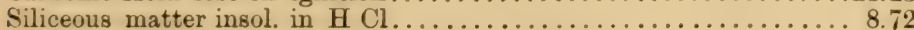

Sulphuric Acid.................................... 0.30

Phosphorus ....................................... 0.03

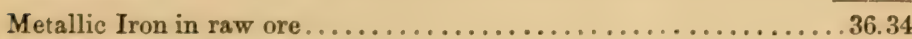

Metallic iron in calcined ore ............................... 49.90

A small quantity of iron is present as peroxide in each ore, but I have not thought it necossary to make a separate estimation of this, 
A third specimen from the Great Valley examined for iron alone, gave a percentage in the raw ore of 37.95 .

A rletailed analysis by I)r. B. J. Harrington, of a specimen of ironstone obtained by Prof. Bell, near the Dirt Hills, will be found in the Report of Progress of the Geological Survey of Canada, 1873-74, p. 241.

429. It would appear that the iron ores of this formation rank high in the class to which they belong, and that if occurring in sufficient quantity, they might eventually become of great economic importance. I have rot seen, howerer, in the vicinity of the Line, any place in which they are so abundant as to warrant the hope of the profitable production of iron. In some localities, great surfaces are more or less thickly covered with nodules which have been left behind by the erosion of the containing rocks; and it is of course possible that further search may lead to the discorery of sections in which so many bands occur as to render it profitable to work over the entire bank for their extraction.

430. The poor ironstones of the eastern out-crop of the Cretaceous have already been described (\$185). In the western extension of the same division of the Cretaceous, ironstone is much more abundant, especially where it holds the large septarian nodules described by Dr. Hector as characteristic of his group C. These in some places are rich and pure ironstones, and were noted to be specially abund:unt in some of the sections south and west of Wood Mountain. These rocks may in some places occur with sufficient ironstone, near good lignites of the Tertiary, to be of economic interest.

431. If the manufacture of iron is ever to le carried on on a large scale, for the supply of the interior region of the continent, it will probably be, however, toward the eastern base of the Rocky Mountains. There the fuels are better suited for this pupose, and ironstone probably still occurs quite as abundantly in the formation. There, too, it may confidently be expected that search will bring to light deposits of the richer clasises of ores among the palaozoic rocks of the mountains. 


\title{
CHAPTER VIII.
}

\section{AGE OF THE LIGNITE-BEARING FORMATION AND POSITION OF THE LINE SEPARATING THE CRETACEOUS AND TERTIARY.}

\begin{abstract}
AGE OF THE LIGYITE FORMATIOs-Nature of the question-Physical break between Cretaceous and Tertiary of Europe-No physical break in Interior Continental region - Unity of the Lignite formation - Tertiary age of Eastern representatives not directly questioned-summary of facts and opinions bearing on the age of Lignite formation-Stratigraphical-Invertebrate fossilsFossil plants-Vertebrate remains-Character of Junction Cretaceous No. 5 and Lignite formation-Contemporaneous deposit of No. 5 over the entire area-RETIEW OF THE EVIDENCE-Plants-Fresh-water molluses-Marine molluscs-Vertebrates-General conclusions.
\end{abstract}

432. In adopting the name Lignite Tertiary, as that of the great newer coal-bearing formation of the west, and using it-as has been done throughout - to designate the part of the series which lies abore the כ̃th or Fox Hill group of Meek and Hayden's Cretaceous section, I hare not done so carelesily, but as the result of a careful, and I hope impartial, review of all the eridence bearing on the age of the formation, to which I hare access; as well as the stuly of the rocks in the ricinity of the forty-ninth parallel, which hare come under my more immeliate attention, and which seem to throw important light on the question. It would appear only proper to state the reasons which have had most weight in leading to the formatior: of this conclusion, and this will now be done as briefly as pussible. T:e subject is a delicate one, insomuch as it has been the topic of muc: $\mathrm{n}$ eager controversy, but it is hoped that injustice has not leen done tu the riews of any of the gentlemen concerned, and that if errors have crept iu unobserved, good intentions will serve as an apology. Nor can the gradual change of opinion-now a matter of geological history-which has taken place on some points with the advance of knowledge with regard to the beds, be comsidered derogatory, for nothing can be more honorable or truly scientific than that impartiality which allows, on the knowlerdge of new fitcts of a different tendency, the prompt retractation or modification of riews formerly upheld.

433. There is, perhaps, no more interesting problem in American geology, than that presented by the later deposits of the interior region 
of the continent, and especially by that part of them supposed to represent the closing epoch of the Cretaceous and the introduction of the 'Tertiary. This question is at the same time one of considerable difficulty, so much so, that the systematic position of a great series of beds, in some places several thousand feet in thickness, and including the greater part, if not the whole, of the valuable lignite deposits, is at present in doubt. Various geologists who have devoted much time and study to the formation, are almost equally divided in opinion as to the Cretaceous or Tertiary age of the rocks, or the correlation of a portion with the former and a portion with the latter formation, and the position of the separating line.

434. Much of the difference of opinion, howerer, appears to have arisen from approaching the problem with preconceived ideas, and the attempted application of palaontological generalizations derived from the study of other localities, which have been formulated under too rigid laws. The break between the Cretaceous and Tertiary in England, and in Europe generally, is one of the most complete and striking in the entire rock series, and justifies not only the strict separation of the Upper Cretaceous and Eocene beds, but the introduction of the great classificatory line dividing the Secondary from the Tertiary. The Mrestricht and Faxoe beds, and the Pisolitic limestone of France, it is true, show an approximation to the fauna of the Eocene, but are still distinctly Cretaceous, and go but a little way toward bridging the great hiatus between the formations. The Upper Cretaceous beds of New Jersey, and the interior continental region, appear to represent these highest European members of the Cretaceous; and in the eastern coast region of America the localization of the break between the Cretaceous and Tertiary at this horizon is also borne out, the lignitic series of the West being unrepresented.

435. It has been a common palæontological aphorism, based especially on the study of the European series, that no single species is known to have passed upward from the Cretaceous to the Tertiary, but this, like most negative generalizations in geology, is already found to be imperfect. On examining the typical localities, we find that the change in the form of lise is not alone, but synchronous with vast physical changes, indicated by an entire alteration in the character of the deposits. There is every reason to believe, that the physical break was more sudden and potent in its effect on the forms of life, than any slow replacement of old types by new, by development or otherwise. 
Animal life of a form hitherto scarcely represented, is by the changed physical eircumstances brought prominently forward, and adds much to the apparent completeness of the replacement. It was an appreciation of this fact, which led a few years ago to the extreme statement, that the Cretaceous period still exists in the deep sea.

436. In the interior region of America, no great physical break took place at this time, and though the change in facies of life forms there, is probably much more rapid than can be accounted for without adding the acceleration due to physical change, the latter advanced slowly and uniformly, and, as might be foreseen, no distinct separating palæontological line can be drawn. As geological knowledge increases, it is found that its record of time in any one locality is much more imperfect than had been supposed. A combination of the records of all regions would, no doubt, suffice to fill the gaps; and the Lignite formation of America appears to go far to close one of the greatest of them.

437. Dr. Hayden, who has been actively engaged in working out the geology of the great area west of the Mississippi, included in the Territories, has affirmed and reiterated his belief, that the whole of the lignite-bearing rocks of the west belong to one great connected series, howerer separated now in some regions by the upheaval of mountain chains, or by denudation. * This view is also insisted on by Prof. Lesquereux for a great majority of the different localities, $\dagger$ and is apparently accepted by Prof. Cope and others. The evidence is also irrefragable that these rocks, wherever their relations are clearly shown, or have been carefully worked out, rest directly on the upper member of the well marked marine Cretaceous, in a perfectly conformable manner. The underlying rock is invariably, or almost invariably, the yellowish arenaceous clay or sandstone referable palæontologically-wherever that criterion admits of application - to Meek and Hayden's 5th group, and entirely distinct in appearance from the greater part of the beds associated with the lignites above. $\$$ I can not find in the reports of the $\mathrm{U}$. S. geologists, mention of the occurrence, in the Rocky Mountain region or eastward, of beds of lignite or coal in the lower weil-marked members of the Cretaceous, comparable to those of the Saskatchewan, which are provisionally placed on that horizon by Dr. Hector; with the possible exception of the coal observed by Prof. Marsh on the south side of the

* Am Journ. Sci, and Arts, 1868. U. S. Geol. Surv. Territ., 1870, p. 165. U. S. Geol. Surv. Territ., 1872, p. 14, \&c. † Ibid., p. 350. † †ayden. U. S. Geol. Surv. Territ., 1867-69, p. 121, \&c. 
Uinta Mountains in Utah,* and the Placière coals of New Mexico, deseribed by Prof. Newherry, which are consildered as Tertiary by Prof. Lesquereux, and have been stated to be so by Dr. Hayden. $\dagger$ With these exceptions, therefore, and leaving out of consideration a few localities in Utah and elsewhere, with regard to which there may still remain some slight doubt; the age of the whole of the valuable lignite deposits of the West depends on that assigned to the series of beds immediately overlying Cretaceous No. 5, with which they are associated.

438. The Tertiary age of the eastern representatives of these beds, in their typical localities, has never been directly questioned. It is only if the Lignite formation of the eastern base of the mountains be referred to the Cretaceous, that it becomes necessary, from the homogeneity of the group, to consider these beds Cretaceous also. Prof. Newberry, however, has throughout maintained that these beds are Miocene, $\ddagger$ while Prof. Meek more than hints at their ultimate inclusion in the Cretaceous, \$ and Prof. Cope now definitely classes them as Cretaceous; the two latter gentlemen arguing from the western beds eastward, in the manner above indicated. There seems little donbt, howerer, that the general tenor of the evidence of these beds, when considered alone, farours their Lower Eocene age. Their exact synchronism with the European Eocene is a question apart from the present inquiry.

439. It is in the western extension of the beds of the Lignite formation, in the Rocky Mountain region,--where, though preserving the same entire conformity with the underlying well-marked Cretaceous, and nonconformity with the later Tertiary beds above them,--they have assumed preponderating salt and brackish-water characters; that the dispute with regard to their age has been closest, and the arguments on either side most equally balanced. The shells of marine and brackish-water type, instead of occurring merely in the lowest layers, here characterize a great thickness of the strata. At Hallville, in Utah, 3,000 to 4,000 fect of coal-hearing heds were laid down before the sea waters were finally excluded. $\|$ Yet the tendency of the eridence seems to point to the necessary inclusion of these coals of Utah, in whaterer series those of Colorado are ultimately placed, though Mr. Marrine appears

* See Cope. U. S. Geol. Surv. Territ., 1873, p. 433, Prof. Dana in the last edition of hls Manual of Geology refers to those beds as belonging to the disputed Lignite formation. + U. 8. Geol Surv. Territ., 1859. Am. Journ. Sei. and Arts, June, 1874

: Genlngical Report Yellowstone and Missouri Expedition, 1869. Am. Journ. Sci. and Art8, April, 1874. 3 U. B. Geol. Surv. Territ., 1872, p. 460. IHayden, U. S. Geol. Surv. Territ., 1870. p. 166. 
to beliere that they represent a different horizon. * The lignitebearing rocks of the forty-ninth parallel, from about longitude $110^{\circ} 30^{\prime}$ Westward, helong with few exceptions to the salt and brackish water series, and closely resemble those of the eastern and western flanks of the Rocky Momntains further south, both lithologically and palæontologically. Specitic identity probably obtains between molluses from the ricinity of the Buttes, and both those of the Coalrille and Bitter Creek series of Dr. Hayden.

440. Dr. Hayden, whose authority with regard to the stratigraphical relations of the western beds can scarcely be disputed, in all his earlier publications and reports, refers the whole of the lignite-bearing rocks, which as already stated he considers as an umbroken series, - to the Tertiar 5 , and attaches them to the Miocene dirision. Writing in $185 \%$, in conjunction with Prof. Meek, he says:- "We have no eridence that any of the Tertiary deposits now known in Nebraska are older than the Miocene. The great lignitic basin, and the Mauvaises Terres of White Rirer, though probably both Miocene, are not exactly on a parallel." $\dagger$ Again, in the same year, in his Notes explanatory of a Map and Section, he writes of these beds. "The collections of fossils now obtained show most conclusirely that it posesses the mixed character of a fresh-rrater and estuary deposit, and that it cannot be older than the Miocene period." + In the published results of the Yellowstone and Missouri Expedition of $1859-60$, § we find the entire formation still retained in the Tertiary, but placed doubtfully on the horizon of the Eocene of Europe. The doubt seeming to obtain chiefly with regard to the propriety of its separation from the Miocene, and to be based on Dr. Newberry's opinion on the plants. The comparison by Prof. Liedy of the animal remains with "types even older than the Tertiary" is, howerer, mentioned. In 1868 Dr. Hayden still maintains the Tertiary age of the formation, and mentions especially the coal-bearing beds of the Laramie Plains, although in this locality, as he says, "some marine fossils are found in strata connected with the coal." $\|$ The admission is also made that there may here be "some thin seams of impure coal in the upper Cretaceous beds." In 1870 , Dr. Hayden refers to the Lnwer Eocene, the coal formation of the Green River and Bridger regions, but designates his classification of the beds there as

U S. Geol. Surv. Territ., 1873, p. 107. + Description, New Species and Genera Fossils, \&c. p. 19 ; Notes Explanatory of a Map and Section of the Country Bordering on the Missouri River. p. 9. $\$$ Gerlogical Report Yellowstone and Missouri Expedition. p. 29, et seq. || U. S, Geol. Surv. Territ, $1807-69$. p. 100. 
provisional only.* In the same report the position of the Coalville lignite series is almitted as doubtful, the uncertainty being caused, howerer, by the local disturbances of the strata, the beds of Cretaceous No. 2 appearing to overlap them. The conclusion arrived at is, however, that the coal is probably in reality "above the black Cretaceous clays of No. 2, and forms a part of the Upper Cretaceous group." $\dagger$ On another page of the same report it is stated that while in some localities the line between the Cretaceous and Tertiary is well marked by the absence of some beds-presumably those of marine and brackishwater aspect-that in otherw, as in the Bridger Pass district, the division, howerer minutely the beds may be studied, must always be an arbitrary one. I In 1872 Dr. Hayden is fully prepared to admit the Cretaceous age of a great part of the series. He considers the evidence of the Cretaceous age of the lower coal beds in Utah, especially at Bear River and Coalville, to be conclusire, and writes: "But if we admit that the coal beds of Wyoming and Colorado are all of Cretaceous age, I think we may extend them all over the North-west and ignore the evidence from the fossil plants entirely. The facts, as we possess them at the present time, seem to point to the conclusion that the lignite strata commenced during the latter portion of the Cretaceous period, and continued on into Tertiary times without any marked physical break, so that many of the Cretaceous types, especially of the vertebrata, may have lingered on through the transition period, even into the Tertiary epoch."s Also, in speaking of the lignite-bearing strata of the region of the Gallatin Valley: "The evidence at the present time points to the conclusion that the lower portions of this group are Cretaceous, passing up by gradual transition into the Tertiary, and that the greater portion may be regarded as of the age of the latter period." In the maps and sections published with some of the reports referred to, the Tertiary classification of the beds in question is alhered to. $\|$ Professors Hitchcock and B!ake have also adopted Dr. Hayden's colouring in their general Geological map, bearing date 1872 .

Dr. Hayden's explorations were begun on the eastern margin of the formation, but previous to 1857 he hal examined the country bordering the Missouri as far west as Fort Benton, and on the present line of the Pacific Railway, to Green River.

* U. 8. Geol. Surv. Territ., 1870. p. 73 I Ibid.,p. 157.

$\$$ Ibid., p. 76 .

lise Map and Section illustrating (ieol. structure of Country bordering the Missouri, 1857. Map accompanying Yellowstone and Missouri Report, 1s69. Map accompanying fimal Report on Nebraska, 1872, 
441. Prof. Meek, early in the field, concurs with Hayden, as we have seen, in 1857, in ascribing the lignite strata to the Miocene. As early as 1860 , it would appear, however, that he har referred some molluses from the lower part of the coal-bearing series to the Cretaceous, and in $\mathbf{1 8 7 0}$ he takes the view that the beds of Bear River and Coalville in Utah, are Upper Cretaceous, passing up through a series of transition strata to Eocene; though he is at the same time careful to guard against the supposition that he considers the limits of either one formation or other, to be exactly synchronous with those of the same names, and typified by similar fossils in Europe.* Reasoning entirely from the results of his examination of the invertebrate fossils, he places the lower beds, containing undoubted marine forms in the Upper Cretaceous, assigning them a position superior to Cretaceous No. 5, of the typical sections, Those with estuarine forms, are referred to the Tertiary; though in the conclusion of a note, on fossils submitted to him by Mr. Clarence King, he remarks:- "While I am, therefore, willing to admit that facts may set be discovered that will warrant the conclusion that some of the estuary beds, so widely distributed here, should be included rather in the Cretaceous than in the Tertiary, it seems to me that such evidence must either come from included Vertebrate remains, or from further discoveries respecting the stratigraphical position of the beds with relation to other established horizons, since all the molluscan remains yet known from them seem to point to a later origin." $\dagger$ The most typical Cretaceous forms recognised in the marine beds are, Inoceramus, Anchuria and Gyrodes, "Genera that seem not to have survived the close of the Cretaceous period." $\$$ Several other fossils of Cretaceous aspect, howerer, occur, and in some cases are compared specifically with those of the higher Cretaceous beds of California. \$ In summing up his arguments for the Cretaceous age of the lower beds of the Green River Basin, Prof. Meek lays especial stress on the occurrence of Inoceramus, and a somewhat doubtful specimen of Anchuria, and also on the fact that there is no evidence of the existence of any strictly marine Tertiary deposits in the interior region of the continent. He admits that if the remainder of the molluscous fauna were presented to any palieontologist unaware of the existence of the Cretaceous forms mentioned, and the generalization * See Prof. Meek'g very interesting review of the question in U. S. Geol. Sur. Territ., 1870, pp.
$\begin{aligned} & \text { 290, } 291 . \\ & + \text { U.S. Geol. Exploration Fortieth Parallel ; vol. III., 1870, p. 466. }\end{aligned}$ + U.S. Geol. Exploration Fortieth Parallel ; vol. III., 1870, p. 466.

+ U. S. Geol. Surv. Territ., 1870 , p. 290. \$ The inclusion of remains derived from the disintegration of older but unconsolidated beds may account for some of these facts. In the drift clays of the western plains, I have seen little altered Cretaceous shells imbedded, in a manner which would have been very puzzling, had their Cretaceous affinities not been known. 
above stated, they might be unhesitatingly referred to the Tertiary.* In 1872, Prof. Meek male a caredial examination on the spot, of many of the most interesting localities in the Rocky Mountain Region, and in his report reaftirms and extends his former views. It would seem, howerer, that the question was approached with some ready formulated rules. He writes, for instance, in mentioning the reference of the fossils to the Cretaceous in 1871. "This I did, mainly because there were among them no fresh-uater or strictly brackish-water types; uhile up to this time we know of no Tertiary of marine origin in all the interior region of the Continent." $\dagger$ At the same time two of the shells of brackish-water aspect were referred, to the Eocene, though-as he himaelf afterward states-they were subsequently found to have belonged to the marine beds last referred to. Nothing can show more clearly than this error, the delicacy of the investigation, even when followed on the evidence of the molluscan type only; or the danger of depending on the change from marine, to brackish, and fresh water, as a definite line. It is but fair to add, howerer, that the collection including these forms was small and apparently in imperfect preservation. On another page, Prof. Meek says of the lower marine beds, represented in the Bitter Creek Series: "Although partly committed in farour of the opinion that this formation belongs to the Cretaceous, and still provisionally viewing it as probably such, I do not wish to disguise or conceal the fact that the eridence farouring this conclusion to be derived from the molluses alone, as now known, is by no means strong or convincing." † The absence of all the characteristic Cretaceous Cephalopola is noted as not satisfactorily explicable, and the decidedly Tertiary facies of the Corbula commented on. Some of the latter, are similar to species found in the brackish-water beds of the Judith River on the Upper. Missouri, which have generally been regarded as Excene, though now, together with the Fort Union beds, by some included in the Cretacens. An Anomia, at the same time, so elosely resembles one from the cretaceous of Texas, that it is supposed to be identical with it. Directly associated with the Dinosaturian remains in the heds at Black Butte, is found a shell indistinguishable fiom Viciparus truchiformis, origrinally described from the typical Fort Linion beds, near Fort Clarke, on the Minsouri. The unity of the lignite series now renlers itself apparent, and the impossibility of referring their eastern

" This seenis to have already occurred, as Mr. Etheridge, Pelaontologist to the Geological Survey of Groat Britain, has referred shells ohtained lo Dr. Heeter at the Cypress Hills, - which in all probability bolong to this formation-to the marine Eocene.

$$
\text { † U.S. Geol. Surv. Territ., 1872, p. } 458 .
$$


and western representatives to different formations. It becomes necessary, if consistency shall be preserved to include the whole series in the Cretaceous or Tertiary, and the former course is adopted. Prof. Meek writes:- "The occurrence of this last named species here, along with a Cretaceous type of reptilian, and a Corbicula apparently identical with C. cytheriformis of the Judith River brackish-water beds, together with the presence of Corbulas, very closely allied to Judith River species, at lower horizons in this series, and the occurrence of some rertebrates of Cretaceous affinities at the Judith River localities, would certainly strongly farour the conclusion, not only that this Judith River formation, the age of which has long been in doubt, is also Cretaceous; but that even the higher fresh-water lignite formation at Fort Clarke and other Upper Missouri localities may also be Upper Cretaceous, instead of Lower Tertiary.'*

442. Professors Newberry and Lesquereux have investigated the numerous and rich collections of plants obtained from beds associated with the lignites. Prof. Newberry, in 1869, in describing plants obtained by Dr. Hayden, throughout refers to the deposits as of Miocene age. The specimens examined at this time were from various localities in the valley of the Missouri, from the extreme eastern edge of the formation at Fort Clark, to a point 100 miles up the Yellowstone. $\dagger$ Prof. Newberry still maintains the Miocene age of the Upper Missouri lignite beds, on account of the great similarity of their flora to that of the Miocene of other regions, but inclines to refer those of Colorado, Wyoming, and Utah to the Upper Cretaceous. \& This arrangement is apparently quite at variance with the stratigraphical unity of the formation, insisted on by Hayden and others, and the resemblance of many of the molluscan types throughout.

443. Prof. Lesquereux, while admitting the Miocene facies of the plants from the lignite deposits, when compared with those of the old world, places those of the Missouri basin in the Lower Eocene, and includes in the same category the greater part of those of the western Rocky Mountain region. He, howerer, points out the close correspondence of American Tertiary and Cretaceous forms-plants from the lower herls of the Cretacenus having originally been referred to the Miocene of Europe. Prof. Lesquereux visited and carefully examined some of the most interesting localities in 1872 , and appear's to have been

* U. S. Geol. Surv. Territ. 1872 . p. 460.

+ Geological Report Yellowstune and Missouri Expedition. † Am. Juurn. Sci. and Arts, April. $18 \pi 4$. $\$$ Am. Journ. Sci. and Arts, April. 18\%4. 
confimed in his opinions previously expressed. Ite believes the Eocene of America and Europe to be identical in general characters, and as a resumé of his conclusions writes:- "I am, I think, authorized to deduce the following conclusions: That the great Lignitic group nust be considered as a whole and well chaiacterized formation, limited at the base by the fucoidal sandstone, at its top ly the conglomerate beds; that independent from the (retaceous under it and from the Miocene above it, our Lignitic formations represent the American Eocene."* In 1874, Prof. Lesquereux appears in some degree to mollify this statement, by placing the heds at Carbon in the middle Miocene, and including those of Evanston and a few other localities, in the Upper Eocene, while classing the great majority of lignite-bearing rocks-including those of Colorado and Wyoming, with those also of Coalville in Utah, Nanaimo in Vancouver Island, and the Placière coal of New Mexico-as Lower Eocene. $\dagger \mathrm{He}$ believes that the age of the flora of many of the European beds referred to the Miocene, has not been fixed with sufficient precision to admit of their being used as terms of comparison.

444. Prof: Newberry draws attention to the fact of the diversity of Prof. Lesquereux's so-called American Eocene plants from those of the recognized Eocene of Europe, and does not think his reference of the lignite beds to the Eocene justified, writing:- "This conclusion I am unable to accept, firom the fact that the general facies of the Missouri lignite flora, is altogether unlike that of the European Eocene, and it is identified with the Miocene flora of Aretic America, Iceland, the Hebrides, and Central Europe, by most of its genera, and by a considerable number of well-marked species." $\ddagger$

-445. Prof. Cope appears first to have referred beds of this formation to the Cretaceous, on account of their reptilian famna in 1869. $\$ \mathrm{He}$ has described the remains of the Dinosaurian reptile from the Bitter Creck series near Black Butte, where they oceur in the closent relation with a coal bed, and were surrounded by a mass of regetable debris, and associated with Viviparus trochiformis, alrealy mentioned. Ife insists on the importance of this discovery, and writes:- "It is thus conclusively proven that the coal strata of the Bitter Creek Basin of Wyoming Territory, which embraces the greatest areal yet discovered, were deposited during the cretaceous period, and not during the Tertiary, though not very long preceding the latter." ||

+ Am. Journ. Sci. and Arts, June, 1874. U. S. Geol. Surv, Territ, 1873.

: An. Journ. Sri. and Arts, April. 1st4. \$ See C. S. Geol. Surv. Territ., 1873, p. 434. $\|$ On the existence of Dinosauria in the Transition beds of Wyoming. 
Prof. Marsh is stated to have found, "over the coal series, six miles from Green River, near Brush Creek, in Utah, a layer full of Ostrea congesta, ('on., a typical (retaceous fossil, and abore this a crinojel, perhaps related to the cretaceous Marsupites, and also scales of a Beryx; a genus of ('retaceous fishes; and in shales below the coal bed, remains of turtles of ('retaceous types, and teeth resembling those of a Megalosaurus." * These beds, howerer, according to Prof. Cope, $\dagger$ do not belong to the horizon of the lignite formation of Bitter Creek, but perhaps to Cretaceus No. 3. and cannot be accepted in eridence for the Cretaceous age of the Lignite formation properly so-called.

446. The Cretaceous age of at least a considerable part of the Lignite formation of the West is also held by Messrs. Marsh, Stephenson, Em mons, and King. The latter places the line of division between the Cretaceous and Tertiary at Bitter Creek, at the lerel of the highest horizon of brackish-water shells-a distinction which has the appearance of being a purely arbitrary one.

447. The issue is perhaps closest with regard to these Bitter Creek representatives of the formation. By Prof. Cope, they are referred to the upper part of the Cretaceous, from the occurrence of the Dinosamian, Agathaumas sylvestris. Prof. Meek, as we have seen, though not without much doubt, also relegates them to this formation; while Prof: Lesquereux believes the plants to be unquestionably Tertiary and Lower Eocene. Prof. Hayden had previously remarked the impossiblity of laying down any exact line between the Cretaceous and Tertiary of this region, and believes a considerable thickness of "transition beds" to be dereloped; $\ddagger$ a feature also insisted on subsequently by Dr. Bannister. \$ Here at least, we find the co-existence of the remnants of a Cretaceous fauna, with a flora such as is usually considered Tertiary by palæontologists.

448. In the ahove brief summary of facts and opinions, it has been endearored to bring together the more important data bearing on the age of the western Lignite formation, and to illustrate the gradual change of opinion which has taken place concerning it. For details and illustrations, it will only be necessary to refer to the elaborate and valuable reports of the gentlemen referred to.

449. The physical nature of the junction of the Lignite-bearing berk, and "transition beds," with the well marked Cretaceous, has alrearly 
been alluterl to ; and that examined in the course of my own explorations, is fully described in another par' of this Report. As this junction is, howerer, a matter of great importance, a few additional facts concerning it may be alduced. Though in some localities, as at Bitter Creek, the separation between the unirersally recognized Cretaceous, and beds belonging to the Lignite formation, may not be clearly definable, this is very seldom the case. Notwithstanding the locally variable characier of No. 5, no division of the Cretacious seems to be more constant in its general characters and appearance, over the whole western area of the interior region, an well as in the typical eastem sections. Palaontologically; it is to a great extent a continuation upward of No. 4 , and the changes it presents as compared with that division, are mostly those necessarilly brought about by the shoaling of the waters of t'ic sea. There also appear's to be, in many localities, a second zone of sandstone at about this level in the series, which has sometimes been attached by observers to the base of the Lignite formation, and sometimes to No. 5, and to which Prof: Lesquereux has drawn particular attention. It is characterized by the abundance of fucoidal remains in many places where he has examined it. It is not always easy to decide at once between these sandstones, and those more closely attached to the summit of the Cretaceous, nor does the division appear to be one of great importance, as there is no real physical, or great palaontological break. In the valley of the Yellowstone. Dr. Hayrlen describes, "a deep reddish-yellow Sandstone resting on the well marked Cretaceous rocks which I cannot positively affirm as belonging to the upper part of No. 5, or to the lower bed of the Tertiary." A similar bed is found holding the same position, high up on the Missomri, and round the rim of the Lignite Basin where it skirts the Black Hills.* Again near the Raton Mountains, Dr. Hayden descril es " a massive heavy-bedded sandstone. yellowish-grey or whitish, and rather concretionary in structure" as overlying Cretaceous No. 4 ; and this aceording to Lesquereux forms all round the mountains, the hase of the Lignitic formation. There sandstomes are also described south of the Raton Pass, along the base of the liecky Momntains hy Dr. Leconte, as "formed like an immense terrace, which extends as far south as the valley of the Torejo, and perhaps even to the North lank of the ('imarron." + In the valley of the Arkansas, Dr. Hayden mentions as resting on No. 5, a "thick led of rusty-yellow 
sandstone," which is regarded as the lower bed of the Tertiary.* Though the Cretaceous sublivisions are not well defined in the Southern Rocky Mountain region, so much so that it has been said by Hayden, that " if they had first been studied along the base of the mountains only from Cheyenne southwarl, it is very doubtful whether the five distinct groups of strata would have been made out," yet, even where the lines are thus indefinite No. 5 is clearly represented, and holds the same relations to the underlying and overlying series that it does on the fortyninth parallel. The black shales of No. 4 are said to " pass gradually up into yellow rusty arenaceous clays which characterize No. 5, and No. כ passes up into the Lignite Tertiary beds where they can be seen in contact, withont any well defined line of separation that I could ever discorer" † In other localities Dr. Hayden has denominated arenaceous layers which seem to occupy the same horizon, "transition beds." He writes "In various portions of the Laramie Plains, Colorado, Raton Hills, \&c. I have observed between the well defined Cretaceous and Tertiary beds, a group of strata composed of thin layers of clay with yellow and grey sands and sandstones, which I have called transition or beds of passage." "There is no proof so far as I have olsserred in all the Western country of non-conformity between the Cretaceous and Lower Tertiary berls." + Examples might be multiplied, but sufficient have been given to illustrate the nature of the junction, and its similarity orer the broad area explored by the U.S. geologists, and on the fortyninth parallel and northward.

450. The perfect stratigraphical continuity of the Upper Cretaceous and Lignite formation is apjarent everywhere. No break occurs from the base of No. 4, up through that division and No. 5, onward through the whole thickness of the beds associated with the lignites. The period of the deposition of the Lignite formation, is however, almost everywhere, brought definitely to a close by the occurrence of a mountain-making era, during which a great part of the Rocky Mountains was elevated, and the succerling Tertiary beds, when they occur, are frequently found to rest unconformably on the Lignite strata below. One horizon only, in this great Upper Cretaceons and Lignitic series, is well marked, and that is fixed as definitely as any geologrical mark of time can be. The yellow arenaceous beds of No. 5 are almost everywhere recognizable, and with them the lower sandstone of the Lignite formation is at least physically connected. 
451. That the changed physical conditions, and more turbulent waters, causing this sandstone deposit, were circumstances simultaneously affecting the whole area in question, and not progressively passing over it in any direction, appears certain. This is shown by its palæontological similarity, and by the fact that while almost immediately succeeded by fresh-water conditions in the east, it lies far down among brackish-water and marine fossils in the west. The elevation of the continent following the deposition of these sandstones, taking place gradually, and probably in a somewhat intermittent manner, and with occasional slight relapses, brought certain areas above the surface in thie eastern part of the interior continental region, and also even toward the west, at least as far as to the position of the present Rocky Mountain uplift. The sea was not perfectly excluded from the intervening shallor:s in the east, while in the west, the waters surrounding the low-lying, forest-clad land, were essentially marine, The eastern area was, however, soon converted into one characterized by shallow lakes of fresh-water, from which the sea was permanently excluded. In and around these, the lignites and associated beds were formed; while westward, and separated perhaps by no distmet barrier, was a region more or less subject to alternations, and mingling of estuarine and marine conditions, but where also the deposition of lignites was taking place in much the same manner as in the east. Everything seems to farour the belief that the deposit was simultaneous, as here indicated. Thus it is, that while the change from salt to fresh-water forms, in the eastern area happens to be roughly synchronous with the inception of the Lignite formation, it is valueless when extended westward as a criterion.

452. In the eastern region, the change from ('retaceous to Tertiary life-forms has been manifestly accelerated by the change of physical conditions. In the west, a similar acceleration has also obtained, but has not been so great, and while several thousand feet of strata were being deposited, occasional relapses of physical conditions allowed marine forms of Cretaceous aspect to re-appear. The change in type of life on which a palaontological classification is based, and which the increase of knowledge continually tends to show was more uniform and gradual than formerly supposed, is therefore complicated over the interior area of the continent by a superposed change from marine, through brackish, to fresh-water conditions; and this did not take place simultaneously in all parts of the area.

453. The dividing lines of geology are necessarily to a great extent 
founded on our ignorance, or local knowledge, and had the recognised classification of formations been based on a study of the western interior region of North America, it is probable that there would have been no line drawn between Mesozoic, and Tertiary or Cainozois; or had there been, it would be placed altogether above the Lignite series, which represents, at least in part, the lower Tertiaries of other countries. This at least would have been the grand classification founded on great areas, and not invalidated by the existence in a few places, - as probably at Eranston, - of beds of transition upward. If, however, it is desirable to draw a line between Cretaceous and Tertiary for the sake of uniformity with other and better known regions, and for use as a boundary in geological mapping; no physical non-conformity offering, it becomes necessary to turn to the included organic remains, which might indicate the position of some gap otherwise concealed. These we have seen, howerer, do not offer evidence of a very certain tenor; but from it, such as it is, our conclusions must be drawn.

454. The plants and fiesh-water molluses do not appear to be capable of rendering much service. The flora of the Dakota group,- - the lowest of the Cretaceous of this region, and the probable equivalent of the lower or grey chalk of Europe-is well represented in some localities, but is so essentially modern in type, that it was by competent authorities referred to the Miocerre period. The distinctive facies of the flora of A merica, seems even then to have been sketched out; and from this early period to the present day, wherever a land surface presented itself, plants very similar in appearance, and differing for the most part only specifically, were ready to occupy it. No great wave of regetation of Indian and Australian type, like that characteristic of the typical Eocene of Europe, seems to have swept over this continent, and thus the plants of the American rocks are not strictly comparable with those of the old world. They belong to a separate region, the features of which are its own, and must be worked out by themselves.

455. Yet further doubt, however, rests upon the evidence of the plants; for Prof. Lesquereux, from a careful comparison of the flora of different localities of the newer formations of the interior and western regions, is led to a sub-division and arrangement in series of the beds of these places, which is in many instances manifestly untenable in the face of other evidence. This is especially the case when he includes the Placière coal beds of New Mexien, and the Nanaimo coals of Vancouver Island, from palarophytological reasoning, in the Lower Eocene. The 
plant lieds of the former locality being overlaid by some hundreds*-in the latter by several thousand $†$-feet of beds, with well-marked marine Cretaceous forms. Prof: Newherry, also, -as pointed out by Cope, + though so familiar with the plants, is himself obliged to appeal to the evidence of the animal remains to fix the age of the deposits; the plants not being sutficiently closely comparable with the European. Nor does the wide difference of opinion, with regard to age, of two so able palarontologists in this field, tend to inspire contidence in the flora as a gruide. It would indeed appear, that the Cretaceous and Tertiary floras of America and Europe are not yet sufficiently known to enable their use as tests of age. The differences established between various localities, and thought when only a small area was known to indicate steps in a general progress; now seem to be due, to a great extent, to the replacement of one flora by another by migration, or to original differences in climate or condition, of the various places.

456. In one respect, however, the plants appear capable of affording a useful addition to the evidence. If, as appears probable chiefly from their study, a well marked maximum period of warmth was co-incident with the early part of the Lignite formation, preceded and followed by cooler periods, represented by the Dakota and later Tertiary deposits respectively; it may be possible to correlate this with the warm period of the early Eocene in Europe, and thus establish a direct synchronism. This carries with it additional probability, now that the possible dependence of such regular cyclical changes on astrotiomical causes, has been shown.

457. Fresh-water molluses, do mot ustually offer to the palæontologint a very safe criterion. They preserve, from their earliest known appearance, a wonderfinl similarity in genera and species; and their forms are longer lived than those of most animals, and fiom the nature of the shell and its ornamentation, changes which may be specific, are not so well defined or clearly recognisable as in marine shells. Specific reiations, howerer, when demonstrable are of ralue, and it would appear that such exist between some, at least, of the molluses of the disputed beds of the west, and those of the eastern border of the Lignite formatim, the Tertiary age of which has only been in dispute since it became necessary for the preservation of consistency, to include it with the firmer in the Cretaceous. The general facies, however, of the freshwater shells in wo far as it may weigh, is certainly Tertiary.

"Newberry. Am. Journ. Scl. and Arts, 1874. 
4ว8. The evidence of the marine Mollusca. has been found in palacontology the most valuable, and from the larose area occupied by the ocean, the most complete of any. The able palaontologist who has deroted his attention specially to the study of this line of life forms, in the area in question; though assenting to the classitication of the disputed berls with the Cretaceous, regrister's his opinion as to the preponderance of forms of Tertiary facies. He admits in evidence against these a few scattered genera, which in other countries, where the Cretaceous and Tertiary are widely separated by physical conditions, have been found characteristic of the former. He candidly allows, howerer, the eridencewhich, though negative, must be accepted as of some importance-afforded by the non-appearance of the C'retaceous Cephalopoda, even in those regions where marine conditions hare prevailed most extensively. A disposition has been shown, to fortify the Cretaceous position of the beds, by using the change from marine to fresh, or brackish-water conclitions, as a line. It has been said, in discussing the age of the rocks of certain localities, that no marine Tertiary beds are known. They can eridently nerer be known if all marine beds discorered are affixed to the Cretaceous. The non-occurrence of Inocerami, and other such Cretaceous forms, in the base of the Tertiary of a region in which the change took place so gradually, would be a matter of surprise. Elward Forbes, and Sir Charles Lyell, have long ago pointed out the mingling of such types, and Barrande and others have shown it to occur extensively, without at all invalidating the general tenor of the record. A certain form, may be characteristic of a formation in a given locality, but may not be capable of use as a touchstone, in another and widely separated one. Prof. Lesquereux has, m reover, lately shown that the really authentic cases of the discorery of Cretaceous molluscs in the Lignite formation, are much fewer than had formerly been supposed.*

459. To the evidence derived from the vertebrate remains, great weight, no doubt, attaches, as must always be the case with that from the highest forms of life of any period. The few relics of dinosaurians, and other reptiles of Cretaceous type, have really afforled the initial point and strongest retreat, of the arguments for the Cretaceous age of the formation. If no other facts were forthcoming, a palzontologist, would with every probability in farour of his classitication, place the beds containing these in the Cretaceous, doing so, as would alone be possible, from analogy with other regions. It can hardly be admitted, however, that 
by the discovery of these dinosaurian bones anong them, it is "conclusively proven" that the lower lignites were deposited in the Cretaceous. The fact of the occurrence of these animals so high in the series, like that of the recurrence of plants and fresh-water molluscis of types similar to those of the earlier Cretaceous, depended no doubt, on the uninterrupted continuance of land areas with similar climatic conditions. The changes which operatod in the comparatively rapid exclusion of such Cretaceous salt-water molluses as still lived, from the area in question, must have tended to spread and perpetuate the terrestrial fauna and flora, and the fact of the extinction of the few remaining dinosaurians, while the conditions continued at least as favourable to their existence as in the preceding period, shows that they belonged to a type, gradually succumbing to that decay, which seems to effeet not only the inclividual, but the species and the race. This result may perhaps have been accelerated, as suggested by Prof. Cope, by an irruption of mammals from some other quarter.

460. The Cretaceous formation cannot be defined as exactly co-extensive with any one form of life, however great its classificatory value may be supposed to be ; and no classification, of any natural objects or periods, based on a single structure or law, has proved sufficiently facile to include the facts, when all were known. By the comparison of certain conditions now existing, and their accompanying forms of life, with those of the Cretaceous, we may in a similar way prove its continuance to the present day. The vertebrate fauna, when taken as a whole, is not by any means an exclusively Cretaceous one, but includes according to Prof. Cope's comparative lists,* both in Colorado and Dakota, some forms elsewhere supposed to be characteristically Tertiary. Of the vertebrate remains found in connection with the lowest beds of this series on the forty-ninth parallel, Prof. Cope writes:- "This is a characteristic collection of the reptiles of the Ft. Union Cretaceous, but with increased admixture of Eocene forms. Plastomenus is an Eocene genus, but the reference of the new species to it is not final. But you send two Eocene gar scales which have every appearance of belonging to the same formation. Will you re-examine your notes to inform me whether they really belong to the same horizon as the others?"' + The gar scales referred by Prof. Cope to the genus Clastes, were obtained at the rery base of the Lignite forma-

- U. S. Geol. Surv. Territ., 1873, p. 438.

$\uparrow$ Prof. Cope refers the Green River and Bridger beds, overlying the Lignite formation, to the Encene. I'rof. ('ope also says of this collection, in a paper read before the Academy of Natural Sciences, Philadelphia : - "The list of species, short as it is, inclicates the future diseovery of a complete transition from Cretacenus to kiceno life more clearly than any yet obtained in the West," 
tion, and helow the lowest lignite bed. They were not stray specimens, but were brought to light in digging out some of the turtle bones in the Bad Latnds south of Wood Mountain (on the horizon marked by an asterisk. Plate VII. Fig. 2.) Dinosaurian bones occurred within a few feet of them.

461. It should be remembered in discussing the age of these beds, that the fossils of Yo. 5 have been compared with those of the Mastricht, \&c., of Europe, the Cretacenus position of which has not at all times been undisputed, and should any isolated patches of higher beds than the Mastricht and associated formations occur, showing eren the strict continuance of marine conditions; it is to be doubted whether they would be referred to the Cretaceous. Dr. Hayclen thus writes of the fifth division of the western Cretaceous :- " We would also remark that a few of the forms found in our Fox Hill beds, particularly the Gasteropoda, present such close specific affinities to Tertiary shells, that we would have doubted the propriety of referring them to the Cretacenus epoch, were it not for the fact that we find them associated in the same bed with Baculites, Ammonites, Scaphites and other Cretaceous genera and species."

462. The general bearing of the eridence, in so far as it is now known, seems in farour of the Eocene Tertiary age of the western Lignite formation, though it may not be exactly synchronous with that of Europe; and its base is rery probably somewhat lower than that of the formation in its typical European localities. Taking into consideration, however, the acceleration of the extinction of those pelagic forms, on which our definitions of the Cretaceous period are largely based, by gengraphical change in the area in question, there would seem to be no impropriety in allowing a great part of the strata to be caller beds of transition. I am also of opinion, that further and more complete investigation of these rocks of disputed age, instead of indicating more precisely any line between the Mesnzoic and Cainozoic of the interior region of North America, will tend to show the orerlap of life forms of different type to be more and more complete, and the sequence more perfectly uniform. It will also prohably be found, orer this area, that the rocks of many different localities, with more or less distinct organic remains, now considered as representing the life of separated periods in a linear succession, may be found by the mingling of the fauna and flora in other localities, as the area of study 
extends, to be more or less nearly contemporaneous. From these very circumstances, the exploration of these beds acquires an additional importance, and may yet be found to throw much light not only on geological, but on biological classification.

463. The position of the Lignite-bearing formation as a whole, is in fact such, that even allowing the classifactory importance of the included Cretaceous forms, an observer beginning his stuty of the beds on their eastern margin, and proceeding westward, as Dr. Hayden has done; would be completely justified in placing the whole series, at least down to the top of Cretaceous No. 5, in the Tertiary; while a geologist familiar in the first instance with the fossils of the underlying Cretaceous formations, and following the Lignite strata eastward from their appearance in the Rocky Mountains, would in all probability include the whole series in the upward extension of the Cretaceous, though doubts might begin to assail him before he reached the upper, or most eastern beds.

464. Should it be desirable, however, to draw a line in this region, it seems to me from a careful consideration of the facts which have come under my own observation, and the eridence adduced from other localities; that it can only be placed above the sandstones of No. 5. Above this zone the characteristic Cretaceous Cephalopoda are found rarely, if at all, and here lies the only physical circumstance which can be used in the delineation of the formations on a map. From its universality, and the prominent effect it sometimes has on the surface of the country, it seems particularly well suited for the purpose. It has therefore been adopted as representing the summit of the Cretaceous in the maps accompanying this Report, and the beds overlying it have been referred to throughout as the Lignite Tertiary. 


\section{CHAPTER IX.}

\section{GLACIAL PHENOMENA AND SUPERFICIAL DEPOSITS.}

Glaciation and Superficial Deposits, Lake of the Woods-The lake-basinDepth of the lake-Direction of glacial striation-Superposed striation in different directions-Special instances of glaciation--Pre-glacial age of outfall of lake-Distribution of boulders-Upper Silurian limestone boulders with fossils-N. E. limit of limestone drift-Methods of accounting for limestone drift-Drift plateau of Eastern Manitoba and Northern MinnesotaKames and Eskers-N. W. limit of red drift-Height and contour of the plateau-Sections on Roseau River-General Features of Glacial PheNOMENA E. OF RED RIVER-Elevation and slope of the Laurentian axisConfluent glacier covering the Laurentian region-Former southern outfall of Lake of the Woods-Drift Deposits of the Second Pratrie Plateau, And Turtue Mountain - Surface of the plateau - Terraces of Pembina Escarpment-Sections on Long River -Numerical analysis of constituents of the drift-Turtle Mountain-Boulder covered region-MARGIN AND EASTERN Region of the Thiri Platead-The Missouri Coteau-Ancient river valleys -Erratics of the Coteau-Quartzite drift.

\section{Glacial Phenomena and Superficial Deposits, Lake of the Woods.}

465. The general form of the lake has already been noticed (\$37). It consists of two chief parts-Clear-water Lake to the north, and Sand-hill Lake to the south. The basin of the former may be said to be excarated entirely in rocks of so-called Huronian age. Sandy or gravelly beaches are exceptional, and, as a rule, the rock dips rapidly below the surface of the water, and shows wherever exposed, the rounded forms due to ice action. This northern part of the lake is also deep, and with regard to its form and extent, it may be considered to have remained exactly as it now is, since the glacial period. The southern and larger part of the lake, properly called Sand-hill Lake, washes bare Laurentian rocks along its northern edge, while the whole of its southern and southwestern margin, is formed of sand and detrital matter, and sweeps round in large gently rounded bays, very different from the narrow, irregular passages of the north. This southern part of the lake is also comparatively shallow, and perpetually extending its border southward and westward, among the swamps, sand-hills and lagoons by which it is there surrounded, and spreading detritus thus obtained over its bed. The evidence of this is everywhere apparent along its southern margin, where tamarack swamps are in some places being so rapidly encroached 
on, that the trees may be seen along the shore bending forward at erery angle and falling into the lake. Some parts of the shore, have in this way become surrounded by an almost impassable belt of tangled and waterworn trunks and branches. The water of the southern part of the lake is turbid from the wash of the wares on the soft shores, and matier brought down by Rainy River ; giving rise to a formation of deposits of sand and clay now going on over the greater part of its bed. Before the water in its slow passage northward, through the narrow and complicated passages opposite the North-west Angle, gains the northern expansion; it has parted with nearly all its sediment, and does not receive any from the rocky shores by which Clear-Water Lake is bounded. The deposit forming here, as shown by soundings, is a fine slimy ooze, which is composed in great part of the shells of Diatomacer with spicules of Spongilla and organic matter. The lake is thus an interesting example of contemporaneous deposits of two entirely dissimilar kinds, taking place in different parts of the same sheet of water.

466. The deepest soundings found in Clear-Water Lake, were at its extreme northern end, and near where the waters begin to collect themselves for their fall at Rat Portage, and show a considerable current in that direction. The following depths were observed at intervals from that place southward to the North-west Angle Inlet, the soundings being taken generally in mid channel between the islands. The depths are given in feet:-
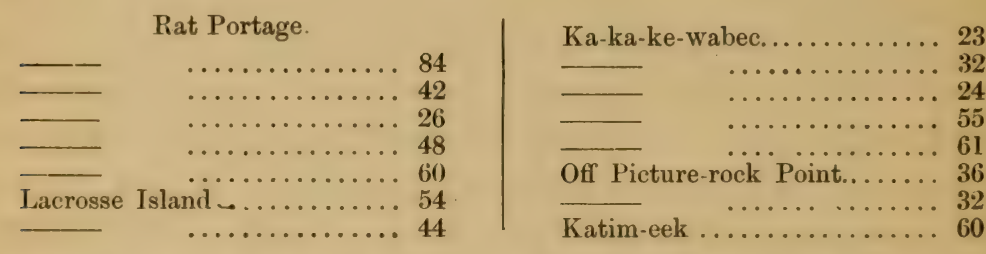

The bottom of the lake is generally flat, and deep water lies close off shore.

467. The outline of the lake follows very closely the changing character of the rock, spreading out where the schistose, and thinly cleavable varieties predominate, and becoming narrow and tortuous when the shores are composed of compact dioritic rocks, greenstone conglomerates, and gneiss. The laminated schist, and thin-bedded slates, offer little resistance to weathering. and even since the glacial period have been much broken down and shattered, in many parts of the lake, giving a peculiar character to the shore. The same rock, however, would, in its 
present vertical position, offer a much greater resistance to mechanical riolence; and before its layers had been widened by frost and weather, would support pressure and abrasion at right angles to its original bedding, almost as well as the most solid rock. So far as it goes, then, the close connection of the bed of the lake with the slaty rocks, would tend to show that it had been deeply outlined by sub-aerial weathering, before being subjected to glacial action. All the harder rocks of the region still show with the utmost perfection the scratching and grooving of the glacial period, and some of the more compact granites and intrusive diorites, retain a surface still perfectly bright and polished. Though the general direction of the northern part of the lake closely follows that of the ice action, its form is probably due in the main to the strike of the rocks, which is parallel to its greatest diameter. Still, on a small scale, eren the hardest and most homogeneous of the rocks show a tendency in the longest axis of their elevations, to parallelism with the glacial groovings.

468. The following table, shows the directions of glacial strix observed on the rocks in the rarious parts of the lake, the bearings being magnetic. * The directions connected by a bracket, were observed to occur together on the same rock surface:-

\section{N.W. Angle Inlet.} Place.

Direction.

McKay Island....S $48^{\circ} \mathrm{W}$ to $\mathrm{S} 50^{\circ} \mathrm{W}$

Bucketé Island............. S $35^{\circ} \mathrm{W}$

N. Shore.............. S $39^{\circ} \mathrm{W}$

Southward from N.W. Angle Inlet.

Flag Island............ S $40^{\circ} \mathrm{W}$ . S $27^{\circ} \mathrm{W}$ ........... S $42^{\circ} \mathrm{W}$

Southern Promonitory.

N. E. Point............ $\left\{\begin{array}{l}\text { S } 23^{\circ} \mathrm{W} \\ \text { S } 60^{\circ} \mathrm{W} \\ \text { S } 25^{\circ} \mathrm{W} \\ \text { S } 20^{\circ} \mathrm{E} \\ \text { S } 55^{\circ} \mathrm{W}\end{array}\right.$

Cormorant rock........... S $23^{\circ} \mathrm{W}$

N. of Rainy River (Mainland.)

$\ldots \ldots \ldots \ldots \ldots \ldots$
$\cdots$$\quad$ S $12^{\circ} \mathrm{W}$
Bigsby Island.

Place. Direction.

South end of ............S $27^{\circ} \mathrm{W}$

is $64 \ldots \ldots \ldots \ldots \ldots$ S $30^{\circ} \mathrm{W}$

" $" 6 \quad \ldots . \ldots \ldots$. S $20^{\circ} \mathrm{W}$

West side of ......... i s $10^{\circ} \mathrm{W}$

64 6

$\left\{\mathrm{S} 23^{\circ} \mathrm{W}\right.$

Mirldle Island.

East side of........... S $5^{\circ} \mathrm{W}$

" " $\quad \ldots \ldots \ldots \ldots \ldots$ S $13^{\circ} \mathrm{W}$

North end of ............. S $25^{\circ} \mathrm{W}$

North Island

............ S $30^{\circ} \mathrm{W}$

North Shore Sand-hill Lake, District of Shebashca

$\ldots \ldots \ldots$ S $25^{\circ} \mathrm{W}$

$\ldots \ldots \ldots \ldots$ S $40^{\circ} \mathrm{W}$

......... S $35^{\circ} \mathrm{W}$

$\ldots \ldots \ldots$ S $34^{\circ} \mathrm{W}$

........... S $25^{\circ} \mathrm{W}$

........... S $20^{\circ} \mathrm{W}$

$\ldots \ldots \ldots$ S $25^{\circ} \mathrm{W}$ 


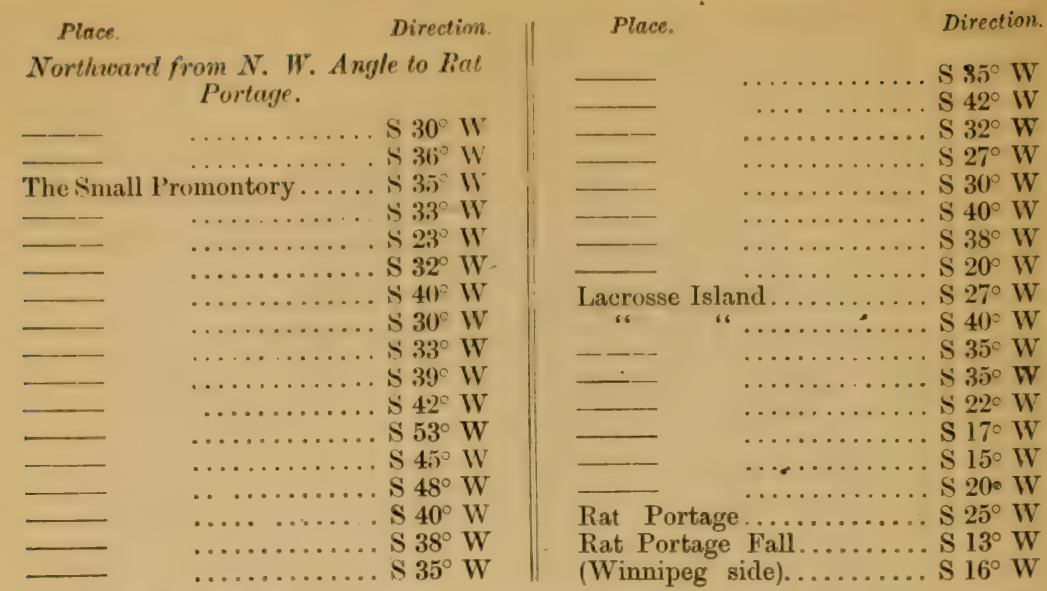

469. It will be observed from the abore table, and on reference to the map, that the direction of glaciation is very constantly from the northeast and north-north-east, and only appears to suffer oceasional slight deflections when brought in contact with masses of resistant rock running athwart its course. In the vicinity of Lacrosse Island, the grooves shuw more westing than they do northward of that place to Rat Portage. Between Ka-ka-ke-wabec and Picture-rock Point, a well-marked westward deflection takes place, the ice appearing to have been crowded off the high rocky land to the south. The pressure exerted by the ice in this neighbourhood, as it forced its way among the rocky islands and channels, has been exceptionally severe. South of this, the grooring resumes its normal direction, but at the mouth of the Angle Inlet again takes a marked sweep westward, toward the low-lying country in that direction, and away from the high rocky islands. The ice, as it has passed down over the rocks forming the north shore of Sand-hill Lake, has left remarkably uniform traces. Southward, among the islands, the ice appears to have turned a little from the west. The south end of Bigsby Island, shows a convergence of directions, as though ice coming from the eastern and western divisions of the lake had met at an acute angle, and overridden it to form a junction. The glaciation here also is very severe

470. At two places on the west shore of this island, glaciation in the orlinary direction, which gives form to the rock masses, was observed to he superinscribed with coarser scratches, nearly east and west in direction. On a small anea of granite and greenstone rock, forming the N. E. point of the southern promonotary of the lake, a remarkable series of strie exist. The most important direction, and that with which the form of 



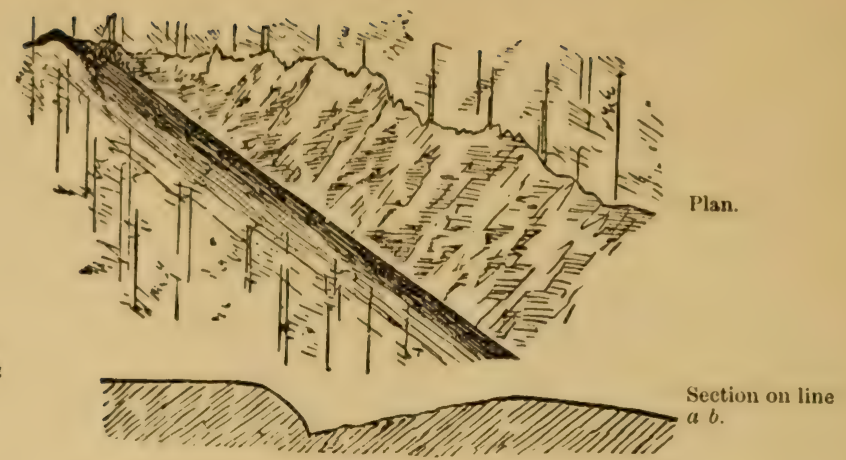

Figure 1-Glacial striation crossing a pre-formed hollow. (\$ 471.)

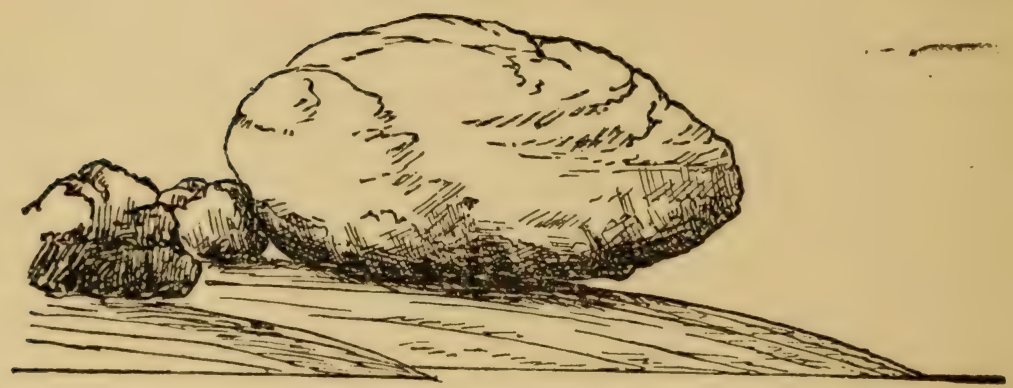

Figure 2-Perched blocks. ( $\$ 476$ )
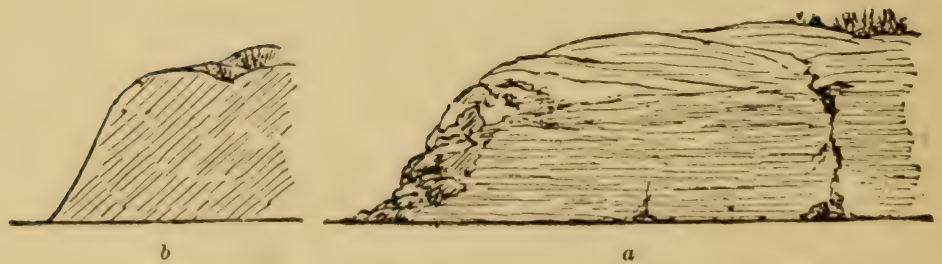

Figure 3-Glaciation of a point, indicating lateral pressure. (\$ 471.) $a$, elevation. $b$, sectional elevation in a plane at right angles to $a$. 
the rock coincides, is $\mathrm{S} .23^{\circ} \mathrm{W}$; superimposed on which, at one place, are scratches S. $55^{\circ} \mathrm{W}$., or N. $55^{\circ}$ E. Near this a direction of S. $60^{\circ} \mathrm{W}$., or $\mathrm{N}$. $60^{\circ} \mathrm{E}$. is seen, on which is superimposed striation $\mathrm{S} .25^{\circ} \mathrm{W}$., a direction closely agreeing with the general one, and probably indicating a brief resumption of the original force after a short interval. Another surface showed scratches S. $20^{\circ} \mathrm{E}$, or N. $20^{\circ} \mathrm{W}$. A part of this marking may be accounted for by the packing of ice on the shores of this open reach of the lake, but much of it is not of this nature, and appears to indicate the combined action of glacier and floating ice in the lower part of the region, toward the close of the glacial epoch.

471. On the eastern side of Flag Island, a small point composed of hard hornblendic rock, was observed to have its nearly perpendicular eastern front planed off perfectly smooth, and beautifully striated and polished, while its summit was only gently rounded, and showed comparatively little evidence of glaciation, and its southern front remained rough; the whole evidencing a strong movement of propulsion from the north, and intense local and lateral pressure. (Plate X., Fig. 3.) Not far south of this, on a surface of granitoid gneiss, the ice action was seen to have shaped and rounded previously existing asperities of the rock without obliterating them. One instance was especially remarkable, a little hollow in the rock, obliquely transverse to the general direction of the force, had originally a sloping northern and perpendicular south-western side. The ice had not touched the weathered surface of the former, while it had bevelled off and polished the latter in the most perfect manner. Such phenomena as this, appear to show great preponderance of onward movement over downward pressure in the action of the ice. (Plate X., Fig. 1.)

472. The passages by which the lake finds its way orer the junction of the Laurentian and green slate series to the Winnipeg River, do not depend on any evident conformation of the rocks. They cut across the hard ridge which marks the position of the fault bringing these formations together, nearly at right angles, and in a direction a few degrees west of north. They are probably due to some fault or crack structure traversing the rocks with that bearing, a course which agrees almost exactly with that of the fracture containing the large intrusive diorite of the south end of Lacrosse Island ( $\$ 84)$, and may tend to prove some connection between it and the similar rock which appears near the line of junction at Rat Portage. The grorge of the fall is certainly pre-glacial in date, and has probally arisen from subaerial weathering along some such 
line of weakness. The glacial striae cross over it obliquely, at an angle of about $30^{\circ}$ with its direction, and the iec has had wonderfully little effect on its shape, having suceeded only in rounding off somewhat the exposed angles of the cliffis. Nor has the river had much effect on the rocks, for they still retain their rounded aspect and show ice striation almost everywhere.

473. The distribution of boulders and travelled material in the Lake of the Woods region, is worthy of some atteation. The whole southern part of Sand-hill Lake is characterized hy the abundance of fragments of limestone, in association with boulder's of rocks represented in the northern part of this division of the lake, and in Clear-water Lake. Dr. Bigsby in his paper alrealy referred to* gives reasons for believing " that a deposit of limestone of Upper Silurian Age, orerlaps the metamorphic series in the southern part of the lake, and though I have been unable to confirm this idea by the discovery of any of the rock in sim, there is considerable evidence tending to show that his suppoposition may he correct. At Driftwood Point, five and three quarter miles south of Flag Island, the gravel of the shore is largely composed of compact limestone in small fragments. From this place to Reed River Bay, many large Laurentian boulder's stand on the shallows far out in the Lake, and much of the shore-gravel is of limestone. In the north-eastern angle of the Bay, in many places, about one half of the gravel of the shore appears to be of the same limestone.

474. A mile north of Reed River, a dry point projects from the general tamarack swamp of the shore, and consists almost entirely of boulder's and gravel. The greater part of the material is Laurentian, the boulders being of granite, gneiss, mica-schist, \&c., precisely similar to that seen to the north, and firom the size of pebbles to six and eight feet long. Next in numerical importance are the limestone boulders. None of these are so large as some of the Laurentian, but this may arise only from the fissile character of the rock, and the manner in which it is affected by frost, nearly all being angular and chip-like fragments. The stone is hard and compact, more or less concretionaly in aspect, often cherty, and giving fire under the hammer. Its colour is greyish-drab, to cream-white, and yellowish or reddish, on fresh fiacture; weathering to pure white. The weather also forms small reniform hollows in it, and in many specimens gives rise to a minutely pitted structure. From the limestones of this locality, and fragments of the same rock found west of the Lake of the

*Also in a paper on the Erratics of Canada, Journ. Geol. Soc., 1851. 
Woods, a few fossils were obtained. They are not in a very good state of preservation, but the following genera are recognizable. Strophomena, Pentamerus, Leperditia, Favosites, Stromatopora; also a few specimens of cyathophylloid corals, and disces of encrinal columns. Mr. Billings, of the Geological Survey, who has kindly examined these fossils, pronounces them to be Upper Silurian forms, though not sufficiently distinct for sperific determination. Dr. Bigsby gives the following list of fossils from the limestone, as determined for him by Mr. Salter. A small Phacops; Orthoceras, Favosites Gothlandica, Cyathophyllum, Murchisonia, Pentamerus Knightii, Leptona, Avicula, Atrypa, Spirifer. Ho probably enjoyed a better opportunity for the examination of the rocks, from the low stage of the water at the time of his visit, and speaks of marses ten to fifteen feet broad, and three deep, which though cracked and fissured, appear to him to be fixed.*

475. Least in numerical importance, at the point above referred to, are the boulders of Huronian origin, from the region of Clear-Water Lake; consisting of indurated slates, dioritic and epidotic rocks, and coarse greenstone-breccia of the kind already described, and with fragments from fou to six inches in diameter. On the shore, in the wash of the wares, a fine yellow-white plastic clay is exposed, which may perhaps be the representative of the boulder-clay of the glacial period. It contains much calcareous matter, efferresing strongly with an acid. Some of the boulders in this locality show traces of glaciation.

476. A mile south of Reed River, a second similar point occurs, where a ridge with an apparently southern course, comes out on the shore. It is covered with boulders in a similar way to the last, and they occur in about the same relative proportion. Off Buffalo point, which separates Reed River and Muskeg Bays, a good many large boulders stand up out of the water, and the shore is gravelly, and shows a considerable quantity of limestone debris. The north-east point of the southern promontory of the lake, is heavily glaciated, and shows many boulders of Laurentian, some of them forming fine perched blocks. One of these, of red granite, and actually lying in the groores it harl made, was found to to be eleven feet long by seren feet high. (Plate X., Fig. 2.) For several miles south-east of this place, sthe border of the lake is molerately high, and whenever exposed, shows whitish-yellow finely laminated clay, which contains many pebbles, especially of limestone, 
and appear's to be rather a former lacustrine deposit, than the representative of the boulder-clay. It is highly calcareous throughout, but did not yiekl any traces of organic remains even when microscopically examined. The sand spit opposite the mouth of Rainy River, called Oak Point, or Pointe du Chene, shows much limestone detritus in the form of gravel and sand. A few miles north of Rainy River, near Windy Point, several boulders of limestone oceur among others of crystalline rocks. They become honeycombed on weathering, in a manner somewhat different from any before seen. On the southern shore of Bigsby Island many boulders occur. They are mostly of Iaurentian rocks, but some of the honeycombed limestone appear, and one was observed of a species of limestone breccia, with yellowish-white pebbles in a reddish paste. Near the northern end of this island, a clay bank about ten feet hisit forms the shore for some distance, the clay being hard, wlere unweathered, grey in colour, and having traces of stratification. It resembles in constitution the other clays examined, efferrescing strongly with an acid; and holds small boulders, and gravel, some of the latter being of limestone. A single limestone boulder was eren as far north as the north end of this island. The limestone-breccia boulder above described, coincides exactly with a rock which Dr. Bigsby mentions as occurring on Rainy River not far from its mouth (§ 47 .)

477. It would thus appear, that a line drawn through Driftwood Point and running south-eastward to near the position of Windy Point, would have to the south west of it a region of abundant limestone debris; while though a careful examination was made to the north-with the exception of two or three boulders near Bigsby Island-not a single fragment of limestone was founcl. (See Map Take of Woods). This line, furthermore, runs in a direction almost exactly at right angles to the prevalent one of the glaciation. The distribution of the debris taken together with the direction of the glacial groovings, and the known courses of other erratic's, would seem to indicate the existence of a limestone flooring to the southern part of the lake, which in this case must have overlapped unconformably the older metamorphic strata; but may have been in great measure removed, before, and during the glacial period. No ontlyers of the limestone were howerer found, and I do not know of any unvisited locality in which such maly yet le looked for, with the exception of Garden or Cornficld Island, which I was mable to reach, and which lies low and flat as seen from a distance.

478 . Two other mexles of accounting for the appearance and distri- 
bution of the limestone debris appear to offer. Icebergs, at some time during the glacial period, may have passed southward over the Laurentian watershed to the north-east, bearing with them fiagments from the limestone formations of Hudson's Bay. In this case, it would be necessary also to suppose a subsequent developement of glaciers on the watershed itself; sufficient to remove this older debris to the south, as indicated by its position; and there is no sign of a heaping up of moraine matter, such as might be expected under these circumstances. It is also possible, that at a certain period of submergence of the region, ice may have floated eastward, over what is now an expanse of drift and detritus, and carried blocks from the Red River and Winnipeg districts, where, though no beds of Upper Silurian age are yet known, rocks of the Lower Silurian and Devonian are found. This appears to be the more probable supposition, as other evidence seems also to point in the direction of a south-eastern drift in this region, toward the close of the glacial period. Whether, however, it be conceded or not, that the limestone fragments of the southern part of the lake, are derived from limestone immediately underlying, it is probable from the general contour of the region, that Silurian or Devonian rocks overlap the older formations about this place.

479. The boulders of the northern part of the lake, are exclusively derived from Laureutian and Huronion rocks. They are generally accumulated on the south sides of the islands, which are apt to show bare rocky shores to the north. The same is true on a greater scale, with regard to their distribution in the region generally, the northern shore of Sand-hill Lake, being much encumbered with boulders. About thirty miles eastward from the North-west Angle, where the shore is sheltered, occasional patches of an old terrace, ten to fifteen feet above the present water-level of the lake, are seen both on the main shore, and on the southern ends of islands. It is composed of gravel and small boulders, and may probably be the littoral representative of the terraces of clay and finer material oceurring in the south. A clay quite similar to that seen in the southern part of the lake, appears underlying several feet of sand, in a decp ditch at the side of the Winnipeg Road, a few miles from the North-west Angle, and not far above the level of the lake. It is rather hard, yellowish-grey in colour, thin-bedded, and mingled with very fine sand. The boulders and erratic blocks of Clear-water Lake, are also entirely Laurentian and Huronian; granite, gneiss, diorite, and greenstone conglomerate being most abundant. 
480. The boulder's observed on the road from the North-west Angle to Winnipeg, were nearly all of the usual Laurentian materials. On the west side of the watershed, some boulder's of limestone appear, and much of the gravel seen in banks is also of this material. It would seem that the edge of the limestone of the Red River basin cannot here be far below the surface.

\section{Drift Plateau of Eastern Mrnitoba and Northern Minnesota.}

481. From the above descriptions of the superficial deposits of the Lake of the Woods, it will be seen that those answering to the boulder clay, properly so called, comparatively seldom appear, being covered for the most part by more modern accumulations, either those of a later period of the drift, or those produced by the lake itself, while standing a! a higher level than at present. Southward and westward, from the Take of the Woods, the country is studded with innumerable small lakes and swamps, which have formerly been more important, and the comparatively modern deposits of which, cover the more ancient glacial debris. The northern part of Minnesota, and the country immediately west of Lake of the Woods, may be represented as a great high-lerel plateau of drift materials, banked up on the sloping spurs of the rocky Laurentian region to the north, and covering, often to a very great depth, its old irregularities. It may also be consiclered broadly as forming the eastern representative of the second prairie steppe, as it stands at about the level which that plateau would have, were its gradual eastern slope continued thus far.

482. The surface of this plateau, though frequently irregular in detail, and covered with banks and ridges of sand and gravel of the nature of "Kames" and "Eskers," is, on the whole, remarkably uniform. A section along the forty-ninth parallel, from the ridge bounding the alluvial valley of the Red River to the east, to the Lake of the Woods-a distance of 77 miles-shows slopes which are so extremely gentle, as to be almost imperceptible; the total general westward fall of the surface in that distance, being only about 90 feet. An examination of the profile of the Northern Pacific Railway, from Duluth, to Morehead on the Red River, 160 miles further south, $*$ shows the nature of the southern extension of this platean, which is here the hirth-place of tributaries of the Red River, the Mississippi and the St. Lawrence. Rising pretty rapidly from

* See First Annual Report, Geol. Surv. Minn., 1873. Prof. N. H. Winchell. 
the shore of Lake Superior, the summit of the platean is reached, and the same level maintained, with an extreme variation in altitude of not much more than 200 feet, for 250 miles westward, when a comparatively rapid descent is made to the Red River Valley. As in the northern region of the plateau, the surface is corered, to a great extent, with lake and swamp, but the railway cuttings give occasional opportunities for the study of the underlying drift deposits. Near the western edge of the plateau, at Thomson Junction; green slaty rocks, apparently Huronian, project above the drift deposits, but beyond this point the underlyi:ng rocks are nowhere visible. The cuttings, which are chiefly through banks more or less closely resembling eskers, show sandy and gravelly material, generally stratified, and not so much of the nature of till or boulder clay, as of beds resulting from its re-arrangement, in shallow, rapidly moving waters.

483. A line drawn north-east and south-west, nearly parallel with the north-western shore of Lake Superior, but lying a short distance back from it, and cutting the Northern Pacific Railway some miles west of Thomson, in this part of Minnesota separates superficial deposits of different aspects. North-west of this line, the prevailing tint of the drift material is pale yellowish-grey, or drab; south-east of it, reddish tints are almost universal, and become specially prominent on the northern part of the line of the Lake Superior and Mississippi Railway, and continue to St. Paul. The junction of these two varieties of drift, cannot of course be exactly defined, but is interesting as an indication of the direction of transport of material in this region; the reddish matter being derived from the red rocks of the lake shore.*

484. The average height of the Plateau above the sea, on the line of the Northern Pacific Railway, may be estimated at about 1,350 feet. Where crossed by the forty-ninth parallel, it has a general altitude of rather under 1,000 feet, showing a decline northward. The highest part of the plateau appears, however, to lie about midway between the Lake of the Woods and the line of the Northern Pacific, the elevation of the sources of the Mississippi being, according to Nicollet, at an altitude of 1,680 feet.

* The junction of the red drift of Lake Superior with the lighter-coloured western material, of northern Minmesota, has, I find, been already noted by Whittlesey, in his valuable memoir on the "Fresh water Glacial Drift of the North-western States." (1864.) "In descending the St. Louis River, the ashcoloured drift clay of the Embarras and Savannah rivers, assumes a more purple bue near the mouth of the savannah.. The purple graduates into red, between this point and the Knife Rapids, and becmes entirely red on the Grand Portage. The red extends along the shores of Lake Superior ti St. Mary's and to Lake Huron. It is found on all the tributaries of Lake Superior which flow into it from the south up to their sources, and beyond the summit, on the streams that run southerly into Lake Michigan." p. 9. 
485. The most instructive sections of this great plateau were, however, observed on the Roseau River, which rising a few miles westward of the Lake of the Woods and approximately following the fortyninth parallel, though sometimes dipping to the south, finally flows into the Red River, north of the Line. From the eastern edge of the plateau where it fronts on the Red River Prairie, for about twenty-five miles eastward, high cliff-like banks with good sections, frequently orerlook the stream. In their general character they all agree more or less closely, and the sections often present features almost identical for long distances. The lowest beds are of very fine sand, and arenaceous clay, often quite plastic. These generally show irregular and current bedding, and do not include large stones or boulders. Above these beds, and resting on their denuded edges, lie coarser horizontal deposits of rounded pebbles, and small boulders, chiefly of white limestone, and apparently indicating littoral conditions; which as the country slopes gently westward, must have passed over it in that direction, as the former great lake of the Red River Valley grew smaller. Above these gravel beds, yellowish, or white, clean, fine sand, several feet in thickness, is very generally found; over which is a second pebble-bed, the fragments generally of limestone, and smaller and better rounded than in the lower. On this rests the present soil, usually from one, to two, or three feet in thickness, and coloured with vegetable matter.

486. Some sections showed near the water's edge, clay beds filled with stones, which though not well exposed, probably represent the houlder-clay proper. From it must be derived a great part of the large boulders which so encumber the course of the stream. The false-bediled sands, and associated clays, thus seem to intervene between the boulder clay and the littoral lake deposits, and appear to inclicate moderately deep water, with string currents, but as a rule without ice. Careful search was made for organic remains, but with little success. Not a single Molluse of any kind was discovered, but one section showed a considerable quantity of carbonaceous and peaty matter along the irregular deposition planes of the sand, and about thirty feet from the top of the bank, a decayed tree trunk stood out. The wood is soft and crumbling, and stained yellow by oxide of iron, but from its microscopic characters appears to be a fragment of the ordinary cedar. (Thuja occidentalis.)

487. Figures 1 and 2 Plate XI, illustrate the nature of the drift and superficial deposits of the plateau in this region. Section 1 , is remarkable for the great thickness of the first gravel bed, and the large sized 


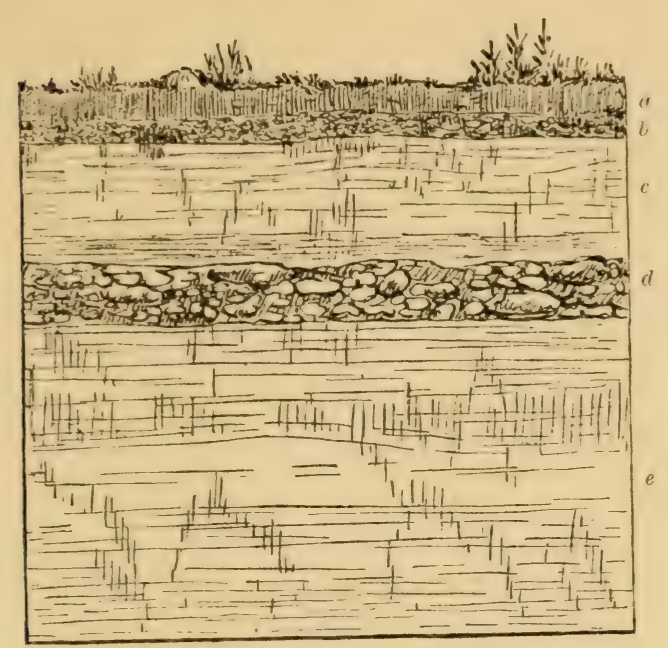

Figure 1. (\$487.)
(a), Soil.
(b), Upper gravel.
(c), Sand.
(d), Lower gravel.
(e), Siratifie l clay.

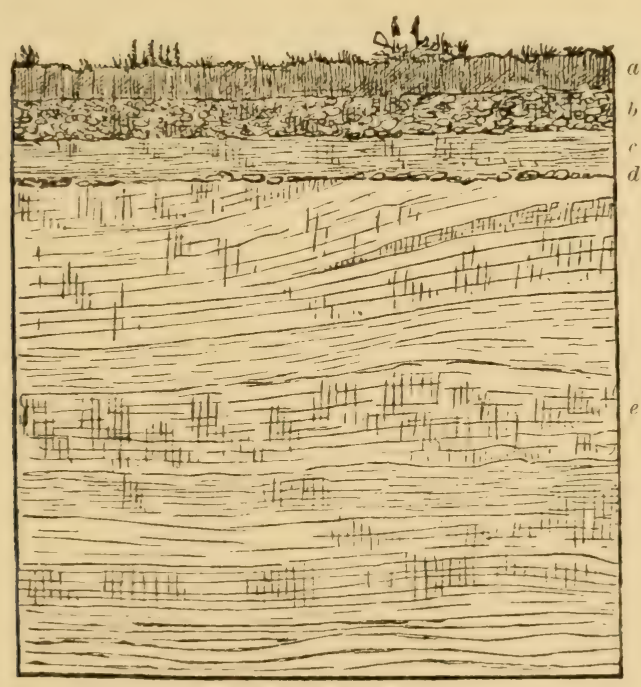

Figure 2. (\$ 487.) 

boulders imbedded in it. Section 2, is from a point about twenty miles east of Red Rirer, and is a good typical one. The lower irregularly bedded series, was here composed of yellowish-grey, fine arenaceous clay, so hard as to form a perfectly perpendicular front; and where it had been undermined by the water, it had fallen down and actually separated into slab-like masses, along the planes of bedding, like a soft sandstone.

488. About seren miles above Roseau Lake, on the East Roseau River, a little section showing the former extension of the waters of the lake, and their gradual recession, was observed. The lower layers ane of yellowish-white, fine, arenaceous clay, like that forming in the beds of the present lakes. Above this, lay about a foot of laminated peaty matter, showing the swamp or "muskeg" stage, and then about two feet of coarser arenaceous clay, forming the present soil, and indicating the deposition of matter still going on from the occasional orerflow of the river. A similar series of erents, is slowly taking place over the whole of this flooded region of the drift plateau, as the streams draining the lakes cut down their beds; and lakes and swamps in every stage can be found.

489. Forty miles northward of the Roseau River, where crossed by the road connecting Winnipeg and the North-west Angle of the Lake of the Woods, the drift plateau appears to retain much the same structure and altitude. It is, however, much less uniformly corered with swamps and lakes, the flooded region being confined more closely to the vicinity of the actual watershed.

490. The surface of the plateau, is very generally strewn with a profusion of erratics, and some of them are of great size. They are chiefly derised from the Laurentian and Huronian to the north, but there are also many of white limestone, with regard to the origin of which the remarks mar'e in connection with the part of the district more immediately surrounding the Lake of the Woods, will apply.

\section{General feutures of Glacial Phenomena East of the Red River.}

491. The rocks of the Lake of the Woods region, lying on the southwestern side of the great Laurentian watershed, follow in their contour its general direction of slope. The bare rocky hills forming the northern shore of Sand-hill Lake, seem seldom to exceed 150 feet in height, and the average level of the country, as seen from the lake, probalily falls below 100 feet. The rocky substratum of the region, slopes away gradually toward the south-west, till in the southern part of the lake, but one or two, low, rounded masses, rise at all above the level of the 
water. It may thus be safely assumed that the general fall of the surface of the rock; from the northern to the southern part of the region covered by this portion of the lake, is pretty nearly 100 feet. The distance by the direct course of the glacial striation is about thirty miles, and the resulting general slope of the country would be somewhat less than $3 \cdot 5$ feet to the mile. The general height of the Laurentian watershed, whereever it has been ascertained, is extremely uniform, and the slope so gradual that it does not merit the designation of a mountain region, but rather may be called a rocky plateau. The arrage elevation above the sea, according to Sir William Logan, may be estimated at 1,500 to 1,600 feet.* where crossed by Prof. Bell, between Lake Superior and Hudson's Bay, it is only 1,200 feet. The southern extension of the watershed, passing between Lake Superior and Lake of the Wonds, is estimated by Palliser at 1,500 feet. North-east of the Lake of the Woods, the watershed region is but little known, but near Lac Seul, which closely corresponds with the direction required by glaciation, according to $\mathrm{Mr}$. Selwyn's measurements it cannot be orer 1,400 feet. The summit of this great watershed, lies at from 200 to 250 miles north-eastwarl of the lake, and the glaciation is pretty nearly at right angles to its general direction. Estimating the maximum height of the watershed at 1,600 , and the elevation of the lake at 1,000 feet, a general slope of about three feet per mile results, and nearly coincides with that ascertained on a smaller scale in the Lake of the Woods district itself.

492. This rate of descent is scarcely sufficient to account for the spontaneous descent of an ordinary glacier, over a country which Sir W. Logan has well characterized as " mammillated," yet the surface is heavily marked by glacier action, and the supposition of the existence of many local glaciers, is negatived by the extreme uniformity of the striation. If icebergs and floating ice, be called in to account for the facts, the difficulties appear even more insuperable. To give rise to such heary parallel marking, it would be necessary to suppose ice moring under the influence of a determinate current, which must have crossed the watershed to the north-east. Icebergs having passed orer this ridge, would in their subsequent course float gradually into deeper water, acting on the rocks very feebly if at all; the more so, as in their southern journey they would no doubt be continually decreasing in size. Two suppositions only, remain; either the glaciation was aceomplished by the irresistahle movement of a great polar ice-cap, - wuch as has been consiclered a neces- 
sary agent by some geologists - or the Laurentian axis was occupied at one time by a great confluent glacier, pressed outward mainly by its own weight and mass, and directed only, by the pre-existing inclination. Haring met with no evidence of the former, I prefer to account for the fircts on the latter hypothesis, which will receive more extended notice on a subsequent page.

493. The general contour of the country surrounding the Lake of the Woods, and its position with regard to the watershed, and axis of Laurentian elevation, seem to show that the direction of drainage has not always been as at present. The initial cause of the Lake of the Woods basin, has no doubt been the occurrence of an area of softer Huronian rocks, among the Laurentian; and the rocky surface as already shown, sinks gradually but persistently away to the southward and westward, and in that direction, soon becomes buried under a vast accumulation of drift and alluvial deposits. It is probable from the conformation of the country, that were the drift deposits now blocking up the southern part of the lake removed, its waters would flow southward, in conformity with its general, primary inclination. The watershed between the lake and the Red River Valley, lies close to the former, and has an average height of perhaps not over thirty feet, the summit being occupied by great muskegs. Sections were seen on the East Roseau River, not twenty miles west of the southern part of the lake, which showed nothing but sand and detrital matter, to far belew the level of its waters. Supposing then the absence of this drift material, the small streams now running into the northern part of the lake, would flow southward, along the belt of softer Huronian rocks, forming a valley; and toward the southern part of the region now occupied by the lake, must have joined the larger stream of Rainy River, and then flowed south-westward through the northern part of Minnesota, toward the valley of the Red River, which-as elsewhere stated,-may very probably at this time have passed southward into the representative of the Mississippi of to-day.

494. During the glacial subsidence, the great deposits of sand and clay were formed, blocking up the entire southern part of the lake, and producing the low watershed to the west; through Clear-water Lake, as it formel a bay in the Laurentian, and from its rocky and tortuous outline, may probably have escaped the action of the currents bearing silt and debris. On the emergence of the country, the waters of the Rainy River being dammed lack from the south, would probably creep round the junction of the metamorphic rocks and drift deposits, to Clear-water 
Lake, and finding the lowest part of its rim in the pre-existing notches across the junction of formations at Rat Portage, would pass over, and pursue its way by the Winnepeg River to Lake Winnepeg. This river does not follow a true river-valley, but falls rapidly westward through a series of rock-basins, which often lie transverse to its course; passing down the slope of the Laurentian axis, and accommodating itself to the surface of a country previously shaped by other agency. The subsequent great spread of the Lake of the Woods, southward, must have been due chiefly to the action of the wares on the incoherent drift material, a process which is still going forward rapidly.

\section{Drift deposits of the Second Prairie Plateau West of the Red River, and of Turtle Mountain.}

495. In proceeding westward with an examination of the drift and superficial deposits, those of the Red River Valley would next claim attention. As, however, they belong to a later period, than those of the higher region to the west, and represent a distinct phaze in the great series of physical changes which have passed over the interior of the continent, it will be better to reserve them for subsequent consideration. Beginning at the Escarpement of Pembina Mountain, the western shore of the former Great Lake of the Red River Valley-I shall describe those sections of the later deposits which seem to be typical.

. 496. The surface of the second prairie steppe, appears to be almost everywhere thickly covered with drift deposits, and the undulations and slight irregularities of its outline, are in the main due to the arrangement of these surface materials, and though no doubt somewhat modified by sub-aerial waste, does not seem to have been much changed in this way. Over large areas, no system of coulees or stream vallies is to be found, and the generally undulated surface, must be due to original inequality. of deposition, denudation having acted only in remoring a certain quantity of the material from the rounded hillocks, into the intervening gentle hollows. Such an arrangement, implies not only the porous nature of the subsoil, but is in accord with the comparatively very small rain-fall of the region, and would tend to show, that at uo time since its emergence has the rain-fall been very great. The drift material is found generally to consist in great part of local dehris, derived from the immediately underlying soft formations, but this is always mixed with a considerable quantity of far-transported material, which is generally most abundant in the upper layers. Large erratics are in some localities very plentifully strewn over the plain, 
but they too, seem to be essentially superficial. They are generally of Laurentian rocks, but often of whitish, or yellowish limestone; the latter in some places being very abundant.

497. The eastern front of Pembina Escarpment, is very distinctly terraced, and the summit of the plateau, even at its eastern edge, thickly covered with drift. The first, or lowest terrace, which is about one-third from the prairie level toward the top of the escarpment, is the best marked; but in different parts of the escarpment does not seem to preserve exactly the same altitude. On the Boundary-line, its height above the general prairie level, was found to be about 90 feet, a second terrace 260 feet, and that of the third level, or summit of the plateau, about 360 feet. The surface of the first terrace, which is here wide, is strewn with boulder's, as is also that of the second terrace and plateau above. There are chiefly of Laurentian gneiss and granite, but a few smaller ones of limestone occur. The banks of ravines cutting the top of the plateau, and draining westward into the Pembina River, show, in some places, a great thickness of light-coloured, yellowish, marly drift, with few boulders embedded in it.

498. South of the Pembina River on the line of the trail from St. Joseph's to Totten, only one well marked terrace level, besides that of the summit of the escarpment, was found. Its height was about 270 feet above the Pembina River, the summit of the plateau being about 747 feet above the same datum.*

499. The Pembina River, where it leaves Pembina Escarpment at St. Joseph's, shows high banks of yellowish drift material. The pebbles in the river valley, derived from the drift, are very varied in aspect, including Laurentian, and other metamorphic rocks which may be Huronian; also whitish limestone like that of Winnipeg, fragments of calcareous and gypseous nodules from the Cretaceous clays, and a single specimen of silicified rood, similar to that found so abundantly in the drift of some localities much further west.

500. On the west side of Pembina River-beyond the escarpment, where its course is nearly north and south-many coulees and banks show yellowish and light-grey arenaceous or marly drift, often resting directly on the clays of the Pembina Mountain group, and then always charged with half-rounderl pebbles of the underlying rock. The river valley, where crossed by the Commission Trail, is over a mile in width,

\footnotetext{
* The measurements of terraces here given must be considered approximations merely, the weather being unsettled, and the readings from a single small barometor.
} 
and was found to be 300 feet deep. A terrace occurs, which is specially prominent on the western bank, and has a wille tread. It is about 200 feet above the stream, and in some places is thickly strewn with boulders. Allowing something for the fall of the river, it would thus nearly correspond with the first terrace met with on the St. Joseph's and Totten Trail. The existence of this terrace in the river valley, is interesting, as showing that it must have formed a narrow arm of the great postglacial lake of the Red River Valley when near its highest, and is therefore probably of pre-glacial age.

501. Westward, toward Long River, for many miles, wherever the subsoil is turned up by the burrowing of badgers, yellowish, marly drift appears, and holds many small pebbles of the Cretaceous shales, which though sufficiently firm to bear shaping in water, rapidly split up, and become disintegrated when exposed to the air.

502. In the valley of Long River, a very interesting section was observed. (Plate XII., Fig. 2.) The bank in which it occurs is about thirty feet high, perpendicular above, and composed at the foot of the Pembina Mountain Cretaceous. The lowest portion of the drift, is of stratified sands and gravels, very evidently false-bedded. The pebbles are chiefly from the underlying rock, but there are also a few of foreign origin, and the whole is arranged in a manner implying a very strong flow of currents in different directions. About eleren feet from the top of the bank, the false-bedded layers end abruptly, being cut off by a horizontal plane. Above this the bedding is regular, and the drift includes many, and some large, travelled boulders of Laurentian and white limestone, together with much small Cretaceous material. Large boulders are also abundant protruding from the soil of the prairie above. The surface of the Cretaceous, on which the drift is deposited, is not a smooth one, and there appear's to be some evidence that the valley of Long River was indicated before the period of the drift. We have here, at least, a hollow filled at first under the influence of powerful currents in shallow water, and then, it would seem, a deepening of the sea to such an extent, as to allow the passage of heavy, far-travelled ice, which planed smooth the summits of the current-formed banks below, and brought larger fragments of foreign rock to add to the deposit.

503. The largest boulder observed in this region was in the valley of Long River. It was of coarse grey granite, and the portion projecting from the ground measued about ten feet square.

504. Bauger Creek, fourteen miles west of Long River, ('uts deeply into the surface of the prairie, and exposes drift, resembling that of 


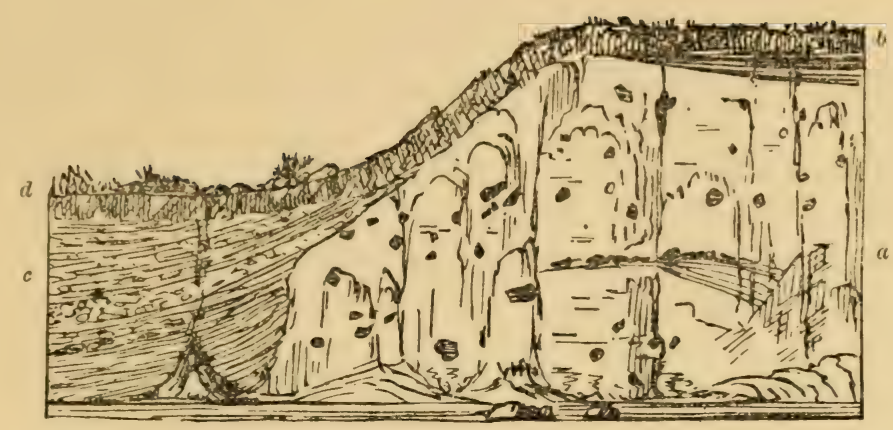

Figure 1-East) Fork of Milk River. (\$552) a, boulder clay $b$, older river alluvium. $c$, newer river alluvium. $d$, surface stratum disturbed by frost, \&c.

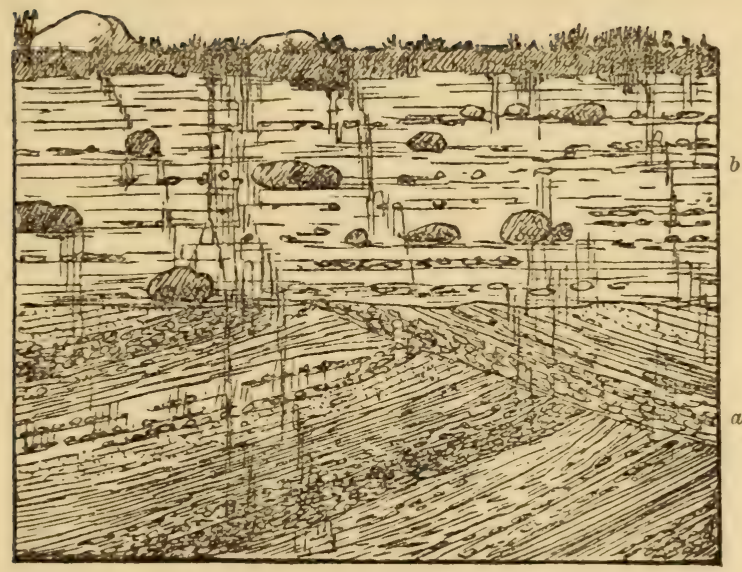

Figure 2-Long River (§ 502.) a, lower drift, chiefly local. $b$, upper drift, with large travelled rocks. 

Long River, but not so clearly. At orie place 20 to 30 feet of drift forms a vertical clitf. Boulilers are abundant in the bed of the stream, and appear to be chiefly Laurentian.

505. In order to ascertain as far as possible, the origin of the foreign material of the drift, and the relative proportions of its various constituents, the following method was arlopted. An average collection of pebbles, taken at random from the grarel of any locality, was made; stones above or below a certain size being rejected for convenience, and care being taken where possible, to combine gatherings from two or three spots for each locality, and to make the collection a large one. The pebbles so obtained, were then carefully enumerated, and divided lithologically into groups, which were referred as far as possible to their formations. From the numbers thus ohtained, percentage ratios have been calculated. The comparative simplicity of the geological features of the interior of the continent, the similarity of the lithological characters of the formations over great areas, and the absence of harder metamorphic rocks in the strata of the plains; are specially favourable to such an investigation, and the results serve to show the general course of the drift in a region where rock surfaces capable of preserving glacial striæ are entirely absent. It was at first intended, to enumerate the boulders and larger erraties in this way, but the criterion by smaller pebbles was found more frequently applicable, and whererer comparison was possible, the result obtained from them appeared to agree closely with the proportional importance of the larger masses. In one respect, the information to be derired from the smaller constituents of the drift, is more trustworthy than from the larger, as the limestone suffers rapidly from frost and weather, breaking down and ceasing to occupy a prominent position among the boulders of harder metamorphic rocks. Particular attention was, however, given to the larger erratics also, and it is hoped that information derived from different parts of an east and west line, over 800 miles in length, across the central portion of the continent, may not be unimportant.

506. The first numerical examination was made on the Line about eighteen miles east of the present western boundary of Manitoba, with the following result :-

1. White limestone, of the ordinary kind............. 48.18

2. Granitic and gneissic rocks, generally pinkish........... 38.48

3. Felspar.............................. 1.22

4. Pebbles, chiefly or entirely of crystalline quartz....... 9.75

5. Yellow chert............................ 2.43

6. Dark coloured, harl, metamorphic rocks............ 4.87

7. Soft reddish deconuposed rock. ................. 1.22

8. Grey rock; probably fragments of Cretaceous nodules. .. 1.22 
Also many splinters of Pembina Mountain shale, being fragments of disintegrated pebbles.

507. The limestone resembles that of Fort Garry, of Lower Silurian age, but is also indistinguishable from the Devonian limestone occurring north of that place, and from the L per Silurian debris already mentioned as appearing in the vicinity of the Lake of the Woods. The fragments included under No. 2, are no doubt Laurentian. Nos. 3 and 4 are also probably Laurentian. No. 5, derived from the limestones. No. 6 probably Huronian. Non. 7 and 8 are local. The great quantity of limestone here present is remarkable, but will be found to be characteristic of many other localities.

508. In this vicinity, and westward toward Turtle Mountain, the undulations of the prairie become more striking and apparent, and often form rather steep-sided little hills. These are also frequently grouped together in miniature ranges, or form more or less definite lines across the plain. The whole of these surface features, so far as could be ascertained, are due to the arrangement of the drift deposits. It is also observable, that wherever the ground rises slightly to form elevations of the kind mentioned, basin-like swamps, and small ponds, are almost certain to be found. They do not therefore, as a rule, occur on the lowest parts of the prairie surface, but rather the reverse. It is also a curious fact, that the hill-tops and swamps should be often equally characterized by the abundance of boulders, while the intermediate slopes, and the general surface of the prairie, are almost free from them. A similar observation has also, I find, been made by Prof. Bell in a part of the second prairie steppe, considerably further north. As already mentioned, sub-aerial denudation has taken place to a very slight extent, and the association of these features, would appear to indicate slight erosion by currents, while submergence was still complete. These might easily scoop out hollows in some places, learing the boulders and hearier masses; and at the same time be removing the finer debris from the exposed surfaces of hillucks.

509. An examination of the constituents of the drift about ten miles east of Turtle Mountain, and seren north of the Line, gave the following result:-

1. White limestone......................... 45.63

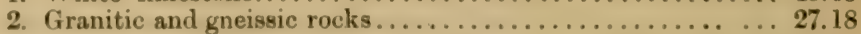

3. Dark, grey and greenish, compact or schistose altered rocks 16.50

4. Quartz and quartzite....................... 6.80

5. Crystalline diorite...............................

6. Reddish decomposerl rock........................ 0.97

7. Fragments of nodules (probably Cretaceous).......... 0.97 
510. The drift here closely resembles that of the last locality, differing chiefly in the comparative abundance of dark coloured metamorphic rocks, which are probably Huronian. Among the fragments of crystalline quartz, were some of quarzite, of which special reckoning was not kept. They may, from their appearance, hare been either Laurentian or Huronian, or eren derived from the Rocky Mountains, as afterwards ascertained. Some of the hard greenish altered specimens, may also have come from the latter source.

511. Turtle Mountain, so called, will be described more fully in a subsequent page, but should also be mentioned in connection with the drift deposits. It is a broken, hilly, wooded region, with an area of perhaps about twenty miles square, and slopes gradually upward from the plain around it, above which it is elevated, at its highest points, about 500 feet. It appears to be the culmination westward of the hilly drift region previously described, and forms a prominent object when viewed across the eastern prairie, from the contrasting sombre tint of the foliage of its woods. From the west it can be seen from a distance of forty-five miles, and when thus viewed, has really much the general outline of a turtle shell. It is bisected by the forty-ninth parallel.

512. Captain Palliser's expedition followed the Beundary-line thus far west before turning northward, and Dr. Hector, from a general examination of the mountain, considered it to be composed of drift. I have had the opportunity of examining not only the outskirts of this region, but of penetrating completely across it in the direction of the Line, and my observations tend to confirm those of Dr. Hector. The existence of a bed of limestone in the channel of one of the brooks in the interior of the mountain, was reported to me, but after having made a special trip, occupying three days, for the purpose of visiting the spot, it was found to be merely a large boulder of rock, much resembling the Lower Silurian limestone of (Farry, which had been lodged in an inclined position among many others of granite and gneiss, and was breaking up under the weather. Nearly all the abrupt slopes and ridges - of which there are many-show boulders in abundance, and these appear to be chiefly of Laurentian rocks. The shores of some of the numerous lakes are largely composed of white limestone with Laurentian fragments, and some greyish and greenish Huronian-like rocks. The western is more abruptly hilly than the eastern side, and the more prominent ridges have a general northerly and southerly direction, with intervening vallies 
characterized by swamps and lakes. Large areas of comparatively level, or only gently undulated grouml, are however foun in some places. The surface of the "mountain" appears to be that of the drift, as deposited, and has been but little modified by subsequent sub-aerial action. The lakes ie in basin-like hollows, and notwithstanding their great number, drainage vallies and stream-courses are few and unimportant. A considerable quantity of finer material, however, seems to have been removed firom the hills and ridges, and re-deposited in tl.e hollows, causing the former to be stony and gravelly.

513. In many respects the structure of Turtle Mountain closely rescmbles that of the Coteau, elsewhere described, and from its altitude it is entitled to rank as an outlyer of the third steppe. Similar hills, more or less well marked, and composed of drift materials, appear also to occur in other parts of the second prairie steppe. These, with Turtle Mountain, form a line east of the escarpment of the third steppe, but nearly parallel with it, including from south to north :-Turtle Mountain, Moose Mountain, Wolf Hills, File Hills, Little Touch wood Hills, and Touchwood Hills. These elevations do not appear to be connected with anything like a continuous escarpment, at least there is no such comnection northwest of Turtle Mountain; nor can their arrangement be shown to be due to any feature of the underlying rocks. They lie, howerer, nearly on a line of equal altitude on the eastward slope of the plains, and show a rough correspondence to the main gaps in the high land, connected with the escarpment of the second steppe, to the east.* Putting aside the hypothesis of a nucleus of limestone, or other solid rock, for which there appears to be no support, these elerations would seem to have been formed by the tendency of icebergs bearing debris to congregate in certain positions under the influence of currents. A shoal once produced in this, or any other way, would tend to increase rapidly when the water became sufficiently shallow for the ice to ground on it, and its extent and dimensions would only be limited by the length of time during which suitable conditions prevailed, and the erosive power of the currents passing over it.

514. A careful examination of the pebhles of the drift, on the prairie eant of the first crossing of the Line and Souris River, 170 miles west of Red River, gave the following ratios:-

"For a description of Mone Mountain. see Exploration of British North America, p. 49. For the Tuuchwood Hills, Report of Prugress Geol. Surv. Canada, 1873-4, p. 28 . 
1. Whitish limestone ......................... $62 \cdot 41$

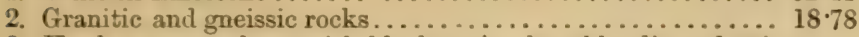

3. Hard, green, and greenish-black rocks, hornblendic and epi-

dotic, sometimes schistose................. $7 \cdot 38$

4. Dark greenish rock, evidently fragmental............ $2 \cdot 68$

5. Crystalline quartz.......................... $2 \cdot 68$

6. Quartrite and hard jasper-like rock.................. $2 \cdot 34$

7. Fragments of ferruginous concretions ................ 100

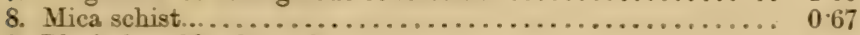

9. Black hornblende rock.................................. 0.67

10. Hard, coarse-grained, light-coloured quartzite ......... 0.67

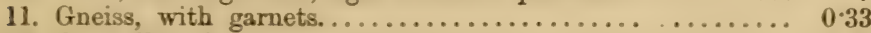

12. Crystalline diorite............................ $0 \cdot 33$

515. With regard to derivation, Nos. 2, 5, 8, 9 and 11, are almost certainly Laurentian. Nos. 3 and 4 are Huronian. No. 7, Cretaceous or Lignite Tertiary; and No. 12 indeterminate. Nos. 6 and 10 are the first undoubted examples of a species of drift which further westward becomes increasingly prominent, and which I have called, for distinction, Quartzite drift. After having been observed in numerous places during the season: of 1873 and $\mathbf{1 8 7 4}$, this drift was finally traced to the Rocky Mountains, as its probable place of origin. It is of course possible, that some stray pebbles indistinguishable from the true Quartzite drift, but coming from the east or north-east may occur; or that some fragments from the Rocky Mountains may be indistinguishable from those of the Huronian, and included with them here; but I think, in the main, the conclusions as to origin may be relied on. From this point onward to the flanks of the mountains the Quartzite drift will be found to occur more abundantly in the travelled debris.

516. Between the first and second crossings of the Souris River, and near the Antler Creeks, no sections of the prairie sub-soil are found. Boulders, however, are very numerous in some places, and are as usual mostly Laurentian, though there are some of limestone, and also a few of hard metamorphic blackish and greenish rocks like Huronian. Occasional boulder's of pale pink sandstone, with darker coloured stratification planes, and also blocks of compact, rather coarse-grained, whitish sandstone, were also for the first time seen here. They belong to the Quartzite drift series and exactly resemble some rocks of the mountains near the forty-ninth parallel.

517. Near the 192 mile point, the sujerficial drift was found to be composed as follows:-

1. White limestone. ..................... $51 \cdot 63$

2. Granitic and gneissic rocks, greyish and pinkish ........ 29.77

3. Greyish, hard, altered rock, resembling quartzite........ 6.54

4. Quartzites and hard altered rocks.................. 4.10

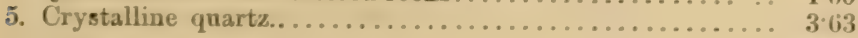


6. Hornblende schist....................... 1 $\$ 66$

7. Yellowish quartzite............................. 1.45

8. Diorite........................................ 075

9. Ironstone............................ 0.36

518. The limestone is probably altogether from the Red River region or northward. Nos. 3 and 4 camnot be very definitely placed either in the IIuronian or Quartzite drift, while No. 7 almost certainly belongs to the latter. The introluction of the material included under No. 3, in such large quantity is rather anomalous. Nos. 2, 6, and probably also most of No. 5, are Laurentian.

519. The prairie south of the south bank of the Souris River-which beyond the Second Crossing runs nearly parallel with the Line for about thirty miles-is for a breadth of sereral miles, strewn with an immense number of boulders. These are grenerally half buried in the soil, and in some places over extensive areas they are almost in contact. They ronsist mainly of Laurentian rocks, but there are also a good many of limestone, and some of the harler parts of the local Tertiary s.ndstones. Sume are of large size, though most are not over a foot or two in diameter. They do not appear to be arranged in groups, but are scattered very uniformly everywhere. The north bank of the river as far as I examined it, is characterized in the same way; and Capt. Palliser who crossed the country beyond it on his way to the Roche Percée, writes:- "As we approached this river, the ground was so covered with boulder's that our cart could barely get along."* The region thus evidently strewn with erratics, seems to be that which slopes gently toward the edge of the steep bank of the river. The boulders are by no means so frequent on the general surface of the prairie in this locality, and they would there seem to be covered with a finer superficial deposit, which has been removed where denudation has taken place. The layei containing the boulder's, howerer, cannot be a thick one, as where waste has penetrated to a much greater depth, in the small valleys tributary to the Souris, the covering of boulders is not sensibly increased.

520. Near Wood End, 260 miles west of Red River, some good sections of the drift occur on the Souris. The surface of the prairie here rives to form a rather well marked plateau, but of small eleration, which may be considered as being the first ascent toward the elevated region of the Missouri Cotean. The underlying rocks are here of Lignite Tertiary age, and as when resting on the Cretaceous, the drift reposing on 
them is found to be very largely composed of their soft debris. At one place about three miles west of the former yosition of Wood End Depôt, a scarped bank of the stream, about fifty feet in height, is seen to be entircly composed of drift; which is a yellowish sandy and gravelly deposit, hard enough to stand in perpendicular-faced banks, and in a general way much resembling that already described at Long River and elsewhere. The boulders are of Laurentian and Limestone, with a good many belonging to the Quartzite drift, and fragments of local sandstones. Many of the boulders and pebbles are polished flat, on one or more faces, and scored with glacial markings. Agates and fragments of silicified wood, though not actually observed imbeded in it, must also occur in the drift of this vicinity, as they are not unfrequently found in pebble beds formed from its re-arrangement. The agates were here found more abundantly than elsewhere, but were not in any locality observed in the parent rock, though they no doubt occur in some of the Tertiary or Cretaceous beds of the region. They do not usually show conspicuous banding, but are semi-transparent and of a pale yellow colour.

\section{Margin and Eastern Region of the Third Prairie Plateau to Wood Mountain.}

521. The localities so far described, may be considered as belonging to the second prairic steppe, and illustrating the nature of the drift of that level. Westward from this point, the country though belonging in the main to the third or highest prairic level, is much more dirersified, and to understand the arrangement of the deposits of the glacial period, it is necessary to bear in mind its general contour, of which an outline has already been given in treating of the watershed which runs through it to the Rocky Mountains ( $\$ 9$ et seq.)

522. One hundred and twenty miles west of Turtle Mountain, the recond prairie plateau comes to an end against the foot of the great belt of drift deposits, known as the Missouri Coteau. Beyond this point, three diverse zones of country cross the forty-ninth parallel in the order subjoined.

1. Tumultuously hilly country based on a great thickness of drift, and forming the Coteau de Missouri, properly so called.

2. Flat topped Watershed Plateau, formed of rocks of the Lignite Tertiary, and constituting a part of the First Transverse Watershed already described.

3. Lower broken down region south of the Plateau, partly based on the 
Lignite Tertiary, and characterized by gorges and large vallies draining toward the Missour:.

The second region can, perheip, scarcely be said to cross the Line, but appears immediately north of it. On the Line and southward, the streams flowing to the Missouri, rise near the southern edge of the first division, the greater part of the plateau having succumbed to denuding agencies.

523. The Missouri Coteau is one of the most important features of the Western Plains, and is certainly the most remarkable monument of the glacial period now existing there. Though frequently mentioned in western reports, I cannot learn that its structure has yet been carefully studied. I lave had the opportunity of examining more or less closely, that portion of it which crosses the forty-ninth parallel, for a length of over 100 miles.

524. Where cut somewhat obliquely by this parallel, the Coteau may be said to extend from the 290 , to the 335 mile point, a distance of fortyfive miles. At right angles to its general course, however, its extreme width at this point cannot be more than about thirty miles. On approaching it from the east, on the trail from Wood End, which as already stated, is somewhat more elevated than the prairie lying east of it, a gradual ascent is made, till the edge of the Coteau is reached; amounting in a distance of twenty-five miles, to about 150 feet. The country at the same time becomes more distinctly undulating-as on approaching Turtle Mountain from the east-till almost before one is aware of the change, the road is winding among a confusion of abruptly rounded, and tumultuous hills, which consist entirely of drift material, and in many cases seem to be formed almost altogether of boulders and gravel, the finer matter having been to a great extent washed down into the hollows. Where it appears, however, it is not unlike that of the drift of the lower prairies, being yellowish and sandy. Among the hills are basin-like vallies, round, or irregular in form, and without outlet; which are sometimes dry but generally hold swamps or small lakes, which have frequently been fillod in with material washed from the hills so as to become flatbottomed. The hills and vallies have in general no very determinate direction, but a slight tendency to arrangement in north and south lines was observable in some parts of this region. The hills culminate on the Line about the 305 mile point, and westward from this place, they are neither so steep nor so stoney. The country gradually subsides from its rough and broken character, to that of rather boldly undulating prairie, 
without howerer falling much in general eleration below the tops of the bolder hills further east. We have in fact passed up over the margin of the third great prairie steppe.

525. The whole of the Coteau belt is characterized by the absence of drainage valleys, and in consequence, its pools and lakes are very often charged with salts, of which those most abundantly represented are sodic and magnesic sulphates. The saline lakes very generally dry up completely toward the end of the summer, and present wide expanses of white efflorescent crystals, which contrast in colour with the crimson Salicornea, with which they are often fringed. The crystalline crust generally rests on a thick stratum of soft black mud.

526. The boulders and gravel of the Coteau were here observed to be chiefly of Laurentian origin, with however a good deal of the usual white limestone, and a slight admixture of Quartzite drift. On the western margin, some rather large disused stream vallies were seen, holding chains of saline lakes; but their relation to the drift materials of the Coteau were not so clearly shown as in other localities further north, to be described.

527. In passing westward, from the last exposures of the Tertiary rocks near Wood End, to the locality of their first appearance within the Coteau, a distance of about 70 miles; we rise about 600 feet, and attain an elevation of about 2,500 feet above the sea. The slope of the surface of the Lignite Tertiary then, assuring it to be uniform, is a little less than one hundred feet per mile; and on and against this gently inclined plane, the immense drift deposits of the Coteau hills are piled.

528. The general structure of the Coteau on the forty-ninth parallel, is illustrated in figure 1, Plate XIII. It agrees well with the section given by Dr. Hector, of the bor :er of the Coteau, on the Elbow of the South Saskatchewan.* but it is interesting to observe that, in that locality, the underlying slope is composed of Cretaceous strata; showing that the Coteau is not connected with any particular formation, but forms a border round the north-eastern edge of a gentle elevation, in which both Cretaceous and Tertiary rocks are involved, and which determines the watershed.

529. Passing westward for about seventy miles, it is found to preserve much the same appearance. The prairie of the Coteau foot, is rather undulating, and slightly raised above the general level, but the edge of 
the hilly comntry of the Coteau itself, is always from a distance well defined. To the northward and eastwated, boundless, level, treeless plains stretch to the horizon. The Traders' Road to Word Mountain, after passing along the base of the Cotean, for the distance above indicated, turns westward, and crosses it, taking alvantage of a deep hay in its edge, in which also rises a main tributary of the Souris River. The road then passes for about fifty miles through the Coteau belt, which must here he about thirty miles wide, and repeats almost exactly the physical features already described, though in this particular locality neither quite so tumultuous nor so stoney as on the Line.

530. Following the Traler's' Road westward, for about twenty-five miles, toward Wood Mountain, it pasises for the most part between the southern edge of the Coteau proper, and the northern margin of the Tertiary plateau. Wherever, from any hill, a view orer the Coteau to the north can be obtained, it is seen to stretch away to the horizon in a succession of wave-like mounds and ridges, which do not differ much in average altitude.

531. The intervening region, followed by the road on account of its facility, has characters of its own. Wide and deep vallies, often flat-bottomed, with systems of tributary coulées, are found ererywhere cut in the soft rocks of the foot of the Tertiary plateau. Some have small streams still flowing in them, fed by the drainage of the plateau; but for the most part these old vallies are dry or oceupied by chains of small saline lakes, the waters of many of which disappear early in the summer. The lakes usually have the long river-like forms of the vallies which contain them, and receive the waters of the brooks which still flow. One of the most important, probably nine miles in length, forms the drainage-basin for the streams of Wood Mountain ; its sides are abrupt, and the water appears to be deep. These old vallies are evidently of pre-glacial age, and have formed a part of the original sculpture of the country. The heaping up of the great drift deposits of the Coteau along the foot of the Tertiary plateau, has blocked them up, and prevented the drainage finding its way northward as lefore. Since the elevation snceeding the glacial subsidence, the rainfall of the district has never been sufficiently great in proportion to the evaporation, to enable the streams to cut through the harrier thus formed. The existence of these vallies, and the arrangement of the drift deposits in this region, have important barings on several problems connected with its general history, which will be again referred to, 


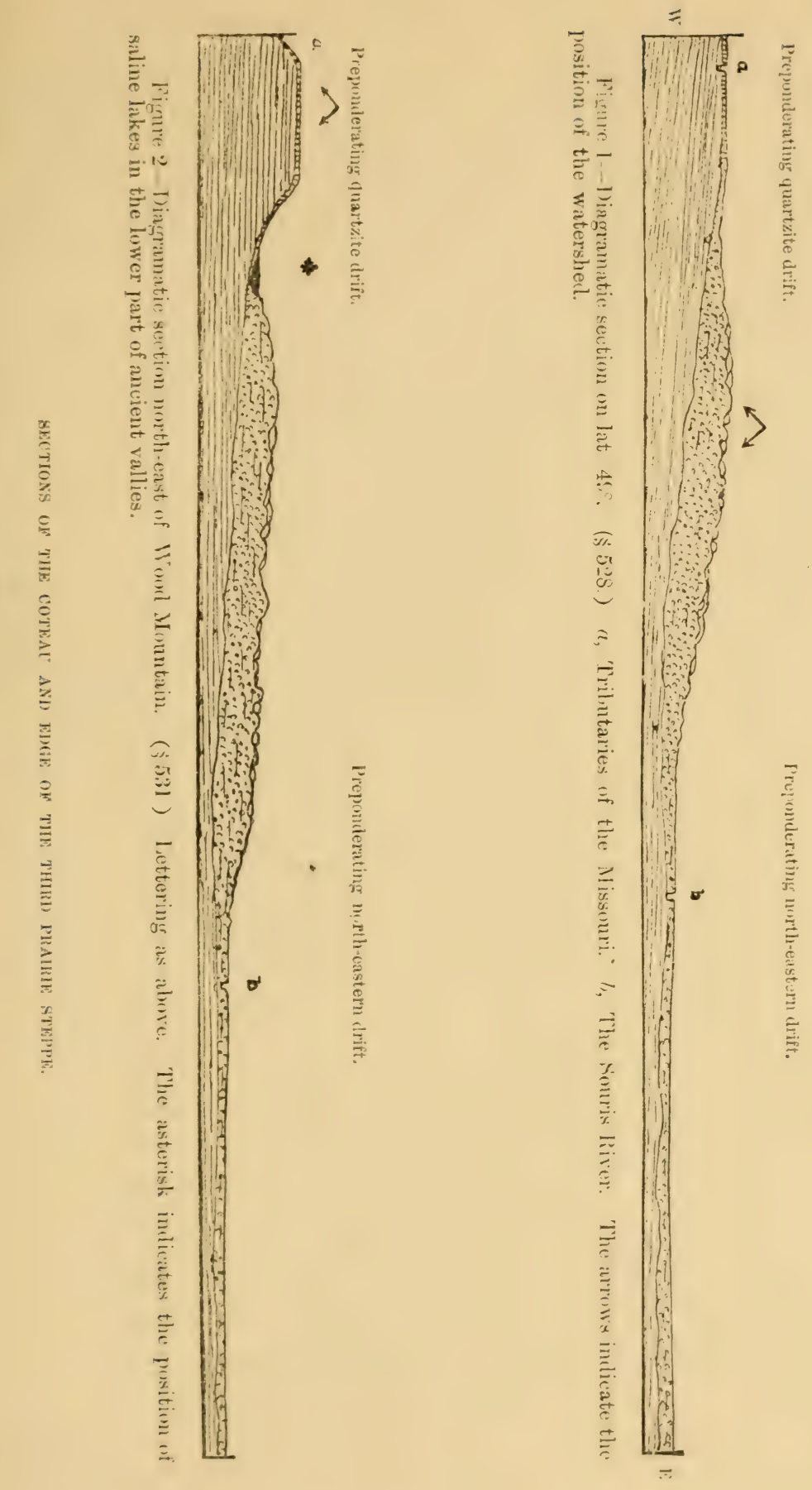



Figure 2. Plate XIII. illustrates diagramatically the structure of the Coteau, \&c., in localities north-east of Wood Mourıtain.

532. The Coteau itself, and the degraded norther'n edge of the Lignite plateau are equally characterized by the abundance of Laurentian and Limestone fragments, the drift being in fact chiefly composed of northern travelled matter. On ascending toward the summit of the plateau, howerer, the drift rapidly changes its character, the rocks previously abundant becoming comparatively scarce; and on reaching its upper surfice, it is found to be but scantily covered with drift deposits of any kind, and the material of these to belong to the Quartzite drift with but a very slight intermixture of Laurentian. South of the Tertiary plateau, and where it is broken down toward the tributaries of the Missouri, the country still remains but thinly covered with d.?ift. Fragments of Laurentian origin and Limestone are rare, and quartzite abundant.

533. The Quartzite drift, where typically developed, differ's not only in its composition, but in its appearance and mode of deposition, from that of north-eastern origin. The fragments composing it, while of rery resistent rocks, are not of great size, and rarely show any evident marks of glacial polishing or scratching. They are rounded and smooth, like beach pebbles, or shingle, and appear to have been for a long time subject to the action of the waves. They do not generally form thick deposits or banks, but are pretty uniformly spread, and often form a bed only a foot or eighteen inches in thickness, with little admixture of clayey matter, which rests on the eroded surface of the Lignite Tertiary leds, and intervenes between them and the soil. Sections in Porcupine, and Pyramid Creeks, and in the Great Valley, all showed a capping of this material, and the mole of its occurrence may be seen in some of those represented. The quartzites and similar rocks forming this drift, which are here classed together, are often very varied in appearance, though all agreeing in the preponderence of fragmental silica. In colour, the prerailing tints are yellowish and brownish, sometimes verging on red. In texture, rocks may be found from those of a compact jaspery appearance, to others in which the grains of sand are coarse, and still plainly distinguishable from each other. Fragments of silicified wood also oceur. 


\title{
CHAPTER X.
}

\section{GLACIAL PHENOMENA AND SUPERFICIAL DEPOSITS-(Continued.)}

\begin{abstract}
Marcin and Eastern Rkgion of the Third Plateau (Continued)--Drift deposits near Wood Mountain-Northern extension of the Coteau-Southern extension of the Coteau-General aspect of the Coteau-Methorls of accounting for the formation of the Coteau-Driti Deposits of The Third Plateau west of Wood Mountain-Boulder-clay of East Fork of Milk River, \&c.-Composition of the Drift near Milk River-The Three Buttes-Western limit of Laurentian drift-Glacial action in THE Rocky Mountains-Former glacier of Waterton Lake-Terraces in the mouth of the S. Kootanie PassOrigin of gold-Moraines and lakes-Cirques-General CoMposition of THE DRIYT-THE RED RIVER VALLEY - Its character and inclination-Alluvial deposits-Sections from borings at Winnipeg and Fargo--Yellow marl deposits - Connection of deposits of Red River Valley and Missouri Country-PREGLACIAL ASPECT OF THE CounTRY-Former southern flow of Red RiverFirst stage in depression-Correlation of levels of plateaus and terraces-Depth of submergence when greatest, and action at this time-Emergence of the continent-Difficulties met with in explaining the phenomena-POsT-GLACIAL Phenomena-Possible existence of a pluvial period-Great river valliesAlternative vallies-Valley of the Red River-The formation of coulees.
\end{abstract}

\section{Margin and Eastern Region of the Third Prairie Plateau to Wood Mountain (continued.)}

534. Following in the description of the drift deposits, as nearly as possible, the order pursued in systematically deseribing the older formations, it will next be necessary to consider the region westward of Wood Mountain, and between it and White Mud River. The three belts of country already defined, are here not so distinctly marked, as the watershed plateau turns north-westward, and does not maintain its elevation so uniformly as before. The third region, or that sheltered by the plateau, consequently shows a somewhat greater admixture of foreign matter, though the preponderance of the Quartzite drift is still remarkable, and the size of some of its component fragments is greater than in any locality previously observed. After passing the 425 mile point, it rests upon the surface of the clay-shales of No. 4 of the Cretaceons formation. The average elevation of the region above the sea is about 3,000 feet.

535. A numerieal exsmination of the pebbles of the drift, near the 450 mile point, gave the following ratios for its constituents :-

1. Quartzite drift, brownish, yellowish, purplish, and dark grey, and varying in texture as already described...........40 66

2. Granitic and gneissic rocks........................ $25 \cdot 83$

4. White limestone............................ 19.95 
5. Fragments of ironstone nodules (local).............. 4.60

6. Blackish and dark-green hornblendic and felspathic rocks, some of which might be called diorites ............ $3 \cdot 84$

7. Crystalline quartz....................... 1.53

8. Soft yellowish sandstone $($ local $\ldots \ldots \ldots \ldots \ldots \ldots \ldots \ldots \ldots$

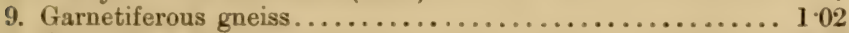

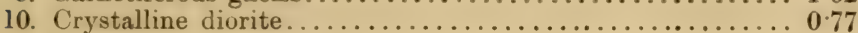

11. Chert ................................... 0.51

536. Part of the coarser quartzite of No.1, almost exactly resembles that described in the enumeration of pebbles on the Souris River. ( $\$ 514)$ Nos. 2, 7, and 9, are Laurentian; No. 6 is probably almost entirely Huronian. In this locality there are also a good many boulders of granite and gneiss of some size. A large limestone boulder, weathering pinkish white, but grey internally, was found to measure 10 by 6 by $2 \frac{1}{2}$ feet, neither the length nor thickness being fully exposed. Near here also, in some of the limestone erratics, specimens of a peculiar Stromatopora were found in some abundance. The Quartzite drift of this locality, is mingled with a greater proportion of eastern and northern debris, than that of the country more completely sheltered by the Tertiary plateau, further east, but is still well characterized.

537. North of the plateau, the increase of limestone and Laurentian rocks is very apparent. At a point about twenty-five miles west of Wood Mountain, near the junction of the Coteau deposits and northern slope of the plateau, an examination gave the following result:-

1. Limestone ...................................... 33

2. Granitic and gneissic rocks (prevalent tints reddish and

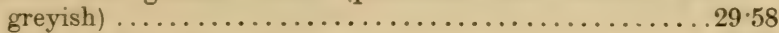

3. Quartzite drift................................ 24

4. Blackish and greyish altered rocks......................6. 6.99

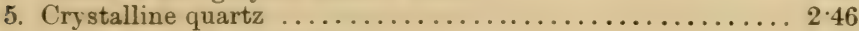

6. Chert (from the limestone) ....................... $2 \cdot 10$

7. Black hornblende rock and diorite.................. $1 \cdot 20$

538. Westward from Wood Mountain, the drift region of the Coteau trending northward, follows the base of the Lignite Tertiary plateau, and is not again seen in the vicinity of the Line. It would appear from Captain Palliser's map to run with a course about west-north-west to the Elbow of the South Saskatchewan, where, as already mentioned, it was met with by Dr. Hector. Here the edge of the Tertiary ceasing to be coincident with that of the third prairie steppe, appears to travel southwestward, while the edge of the third steppe is continued northward, by an escarpment which, according to Dr. Hector, is of Cretaceous rocks; and appears to be closely followed by the bordering drift region of the Coteau as before. The Coteau deposit, would even seem to extend to the latitude of the Thickwood.Hills, north of the North Saskatchewan, as Dr. 
Ifector says of them, that their whole eastern slope, with its broken country is "strewn with boulders, and worn into conical knolls and deep pot holes," forcibly reminding him of the country where the south Saskatchewan intersects the Coteau des Prairies;* and again on a foliowing page-" The abrupt slope, facing to the east, follows a curved line to the north-west, and is everywhere strewn with boulders, principally of primitive rocks, and angular masses of chert and magnesian limestone."

539. The edge of the third prairie platean is, however, toward the north, less definite than southward, and is broken up into separate systems of flat-topped hills; and the arrangement of the drift deposits no doubt partakes of the same irregularity. I camnot but believe, however, that the deep vallies, without outlet, which seem to have perplexed Dr. Hector in this region, are explicable in the same way as those found within the Coteau near Wood Mountain, and that there also great deposits of drift material have been piled on old surfaces seamed with pre-glacial vallies. Of these Dr. Hector writes-with special reference to certain instances in the Ear Hills, south of Battle River:- " The surfaces of the higher plains are in some localities traversed by profound rents, resembling the vallies of great rivers, but which, after running for some niles, are generally found to be closed at both ends. They are often occupied by deep lakes of salt water, depressed 200 to 300 feet below the plain, and from 500 yards to a mile in width." $\dagger$

540. The frequent occurrence of saline lakes, in the rugged district of the edge of the highest prairie steppe, is also mentioned; and their position, generally at the same altitude, and along a well-marked old coast line, leads Dr. Hector to attribute their salinity to the remains of the salts of the sea itself. To me it would appear more probable, both from the composition of the salts, and the fact that similar saline waters were frequently found issuing from the rocks-especially those of Cretaceous No. 4-that they primarally owe their salinity to chemical action proceeding : :mong the little consolidated beds of the Tertiary or Cretaceous; and its persistence to the want of drainage vallies. Be this as it may, they are totally distinct in character and origin from the salt springs of Lake Manitolsa. and the Red River Valley to the east.

541. South of the forty-ninth paraliel, the continuation of this belt of drift material can also be traced. It runs south-eastward, characteriaing the high ground between the tributaries of the Missouri and the 
Red River, but wanting the backing of the Lignite Tertiary plateau, it appears to become more diffuse, and spreads more widely over the country. The drift deposits do not form the high ground, but are merely piled upon it; and it seems to be based at no very great depth on a nucleus of hard palceozoic rocks, over which the Cretaceous is generally thinly spreal, but which appear at the celebrated Pipe Stone Quarry and elsewhere. From what I can learn, it would appear that the so-called Coteau de Prairies and Cotean de Missouri, between which a distinction is often here made, are parts of the same great feature. Their elevation is similar, and nearly the same as that of the Coteau on the Line, and they are equally characterized by the immense profusion of erratics, with which they are strewn, and by basin-like swamps and lakes.

5+2. The following description of the Coteau south of the Line, by Prof. Thomas, is the best I have been able to find for that.region, and will be raluable as a term of comparison. "The surface of the country between the valley of the Ped River on the east, and Missouri River on the west, may be describerl, in general terms, as consisting of high, rolling prairies, intersected by the rallies of a few streams which run south. But this general contour is interrupted ly two elevated plateaus, which stand high above the general level, as monuments reared by the rast aquatic forces of the past, as if to give us some idea of their stupendous prower. The smaller of these elevated plains, the Coteau des Prairies, extends from a point about forty miles west of the north end of Lake Traverse, latitude $46^{\circ}$, longitude $97^{\circ} 30^{\prime}$, southward, expancling and somewhat dividing towards its southern extremity. The western arm of this southern extension encroaches close upon James River Valley, about latitude $44^{\circ} 15^{\prime}$, where it ends; the other arm reaches south-east, passing down on the east side of the head waters of Big Sioux, and graduaily fades out in the southwest ('orner of Minnesota. The elevation of its surface arerages nearly 2,000 feet above the level of the sea, varying from 1.860 feet, to 2,040 feet, showing a rise above the plains east of it of about $800^{\circ}$ feet, and above the valley wrst of it of 700 feet. The other platean is the Coteau of the Missouri. This hugs the valley, and follows the course of the Missouri, northward from Fort Sully to the great bend of the river near the mouth of the Yellowstone. Here it it recerles, and extends in a northwest direction into British Possessions, where it gradually fades out and is lo-t (?). It varies in width from thirty to fifty miles, and in height from 1800 to 2000 feet above the sea; but the surface is more irre- 
gular than that of the other Cotean, portions of it rising as much as 200 feet above the general average. The general elevation corresponds very closely with that of the Coteau des Prairies, showing very clearly some relation between the origin of the two. On each are numerous small lakes, mostly impregnated more or less with saline matter, and at many points on each boulders are quite plenty."*

543. Dr. Hayden, treating of the same region, writes: "North of the Missouri River, from the Big Sioux River to Fort Clarke, there are districts where one might walk for miles across the plains, and over the hills without stepping upon the ground, so closely paved is it with worn or partially-worn boulders." $\dagger$ Prof. Winchell describes the extreme south-eastern part of the Coteau, near Lake Traverse, as characterized in a similar way, by the abundance of erratics, which, though some limestone boulders occur, are chiefly of granite. $\ddagger$ Minne Wakan, or Devil's Lake, in the watershed region of northern Dakota, may be but a larger example of the kind of lakes characteristic of the Cotean. Its waters are saline, and its shores appear to be fringed with innumerable boulders of great size.

544. In the Missouri Coteau, we find a natural feature of the first magnitude. A mass of glacial debris and travelled blocks, with an average breadth of, perhaps, thirty to forty miles, extending diagonally across the central region of the continent, with a length of about eight hundred miles. It would appear to go far toward satisfying the requirements of the thenry which accounts for the glaciation of northern America and Europe, by the southward progress of a great polar ice-cap. It may be supposed that a projection of this great ice-sheet, filled the whole northern part of the interior of the continent, from the high ground at the foot of the Rocky Mountains on the west, to that of the Laurentian plateau to the east. It would be supplied by ice generated in the polar regions, and fed also by that of the Rocky Mountains and Laurentian axis at its sides, and may be supposed to have passed southward, impressing on the country all the features which now characterize it, and especially excavating the basins of the great series of lakes which lie along the western base of the Laurentian. Hemmed in on the west by the higher ground of the watershed, it may be supposed to have been forced eastward, and leaving the Coteau as a gigantic lateral moraine, to have sent a tongue far southward in Dakota and Minnesota 
over the low country of the Red River Valley. By such a series of suppositions, nearly all the observed phenomena may be accounted for; while it is easy to attribute the uniformity of the plains, to the action of such a glacial sheet planing its surface; but an almost infinite amount of force, acting from behind, must be among the first of the assumptions; a force capable of moving the supposed great ice-mantle across the northern transverse watershed, down into the valley of the Saskatchewan, lying athwart its course, and then for hundreds of miles up the northeastward slope of the plains.

545. The main facts to be accounted for are these:-A plateau in continuation of the high land stretching eastward from the mountains; thinly covered with drift material of the nature of shingle, in which quartzite fragments from the slopes of the Rocky Mountains greatly preponderate.

A lower region to the southward, also characterized by quartzite drift, in which, when most perfectly sheltered from the north, northern and eastern drift, rarely occurs; but appears to increase in abundance in exact proportion to the deficiency of the northern barrier.

A second lower region to the north, thickly covered with glaciated northern and eastern debris, with comparatively little intermixture of western material, and heaped up especially on the font of the plateau before mentioned.

546. From a careful examination of the Coteau and its surroundings in the vicinity of the Boundary-line, I have been lead to the opinion that not glacier-ice as such, but sea borne icebergs only, can account for the phenomena there presented. From the great similarity of the natureof the Coteau in all parts of its length, and its essential unity, it would seem that the nature of the origin of any one part must be that of the whole. Without therefore at the present time entering at any length into the general question of glaciation, it may be well to attempt to account as far as possible for this its greatest record on the plains.

547. It will be shown subsequently, that a depression of the continent amounting to at least 4,000 feet, as marked in the Rocky Mountain region, has taken place in post-tertiary times, and during the subsidence and emergence preceding and following the period of greatest depression, it would seem that most of the features of the later deposits of the plains were produced. To account for the Coteau deposit, it must be supposed that from some cause the level of greatest deposition of drift material, for some time coincided with its general altitude; but whether this line was 
one at which the causes producing the drift dejosit acted for a very long period, or whether its accumulation marks a stage of depression at which the Iaturentian axis, and its flanking Silurian rocks were most favorably situated for degradation, are gencral questions best discussed in the sequel. The Cotean belt is not exactly a shore deposit, and its position during the period of greatest subsidence must have been deeply submerged, though this may have been for a comparatively short time.

548. Here on the foot of the Tertiary plateau, from the North Saskatchewan to the Line, heary ice from the north and east must have grounded, bearing material from the Laurentian hills, a distance of at least four huncled miles; while at the same time from the north-west or, perhaps, even from the south-west, came lighter ice bearing debris from the glacier's and coast line of the Rocky Mountains, and moving probably under the influence of superficial currents, or prevailing winds. The material from the latter source, must either have been originally shore gravel, or have lain for a long time subject to the action of the waves on the shallow surface of the plateau, and been there impressed with the character of shingle-a character not assumed by the debris of the Coteau. It is worthy of remark in this connection that while fragments of siliceous rocks from the Rocky Mountains, which are mingled with the Laurentian matter of the lower levels, frequently retain marks of severe glaciation, those of the summit of the platean and higher levels, rarely show traces of it. South-westward of the Boundary-line, the Tertiary plateau being in most places absent, and the general surface of the country lower, it would seem that the Coteau region is broader and more scattered, and that much of the northern ice may have passed over it southward. There is nothing to show that the siliceous drift is in any sense confined to the higher levels. It appear's most abundantly there, and decreases eastward, but in many western localities where the northern drift preponderates, as great a quantity of the western material may exist as in the thin covering of the plateau; but it loses its prominence, from its insigniticance relatively to the north-eastern material. The total quantity of drift, area for area, on the third as compared with the second steppe, is probably not over one twentieth. It would appear from their mingling, that the two deposits if not exactly contemporaneous, are very nearly so. 
Drift Denosits of the Third Prairie Plateau West of Wood Mountain.

549 . On the western side of White Mud River, is a region of gentle hills somewhat elevated above the prairie to the west of it, and which ten miles north of the Line, is about ten miles in width. From the contour of the surface it would seem that this is in great part caused by an accumulation of drift, though it may also be connected with the occurrence of outlyers of Cretaceous No. 5. From the 505 to the 535 mile points, an outlying portion of the Tertiary platean extends, and runs north-westward to an unknown distance. Its eastern edge is somewhat cut up by old disused vallies, in one of which a large saline lake occurs. These may be of pre-glacial age. The western firont is comparatively little broken by vallies, and is abrupt and escarpment-like. No sections or features of interest in connection with the drift were observed, though some parts of the region show many boulders of mixed origin.

550. Westrard, a flat, arid plain stretches to the East Fork of Milk River. It is very stoney in many places, and an examination of the constituents of the drift near the 540 mile point gave the following result:-

1. Quartzite drift .......................... 57 14

2. Granitic and gneissic rocks....................... 23.07

3. Limestone, some of it resembling that of the Rocky Mountains $\ldots \ldots \ldots \ldots \ldots \ldots \ldots \ldots \ldots \ldots \ldots \ldots \ldots \ldots \ldots \ldots \ldots, 15.02$

4. Crystalline quartz........................ 1.83

5. Soft sandstone (local) ........................... 1.09

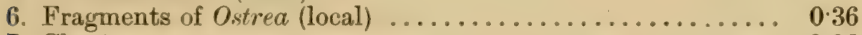

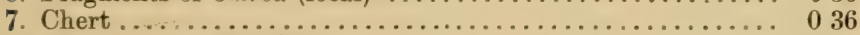

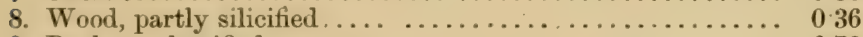

9. Rocks unclassified ............................ 0.73

551. In the valley of a stream near the $\mathbf{5 4 7}$ mile point, good sections of the drift appear. The material is a rather hard arenaceous clay, of a general brownish-grey colour, and some appearance of rough stratification. It shows stones of all sorts irregularly imbedded in it, many of them very evidently glaciated; and also contains specimens of a Cretaceous or Tertiary fossil Ostrea, crystals of selenite, and small angular fragments of a material more resembling true coal than lignite.

552. The surface of the country; before reaching East Fork of Milk River, again rises somewhat, and is very thickly strewn with erratics, which show a mixture of northern and western drift. In the valley of East Fork, though there are no sections of the Cretaceous or Tertiary, very interesting exposures of true boulder-clay, resembling that last described, are found. The banks in some places, where the stream has cut away their base, are nearly vertical, and about forty feet in height. (Plate XII., Fig. 1.) The material is a very hard sandy clay, varying in 
colour from yellowish to dull bluish-grey, and with rusty cracks traversing it in many directions. It is usually so homogeneous, that on weathering it assumes vertical forms, and a rudely columna: appearance. It seems to have been moved, and to some extent stirred together after its deposition, and contains miny glaciated stones and small boulders scattered irregularly through it, and resting in all positions. In some places, however, current structure and false bedding are very apparent. The included fragments are of the usual metamorphic rocks, and Quartzite drift, with some white limestone, and iionstone nodules, selenite, fossil Ostreas and Cephalopods from the Cretaceous. Lignite and coaly lignite, like that already described, are not uncommon. The appearance is that of very heary ice action, and it would seem that a great part of the material has been derived from the underlying clays of Cretaceous No. 4, which have been poached up, without having been far removed, and mingled with travelled erratics.

553. The valley of the West Fork of Milk River, shows some sections of similar clay. An examination of the superficial drift of this vicinity gave the following numerical result:-

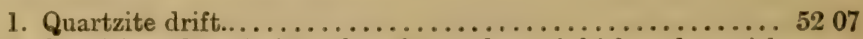

2 Granitic and gneissic rocks, of prevalent pinkish and greyish

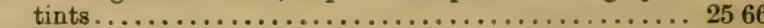

3. Limestone ............................. 717

4. Soft sandstone, clay-shale, \&c., (local).............. 566

5. Crystalline quartz......................... $3 \cdot 77$

6. Chert.................................. 2.64

7. Ironstone, (local).............................. 1.88

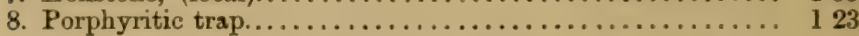

554. The colours of the quartzite pebbles of No. 1, are generally yellowish, brownish and whitish, but among them have been included a few fragments of greenish slaty rocks, and many apparently intermediate between this and quartzite, but not clearly referable to either. The whole have therefore been placed under one heading, as probably derived from the mountains, though some-especially of the slaty samples-may be Huronian. Among the limestone pebbles also, are one or two which resembled those of the mountains. It is interesting to find here a few specimens of the trappean rock of the nucleus of the Buttes, which are situated sixty miles due west. A fragment of an Ostrea was also found though not enumerated.

555. No instructive sections of the drift were met with in the vicinity of Milk River. The surfare of the plain is strewn with boulders in many places, but the drift deposits do not appear to be thick. Near the 610 mile point, the plaun has a general elevation of about 3,600 feet. An 
examination of the superficial drift at this place gave the following result :-

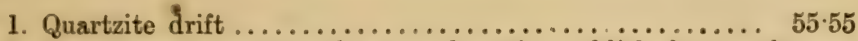

2. Granitic and gnessic rocks, prevalent tint reddish, but much

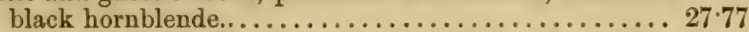

3. Limestone, one fragment at least from the Rocky Mountains 6.11

4. Crystalline quartz........................ 3.87

5. Hard altered clay-rocks, yellowish, greenish-grey and

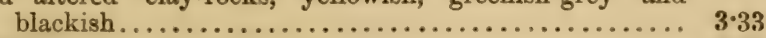

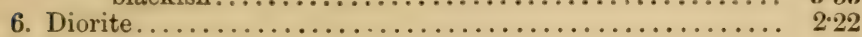

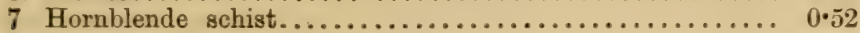

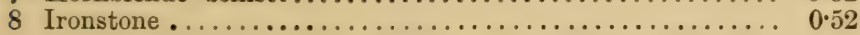

An analysis by colour of the components of the Quartzite drift was also here attempted, and with the following result:-

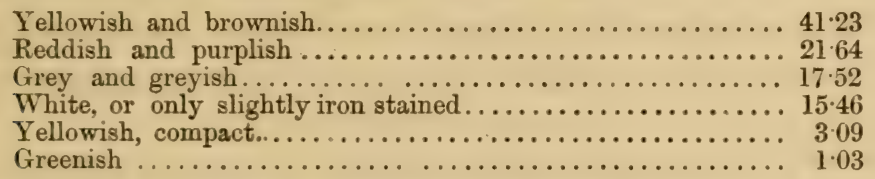

The yellowish and brownish specimens are as a rule very compact, though some are of coarse, granular quartzite. In the purplish and reddish series, coarse-grained and compact varieties are about equally divided, and sereral of the greyish, are quite coarse-grained, the constituent particles being of different coloured rocks.

556. The Three Buttes, or Sweet Grass Hills, already briefly described in treating of their structure, yielded but few traces of action during the glacial period. Aware of the importance of these isolated mountains, I searched carefully for any glacial markings upon them, but the shattered nature of the hard rocks of their summits, and the softness of the strata flanking thein, has prevented the preservation of such striation, if it originally existed. The terraced aspect of the foot-hills, though at first attributed to marine action; was afterwards found to be mainly, if not entirely, due to the arrangement of the subjacent rocks. The boulders of their immediate neighbourhood are frequently composed of the trappean rock of the summits, mingled largely with Laurentian and Quartzite erratics. A stream, flowing from the West Butte, at the foot of the steep slope of the mountain, has cut through a considerable thickness of rough, mostly angular, though not evidently glaciated stones, with which its valley had been filled. Of these the greater part were local and trappean,but some of foreign origin. Laurentian and Quartzite erratics are found in abundance to a height of over 4,000 feet.

557. The main stream of trappean fragments, which, in whatever 
way the glaciation of the plains is accounted for, must be supposed to have flowed away from the Buttes, cannot have taken a direct easterly or westerly course, as specimens of the rock are scarce in both these directions. Nor does there appear to be any considerable accumulation of debris immediately north of the Buttes; and a southerly course, for the drift in this region, would seem to be inclicated.

558. The First Branch of Milk River, where it crosses the Line, flows in a moderately wide valley with banks forty to fifty feet high. These show good sections of boulder-clay, which almost exactly resembles that described in the East Fork, 140 miles eastward. It is, perhaps, however, of a paler tint, and rather yellowish in colour. It includes graciated stones, and shows here and there traces of stratification; and as before, tends on weathering to break into upright columnar fragmerits, which give the cliffs a peculiar appearance. Pale green, slaty pebbles were noted here in some abundance for the first time.

559. The superficial drift examined in a favourable locality, six miles west of this place, gave the following percentage ratios:-

1. Quartzite drift...........................4257

2. Granitic and gneissic rocks, chiefly pinkish and blackish... 22.27

3 Slates and altered clay-rocks, pale greenish, and greyish.... 18:31

4. Limestone, some evidently from the mountains, but the majority of fragments resembling that of the Red River country ............................ 6.43

5. Soft sandstone and clay-shale (local) ............ 4.45

6. Diorite ................................... 2.47

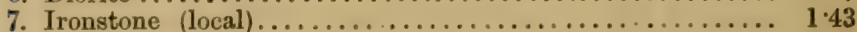

8. Fragments of Ostrea (local) .................. 0.99

9. Crystalline quartz $\ldots \ldots \ldots \ldots \ldots \ldots \ldots \ldots \ldots \ldots . \ldots . . \ldots . . \ldots 9$

560. Nos. 1 and 3 are, no doubt, identical in origin, and in considering the derivation of the material should he treated of together. The most striking feature in this collection is the remarkable abundance of the softer rocks, which though associated with the quartzites in the mountains, have not previously been observed to accompany them on the plains in any quantity. A portion of No. 4 is also from the mountains, but it is almost impossible to draw distinctions in all cases between the limestones of eastern and northern, and those of western origin. They have therefore been classed together.

561. Near the Second Branch of Milk River, the plains have an average elevation of somewhat over 4.000 feet, and lie about thirty miles from the nearest spurs of the Rocky Mountains. The drift, while chiefly from the mountains, contains boulders of Laurentian origin, and apluarently also a few of the eastern white limestones. Fifteen miles 
further west, in the neighbourhoor of the St. Mary River, at ahout the same elevation, Laurentian fragments were observer in certain places in some abundance, but were lost sight of beyond this point. The distance of these travelled blocks from the nearest part of the Laurentian axis is over 700 miles.

562. We have here then, as closely as it can be defined in this latitude, the most western, and highest limit of the Laurentian drift, but not necessarily that attained by the waters when at their highest stage during the glacial submergence. Terraces, clearly implying a sea margin, are, indeed, found higher on the flanks of the mountains. A depression of the eastern region to an extent of 3,000 feet, would more than suffice to cover the Laurentian axis, as it is at present, and though in pre-glacial times its height was greater, it must have stood, at this stage of subsidence, scarcely, if at all, above the level of the sea.

\section{Glacial Action in the Rocky Mountains.}

563. In the part of the Rocky Mountains crossed by the Boundaryline, the effects of glacial action are very frequently apparent, though no glaciers, properly so-called, now exist. The streams flowing from the mountains, cut through banks of well-rounded gravel, and small boulders, similar in general character to that which has been called Quartzite drift. The stones were not observed to be glaciated.

564. Waterton, or Chief Mountain Lake, occupies a deep valley with exceedingly steep and precipitous sides, which opens northward. Its height above the sea is 4,213 feet, and it is about ten miles in length, and fills the valley from side to side, with an average width of about threefourths of a mile. Near its northern end, is a collection of rounded and hummocky hills, which are evidently composed of moraine matter, and show rocky fragments of all shapes and sizes; where these are not concealed by softer material, or the luxuriant vegetation of the region. The hand limestone of series B., where it crosses Waterton Lake, though not observed to show glacial markings, has the general rounded outlines produced by ice action. There is thus evidence that a great glacier pushed northward down the ralley of the lake, and deboucherl upon the plain, being fer, no doubt, from the numerous smaller transterse ravines which enter it.

565. Without going into detail in every case, it may be stated, that in all probability every valley of importance was in like manner ocenpied by streams of moring ice; and to their moraines much of the contour of 
the immediate foothills of the mountains is due. The brook issuing eastward from the mouth of the South Kootanie Pass, has cut through a great thickness of clean gravel drift, composed of large and uniform, well rounded pebbles, of which the general tint, as viewed from a distance, is pale purple. Above the bed of the brook, on the flanks of the mountains, on the south side, are some well preserved terraces. In one place these were obserred to have suftered an apparent dislocation, the top of each terrace on one side, corresponding in eleration with the middle of the slope of that on the opposite side; the two systems being separated only, by a straight narrow water-furrow down the mountain side. The arrangement altogether was highly suggestive of faulting on a small scale, since the formation of the terraces; an explanation rendered the more probable from the fact, that terraces on the west side of the mountains discribed by Dr. Hector, seem also to have been affected by very recent movements.* The highest of these terraces in the Kootanie Pass, though its altitude was not actually measured, was estimated from that of the pass, to be about 4,400 feet above the level of the sea, and above this no reliable sea-mark was found. From the position of the terraces in the open eastern throat of the pass, from which the ground falls rapidly away, it would appear that they cannot have been formed by any smaller sheet of water; nor would the nature of the locality allow me to explain their formation on any hypothesis of a former moraine blocking up the valley.

566. The material of the drift, westward from a line which may be drawn near the valley of the St. Mary River, appears to be composed altogether of the debris of the mountains of this immediate vicinity; nor were any fragments seen which could not with great proprietr be assigned to one or other of the beds observed in place. The gold, which is known to exist in small quantity, in almost all the streams which have been prospected for it, can therefore hardly have other origin than that of the drift, of which it appears to form a part. Though no metaliferous veins were observed in this part of the mountains, they are found southward in Montana, and may exist also here, but if so nothing was observed which would lead to the belief that they were either rich or numerous.

567. About four miles westward from the West Fork, in the valley of the Kootanie Pass, well preserved glacial strie were found, on a surface of hard green slate. Their direction was S. $40^{\circ} \mathrm{W}$. (mag.) or coineident with that of the main trough of the valley. This is the only locality in

* Exploration of British North America, p. 317. 
which glacial striation was actually observed, the surfaces of the rocks having generally been too much broken up for their preservation. Near here also, some large gravel terraces remain on the mountain sides, and in one place the brook has cut through a mass of tough boulder-clay of a light fawn colour.

568. Four miles up the valley, on the western side of the watershed which runs south-eastward from the Forks, it is blocked by a series of very evident and perfect moraine mounds, traces of which extend for nearly a mile. Those lowest down the valley, have been much modified by water, and are merely steep rounded and irregular knolls; while those last left by the glacier, still retain their abrupt ridge-like form, and are conrex downward. Where a small lateral valley joins the main one, a straight-edged ridge has been produced by the interference of its glacier, after the retreat of the larger one. The moraine has, no loubt, at one time held in a lake, similar tọ those now existing in many of the vallies, but has long ago been cut throrigh by the stream. The highest portion of the moraine is situated about five miles below the head of the valley, and no intermediate ridges were observed. Here, and elsewhere, there are indications of the rather sudden conclusion of the period of cold, and retreat of the glaciers.

569. The upper ends of the valleys, surrounding the higher peaks and ridges, are generally very abrupt, and take the form of cirques, or amphitheatrical depressions, of great depth, in the mountain sides. The backs and sides of these are often nearly vertical, and they are sometimes only separated laterally, by steep knife-edge-like ridges, the crests of which form the most practicable paths to the summits. Each of these upper terminations of the valleys, generally also shows a smat lake, or pond, in the hollow of the surrounding clift's; the basin of which has eridently been formed by glacier ice-which must here have been descending almost vertically - in the moraine matter or shattered rocky floor. Further down some of the ralleys, long river-like lakes are seen, evidently occupying the beds of old glaciers, but whether held in by moraine matter or not, I was unable to determine. The water of the smaller lakes in the upper ends of the valleys, as seen from the heights around, is of a beautiful semi-opalescent indigo-blue, and must be of considerable depth. The lakes are supplied in part by the great banks of perennial snow, which appear in these sheltered hollows. The snow though not of the consistency of ice, is firm enough to be walked over with ease, and has, no doubt, kept up the direct succession, from the 
time when great nevées filled the heads of the valleys, and the mountains around them were completely snow-clad; and are waiting only some change in the climatic conditions, to advance again down the lines of the old valleys, and occupy the places they formerly filled.

\section{General Composition of the Drift.}

570. In the subjoined table, the results of the numerical analyses of the drift, have been rearranged more broadly; that a general idea of its composition may be arrived at. All clearly Laurentian material is clasied under that name. In the limestone column, chert plainly derived from the same beds, has been included. It being impossible in all cases to separate the mountain drift from the Huronian, I have distinguished those figures in which any uncertainty of this kind may exist. It is probable also that a small proportion of Huronian, the fragments of which have been included in the now preponderent Quartzite drift, runs on even as far as the Laurentian is found. The results here arranged, are founded on the travelled drift only, all local samples having been thrown out. The great mass too, of the lower and undisturbed drift, composed of soft matter mostly of local origin is, of course, here quite unrepresented; as not throwing any light on the direction of travel. Crystalline quartz, diorite, \&c., though appearing in the calculation, are not represented in the table, as their origin is more or less uncertain.

571. The limestone is all included in a single column, and has been almost altogether derived from the eastern limestone beds, though from No. 7 , onward, fragments clearly referable to the mountains begin to appear, and in some of the more western localities, material of the latter kind may amount to even fifty per cent. of the whole. The small quantity of limestone from the mountains compared with other rocks of this origin in the drift, except immediately on their flanks, is remarkable. The limestone beds, though forming so prominent a feature in the mountains, are, however, chiefly developed in the higher regions; and it may be that the action of the wares was chiefly directed on the rocks of Series C., the general character of which closely resembles that of the quartzite drift, and which forms the lower and outer ranges. The eastern limestone, though from the same direction as the Laurentian debris, which appear's at nearly the same percentage throughout; in constrast to it, runs out very rapidly toward the upper levels, a fact to be accounted for by its lower position on the flanks of the Laurentian highlands, and consequent rapid submergence below the line of efficient action of the ice. The constant per- 
GLACIAL PHENOMENA AND SCPERFICIAL DEPOSITS.

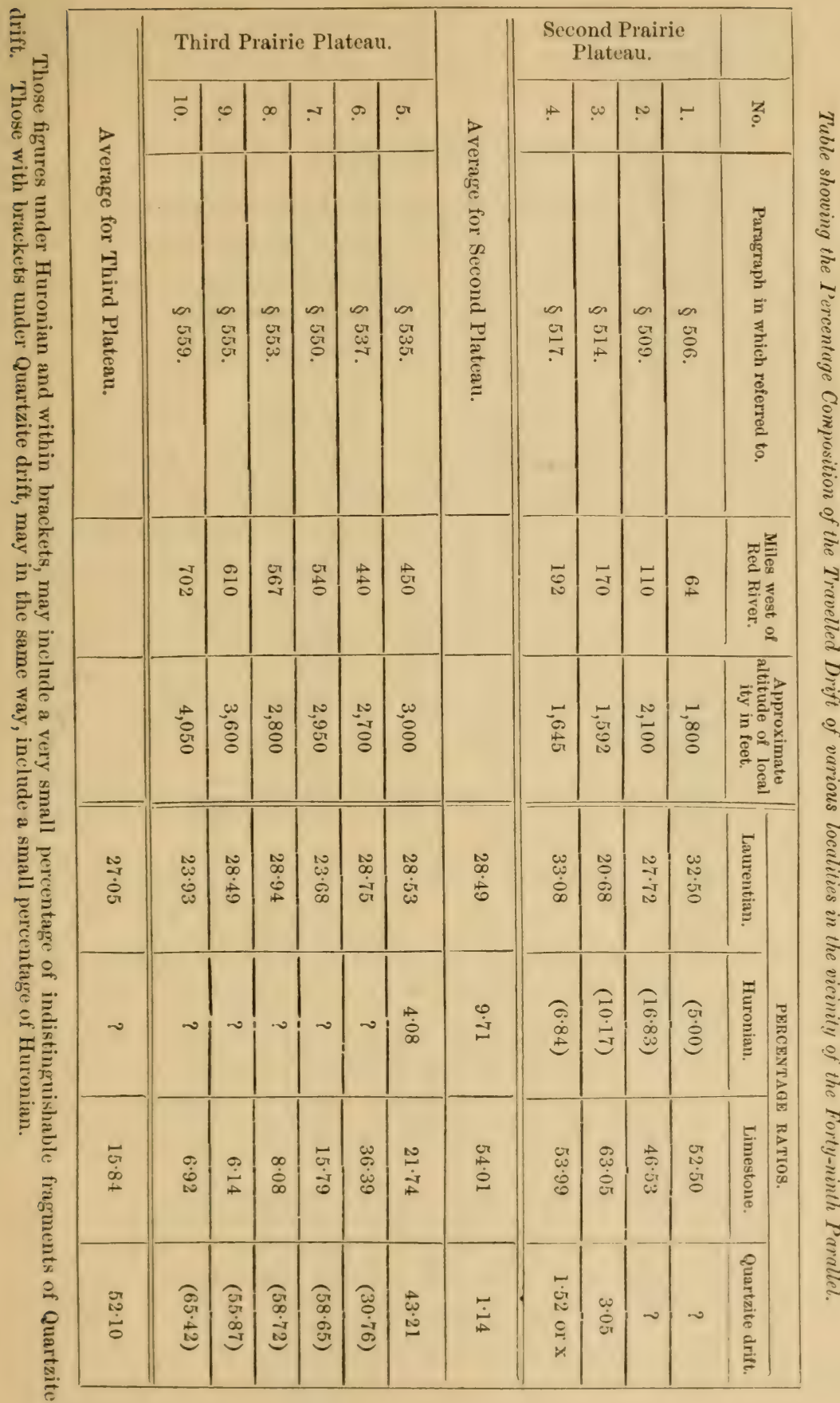


centige of Laurentian, must not be supposed to show that erratics of that origin are equally frequent orer the second and third steppes, for the total quantity of drift on the latter is comparatively small.

\section{The Red River Valley.}

572. The valley of the Red River, is a continuation of the trough, in the northern part of which Lakes Winnipeg, Winnipegosis, and Manitoba lie. On the east, it is bounded by the plateau of drift materials, already described, which stretches southward from the Laurentian region. On the west, the nearly straight line of the Cretaceous escarpment, with the terraced front of Pembina Mountain form its limit. The part of this valley lying north of the Boundary-line, and between it and the southern shore of Lake Winnipeg, is ninety miles in length; while from the Line southward to Traverse Lake, it is 225 miles, giving a total length of 315 miles. On the forty-ninth parallel, its width is forty-six miles, and for a

- long way south of the Line, it preserves an average breadth of about thirty miles, though finally narrowing near Traverse Lake. The general course of the valley is exactly north and south, to which the river conforms, but not very precisely; for at Grand Forks, seventy miles south of the Line, the Red Lake River-a stream of magnitude, equal to, or greater than, the southern branch which continues to bear the name of Red River-comes in at right angles without producing any corresponding bifurcation or change in the valley. The valley appears to have been adopted by the river, not formed by it.

573. The slope of the valley northward from the Line, probably does not exceed six inches in the mile. From Morehead in Minnesota, 150 miles south of the Line; the average fall of the river is a little less than one foot per mile, by railway levels, and that of the valley must be even less. The inclination of the sides of the ralley, east and west of the central depression, probably seldom exceeds ten or twelve feet in the mile, and frequently falls much below this. Its general aspect is that of a perfectly lerel plain, bounded only by the horizon, or by a belt of trees fringing some stream.

574. The whole of this valley, has at a time geologically recent, been occupied by a great lake, with the fine silty deposit of which, it is now floored. The alluvial deposit is uniform and of great depth. I have never observed any organic remains in it, but leaves and fragments of wood appear to have been found in some places. The lake must have been a firesh-water one, but the remains of molluscs are not found. The 

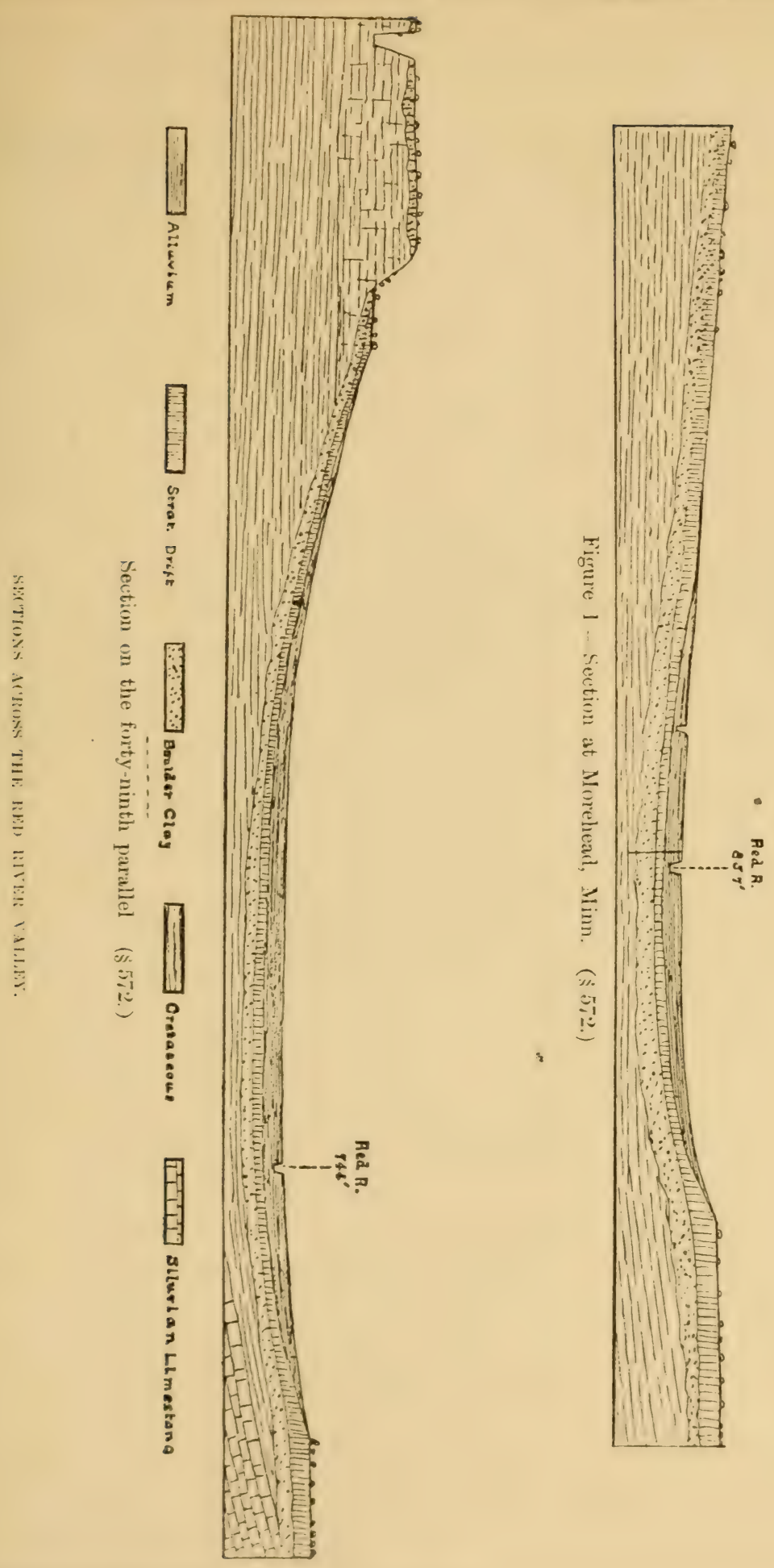

lower layers of the deposit, are as a rule the finest and most uniformly stratified. Those near the surface, though rarely showing any material so coarse as to be called sand, sometimes take the form of moderately coarse arenaceous clay. A portion of these upper layers may have been formed by the overflow of the river itself, after the recession of the lake. Pebbles or boulders of any kind are exceedingly rare, and where seen were projecting above the surface of the soil. The total number observed in all my excursions in this valley, might almost be counted on the hand. They are usually of Laurentian origin, though one or two of limestone were met with.

575. The depth of the alluvial deposit near the forty-ninth parallel, has not been ascertained, it is, however, certainly greater than the depth of the immediate valley of the river, where a section of from thirty-five to forty feet is exposed. Some of the lower and finer beds are often, twisted and bent, though not showing any evidence of false bedding. This I can only attribute to the action of floating ice-cakes in the former lake. Small flattened nodules are occasionally found forming horizontal lines in the deposit. Though deep and very uniform in the centre of the valley, the alluvium does not maintain the same homogeniety on approaching the sides, and these appear to have been occupied by banks and shoals of rather coarser materials. Several miles before reaching the base of Pembina Mountain, on the West, the subsoil is found to contain small rolled pebbles, of which the greater part are derived from the clay-shales of the Pembina Mountain group. Nine miles from the base of the mountain, a well, dug eight feet deep, passed for that depth through very fine, clean, silicious sand. Occasional thin layers holding coarser particles occur even in the centre of the valley. One which was called a "sand," when the argillaceous matter was washed away, was found to consist of very minute rounded fragments of the Cretaceous clay-shales above mentioned.

576. The typical deposit, however, where I have examined it, in the vicinity of Red River, is a fine yellowish marly and arenaceous clay, holding a good deal of calcareous matter, and effervescing freely with an acid. Under the microscope the coarser siliceous particles, in their average size, vary from 0.002 to 0.001 of an inch in diameter, and there is much formless argillaceous matter.

From the occurrence of recognisable fragments of Cretaceous No. 4 in many places, it is probable that rocks of the Cretaceous series may have contributed largely to the formation of the alluvium, as indeed 
might be presupposed from their relative positions. It is likely that the calcareous matter is much of it derived from the chalky beds of No. 3.

577. In sections on the Roseau River, the edge of the alluvial deposit is found resting on the coarser sands and gravels of the drift; and in the neighbourhood of Lower Fort Garry and elsewhere, according to Prof. Hind's rections, it rests directly on boulder-clay.* In the vicinity of the town of Winnipeg, boring for water has already been somewhat extensively carried out, for information concerning which I have again to thank Mr. A. L. Russell. Water has generally been obtained at from forty-five to sixty-five feet, the average being about fifty. The general section met with is thus stated:

Black loam

Yellow mud and sand $\ldots \ldots \ldots \ldots \ldots \ldots \ldots \ldots \ldots \ldots$ " about 4 feet

Limestone concrete, resembling the bed of a river, and carrying water.

The most instructive Section of the deposits of the valley, is, however, that obtained in a deep boring at Fargo, Dakota, about 150 miles south of the Line. The record is as follows, as given by Professor Thomas:- $\dagger$

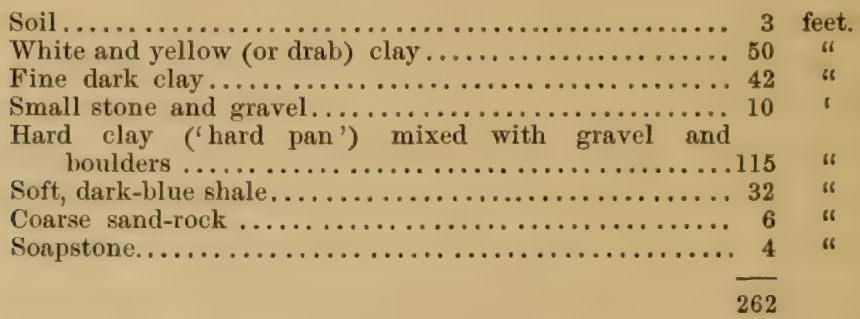

The two sections may be thus paralleled :-

\begin{tabular}{|c|c|c|c|}
\hline & Winnipeg. & Fargc & \\
\hline Soil .............................. & 4 & 3 & $\begin{array}{c}\text { feet } \\
"\end{array}$ \\
\hline 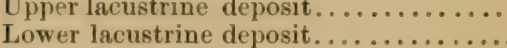 & $\begin{array}{r}6 \\
30\end{array}$ & $\begin{array}{l}50 \\
42\end{array}$ & " \\
\hline Modified drift........... & unknown & 10 & \\
\hline$\ldots \ldots \ldots \ldots \ldots \ldots$ & " & 115 & \\
\hline etaceous roc & $"$ & 42 & \\
\hline
\end{tabular}

The lower parts of the lacustrine deposit may have been formed at a time when the sheet of water was not limited by the Red River Valley, and perhaps eren hefore the sea water finally left the area. 
578. The deposit of the Red River Valley, compares closely with the loess of the Rhine, and with the alluvial deposits which occur on the Missouri River and its branches, as high up as Ft. Pierre. The valley of the Missouri, like that of the Red River, appears to be floored by a very fine deposit, from beneath which as the ground rises at the sides, the stony material of the drift emerges. The term yellow marl, has been applied to these light-coloured alluvial beds, but some confusion has arisen from the use of the same name, to designate similar but coarser deposits, of the surrounding highlands, which belong properly to the glacial drift. The yellow marl deposits of the vallies, and the light coloured marly drifts from which much of their material has been derived, are alike characterized by their extremely favourable influence on the overlying soil; and all who have studied the agricultural resources of the Western States and territories, concur in attributing the inexhaustable fertility of the soils of the lower level prairies, to the wide distribution of this marly material.

579. South of the Line, the pale marly drift seems to extend on the Missouri as far west as the great bend, and southward to cover the entire eastern part of Nebraska. It would appear to be limited westward, by the gradually increasing elevation of the prairie, in that direction, and to spread out in a fan-shaped form, from the southern end of the great Enorth and south depression, which the Red River Valley in part occupies. It is, no doubt, connected with the northern drift, and by description agrees exactly with the pale-coloured and marly drifts developed in British America, from the edge of the Pembina Escarpment westward to the foot of the Missouri Coteau, thus occupying the whole of the second great prairie steppe.

580. The similarity of the yellow marly alluvium of the Missouri and Red River vallies, is not one of chance merely, nor to be accounted for altogether by the resemblance of the glacial drift from which much of the material has been derived. The trough of the Red River Valley is continuous beyond the source of the river, and passing southward from Traverse Lake, from which the river rises, it still preserves its character and direction, and in about six miles, Big Stone Lake, the waters of which empty into the Miswisippi River, is attained. In thus passing over the watershed between Hudson Bay and the Gulf of Mexico, the elevation is found to be at no point sreater than from 960 to 970 feet abore the sea. The figures are from Prof. Thomas' report; who has drawn attention to the importance of this remarkable physical feature.* 
Prof. Winchell, who has visited the locality, thus describes it:- "A continuous valley, between blutfs of the same form and appearance, and of nearly the same depth, connects the two lakes, giving the impression of one valley instead of two. The short interval constituting the divide between the two lakes is usually without water, but is often overflowed by the spring froshets, when a continuous overland watercourse is established between the Gulf of Mexico and Hudson's Bay." *

581. The waters of the lake of the Red River Valley, even if only attaining the level of the margins of the great alluvial deposit on the Boundary-line, would flow treely through this gap, which must then have formed a narrow strait, connecting the great northern lake, with that occupying the vallies of the Mississippi and Missouri ; and at an earlier stage in the history of the continent, when the waters were deeper, the communication must have been quite free. In some parts of the loess deposit of the Missouri, the remains of fresh-water and land shells, mingled with bones of the Bison, the Mastodon and other lately extinct, or still surviving forms, have been found. $\dagger$ The fresh-water origin of the deposit is thus demonstrated, but the further difficulty at once presents itself, that there is no trace of any efficient barrier southward to hold in the great lake now required, and if the depression of the continent was such as to render a barrier unnecessary, the water filling the vallies must almost certainly have been that of the sea. This has been ingeniously accounted for by supposing that in such a comparatively land-locked area, the flow of fresh water from the rivers and streams would be sufficient to effect the exclusion of the salt.

582. Information is wanting as to the nature of the barrier existing in the northern part of the great Red River Valley, which prevented the waters of the region from draining away, as they now do, by a hollow across the Laurentian plateau. It may probably, however, have consisted of moraine rubbish, or boulder-clay. On the supposition that the deposits were formed in a fresh-water arm of the sea, which opened southward, it cannot be supposed that any passage existed northward also, or the tidal currents would have rendered the entire area salt.

583. The wide trough-like ralleys, much depressed below the general level of the plains in which most of the rivers of the west flow, and in which the river itself is generally small and pusues a winding course, usually show a considerable thickness of nearly horizontal alluvial deposits, which, like that of the Red River Valley, have been 
produced in post-glacial times. Some of these have been already incidentally touched upon, and as the importance of these deposits is small they will not be further mentioned. In the alluvial deposit forming the present bank of the stream, in the bottom of the Souris Valley, near the second crossing; about fifteen feet from the surface of the water, and six feet below the summit of the bank; a layer was found to contain numerous artificial chips and flakes of a hard cherty quartzite, for which the position indicates a very considerable antiquity. Butfialo bones are also frequently imbedded in these deposits.

\section{Pre-glacial aspect of the Country.}

584. Having in the above systematic detail, stated the facts as they came under observation, it may be well in briefly reviewing the phenomena, to arrange them in sequence as far as possible; and that they may be better understood, compare these observations with those made in other neighbouring regions, and without entering at length into the disputed questions of glaciation, account for them as seems to me most probable.

585. Before the close of the Tertiary, then, we find that the interior region of the continent had lost its character as an area of deposition, and had become one in which denudation was progressing rapidly-the soft deposits, especially of the lately formed Tertiary beds, suffering by this process. We know that waste had been progressing for a very long time, not only on the mountains, but over the whole surface of the plains, before the advent of the period of cold. There is every reason to beliere, that the Laurentian highlands had at this time a very much rougher and more mountainous character than at present; while on the plains, the main drainage systems were already marked out, and there is much evidence to show that every river and stream, if not flowing in exactly the same course as now, had at least its prototype.

586. The position of the valley of the Red River, must always have been that of an important stream, from its relations to the slope of the Laurentian on the east and the softer Cretaceous rocks on the west. I think it very probable, howerer, that in pre-glacial times it flowed southward, and it is even possible that the waters of the great Saskatchewan River also thus found exit, and were tributary to the representative of the Misisipipi of to-day. For the Red River, a southern course would be the one coinciding with the general slope of the country ; and by the flow of a large volume of water in this direction, the excavation of the basins 
of the Winnipeg group of lakes, and the great valley of the Red River itself, can be explained; the river cutting downward and westward on the sloping surface of the Laurentian rocks, at the expense of the Cretaceous strata, and later, of the limestones of the Devonian and Silurian. The subsequent blocking up of the southern exit, and changed direction of flow, being a phenomenon only similar to that which is known to have taken place with the Great Lakes of the St. Lawrence.

587. The altitude of Lake Wimipeg is about 710 feet. That of the surface of the prairie on the forty-ninth parallel, 786 feet, the depth of the alluvial deposits and drift being unknown. At Fargo, the elevation of the surface of the prairie is 900 feet, but that of the surface of the underlying Cretaceous beds, as proved by boring, is only 680 feet, and the rod may not have descended in the deepest part of the old valley. The surface of the ground forming the watershed between Traverse Lake and Big Stone Lake - as already stated-is only from 960 to 970 feet, and here the continuation of the great drift ridge of the Coteau should cross the valley. The present surface of the Mississippi at St. Paul is 670 feet. Prof. Thomas has drawn attention to the general direction of the tributaries of the Red River; as a rule those on the west side flow south-east, and those on the east side south-west, till they approach the main stream, when some of them tend abruptly northward.* This is a sugestive fact, as indicating the primitive southern slope of those parts of the hollow least encumbered by drift or alluvium.

The evidence with regard to the former drainage of the Lake of the Woods region, and the course of the tributaries of the Red River, has already been fully stated. $\dagger$

588. Exactly how the glacial period was introduced, in the area in question, or by what phenomena its beginning was marked, it is now very difficult, if not impossible to tell. Nor can any reliable estimate of its duration be formed, for the effect of the later periods has been, not merely to obliterate more or less many of the former physical features of the coun. try, but such as to (cover up and eonceal those which antecedent glaciation may have produced. There is nothing to show, howerer, that glacial

- U. S. Geol. Surv. Territ., 1872, p. 283.

+ Since the above was written, I find that similar conclusions have been arrived at by Major General (i. K. Warren, and published by him as "An Essay concerning important Physical Features exhihited in the Valley of the Mimesuta River, and upon their signifiention " being part II. of Report on Minnesota River, submitted to Brig. Gen. A. A. Humphreys, Chief of Engineers, Oct. 31, 1874. I am indebted to Maj. Cen. Warren for copies of his essay, to which I would refer, as throwing very important light on sone phenomena connected with the glavial period. It is very gratifving to find my conclusion as to the former southern outflow of Lake Winniper, cc., borne out by an entirely independent study of the Minnesota River, which must have carried its waters. I cannot agree with Gen. Warren, however, in making the furnation of the great southern wutlet pest-slacial [ loc cit. p. 8,] as I think the eviclence of its pre-glacial formation is complete, and that it was after the glacial period re-occupied. 
conditions prevailed for a very long period before that of the greatest subsidence, nor do we meet with any phenomena not easily explicable by the action of the waters and ice during the subsidence and subsequent elevation. There is also reason to believe that the elevation took place rapidly as compared with the subsidence.

589. The first act, then, in the sequence of the cold period, which can be definitely recalled by its effects, is that in which we find the waters gaining upon the land, and flowing up over a great part of the eastern plains. The wide channel thus formed along the western base of the Laurentian region, though it may have existed for some time in the form of two deep bays, one opening northward to the Arctic Sea, the other southward, and separated by the highland of the present second transverse watershed ; must soon have formed an open strait between the Arctic and Southern Oceans. At this period, if not before, it must have been invaded by the saltwater's of the sea; and it was encumbered with icebergs which were strewing boulders and finer detrital matter over the former surface of the land, and producing the lowest portions of the drift. There is no indication on the Laurentian plateau to the east and north, of a great northern ice-cap, such as has been supposed to be necessary to account for the glaciation of certain regions. The slopes of the platean, as already shown, are too gentle to account for the descent of glaciers from it in the ordinary way except on a scale altogether too small to explain the general uniformity and amount of its glaciation. I can therefore only suppose that this plateau, or gently sloping ridge, of granitic and gneissic rocks; was covered by a thickness of ice sufficient to form a confluent glacier, which by its own weight, reinforced by the gentle inclination of the rocks, moved forward along its whole front into the sea. The subsidence continuing, the conditions of a sea margin passed in succession westward over each part of the plain; then that of water deep enough for ice of small burthen only, and lastly deep water, bearing icebergs of great size. In conformity with this sequence, we find on the higher levels the lower portion of the deposit to have a decidedly local character, and that in ascending in it, travelled stones become larger and more frequent, while in the superficial layers the larger boulder's are most abundant.

590. On leaving the eastern region, we cease to find in grooring and striation, a guide to the direction of the action of the glaciating force, and must trust instead to the distribution of the rocky fiagments. Southward, however, as far as lat. $41^{\circ}$ on the Mississippi River, 
where Carboniferous limestones come to the surface, they are smoothed by the action of ice, and show north-east and south-west striation, crossed by scratching in other directions.* Similar phenomena would no doubt generally present themselves over the area of the plains, were there surfaces of hard rock to receive and preserve them.

591. Reaching the level of the foot of the third prairie steppe, the edge of which had already been marked out by sub-aerial denudation, the action of the waves on its base no doubt rendered it more definite, and the heavier ice following them, and grounding on its lower slopes, began the deposition of the Coteau. It may be that the degredation of the Laurentian hills was at this time proceeding with increased rapidity, but in any case this deposit, formed in great part of their material, must have increased equally fast with the depression of the land, and preserved the edge of the Lignite plateau from the destructive action of the waves.

592. The average height of the Cotean near the forty-ninth parallel, may be taken at about 2,200 feet; and above this the higher hummocks and ridges probably do not rise more than fifty to eighty, or one hundred feet. Its southern extensions have an average altitude of 2,000 feet. It is not necessary to suppose that the shore line stood for a long time nearly at this level, for the heavier ice masses no doubt continued grounding on the edge of the third plateau, eren when the waters stood near their greatest elevation. The data are perhaps yet too slight for generalization, but there appears to be a tendency in the Coteau to occupy a somewhat lower level southward, which may indicate a less subsidence in that direction.

593. East of the Red River, we find the great drift plateau stretching southward and westward from the Lake of the Woods, with an average eleration varying from 1,600 to 1,000 feet; and which, though doubtless everywhere based on the boulder clay, shows in its upper layers a considerable thickness of roughly stratified sands and gravel, indicating the action of rapid and varying currents. On these rest the scattered boulders deposited at a still later period.

594. Probably contemporaneous in origin with the plateau just referred to, are the terraces with a level of 1,435 feet, which Prof: Hind describes at I)ogr Portage, two hundred miles east of Lake of the Woods, on the Lake Superior side of the watershed. These he afterwards

"U. S. Geol. Surv. Territ., 1870. p. 99. 
compares with high-lerel terraces, found on the hills west of Manitoba Lake, with an estimated height of 1,428 feet, and five hundred miles distant. We have therefore the most satisfactory evidence of the former depression of the land to this extent in the eastern region, and it is difficult to understand by what waters it was covered, if not those of the sea. The correspondence in height of these terraces, and the plateau south of the Lake of the Wools, is remarkable. The height of Methy Portage1,566 feet-which according to Sir J. Richardson's description may be a similar drift plateau, with a northward-facing escarpment, also corresponds; and so, in a general way, does the arerage height of the Laurentian axis, and that of the southern part of the Coteau. Supposing the depression to have been everywhere equal, the water must at this time have reached to near the foot of the third prairie steppe, on the fortyninth parallel.

595. On passing up on to the higher levels of the prairie, we continue to find proof of the former action of the sea at yet greater elevations. On the summit of the third prairie steppe, with an average altitude of about 3,000 feet, debris of Laurentian and its flanking Silurian limestones is found over nearly the whole area; though now mingled with a preponderating quantity of Quartzite drift from the Rocky Mountains, and in many cases with a great proportion of softer material from the underlying rocks. The river valleys, and lower levels, frequently show true till or boulder-clay, while the summits of the plateaus are generally covered with shingly deposits, which may have been derired in part from the re-arrangement of boulder-clay, but appear to consist chiefly of beach material, like that of the flanks of the Rocky Mountains, and may have been carried here by small icebergs from the mountains themselves, or by shore ice. The larger icebergs, with Laurentian and Silurian limestone debris, must have drifted to the west or south-west with a prevailing current, bearing the moraine matter of glaciers; while the smaller bergs and floes of the Rocky Mountains, came generally eastward with prevalent winds or surface currents. It does not appear probable that they came directly eastward. They may have come from the south-east, borne by a superficial current mingling with a deep northern flow, in a manner analagous to the Arctic current and Gulf stream on the Newfoundland banks; or, perhaps even more probably, have floated from the north-west, or posibly from the north, touching here and there on their way on the shores of the Rocky Mountain land. 
596. Fragments of Laurentian, and of eastern limestone, were met with on the forty-ninth parallel, as far west as longitude $113^{\circ} 20^{\prime}$, at an elevation somewhat exceeling 4,000 feet. Dr. Hector, examining a regron fiuther to the north, did not find the ordinary Laurentian crratics above 3,000 feet, but described a remarkable line of very-large red granite boulders, as occupying a level of 3,700 feet.* He is uncertain whether these may have come from the Laurentian or not; but taking into consideration the absence of granitic rocks on the eastern flanks of the mountains in British America; and the fact that such rocks do not occur in place over the entire area of the plains, it is highly prolable that they are of eastern origin.

597. The estimated height of the highest terraces observed, those in the mouth of the South Kootanie Pass, is 4,400 feet, and I have little doubt but that these are of marine origin. About thirty-six miles north of the Line, Lieut. Blakiston measured three terrace levels, and found them to be $4,226,4,176,4,085$ feet, respectively, in altitude above the sea. He describes them as "very marked, appearing as a suecession of steps from the level of the river to the plain above, often in sight for miles, and running horizontally." Dr. Hector also measured similar terraces at the head waters of the Bow, North Saskatchewan, and Athabasca Rivers, and states that they "may be considered as ranging on the east side of the Rocky Mountains, from 3,500 to 4,500 feet above the sea." $†$ He further says "until we approach close to the mountains, these terrace deposits are confined to the vallies of the larger streams, but sradually they spread out, and at last cover the whole country along the base of the mountains, filling up the hollows and vallies of the outer ranges to a depth of several hundred feet." + " "Shingle beds of a similar kind are found to cap the Cypress Hills, which have an altitude above the sea of 3,800 feet." These hills, as has been already stated, are without doubt an extension of the plateau of the Lignite Tertiary, and the whole of these shingle beds and terraces belong to the deposit which I have called the Quartzite drift. Yet further north, on the upper waters of the Peace River, Sir Alexander Mackenzie describes the country as steplike or terraced as far as the eye conld reach. His royage was made in the year 1793 , and though not viewing the country with the eye of a geologint, he appears to have made remarkably careful and accurate observations. 
598. Dr. Hector concludes from the relations of the drift deposits of the west side of the Rocky Mountains with the Cascalle Range, that the depression there cannot have exceeled about 4,000 feet.* The water which stood at this eleration cam have been that of the ocean only; and though foreign drift is not met with on the Rocky Mountains, or their slopes, it is not to be concluded that the sea was free from ice ; for at this time the eastern granitic region, which had always been the great source of erratics, must have been deeply submerged. Its ponilerous icecap may hare maintained itself for some time after the water was actually above the level of the rocky substratum, but must ere this have succumbed.

599. Dr. Hayden speaking of regions further southward, where the elevated plains of the extreme west are higher, and stretch further from the mountains, insists on the same fact. He writes: "As I have so often stated in my previous reports, I have never been able to find any evidence in the Rocky Mountain region of what is usually termed a northern drift." $\dagger$ In mentioning the occurrence of terraces on the westem tributaries of the Missouri, in the Rocky Mountains, he states his helief in the common origin of these, and those on the western side of the same range, and in the fact that the mountains may have been depressed, till only their highest peaks rose above the waters. I

600. There is no evidence that this period of maximum depression endured long, nor that during the re-elevation of the continent, the waves acted long at any particular level; and though ice, bearing debris, no doubt still encumbered the waters, it does not seem necessary to suppose that any important additions to the deposits took place at this time. Some beds which may in part be composed of modified and re-arranged boulder-clay, such especially as those of the third prairie steppe, and of the plateau south of the Lake of the Wools, may perhaps, howerer, owe their present appearance to action at this time.

601. On the retreat of the sea, each part of the country would again hecome for a short time a shore-line, and the rivers and streams on the emergence of the land, appear in most cases to have resumed their former channels, and began to re-excavate their beds in the drift material with which they har been filled. At one periol, as Dr. Hector has pointed nut, a great bay must have existed, bounded southward and westward by the curved line of the Coteau and third prairie escarpment, and north- 
warl by the high ground beyond the position of the prevent Saskatchewan River. At this time, the north and south branches of the Saskatchewan formed separate rivers, and divided between them the whole of the drainage of the third plateau. Turtle Mountain, and other similar accumulations of drift, and the high hills of the Cretaceous, overlooking Manitoba Lake, formed islands or shoals. The edge of the Pembina escarpment and the second steppe next becoming the shore, the united waters of the Saskatchewan, the Assineboine, and other smaller streams, flowed eastward into the inlet of sea-water, occupying the lowest prairie level, which, as the eleration continued, became that great lake of the Red River Valley, the history of which has been already traced. There is evidence, too, to show that as the Laurentian region rose above the water, it was again covered with glaciers for a short time; but that these did not last till the very close of the submergence, appears to be shown by the very fine character of all the later deposits of the Red River Valley. The few fragments of rocks which are found, being not more than may, with probability, be attributed to the ice of the great lake itself.

602. In attributing the glacial phenomena presented by the central plateau of the continent, almost entirely to sea borne ice-bergs, I have adopted that explanation which appeared on consideration of the facts, to embrace them best, and which would account for them most simply. In so doing I am in accord with Dr. Hector, and also I believe with Dr. Hayden; who have studied the phenomena most extensirely on the ground. That some circumstances, however, give at least negative evidence against marine glaciation, must be admitted. The most important of these is the complete absence, so far as I have observed, of any marine animal remains in the drift. This is found equally over the entire western portion of America, and though it has been supposed to show that the drift was deposited in fresh water, this explanation does not seem to remove the difficulty. It is impossible to imagine a submergence so great in amount as to overflow nearly all the barriers, with the continued exclusion of salt waters; and though the absence of marine shells is remarkable, on one supposition, that of lacustrine forms is almost equally so, on the other. That molluscous remains might have been preserved, hal they been imbedded in the deposit, is shown by the occurrence of specimens of Cretaceous or Tertiary Ostreas. The nonorcurrence of molluses in sreat deposits older than the drift, and known to be of marine origin, is; however, an accepted fact ; and in such conglomeritic beds as those of the drift, it is most frequently obrerved. Recent 
dredging operations, also, in the vicinity of the south polar glaciers, seem to show the possibility of the deposit of non-fussiliferous marine boulder-clay.

603. The second difficulty, is found in the comparatively small amount of ehange, which has been wrought on the extensive area of the plains, composed of yielding, scarcely solidified sediments, by so rast a rerolution in physical geography as that implied by the old water marks. This objection, however, applies even more forcibly to any general system of glaciation by a northern ice-cap; and it is scarcely possible to imagine a mass of ice, like that implied by such a theory, passing southward across the soft rocks of the plains, against the general slope of the country, and yet not obliterating its pre-formed river valleys and features. Such a continental glacier, too, though it might have been loaded with Laurentian debris on its eastern margin, and with fragments from the Rocky Mountains on the west, can scarcely account for the west and east transport of these materials for hundreds of miles, and their deposit in great quantities in the central region. If such an ice mass, be supposed instead, to have moved down at right angles to the Laurentian axis, and passed out across the plains in an unbroken sheet; setting aside the difficulty of supplying an efficient motor power, and other minor circumstances; it will be found necessary to suppose that it climbed up and over the abrupt eastern edge of the second steppe, without destroying it, and proceeded .700 miles westward up an incline averaging about five feet per mile.

604. Mr. Belt, in an interesting paper lately published, $*$ deals with similar difficulties in explaining the glaciation of Siberia. The northern part of Asia, surrounded on all sides save the north, by mountain chains, forms an interior continental basin, covered with "vast level sheets of sand and loam." Marine shells are absent from the deposits, except near the low ground of the northern coast, and true boulder-clay is apparently not found. Mr. Belt, to account for the facts, resorts to a theory first suggested by him eight years ago, by which he supposes the existence of a polar ice-sheet, capable of blocking up the entire northern front of the country, and holding back its waters to form an immense fresh-water lake. Prof. N. H. Winchell, in an article in the "Popular Science Ifonthly," of June, 1873, hroally accounts for the glacial phenomena of the North-west, on the supposition of a polar glacier. His illustrations 
are chiefly horrowerl from a careful sturly of the region south of the great lakes of the St. Lawrence, bat as he includes the valley of the Red River, and the entire North-west, in his deductions, its mention here may not be inappropriate. The most suggestive part of the paper is that in which-like Mr. Belt - he traces the necessary production of a great inland seal, or lake, as the foot of such an ice-sheet as that supposed, gradually retreats northward down an inclined plane.

605. Ingenious as this hypothe: is undoubtedly is, its inapplicability to the phenomena and physical features of the region now under consideration, must be at once apparent. The great depth to which submergence took place is one of the most patent difficulties. From the description of the Red River Valley alicaly given, it will be evident that the entire drainage of the great lake must have passed southward by it. There is here nu range of mountains to be crossed, and unless the retreat of the glacier was rery rapid, no reason can be assigned, why a channel once formed, should not have been cut down through the gentle swell of the watershed, and remained the permanent exit of the drainage of the country. Again, the distribution of northern erratic's in lines fixed by the altitude of the country, and their equal spread ove: the central and marginal regions of the plains, and the interpenetration of the eastern and western drift, do not admit of explanation on the supposition of a southward moring ice sheet; nor loes the surface of the country show any trace of the progress of such a mass. The whole question is a rery interesting one, and it would seem probable that a solution once arrived at, will be found to apply equally to North America and Northern Asia.

\section{Post-Glacial Phenomena.}

606. The existence of a period characterized by great rainfall, or phrvial period, has been very generally supposed for the West. Such an event may probably have supervened at the end of the epoch of graciation, but it would secem that much of the evidence brought to prove its occurrence is not of the most unexceptionable nature.

607. Chief among the phenomena which at first sight seem to imply the action of large bodies of rumning water, are the great rallies which the strams of the pratie country, themselves often so insignificant, have jorluced in the yiolding strata. These vallies, like that of the Pembina River, are sometimes more than three hundred feet in depth below the flain, and orer a mile in wilth; and are frequently depressed more than one humberl feet below the general surfice. The stream generally oceu- 
pies but a very narrow strip of the bottom of the valley, and winds often in the most tortuous manner from side to side of its level floor. It is usually the first idea of a traveller, that a great river has occupied the valley at some former time, and completely filled it. A little consideration, howerer, serves to modify this belief, and it is very generally found on examination that the comparatively puny stream by reason of its tortuous character, is still in some places excavating and undermining the banks of the main valley. Evidence is also found of the constant change of the position of the stream in the flat valley bottom, and places may be seen, where the excavations of late year's are being covered by a sod of grass. Given only time enough, and the formation of these great troughs in the prairie, is accounted for by forces still in operation. There are valleys, it is true, which do not show any erosion of their sides now going on, and in which the immediate hollow of the stream is deeply cut, and a condition of comparative equilibrium attained. Some of these, may require for their explanation a period of greater rain; but at a certain stage of developement, every valley is apt to fall into this state, if the flow of water be not actually increasing.

608. The valley of the Souris River, gives some excellent illustrations. Near Wood End it is of an arerage width of about one fourth of a mile. The stream is quite small, and in summer barely runs firom pool to pool, between the stones of its bed; jet it is found, that at afmost every convex bend, the banks are scarped and bare, and are year by year being undermined. For about six miles, the river preserves the same character, and then joins, almost at right angles, a larger old valley, about a mile wide; in which there is no flow of water above the place of junction. Here, though there is abundant evidence of the changeable nature of the river bed, in the presence of lagoon-like ponds, the banks are comparatively ruinous, and covered with regetation, and are seldom approached by the stream.

609. The rivers are "proved to have frequently changed their courses, and great valleys occur in which little or no present waterflow takes place, but which may once have carried important streams, now diverted. Prof. Hind has shown that the South Saskatchewan probably flowed at a firmer perion by the great valley now occupied by the Qu'Appelle, and Rirer. That Turns, to the Assineboine** If the part of 
the valley separating the sources of the Qu'Appelle and River That Turns, has not been heightened very considerably by the accumulation in it of debris from its sides, the South Saskatchewan must have cut down its present bed, since its occupation, about eighty-five feet. Prof. Hind also believes that the Souris River flowed southward at one time through the great depression now occupied by the Back Fat Lakes, and joined the Pembina River, a fact which may assist in explaining the formation of the great valley of the latter. Such changes of bed may have arisen from some general alteration in the inclination of the country, and it is perhaps worthy of remark, that both the instances cited, show change from courses easterly and southerly, to north-easterly; and such as would be brought about by a slight elevatory movement of the transverse watershed in the vicinity of the forty-ninth parallel, or an increasc of depression northward.

610. One of the most remarkable instances met with of this sort of change, is that of the disused second valley of the Souris, near its first intersection with the Line. The old valley lies to the east of the present one, and is separated from it by about two miles of prairie. They are about equally wide, and depressed about 90 feet below the general surface, though from a barometric comparison, the valley of the present stream appears to be from ten to eighteen feet below the disused one. In the old valley, the course of the stream is still discernable, and is occupied in some places by small, and somewhat saline pools.

611. Another striking instance is found in the Cireat Dry Conlée, which joins the valley of the Milk River, a few miles north of the Line, and, according to Palliser, extends north-westward to the junction of the Bow and Belly Rivers. About equidistant from the Milk River and the latter locality, the valley contains a large saline lake, known as Peekopee. It would appear that the water's of the Bow and Belly must at some time have passed thus to the Milk River, and if this is the case, a northward diversion of the water must have taken place here also.

612. The so-called Riviere des Lacs, which crosses the Line at the 227 mile point, also seems to occupy the bed of a former stream. This sheet of water, where it is inter'sected by the Line, must be nearly three quarters of a mile wide, and is not fordable. It occupies the bottom of a valley, and is over fifty feet below the prairie level. Northward, it extends about four miles, hecoming gradually narrower, and ending in a broad, dry (oulée, which shallows and dies away in a strip of boulder-covered ground, which stretches northward toward the Souris River, five miles distant, 
and is somewhat lower than the general surface of the plain. Southward, it is said to extend about serenty miles, and finally to join the southern bend of the Souris River, where it gives issue to a small running stream. The present condition of affairs, howerer, will not serve to explain its formation, nor does it resemble the bed of an old tributary to the Souris, from its sudden northward encling, and the absence of systems of coulées ramifying from it. It may be accounted for by supposing that it has been a former shorter channel of the Souris itself, but in that case, either its northern end must since in some way have been blocked up; or the river being dammed back in its own channel, has spread over the prairie in a lake-like expansion, which has finally found exit southward by the Riviere des Lacs Valley. The valley occupies just the position, which such flood water would take, and bends round the most eastern portion of the high ground, rising toward the third prairie steppe.

613. Vallies such as those above described, appear, from the accounts of different explorers, to occur in many parts of the great prairie region,* and though some of them may tend to show the action of greater bodies of water than those now flowing in them, they cannot all be accounted for in this way. It is difficult to conceive any ordinary circumstance, which would cause a stream to leave a wide valley, often over 100 feet in depth, and to commence the formation of a new channel of like proportions. The blocking of the stream by ice jams, or accumulations of timber, though capable of explaining change of course in rivers flowing through alluvial country, not much below the general level, cannot be supposed to be a sufficient cause for deflexion on so great a scale. A careful study of these phenomena, over great areas, may eventually bring to light some general cause, such as local, or unequal, elevation or depression. At present I can only account for these duplicate vallies, on the supposition that most of them are alternative channels, of the streams at present in existence. In a level region, composed of soft materials, it is probable that since the rivers first flowed across its surface, they have been subject from ice and timber, to frequent obstruction in certain places. Before the river bed had been deeply worn into the surface, the stream might thus easily be turned aside; and before many years, a similar occurrence in the new channel might cause it to revert to the old. By such oscillation, a single river may cut out two or more beds simultaneously, and to nearly an equal depth. Some of these great dry vallies, may again 
become river channels, but in most cases they reem to have been now long disused. This may arise either from a gradual decrease in the annount of flowing water, and in the intensity of the spring floods; or from an increasing scarcity of timber capable of forming obstructions, in the regions trarersed by the streams, which seems on other grounds to be undeniable.

614. The Red River is still not fur below the level of its bordering prairie, and from the fixed elevation of its out-fall in LakeWinnipeg, cannot be lowering its bed appreciably, though the sordering prairie is no doubt gradually gaining somewhat in height from the sediment deposited in seasons of flood. The course of the river is exceedingly tortuous, and it is yearly becoming more so. An examination will show that all the concare sides of the bends are being eaten away by the stream, and the stumps of old half-buried oak, and elm trees, being there exposed; while the opposite, or convex sides are almost invariably gaining by the addition of banks of sediment, which as soon as they are formed are taken possession of by thickets of young willows, and consolidated hy their roots. When this process has been carried to an extreme, it is naturally remedied by the breaking of the water across one of the narrow necks separating two of the bends, during some period of excessive flood, and the formation of a new course. I do not know of any very modern instance of this, but old portions of the river-channel, may frequently be observed forming ponds and small lakes on the prairie, sometimes more than a mile from the present stream. These, like the parent river, may be fringed with trees, and are generally surrounded by a dense growth of reeds, and filled with rank aquatic vegetation.

615. The floods of this river, arising from the melting snow in spring, are intensified by its northern course; the soures being broken up and in flood, while the ice at its mouth is still quite firm. Extensive ice-jams are apt to form, and a small increase in the elevation of the water above the banks, nerves to overflow a great area of g'ountry. The silting up of the mouth of the river, may also, as has been suggested, have something to do with the recurrence of great floods at somewhat regular intervals, and may require some such natural paroxysm for its remedy.

616. The systems of ramifying coulées with gently sloping grassy hanks, but with neither brooks nor regular stream courses, when seen during the dry weather of summer, may seem to require for their expla- 
nation some aqueous agency more potent than the present, and appear to resemble the disused beels of large tributary streams. To any one, however, who has examined them in early sping, and during seasons of flood, their origin is apparent. The whole thickness of the soft prairie alluvium, is then completely saturated with moisture, and the coulées are brimfull with water, holding in suspension a great quantity of fine earthy matter, and flowing with a regular, though gentle and often scarcely perceptible current, toward the main stream. At their extreme ramifications, little streams may be found, gathered together almost imperceptibly from the half-flooded surfice of the prairie, and directed into a certain course-perhaps by means of snow-banks, which have not yet entirely disappeared-and just engaged in cutting through the tough prairie sod in the first process of the extension of the valley.

617. During the post-glacial emergence of the country, every stream must at one time have flowed, as the Red River now does, into a great lake not much below its own level, and have been in the same way, more or less sulject to floods and orerflows. Many of the coulées now found bordering the river vallies in the higher prairies may date back to this time, and may not have since received important incremert.

618. An examination of the beds of the rivers and streams, while probably learing some balance in faror of a period of greater rainfall, does not appear to offer any evidence of its great intensity. Other facts seem to point to the occurrence of a period when the raiufall was greater than at present, and it would even seem that a graulual dessication is yet proceeding over great areas of the west. This does not appear, however, to be more than can be accounter for by the decreasing area of forest-a subject elsewhere more fully mentioned. It is hardly probable that the prairies as a whole have been at any time wooled, but that large areas of forest have existed where bare plains now spread, is undoubted. The existence in some places of great quantities of the remains of land and fresh-water shells in the older river deposit of the Missouri, which now occur rarely if at all in the neighbouring region, has been mentioned by In. Hayden; and seeming to imply for the upper waters of that river at no very distant time, a considerable firest area, is one of the most striking facts in favour of a change of climate. Any very great or long continued excess of rainfall over the prairie region is, howerer, negatived by the appearance which its surface presents, and 
especially by the existence of large areas which since the drift period have never developed systems of drainage valleys, and yet retain with little modification the irregular appearance of the original surface of the drift deposit, and are dotted with numerous ponds and lakes without outfall. The pre-glacial streams too, choked up along the edge of the third steppe by the drift of the Coteau, aud which have since been unable to clear their channels, give evidence of this kind. 


\section{CHA PTER XI.}

\section{CAPABILITIES OF THE REGION WITH REFERENCE TO SETTLEMENT.}

REgION IN THE VICINITY OF THE LAKE OF THE WOODS-Areas capable of cultivation - Barren region-Vegetation of the lake-REgION BETW FEN THE LAKE OF THE Woods and Red River Prairie-Country in the vicinity of the Govern. ment Road-Country bordering on the Reed and Roseau Rivers-Height of Land Muskeg-The Red River Pratrie-Soil, and nature of the surfaceMeasure of agricultural capacity-Wood-Climate-Progress of the spring here and at other points in the Fertile Belt-Rainfall--Water supplyCocstry of the Second Prairie Steppe-Pembina Escarpment-Western margin of the great plains - Turtle Mountain - Timber - Country in the vicinity of the Souris River-Meteorological cycle-Country of THE ThIRD Prairie Steppe-Plateau of the Tertiary-Eastern limit of buffalo-Big Camp of half-breeds-Fertile Belt at the base of the mountains-Timber of the mountains-Climate of the Third Steppe.

619. In this chapter it is proposed to examine briefly the nature of the country in the vicinity of the 49th parallel; with regard especially to its adaptability for settlement and agriculture, and its superficial features. The nature of the surface, however, depends so closely on the underlying rocks, and especially on the drift deposits, where these are largely developed, that much has already of necessity been given, which might properly be included here. It is not intended to go over any of those general points which have received notice, but merely to touch on those which have not yet been mentioned, using the material of the foregoing chapters as a substratum.

\section{Lake of the Woods Region.}

620. A rery small proportion of the country immediately surrounding the Lake of the Woods, is at all suitable for agricultural settlement. The northern and eastern shores are entirely composed of barren rock, and though valleys in this district-and especially in the part of it occupied by Huronian rocks-may be found of better appearance, the soil will probably be sandy and poor. Pine timber of fair growth occurs in some localities, but forest fires have already 
denuded great areas of both trees and soil, leaving only the bare, rounded, rocky substratum of the country.

621. The areas capable of cultivation are chiefly those based on the low terrace level, which has already been described. Lacrosse Island, and other islands, and sheltered bays, show considerable remnants of this terrace. It also forms the flat ground surrounding the Northwest Angle, and has there been cultivated to a small extent, the Indians growing patches of maize, which thrives well considering the small amount of attention given to it. Wheat, I am informed, has been sown as an experiment, and succeeds well. Potatoes yield excellent (rops, and all the ordinary regetables and cereals would doubtless flourish, with careful farming; were there sufficient inducement for their cultivation. The same terrace forms some flat land in the chain of large islands of Sand-hill Lake, and it is also extensively developed on both sides of Rainy River, and from the accounts of Prof. Hind and others, would appear to run a long way up that stream. Wentward from the mouth of the rirer, and forming the northern shore of Minnesota, it extends for about ten miles, and though generally swampy, has an eleration sufficient to admit of drainage, and sustains a fair growth of elm, poplar, cedar, spruce, and birch. The eastern front of Buffalo Point, probably belongs to the same terrace, though considerably higher than elsewhere. Its surface is dry and clad with a thick growth of poplar and birch. Kit-a-gane-minis, or Garden Island, has been from time immemorial cultivated by the Indians of the lake, and is one of their great meeting paces and head quarters. Its area must be from one to two square miles, and though I was unable to visit it, it appears from a distance to be level, and to suppot a fair growth of timber. It is now almost deserted.

622. All these localities are based on the old plateau or terrace level, a former lake bottom; and the soil where I have examined it, is composed of fine sand and calcareous debris, deficient in regetable matter; which when it oceurs, is apt to form a peaty aceumulation on the surface.

62:3. 'The greater part of the southern and western margin of the lake is utterly useless, and a more forbidding and desolate region can scarcely he imagined. The immediate borler of the lake, is here formed by a low ridge of samd, often blown into miniature sand-hills, but sometimes bound together hy the roots of various grasses. Behind this margin is very generally a stretch of grassy swamp and lagoon, of a mile or two in width, and bordered in the distance by a forest of 
tamarack (Larix Americana) growing on a scarcely less flooded soil. In some places, low, swampy savamnah fironts directly on the lake, and this I have seen fringed after a gale, by a belt many feet in wilth, of brown regetable pulp, equally impossible to walk on, and impassable for the canoe. On other parts of the coast, on gaining the summit of a peaty bank a few feet in height, which is breaking off under the action of the waves, an expanse of swamp, with small dead tamarack trees, stretches as far as the eye can reach.

624. In the shallow water of the lake, a large species of rush abounds, and is used by the Indians for making mats. The root is also eaten at certain seasons. Where the water is quite shoal, and in reaches protected from the full force of the waves, the roseau grass (Phragmites communis) corer's great areas. It does not appear to be tough enough for the manufacture of paper, and I do not know any other purpose to which it can be applied. The wild, or Indian rice (Zizania aquatica,-ma-nu-min of the Chippeways) does not occur abundantly in the southern part of the lake, so far as I have seen, but must grow luxuriently in some parts of the northern division, and especially in Lac Plat, where the Indians collect large quantities of the seed in autumn, for winter use. The plant appears to thrive best, where growing up through several feet of water in sheltered lagoons and inlets, and certain areas formerly noted for its production, have of late years, from the higher level of the water, become unproductive. Scarcely sufficient attention seems to have been given to this native grain. Growing far to the north, in areas altogether unsuited for other crops, it seems to afford a prospect of utilizing great regions of lake and swamp, otherwise irreclaimable. Its growth might no doubt be encouraged by the use of proper precautions, and improved rarieties result from careful selection. The grain, though dark in colour, is palatable, and the straw is now coming somewhat extensively into use in the manufacture of paper.

6.25. Many of the less deeply submerged swamps would yield large quantities of natural hay. Those in the vicinity of the North-west Angle are already made to furnish hay for the stock kept there, which though rather coarse, it is found to be nutritious.

626. The flora of the country surrounding the Lake of the Woods, closely resembles that characteristic of the Laurentian region, north of the S'. Lawrence River, and differs from that of the prairie country to the west. A few western and southern forms, howerer, occur in association with those of eastern and northern aspect. The majority of the forest 
trees are coniferous, and from the swampy character of the country, the tamarack is perhaps most abundant. The cedar (Thuja occidentalis) was in a few places observed, forming groves of limited extent. The red pine, Banksian, or scrub pine, and white pine, (Pinus resinosa, $P$. Bankiana, and $P$. strobus,) also occur where the ground is dry, and especially on the sandy ridges separating the swamps; but not in very large groves. All the ordinary eastern spruces and firs are also represented. Of deciduous trees, the poplar is most common, and generally represented by the aspen or balsam poplar ( $P$. tremuloides and $P$. balsamifera) willows of many species form thickets in the swamps and along the edges of the woods. Elm, oak, birch, and the ash-leaved maple, also occur sparingly.

627. The climate of the region immediately bordering on the Lake of the Woods, is much improved by it. The shallow expanse of water becomes heated by the rays of the sun, and in July and August was very generally found to have a temperature of from $70^{\circ}$ to $75^{\circ}$ Fahrenheit. Early frosts are thus prevented, and the nights, which at a like elevation on the prairic west of Red River are frequently cold, are here, as a rule, deliciously balmy. Should land for agricultural purposes ever become of value in this region, a great area of the bottom of the lake might be laid dry, at comparatively small expense, by removing the rocky barrier at Rat Portage, the water being thus lowered about eighteen feet.

\section{Region between the Lake of the Woods and the Red River Prairie.}

628. West of the Lake of the Woods, is an extensive wooded, and very generally swampy region, which extends to the eastern edge of the alluvial prairie of the Red River. Where crossed by the road from the North-west Angle to Winnipeg, the wooded region is about sixty miles in brealth; on the forty-ninth parallel, about seventy-five miles. On the northern line of section the character of the country is as follows :-From the North-west Angle to Birch Creek Government Station, is for the most part thickly wooded, but almost a continuous swamp, with here and there a rocky or sandy ridge rising above the general level. Much of the soil would dry up if the woods were removed, but appeared to be sandy and poor, and of little or no use for agricultural purposes. There is much tall, but slight, pine timber, suitable for railway sleepers, but not of much use for the saw mill. The sand of the ridges is generally of yellow ferruginous colour, and the gravel, when it occurs, is chiefly of small limestone 
fragments. Ten miles east of Birch Creek, is the watershed swamp, here known as the Caribou Muskeg. It is a flonded sarannah, of perhaps, a mile and a half in width, and is an extension of the swampy watershed region, crossed further south. From Birch Creek to White Mouth River, the surface slopes gently westward, yet more than half the area is occupied by swamps. The dry tracts are covered with a sandy soil, which though warm, is too light to attract the agriculturalist. The Banksian pine abounds. From this place to Broken Head River, and thence to the edge of the wooded region, near Point du Chêne, the surface is not so wet, but still shows numerous swamps; and the soil in no place compares favorably with that of the prairie to the west.

629. An examination of the southern part of the region lying west of the lake, was made by crossing it by the Reed and Roseau Rivers; the former, a small stream flowing into the Lake of the Woods, the latter, inoscolating with it in the watershed swamp, is one of the largest tributaries of the Red River. The route thus indicated, in the main nearly follows the Boundary-line, though a considerable portion of the Roseau River, and the whole of Roseau Lake, lie a short distance south of it, and in the northern part of Minnesota. The crossing was effected in the latter part of August, 1873, with two men, and a single 'three fathom' bark ('anoe; and from the waters of the lake to those of the Red River, occupied nine clays; much delay arising from obstructions by drift timber in the rivers, the state of the portage on the height of land, and the bad rapids on the lower part of the Rosean River. The route though long lnown to the Indians; and used by the Chipperrays and Sioux as a war-path between their respective countries, has remained almost wholly unknown to explorers. Prof. Hind, and Mr. S. J. Dawsón had intended passing by this route to Red River in connection with the Assineboine and Saskatchewan Exploring Expedition, in 1857, but were turned back by a large force of Indians collected on Garden Island.

630. On entering the mouth of the Reed Rirer, a sand-bar is crossed, the water on which is, apparently, not more than four or five feet deep. The lower portion of the river itself, for about four miles, is both wide and deep, and not very tortuous. Near the mouth, it passes through a grassy swamp, and for some miles the shores continue swampy, though generally covered by bushes and small trees. Beyond this the river, though still deep, becomes narrow and tortuous, and retains this (haracter throughout its upper part, which for several miles before reaching the source is often not more than sixteen feet in width. At the same time, 
the current becomes much stronger, though not assuming anything of the character of a rapid. For about two and a half miles from the beginning of the narrow portion of the rirer, in a general south-westerly course, the banks rise several feet above the water, and support a moderately good growth of aspen and balsam poplar, with some oaks, and a few tamaracks. Most of this higher ground has, howerer, been burned over years ago, and the greater part of the timber thus destroyed. The soil is rather retentive, being composed of a fine, grey, sandy. clay. Beyond this, and to its source, the stream is fringed by grassy swamps, bordered at a short distance by a dense growth of tamarack, scarcely, if at all above the level of the water. The current, however, is still strong, and the stream, though very narrow and tortuous, remains ditch-like and deep.

631. On approaching the east end of the Portage the tamarack first retreats further from the stream, and the latter remains merely as a narrow rut among the reeds. The bottom of the swamp, though here covered by a few inches of water and decayed vegetable matter, is hard, and firm, and consists of fine whitish arenaceous clay, of such a nature as to be almost completely impermiable to water. It here becomes necessary to track the canoe with ropes, and for a few hundred yards the swamp was found so shallow, that it was best to lighten the canoe, and portage the stuff by hand. On thus entering the Muskeg Portage Swamp, the tamarack trees become small and scattered, and soon remain only in isolated grores, standing out like islands in the grassy expanse. After passing the shallow edge of the swamp, above described, which may be about half a mile in width, it becomes softer and leeper, and is entirely composed of peaty matter and soft swamp muck, in which in some places one sinks from knee to waist deep, and often no firm bottom exists for a depth of five or six feet, and probably much more. In some spots small fishes were seen among the grass. In the softer parts, gas arising from the decomposing vegetable matter, buoys up portions of the sod, which, however, easily sink under any weight.

The surface of the swamp is usually grassy, but some extensive patches of Spirce bushes oceur. Ledum latifolium, or Labrador tea, Sarracenia purpurea, the pitcher plant, and Andromeda polifolia, also occur abundantly ; Lobelia Ka!imi, Parnassia Caroliniann, and Drosera longifolia, were found in flower.

632. The source of the North-east Rosean Rirer, is six and three quarter miles from that of the Reed River, in a south-westerly direction; but the track through the muskeg deviates considerably in some places, 
to avoid tamarack groves, \&c., and increases the actual distance which must be passed over in taking a canoe from one river to the other. On approaching the source of the Roseau River, the swamp again becomes shallow and hard-bottomed. The stream, as at first found, is a riunnel scarcely wide enough for a canoe, but falling westward with a swift current. The height of land muskeg, judging from the line of levelling on the forty-ninth parallel-about six miles south-and from the current of the Reed River, cannot be more than ten or twelve feet above the Lake of the Woods. It has all the appearance of having been at one time a shallow lake-basin, with a hard bottom of drift material; and has been gradually filled by the growth and decay of vegetable matter.

633. I believe that this and other swamps of the region of the watershed, might yield important supplies of peat fuel to the woodless prairie country to the west. The peat would, of course, require to be manufactured by one of the processes now employed elsewhere, and advantage might be taken of the upper part of the Roseau for its shipment. The peat here found must be pretty pure, though not formed by the accumulation of the Sphagnum or peat moss, but from grasses and other aquatic phænogamia.

634. The North-east Roseau, is at first narrow and tortuous, like the upper part of the Reed River, and the surrounding country is swampy and corered with tamarack, and willow bushes. The banks soon, however, begin to rise higher, and poplar becomes the prevailing wood. Fine oaks, elms, and ash-leared maples also fringe the stream. The forest retains this character as far as Roseau Lake, and where small openings occur, rose bushes, asters, convolvulus (Calystegia sepium) wild hop (Humulus lupulus) the prickly cucumber (Echinocystis lobata) and high-bush cranberry (Viburnum opulus), form a tangled thicket.

635. About three miles from the source of the river, and two-and-ahalf from its crossing with the forty-ninth parallel, a tributary nearly as large as the main stream enter's from the north. A few miles above Roseau Lake, a second large stream comes in from the south-east, and may be callerl the South-east Roseau. The banks of this part of the river are usually high, and are as much as fifteen feet above the water level where it crosses the Line. As far as can be seen from the edges of the river, the land continues in most places dry, and supports a good growth of timber. For several miles before reaching Roseau Lake, however, the dry banks merely form narrow ridges at the sides, and open grassy swamp lies both north and south of them. The whole upper on North-east Roseau 
river is at present much encumbered by jams of drift timber, and beaver dams.

636. Roseau Lake, is a shallow expanse of open water in the midst of a great region of reedy swamp. It lies about four miles south of the Line. The East Roseau enter's at its southern part, and the West Roseau flows out on the same side, at less than a mile distant from it.

637. The upper part of the West Rosean River, for about ten miles following its course, has banks sufficiently high to support a small growth of poplar, oak, and willow bushes. The trees then disappear, the current becomes much more sluggish, and the river enters the Great Roseau Swamp. This vast muskeg is absolutely without trees or bushes of any kind, but is corered by a rank growth of grass and reeds, and interspersed with small ponds and lagoons. The distance through the swamp, following the course of the river, which is exceedingly tortuous, must be at least twenty miles. For a few miles before reaching the fortyninth parallel, the river is again fringed with trees-oak and elm being abundant.

638. A short distance south of the Line, and before re-crossing it, the first island occurs, and boulders become plentiful in the bed of the river, which, though unencumbered and deep from Roseau Lake to this point, now becomes shallow and rapid, and so continues till the border of the Red River prairie is reached. The banks are high throughout, and this belt of country, about twenty miles in width, is of much improved appearance. The sub-soil is of gravel and fine sand-as already noted in connection with the drift deposits-and most of the surface is dry, though large swamps still occur. It is partly of a prairie character, but is broken up by extensive groves, which are usually of poplar. The soil, though lighter than that of the Red River Valley, shows in some places a considerable depth of vegetable mould; and would be warm and easily worked, and bring crops rapidly to maturity with careful cultivation. The presence of so much limestone debris in the drift, has a favourable influence.

Poplar, oak, and elm, attain a large size along the margin of the river in this part of its course.

639. In this region of oak and poplar 'openings,' there is, to some extent, a mingling of eastern and northern woodland plants, with those of the plains. East of the edge of the true prairie land, the coniferous forest comes to an end, in about longitnde $96^{\circ} 30^{\circ}$; and coniferous trees are not again found in any force-with the single exception of the moun- 
tains known as the Three Buttes-till the immediate flanks of the Rocky Mountains are reached

640. The West Roseau River would seem to be navigable by steam launches, or stern-wheel boats of light draught, from the Red River nearly to its intersection with the old St. Paul and Garry roal. From this place to its crossing of the forty-ninth parallel, it is barred by the rapids above mentioned, which, from their shallow and boulder-strewn character, are difficult of navigation, even in a bark canoe. From a point a few miles south of the Line, a small steamer might pass through the Roseau Swamp and Roseau Lake, and possibly ascend the East Roseau, nearly to its intersection with the forty-ninth parallel.

641. Of the wooded country between Lake of the Woods and the margin of the Red River prairie, a comparatively small proportion therefore appears to be fit for cultivation, though much of the surface could be reclaimed at small expense. The areas formerly occupied by small lakes show better soil than the ridges and higher grounds, which are generally sandy or gravelly. The chief present value of the region would however seem to be as a reserve of fuel, and timber for construction, for the more fertile prairie land bordering the Red River. A large quantity of valuable red pine (Pinus resinosa) lumber has been cut during the last few year's on dry ridges near the Pine River, which runs into Roseau Lake from the north; and similar pine-bearing highlands, will probably be found in other parts of the area. The timber cut on Pine River, was floated into Roseau Lake, and thence by the West Roseau River, to Red River. It therefore passed for a portion of its course through the northern part of the State of Minnesota. The Roseau, and probably also the Rat River, may be used in the conreyance of fire-wood to the Red River country, should the demand require it.

\section{The Red River Prairie.}

642. Of the alluvial prairic of the Red River, much has already been said, and the uniform fertility of its soil cannot be exagrerated. The surface for a depth of two to four feet, is a dark mould, composed of the same material as the subsoil, but mingled with much vegetable matter. Its dark (oolour is, no doubt, in part due to the gradual accumulation of the charred grasies left by the prairie fires. The soil may be said to lie realy for the plough, and in turning the tough thick prairie sorl, the first year, a crop of potatoes may be put in, though it is not efficiently broken up) till it has been subjected to a winter's frost. When the sod has rotted, 
the soil appear's as a light friable mould, easily worked, and most favorable for agriculture. The marly alluvium underlying the vegetable mould, would in most countries be considered a soil of the best quality, and the fertility of the ground may therefore be considered as practically inexhaustible.

643. The area of this lowest prairie has already been approximately stated as 6,900 square miles, but of this the whole is not at present suited to agriculture. Small swamps are scattered pretty uniformly over its surface, and in some places very large areas of swampy land oceur, as will be seen on reference to the large map of Manitoba lately published hy the Gorernment. The greater part of these swamps, are, however, so situated, as to be easily drained, either into the Red River or some of its tributaries, which are ustally depressed thirty to forty feet below tice level of the surface. At present the swamps in the vicinity of the set+lements are made to yield supplies of natural hay ; and until hay-grass is sown and regularly cultivated, the 'hay-swamps' will continue to be a necessary part of the economy of the settler. The wide overflow of these swamps in the spring, when the season is wet, or when the dissolution of the winter's snow takes place very rapidiy, is shown by the large area often found to be strewn with the dead shells of fresh-water molluses, chiefly of the genus Limnoca. .

644. As a measure of the possible agricultural capacity of this great valley, take one half of the entire area, or 3,400 square miles equalling $2,176,000$ acres, and, for simplicity of calculation, let it be supposed to be sown entirely in wheat. Then, at the rate of 17 bushels per acre-which, according to Prof. Thomas, is the average yield for Minnesota-the crop of the Red River valley would amount to 40,992,000 bushels.

645 . The wooled area of this lowest prairie steppe is quite small. The Red River and its tributaries are fringed with trees, of which oak, (Quercus macrocurpa, var.) elm, (Clmus Americana) poplar, (Populus tremuloides, ife.) and anh-leared maple, (Teyundo aceroides) are the most abundant. In some places the trees attain a large size, and the oak wookls borlering many of the streams are especially beautiful. Much of the best timber has, however, already been culled out, and it is yearly decreasing. without any systematic attempt for its preservation. The steamers running on the Red River are among the largest consumers. A way from the immediate borders of the streams, the prairie, though corered with a luxuriant sorl, in alsolutely trecless. It is fortunately the calie, howerer, that the Red River Valley is bordered on the east by the 
forests already described, and on the west by the wooded district of Pembina Mountain and its northern extensions.

646. The climate of the Red River Valley, like that of the whole interior of the continent, is an extreme one, the cold of winter being exceedingly severe, and the heat of the summer season also excessive. The courses of the summer, and winter isothermal lines across the continent, do not require notice here, as they hare already been ably discussed, and laid down as far as the observations now at command allow. It would seem, however, that between the Laurentian highlands on the east, and the Rocky Mountains, a great summer wave of warmth passes far to the north, reaching its highest latitude near the eastern base of the latter range; while in winter a compensating and long-continued flood of cold air invades the whole region of the plains, and the eastern and western flanking ranges.

647. The watershed between the Red River, and the St. Louis and other streams flowing into Lake Superior, forms a pretty well marked climatal line. The influence of the lake, and the high wooded ground forming a partial barrier to the north-westerly winds, renders the autumn in the latter region warmer; while in spring the ice accumulations of the lake, and wooded character of the surrounding country, keep the temperature much lower than in the Red River Valley. The temperature of the Red River country, like that of the prairies generally, depends rery closely on the direction and origin of the wind, though in years to come, when great regions of the plains have been planted with trees, much amelioration may result. A single instance-though an extreme one-may be mentioned. On the 8th of May last year, a strong south wind raised the temperature at Dufferin to $100^{\circ} \mathrm{F}$. At Winnepeg, 60 miles further north, the temperature was $94.5^{\circ}$, the mean temperature for the month being $52 \cdot 52^{\circ}$. The Red River Valley, as the lowest trough of the interior region of the continent, would also seem to serve as a channel of eflux for the cold northerly winds in spring; for immediately on passing out of it, and up to the level of the second steppe, the regetation was found to be slightly, but distinctly, more advanced.

648. The following notes taken at Dufferin in the Spring of 1874, will illustrate the adrance of the season, and serve for comparison with other localities :-

A pril 15.-General surface of the prairie free from snow, and in some places alrearly quite dry, though frozen below. Coulees holding large snow-banks. Ponds beginning to open. Ducks observed, and several of the smaller birds of passage. 
A pril 24. - Ploughing commenced, but ground still partly frozen.

" 25. - First frog heard.

“ 26. - Many ducks, geese, and cranes, flying northward.

“ 27. - Quite a concert of small bircls in the thickets for the first time. Buds of the earlier willows and poplars bursting.

“ 29. - Flies and Mosquitoes becoming abundant. Frogs noisy.

May 1.-Grass beginning to look a little green in swampy hollows.

" 8.-First thunder-storm.

“ 9.-Most of the willows, and the aspen poplar (Populus tremoloides) in full bloom. Also elm, (Ulmus Americana) ash-leaved maple, (Negundo aceroides). Sweet Coltsfoot ( Nardosmia sayittata) in Hower. First Strawberry blossom found (Fragaria Virginiana.)

" 10. - Grass beginning to assume a general green tint.

“ 18.-Mosquitoes troublesome for the first time. Many geese flying overhead, with a favouring south wind.

"21.-Grass in hollows, where the ground has not been burned over, now forming pretty good feed; where the fire has passed last autumn, though very green, still quite thin. Geum triflorum, abundant in some localities; in full bloom Anemone patens, in many places with seed already forming, sepals having fallen. Carex Douglasi, Ranunculus rhomboideus, in full flower.

" 22-The common blue Violet (Viola cucullata,) in full bloom, abundant. Viola pedata, $V$. Canadensis and $T^{r}$. pubescens, just in flower. The Serviceberry (Amelanchier Canadensis) Choke-cherry (Prunus Virginiana) Wild Red Cherry (P. Pennsylvanica) Wild Plum (P. Americana); just about to bloom. Poplar groves showing green.

649. A reference to the catalogue of plants will serve to continue this record, though after the above date, the observations for 1874 refer to the country west of the Red River Valley. The plants in flower in June, 1873, can however be found by referring to the list.

650. The following list gives the arrival of some of the more important birds in the spring of 1874 :-

Birds arriving previous to April 15th.

Corvus Americanus.-Common Crow.

Eremophila alpestris.-Horned Lark.

Spizella monticola.-Tree Sparrow.

Plectrophanes Lapponicus.-Lapland Longspur.

Circus Hudsonius. - Marsh Harrier.

Falco columbarius. - Pigeon Falcon.

Accipiter fuscus. - Pigeon Hawk.

Junco hyemalis.-Black Finch.

Collurio borealis - Great Northern Shrike.

Scolecophagus ferrugineus-Rusty Grackle.

$$
\text { April 15th to anth. }
$$

Anas boschas-Mallard Duck.

Querquedula Carolinensis-Green-winged Teal.

Turdus migratorius - Robin.

Ageleus phreniceus - Red-winged Blackbird.

Totanus melanoleucus - Greater Tell-tale.

Ergialitis vociferus-Kildeer Plover.

Gallinago Wilsonii? Snipe.

Colaptes auratus - Golden-winged Woodpecker.

Passerella iliaca-Fox Sparrow

Regulus calendulus-Ruby-crowned Kinglet 
A pril 20th to 25th.

Mergus cucullatus-Hooded Merganser.

Spatula clypeata-Shoveller Duck.

Bucephala albeola-Buffle-headed Duck.

Dendraca coronata-Yellow-crowned Warbler.

April 25th to 30th.

Fulica Americana-Coot.

Grus Canadensis-Sand-hill Crane.

Dafila acuta-Pin-tailed Duck.

Mareca Americana-Widgeon.

Fuligula marila-Scamp Duck.

Botaurus minor-Bittern.

Ceryle alcyon-Kingfisher.

Sturnella magna-Prairie Lark.

Xanthocephalus icterocephalus-Yellow-headed Blackbird.

The remaining birds appeared rapidly after this time.

May sth-Antrostomus vociferus - Whippoorwill.

May 17th-Trochilus colubris-Ruby-throated Humming Bird.

May 17th-Ectopistes migratorius-Wild Pigeon.

651. Observations comparable with those above given for the Red River Valley, are on record for three points on the Saskatchewan River, approximate to various parts of the 'fertile belt.'

652. Sir John Richardson compiled the record for Cumberland House, from which the following extracts are selected, from his own observations, in 1820, and those of Chief Factor Lewis, in 1839-40*. Cumberland House is situated in about lat. $54^{\circ}$, long. $102^{\circ} 20$, or west of the Northern end of Lake Winnepeg.

April 7.-Crows (Corvus Amerieanus) seen. Not till April 19th, in 1820.

" 8. - Snow-birds (Plectrophanes nivalis) seen.

“ 9--A Merganser seen, 1820.

" 10.-Willow catkins beginning to burst.

" 12.-Geese and Swans seen, 1820. In 1840 not seen till 20th.

" 13. -Buds of Populus balsamifera bursting 1820.

" 17.-Plovers, Grackles, and Orioles seen, and on the following day, Canadian Jays, and Fly-catchers, Frogs croaking.

"20.-Coltsfoot (Navlosmia palmata) flowering. Sap flowing in Ash-leaved maple (Negundo aceroides.)

"26.-Alder flowering.

May 1.-Anemone patens in flower, leaves not yet expanded.

"2. - A fall of snow to the depth of two feet.

"13.-Planting potatoes.

" 14.- Sowing barley, 1820. Tegumclo acervicles, and gooseberry bushes in flower.

“ 17. - Willows, gonseberries, and Aspen (Populus tremuloirtes) in leaf, 1820.

In 1840 the trees only bursting their buds at this time.

" 24. - Ulmus Americanus flowered, in 1820.

" 25.-Prunus Pennsylvanica, P. Virginiana, and Amelanchier in flower.

- Journal of a Boat Voyage through Rupert's Land, Vol, 11, p. 235. 
The Spring of 1840 would appear to have been a remarkably late one. Allowing for this, the indications of the adrance of the season, correspond very closely with those at Dufferin; leaving only a day or two in farour of the latter, though Cumberland House lies orer 300 miles further north, and 220 further west.

653. At Carleton House, in lat. $52^{\circ} 52$, long. $106^{\circ} 15^{\prime}$, the progress of the spring is illustrated, by the following memoranda of events, compiled from Sir J. Richardson's observations in 1827,* and Mr. Bourgeau's botanical notes in $1858 . \dagger$

March 13. - Sparrow Hawks, (Falco sparverius) arrived. and on the 17th several migratory small birds noticed, 1827.

“ 29. - Large flocks of Snow-birds (Plectrophanes nivalis), 1827.

A pril 1.-Many Fringillid $\circledast$ seen, and on the 2nd, Swans arrived, 1827.

“ 4.-Sap flowing in the Negundo, 1827. Not till April 10th, 1858.

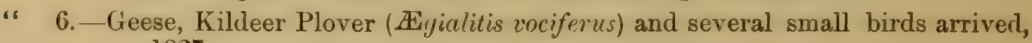
1827.

" 12.-Alder gathered, 1858.

“ 13. -Anemone patens, 1858. In 1827 not till April 22nd.

" i4.-Four inches of snow fell, 1858.

" 18. - Buds of Poplars, Willows, \&c. swelling, 1858.

" 22. - Robins (Turdus migratorius) and the Butcher-bird (Collurio borealis) seen.

“ 27.-Frogs began to croak, 1827.

“ 28. - Sand-hill Cranes (Grus Canadensis) arrived, 1827.

May 1.-The Prairie Lark (Sturnella mayna) appeared. Last flocks of Plectrophanes nivalis left for the north, 1827.

“ 2.-Red-winged Black-bird (Ageloeus plueniceus) and Rusty Grackle (Scolecophagus ferrugineus), 1827.

" 3.-Phlox Hoodii in flower, 1858. (On the 4th, 1827), also Populus tremuloides, $P$. balsamifera, two species of Salix, and Corylus Americana. (The latter with $C$. rostrata, flowered on the 7th, 1827), Equisetum arvense, 1858.

" 5.-Ranunculus rhomboideus, Viola debilis, Nardosmia palmata, and several Carices flowered, 1827.

“ 6. -White-lellied Swallow (Tachycineta biculor) and many Gulls, arrived, 1827. More species of Salix; two species of Sheperdia, and Negundo, flowered 1858. Sheperdia Canadensis, and Negundo, flowered on the 9th, 1827.

“7.-Andrusace, Viola Canadensis, Fragaria Virginiana, Astragalus (probably $A$. caryocarpus), \&c., 1858. Recurvirostra Americana arrived 1827.

" 12.-Thermometer fell to $145^{\circ} \mathrm{F}$. during the night, and nearly all the plants in flower frozen, and the season thrown back, 1858.

"19.-Viole Nuttalliana, flowered, 1827. On the 20th, 1858.

“ 20.-Amelanchier Canadensis, Betula prapyracea, 1858.

It will be observed, on comparison, that the progress of events at Carleton Inouse is distinctly in advance of that in the Red River Valley in 1874 . The difference, howerer, does not seem to be more than a week, 
and considering the grenerally admitted retardation of the spring of 1874 , may be less.

65. Still further west at Fort Filmonton, in lat. $53^{\circ} 31^{\prime}$, long. $113^{\circ}$ 17 , the progress of vegetation in the spring of 1859 has been observed by Mr. Bourgeau. The dates at which the more important plants blossomed are as follows:-

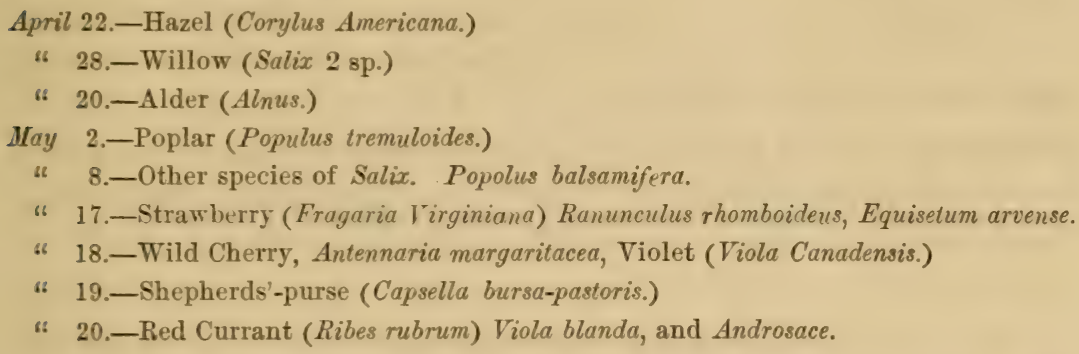

Comparing this with the spring of 1874 , at Red River, though the order of flowering does not in some cases exactly agree, it would appear to gire an adrantage of a few days to Edmonton. A direct comparison of the dates for three years at Carleton, with those of 1859 at Edmonton, shows only a day or two of difference in farour of the former. The comparisons are based chiefly on the times of flowering of the plants, which are more trustworthy than those of the arrival of the birds of passage.

655. Too broad generalizations on the results of a few seasons would be unwise, especially as the years do not correspond, but enough is known to prove the remarkably uniform progress of the spring along the sin-called 'fertile belt,' which, passing north-westward from the Red River Valley, nearly follows the Sarkatchewan to the Rocky Mountains, and will be the first region occupied by the settler. From the data now at command, I believe that the difference in advance of the spring between any of the abore four stations, is not so great as that obtaining'at the same season between the ricinity of Montreal and that of Quebec.

656. The Rerl River country does not agree with the greater area of the western plains in showing a rainfall scarcely sufficient, or altogether too small for surcessful agriculture. With regard to the Western States, thrse who have examined the matter very generally concur in stating that beyond the 99th or 100th meridian agriculture is impossible unless irrigation be adopted. There are; of course, special small areas not included in this general condemnation, but there is probably also at leant as great an area of the region eant of the 99th meridian, which does not receive sufficient rainfall. The statements concerning 
the nature of the western ferritories south of the Line, have passed through so many phases, that it is important to know that there is a a practical limit to the tide of settlement in that direction. Since it has been discorered that a great part of this region is not of the nature of the typical desert, as had been supposed, there has been a tendency, aided by the statements of interested railway and other companies, to elevate it to the imaginary position of an agricultural country. Now, however, that the crucial test of experience is being ajplied, and systematic meteorological observations are being obtained, it becomes evident that if settlement for agricultural purposes is to pass the 99th meridian, it must do so slowly, and strengthening its advance by irrigation and arboriculture. The great area based on Cretaceous No. 4, would appear to be absolutely irreclaimable.

657. In estimating the least necessary amount of rainfall for the support of cereals, so many circumstances occur to complicate the subject, that it is often difficult to arrive at any very exact conclusion. Chief among these is the distribution of precipitation with regard to various seasons. In ordinary circumstances, only that rain which falls during the spring and summer, when the crops are in the ground, is of importance. Much, however, depends on the nature of the subsoil, for, where a considerable thickness of porous material is based on impervious rocks or clays, with a nearly horizontal, or slightly basin-shaped surface, a part of the autumnal and winter precipitation, and especially the flood-water of the melting snow in spring, may also be counted on. Many considerable areas of prairie country are thus situated. The general water level has in some cases been ascertained to be not far from the surface, even in the autumn, and the moisture rising by capillary attraction prevents the entire desiccation of the surface soil. The nature of the soil here enters as an important factor.

658. It is stated by Boussingault, however, that in Egypt, where no rain falls during the period of growth, that the distribution of seventeen and one-third inches of water over the surface, during the season, of one hundred and fifty days, suffices to bring the crops to maturity. The ground is here water-soaked to begin with. In India, in a season, of the same length, sixteen and one-third inches of irrigation water are distributed, the rainfall making the amount up to nineteen and one-half inches. The evaporative effect of the air of the western plains is no douht usually less than that in the countries above named, rendering a somewhat smaller quantity of water necossary. 
659. Prof. Thomas estimates the rainfall for the Spring and Summer months, on the western portion of the plains, at only 7.34 inches; the defieiency of which will at once be apparent, whether compared with the estimates giren above; or with the rain fallin other and better known regions. During the same period, New York receives 23 inches, Cincinnati 25, Missouri 26, Michigan 18.* At the town of Winnipeg, the average fall of rain during the spring and summer months, derived from the observations of the three past years, is 15.96 inches.

660. The following detailed table of rainfall at the last mentioned locality, for which I am indebted to Prof. Kingston, gives a better idea of its distribution throughout the year, and it will be apparent that the greatest precipitation takes place at the seasons when it is most required for agriculture.

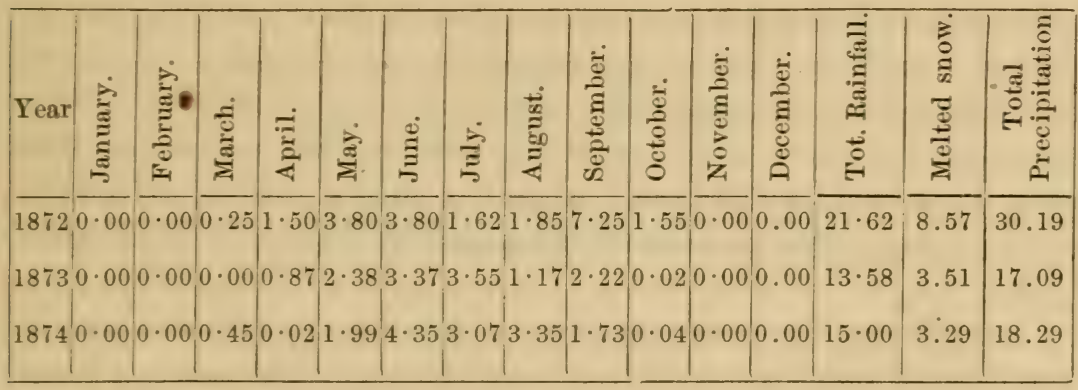

The precipitation in the Red River Valley would appear to be least near the Boundary-line, as at Pemlina the average for three years is stated to be 13.16 inches. In 1873 , it was 14.185 inches, against 17.09 at Winnepeg, while at Fort Abercrombie, 180 miles south of the forty-ninth parallel, it was about 15.5 , and at fort Wadsworth, 50 miles further south, 29.45 ; the average for five years at the latter place being $18 \cdot 95, \dagger$ or probably about the same as at Winnipeg.

661. Prof: Dana's general means of total precipitation for different areas of the continent may be compared with the above. It is estimated that the eastern portion of the continent, from the Gulf States to Labrador, including the greater part of New England, New York, and the Atlantic States, and Tennassee and Kentucky; receive 40 to 45 inches or more. Michigan 30 inches. A large part of Ohio, Indiana, Illinois, and New York, toward the St. Lawrence, 33 to 40 inches. Regions beyond the Mississippi, 25 to 15 and 10 inches. 
662. It would appear not only on theoretical grounds, but as the result of experience, that the rain-fall of the Red River Valley, assisted by the water remaining in the soil from the spring floods, is as a rule amply sufficient for agricultural purposes.

663. The question of water supply, seemed some years ago a difficult one in the Red River Valley. Great areas of level and fertile prairie, lie far from any stream, or are only traversed by coulees, which dry up completely during the summer. The structure of the country renders the existence of surface springs almost an impossibility. This apparent difficulty is, however, being solved in the most satisfactory manner ; as it is found that there are few regions where ordinary wells of moderate depth do not succeed in finding ample supplies of water; and this not only far removed from the rivers, but in their immediate vicinity, though the water level of the stream may lie considerably lower than that of the bottom of the well. The rather impervious nature of the prairie subsoil, renders it probable that these wells are supplied eithe by intercalated coarser layers, or, - as appears to be more likely-by water circulating in fissures; which formed originally by the cracking of the soil at the surface, often penetrate its homogeneous mass to a considerable depth.

664. The success of artesian wells, at Winnipeg (\$577) also tends to show that no apprehension need exist, with regard to water supply. Water is there formed in a gravelly stratum lying above the boulder-clay, and has, I believe, sufficient head to form flowing wells. It is further probable that a second water-bearing stratum might be reached by continuing the boring through the boulder-clay, to the more porous stratum which usually intervenes between it and the solid rock.

665. For the supply of the shallower wells first referred to, the water is no doubt mainly derived from that which falls during the wet months, on the surface of the prarie itself. The water obtained by the artesian wells, however, has not this source, and comes from below the most tenaceous beds of the alluvium. It is introduced, no doubt, at the edges of the more permeable layers where they (ome to the surface east and west of the alluvial valley. That there must necessarally be a considerable underground circulation of water, is rendered evident on inspecting the region near Pembina Momtain. The gaps worn in the front of this escarpment, are oceupied by streams, some of which drain considerable aroas, and are not dry even in the latter part of the summer. All these, except a few of the very largest, where they debouch on the low-level 
plain, occupy coulées at some depth below its general surface, which, howerer, gradually die out, the stream at the same time disappearing.

\section{Country of the Second Prairie Steppe.}

666. The extreme western margin of the Red River prairie, in the vicinity of the slope of Pembina Mountain, is diversitied by groves of oak, which stretch out from its base; and would no doubt, be much more extensively wooded, but for the constant recurrence of prairie fires. The front of the escarpment, and its summit, forming the edge of the second prairie steppe, are in some places thickly wooded, and always show extensive patches of timber. The forest-corered area increases northwestward. In the vicinity of the Line, the woods owe their preservation to the protection against fires afforded by the broken nature of the edge of the escarpment, by the great valley of the Pembina River, and its systems of tributary coulees, and to the frequent occurrence of patches of swamp. Poplar is probably the most abundant tree, though eren after ascending the escarpment, grores of oak are found. The wooded region has, however, in all localities suffered much from local fires; most of the trees at present living are small, while traces of a former heavy forest growth frequently appear.

667. In some places pretty extensive prairie areas occur between Pembina Escarpment, and Pembina River, and with the exception of a few localities, near the edge of the escarpment, where the Cretaceous clays are near the surface, the soil is of excellent quality, and differs from that of the Red Rirer Valley by the addition of a considerable proportion of sandy material. Swamps are here pretty thickly scattered, and some of them attain large dimensions in spring. Those parts of them which are permanently wet, howerer, bear luxurient crops of natural haygrass, and the general aspect of this region is favourable.

668. On crossing the Pembina River, the eastern margin of the great treeless plain is entered on. No woods now appear, except those forming narrow belts along the vallies of the streams, and soon, even the smaller bushes become rare. The shrubs met with are generally stunted, from the absence of shelter against the wind, and the frequent passage of prairie fires. The little thickets consist, according to situation, of dwarfish snow-herry (Symphoricarpus occidentalis) S'pircea, roses, and willows fringing the small swamps and pools. The metallic-leared silverberry (Eleagnus argentea), comparatively rare in the Red River Valley, now begins to occur in abundance on the drier areas. In the last 
week of May, 1874, the common flowering plants on this eastern part of the first prairie steppe, were; Viola cucullata, $V$. pedata, Ranunculus rhomboideus, Anemone patens then going to seed, and the whole prairie covered with its brownish woolly heads; Geum triflorum, found most abundantly near the edge of the escarpment, less common westward; Astragalus caryocarpus, becoming rapilly more abundant westward, Atennaria plantaganifolia, Lithospermum canescens, first blossoms.

669. The undulating character of the prairie between Pembina Escarpment and Turtle Mountain, and the occasional occurrence of stony and gravelly hillocks, has received mention in the chapter's on the drift. With reference to the soil west of Pembina River, nearly the same remarks apply as to that east of it. It is fertile, though not so deep or inexhaustible as that of the Red River Valley, and rests on a grarelly, drift sub-soil. Swampy bottoms bearing a good growth of hay-grass abound, but their area is quite small as compared with that of the dry ground. Toward the end of the summer, most of these swamps dry up completely, and extensive regions are then without other water supply than that derived from the streams and rivers, which lie in deep vallies, and are often far apart. I do not think, however, that difficulty would be found in obtaining water, by wells sunk in any of the lower parts of the prairie. The rainfall of this region is probably slightly less than that of the Red River Valley, but appear's to be sufficient for agricultural purposes.

670. It seems probable that at a period not very remote, a great part of this district was covered with forest trees. The humidity of the soil and climate is sufficient for their growth, and in some places, little hummocks, resembling those formed in a forest, and known as ' cradle hills' were observed. On approaching Turtle Mountain, the tenclency of this part of the prairie to reclothe itself, is shown by the occurrence of thickets of seedling poplars on the sheltered sides of the undulations, wherever the fires have not passed for a few years. Between Pembina River and Turtle Mountain, and especially toward the latter place, the deep narrow paths, or ruts, made by the buffilo when travelling, are still quite apparent; though the animal has not been known so far east for many years. They have here a remarkably uniform north-west and south-east direction.

671. The water of the swamps and ponds of this part of the prairie is generally sweet, but one distinctly saline lake was seen. It had not the thick fringe of grasses and sedgers of the other ponds, and here, for 
the first time, the Salicornea was met with in some abundance. There were also many dead shells of Limnaa, and Planorbis parvus; but whether these molluses lived in the saline water, or were washed thither from some neighboring swamp, I was unable to determine.

672. The extent and general contour of Turte Mountain have already been described in another connection (\$511). Forming as it does, a more or less thickly wooded area, which may be estimated as oror 300 square miles, it cannot but be a valuable nucleus for the utilization of the surrounding treeless plains; serving as a supply of fuel and building material, and as a refuge for wintering stock, which during the summer has been herded at large over the prairie. Though the elevated and broken area of the 'mountain' is pretty nearly equally divided by the Line, the northern half is more uniformly covered with woods, and probably embraces two-thirds of the forest area. There are also large regions of the so-called mountain, which, though more boldly undulating than the prairie, show good soil, and will erentually be cleared for agriculture. There are indications that this wooded area receives a much more copious rainfall than that of the surrounding country. The 'mountain' is now the head quarter's of a large band of Sioux Indians, many of whom were concerned in the Minnesota massacre. They are a rather good looking and well-disposed race, and derive a moderately comfortable subsistence from hunting the moose, wapiti, \&c.

673. The wood is chiefly poplar ( $P$. tremuloides, $P$. balsamifera, \&c.) Oak (Quercus macrocarpa) howerer, occur's abundantly along the margins of the forest, and forms groves on the ridges, or grows interspersed with other trees. White birch (Betula alba) is abundant, though not forming large groves, and black birch (B. lenta) also occur's. The ash-leaved maple, or 'box elder' (Negundo aceroides), and the elm (Ulmus Americana) are also found, the latter attaining considerable dimensions in some of the more sheltered vallies. The largest poplars observed must hare been over two feet in diameter at the base, and of gord height. The average size in many groves is about eighteen inches. The oak and birch are seldom over two feet in diameter, and the latter are generally much less; but growing in thick masses, and rery tall. Most of the swamp are grassy, and would yield excellent hay. They are generally finged thickly with willows of diflerent spereses. The mulerwood is composed of hazles (Corylus Americuna), choke cherries (Prunus Virginiana), thorms (Cratorgus coccinea), roses, rasploerries (Kulus strigosus), \&e. T'eas and retches are atumdant, and ocror with the fire- 
plain. Last year, this region was passed over during the last days of September and first of October, and had then a general green tint, the grass being fresh and good. The short prairie grass, however, eren when dry, proves nourishing foor for animals, and is preferred by them to that of the swamps and hollows.

683. West of Turtle Mountain, the country is unquestionably dryer than before. The short buffilo-grass (Bouteloua oligostachya) becomes alundant, and it would appear at least doubtful, whether the rainfall over much of this region is sufficient for the maturing of crops, with a soil and subsoil too light to retain much moisture. Irrigation, though much talked of as a remerly for the deficient rainfall of many western regions, is only applicable o ier those comparatively small districts, where water can be obtained at a sufficientelevation. Most of the western rivers $f$ ow in rallies much depressed below the general level of the plains, and haring a very small rate of descent, camnot he used in this way. It would appear that vast areas of the western plains, south of the Fertile Belt of the Saskatchewan region, and west of the Missouri Coteau, must remain as pasture grounds, for which they are in great part well fitted.

68t. The precipitation during the summer months, on these great plains, appears to be almost wholly of the nature of local showers, accompanied by discharge of electricity. The extreme uniformity of the surface of the country,-when the weather is settled-allows a well marked meteorological cyele to recur. The mornings are generally clear and often completely cloudless, but as soon as the sun's heat begins to he felt, small cumulus and cirro-cumulus clouds appear, produced by local ascending currents from the heated surface of the ground. These growing continually larger, and more numerous, drift with the prevailing wind-which is generally westerly-and about three or four o'cluck in the afternoon, small local thunder storms are developed. Several of these may often he secu at one time, and though occasionally the clouds coalenee to form larger storms, this is comparatively rare. During the night the storms gencrally dissifate, and equilibrium is restored before dawn.

655. It would keem that the character of the second prairie plateau where crossed by the forty-ninth parallel, is that of much of the northcron part of this areat steple. While its more firtile eatstern border rapidly expands northward, its south-western ence appears to become in the vicinity of the Qu' Appelle, and South Saskattchewan Rivers, even drier and less mviting. 


\section{Country of the Third Prairie Steppe.}

686. A general description of the Missouri Coteau, is introduced more appropriately in connection with the drift deposits. (\$522 et seq.) The strip of broken country embraced under that name, from where it crosses the Boundary-line to the Elbow of the South Saskatchewan, has an area of about 7,500 square miles; of which the greater part must always remain unsuited to agriculture, from its tumultuous and stony character. It would, however, be an excellent stock raising district. Though some of the steeper hills are but scantly clad with regetation, a good growth of short nutritious grass covers most of the surface ; and swamps and sloughs with excellent hay-grass, are scattered everywhere. In its physical features the Coteau resembles Turtle Mountain, and like that place would no doubt naturally be thickly wooded, but for the prairie fires, which here sometimes run hundreds of miles in the dry weather of the autumn. As it is, the want of wood is one of the most serious drawbacks; and animals fed orer these hills in summer, would require to be wintered in some of the river vallies to the north, or in the wooded ravines of the Tertiary plateau to the south.

687. A sample of the efflorescent saline matter, of one of the 'Alkaline' lakes of the Cotean, gave on analysis, the following result :-

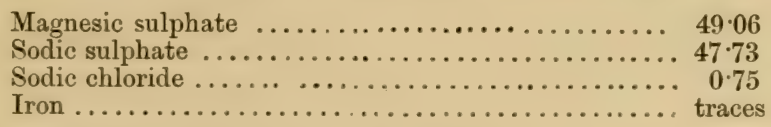

The iron occurs as protoxide, and appears to be protected by organic matter present in the mass. A qualitative examination of a similar saline incrustation from the Souris Valley, near Wood End, showed the presence of magnesic and sodic sulphates, only. A small quantity of this saline matter or ' alkali' is not found to be injurious to crops, in the Western States, where sufficient moisture exists; nor does it appear to be detrimental to the growth of grass.

688. South and west of the Coteau, lies the great plateau of the Lignite Tertiary, which may be said to begin about the 350 mile point, and extend as a well defined table-land, as far as White Mud River-a distance of 115 miles-in the vicinity of the Line. Its form is very irregular, but its area may be about 12,000 square miles. The soil of this plateau, appear's as a rule to be of a fertile character, but the indications are that the rainfall, except in a few favoured spots, is too small for the growth of the ordinary crops. Its elevation also, no doubt, renders it 
more sulject to early and late frosts, than the prairie to the east, though the winter is probably not so revere as that of the Red River Valley. On reaching this part of the third platean in June of last year, the vegetation-from a comparison of the flowering plants-appeared to be about a week behind that of the second steppe. The platean of the Tertiary is for the most part, only adapted for pastoral occupation; but being covered with a good growth of grass, is well suited for this use. The strip of country between the plateau and southern edge of the Cotean, partakes in some measure of its character, but has a less favourable appearance.

689. An important advantage of this plateau, is the existence along its edges of sheltered ravines and vallies, containing groves of poplar; and alio the presence beneath it of great deposits of lignite coal. In one of these sheltered valleys, the half-breed settlement known as Wood Mountain, is situated. No cultiration of the ground has been attempter by the few families frequenting the place, and its prosperous days are already over, as the buffalo, on which its existence depends, now rarely come so far east. It is, in fact, merely a base for a certain number of hunters and traders, who have found it convenient to erect wintering shanties there.

690. South of the platean, as far west as Wood Mountain, the region draining to the Missouri, is also based on the Tertiary, and generally bears a close, short growth of grass. Beyond Wood Mountain, the low ground, both to the north and south of the platean, is based on the Cretaceous clays, and is, in most places, dry and barren. The 'grease-wood' (Sarcobatus) and other peculiar chenopodium., now appear in the flat, clay-lottomed vallies of the streams; and mary varieties of 'sage' (Artemisia), and other shrubby composita are found. The disc-leaved cactus (Omuntia Missouriensis), in some places forms extensire beds, and in the last week in June, was found to be in full flower. The drier slopes, which are scarcely capable of supporting a sod, show among the stunted grass Selaginella rupestris, and a small species of lichen. Many peculiar southern, or extreme western plants, were here met with for the first time, and here also the 'jack rabbit,' and 'sagge cock ' (Centrocerus urophasianus) find their eastern limit.

691. The White Mud River, or Frenchman's Creek, may at present he considered the eastem limit of the buftalo, in this lattitude. During the last sixteen years, their front has heen driven back, in the ricinity of the Tine, over two hundred miles, and it is probable that their northern limit has been contracted to at least a like anount. 
692. West of White Mud River, to the 505 mile point, an undulating prairie is passed over, resembling in its regetation the surfice of the Tertiary plateau. It is deeply drift-covered. Beyond this point, an outlying portion of the Tertiary platean stretches for about thirty miles. It is much eut up by ravines, and sometimes very stony, but is covered in general by a close sod, and shows a few swamps with good grass.

693. There is evidence that over the whole eastern part of the third prairie steppe, and especially over the Tertiary plateau, the season of 1874 was an exceptionaily dry one. Grasses on the drier hill-sides, which had ripened their seeds the season before-as eridenced by the seed stalks-in $187+$ showed no flower, and eren the leaves were scarcely green.

694. Beyond this portion of the Tertiary platean, an arid plain stretches with little interruption for fifty miles, or nearly to the Milk River. It also extends far north-westward toward the Cypress Hills, and appears to coalesce, along their western front, with a similar desert region, which-according to Palliser-exists to the north. It appear's to be irremediably sterile and usele.ss, being based on Cretaceous No. 4 , and in great part composed of the debris of these rocks. ( $\$ 351$.) In early spring it is evidently, in many places wet, but in summer, dry, hard, and fissured, and scarcely supporting a sol. It is traversed by the rallies of the East and West Forks of Milk River, which rise in the ricinity of the Cypress Hills; but both the main streams and their tributary coulées become nearly dry before the end of the summer.

695. The western limit of this plain, is formed by a strip of more elevated land, lying betwen it and the Milk River, and about five miles wide. This is again bared on the Lignite Tertiary formation, and shows a uniform. short sod; with some lakes and swamps, surrounded with fine hay-grass, along its eastern border.

696. Here, during July and August of last year, the greater part of the 'Big Camp' of the half-breeds, wis situated. The hunter's and trader's in this region congregate for mutual protection, and form, as it were, a tribe among the Indians. They live under no law or restraint, other than that imposed by necessity and by the general consent, or by the priest who accompanies them. Spending the summer at large, in the neighbourhood of any district which happens to be well stocked with buffalo, they fall back eastward for winter quarter's. A few of them going to Wood Mountain, but most to the White Mud River, south of the Line, near a traling post known as Fort $\mathrm{N}$. J. T'urnay. A compara- 
tively small proportion of the robes obtained by these people, find their way to Wimmipecr most of the trate being carried on toward the

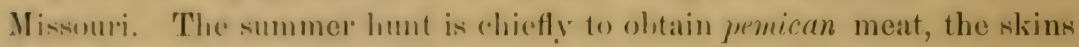
of the buthilo killed being frepuently wasted, In the autumn and early winter, when the skins are prime, roles are the chief olject. The Indians, though some of them are friently to these half-breeds, and glad enough to trate with them, are naturally jealous of their hunting, and slaughtering lufialo for themselves. In July last, the 'Big Camp' consisted of orer two hundred tepees, most of them of dressed skin, like those of the Indians, lut some of canvas. Every family owns carts, at least equal to in number to that of its members; and when the camp is macle, these are arranged in a circle, to form a 'corral' for the horses; the tents being pitched round the whole. The total number of horses possessed by the camp was stated to be about 2,000, valued at from $\$ 20$ to $\$ 100$, according to their aptitude in buttalo running. A few weeks before our arrival, the half-breeds had been in the Cypress Ifills, and had there assisted, or countenanced, the Sioux in a fight with the Blackfeet, in which eight of the latter tribe were killed. The camp is assiduously guarded, to prevent surprise or horse stealing.

697. From what I could learn, I believe, that at the present rate of extermination, twelve to fourteen years will see the destruction of what now remains of the great northern hand of buftalo, and the termination of the trate in robes and pemican, in so fur as regards the country north of the Missouri River.

698. Westward from the Milk River, the infertile Cretaceous clays do not recur, the country boing based on the Lignite Tertiary. To the lase of the East Butte, the surfice, though not of the same desert charactor as that met with east of Milk River, is covered by a short, thin sod only, and is in many places stony also. The unfivourable appearance of all this region, does not ariseso much from any deficiency in the soil itself, as from the alsence of sufficient moisture. The vegetation, in fact, depends chiefly on the saturation of the ground ing the water of the molting snow, and spring rans; and, when this is exhausted, is brought to an end ats eflectually as if hy the onset of winter, though long before that event.

699. The general appearance and extent of the Sweet Grass Hills, or Three Butles, have alrealy been noticel (\$303.) Their height and mass is sufficient to canse the formation and arrest of clouds in their immediate ricinity, where the ranfall is in conseguence much more copious. 
These mountains, and the broken ground around them, form a farourite haunt of the buffalo; which here find abundance of food and water. The spring, arising from some parts of the Buttes are very eol ious, and form streams, which on leaving the shelter of the wooded rallies, and issuing on the plains, are rapidly absorbed by the dry soil and atmosphere-at least in the summer season. One of these was observed to be a rapidly flowing brook during the night and morning hour's, but in the afternoon became quite dry. The timber of the Buttes is chiefly pine, ( $P$. Banksiana ?) much of it has been burned, but it shows a tendency to renew itself. The trees are not of great size, and generally in somewhat inaccessible parts of the mountains, but cannot be considered unimportant in a country so treeless. A few of the plants, found at elevations above 6,000 feet in the Rocky Mountains, appear also on the summits of the Buttes.

700. The country surrounding the Buttes, is said to have been for a long time a neutral ground between various hostile tribes of Indians. That it has been so, is eridenced by the almost complete absence of buffalo bones in their neighborhood, and the rare occurrence of the circles of stones, marking camping places. The region is at present a debatable ground between the Blackfeet, Peagans, and Bloods of the west; the Sioux and Assineboines of the east, and the Crows and other tribes of the Upper Missouri. It is not passed through save by war parties, strong in numbers, and travelling rapidly, Ten miles north of the central Butte, the bodies of orer twenty Crow Indians were found, unburied, on the scene of a conflict.

701. From the Sweet Grass Hills, toward the Rocky Mountains, the country improves in appearance, and shows evidence of a greater rainfall. The cactus, grease-wood, and Artemisia cease to appear. To the Second Branch of Milk River-a distance of 55 miles-the country is generally much broken, but show's remains of a former more elevated surface, in somewhat extensive flat-topped hills, which, when ascended, are found to be nearly of equal height, and show much drier and more gravelly soil than elsewhere found in the region. There is usually a close, thick growth of grass, and the swamps and sloughs, which are numerous, generally hold grasses and Carices to the exclusion of the rushes formerly most abundant. The watershed region, from the Second Branch of Milk River, to the St. Mary River, is of a similar character.

702. The portion of the fertile belt fringing the eastern side of the Rocky Mountains, in the neighbourhood of the forty-ninth parallel, is 
about twenty-five miles in width. On crossing the St. Mary River, a very marked and rather sulden change for the better is observed. The surface, at the same time, becomes more undulating and broken, and is quite hilly before the actual base of the muntains is reached. It is now covered with a thick vegetable soil, supporting a luxuriant growth of grass; and wherever the fire has spared them, trees are to be found in all stages of growth. Many plant, last seen in the neighbourhood of Pembina Mountain and the Red River Valley, and which across the more arid plains have been lurking only in sheltered hollows and damp, coulées, now re-appear over the surface of the country generally. The rivers and streams, also, entirely change their character, and instead of flowing sluggishly with a milky opacity, now hold clear blue water, r'un swiftly over stony and gravelly beds, and are filled with trout.

The thickets are generally of poplar, but in the immediate vicinity of the mountains show birch and coniferous trees also. The Elocagnus found in stunted thickets on the plains, now forms a well-grown bush, and the vallies and hill-slopes in August were gay with various species of Aster, Solidago, Epilobium, Castilleia, and with Geranium Fremontii.

703. I was informed by traders, who had wintered in the vicinity of St. Mary River, that the snow does not lie here for more than about three months, the temperature also being much milder than in localities further east. 'It would appear probable, however, from the altitude of the country, that early and late frosts may shorten the season agriculturally, to a greater extent than indicated by the above statement. As the Younted Police are, I believe, at present wintering in this neighbourhood, more anthentic information on the climate will no donbt soon be forthcoming. The buffalo are said to frequent the foot-hills of the mountains in winter, in great numbers, and their remains were found in the South Kootanie Pass, as far as the last patch of meadow land, on the east side of the watershed.

704. For this part of the country, the mountains form an inexhaustable source of wood for construction, and also for fuel, though extensive areas are known to he underlail by coal. The timber in the mountains is chiefly coniferous, and not of large size, except in certain sechuled vallies. A species of pine, somewhat resembling the Banksian pine, but which I believe to be Pinus contorta, is found pretty abundantly in some localities, expecially on the gravel terraces, and valley bottoms. It would afford good straight timber, but does not attain a great girth. The Douglas pine (Abies Domylusii), also occurs on both sides of the 
watershed, but is generally small. The largest timber observed, was in some of the higher and more secluded vallies. The trees resembled the black spruce, but were probably Abies Engelmanni. It is unnecessary here to enter into detail with regard to the alpine and aretic flora of the higher parts of the mountains. I was only able to devote a few spare hours to the collection of plants, but a number of very interesting forms were obtained, and will be found catalogrued in the appended list.

705. The foregoing descriptions will show that the character of the third steppe is much more raried than that of either of the others; but also that no part of its southern extent compares favourably with the land of the Red River Valley, or that of the best parts of the second steppe-always excepting the land along the immediate base of the mountains. At the same time, the explorations in connection with the Boundary Survey have served to show, that this country, formerly considered almost absolutely desert, is not-with the exception of a limited area-of this character; that a part of it may be of future importance agriculturally, and that a great area is well suited for pastoral occupation and stock farming.

706. The fertile region at the base of the Rocky Mountains, according to Palliser and other explorers, narrows somewhat about fifty miles north of the Line, but then spreads eastward, while the mountains tread to the west, and includes a great area of fertile country in the vicinity of the North Saskatchewan, the more northern position of which is more than compensated for, by its decreased altitude, and the lower and more open mountain passes to the west.

This fertile belt to the north, must form the basis for the settlement and utilization of the western plains. The cactus-covered desert tract does not seem to stretch far to the north of the Line; but there is an extensive region of the third prairie steppe south of the fertile belt, which is described as haring a poor soil, with scanty herbage, and no wood, except on northern exposures.

707. With regard to the climate of the third prairie steppe in the vicinity of the Line, not much information is at command. In two places, I was able to observe the temperature of copious springs, flowing out at such a depth from the surface, as to render it probable that their waters were not far from the mean annual temperature. On both oceasions, the thermometer indicated $466^{\circ} \mathrm{F}$. One of the localities is near longtitude $106^{\circ} 30^{\circ}$; the other at $113^{\circ}$. The mean temperature of 
the grreater part of Montana, to the south, is estimated to be $48^{\circ} *$; showing, if the observations are to be trusted, a lower mean temperature by two degrees on the forty-ninth parallel. Climatal lines, however, are not very strict or well marked on the western plains, and it is probable that the climate of a great part of the third steple nearly coincides with that of northern Montana, where more continuous records exist than any available for the region to the north.

708. The mean temperature for each month at Fort Shaw, one hundred miles south of the Line on the 112th meridian, is, in the following table, placed side by side with that of Winnipeg $\dagger$ :-

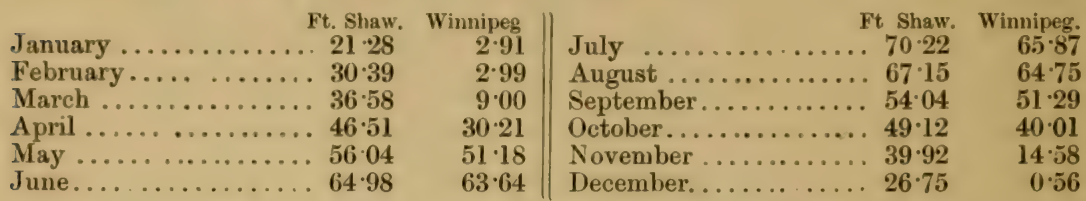

The mean annual temperature of Fort Shaw is 4.7 .33 , while that of Winnipeg is 32.59 . The temperature of the six warmer months, May to October inclusive, in northern Montana and the Red River country is pretty nearly equal, showing a balance of only about four degrees in favour of the former. The six winter months are, however, very much colder in the eastern locality; and this notwithstanding the fact that Fort Shaw is about 3,000 feet higher than Winnipeg. Thus, while the mean annual temperature of the Red River Valley stands about 14 degrees lower than that of Montana, this is not brought about by any great deficiency of summer heat, but by the long continuance of steady cold weather in the winter. The extreme of winter cold is probably almost as great in Montana as in the Red River country, the thermometer at Deer Lorlge showing a minimum of $-30^{\circ} \mathrm{F}$. in several years, but the cold weather is not of long continuance. The snow fall is rery light, and seldom exceeds a few inches in depth at any one time. The total annual precepitation-mean of two years-amounts to 8.95 inches only.

As a pastoral and stock-raising country, the higher mean annual temperature gives the third plateau an important advantage over the region to the east.

U. S. Geol. Surv. Territ., 1872, p. 811.
† Temperature of Fort Shaw from the mean of two years. U. S. Geol. Surv. Territ, , 1871, p. 266, That of Wimineg, from three years observations, is kindly supplied by Prof. Kingston. 


\title{
CH APTER XII.
}

\section{CAPABILITIES OF THE REGION WITH REFERENCE TO SETTLEMENT.-(Continued.)}

\begin{abstract}
Causes Deterrent to Setrlement and Agriculture. - Future of the North-west -Climate-Wintering of stock-Difficulty of access-INROADS of THE GRASSHOPPE R-Origin of the insect-Its range-The young and winged swarmsIts flight-Y Years when it has appeared in Manitoba-Means of preventionTHE SUPPLY OF WOOD IN THE NoRTH-WEST-The plains never entirely wooded-Causes tending to destruction of forest-Causes of treelessness of prairie-Dryness of soil and atmosphere-Causes of drought-Causes of greater rainfall on wooded areas-Facts tending to show progressive desiccation in the west -Similar drought brought on elsewhere by destruction of forest-Amelioration of climate by planting forest-Treeless area of the continent-Normal area of country which should be in forest-Successful growth of trees in the west-Scheme for the planting and preservation of trees.
\end{abstract}

709. The description of the region in the vicinity of the Boundaryline, given in the last chapter, may serve to indicate those areas best fitted for settlement, in that direction. Accurate and detailed information of the same kind is now in process of accumulation over a great part of the North-west, and it will ere long be possible to estimate the probable value of the whole interior portion of the Dominion. Facts as at present known, appear to show, that after the fertile valley of the Red River is taken up, the progress of settlement will follow the valley of the Saskatchewan Rirer to its heal, and then spread north and south along the eastern base of the mountains; that the great pastoral area of the plains south of the Fertile Belt, will be entered from the north, while the northern forests and lakes will become tributary in their products to the settled region, from the other side. To a certain extent this progress of settlement will regulate itself', and will be a natural growth taking advantage of the capabilities of the country, but there are certain adverse influences, which will require early and close attention, if this grow th is to be as rapid and sound as it should. It is proposed here-without enlarging on the great advantages of the North-west-hriefly to discuss some of these, and to indicate the bearing on them if the results of experience gained in other regions similarly situated.

710. Manitoba, and a great part of the North-west, has before it the future of a great agricultural country, and enough is alrearly known to show that orer immense areas mines of metallic minerals cannot be relied 
on as somres of wealth. It is improbable that metallic ores, other than those of iron, will be found over the anea of the plains, underlaid as they are by the soft and little disturhed rocks of the Mesozoic and Tertiary. Gold, it is true, is known to exist in small quantities in the drift materials of rome localities, * and may here and there be found in remunerative proportion, but its production will probably never assume nuch importance. The great area covered by the coal and lignite-bearing formations, as they are at present known, insures a supily of fuel for all time, to the settlers of the western portion of the plains, but coal mining will only become an important industry, when the country has been opened up, and there are extensive agricultural communities depending on it. The great present object of those interested in the North-west, should therefore be to further agriculture, and the interests of the agriculturist and stockfarmer, in every possible way.

711. Climatic conditions have already received some attention, and it is not here proposed to discuss them further. They have a very direct bearing on the utilization of the country, but for the present they must be taken as they are, and the special problems presented in each district will be solved by experience rapidly acquired. The severity of the winter season is certainly one of the greatest disadvantages of the North-west, as an area for settlement, but, agriculturally, the intensity of the cold is not so much a matter of importance as its duration; and where-as in this region-the length and heat of the summers are known to be sufficient to mature all the ordinary crops, it may, to a great extent, be disregarded. For stock raising, both the duration and intensity of the cold must be taken into account, though eren here the former is the more important. I am aware, that in this region, horses and cattle are at present frequently allowed during the winter, to feed themselves as best they may. They generally survive, and often do not look much the worse for their harel treatment; but this haphazard plan will not find farour with careful farmers. In the Rer River country, animals to which proper attention is shown, require additional food to be supplied to them, either in the form of hay or roots, for at least six months in the year. For the cultivation of the latter variety of crops, the soril of the Red River Valley appears to be excellently suited.

712. In northern Montana, the eonditions are somewhat different, and stock is there systematically allowerl to winter out imlependently, or with only rery slight aid in the way of feed. Similar conditions of

- Report of Progress, Geol. Surv. Canada, 1873-74. 
climate no doubt prevail over the greater part of the third steppe. To rear horses in this region is very easy, and the Indians and trader's consequently possess large bands of fine, though small animals, which they value at a low rate. Mr. Selwyn, in adrocating the idea of inducing the Indians to become stock-raisers, and cattle-herders, as the buffalo become extinct, mentions instances of stray cattle wintering out successfully on the North Saskatehewan.* In July of last summer, I saw a band of cattle in the ricinity of the Line, south of Wood Mountain, which had strayed from one of the U.S. forts to the south. They were quite wild, and almost as difficult of approach as the buffalo; and notwithstanding the fact that they had come originally from Texas, and were unaccustomed to frost and snow, they had passed through the winter, and were in capital condition.

713. In the future, when the North-west is somewhat thickly settled, the long period of the year during which out-door agricultural work is impossible, will tend to foster the growth of manufactures; and expecially of mills and factories for the elaboration of the crude materials produced in the country itself. Then only will the full advantage of the enormous lignite and coal deposits, and water-power be developed.

714. The three most important remaining natural deterrents to the settlement of the North-west appear to be:-Distance from markets, and difficulty of attainment by the immigrant; the grasshopper visitations; and the treelessness of great areas of the plains, and general scarcity of timber.

715. The first of these difficulties, will soon be to a great extent remedied, especially as regards the access of immigrants. The remoteness of markets will, however, continue to be felt in some measure, and when the Incal demand for the cheaper grains, and heavier food stuffs, is satisfied, stock raising and the production of light and valuable crops, which will bear a considerable charge for transport, will remain the most profitable for a long time to come. Though wheat may be easily grown in immense quantity, the profit to the farmer must be light, as long as the cost of transport forms so large a part of its total value at the eastern ports. Wool and dairy produce will demand attention, and for the growth of flax, hops, \&c., a great part of the western regions, -and especially of the Red River Valley-is well suited. Flax and 
hemp have already been "ultivated with success in the Red River country, in former years, the IIudson's Bay Company granting a small bounty for their production. Their growth was discontinued chiefly, it would seem, from the want of proper milling facilities.* The natural limit of agricultural rettlement to the west, render's it certain, that as the eastern regions are more exclusively taken up for this purpose, the western plains, unfit for other use, will become more valuable as pastoral lands.

716. The inroads of the western deva: 'ating grasshopper, or locust, must be counted among the greatest discouragements to the settler, and in some of the newly occupied Western States have caused actual ruin and famine. The grasshoppers forming destructiveswarms in the region of the plains east of the Rocky Mountains, appear to belong to a single species, which has been called Caloptenus spretus. This insect much resembles the Caloptenus femur-rubrum, or red-legged grasshopper, which in exceptional years has been destructive to crops in rarious parts of the Eastern States. $\dagger$ Spretus differs, however, from femur-rubrum specifically, and can not only be distinguished from it in form, but possesses to a far higher degree the instinct and power of migration; circumstances sniting it to the almost boundless plains which it inhabits. It is not here intended, howerer, to enter into a zoological description of the insect, for which Prof. Thomas' Synopsis of the Acridide; or the Seventh Annual Report on the Insects of Missouri, by Mr. C. V. Riley, may be referred to.

717. The locusts are not natives of the eastern region of the plains, where their devastations are most severely felt. They come from the far west as a winged swarm, and where they happen to be when they are mature, their eggrs are cleposited. From these eggs, in the ensuing spring, the young come forth, and cause often more complete destruction of crops than the winged arlults; for they attack the young grain, eating it down an fast as it grows. The young so produced, however, appear not to have so much vitality as those coming fresh from the west. A great part of them may reach maturity and migrate some distance, but their progeny in the third season seems rarely to give much trouble.

718. The real home and permanent somre of supply of the locusts, hats been a question giving rise to considerable discussion. Mr. Walsh and others hase supported the theory that they rome from the alpine

-Prof. Hind, Assineboine and Naskatchewan Exploring Expedition.

1. See 8. H. Sendder in Iluyilen's Final Report on Nebraska, p. 252: also, Harris' Insects Injurious to Vegetation, 1. 165. 
regions of the Rocky Mountains, and issuing from their vallies and canôns, spread eastward over the plains. It seems, however, to be now very generally conceded, that the high and dry plains along the whole eastern base of the mountains, are their chief breeding places; to which in British America may, I believe, be added the entire area of the Lignite Tertiary plateau, and probably also the greater part of the third great prairie steppe.

719. The range of the insect (meaning by that term not only their chief breeding places, but the whole area known at one time or other to be orerrun by them) is not bounded to the west by the Rocky Mountains, except where these constitute, as in British America, the unbroken firont of the western region of forest. They spread across the watershed in Colorado and Utah, and appear to have been observed by Mr. Byers in the valley of the South Fork of the Columbia River, near Fort Hall. Southward, according to Prof. Thomas, they extend as far as the Raton Mountains and into Texas; while to the east they have spread to the prairie country of the Mississippi, and have been known, on more than one occasion, to penetrate far into Iowa. The entire Province of Manitoba is liable to their incursions, and they have penetrated in swarms as far east as the Lake of the Woods. Northward, they are probably only limited by the line of the coniferous forest, which approximately follows the North Saskatchewan River.

720. The eggs of the locust are not deposited promiscuously, or uniformly distributed over the surface; whether in their native breeding places or in their eastern colonies. High and dry situations, with hard soil, are preferred. Thus, when the young are hatched, from this original disposition of the eggs - and no doubt also from a natural gregarious tendency-they form colonie;, which are often widely separated. These I have seen on the third prairie plateau in 1874, and the young insects are also noticed to be thus distributed in the Red River country this year,* and elsewhere, wherever they have been carefully observed. The insects do not seem to travel far from their hatching place for some days; but when they have increased somewhat in size, legin to move forward together, and in a determinate direction, though not by any means invariably from north-west to south-east. Dr. Studley, of Kansas, has experimented on the unflerlged grasshoppers, by sifting flour on them in the morning, and measuring the distance travelled over by the insects so marked at night; and finds that 
their rate of progress is from one-fourth to one-half mile per diom: In the last week of July, 1873, I met the grasshoppers hatched out in the northern part of the Red River 'ountry, travelling southward down the valley. They were in the pupa stage, and appeared to be advancing more rapidly than the above measurement would indicate. Their fixed determination to travel southward was remarkable.

721. On obtaining their wings, the grasshoppers prepare for flight, and only wait the advent of a favouring breeze, to set out in the direction which their instinct leads them to pursue. On July 12 th of last year, I observed swarms ready for flight on the high plains of the third plateau, west of White Mud River, (long. $107^{\circ} 35^{\prime}$.) The day was hot and calm, and though many of the insects were on the wing at all altitudes in the atmosphere, they were following no determinate direction, but sailing in circles, and crossing each other in flight. The greater number were hovering orer the swamps and spots of luxuriant grass, or resting on the prairie. A slight breath of air wonld induce them all to take to wing, causing a noise like that of the distant sound of surf, or a gentle breeze among pine trees. They appeared ill at ease, and anxiously waiting a favorable wind.

722. The grasshopper has not intrinsic power of swift flight. It can bear itself up on the wing for a long time, but depends chiefly on the wind for propulsion, and travels fast or slow according to its motion. It flies only in the sunlight and during the warmer hours of the day, coming to the ground about 4 p.m., if the day be fine; or at any time when a heavy clond cover's the sun, or on the approach of a storm. Nor does it fly in any direction the wind may happen to blow, but has the extraordinary instinct to travel only on those days when the wind may favour it in its appointed course. This, as already mentioned, is generally south-eastward, from its high-land breeding grounds to the lower and more fertile eastern regions. It is not by any means invariably so, however; and some of the broods hatched this spring are already showing a similar persistent desire to move northward, while yet in their full strength and vigour. When the locust reaches nearly its eastern or southern limit, the organization of the swarms appears in great measure to fail, they move in almost any directon with the wind, or remain long on the ground where food is abundant. After the deposit of eggs, which in the normal equence of events next happens, the insects are much exhausted, and soon die, though often making a last short fickle flight.

723. Such is the usual life-history of the insect. The causes which 
fortunately prevent its increase and continued abode in the eastern prairie region, appear to be chiefly climatic. It would seem that the locust requires to bring it to healthy maturity the dry warm climate of the higher plains. In the eastern colonies the young are sometimes hatched in considerable numbers by a mild autumn, and perish in the succeeding winter. A relapse of cold and damp weather after their hatching in the spring, causes the death of great numbers. The eastern brood is a weaker one, and is accordingly more subject to the attacks of disease, and parasites. Mr. Riley catalogues four of the latter.* The two first (Trombidium sericium, and Astoma gryllaria) are mites; the two latter (Tachina anonyma, and Sarcophaga carnaria) flies, the larvæ of which feed on the grasshopper and lire within it. All these seem to have appeared in connection with the swarm of 1874 , and their progeny of this spring, in Manitoba. The Trombidium or silky mite attacks the egg. The Astoma attaches itself to the mature insect, generally under the wings.

724. The first appearance of the locusts in formidable numbers in the Red River Valley, seems to have been in the year 1818, six years after the foundation of Lord Selkirk's colony. They then arrired on the wing in the last week of July, and destroyed nearly everything but the wheat crop, which partly escaped, being nearly ripe $t$ Eggs were deposited, and in the following spring, the wheat and all other crops were destroyed as fast as they appeared above ground. Eggs seem again to have been deposited in 1819, and in 1820 the crops are said once more to have suffered greatly. The next recorded incursion is that of 1857 , from which it would seem that for 36 years the insect had not appeared. In 1857, the crops are said to have been so far advanced as to escape great damage, but eggs were reposited, and in 1858 all the young grain was devoured. In 1864, they again appeared, and left their egos, but neither the adults, nor the young of 1865 were sufficiently numerous or widespread to do much damage. In 1867, numerous swarms poured in, but did little injury, the crops being too far adranced; their progeny in the ensuing Spring, howerer, deroured everything, causing a famine. They again appeared in 1869 , the young in 1870 doing much harm. In 1872, fresh swarms arrived, but as usual, too late to do much rlamage to wheat. Eggs: were left in abundance in the northern part of the Province, and in the following Spring the farmers over considerable districts did not sow. 
In 187t, winged swarms again came in from the west, arriving earlier than usual, and inflicting great injury on the crops in some districts.ligns were deposited in almost all parts of the Province, and the result has yet to be seen.*

725. To the question: what can be done to prevent the ravages of these insects? The answer is by no means so satisfactory as could be desired; yet it appears that much may be done by combination, and the cultivation of a self-reliant spirit among the frontier settlers, aided bysuch wise lecrislative measures as may be framed, and carried into execution with a brealth commensurate with the territory to which they should apply. It is now known that a very great area, comprising the chief breeding grounds of the locust, must always remain unsettled, or occupied only as pasture grounds. It cannot therefore be hoped, that advancing cultivation will restrict the breeding area; yet eren here it seems that some effort may usefully be made. The vast extent of the western plains might at first seem to preclude the possibility of embracing them in any comprehensive measurg, but their character renders this less difficult than would appear. By a system of inspection, in which many men need not be employed, the chief localities in which egrs were deposited in the autumn, over immense areas, might be learned. Then when the Joung brood appears in Spring, the systematic firing of the prairie grass orer these areas, would, if it did not destroy the whole of the young insect--yet render the country for a time so barren that the greater part of them would probably perish. To preserve the prairie grass from fires the preceding autumn, would be the nost difficult part of this scheme, but by taking advantage of rivers and other natural features, and the addition of ploughed lines, as fire-guards in some places, a very great area might he so divided into isolated blocks, as to prevent the very wide spread of any accidental fire. This precaution seems a desirable one also, as a measure in the systematic preservation of timber trees. Supposing, howerer, that it became known that grasshoppers in great numbers had hatcherl. and were likely to descend on the settlements, it would appear possible hy preconcerted arrangements, to form, by firing the prairie at the appropriate time, a broal black zoue across the line of their migration, which the insects would not willingly cross. There would be little

- With the Idea of ncquiring as much information as possible on the invasion of $1874, I$ isgued a number of circulars to Munimbs, the Westem States, and various parts of the $\mathbf{N}$. W. Territories. I have to thank the gentlemen who have been kind enough to return these circulars, for much valuable information. The number received has, however, not been so great as expected, nor has the information in all cases been precise as to direction aud date. I bave therefore been obliged to abandon the idea of coustructimg a complete nup of their migrations for last summer, but may yet make use of the general information obtained. 
difficulty-supposing the existence of proper fire-guards, as above suggested-in producing within a few days a belt of black country 100 miles wide, altogether beyond the present limits of the Province of Manitoba.

726. When a horde of winged locusts comes down on the settlements, comparatively little ean be done to prevent the destruction of the crops. Swarm follows swarm, often for days together, and eventually overbear resistance. By the use of smoke, which is allowed to drift across the fields from smothered fires or 'smudges,' many of the insects may be prevented from alighting. In southern Minnesota, a process called roping' the grain has been attended with considerable success. A horse being fastened to each end of the rope, it is dragged to and fro across the field, brushing the insects from the stalks, and often causing them at last to fly off. They may also be caught in great numbers in scoop-nets and bags, especially when somewhat torpid, in the evenings and mornings; and where the area affected is limited, this may be usefully employed.

727. Whenever the grass-hoppers have deposited their eggs, attention should be turned to these. The method of destruction which seems to have been found most successful in the Western States, and clsewhere, is fall ploughing. The egg-tubes are thus deranged, and most of them buried by so deep a layer of earth, that they either do not come to life at all in the succeeding spring; or hatch so late, and in such small numbers, that they do comparatively little injury to the crops. This also allows early spring sowing, and gives the grain time to attain some growth before the young locusts come down on it. This ploughing should extend, as Mr. Taylor has shown, to roads and other bare spots where great quantities of eggs have been laid. Of more limited applicability is the collection of the eggs by hand, as practised in different parts of the old world.* The inhabitants, armed with sharpened sticks or hoes, go out together to the spots where the eggs are known to be most abundant, and receire a gorernment bounty by measure for the egges collected. In a country where the settled area is quite small, in comparison to that lying waste, this would probably have little result, except in cases where the deposit of eggrs wals confined to a somewhat limited area, when its rigorous adoption might not only save the crops of the immediate vicinity, but those of other localities which the grasshoppers might visit, when afterwards taking flight.

728. In spring, the war should be continned, and as soon as the young

* See the translation of an essay by V. Motchulsky, in the Smithsonian Report, 1858. Many plans of destruction of locusts are here mentioned, and statistics, \&c., concerning them given. 
are hatched, mean: must he devised for their destruction, aided if need be by government bounties. Burving the prairie in dry weather; the use of heary rollers; driving the young insects together by converging circles, and destroying them with flat wooden shovels; driving them into straw, which is afterwards fired, or inito fires, streams, or ditches, have all been employed with greater or less success. The various species of blackbirds, the prairie hens, and other birds, will also aid in their destruction at this season, and where large flocks of domestic fowls are kept they will materially assist. Fields may also be protected from the young insects wherever a ditch of moderate width surrounding them, can be filled with water.

729. The locust appear's to be well nigh omnivorous, and though showing a preference for certain kinds of food, will eat almost any pliiit in case of need. There is therefore no crop which may be grown with assurance in a grasshopper year. It is rery generally found, however, that they avoid sorghum and broom-corn; and when other food is to be had they do not eat potatoe-tops, beets, or tomatoes. They also appear to have a general dislike to the Leguminosæ, and prefer other plants to peas and beans. This last fact may stand in causal connection with the great abundance of leguminous plants found on the western plains, an abundance obtaining buth specifically and numerically. Wheat would appear to be one of the surest crops, when foreign swarms are expected, as it very generally ripens before their arrival. That it may do so, however, it is necessary that the seed should be sown as promptly as possible in the spring.

730. Manitoba, from its more northern position and proximity to the great forest regions, appear's to be less liable to wide-spread risitations of the locust than the regions further south, and the swarms which appear do not reem to be so dense or destructive. Some of the above mentioned means may consecquently be employed here with success, but I believe that a great part of the Western States and territories will always remain sulject to periodical invasions. The extensive planting of trees, and the establishment of belts and groves of woodland orer the area of the plains suitahle for ingriculture, seems to offer a future prospect of amelioration. The breaking up of the surface of the country in this way, will not only tend to prevent the swarms from spreading themselves on widely and uniformly, lut will encourage the increase of Bhids and other animals likely to prey on the inseet; and will besides dent to hring alont a change in climate, which will render it less 
suitable to the invaders, and especially unsuited for their propagation and increase.

731. The supply of wood for building, fencing; and fuel, over a great part of the North-west, is a matter which appear's to require immediate attention. The existence of great areas of plain, almost entirely destitute of timber trees, is now generally known, and on another page of this Report, it has been attempted to estimate the part of this region which lies to the north of the Boundary-line. A part from the great immediate disadvantages of so vast an extent of treeless prairie, its presence, and the complete absence of forest-clad areas, cannot but have a very serious effect on the climate of the whole interior region of the continent.

732. Several writers have devoted attention to the cause of the treelessness of the plains; and while on one hand it has been argued that the whole, or almost the whole, interior legion of the continent has been forest clad; it has been contended by other's that the greater part of the area has nerer been covered with trees, and certain reasons have been brought forward which show, in the opinion of those on this side of the controversy, that the prairies are incapable of supporting a forest growth. The plains are known to have been thickly clad with coniferous and other forests, in the Tertiary period, but there are other circumstances tending to show that in comparatively modern, and post-glacial times, a rery much greater area was tree-clad than at present. Chief among these is the great abundance of land and fresh-water shells, in the later deposits of the Missouri, already mentioned, and the gradual dericcation, which, on the testimony of many observer's, has been, and is still, groing on orer great areas of the West. This, though it may at present be intensitied by extra-terrestrial influences, bringing about cyclical changes of climate, cannot be entirely attributed to such causes, but is the natural result of the decreasing area of the region of forest. Against these facts may be placed others tendirg to an opposite conclusion, or at least to the modification of the idea of the former universality of forests. The absence of systems of drainage vallies in many regions, has been already referred to, as showing the improbability of former great rainfall. The absence of any remains of old forests, or of roots, or drift-wood in the subsril and alluvial deposits of the rreater part of the plains, would appear to have a like meaning. It wonld secem most accorlant with the farts, as they are at present linwwn. (1) (o) clude that, since the glacial period, the plains have never leen entirely 
covered with forest; but that extensive prairies bave continued to exist in the drier regions, from that time to the present day.

733. The causes now in operation tending to the perpetration and spread of the treeless area, are sutticiently obvious, being prairie fires and their attendant consequences. Julging from the present origin and influence of these conflagrations, it can hardly be doubted, that ever since the first peopling of this continent, the area of treeless prairie has been in process of enlargement in an increasing ratio.

734. In the vicinity of the forty-ninth parallel, west of Turtle Mountain (long. $100^{\circ}$ ), trees are norer found growing on the open surface of the plain. When they exist, they lurk in sheltered river vallies and ravines, where they are protected, in great measure, from the sweep of prairie fires, and find more abundant moisture; yet even in these retreats, they suffer periodical destruction. On the growth of trees for a number of year's, they become surrounded with much regetable matter, and the fire catching in this, burns down into the valley, and sweeps away a greater or less area of woodland.

735. The increase of the area of the plains at the borders, and the destruction of the forest, are clearly perceptible, and have been noticed by ail the explorers of the region. Capt. Palliser writes :- "Large tracts of country now prairie lands have at one time grown valuable forests, and their present absence is the result of the repeated ravages of tire. Where a scattered and stunted growth of willows is found, as a general rule was ancient forest land, which, when dug to a sufticient depth, still discloses numerous roots of destroyed timber," and in another place:- "It is most lamentable to see so often such masses of valuable timber destroyed, almost invariably by wanton carelessness and mischief. The most trivial signal of one Indian to another has often lost hundreds of acres of forest trees, which might have brought wealth and comfort to the future settler, while it has hronght starration and misery to the Indian tribes themselves, by spoiling their hunting grounds. The Indians, however, never taught by experience, still use 'signal fires' to the same extent as in former years, driving the animals firom their retreats, and marring the fatir face of nature for the future colonist." * Mr. Selwyn, in his last published report, makes the following remarks on the same sulpien: " The drying up of the country alleady alluded to has beren aserihed to various causes, but is generally supposed to be con-

'Expluration of British Nurth America, pp. 88, 89. 
nected with the gradual destruction of the forests over large areas, by fire, diminishing the rainfall. Whatever the effect may be of these destructive conflagrations, in reference to the water supply of the region, there is no doubt that at different times almost every square mile of the country between Red River and the Rocky Mountains, has been subjected to them ; and that hundreds of miles of forests have thus been converted into wide and almost treeless expanses of prairie." Now that attention is so prominently drawn to the North-west as a region for settlement, it seems time that some legislative action, having for its object the prevention of these disasterous prairie fires, should be taken.

736. With such a potent cause as this still in active operation, it would scarcely seem necessary to search further; yet to account for the present treeless condition of the plains, many theories have been brought forward. It has been contended that the extreme fineness of the prairie soil prevents the growth of trees,* but in the Red River and Mississippi Vallies, trees are found growing, and attaining a very large size, on the finest varieties of this soil. Again, the peaty character of the soil, is urged as a cause of treelessness. It is supposed to have been formed during the gradual recession of great lakes, and to be unfavourable to the growth of trees, like that of modern peaty swamps, from the proportion of ulmic acid which it contains. $\dagger$ The firm and tough nature of the prairie sod, and the well established supremacy of the grasses, is also mentioned, and is no doubt a true cause to a certain extent. The presence of 'alkali' or saline matter in the soil, has also been suggested as a canse, and though it may have some effect in exceptional localities, I have not observed that its occurrence in small quantity is incompatible with the growth of trees, except in so far as it may tend to show the too great dryness of the soil. It has also been stated, that as at a comparatively modern period, the whole interior region of America has been submerged, and as large lakes are known to have covered extensive areas of low-lying prairie in even more modern times; that the forest growth has not yet had time to spread again over the re-elevated surface. $\ddagger$ It seems to have been forgotten by the advocates of this last theory, that many of the trees best suited for growing on the prairie, have light winged and 
feathered seeds, capable of long aerial flights. The various species of poplars and willows may be specially mentioned, and it is a fact which any one can observe, that the reeds of the birch are often found far from woods, drifting over the open country with the snow. There are probably few large areas of the plain, which are not every year more or less thickly seeded with, at least, willow and poplar.

737. The excess of moisture in the soil, during some months, has also been brought forward, but certainly cannot apply to any considerable area went of the Mississippi and Red River. The dryness of the soil and atmosphere, as a cause of treclessness, has deservedly received more attention, and is undoubtedly a true cause over great areas. Prof. Dana upholds this theory, and has very clearly shown the relation of prairies and regions of drought.* The seeds of trees and shrubs, and of all plants, except those suited to withstand the greatest desiciation, though they may be scattered broadcast, and may germinate in the spring, are, in many districts, within a few months killed by drought; or, even where the moisture may be sufficient for their growth, it may not be enough to afford protection from fire. In these regions a patch of forest once destroyed does not renew itself, and can only be restored by care and cultivation.

738. The area of the interior plains can never, since the complete elevation of the Rocky Mountains, hare been a very moist one. The winds with their prevailing direction toward the east, in passing over three to five hundred miles of serried peaks and ridges, loose a great proportion of their moisture; and a great part of the rain which should be spread over the entire west, is expended on a comparatively narrow strip of country along the coast. All the facts at present known, however, strengthened also by analogy with other countries, appear to show that the dryness of the plains is in great measure intensified by their treelessness. The very dryness of the atmosphere and soil, is thus brought about, to a great extent, by the destruction of forest areas by fire, and the effect is a cumulative one. When therefore it is asked-why, if the prairies were originally in great part forest-clad, they do not now show any tendency to revert to that condition, or even to renew the growth of trees over lately burned areas? It may be answered: that while the area of prairie was still quite small, there would be an immediate effort in that direction, but that as the prairie with its hot, parchel, and rain-repelling

- See especially Am. Jour. Sci. and Arts, vol. xL., p. $29 \%$. 
surface increased, the effort would become more feeble. Around its borders the forest is however still capable of spreading spontaneously where protection from fire is afforded; and it is observalle, that in many directions the prairie land has already reached its natural limit, and that its further extension, and the accompanying increase of drought, are checked against regions too much broken by irregularity of surface, or sub-divided by swamp and lake, to allow wide-spread conflagrations.

739. Many facts are already known which tend to show the progressive desiccation of the West in modern times; and explorers are constantly meeting with additional evidence of the same kind. Over the greater part of Montana, forest once destroyed is not naturally renewed, here and there a few trees are found which appear to be remnants of former forests, and there is some reason to believe that "even where undisturbed by the hand of man, the forests are gradually disappearing from natural causes."* Similar facts are also observed in California. In Dakota, Prof. Thomas finds 'dry lakes,' or the dry basins where lakes formerly existed, now entirely devoid of water, and which do not appear to have been in this state many years. Even the lakes which still contain water, are said to have the appearance of decreasing year by year. There are also evidences of former swampy spots where the grass is still more luxuriant than that surrounding it, but the water has disappeared from the surface." $\dagger$ These hollows and lakelets no doubt resemble those of the second prairie plateau north of the Line, and though I believe many of the appearances bear other interpretations, there still appears to be a residuum of eridence in favour of change of climate for the worse. In south-western Minnesota, Prof. Winchell has recorded facts concerning the former deposit of calcareous tufa, which appear to have a similar bearing. $\$$ Mr. Selwyn's observations to the same effect on the second prairie steppe between the Qu' Appelle and the Saskatchewan, have been already referred to, he writes with regard to the little lakes of the prairie :-_ "They appear all to be gradually diminishing in size or drying up. This, Macdonald tells me, has been going on steadily for several years. He says that what were formerly large lakes are now small pools, and all the lesser ones are already quite dry, and their beds overgrown with grass and weeds." §

740. Evilence similar in tenor to the above, is met with constantly

* U. 8. Geol, Surv. Territ., 18\%1. 
on the plains, and the change toward desiccation would therefore appear to be widespread, and is often, even by the least scientific observer's, attributed directly to the decreased area of torest. That this may at least be a great part of the cause, is rendered evident from the proved effect of the destruction of forest-land, in other and better known regions. Where countries situated in a too humid and chilly climate, have been to a great extent bared of forest, direct amelioration appears to have resulted, but where this denudation has been carried to excess, or where the rainfall is naturally not more than sufficient, disastrous effects have followed. The annual rainfall has been observed to diminish, or in places where it is small, the summer precipitation has failed altogether. The climate has become more ext:eme, springs have disappeared, and districts formerly under cultivation have had to be abandoned.

741. Sir R. Murchison observed such effects in Russia. He writes: "The axe of the miner has been a prime cause of this increasing drought. The inhabitants of the Ural Mountains, complaining of the annual decrease of water, invariably refer this effect to the clearing away of the forest." Dr. Strzelecki, speaking of New South Wales, says: "The destruction of forests has rendered the climate drier, and is threatening the interests of agriculture."* Similar results have been observed to follow the clearing of forest lands in France, Spain and other countries of Europe, in Africa, in India, and elsewhere; and were the fact disputed it might be substantiated by other references and quotations. Boussingault, Sir John F. W. Herschel, and other meteorologists, who have given the subject attention, concur in their estimate of its importance.

742. The converse of this proposition can, however, fortunately be proven, and increased rainfall and general amelioration of excessive climates, have been found, to a greater or less extent, to follow the renewing of forests, and in some cases to result from the judicious planting of comparatively inconsiderable areas of trees. These results have naturally been observel, for the most part, in the old world; and especially where attention has been paid to forest growth and eulture for some time. Babinet and Blangi concur in stating that rainfall has been catused in the previonsly rainless region of Lower Egypt by the

\footnotetext{
- Quoted by A. Fryer, in a series of articles, entitled the Influence of Forests on Rainfall, published in "The Sugar Cane." Much valuable information on this subject has been collected by Mr. Fryer. See also memorial on behalf of the Board of Agticulture to the Legislature of Maine, 1869.
} 
growth of plantations, and a similar effect, coupled with the increase of springs in number and rolume, has been noticed in France, South America, Australia, Madeira, St. Helena, and other countries.*

743. A country clothed with arboreal vegetation is, to a great extent, protected from denuding agencies, by the mat of regetable soil with which it becomes covered. The shade aftorded by the trees, also prevents the too rapid abstraction of moisture from the soil, and it is accumulated in the subsoil, and the supply of springs and rivulets regulated and maintained. The precise manner, however, in which a mantle of trees acts, in causing increased precipitation, is not so well known. The foliage, no doubt, tends to retard and arrest currents of air, and by lowering the temperature of the stratum nearest the earth causes the formation and growth of clouds. It would appear, however, that a great part of the influence is of a more subtle nature, and depends on the electrical state of the air and earth. Mr. Fryer evidently inclines to that opinion. Trees rooted deeply in the damper layers of the soil, and ending upwards in innumerable conducting points and edges, must tend silently to neutralize the differently electrified air and earth, and relieve that state of tension, which, when it exists in the former, causes the repulsion of the aqueous particles, and prevents their coalesence and precipitation. The prairie grass when it is green and fresh, may, to some extent, hare, in this way, the same effect as trees; but it is at once apparent, that a hot and parched surface, whether of rock or sand, or dry, withered grass, must not only not attract rain, but actually tend to repel it, and prevent the precipitation of the moisture existing in the atmosphere. Last year, on the second prairie steppe, I noticed the formation of clouds orer the broken and wooded area, known as Turtle Mountain, which, though it may have been brought about in some measure by its clevation, seemed to be caused chiefly by its forest-clad surface. The wind was fresh, and blowing from the south-south-east. and though the whole sky was hazy, with light cloudr, a persistent cloud-cap seemed to form orer the higher wooded area, and tail away towards the north, some light showers falling upon the mountain at the same time.

74t. The Great West of America is too new to have yet accumulated many facts from experience, but in several directions, encouraging results have already been observed to follow the advance of settlement, and the planting of trees. "When the Mormons first settled in Utah, they found 
the district barren. Water had to be brought almost incredible distances, in wooden pipes. Trees were carefully planted, and nourished with the water so brought, and now the district may be termed the garden of the world, and is not dependent on water brought from a distance, but enjoys a steady rainfall."* I am informed by Mr. Groo, editor of the Salt Lake Herald, that the climate is still changing rapidly, he writes: "The lake is gradually rising, and has been for many years. It is perhaps four or five feet deeper than it was twenty year's ago. This is doubtless due to change in the character of the seasons. Each year the amount of rain that falls in this valley is greater than that which fell in the previous season; hence the streams of water which flow into the lake are larger. The water of the lake is not so strongly impregnated with saline matter as formerly, and not so much salt is found on the shores, as there was a few years ago." Dr. Haydlen, as far back as $\mathbf{1 8 6 7}$, is able to write:- "The settlement of the country, and the increase of the timber have already changed for the better, the climate of that portion of Nebraska lying along the Missouri, so that within the last twelve or fourteen years, the rain has gradually increased in quantity, and is much more equally distributed throughout the year." $\dagger$ And again, in 1870, "It is true that, over a width of one hundred miles or more, along the Missouri River, the little groves of timber are extending their area; that springs of water are continually issuing from the ground where none were ever known before; and that the distribution of rain throughout the year is more equable." $\ddagger$ Mr. R. S. Elliot states that there is a popular persuasion in Kansas, "that a climatic change is taking place, promoted by the spreal of settlements westwardly, breaking up portions of the prairie soil, and the corering of the earth with plants which shade the ground, more than the short grasses. The fact is also noted, that even where the prairie soil is not disturbel, the short buffialo-grass disappears, as the 'frontier' extends westward, and its place is taken by grasses and other herbage of taller growth."

745. The treeless plains of the western portion of the United States are estimated to have an area of 400,000 square miles; adding to this the plains north of the forty-ninth parallel, with a probable area of 192,000 square miles, we obtain as an approximate total area of the great treeless plains of North America, the sum of nearly six hundred thousand square miles. The injurious effect of a treeless region so vast 
as this, on the climate of the western part of the continent generally, cannot but be very great; and if in the course of time, any considerable fraction of it can be planted with trees, or brought under the plough, the resulting amelioration in climate will be remarkable.

746. Mr. Elliott in his report, makes the following very suggestive remarks:- "Were it possible to break up the surface to a depth of two feet, from the ninety-seventh meridian to the mountains, and from the thirty-fifth tc the forty-fifth parallel, we should have in a single season a growth of taller herbage orer the entire area, less reflection of the sun's heat, more humidity in the atmosphere, more constancy in springs, pools, and streams, more frequent showers, fewer violent storms, and less caprice and fury in the winds. A single year would witness a changed vegetation and a new climate. In three years (fires kept out) there would be young trees in numerous places, and in twenty years there would be fair young forests. - The limited area which it is in our power to turn up by the plough, will have the same results in kind, to follow a breaking of the entire surface, but less effective than if the operation were universal. Yet a beginning can be made by the Railway Company, and by individuals. - A few acres at intervals across the plains, or only a few clumps of trees growing without regularity will be a demonstration more effective than theory."*

The possibility of the successful growth of trees on the prairie, when the most suitable localities are chosen, and proper care given to their planting and cultivation, has already been demonstrated in many parts of the West. Many interesting facts on this point, and on the rapidity of growth of the trees, will be found scattered through the various reports on the Western Territories of the United States. Dr. Hayden gives the following statistics of growth of plantations in Nebraska, some of them situated on the higher level prairie, six hundred feet above the Missouri River.† Cotton-wood (Populus monilifera) of seven years growth, with : circumference of 2 feet; ten years growth, 2 feet 4 inches to 2 feet 11 inches, and 25 to 30 feet high. Soft maple (Acer rubrum) of seven years growth, with a circumference of 1 foot 10 inches, to 2 feet 1 inch, and 15 feet high; ten years growth 2 feet 8 inches. Box-elder (Negundo acervides) ten years old with a circumference of 2 feet 2 inches. And other varieties of trees showing similar rapid increase in size. Dr. Hayden is of opinion that within thirty to fifty years forest trees may be 
grown large enough for all economical purposes, and instances a case in which, in ten rears' time a farmer was able to supply his own fuel from the limbs and dead trees of his plantations, which would otherwise have gone to decay.

747. It has been estimated that about one-third of the surface of a country should be in the state of forest to secure the greatest climatic advantage, and to yield a sufficient supply of wood for the various purposes of rettlement and civilization. Such an estimate is necessarily only approximately correct, and there are various circumstances, differing in each locality, which tend to modify it, chief among which is the presence of mineral fuel, and the neighbourhood of extensive and unbroken tracts of forest. If, however, it be reduced to one-fourth, to cover the case of the parts of the North-west more immediately suitable for settlement, it will still be apparent how far these fall short of the required proportion. In the territory of Dakota, the highest estimate places the timbered area at from 3 to 5 per cent of the whole only. The proportion of timber in the Province of Manitoba, as at present constituted, is much greater, but is still too small ; especially when it is taken into consideration that a great part of the woodland lies together in the eastern region, and is far removed from many of the districts best suited for agriculture. West of the 100th meridian, there are regions of greater size than this Province in which the tree-covered area is almost nothing.

748: In Manitoba, and the North-west generally, then, on the first introduction of settlement aud civilization, problems concerning the maintainence and planting of forests are found, which have not presented themselves till late in the history of most countries, and have then given rise not only to extensive enquiry and research, but to the inclusion of Forestry as a branch of the Civil Service, and the appointment of skilled superintendents and conservators. Though it has been clearly proven that there is an area of the Canadian North-west capable of immediate settlement, and sufficieut for some time to come; there are vast regions in which the evils of the absence of timber, and its attendant results, are too great for the settler to struggle against unaided. Considering that the amelioration of the conditions in these regions must be a work of time, it cannot be too soon begun, and must proceed either as a public work, or one encouraged and protected by the Government. Woods and belts of timber, already existing, should be protected and maintained ; areas formerly wooled, replanted; and the planting of woodland de novo pushed forward in every suitable locality. It cannot be 
doubted that the results of such a policy will be, not only the redemption of great areas of wild, open prairie, but a rery sensible improvement of climate.

749. The question, however, for its satisfactory and rapid solution, requires the formation and execution of a comprehensive scheme, which shall embrace not only the direct planting and protection of trees, but he shaping of the general policy, with regard to the settlement of the country, to the same end. In such a scheme it would appear to be necessary to consider the following points :-

\section{The planting of trees should be undertatien and encouraged.}

750. This might require to be carried out as a public work in the remote districts, but where settlement is going on, or has taken place, the planting of sufficient areas might be brought about by legislative action ; which might take the form of exemption from taxation for a certain number of trees set out, or eren in exceptional circumstances, be of the nature of a direct bounty on planting. In several of the Western States and Territories such a course has been adopted. In Nebraska, where more planting has probably been done than in any other country so new, the act of 1869 exempts firom taxation property to the value of $\$ 100$ for fire years for each acre of forest-trees planted and cultivated for timber. It being provided that the trees are kept in good growing order and set not more than twelve feet apart. This enactment is said already to have produced a very considerable effect, many settlers availing themselves of it. The French, Italian, and other Governments have similar regulations.*Russia with regard to the distribution of its forests much resembles British America, for though its wooded area is estimated at forty per cent of the whole, it is very unequally distributed, and internal communication is yet imperfect. The Southern Provinces are very poor in timber, and since 1842 a Ciovernment Forest Aclministration has been planting largely. Between 1866 and 1870, 20,000 acres have been planted exclusive of the action of private owners. $\dagger$

751. An important item under this head is the collection and circulation of infornation, both with regard to the species of trees most suitalule for each locality, and the best methorls of planting and cultivation. Experimental plantations of different kinds of trees, indigenous and foreign, in the various districts, would be rery instructire. Nature, of eourse, to a certain extent, indicates the best species to occupy advanced positions 
on the plains, but there may be others, which if introduced, would succeed at least equally well. The various species of spruce and pine, though not occurring naturally on the prairie region, if they will grow there, would form efficient wind-breaks. Among other trees partieularly suitable, may be mentioned the various species of poplars and willows, which have the alvantage of being easily propagated by cuttings, where the soil is at all damp in spring; and also the ash-leaved maple. All these are trees of rapid growth. For low ground or the border's of sloughs and coulées, elms suggest themselves as a valuable addition; and to secure the permanence of woods when once established, oaks-of which several species would no doubt succeed-birch, and other hard-wood trees, should be planted among the poplars and maples, and when these are failing, will still be in their first vigorous growth. It has also been argued with much show of reason, that to produce the greatest amount of wood, and timber of real practical utility, suited to fencing, and other needs of the settler, the trees should be planted much closer toge her than suggested by the Nebraska law. They then support c.ch other better against the boisterous winds of the prairie, and form clean long sticks, which can be thinned out as occasion requires. It has also been pointed out by Mr. Hodges that they shade the ground when thickly planted, and prevent the growth of grass from interfering with them.

752. From facts already stated it will be seen that the growth of trees of fair size is not necessarily the work of a great many years, especially if some care be given them, and ploughing about their roots attended to while young. The wood cut out in thinning a few acres, will, after a few years, serve the farmer for fuel, which if counted at the current rates, will in a short time pay the cost of planting and attention. The settler then finds himself with a valuable area of woodland, worth perhaps $\$ 100$ to $\$ 200$ per acre. When it once becomes well unclerstood that the growth of timber trees from the seed, is as certain as that of any other (rop, and that they require a comparatively small amount of cultivation, it will cease to be necessary to induce the settler to plant and eare for them.

\section{Economy in the use of Wood should be observed}

753. This must be doue for the most part indirectly, by popularizing sulsstitutes for this material. For luilding purposes, where wood is wrarce it has only to be shown that it is possible to make concrete or artificial stone from some of the gravels of the district; which will make 
as substantial and warm buildings, and more permanent ones, to discourage the use of trees for this purpose. Many of the prairie subsoils and clays will make bricks, but fuel is usually required to burn them. It has been found, however, in some parts of the western territories that pressed and sun-dried brieks stand very well.

754. It is for fuel, however, that the greatest quantity of wood is required; and to economise in this respect it is necessary to encourage in every way the opening up of the various beds of coal and lignite. Also to have the areas likely to yield such fuel carefully surveyed and tested by boring or otherwise, so that the most eligible parts of them, and those nearest the thickly settled districts shall be determined. The probability of the discovery of such fossil fuel in various parts of the prairie region, has already been discussed, and something has been said on the possibility of obtaining a supply of peat, with especial reference to the valley of the Red River. This is a material not to be despised, when it can be obtained of the best quality; and which, when the price of fuel is rather high, will bear transport to a considerable distance. There are also many areas which yield an inferior peat, much mixed with earthy matter, which may yet be dug and used on the spot with advantage. This may be distinguished as slough peat, and as it occurs on the prairies, generally forms a comparatively shallow stratum of a foot or two at the bottom of the little depressed swamps, or half-dry lakes. Many a farmer, by a little search in his immediate neighbourhood, might find spots where it would be easy to obtain this material, and by digging it out in blocks and stacking it, might lay by the greater part of his winter's supply of fuel at a small cost in labour.*

755. Under this head, too, comes the opening up of proper means of communication, by wlich coal from the mines, which may be established, and wood from the larger forests, may be brought to districts imperfectly supplied, and prevent the destruction of scattered areas of woodland.

\section{III.-Prevention of Prairie and Forest Fires.}

756. No subject requires more immediate and strict attention than this, for unless measures are taken to stop these destructive conflagrations-the effects of which have been already referred to-no appreciable benefit will result from the adoption of the other means. It may be said that it is very difficult to prevent the Indians from firing the

* Compare N. H. Winchell in Second Annual Report Geol. Surv. Minn., where an interesting rasume of the various processes employe $\mathrm{J}$ in peat manufacture will also be found, 
prairic, which is true, but only applies to the regions far beyond any in which settlement is likely to take place for a long time; and these fires seldom spread many hundred miles, without being checked by rain or otherwise. It is unfortunately the ease, however, that the settler's themselves have acquirel a habit of firing the grass in autumn or early spring, with the idea of producing better grazing, and clearing out the hay swamps. It seems urgently necessary that iegislation, enforced if need be by rather serere penalties, should bring this custom to an encl; or at least if it he considered a hardship to prohibit it altogether, to restrict it greatly, and allow it to he applied to small areas only, which are surrounded by a good broad ploughed line. It should also be rendered imperative that the fire should be watched during its progress, that if through any carelessness, it surpasses the bounds, the person setting the fire should be in a measure responsible for the consequences. It is of course easy to circumscribe fields, buildings, and fences, or plantations, with a few plough furrows, which if carefully turned, form a very efficient barrier to the flre; but the wood growing at large on the prairie, and the belts of timber along the rivers and coulees, suffer almost annually from the incursions of fires, and are prevented from sprealing, as they otherwise would. A better illustration of this cannot be found than the Red River Valley south of the Boundary-line. The fires on the western, or Dakota bank, are much more frequent, and have a broaler sweep, and are also very generally urged forward by the prevailing wind. The woods fringing the stream on this side are consequently thin and poor, compared with those on the eastern bank; and there are great areas covered only with burned 'rampikes,' and straggling bushes. The fire sweeping across the prairie is almost immediately extinct, but when it is carried forward to the thick belt of oak or elm trees, maintains itself in the dry regetable soil and half-decayed timber, and may be detected by its lurid glare at night, often for a long time.

757. The adrantage derived from burning the old grass is very slight, and the young blades are exposed to the action of the night frosts, and to drought, in a manner which causes them to become stunted and soon dry. If the hay-swamps were properly eut the preceding year, they woull not require to be lumed. It will also be found more advantagreous to enclose ground, and sow proper hay-grass, and to place less reliance on the compuraticely poor and thin prairie hay, which the farmer has sometimes to go a long way to obtain. 



\section{A P P E N D I X.}

(A) Note on the Plants, collected by Mr. G. M. Dawson, from the Lignite Tertiary Deposits, near the Forty-ninth Parallel.

By J. W. DAwson, F.R.S.

The specimens consist of leaves and other remains preserved in shale, and of silicified woods, mostly found loose ; but without doubt derived from the same formations with the other remains. Vegetable structures also appear in some of the Lignites, and can be developed by the action of caustic potash, or nitric acid.

\section{I.-LEAVES ETC., IN SHALE.-(PLATE XVI.)}

The greater part of these are in a light grey or brownish shale, from Porcupine Creek, and the vicinity of Wood Mountain; but another and somewhat distinct group of species occurs in dark grey shale from Great Valley, from beds believed to be very nearly on the same geological horizon with the others. The first and more important group, with reference to numbers and state of preservation, we may designate the the Porcupine Creek Group; the second, the Great Valley Group.

The plants of the first of these groups are for the most part identical with those found by the American Geologists in the Fort Union series, and which have been described by Prof. Newberry and Mr. Lesquereux. They are also similar to plants collected by Dr. Richardson in the Lignite series of the Mackenzie River, as described by Heer, and represented by specimens in the collection of the Geological Survey and of the University. They also approach very closely to the so-called Miocene floras of Alaska and Greenland, as described by Heer; and in their facies and in several of their species, they coincide with the Miocene flora of Europe.

If we were to regard the affinities of the plants merely, and to compare them with the Miocene of other countries, and also to consider the fact that several of the species are identical with those still living, and that the whole facies of the flora coincides with that of modern temperate America, little hesitation would be felt in assigning the formation in which they occur to the Miocene period. On the other hand, when we consider the fact that the lower beds of this formation hold the remains of reptiles of Mesozoic type, that the beds pass downward into rocks holding Baculites and Inocerami, and that a flora essentially similar is found associated with Cretaceous marine animal remains both in Dakota and in Vancouver's Island, we should be inclined to assign them at least to the base of the Eucene. They bave in fact been thus variously placed, and recently Lesquereux has attempted to sul-divide the beds of the corresponding rocks in the United States into a series of groups, ranging from the Cretaceous to the Miocene. 
In my judgment, any precise decision as to their geological age is premature. We have before us the fact that at a time when the Cretaceous fauna still prevailed in the sea, the land plants of $\Lambda$ merica had already come in under the existing generic forms, and that some modern species had been introduced, and in the intervening time, while very decided changes have taken place in animal life, this flora has persisted with only specific change, and with no marked breaks. At the same time, it is evident that local diversities of station were sufficient to produce very distinct floras in different localities at one and the same time, and the palæontological botanist is constantly in danger of mistaking local diversities for differences in age, and on the other hand, if correlating beds of different ages, in consequence of the similarity of their fossils.

In these circumstances, it is rash to identify the beds, on the evidence of plants alone, with particular sub-divisions of the Tertiary elsewhere. In order to do this with certainty, it will be necessary to wait until the stratigraphical relations of the beds are better understood, and until sufficiently extensive collections have been made to enable us to eliminate local differences, and to understand the actual progress of the changes on the great scale which have occurred between the C'retaceous period and the present time. In the meantime, it is sufficient to hold that we have here a flora which in Europe would be regarded as Miocene, but which in America probably began to exist at a much earlier date.

The small collection of plants from a dark clay, at Great Valley, indicates a somewhat different assemblage of species from that of the other localities, though believed to be on the same geological horizon. The leaves are mostly fragmentary, and not so well preserved as those of Porcupine Creek. Among them are Conifers referable to Sequoia Langsdorffii and Glyptostrobus Europreus, a Populus with large round cordate leaf, having distinct obtuse teeth, and pinnate venation, and resembling P. grandidentatus, a Supindus, perhaps S. affinis of Newlurry, a Cinnamomum, one or more narrow-leaved species of Quercus, a leaf similar to IIedera McClureii of Heer, and the remarkable equisetaceous plant described below, Physagenia Parlatorii, Heer Such an assemblage, supposing it to be on the same geological horizon, may be accounted for by supposing a marked difference of station, or some local change of vegetation, depending, for example, on an extensive forest fire, or perhaps the affluence of a river bringing vegetable material from a distance. The flora as a whole has perhaps more resemblance to that of Lesquereux's fourth or Green River group, as mentioned in Hayden's report of 1873.

The following list of species includes all the forms which I can certainly identify with the aid of the present material. In determining several of the species, and in comparing them with those found in the United States, I have been much aided by the kindness of Prof. Newberry.

\section{Filices.}

Osoctea sexsibid, L, L-This well-known modern Fern, which occurs also in the Miocene of the Isle of Mull, in Serotland, and in the Fort Union group of Dakota, is found in great abundance in the clars at Porcupine Creek. Dr. Newberry has shown that it is not distinguishahle from the existing forms, but most resembles that known as var. oblusiloba of Torrey. 
Dataluia (Stenoloma) tenufolia, Sw.-In the collections from Porcupine Creek, there are several fragments both of barren and fertile fronds, which I cannot distinguish from this widely distributed Asiatic specius; I give magnified tracings of portions of the fossils for comparison. I have not had recent specimens of the barren frond, and my determination is therefore based upon comparison of the fertile fronds, for specimens of which from the Himalayas, I have been indelited to the kindness of D. A. P. Watt, Esq., of Montreal. In any case, this fern is of the type of $D$. temifoliu, and represents a genus not now found in Nurth America. It is found in the same beds with Onoclea sensibilis. It appears to me just possible that the barren fronds described by Heer, as Sphenopteris Blomstrandi may be of this species. (Pl. xvI., Figs. 1 and 2.)

\section{Equisetacer.}

Eqcisetcm, sp.-Numerous fragments of an Equisetum, not determinable; but similar to $E$. Arcticu, of Heer, from the Miocene of Spitzbergen; Porcupine Creek.

Physagexia Parlatorir, (Figs. 3 and 4,) Heer, Great Valley.-This curious plant first described by Heer, from the molasse of Switzerland, consists of cylindrical striated stems, with nodes at considerable intervals, and producing whorls of inflated or sack like bodies (ampullae,) which may have been of the nature of roots, or of submerged hollow leaves, or bladders. Heer seems at a loss to refer it to any definite place, but inclines to regard it as submerged portions of an Equisetaceous plant. The specimens from Great Valley are not distinguishable, specifically, from those he figures.

\section{Coniferæ.}

Glyptostrorcs Ecropacs, Heer,-Branchlets and leaves, Porcupine Creek. This species is common to the Miocene of Switzerland, Alaska and Greenland, and is found in the Fort Union group of Dakota, Newberry. South Park, Lesq.

Sequoia Laxfsdorffir, Brt.-Branchlets, leaves and cones, Porcupine Creek ; Dirt Hills, R. Bell; McKenzie River, Greenland and Switzerland; also Fort Union group and Black Hills, according to Lesquereux.

Theja interrcpta, Newberry.-Very abundant at Porcupine Creek, and wood of the structure of Thuja is abundant in the lignites with which it occurs. Remains of its fruit seem more to resemble that of the western $T h$. giguntea than that of the $T h$. occidentalis, which, nowever, the leaves and branchlets are so like as to be soarcely distinguishable. This species is characteristic of the Fort Union group.

\section{Monocotyledones.}

Lemaa (spirodela) scctata, N. S., (Figs. 5 and 6.)-Fronds round kidney-form, entire or slightly undulate at the edges, sometimes an inch in diameter, single or grouped. Roots numerous, filiform, proceeding from a round spot near the notch of the frond.

This species is very abundant at the Bad Lands, south of Woody Mountain, where it is associated with great quantities of roots, and rootlets, or filiform sub-aquatic leaves. It was an aquatic plant with floating disc-like leaves, and I can refer it to nothing else than Lemna.

At the same place is found a smaller tri-lobed frond, with three equal ovate divisions, and a diameter of three or four lines. It may indicate a second species, but as only a single perfect frond was found in the collection, I hesitate to describe it. (Fig. $7, a^{\text {.). }}$. On the same slal, are roots with pinnate or radiating rootlets, and which are very common in these beds.

Phragmites? sp.-Associated with the above and also at Porcupine Creek, are numerous indistinguishable remains of reeds and other grass-like plants.

Scirpes, sp.- Srikes small, numerous, less than a line long, each with four to five pairs of incurved lanceolate scales. Bad lands.

Scirpcs, sp.-Another species, with about six pairs of scales and two lines long. Porcupine Creek. 


\section{Dicotyledones.}

Popcles Richanesoni-Herer, Porcupine creek.-This fine species of Poplar, described hy Heer from Mackenzie Rifer and Greenland, is represented by a few fragments only in these collections.

Salix Rakana? Heer, Great Valley.-This species occurs at Mackenzie River and in Greenland. A few leaves appea! referable to it but not with certainty.

Convets rostrata-Ait.-Leaves not distinguishable from those of the common beaked Hazel, occur at Porcupine Creek. This species is also recorded by Newberry from the Fort Union Group.

C. Americana.-Walt, Poreupine Creek.-This also is a recent species and is credited by both Newberry and Lesquereux to the Fort Union Group. Thus hoth our American Hazels oceur in these deposits; and a still finer species, C. MacQuarri, Heer, is found at Mackenzie River and in the Fort Union beds.

Platanes heterophylues, Newlerry.-Wood End, loose, but no doubt, from the Lignite Tertiary formation. The species is found in the Fort Union group.

Diospyros, sp.-To this genus I refer a few imperfect leaves from Porcupine Creek, but cannot certainly identify them with any of the species described from other parts of these formations.

SApindes affinis, Newberry.-Bad Lands, Woody Mountain. This species 18 found also in the Fort Union Beds.

Rнамхеs, sp.-Great Valley, 345 mile point. A single leaf, wanting part of the tip and base, hut otherwise very perfect. It corresponds, as far as preserved, with $R$. Eridani of Unger, which oceurs in Greenland, but it may be one of the species described by Lesquerewx from the Lignite Tertiary of the United States.

Rhames coxcisnus.-, Newberry.-Porcupine Creek. This species also occurs in the Fort Union group.

Carya antiquorcm.-Newberry, Poreupine Creek.-This species is also found in the Fort Union group.

Juglans cinerea? Porcupine Creek-A leaf so near this species that I hesitate to separate it. It resembles, however, J. bilinica Ung.

Viberncm plbescens-Pursh, Porcupine Creek-Either this species or a large leaf of $V$. lanceolata, Newberry, from Fort Union Group.

Other leaves in this collection may represent a species of Prunus, a Thalictrum different from our modern American species, and several other plants, but not determinable without more material.

Arsceles antiques, N.S. (Figs. 8 and 9.)-Pericarp $1 \frac{1}{2}$ inches in length and 1 inch in brealth; ohovate, truncate at hase, regularly rounded above, with several strong woody spines on the upper half. Seed of similar form but smooth or with a few tortuous impressions. Bad Lands west of Woody Mountain. This fruit is almost certainly an Aeseulus, lut with characters intermediate in some respects between the Horse Chesnut and the American Buck-eye.

Trapa Borealis?-Heer, (Fig. 10.)-A few obscure prints seem to indicate a speceies of this genus, which may be identical with the above species described by Heor from Alaska. They are associated with stems and linear submerged leaves which may have helonged to this plant, and similar to those described by Heer from Alaska. In one of my specimens, the two lateral tubereles seen in Heer's figures secm to be produced into spines, making six in all. The sperimens are from Bad Lands, west of Wouly Mountain, and there is an obscure example of the same form from Great Valley.

Carpolothes, sp.-An ovate fruit of the form and size of C. lunatus, of Newberry, but not distinctly striated. Bad Lands, west of Woody Mt.

The following are the species catalogued by Heer, from Richardson's collections on the Mackenzie. As they belong to this rigion, they are given here for comparison:- 
1. Glyptostrobus Europæus, Brgt.

2. Sequoia Langsdorftii, Brgt.

3. Pinus, sp.

4. Smilax Franklini.

5. Populus Richardsoni.

6. Populus Arctica.

7. Populus Hookeri.

8. Salix Raeana.
9. Betula, sp.

10. Corylus McQuarrii, Fabr.

11. Quercus Olafseni.

12. Platanus Aceroides, Goept.

13. Hedera McClurii.

14. Pterospermites dentatus.

15. Phyllites aroideus.

16. Antholithes amissus.

17. Carpolithes seminulum.

$$
\text { II.-CONIFEROUS WOODS.-(PLATE XV.) }
$$

Large quantities of silicified fossil wood, derived apparently from the denudation of the Tertiary lignite formation, are scattered over the plains, but the trees are rarely found in situ in the beds. Slices of a number of the most promising specimens have been made, and in addition similar slices from the Saskatchewan and the McKenzie River, in the collections of the Geological Survey. The greater number are Coniferous, and some of them, no doubt, the wood of the same species whose leaves and cones are found in the beds, though it is not possible with certainty to identify these, and it does not seem necessary to give specific names to fragments which will possibly some day be referred to their proper species. They indicate a large number of Coniferous trees belonging to different generic types, and may be arranged as follows, in the conventional genera at present recognized by palæobotanists.

Centoxylon.-A wood of this type is very common, and may very possibly have belonged to Thuja interrupta, as it is very closely allied to that of the northern $T$. occidentalis, (Fig. 1.) There is also a seeond species of this genus, with shorter medullary rays, having much resin, and wood-cells with one row of pores rarely seen.

Pitoxylon.-Wood of this type, similar to the modern Pinus, is rare; but one well characterized species occurs, (Fig. 2.) It may have belonged to a Scrub Pine, similar to the northern P. Banksiana, and Heer figures a leaf of this type from Mackenzie River.

Cupressoxylon.-The greater part of the wood presents this type, and may belong to trees of different genera. The following kinds are well characterized :-

Species $(a$.) - With two rows of dises on the wide wood cells, and long resincells. It is closely allied to the wood of Sequoia sempervirens, and may belong to one of the Sequoias found in the beds, (Fig. 3.) It has medullary rays with many rows of cells superimposed and some composite resiniferous rays?

Species (b.) - With one row of discs on the wide wood cells, and wide resin-cells. Resembles the wood of Sequoia gigantea, and probably belongs to that genus.

Species (c.)-With one row of dises on the cells and numerous medullary rays which are very short, having usually only two rows of cells superimposed. Approaches in its characters to the wood of Tuxodium and Cryptomeriu; but may probably have belonged to Glyptostrobus, (Fig 4.)

Species $(d$.$) -Narrow wood-cells with one row of discs and many resin cells.$ Medullary rays of several rows of cells superimposed.

Species (e.)-Wood cells with one row of dises and very long and numerous rays, (Fig. 5.)

Species $(f$.$) -Wood cells very wide, with several rows of scattered dises. This$ wood is not well preserved, but is apparently near to $C$. polyommalum of Cramer from Banks' Land.

Taxoxylon.-A wood not well preserved, but with spirally lined wood-cells of the type of those in the modern Taxus, and dises with a slit instead of a round pore.

There are probably other species, with the wood less distinctly characterized or preserved; and the lignites when treated with caustic potash, show abundant coniferous tissues of the types of Thuja and Sequoir, which thus seem to have largely contributed to their mass.

$$
\text { III.-ANGIOSPERMOÜ WOODS. }
$$

Of these the spreimens sliced which were sufficiently preserved for determination, are referable to the genus Populus, which genus is also largely represented among the fossil leaves. 



\section{(B.) - Report on the Vertebrate Fossils from the Fort Union Group of Milk River.}

By E. D. Cope.

The fossils submitted to my examination by Mr. Dawson, are generally in a fragmentary condition, and belong to a number of distinct individuals. In but few instances are the fragments so characteristic as to admit of specific diagnosis, but they leave no doubt as to the ordinal relations of the animals to which they belonged. These are exclusively Dinosauria, tortoises, and gar-fishes, no Mammalia or marine vertebrata being indicated.

The collection is of especial interest, as furnishing one more station whence a glimpse of the life of the "transition period" of the history of the western part of America may be obtained. And the resulting information is similar to that already derived from studies of the palæontology of the same horizon by Prof. Leidy and myself in Dakota, Wyoming, Colorado, etc. The species are evidently the latest examples of the terrestrial life which characterized the Mesozoic ages, and which preceded the advent of the mammals in the northern hemisphere. The formations in which the fossils occur consist of greenish-brown arenaceous clays of various degrees of hardness, frequently including small gravel-stones, and sometimes forming a hard cement between them. The fossils were found near the base of the formation; and "not more than one or two hundred feet above yellow arenaceous beds, which I conceive represent Cretaceous No. 5, and which are rapidly followed in descending by well-marked No. 4 with characteristic fossils." (Extracted from letter of Mr. Dawson.)

The species are the following: Clastes, sp.; Compsemys ogmius; C. ? victus; Plastomenus costatus;* P. coalescens; Trionyx ? vagans; Trionyx ? sp.; ? Hadrosaurus ? sp.; Cionodon stenopsis.

The dinosaurian remains are quite abundant, and indicate several species, but are mostly so fragmentary as to be unfit for determination. The diagnostic genera of this list are Compsemys, Plastomenus, and Cionodon; the species referred to Hadrosaurus being represented by caudal vertebræ only. The first-named genus is characteristic of the Fort Union epoch only; the fragment referred to $C$. victus, the only species of the list previously known, is too small for final specific reference. The Plastomenus coalescens is represented by a more perfect specimen than any other species referred to this genus from the Fort Union Beds, but is not sufficiently complete to render the reference to this Eocene genus final. It is, in any case, not a member of any other known genus. One species of Trionyx is represented by a hyosternal bone, and is not definable; while the fragment

* Two species are provisionally referred to the Tertiary genus Plastomenus, but are too fragmentary for final determination. 
referred to $T$. vagans, though closely resembling that species, is not large enough for final deterimination. The Cimodon, though based on incomplete remains, is quite sufficient for palæontological purposes.

$2.314:$

In conclusion, it may be stated that there are present two genera in this collection which are diagnostic of the Fort Union epoch, but no species certainly so, though two species are probably identical with species of that epoch; also, that the presence of Dinosanria refers the fauna to the Mesozoic series; and that there is no satisfactory evidence of the co-existence of these reptiles with Tertiary forms; that the species referred to Plustomenus constitute an indication of affinity with corresponding Eocene forms. The presence of garfishes of the genus ('lastes in this formation is as yet peculiar to this and the Judith River localities. As these gars have not heretofore been found in North America below the Eocene, they constitute the first case of apparent commingling of Tertiary and Cretaceous animal life yet clearly determined. Yet the evidence is far from being as weighty in indication of Tertiary relations as is the presence of the saurians in question as evidence of Mesozoic character; for the gars, though now living, are an ancient type, their allies having swarmed in the Jurassic seas, and it is therefore altogether reasonable that they should be found in fresh water deposits of Cretaceous and Tertiary age. The rarity of the localities of the former deposit accounts for the late date of their discovery there.

\section{CIONODON, Cope.}

\section{Bull. U S. Geol. Survey Terrs., No. 2, p. 21.}

Char. gen.-Established primarily on a portion of the right maxillary bone, with numerous teeth in place, of the $C$. arctatus, Cope, a species discovered in the Fort Union beds of Colorado. The following generic characters are derived from the typical specimen of this species. The posterior portion exhibits a suture, probably for union with the palatine hone, while the rest of the interior margin is free. It is removed some distance from the tooth line in consequence of the horizontal expanse of the bone, while the outer face is vertical.

The teeth are rod-like; the upper portion subcylindric in section, with the inner face flattened from apex to hase, while the lower half is flattened by an abrupt excavation to the middle, for the accommodation of the crown of the successional tooth. The inner face of the tooth, from apex to base, is shielded by a plate of enamel, which is somewhat elevated at the margins, and supports a keel in the middle, thus giving rise to two shallow longitudinal troughs. The remainder of the tooth is covered with a layer of some dense substance, possibly cementum, which overlaps the vanishing margins of the enamel. The outer inferior excavation of the shaft presents a median longitulinal groove, to accommodate the keel of the closely-appressed crown of the successional tooth. The apex of the tooth being obtusely wedge-shaped, the functional tooth is pushed forward and transversely, toward the inner side of the jaw. The tooth slides downward in a closely-fitting vertical groove of the outer alveolar wall. The inner wall is oblique, its section forming with that of the outer $a \mathrm{~V}$; it is furrowed 
with grooves similar and opposite to those of the outer wall, but entirely disconnected from them. The base of the shank of the functional tooth, on being displaced by the successional, slides downward and inward along the groove of the inner side ; each lateral movement being accompanied by a corresponding protrusion. At the most, three teeth form a transverse line; namely, one new apex external, one half-worn crown median, and the stump or basis of a shank on the inner. The new crowns are, however, protruded successively in series of three, in the longitudiral direction also. Thus, when an apex is freshly protruded, the shank in front of it is a little more prominent, and the third stands beyond the alveolar border. As each shank increases somewhat in diameter downward in the $C$. arctatus, the section increases in size with protrusion; hence, before the appearance of a new crown outside of it, there are but two functional teeth in a cross-row. Thus, in the outer longitudinal row, only every third tooth is worn by functional use at one time; in the middle series, all are in use; while in the inner, every third one is simultaneously thrown out in the form of a minute stump of the shank, if not entirely ground up.

The dorsal vertebræ are episthocœlian, the anterior more compressed than the posterior: capitular articular faces, if existing, are slightly marked. The zygapophyses are but little prominent beyond the arch. A caudal vertebra is planoconcave, with rather depressed centrum, a little longer than broad. The condyles of the femur have a short are and chord; the head of the tibia displays a large cnemial crest, but is not emarginate behind.

The type of dentition exhibited by this genus is, perhaps, the most complex known among reptiles, and is well adapted for the comminution of vegetable food. While the mechanical effect is quite similar to that obtained by the structure of the molars of ruminating mammals, the mode of construction is entirely altered by the materials at hand. Thus, the peculiarly simple form and rapid replacement of the reptilian dentition is, by a system of complication by repetition of parts, made to sulsserve an end identical with that secured by deep plication of the crown of the more specialized molar of the mammal.

Cionodon is evidently allied to Hudrosuurus, but displays greater dental complication. In that genus, according to Leidy, the successional crowns appear on the front side of the shank of the tooth, not behind, and below the base of the enamel-area, so that the tooth is distinguished into crown and shaft. It also follows, from this arrangement, that the successional tooth does not appear until its predecessor has been worn to the root, in which case there can be only one functional tooth in a transverse section, instead of two or three.

\section{Cionodon stenopsis, Ćope.}

This Dinosaur is represented by fragments of maxillary bones, with a few contained pieces of teeth. Probally, several of the numerous bones of reptiles of this order, olitained by Mr. Dawson, pertain to the same genus and species; but there are as yet no means by which to distinguish them fiom other species of IIadrosiruridie in the collection.

The maxillaries exhibit the vertical groores characteristic of the genus, and the teeth are of the rod-like form of those of the C. arctatus, Cope, and the roots are similarly compressed. An important difference in the teeth is seen in their lack of 
the carina on the enamel-face of the base of the crown at least; the apices being in each case broken away. Accordingly, the root exhibits no corresponding groove on its inner side, as is the case in $C$. arctatus. The form of the maxillary bone is also characteristic. In $C$. arctatus, this piece bears a longitudinal protuberance on its inner side, so as to have given the face great proportionate width. In $C$. stenopsis, this protuberance is much less pronounced; the inner face, instead of being nearly horizontal above, is eurved abruptly downward, and a shallow horizontal face of no great width replaces the wide oblique cornice which extends from the alveolar border in $C$. arctatus. The remains indicate a species of the size of $C$, arctatus.

From six miles west of First Rranch of Milk River, near latitude $49^{\circ}$.

\section{Measurements.}

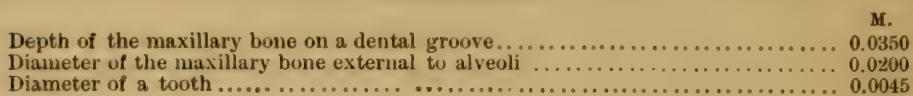

\section{COMPSEMYS, Leidy.}

This genus presents the characters of Emys in its well-developed marginal bones, united to the costals by suture. The surfaces of the carapace possess a dense layer, which is sculptured in two of the known species. One of these, the $C$. victus, Leidy, has been found to have had a wide range in the West during the Fort Union epoch; while a second has been found in corresponding strata near the northern boundary of Dakota.

\section{Compsemys ogmios, Cope.}

Represented in the collections of the British American Boundary Commission by portions of the carapace and plastron. These are massive, and indicate a species of large size. As in other species of the genus, the external surface is a dense layer of cement or allied substance, which is sculptured with shallow pits.

A portion of the costal bone is concave, and increases rapidly in thickness in one direction. The suture is coarse, but neither gomphosial nor squamosal. A portion of the plastron is thinner, not curved, and displays a very coarse median suture, in part squamosal in character. The sculpture consists of shallow pits, not wider than the low, smooth ridges which separate them. There are deep superficial grooves, marking the boundaries of dermal areas; a feature in which this tortoise differs much from the Plastomenus coalescens, and resembles the species of Compsemys. Should marginal bones be found to exist in the $C$. ogmius, its reference to that genus will be further established.

From six miles west of First Branch of Milk River, near latitude $49^{\circ}$.

\section{PLASTOMENUS, Cope.}

This genus has been discovered to (mbrace tortoises having characters of both Trionyx and Emyse. The carapace is like that of the former, in the absence of articulated marginal bones, and the presence of a superficial cement layer, which is seulptured in various patterns. The plastron resembles that of some emydoid genera, but presents certain fontanelles indicating an incomplete grade of ossification. The species known to possess the typical structure are found in the Eocenes of Wyoming and New Mexico; and those here referred to it are all from the Fort Union or Transition beds of the Cretaceous. In none of them is the sternum so well-preserved as to exhihit the characters which should finally refor them to the genus Plastomenus. This is due to the fact that they, as well as other vertebrate remains from this horizon, are always much broken or dislocated. 


\section{Plastomenus coalescens, Cope.}

This species is represented by large fragments of carapace and plastron of a single individual. These indicate a large animal of adult age. The fragments are thick, and the sutures separating the component elements have disappeared. Dermal sutural grooves are also wanting. The portions of the plastron preserved are emydoid in character, being most thickened in the lateral portions, especially in the inguinal region. The borders of the carapace are free and obtuse; at some points, somewhat thinned out. The ribs proper, in the portions preserved, terminate in a short, free extremity, shorter than in most species of Trionyx. There is no indication of the existence of marginal bones.

The surface of plastron and carapace is covered with a dense layer, which is thrown into rather coarse, inosculating folds. These form an open, reticulate pattern towards the middle portion of the carapace, and become obscure near the borders. They are well marked on the plastron, and are more or less longitudinal. The appearance is that of a Trionyx.

The costal axis scarcely projects on the inner face of the carapace. The anterior border of the carapace is a free, thickened margin, divided by a horizontal groove. The presence of nuchal bone cannot be ascertained.

\section{Measurements.}

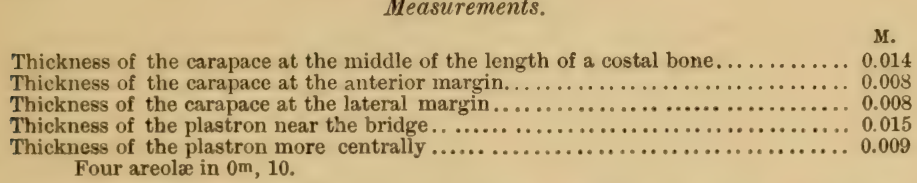

This species is found in a greenjsh-brown arenaceous clay deposit in the Bad Lands south of Woody Mountain, latitude $49^{\circ}$.

\section{Plastomenus costatus, Cope.}

Represented, in the collections made by Mr. Dawson, by small portions of plastron and carapace, which display distinct osseous, but no dermal scutal sutures. These specimens were discovered together, and are believed to belong to the same individual. The bones are thinner than corresponding ones of the two other species of tortoises described, from the same locality, excepting at the costal enlargement, which is remarkably prominent and well-defined on the under side of the carapace. The dense or cement layer of the carapace is thrown into very delicate, but preminent ridges, which run parallel to the axis of the carapace, and occasionally inosculate, or are crossed by a similar ridge running at right angles to them. The sculpture of the plastron is similar, but more obtuse and obscure. The superior edge of the free border of one of the lobes of the plastron projects beyond the inferior, and is not, as is usual, less prominent than the inferior.

\section{Measurements.}

.

Thickness of a costal at the margin $. \ldots \ldots \ldots \ldots \ldots \ldots \ldots \ldots \ldots \ldots \ldots \ldots \ldots \ldots, 0.005$

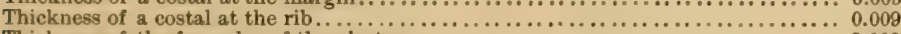

Thickness of the free edge of the plastron ......................... 0.009

The costal bone of this species is much like that of a Trionyx, but the character of the plastron refers it to Plastomenus. 

(C) Lake of the Woods.-Table showing the nature and directions of the dykes and veins observed, and the rocks which they traverse. (The larger granitic outbursts already fully referred to are here omitted.)

Those bracketed on the left occur on the same spot. Those bracketed in addition on the right intersect, their relative ages being in the order of the list.

\begin{tabular}{|c|c|c|c|c|}
\hline Name of Place. & & $\begin{array}{l}\text { haracter of Dyke } \\
\text { or Vein. }\end{array}$ & $\begin{array}{c}\text { Character of rock } \\
\text { traversed. }\end{array}$ & $\begin{array}{l}\text { Course of Dyke } \\
\text { or Vein. }\end{array}$ \\
\hline 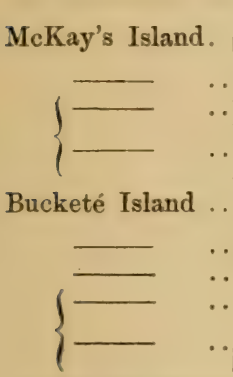 & 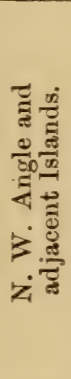 & $\begin{array}{l}\text { Red felspar and } \\
\text { quartz } \\
\text { Red felspar } \\
\text { Red felspar } \\
\text { Vitrous quartz } \\
\text { (small) } \\
\text { Red felspar and } \\
\text { " quartz “ } \\
\text { “" “ } \\
\text { Granite dykes } \\
\text { Red felspar and } \\
\text { quartz }\end{array}$ & $\begin{array}{c}\text { Granite } \\
\text { Gneissic } \\
\text { Hornblendic schist } \\
\text { “" “ } \\
\text { Granite } \\
\text { " } \\
\text { Mica schist } \\
\text { Altered slates } \\
\text { ، "، }\end{array}$ & $\begin{array}{c}\text { E \& W. } \\
\text { N. } 70^{\circ} \mathrm{E} . \\
\text { N. } 40^{\circ} \mathrm{E} . \\
\text { S. } \overline{75^{\circ} \mathrm{E}}\end{array}$ \\
\hline $\begin{array}{l}\text { Cormorant Rock. } \\
\text { Near Windy Pt... } \\
\text { Bigsby Island } \\
\left\{\begin{array}{ccc}\text { " } & \text { " } & . . \\
\text { Middle Island } & . . \\
\text { " } & \text { " } & . \\
\text { " } & \text { " } & . . \\
\text { District of She- } \\
\text { bashca } & .\end{array}\right. \\
\end{array}$ & 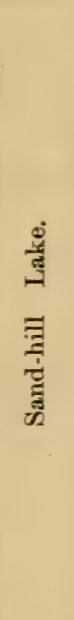 & 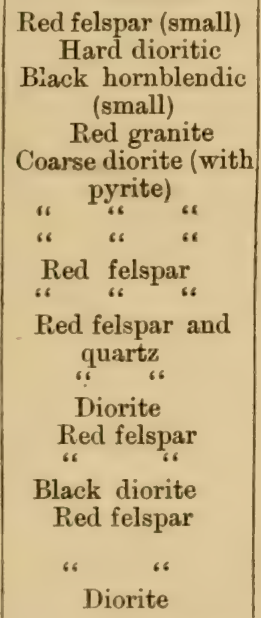 & 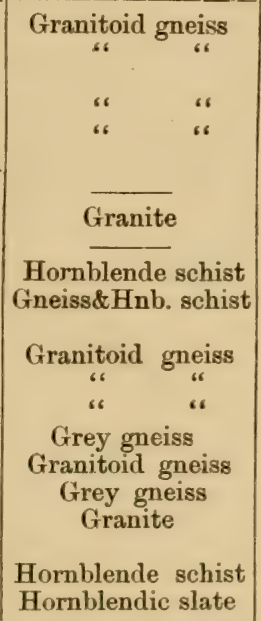 & 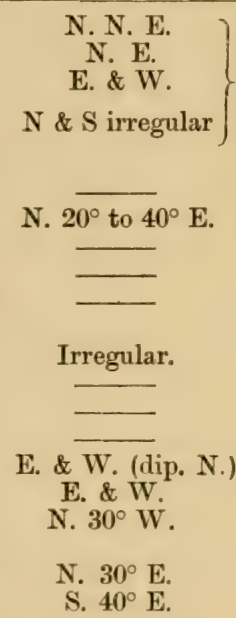 \\
\hline $\begin{array}{l}\text { Picture-rock Bay. } \\
\text { Ka-ka-ke-wabec.. } \\
\text { Rat Portage } \\
\text { Lacrosse Island .. } \\
\end{array}$ & 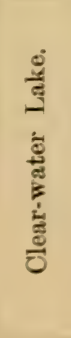 & $\begin{array}{c}\text { Red granite } \\
\text { Grey granite } \\
\text { "“ } \\
\text { Coarse diorite } \\
\text { Diorite } \\
\text { Grey granite } \\
\text { "“ "“ } \\
\text { "“ felspar and } \\
\text { Red fuartz } \\
\text { Grey diorite }\end{array}$ & $\begin{array}{c}\text { Altered slate } \\
\text { " " } \\
\text { " } \\
\text { Junction Laur. \& } \\
\text { Hur. } \\
\text { Altered slate } \\
\text { Slates } \\
\text { " } \\
\text { Quartzite } \\
\text { Granite } \\
\text { " }\end{array}$ & $\begin{array}{l}\text { N. E. } \\
\overline{\text { E. \& W. }} \\
\text { S. } 25^{\circ} \mathrm{E} . \\
\text { N. } 77^{\circ} \mathrm{E} \\
\text { N. } 63^{\circ} \mathrm{E} . \\
\text { Irregular. } \\
\text { Irregular. } \\
\text { N. } 30^{\circ} \mathrm{E} \text {. }\end{array}$ \\
\hline
\end{tabular}



(D.) - Notice of the Butterflies and Orthoptera, collected by Mr. George M. Dauson, as Naturalist of the B. N. A. Boundary Commission.

\section{By SAMURl H. Scudder.}

The insects recorded in this list were taken along the boundary line between British America and the United States, from the Lake of the Woods, in W. long. $95^{\circ}$, to the Rocky Mountains in W. long. 115 . The principal localities referred to are :Dufferin, on the Red River of the North, altitude $780^{\circ}$; Souris River, (a tributary of the Assineboine), between long. $99^{\circ}$ and $102^{\circ}$, altitude about $1600^{\circ}$; and Woody Mountain, about long. $107^{\circ}$, on the watershed between the Missouri River and the streams flowing north, the elevation of whose plains is about 2,500. A few specimens were also taken at Roseau River, lying between Red River and the Lake of the Woods, and flowing into the former; Wood End, on the Souris River, long. $103^{\circ}$, altitude $1700^{\circ}$; the east fork of Milk River, which crosses the line in long. 109 30', at an altitude of $2700^{\circ}$; and West Butte, the western part of the Three Buttes, in long. $111^{\circ}$ $30^{\circ}$, altitude $4,000^{\circ}$. The highest elevation from which specimens were brought, was the summit of the Rocky Mts., in long. $115^{\circ}$, the altitude from 7,000 to $8,000^{\prime}$.

If we compare this list of butterflies with that of the Yellowstone Expedition of $18733^{*}$ we shall find some interesting and striking facts, although no great number of species were taken by either party. The two collecting grounds, while not more than one or two hundred miles apart, lay mostly in different drainage areas; and if we omit from the present list the species found only at Woody Mt. and westward, as being upon the summit of the water-shed between the two river basins, and therefore likely to impair the value of the result, we find that out of the forty-three species found in the two collecting grounds, only seven were taken in both. Of the twenty-two Nymphales, only three occurred in both regions, viz.: Vanessa cardui, Argynnis Nevadensis and Pinyciodes Tharos, the first and the last species of unusually wide distribution. Of the five Rurales, none of the species were taiken in both localities. Of the seven Papilionidæ, two were taken in both, Eurymus Philodice and E. Eurytheme; also species of a very extended range. Of the nine Urbicola, two were brought home by both parties: Thorybes Pylades and Thanaos Persius, the former certainly, and the latter probably, of exceptionally wide geographical distribution. Of the seven species occurring in both regions, only one may be said to have a range at all restricted, and they are mostly such species as one might find in almost any part of America, east of the Rocky Mts.

The same will be noticed, though less conspicuously, on comparing the species of single genera; thus Cœnonympha Ampelos of the Assineboine Basin is replaced by C. Galactina in the Yellowstone; and Basilarchia Arthemis of the former, by B. Weidemeyeri of the latter. B. Disippe was taken only on the Yellowstone, but cer- 
tainly occurs in the Assineboine region. Argynnis Edwardsii of the Yellowstone is replaced by $\mathrm{A}$. Bremnerii in the Assineboine, and probably also by A. Aphrodite, although this was taken at Woody Mountain. The two species of Eurymus, however, were taken in both regions, and a species of Argynnis (A. Nevadensis) was also found common to both.

The watershed between the Assineboine and Saskatchewan basins on the one side, and the basin of the Missouri, of which the Yellowstone is a tributary, on the other $-\mathrm{a}$ watershed which follows a course nearly coinciding with the annual isotherm of $45^{\circ}$ Fahr. (corrected for altitude)-would seem, therefore, to be, in all proability, the dividing line between a more northern and a more southern fauna; or perhaps, more correctly speaking, between a north-eastern and a south-western fauna. The northern branch of the Missouri, to be sure, intervenes between the regions traversed by Messrs. Dawson and Allen, but its fauna must unquestionably have a facies essentially similar to that of the Yellowstone. We shall, however, look with interest for Mr. Edwards' forthcoming report upon the butterflies collected by Dr. Coues through this region, to see whether the facts will add to, or detract from, the weight of the considerations we have presented, from the scanty material at our disposal

Cambridge, U.S., March, 1875.

BUTTERFLIES.

1. Eneis Uhleri.-A single male, remarkably small, measuring but $45 \cdot 5 \cdot \mathrm{mm}$. in expanse, was taken in the vicinity of Woody Mountain, between the middle of June and July 7.

2. Enodia Portlandia.-Two males were taken in the neighbourhood of the Lake of the Woods between the middle of July and the middle of August.

3. Cononympha Ampelos.-A badly broken specimen, probably referable to this species, was taken at Dufferin.

4. Danaida Plexippus.-A male was taken in the Red River valley, June 20.

5. Basilarchia Arthemis.-A female was taken at Dufferin between June 21 and 26 , and another near the Lake of the Woods between the middle of July and the middle of August. The latter specimen is interesting from its large size, (expanding $84 \mathrm{~mm}$.) and in the extent and dullness of the red spots of the under surface, in which it begins to show no inconsiderable resemblance to $B$. Weidemeyeri.

6. Polygonia Progne.-A male was taken in the vicinity of the Lake of the Woods between the middle of July and the middle of August; a female was taken at Dufferin.

7. Papilio Antiopa.-One specimen was taken at Dufferin between June 21 and 26 ; another at the Lake of the Woods between the middle of July and the middle of August.

8. Aglais Milberti-A single male was taken near the Lake of the Woods between the middle of July and the middle of August.

9. Vanessa cardui--Common at Dufferin, June 14.

10. Argynnis Aphrodite.-One male was taken in the vicinity of Woody Mountain between June 15 and July 7 , and another near the Lake of the Woods between July 15 and August 15.

11. Argynnis Nevadensis, - A single fresh male was taken at the close of June at Wood End f fresh specimens of both sexes between Woody Mountain and the base of the Rocky Mountains, from July 15 to August 7.

12. Argynnis Bremnerii.-A male was taken at Dufferin.

13. Brenthis Bellona,-A male was taken at Dufferin in June. 
14. Euphydryas Phaeton.-One female was taken at the Lake of the Woods between July 15 and August 15.

15. Phyciodes Tharos.-Two males were taken near the Lake of the Woods between July 15, and August 15.

16. Everes Comyntas._-One male was taken at Dufferin and another east of Woody Mountain, between the middle of May and the middle of June. These specimens differ from eastern types in having the whole upper surface of the wings of a hoary aspect, such as generally appears only at the costal edge of the fore wings in eastern individuals; and in the remarkable faintness of the dark spots on the under surface of the wings, which bear no small resemblance to those of lightly marked specimens of Cyaniris neglecta.

17. Eurymus Philodice.-A male and a female of the pale form were taken near the Lake of the Woods between the middle of July and the middle of August.

18. Eurymus Eurytheme.-A single male was brought home from the Lake of the Woods, taken at the same time with the preceding.

19. Parnassius Smintheus.-Two fresh specimens were taken on the summit of the Rocky Mts. (near the north-western corner of Montana) at an elevation of from 6-7,000 on August 9. They were both of the type figured by Edwards, in his plate Parnassius II.

20. Thorybes Pylades.-A male was taken at Dufferin.

21. Thanaos Persius.-A female, very badly rubbed, but apparently belonging to this species, was taken near the Lake of the Woods between the middle of July and the middle of August.

22. Anthomaster Uncas.-Two males were taken between Woody Mt. and the base of the Rocky Mts., between the middle of July and the end of the first week in August.

\section{ORTHOPTERA.}

1. Scudderia curvicauda.-A male was taken at Roseau River on August 30, and a female in the vicinity of Souris River.

2. Xiphidium saltans.-One male and five females, Souris River. Heretofore known only from Nebraska and the neighbouring region.

3. Anabrus purpurascens,-Four males and four females were taken at West Butte July 29 ; in the vicinity of Woody Mt., between June 15 and July 7 ; and in the neighbourhood of the Souris River. The specimens from the two former places lack the mottled markings of the abdomen so peculiar to this species; there are, however, no other distinguishing features. Mr. Thomas, while retaining the generic name Anabrus, refers this species to Thamnotrizon; but wrongly, for it is congeneric with A. simplex Hald. the type of the genus.

4. Caloptenus spretus.- Specimens of this destructive insect were brought home from Dufferin, the Souris River, the vicinity of the Lake of the Woods, and the East Fork of Milk River. In the latter place they were "forming swarms" on July 16th. Mr. Dawson also writes me, that his party "met with great swarms of these insects on the high plains north of the Missouri and Milk Rivers, in July, 1874."

5. Caloptenus bilituratus.-Two females were taken at Souris River.

6. Caloptenus bivittatus.-A single female was taken near the Lake of the Woods, July 30. This is the true bivittatus of Say, with which the Acrid. leucostoma of Kirby is probably synonymous; and distinct from the femoratus of Burmeister (the Acrid. flavovittatum of Harris), with which all recent authors, myself included, have hitherto confounded it; this species has the hind tibire glaucous and yellow; in C. femoratus, they are red; and the species can be instantly distinguished by these peculiarities.

7. Pezotettix borealis.-A single pair of this species was taken in the vicinity of the Souris River.

8. Pezotettix Dawsoni nov. sp.-Brownish fuscous; face, sides of head and pronotum yellowish, with the exception of a broad, reddish-brown stripe extending from the eyes to the posterior sulcation of the pronotum; antenna yellowish at the base, 
beyond infuscated ; tegmina half as long as the abdomen, broad lanceolate, acuminate, dark brownish fuscous, with a few scattered indistinct blackish spots, sometimes collected into a mesial series; hind femora very obliquely and broadly bifasciate with blackish brown, the tip black, the superior carina yellowish; hind tarsi dull, almost dusky, yellow. Cerci of male rather small, compressed, simple, but little tapering, rounded at the tip, curved gently upward, obliquely sulcate at the extremity. Length of body, $\$ 14 \uparrow 16 \mathrm{~mm}$.; of tegmina $5 \% 6 \mathrm{~mm}$; of hind femora $8.75 \$ 9.25 \mathrm{~mm}$. One male and two females were taken at the Souris hiver.

9. Gomphocerus clepsydra nov. sp.-Brownish yellow; antennæ infuscated at the slightly expanded tip; head more or less spotted and banded with dark brown and blackish, but with a lighter yellow, immaculate, vertical stripe between the lateral carine of the face, and the deep sulcation following the lower angle of the eyes; this sulcation is black, shading off into brown posteriorly; a broad dark band, blackish above and edged at this point with yellow, axtends from behind the eye upon the pronotum ; it is of equal width as far as the greatest constriction of the lateral carinæ of the pronotum, but beyond this narrows rapidly, and scarcely reaches the posterior edge of the same; a small triangular patch of the same colour appears, however, at the posterior lateral angles of the pronotal disc; and the lateral lobes of the pronotum are heavily marked with the same, especially in front, the lower portion always immaculate; tegmina half the length of the abdomen, brownish, with a few longitudinal fuscous flecks in the lower half; hind femora blackish along the middle, deepest next the carinæ; hind tibir yellowish, flecked minutely with brown, the spines tipped with llack; base of the abdominal joints heavily marked with black at the sides. Lateral foveolæ of the head distinct, three or four times as long as broad, equal, moderately deep, the walls abrupt; median and lateral carinie of pronotum equally sharp and distinct, the latter strongly approximate in the middle of the anterior twothir is of the pronotum; and since they are edged interiorly with yellow, forming, with tr. yellow line bordering the black band of the head, a clepsydral outline. Length oi body $\$ 19 \mathrm{~mm}$.; of antennæ $\& 5 \mathrm{~mm}$.; of tegmina $\& 5 \mathrm{~mm}$.; of hind femora $\$ 11$ mm. Two females were taken on the Souris River.

10. Arphia frigida nov. sp.-Dark reddish brown; antennæ reddish-brown at hase, infuscated beyond; tegmina flecked obscurely and rather uniformly throughout, but least at base, with small dusky spots; wings pale yellow at base, with a moderately broad, blackish fuliginous bent band beyond the middle of the wing, faintly interrupted with pale fleckings on either side of the nervures (though the nervures themselves in this part of the wing are blackish), occupying the entire space between the two principal veins of the upper area of the wing, from the base three quarters the distance to the outer border, but paling next the base, at the extremity bent downward and outward as far as the outer border, thence following it nearly to the anal angle; beyond the band, the apex of the wing is fuliginous, slightly the darkest at the extreme tip; the costal margin is yellowish, tinged with dull orange above the transverse portion of the fuliginous band; hind femora indistinctly transversely fasciate with dark brown; hind tibiæ livid, broadly clouded with fuliginous just before the middle and at the apex, dusky at the base, the spines black, excepting at base. A pair of minute frontal foveolæ separate the lateral foveolæ of the head from each other, and also the vertex from the frontal costa; they are distinct, minute, longitudinally quadrate, confluent above, their bounding ridges, as well as those of the lateral foveolæ, punctulate. Pronotum rugose above, especially on the anterior half; median carina low, uniform, almost straight, once interrupted; posterior border of pronotum bent at a rounded right angle. Length of body : t $18 ; \& 27 \mathrm{~mm}$.; of tegmina: $\delta 22 ; \& 25 \mathrm{~mm}$; of hind femora: $11 \mathrm{\delta} \mathrm{mm}$. A single female was taken near Wood knd in June. I have also a male from the Yukon River, Alaska, collected by the late Mr. Robert Kennicott.

11. Arphia tenebrosa.-A single male was brought from Souris River.

12. Hippiscus phanicopterus.-A male and two females were taken at Dufferin, June 13 and 14.

13. Edipoda trifasciata.-One female was taken at Wood End in June. This is the most northern locality from which it has been obtained.

14. Trimerotropis verruculata. $-\mathrm{A}$ female was taken at Dufferin, 
15. Tettigidea acadica nov. sp.-Head blackish fuscous, rather thickly studded with minute, pallid, raised points; the mouth parts paler, but the tip of the labrum black; pronotum pale cinereous, thickly studded with minute, whitish, raised points and a few little black dots on the upper surface next the middle of the tegmina; the sides, above the tegmina, dark brown like these organs; legs pale cinereous, heavily flecked with black, the hind femora less so than the other parts; hind tibiæ blackish at the base, in the middle, and more broadly at the apex. Median carina of summit of head sharp, equal, extending over its anterior half; pronotum extending backward to the tip of the abdomen, forming a low crest, highest anteriorly, falling rapidly in front, and raised above the level of the head by about as much as the width of the vertex between the eyes; wings reaching to the tip of the abdomen. Length of pronotum, $9.5 \mathrm{~mm}$; breadth of same, $3.1 \mathrm{~mm}$. A single female was taken near the Lake of the Woods.

The Gryllides were not determined. 

(E.)-Land and Fresh-uater Mollusca, collected during the summers of 1873-74, in the vicinity of the Forty-ninth Parallel-Lake of the Woods to the Rocky Mountains.

In referring the specimens to their types, it has been found necessary to take a broad riew of the species, to avoid the too great multiplication of so-called specific names. Over the great area of the plains, every pool and river has its more or less distinct suite of forms. Limnæa elodes is perhaps the most variable of all, and under this name shells have been included, from which specimens might have been selected very different in appearance, but which are all more or less closely connected by intermediate varieties. Bulinus hypnorum is probably one of the most constant in form, in all its localities.

The Gasteropoda of the streams and lakes of the wooded region to the east, differ considerably in general facies from those of the Red River Valley and plains west of it, where a general increase in the thickness and robustness of the shells is found, and gives rise to a distinct series of varietal modifications. In the pools and swamps of the prairies, food and calcareous matter no doubt equally abound. Segmentina armigera there assumes its varietal form campestris ; Planorbis trivolvis often appears in its variety macrostomus; Limnæa stagnalis, and L. elodes increase in size and weight of shell, and other species are similarly affected. By carefully noting the station of each form, and especially the nature of its food, and the probable presence or absence of sufficient calcareous matter in the water; many puzzling shells are found to be varieties depending on these circumstances. The names employed are chiefly those of the monographs in the Smithsonian Miscellaneous Collections.

G. M. D.

\section{RISSOID E :}

GASTEROPODA.

Amnicola pallida, Hald. Lake of the Woods.

Amnicola porata, Say. Lake of the Woods.

Somatogeirus depressus? Tryon. 500 Mile Lake. East Fork Milk River.

\section{PALCDINADE :}

Paludina decisa, Say. Lake of the Woods.

Valvata tricurinata, Say. Lake of the Woods. East Fork Milk River (worn specimens, may have travelled from pools near the Cypress Hills.)

Valvata sincera, Say. East Fork Milk River (worn specimens.)

\section{Helicide :}

Helix striatillu, Anthony. Lake of the Woods. Dufferin. Pembina Mountain. Turtle Mountain. Wood Mountain.

IIelix pulchella, Miiller. Lake of the Woods, Pembina Mountain, Wood Mountain.

IIelix limitaris, Sp. nor._Shell conspicuously umbilicated, globosely depressed, solid, coarse; whorls carinate at the periphery, and sub-carinate near the umbilicus, giving the mouth a distinctly rhomboidal form in young 
specimens; peripheral carination almost obsolete on the last half whorl; aperture roundedly lunate, very oblique, slightly reflexed at the umbilicus, so as to interfere somewhat with its circular outline; peristome acute, thickened within ; callus delicate, transparent; whorls $5 \frac{1}{2}$; suture slightly impressed, becoming more distinct in the last half whorl ; surface marked with coarse transverse wrinkles, and faint revolving lines, the latter scarcely perceptible on the outer whorl; colour, dull yellowish, with four brownish revolving bands, two of which appear pretty constant, and are situated on each side of the peripheral carina, which is generally whitish ; the two remaining bands near the suture and umbilicus respectively, fainter and less constant. Animal resembles $H$. solytaria in general form, pale, with brownish spots.

Greatest diameter $17 \mathrm{~mm}$. ; least diameter $14 \mathrm{~mm}$. ; height $11 \mathrm{~mm}$. Young specimens only $4 \mathrm{~mm}$. in diameter are very strongly carinated, and flattened above; semi-transparent, brownish-tawny in colour; delicately marked with close revolving and transverse lines.

This shell is closely allied to Helix solitaria, but is smaller, darker coloured and rougher, more distinctly carinated, especially in young specimens; the shell is also somewhat thicker, the umbilicus is narrower, and the lip encroaches slightly on its circular outline.

Loc, Waterton Lake. Rocky Mountains.

Vitrina limpida, Gould. Lake of the Woods. Turtle Mountain. Wood Mountain

Hyalina arborea, Newcomb. Lake of the Woods. Dufferin. Turtle Mountain. Wood Mountain.

Hyalina fulva, Draparnaud. Lake of the Woods. Pembina Mountain. Turtle Mountain. Wood Mountain.

Myalina viridula, Menke. Lake of the Woods. Dufferin. Pembina Mountain. Turtle Mountain. Wood Mountain.

Succinea obliqua, Say. Lake of the Woods. Dufferin. Pumbina Mountain. Turtle Mountain. Many specimens showing a decided approximation to $\boldsymbol{S}$. Totteniana, but with intermediate forms.

Succinea avara, Say. Lake of the Woods. Corresponds exactly with Say's description and figure, but many of my specimens exceed $6 \mathrm{~mm}$., the largest measuring 9.5 by 5 mill.

Succinea ovalis, Gould. Lake of the Woods.

Succinea Haydeni, var minor, Binney. Pembina Mountain.

Succinea lineata, Binney. 30 miles E. of Wood Mountain. 20 miles S. of Wood Mountain. The specimens agree pretty closely with this species, and appear to belong to it, though they do not show any distinct revolving lines. The callus is very delicate. The agreement witl Binney's figure is more satisfactory than with the description, my specimens having the aperture longer than half the length of the shell; shell solid, amber coloured, to greenishyellow.

Cionella sub-cylindrica, Lin. Lake of the Woods. Dufferin. Pembina Mountain. Turtle Mountain. Wood Mountain.

Pupa.-Near Saline Lake, east of Turtle Mountain. (One specimen only, immature.)

\section{LIMNAIDA:}

Limnea stagnalis, Lin. Lake of the Woods. Pointe du Chêne. Dufferin. Long River. The specimens from the prairie region are often very well grown and robust, the shell being thick and showing strong growth-lines. Some specimens from pools at Dufferin measured 56 by $26 \mathrm{~mm}$.

Iimnza elodes, Say. Lake of the Woods. Pools and swamps of the Red River prairie. Pembina River. Saline Lake, east of Turtle. Mountain. Turtle Mountain. Rivicre des Lacs. Souris River. Pools near Traders' Road. 500 Mile Lake. Creek near East Fork Milk River. Pool 30 miles west of West 
Butte, \&c. Occurring in very many varictal forms, which are all here included. Specimens from coulée, Traders' Road measured 36 by $13 \mathrm{~mm}$.

Limnar humilis, Say. Lake of the Woods. Dufferin. Pembina Muuntain. Saline Lake, E. of 'Turtle Mountain, Traders' Road.

Limnae decollata, Mighels. Lake of the Woods. Abundant on some parts of the shores of the Lake of the Woods, generally among rocks and boulders on an exposed coast, and creeping over the stones even in the wash of the waves, with the habit of a Littorina. Well grown specimens measure 15 by $11 \mathrm{~mm}$. Colour pale, yellowish-brown; surface marked with lines of growth, which are sometimes rather coarse, and in the outer whorl are sometimes crossed by gentle, irregular, revolving ridges, dividing the surface into quadrate areas, in a manner resembling that frequently seen in Limnæa elodes. Wellpreserved specimens also show very fine and close undulating transverse lines, and delicate revolving striæ, giving the shell a lustrous surface. Lip usually thickened, and tinted brownish-purple.

Limnæa catascopium, Say. Dufferin. Riviere des Lacs. Pool Traders' Road. Creek near East Fork Milk River. West Butte?

Limnæa catascopium. Var pinguis, Say. Creek near E. Fork Milk River.

Limnæa caperata, Say. Dufferin. Pembina Mountain. Pembina River.

Limnæa pallida? Near Dufferin.

Physa heterostropha, Say. Lake of the Woods. Pointe du Chêne. Dufferin.

Physa ancillaria, Say. Lake of the Woods.

Physa ampullacea, Gould. Creek 13 miles west of Wood Mountain. Measurement of largest specimens 22 by $13 \mathrm{~mm}$.

Bulinus hypnorum, Lin. Lake of the Woods. Pools on Red River prairie. Pembina Mountain and River. Turtle Mountain. Riviere des Lacs. Traders' Road. Specimens from Lake of the Woods attain sometimes $20 \mathrm{~mm}$. Those from the prairie region reach $23 \mathrm{~mm}$.

Ancylus parallelus, Hald. Lake of the Woods.

Ancylus rivularis, Say. Roseau River. Souris River.

Planorbis trivolvis, Say. Pools on Red River Prairie. Turtle Mountain. Traders' Road. East Fork Milk River.

Planorlis tricolvis var. macrostomus, Whiteaves. Lake of the Woods. Pools on Red River Prairie.

This variety is not abundant at the Lake of the Woods, but is the common form in the pools and coulées of the Red River Prairie, where calcareous matter and food equally abound. Some specimens $28 \mathrm{~mm}$. in greatest diameter.

Planorbis campanulatus, Say. Lake of the Woods.

Planorbis bicarinatus, Say. Lake of the Woods. East Fork Milk River.

Planorbis corpulentus, Say. Flag Island, Lake of the Woods.-The specimens are from Say's typical locality, and agree perfectly with his description, the form being even better marked than in his figure. $P$.trivolvis, and its variety macrostomus, also occur in the Lake of the Woods. If $P$. corpulentus is also a variety of trivolvis, as has been suggested, it is a very well marked one, and is characteristic of the open reaches of the lake.

Planorbis exacutus, Say. Lake of the Woods. Dufferin. 500 Mile Lake.

Planorbis parvus, Say. Dufferin. Saline Lake, E. of Turtle Mountain.

Segmentina armigera, Say. Lake of the Woods.

Segmentina armigera var cumpestris. Pointe du Chêne. Dufferin. Traders' Road. 500 Mile Lake. This is a large fine variety characteristic of the prairie region, which I have distinguished by the above varietal name. The normal form, with the usual number of whorls (4) is abundant in the Lake of the Woods, and surrounding wooded region. Specimens seldom at all exceed $6.5 \mathrm{~mm}$. 
The variety campestris occurs alundantly in some pools and coulees of the Red River Valley, and prairic region westward. They are much larger, with more whorls, and only in young specimens show the teeth. Colour generally wax yellow or pale brown. 1)iameter of largest specimens from $10.5 \mathrm{~mm}$. to $12.5 \mathrm{~mm}$, whorls often six, specimens to $7.5 \mathrm{~mm}$. often, but not invariably, show teeth; above this size no teeth were recognized.

\section{CORBICULADE :}

\section{LAMELLIBR ANCHIATA.}

Sphsrium sulcatum, Lamarck. Lake of the Woods. Pembina River.

Sphrium striatinum, Lamarck. Lake of the Woods. Pembina River.

Sphærium partumeium, Say. Lake of the Woods. Dufferin.

Sphsrium rhomboideum, Say. Lake of the Woods. Pembina River.

Sphsrium tenue, Prime. Souris River.

Sphærium solidulum, Prime. Lake of the Woods. Souris River. East Fork Milk River (worn specimens).

Sphrerium? stamineum, Conrad. Pembina River.

Pisidium Virginicum, Bourguignat. Lake of the Woods.

\section{UNIONIDA :}

For the identification of species in this family, I am indebted to Dr. P. P. Carpenter :-

Metaptera alata, Lam. Red River; rare.

Unio spatulatus, Lea. Red River.

Unio rectus, Lam. Lake of the Woods. Roseau River. Somewhat rare.

Plectomerus undulatus, Barnes. (=laticostatus, Lea.) Red River. Roseau River.

Hyridella cardium, Raf. (=ventricosa, Barnes var. = subovata, Lea.) Roseau River. Red River; not common.

Hyridella ligamentina, Lam. Roseau River.

Hyridella luteola, Lam. (=siliquoides, Barnes.) Lake of the Woods; very common. Souris River; very common. Roseau River; abundant. Red River. Pembina River.

Lampsilis flavus, Raf. (=rubiginosus, Lea.) Red River. Roseau River.

Theliderma quadrulus, Raf. (=lachrymosum, Lea.) Red River; abundant.

Leptoidea beptodon, Raf. $(=$ plana, Barnes.=purpurascens, Swains. $=$ tenuissima, Lea. $\uparrow=$ velum, Say.) Souris River.

Complanaria complanala, Barnes. Souris River; abundant. Roseau River. Lake of the Woods; somewhat rare.

Complanaria costata, Raf. (=rugosa, Barnes.) Roseau River; rare.

Uniopsis ? Ferussaciana, Lea. Lake of the Woods; abundant.

Strophitus Pennsyleanicus, Lam. (=Anodontu rugosa, Swains. [Not Alasmodonta rugosa, Barnes.] =Anodonta unduluta, Say. [Not Alasmodonta undulata, Say]. Roseau River.

Anodonta Footiana, Lea. Souris River; very common. 
(F.) - List of Plants collected during the Summers of 1873-74, in the vicinity of the Forty-ninth Parallel-Lake of the Woods to the Rocky Mountains.

It has not been attempted to make this list a general one, by the addition of information from other sources, bearing on parts of the same, or on contiguous regions. Those plants only are catalogued, which were either collected or observed, in connection with the Boundary Commission Expedition. The Jocalities given are in general those from which specimens were actually obtained, though in some cases I have added additional information from my note-book. I have also endeavoured to give the date of each specimen, and a note as to its state of advance at the time; that the list may also serve as a contribution to the phenology of the region. The places mentioned by name may be found on the general geological map accompanying this Report.

I must express my obligations to Dr. T. J. W. Burgess, and Dr. Millman-Chief and second Medical Officers to the expedition respectively-for their assistance in making collections. To them many very interesting plants are due.

I am also indebted to Prof. John Macoun, for the determination of the Juncacex Cyperaces, and Graminex, to Mr. George Barnston for that of the Musci, \&c. Dr. Hooker has kindly consented to examine and name several of the more difficult and critical flowering plants, which have been sent to him for that purpose, and if in time will be added to the Appendix.

G. M. D.

RANUNCULACEE

Aquilegia Canadensis, L. Dufferin, (thicket), June 7, '73, in flower.

Aquilegia flavescens, Watson. Kootanie Pass, (thick wood) Aug. 16, '74, in flower, but with mature seed also.

Anemone Pennsylvanica, L. Dufferin, (thicket) June 6, '73, first blossoms. First crossing Souris River, June 3, '74.

Anemone nemorosa, L. Pembina Mountain, (wood) May, 23, '74; in fiower: abundant.

Anemone Patens, L. Var. Nuttalliana, Grey. Near Dufferin, May 4, '74, in flower. May 21, flowering nearly past. Common in certain places on the Red River prairie, probably choosing dry open soil. Very abundant on the second prairie steppe. Flowers were found near Turtle Mountain and Long River on Aug. 7, and in the second week of Sept. respectively, but only where the prairie had been burned early in the summer.

Anemone multifida, D.C. Winnipeg and N. W. Angle Rd, July 2, '73, in flower. Badger Creek, (open prairie) June 28, in flower. Turtle Mountain (open glades) July 10, '73, in flower. Short Creek, July 10, '74. First flowers. The last named is the white variety.

Anemone parviflora, Mx. Rocky Mountains (7,000 feet) Aug. 18, '74, in seed $3 \frac{1}{2}$ inches high.

Anemone Alpina, L. Rocky Mountains (6,000 feet) August 16, 1874, in seed. 
Caltha Palustris, L. Winnipeg and N. W. Angle Road (\$wamp), July. 5,'73. Last flowers. Lake of the Woods. Swamp at base Pembina Mt. May 24, '74, in flower.

Clematis ligusticifolia, Nutt. Waterton Lake (thicket). Aug, 29, '74. Past flowering.

Coptis trifolia, Salisb. Lake of the Woods.

Delphinium azureum, Mx. Plains near Wood Mountain, July 23, '73, in flower but with mature seed also.

Myosurus minimus, L. Near Short Creek, (open swamp) June 10, '74, in flower.

Ranunculus aquatilis, L, var. capillaceus, S. Antler Creek, July 31, '73. Wood End, July 13, '74. Near Wood Mountain, July 2, '74, in flower.

Ranunculus Purshii, Richards. Foot hills of Rocky Mountains (swamps) Aug. 9, '74, in flower. Wood End, July 13, '74, in flower.

Ranunculus flammula, L. var, reptans. Lake of the Woods. Aug. 7, '73, in flower.

Ranunculus abortivus, L. Dufferin (thicket), June 6, '73, in flower.

Ranunculus repens, L. Red River Prairie (open swamp) June 28th, '73, in flower. Lake of the Woods, July 8, '73, in flower. Both the hispid variety.

Ranunculus affinis, Br. Lake of the Woods, (sandy shore), July 12, '73, in flower, but with ripe seed. Traders' Road, (open swamp), June 16, '74, in flower, with fully formed seed.

Ranunculus rhomboideus, Goldie. Red River (prairie), May 22, '74. Pembina Mountain, (open coulée), May 26, in flower, but also with carpels half grown. Common on the open prairie, rarely surpassing 3 or 4 inches. In more sheltered localities taking the form of $R$. ovalis. Hooker.

Ranunculus cymbalaria, Pursh. Dufferin, June 9, '73, (open prairie). Wood End, July 8, '74, near Wood Mountain, June 26, ' 74 . First branch Milk River, Aug. 6, '74. All in flower. Grows on wet prairie, and along the borders of streams.

Ranunculus hispidus, Mx. Dufferin, (swamp), June 16, '73. Wood Mountain, (swamp), June 24, '74. Both in flower.

Ranunculus pygmæus, Wehl. Rocky Mountains, 7,000 feet, Aug. 18, '74, in flower.

Thalictrum dioicum, L. Dufferin, (open prairie), June 4, '73, in flower. Very common. First crossing Souris River, June 5, '74. In river vallies and open prairie, abundant in flower.

Thalictrum dioicum. Var. purpurascens, D.C. First crossing Souris River, June $5, ' 74$.

Thalictrum cornuti, L. Dufferin, (thicket and borders of woods), June 25, '73, in flower.

MENISPERMACEN.

Menispermum canadense, L. Dufferin, (thicket), June 21, '73, in flower.

BERBERIDACE

Berberis (Mahonia) aquifolium, Pursh. Rocky Mountains. With ripe fruit in Aug. Dwarf, rarely exceeding one foot in height. Bourgeau says it is found on west side of Rocky Muuntains only, but on the forty-ninth parallel it is abundant also on the eastern slopes.

NYMPHEACEA.

Nuphar advena, Ait. Lake of the Woods. July 30, '73, in flower.

SARRACENIACEAS.

Sarracenia purpurea, L. Swamps near the Lake of the Woods. Common. July 5 , '73, in flower. 
PAPATERACEA.

Sanguinarie Canadensis, I. Pembina Mountain (Thicket). May 23, '7t, in flower. Unique.

FLMARIACE.⿻.

Corydalis glauca, Pursh. Winnipeg and North West Angle Road. July 4,'73, with ripe seed.

Corydulis aurea, Willd. Dufferin, (thicket) June 3, '73, in flower. Pembina, Mountain, May 23, '74, first blossoms. Turtle Mountain, July 25, '73, with ripe seed. Found generally where burrowing animals have disturbed the ground.

\section{CRCCIFER}

Arabis hirsuta, Scop. Dufferin, June 18, '73, in flower. Turtle Mountain, July 10, '73, still in flower; North Antler Creek, June 7, '74, in flower. 'Trader's Road, June $21, ' 74$, in flower.

Camelina sativa, Crantz. Red River, July 3, '73-still in flower.

Capsella bursa-pastoris, Mœnch. Dufferin, June 12, '73-in flower. Winnipeg and N. W. Angle Rd., July 2 '73-ripe seed.

Cardamine, sp. I. Rocky Mountains, (7,000 feet,) August 18, '74-in flower.

Draba, sp. I. Pembina Mountain, (second prairie level.) Open Prairie, May 25, '74-in flower.

Erysimum cheiranthoides, L. Lake of the Woods, July 8, 73. Turtle Mountain, July 10, '73-both in fiower.

Erysimum lanceolatum, Br. Red River (open prairie) June 21, '73. Trader's Rd. (open prairie) June 21, '74. Short Creek. June 10, '74-all in flower.

Erysimum asperum, D. C. N. Antler Creek, June 6, '74, first blossoms. Badger Creek, June 25, '73. Pembina Mountain, June 4, '75. Both in flower. Abundant on the open prairie.

Nasturtium tanacetifolium, Hook. Second branch Milk R. (Wet border of stream), Sept. 1, 'T4-still in flower.

Nasturtium palustre, D. C. Winnipeg and N. W Angle Rd., July 3, '73-still in fiower.

Sinapis arvensis, L. Dufferin.

Sisymbrium canescens. Pembina Mountain, July 6, (open prairie) in flower.

Sisymbrium brachycarpum, Hook. Red River, June 27, '73, in flower.

Streptanthus sp. I. Short Creek, June 18, '74, in flower.

Turritis glabra, L. Winnipeg, and N. W. Angle Rd; July 3, '73; still in flower.

Thluspi arrense, L. Dufferin, June 6, '73, in flower; near Winnipeg, June 29, ' 73 , with ripe seed; abundant on the Red River, near the older settlements, not yet common as far south as the forty-ninth parallel, but rapidly spreading. A most noxious weed, of comparatively late introduction, and known as Mauvaise herbe, or Herb a Violette, the latter name being derived from the farm on which it was first noticed, in the vicinity of L. Winnipeg, 1857 (Bourgeau.) Occurs abundantly in Quebec and Ontario, and has been a common weed near Montreal since 1821 (Holmes' Herbarium.) Not often found in the Northern States.

Vesicaria Ludoviciuna, D. C. Near Badger Cr. (Dry hillsides.) May 30, '74, in flower.

Vesicaria didymocurpar, Hook. Rocky Mts., (Gravel banks) Aug. 28, '74, in flower. CAPPARIDACE.A.

Cleome integrifolia, T. \& G. S. of Wood Mt., (dry clay-bottomed valley,) June 27 , first blossoms. White Milk R (valley). June 10 , $^{\prime} 74$, in flower. Seems to prefer a dry, clayey, and sub-saline soil. Northward to the Saskatchewan (Bourgeau.) 
Cleome, sp. I. East Butte. Aug. 1, '74, in flower.

Polanisia graveolens, Raf. Wood End, July 12, '74, in flower.

VIOLACE.E.

I'iolu pulveserns, Ait. Dufferin (thicket) May 19, 1874, first blossoms, June 2, '73, in full bloom.

Viola Canodensis, L. Foot Pembina Mountain (thicket) May 23, '74, first blossoms. Winniperg and N. W. Angle lid (thicket), July $3,{ }^{7} 73$, still in flower. Turtle Mountain (shady thicket), July 13, with ripe seed.

Viule perdertı, I. Dufferin (open prairic), Jume, 3, '73, in flower. Pembina Mountain (erlge of second prairic steppe), May $25, ' 74$, first blossoms. Extends to the N. Saskatchewan R (Richardson, Bourgeau.)

Viola cucullata, Ait. Dufferin (thicket), June 2, '73. Pembina Mountain, May 27,74 (thicket), in flower. A form, which apparently represents this species is found on both the first and second prairie steppes, and from its station comes out somewhat earlier than the ordinary variety. It is usually small and stunted, not more than two and a half inches high, and shows well marked varietal differences. The leaves are smaller, longer in proportion, and of firmer texture. Flowers somewhat smaller, dark blue; the spur twice as long in proportion as in common species, and almost resembling that of Selkirkii. Lower petal beardless. Found near Dufferin, in flower, but leaves not fully formed, May 22, '74. In flower, June 3, '73.

Viola Nutlalii, Pursh. Between Long River and Badger Creek, May 30. Plains west of Turtle Mountain, June 2, in flower, and some capsules with seed nearly ripe. Grows on dry, gravelly hillsides. Rare. Olsserved only on the second prairie steppe, but may pass on to the third. Northward to the Saskatchewan (Richardson, Bourgeau.)

DROSERACEX.

Drosern Inngifolin, L. Height of land, Muskeg, between Lake of the Woods and Red River, Common.

PARNASSIACE E.

Parnassia Caroliniana, L. Height of land, Muskeg, between Lake of the Woods and Red River. Aug. 22, '73, in flower. This is probably about the northwestern limit of the species.

\section{HYPERICACE.}

Hypericum Scouleri, Hook. Rocky Mountains. (6000 feet.) Aug. 18, '74, in flower.

\section{CARYOPHYLACE.E.}

Arenuriu luterifom, L. Duffurin (thicket), June 2, '73. Pemlina Mountain, (thicket) May 15, 74. First Crossing Souris River, (thicket) June 3, '74. All in flower.

Arenaria pungens, Nutt. Kootanie Pass, Aug 14, '74, seed shed. Rocky Mountains (7000 feet), Aug. 18, '74, in flower.

Arenaria nardịfolia, Ledeb. Rocky Mountains, (6,500 feet) Aug. 16, '74, few flowers remaining.

Cerastium nutans, Raf. Dufferin, June 18, '73. Turtle Mountain (open prairie), stunted varicty, July 25, '73. Pembina Mountain (open prairie), May 25, '74. All in flower.

Cerastium oblongifolium, Torr. Rocky Mountains (6500 feet), Aug. 18, '74, in Aower.

Silme Wenzimsii, Hook. Sonth Fork lielly liver (wood), Aug. 13, '74, still in flower.

Silem antirhimu, L. Wimniper and North-west Angle load, July 2, '73, in flower. 
Silene Dorglısii, Hook. Rocky Mountains (1500 feet), Aug. 18, '74, in flower. Stellaria longifolia, Muhl. Dufferin (damp thicket), June 12, '73, in flower.

\section{MALYACEE.}

Maleastrum coccineum, Gray. Long River (open prairie), June 25, '73, in flower. Near Wood End (dry open prairie), June 12, first blossoms. Wood End, June 18, (open prairie), in flower. Long River is about the eastern limit of this plant, on lat. $49^{\circ}$. It is common westward, especially on dry plains.

Spharalcen acerifolia, Nutt. Foot Hills of Rocky Mts., (thicket) Aug. 8, '74, in flower.

\section{LINACEX.}

Linum perenne, L. Common from the Red R. prairie westward, growing on the open plains, but especially in sheltered hollows and along river banks, flowering in June.

Linum rigidum, Pursh. Milk River (sheltered valley), July 21, '74. First branch Milk River (bottom land), Aug. 5, '74, 5 to 6 inches high. Both in flower. This plant also noticed on dry upland prairie, near Wood Mt., lut very rarely. It there only attained a height of 1 to 2 inches, and sometimes showed but a single terminal flower.

\section{OXALIDACEN.}

Oxalis stricta, L. Dufferin, June 10, '73, in flower.

\section{GERANIACE}

Geranium Richartsonii, Fisch \& Meyer, (Gr. alliflorum, Hook.) Foot hills of Rocky Mts. Aug. 7, '74, in flower, but with ripe seed also. White variety.

Geranium Fremontii, Torr. Wood Mt. in sheltered valleys), June 23, in flower. Abundant. Also growing with the last in great abundance on the Foot hills; the greater part of the flowers had fallen in the first week of Aug. The roots of this plant, or the last, or both, are used by the Indians as a remedy for diarrhoea.

Geranium carolineanum, L. Winnipeg and N. W. Angle Rd. July 3, '73 ; in flower. Geranium, Sp. I. thicket, Turtle Mountain. July 25, '73; in flower.

\section{BALSAMINACE.⿱一𫝀口:}

Impatiens fulva, Nutt. Lake of the Woods. (Swamp.) August 2, '73 ; in flower.

\section{ANACARDIACEA.}

Rhus glabra, L. Lake of the Woods. July 6, '73.

Rhus trilobata, Nutt. (Rhus aromatica, Gray). Bad Lands south of Wood Mountain. June 29, 74. Berries nearly ripe. Also observed as far east as Pyramid Creek. Grows only on dry barren hill-sides. Few specimens of this plant were seen; and latitude $49^{\circ}$ is probably about its northern limit.

Rhus toxicodendron, L. Dufferin. (Thicket). June 21, '73-in flower.

\section{VITACEN.}

Ampelopsis quinquefolia, Mx. Lake of the Woods. July 19, '73-just flowering. Vilis cordifoliu, Mx. Dufferin, June 18, '73, in flower.

\section{RHAMNACEA.}

Ceanothus velutinus, Dongl. (Var. levigatus, F. \& G.= C. levigatus, Hook.) Kootanie Pass, a shrub abuut 3 feet high.

Rhamnus alnifolius, L'Her. Lake of the Woods, Aug. 7, 73. Kootanie Pass, Aug. 14, '74. Both in fruit. 


\section{ACERINA.}

Acer rubrum, L. Kootanie Pass, Mountains near Waterton Lake.

Negundo aceroides, Moench. Lake of the: Woods, Red River Valley, and westward in the vallies of rivers. In flower at Dufferin, May 8, '74. Finds its northern limit on the $\mathrm{N}$. Saskatchewan in lat. $54^{\circ}$, according to Richardson. Its sap is frequently collected and boiled down to make sugar in spring.

\section{POLYGALACER:}

Polygala polygama, Walt. Lake of the Woods, July 24, "73, in flower.

Polygula senega, L. Rising ground E. of Red River prairie, June 20, '73, in flower. Lake of the Woods, July 22, '73, with ripe seed.

\section{LEGUMINOSA}

Astragalus Canadensis, L. Winnipeg and N. W. angle road, July 5, '73. Red River prairie, June 24, '73. 'Turtle Mountain, July 30,'73. Wood End, July $12, ' 74-$ all in flower.

Astragalus Canadensis, Var. Wood End, June 30, '74. Lake of Wood Mountain, June 27, '74-both in flower.

Astragalus caryocaryus, Ker. Rising ground E. of Red River prairie, June 20, '73fruit fully formed. West of Pembina escarpment, (dry bank,) May 26, '74, in flower. Very common on the second prairie steppe, W. of Pembina River-Var. Wood End, rdry bank), June 11, '74, with larger leaves and fewer flowers, but not agreeing with $A$. mexicanus, and $A$. caryocarpus of the normal form, growing on the same bank, but having its fruit fully formed.

Astrugulus hyproglottis, L. Red River Prairie, May 22, '74, first blossoms. June 4, '73, in flower. First crossing Souris $\mathrm{R}$ (Valley and open prairie), June 3, '74, in flower. Abundant. Traders' Rd. June 19, '74, in flower. White variety.

Astragalus flexuosus, Dougl. Red River Prairie, June 27, '73. Turtle Mountain (dry bank,) July 26, '73. Wood Mountain (dry open prairie,) June 25, '74. All in flower.

Astragulus flexuosus, Dougl. Var. elonyatus (= P'haca Elongata, Hook.) Near Short Creek (open prairie) June 10, '74, first blossoms.

Astragalus Minsouriensis, Nutt. Near Short Creek, (dry hill sides), June 10, '74, in flower.

Astrayalus pectinata, Dougl. First crossing Souris River, (dry open prairie), June 3 , '74, first blossoms. Plant with a strong unpleasant odour.

Astragalus adsurgens, Pall. Traders' Road, (open prairie), June 21, '74, in flower, forming dense tufts about 18 inches high. South of Wood Mountain, June $30, ' 74$, in flower.

Astragalus aboriginormm, Rich. Pemhina Mountain, (open prairie), July 4, '73-in flower. Short Creek, June 10, '74-in flower.

Astragalus Bourganii, (irey. Rocky Mountains, (6,000 feet): August 17, 74 -in flower.

Astragalus lripluyllus, Pursh, (not I'haca cespritosa Nutt.) First crossing Souris River, (dry gravelly lanks), June 3, ' 74 , last blossoms. Forming dense matted tufts, flowers white with bright purple tips when fresh.

Astralagus caspitosus, (irey. White Mud River, (dry bank), June 3, ' 74 , with seed nearly ripe.

Astragalus tegetarius, Watson. Kootanie (Pass, dry bank,) August 14, '74-in Hower.

Desmodium Canadense, D. C. Lake of the Woods. July 28, '73, in flower.

IIed!y:ermu bereale, Nutt. Fout Hills of Rexky Mountains, (thickets and borders of streams). August 15, 74, still in flower in sheltered localities.

Lupinus aryentcus, Pursh. South of Woody Mountain. July 25, ' 
Luvinus argenteus? Wood End. September 1, '73, in flower.

Lathyrus maritimus, Bigelow. Lake of tho Woods. August 7, '73, in flower.

Lathyrus venosus, Muhl. Dufferin. June 22, '73, in flower.

Lathyrus ochroleucus, Hook. Dufferin, (thicket). June 3, '73, in flower-First crossing Souris River, thicket in valley. June 5, '74, first blossoms.

Oxytropis Lamberti, D. C. N. Antler Creek (open prairie) June 6, '74, in flower.

White Mud River (dry bank) July 3, '74, still in flower. First crossing Souris River, June 3, '74, (dry open prairie and gravelly banks) in flower. White variety.

Oxytropis splendens, Dougl. (var. vestita, Hook). Turtle Mountain, (open prairie) July $10, ' 73$, in flower.

Oxytropis splendens, Dougl. (var. Richurdsonii, Hook). Turtle Mountain, thicket, July 11, '73, in flower. My specimens are very different in appearance from the last, and might almost rank as a different species, especially as found growing nearly in the same locality. The leaves are almost all regularly pinnate, with scarcely a trace of verticillate arrangement in the leaflets.

P'soruleu bruchiuta, Dougl. Rising ground tast of Red River prairie, June 19, '73, in flower. Wood End, (open prairie) July 4, '74, still in flower. East Fork Milk River, July 18, '74, past flowering.

Psoralea argophylla, Pursh. Turtle Mountain (open prairie) July 30, '73, in flower. N. crossing White Mud River, July 11,'74, first blossoms. From the eastern edge of the second prairie steppe, to the Rocky Mountains, abundant. Flower, cobalt blue.

Petalostemon violaceum, Mx. Rising ground E. of Red River prairie, Aug. 27, '73, in flower. Turtle Mountain (open prairie) July 25, '73, in flower. West Butte, July 24, '74, in flower.

Petalostemon candidum, Mx, var. Turtle Mountain, (open prairie) July 21, '73, in flower. S. of Wood Mountain (dry prairie and hill-sides) July 2, '74, first blossoms. The leaves nearly all obtuse, and sometimes slightly obcordate. Does not agree exactly with Michaux's figure.

Thermopsis rhombifolia, Nutt. First crossing Souris River and westward, (damp spots on the open prairie and hill-sides) June 3, '74, in flower.

Ticia Americana, Muhl. Lake of the Woods, July, '73, in flower. Dufferin, (open prairie) June 10, '73; (thicket) June 12, '73; near Short Creek, June 10, '74. Both in flower.

Vicia Americana, Muhl, var. B., Hooker. Near Turtle Mountain (open prairie), June 1, '73. Near Wood Mountain (open prairie), June 25, 74. Both in flower. A well-marked variety, inhabiting dry exposed prairies.

IROSACEA.

Ayrimonia eupatoria, L. Turtle Mountain, (thicket) July 23, '73, last blossoms.

Amelanchier Canadensis, T. \& G. Dufferin, June 3, '73, in flower. Foot Pembina Mountain, May 22, '74, first blossoms. Common on the forty-ninth parallel from Lake of the Woods to the Rocky Mountains. West of the Red River country, only occurs in sheltered valleys, but becomes very abundant again on the foot hills of the mountains. In many varietal forms.

C'ratsegue coccinea, L. Dufferin, June 2, '73; second crossing Souris, June 8, '74. Both in flower.

Comarum palustre, L. Winnipeg, and N. W. Angle Road. July 3, '73, in flower.

I) ryus sctopetalu, L. Rocky Mountains, (6,506) feet). Aigust 18, '74, in flower. A hundant on gravelly hanks in the Kootanie Pass, where plants showed half ripe seeds at the same date.

Fragaria Virginiana, Ehrhart. Dufferin, June 2, 73 , in flower. Found growing on the third prairie steppe in sheltered jarts of the valley of White Mud River. 
Fragarin resca, L. Winnipeg and N. W. Angle Road. July 4, '73, flowers and fruit.

Geum triftorum, Pursh. Red River prairie, May 21, ' 74 , in flower. June 19, '73 style's 38 inches long. Northward to Athabasca Lake (Richardson), and the Peace River (Macoun.)

Geum macrophyllum, Willd. Turtle Mountain (thicket). July 15, '73, in flower. Foothills of locky Mountains. August 12,74, tlowering nearly over.

Geum strictum, Ait. Winnipeg and N. W. Angle Road. July 3, '73, in flower.

P'otentilla tridentuta, Ait. Winnipeg and N. W. Angle Road. July 4, 'T3, last blossoms.

Potentilln norvegica, L. Red River. June 29,173 , in flower.

Potentilla fruticosa, L. Eastern border of Red River Prairie. June 20, '73. Winnipeg and N. W. Angle Road. July 3, '73. Woody Mountain, June 22,74 ; all in flower. Abundant near Woody Mountain, and on the Foothills of the Rocky Mountains.

P'otentilla anserina, L. Dufferin, June 10, '73. Near. Short Creek, June 10, '74. Both in flower.

Potentilla arguta, Pursh. Red River, June 28, '73; near Wood Mountain, June $27, ' 74$ (open prairie). Both in flower.

Potentilla glandulosa, L. Rocky Mountains (6,000 feet,) Aug. 16, '74, in flower. Variety, with petals considerably exceeding the sepals.

Potentilla effusa, Dougl. Pembina Mountain (gravelly lank) May 26, '74, first blossoms. Long River, (open prairie) May 29, '74, in flower; first crossing Souris River, (dry bank) June 3, '74, in flower.

Potentilla gracilix, Dougl. Pembina Mountain (open prairie) July 6, '73; Turtle: Mountain, (open prairie) July 9, '73, both in flower.

Potentilla Pennsylianica, L. Var. strigosa, Pursh. Turtle Mountain, (open prairie) July 10, '73; Wood End, (open prairie) June 13, '74. Both in flower.

Potentilla hippiana, Lehm. Wood End, (open prairie) July 7, '74, in flower.

Potentilla Sp. I. Wood Mountain, June 24, '74; Traders' Road, July 15, '74. Both in flower.

Potentilla, Sp. II. Rocky Mountains (6,500 feet), Aug. 18, '74, in flower.

Potentilla (Iveria) Sp. III. N. Antler (reek (open prairie), June 7, '74. Wood End (open prairie), June 14, '74. Both in flower.

Prunus Virginiana, L. Dufferin, June 4, '73. First crossing Souris, June 3, '74. Both first blossoms. Distribution same as Amelanchier Canadensis. The Toqua-e-minare of the Lake of the Woods Chippeways. The Indians collect the berries, beat them till the stones are crushed, and then dry them.

Prunus Americana, Marsh. Dufferin, June 3, '73, in flower.

I'runus I'ennsylvanica, L. Foot Pembina Mountain. May 22,'74, flowers just opening.

Prunus depressa, Pursh. Lake of the Woods.

Rosa blanda, Ait. Dufferin, June 19, '73, in flower. Near Wood Mountain, June 30 , '74, in flower. Grows commonly in a stunted form on the open plains of the Red River, and westward on the second prairie steppe, as far as Turtle Mountain. Beyond this point, it is seldom seen, exeept in sheltered spots in vallies, and along the borders of streams.

Rubus strigosus, Mx. Dufficrin, June 19, '73. Wood Mountain, June 24. Both in flower.

Rubus trifterus, Richard, Dufferin, June 3, '73. Wood Mountain, June 24. Both in flower. 
Rubus Nutkanus, Moe. Kootanie Pass, Ang. 16, '74, in flower. Also common on the Foot Hills with ripe fruit.

Spirrea salicifolia, L. Lake of the Woods. Dufferin. June 30, '73. Badger's Creek, (open prairie). January 7, '73. Pembina Mountain, (open prairie). January 4, '73. Winnipeg and N. W. Angle Road. July 5, '73. All in flower. Abundant on the eastern portion of the second prairie steppe, wherever the soil is at all damp. Forms stunted thickets. The form most characteristic of the open plains seems to be one with small but broad leaves, slender stems, panicle small and close.

Spirrea betulifolia, Pall. West Butte, July 28, '74. Kootanie Pass, August 16,74 . Both in flower.

Sibbaldia procumbens, L. Rocky Mountains, (7,000 feet), August 18, '74, in flower. Abundant but much stunted. Scar ely an inch high.

OXAGRACEE.

Circsea alpina, L. Lake of the Woods, July 9, '73, in flower.

Epilobium angustifolium, L. Lake of the Woods. Turtle Mountain (thicket.) July 13, '74, in flower. Var. canescens. Lake of the Woods. August 7, in flower.

Epilobium latifolium, L. St. Mary River, near the Rocky Mountains. (Border of stream), August 9, '74. Nearly past flowering. Rocky Mountains, (7,000 feet). August 18, '74, in flower.

Epilobium palustre. Var. lineare. Gray. Near Wood Mountain, July 2, '74, in flower. Foot-hills of W. Butte, (border of stream), August 2, '74. Second Branch Milk River, August 4, '74. The two last in flower but also with fully formed pods.

Epilobium palustre, var. albifloru, Hook. Near Wood Mountain, (swamp) July 7, '74, in flower.

Epilobium coloratum, Muhl. Lake of the Woods, July 18, '73, in flower. Foot hills of W. Butte, (border of stream) Aug. 2, '74, in flower, but with ripe pods.

Epilobium origanifolium, Lam. Rocky Mountains, Camp Akamina, (6,000 feet) growing in the shade of thick woods, in flower.

Gaura coccinea, Nutt. Badger Creek, July 7, '73, in flower. Wood End, (dry banks) rare, June 11, '74, first flowers. Common westward from these localities, on the dry places.

Myriophyllum spicatum, L. Lake of the Woods, Aug. 1, '73.

Enothera biennis, L. Lake of the Woods, (dry sandy shore) July 7, '73, in flower. Turtle Mountain, July 25, '73, in flower.

Enothera marginata, Nutt. (=Enothera cœspitosa, Nutt,) in Porter \& Coulter, Syn. H. Col.) Short Creek, June 10, '74, (dry clay bank) fragrant. Acaulescent var.

Enothera heterantha, Nutt. Traders' Road, (open prairie) June 14, '74, in flower.

Enothera leucocarpa, Comien. Turtle Mountain, (open prairie), July 26, '73. Wood End, July 18, '74. Near Wood Mountain, July 9,'74. All in flower. Agrees with Hooker's description, but the anthers appear to be versatile, not adnate.

Enothera pumila, L. Lake of Woods, Aug. 20, 73, last flowers. A depauperated variety, with flowers bright yellow, scarcely four lines in diameter.

Enothera albicaulis, Nutt. Pembina Mountain, Sep. 6, '73, in flower. Unique. Glabrous variety, with white petals.

Enothera, Sp). I (near all,zcaulis). Wood Fnd (open prairie), July 7, '7t, in flower. West Butte (open prairie), July 30, '74, in flower.

Enothera, Sp. II. Second Branch Milk River, Aug. 4, '74, in flower,

Enothera, Sp. III Milk River, July 19, '74, in flower, 
Symphoricarpus occidentalis, R. Br. Lake of the Woods. Red River, June 27 , ' 73 , in flower.

LOASACE.⿱.

Mentzelia ornata, Pursh. and Nutt. Foot-hills of West Butte (sheltered valley), July $31, ' 74$, in flower.

\section{CACTACEX.}

Opuntia Missouriensis, D. C. Specimens appear to belong to var. rufispina of Englemann \& Biglow's Report in connection with the Pacific Railway. The plant is very variable, however, and no doubt other varieties are represented on the forty-ninth parallel. Near Wood Mountain, June 26, '74, in flower. The plant comes very suddenly into bloom, and is very gay for a few days. In '74, from June 26 to July 3 . Common everywiere, but especially characteristic of dry hills and barren valleys, with parched and clayey soil. From Wood End, Long. 103 ${ }^{\circ}$, to near the E. Butte, Long. $111^{\circ}$. East and west of these points the rainfall increases, and it is probably this cause that limits the plant. Collected on the Saskatchewan, by Bourgeau. Macoun collect:d a cactus, which he refers doultifully to this species, near Dunregan, on the Peace River.

Mamillaria (Coryphantha) vivipara, Haw. Wood End, June 27, '74. Near Wood Mountain, July 6, '74. Both in flower. Range similar to last, but not nearly so abundant. Berry edible, ripe in Sept. The flowers, before being dried, are not purple, but carmine.

The locality furthest east where Cacti were observed, on the forty-ninth parallel, was on the plains near Turtle Mountain. The form there seen was not in flower, and did not appear to be growing luxuriantly. It was rare, and may be a depauperated variety of U. Missouriensis, but is probably distinct. Sir J. Richardson mentions the -occurrence of a Cactus on the Lake of the Woods. He writes, "We gathered Opuntia Glomerata, or the Crapaud Verd, of the voyageurs, on the Lake of the Woods." (Journ. Boat Voyage, Vol. Il., p. 277.) Though some time on the Lake of the Woods, I did not succeed in confirming the presence of this form, and from the dampness of the climate am led to suspect that some error in reference has occurred.

GROSSULACE.æ.

Riles aureum, (Pursh). West Fork Milk River, July 18, '74. Fruit formed, but not ripe. Seen only at this place.

Ribes rotundifolium, Mx. West Fork Milk River, July 18, '74. Ripe fruit.

Ribes floridum, L. Her. Dufferin, June 2, '73, in flower. First crossing Souris River. June 3 , '74, in flower. Lake of Woods, \&c.

Ribes rubrum, L. Winnipeg, and N. W. Angle Road, July 4, '73. Ripe fruit.

Ribes cynosbati, L. Pembina Mountain (thicket), May 27, '74, in flower.

CUCLRBITACEA.

Echinocystis lobatu, T. \& S. Lake of the Woods (boggy shore), July 8, '73, in flower. Turtle Mountain, July 23, in flower.

CRASSLLLACEA.

Sedum stenopetalum, Pursh. Summits of three Buttes, or Sweet Grass Hills, July $29, ' 74$, in flower. Kocky Mountains (6,000 to 7,000 feet), Aug. 18, '74, in Hower.

Sedum rhodiola, D. C. Rocky Mountains (7,000 fuet), Aug. 18, '74, past flowering. sedum, Sp. I. Kootanie Pass, dry bank.

BAXIFRAGACEA.

Heuchera eylindrica, Doug. Kootanie Pass, Aug. 14, '74. With ripe seed.

Heuchera Richardsoni, R. Br. Red River Prairie, June 18, ' 73 , in flower. Abundent. From the Lake of the Woods, westward. 
I,eptarrhena pyrolifolia, Brown. Rocky Mountains. Camp Akamina (6000 feet), Aug. 17, '74. Seed nearly mature. Growing on the shady bank of a mouutaiil stream. The seeds are slender, spindle-shaped, thickened in the middle, the two ends slightly bent in different directions.

Mitella nuda, L. Winnepeg and North West Angle Road (thick wood), July 5, '73, seed nearly mature.

Mitella pentandra, Hook. Rocky Mountains. Camp Akamina (6000 feet, thick wood), Aug. 18, '74, seed nearly mature.

Saxifraga heterantha, Hook. Rocky Mountains. Camp Akamina, (6000 feet, bank of stream), Aug. 18, '74, in flower. A weak variety, with smooth leaves.

Saxifraga Dahurica, Pall. Kootanie Pass, Aug. 16, '74, past flowering.

Saxifraga bronchialis, D. C. West Butte (5600 feet), July 29, '74, in flower. Rocky Mountains (6000 feet), Aug. 16, 74, past flowering.

Suxifruga vernalis, Willd. var. B., Hook. in Fl. Bot. Am. Rocky Mountains (7000 feet), Aug. 18, '74, in flower.

Saxifraga Escholtzii, Sternl). Rocky Mountains (7,000 feet), Aug. 18, '74. I first olitained a specimen of this plant from Major Cameron, who found it on the summit of a mountain near the Kootanie Pass. A few days afterward, I found it growing in consideralle abundance on the peaks near the Boundary Monument. It forms a dense, matted sod, and is generally seen growing between stones in the shady and retired parts of the mountains, near melting snow banks. Most of the specimens were past flowering on the date mentioned. Described by Sternberg from Northern Asia, but found also on the north west coast of America, lat. 59 , Behring's Strait, and on the Arctic Sea shore, near Mackenzie River.

Tiarella unifoliata, Hook. Kootanie Pass (wood), Aug. 16, '74, nearly past flowering. Described by Hooker from specimens collected by Drummond on the height of land in the Rocky Mountains, near the sources of the Columbia, and at Portage River.

\section{LMBELLIFERA:}

Cicuta Maculata, L. Lake of the Woods, July 31, '73, in flower. Winnipeg, and N. W. Angle Road, July 2, '73, in flower.

Carum Guirdneri, Benth \& Hook. South Fork, Belly River, Aug. 15, in flower. Abundant.

Cymopteris, Sp. I. Wood End, June 11, '74, in flower.

Heraclium lanatum, L. Red River, prairie, July 3 , in flower.

Osmorrhiza brevistylis, D. C. Kootanit Pass (thick wood), Aug. 16, '74, with ripe carpels.

Osmorrhiza longistylis, D. C. Wood Mountain (thicket), June 24, '74, in flower.

Peucedanum Sp. I. Wood End, June 11, '74, with seed nearly ripe.

Sanicula Marylandica, L. Red River, June 20, '73, in flower.

Sium lineure, Mx. Lake of the Woods, July 31, '73, in flower. Turtle Mountain, July 25, '73. Both in flower.

Thaspium trifoliutum, Gr. Dufterin, Junt 4, '73, first hlossoms. Traders' Road, June 14, '74, in flower. Abundant over the first and second prairie steppes, and very variable.

Umb. I. Foot Hills of Rocky Mountains (dry banks), Aug. 7, 74, in flower.

Umb. II. Near Pembina Mountain (open prairie), May 22, '74, in flower. 
ARALIACEN.

Aralia nudicaulis, L. Wood End, Souris River (thicket), June 11, '74, past flowering.

Aralia hispida, Winnipeg and North-west Angle Road, July 5, '73, in flower.

\author{
COKNACEN.
}

Cornus Canadensis, L. Winnipeg and N. W. Angle Road, July 4, '73, in flower.

Cornus paniculata, L'Her. Dufferin, June 6, '73, first blossoms. Second crossing Souris River, June 8, '74, in flower.

Cornus stolonifera, Mx. Lake of the Woods.

\title{
CAPRIFOLIACE.E.
}

Diervilla trifida, Moench. Winnipeg, and N. W. Angle Road, July 4, '73.

Linnæa borealis, Gron. Lake of the Woods, July 9, '73, in flower.

Lonicera involucrata, Banks. South Fork of Belly River (in the Mountains), Aug. 15, '74. Kootanie Pass (thicket), Aug. 16, '74. Both in flower.

Lonicera oblongifolia, Muhl. Winnipeg and N. W. Angle Road, July 3, '73, in fruit. Lonicera parviflora, Lam. Dufferin (thicket), June 14, ${ }^{\prime} 73$, in flower.

Viburnum opulus, L. Dufferin (thicket), June 12, 73, in flower.

Viburnum lentago, L. Dufferin (thicket), June 13, '73, in flower.

RUBIACEA.

Galium boreale, L. Dufferin (open prairie), June 17, '73, in flower. Wood Mountain, June $23, ' 74$, in flower. Very abundant, especially on the Red River prairie.

Galium triflorum, Mx. Lake of the Woods, July 8, '73, in flower. Turtle Mountain, July 19, '73, in flower.

Galium trifidum, L. Winnipeg and N. W. Angle Road, July 3, '73, in flower.

Houstonia ciliolata, Torr. Winnipeg and N. W. Angle Road, July 3, '73, in flower.

Houstonia tenuifolia, Nutt. Lake of the Woods, July 7, '73, in flower.

VALERIANACEA.

Valeriana sylvatica, Richards, Rocky Mountains, (6,000 feet) Aug. 16, '74, last blossoms.

composite.

Achillea millefolium, L. Red River, prairie, July 2, '73, in flower. Abundant everywhere from the Lake of the Woods to the Rocky Mountains.

Ambrosia psilostachya, D. C. Lake of the Woods, July 18, '73, in flower. Westward, at least over the first and second prairie steppes.

Ambrosia trifica, L. Var. integrifolia. Near Milk River (low, fertile prairie land) July $19, ' 74$, in flower. Specimens about 1 foot high, with a single flowering spike.

Actinella acaulis, Nutt. West Butte (dry hill), July 30, '74, in flower. Plant not uncommon, but only a single flowering specimen obtained.

Amida hirsuta, Nutt. Foot Hills of West Butte, July 30, '74, in flower. Plant with a heavy, unpleasant, minty smell. Number of ray flowers inconstant. Found only in this locality, and growing in a sheltered hollow in great abundance.

Anternariu plantuginifolia, Br. Red River Prairie, May 20, '74, in flower. Pembina Mountain, May 26, '74, in flower.

Antennaria dioiea, var. rosea, Gaertn. Near Short Creek, June 10, '73, in flower.

Antennaria Alpina, Gaertn. Rocky Mountains, Aug. 18, '74, in flower. 
Antennaria Sp. I. 385 Mile Point, Foot Hills of Rocky Mountains, Aug. 1, '74, past flowering.

Aplopappus Nuttallii, T. and G. White Mud River (dry bank), July 3, '74, in flower.

Aplopappus spinulosus, D. C. Turtle Mountain, Aug 23, '73. First Crossing Souris River, July 30, '73. Both in flower. Not common on the second prairie steppe, but abundant westward, on the drier plains.

Aplopappus lanceolatus, T. and G. First Branch Milk River, Aug. 5, '74, in flower.

Aplopappus, Sp. I. Short Cr., June 10, '74. Growing in dense, matted tufts.

Arnica angustifolia, Vahl. Souris River (open prairie), June 7, '74, in flower. Abundant.

Arnica Menziesii, Hook. Kootanie Pass (thicket), Aug. 16, '74, in flower.

Arnica longifolia, D. C., Eaton. Rocky Mountains (7,000 feet), Aug. 18, '74, in flower.

Artemisia frigida, Willd. Rising ground, east of Red River prairie, Ang. 23, '73. Wood End, Sept. 1, '73. Both in flower.

Artemisia Douglasiana, Bess. South of Wood Mountain, dry clay banks in the bad-lands, June 29, '74, in flower.

Artemisia Ludoviciana, Nutt. Var. I. East Fork, Milk River, Aug. 23, '74. West Fork, Milk River, Sept. 10, '74. Both in flower. This is the most common variety of "sage" on the third prairie plateau, and grows very abundantly on dry, open plains and dry valleys. On the second prairie plateau A. frigida is probably more abundant.

Artemisia Ludoviciana, Nutt. Var. gnaphaloides, T. \& G. Wood End, July 14, '74, not yet in flower. 385 Mile Point, Sept. 18, '73, past flowering.

Artemisia Canadensis, Mx. Lake of the Woods, Aug. 7, '73, in flower. Wood End, July 14, '74, not yet in flower. Foot hills of Rocky Mountains, (dry hillsides) Aug. 7, '74, in flower.

Artemisia descolor, Dougl. Kootanie Pass (dry bank), Aug. 4, '74, in flower.

Artemisia dracunculoides, Pursh. Second Crossing Milk River (dry bank), Aug. 5, 74 , in flower.

Aster multiflorus, L. Turtle Mountain Aug. 12, '73. Second Branch. Milk River, Aug. 4, '74. Foot hills, Rocky Mountains, Aug. 26, '74. All in flower. Abundant from the Red River to the Rocky Mountains.

Aster macrophyllus, L. Lake of the Woods, Aug. 7, '73. Turtle Mountain, Aug. 11, '73. Both in flower. A straggling variety, with broad winged petioles.

Aster graminifolius, Pursh. Height of Land Muskeg, between Lake of the Woods and Red River, Aug. 21, '73, in flower.

Aster carneus, Nees. Foot Hills of Rocky Mountains (damp thicket), Aug. 26, '74, in flower.

Aster lavis, L. Second Crossing Souris River (thicket), Aug. 11, '73. in flower. Abundant. Foot Hills of Rocky Mountains, Ang. 26, '74, in flower. Specimens from the first locality coming under var. lævigatus, those from the latter approaching var, cyaneus.

Aster miser, Lake of the Woods, Aug. '73.

Aster salsuginosus, Rich. Rocky Mountains (6000 feet), Aug. 16, '74, in flower.

Aster. Sp. I. Near-Wood Mountain. Saline soil. Sep. 15, '74, in flower.

Aster, Sp. II. Turtle Mountain, (open prairie). July 26, '73, in flower.

Aster, Sp. III. Near Wood Mountain, (saline soil.) September 15, '74, in flower.

Bidens Beckii, Torr. Lake of the Woods. August 18, '73, in flower.

Bidens chrysanthemoides, Mx. Lake of the Woods. August 18, '73, in flower. 
Chrenactis, D. C., Sp. I. Wood Mountain. Shore of Saline Lake. July 20, '74, in flower.

('hrysopsis villowu, Nutt. Rising ground east of Red River prairie. August 22, '73. Turtle Mountain, fopen prairie.) July 23, '73. Both in flower. Abundant everywhere on dry stony plains.

Chrysopsis (Diplopappus) hispida, Hook. Wood knd, or Wood Monntain. (Label of specimen lost.) Abundant in the Coteau.

Cirsium muticum, Mx. Lake of the Woods. July 30, '73, in flower.

Cirsium altissimum, Spring. Turtle Mountain, (open prairie.) August 5, '73, in flower. Kootanie Pass, (meadow.) August 14, '74, still in flower.

Coreopsis tinctoria, Nutt. South of Wood Mountain. July 1, '74, first blossoms. West Fork Milk River. August 22, '74, in flower. Not abundunt, nor observed on the northern side of the watershed.

Crepis elegans, Hook. Kootanie Pass. August 15, '74, still in flower. Found on gravel banks flooded in Spring.

Diplopappus umbellatus, F. and G. Turtle Mountain. August 11, '73, in flower.

Echinacea purpurea, Mœnch. Wood End, (open prairie.) July 8, '74, in flower.

Erigeron Canadense, L. Lake of the Woods. July 22, '73, in flower. var. pusillum, Nutt. August 1, '73, in flower.

Erigeron strigosum, L. Lake of the Woods. July 22, '73. Turtle Mountain August $2, ' i 3$, both in flower. Sweet Grass Hills, July 24, '74, in flower.

Erigeron glabellum, Nutt. Dufferin. June 14, '73. Turtle Mountain. August 1, '73. Near Short Cr, June 10, '74. South Fork Belly River, August '74. All in flower. Abundant across the whole prairie region and assuming many varietal forms.

Erigeron pumilum, Nutt. Wood End, (open prairie,) June 27, '74, in flower.

Erigeron compositum, Pursh. Rocky Mountains, (7,000 feet,) August 18, '74, in flower. Variety with ciliate petioles, but glabrous leaves.

Erigeron alpinum, L. Rocky Mountains, (7,000 feet,) August 18, '73, in flower. Much reduced forms.

Eupatorium perfoliatum, L. Lake of the Woods, July 3, '73, in flower.

Eupatorium purpureum, L. Turtle Mountain, (marsh) Aug. 3, '73, in flower.

Gaillardia pinnatifida, Torr. Red River prairie, June 27, '73. Pembina Mountain, July 4, '74. South of Wood Mountain, June 2 7 , ' 74 . All in flower.

Grindelia squarrosa, Dunal. First Crossing Souris River, Aug. 7, '73. West Butte, Aug. 2, '74. Second Branch of Milk River, Sept. 1, '74. All in flower.

Gnaphalium polycephalum, Mx. Lake of the Woods, July ' 73 , in flower.

Helenium autummale, L. Second Crossing Souris River, Aug. 11, '73; Sept. 20, '74; both in flower.

Heliopsis scabra, Dun. Red River prairie, June 21, '73, first blossoms. Turtle Mountain (thicket), Aug. 2, '73, in flower.

Helianthus rigidus, Duf. Rising ground east of Red River valley, Aug. 23, '73. 'Turtle Mountain (open prairie), July 26, '73. Second branch Milk River, Aug. 6, '74. All in flower.

Helianthus gigantens, L. Dufferin, Sept. 1, '73, in flower. Coming up in great abundance where new prairie land ploughed, probably from seed stored by the gophers in their underground burrows.

Hieracium Canadense, Mx. Lake of the Woods, July 25, '73. Turtle Mountain, Aug. 2, '73. South Fork Belly River, Aug. 15, '74. Foot hills Rocky Mountains, Aug. 26, '74. All in flower.

IIieracium triste, Willd. Rocky Mountains, Aug. 16, '74, in flower. 
Hieracium albiflorum, Hook. Rocky Mountains (6,000 feet), Aug. 16, '74, in flower.

IIieracium venosum, L. Red River prairie, June 20, '73. Wood Mountain, June $23, ' 74$.

IIymenopappus luteus, Nutt. White Mud River (dry bank), June 3, '74, in flower.

Iva axillaris, Pursh. Near Short Creek (open prairie), June 10, '74. Not observed further east than this locality, but abundant westward, growing generally on hard, dry clay soil, which has been flooded in spring.

Lactuca elongata, Muhl. Lake of the Woods, July 28, '73, with ripe seed.

Lepachys columnaris, T. \& G. First Crossing Souris, July 30, '73, in flower. Wood End, (open prairie), July 7, '74, first blossoms. White Mud River, July 11, '74, first blossoms.

Lynosyris Ilowardii, Parry. Second Branch Milk River (dry clay bank), Sept. 1, 174 , in flower. Tufted from a stout low woody.

Lynosyris graveolens, T. \& G. Between Lake of Woods and 350 Mile Point, 1873, (label of specimen lost.)

Liatris scariosa, L. Turtle Mountain, July 30, '73, in flower. Abundant on the first and second prairie steppes.

Liatris punctata, Hook. Rising ground, east of Red River, August 26, '73, in flower. Turtle Mountain, (open prairie,) August 5, '73, in flower. Abundant in patches of prairie, east of the Red River; and also west of the Red River over the second prairie steppe.

Lygodesmia juncea, Don. Turtle Mountain, (open prairie), August 23, '73, in flower. Observed nearly to the edge of the second prairie steppe, but very rare east of Turtle Mountain. Abundant westward on dry plains both north and south of the watershed.

Muchseranthera canescens, Grey. South of Wood Mountain, (dry clay-bottomed vallies, sub-saline soil). Variety 6 to 8 inches high, with entire leaves.

Macrorrhyncus troxamoides, F. and G. Dufferin, June 10, '73, in flower.

Macrorrhyncus glaucus, Torr. Red River Prairie, June 7, 20, '73, (open prairie near Souris River, September, '73. Near Turtle Mountain, (open prairie) June 2, '74, all in flower. I cannot separate this form satisfactorily from the last, which is much less abundant. Specimens from the Red River Valley have leaves 10 inches or more long; scapes 12 to 14 inches. In specimens from the second prairie steppe, the leaves are shorter in proportion to the scape, and have assumed a thicker and more rigid character.

Macrorrhyncus, Sp. I. Rocky Mountains, (6,000 feet), August 16, '74, in flower.

Macrorrhyncus, Sp. II. Kootanie Pass, August 16, '74, in flower.

Mulgedium acuminatum, D. C. Lake of the Woods, July 30, '73. Turtle Mountain, July 26, '73. White Mud River, July 4, '74. All in flower.

Mulgedium leucophrum, D. C. Lake of the Woods, July 31, '73, with ripe seed.

Nabalus Boottii, D. C. Var. South Fork Belly River, Aug. 13, '74, in flower. Growing in thickets and much taller than usual. Proper scales of involucre about 12. Head about 12-flowered. Leaves below triangular, tapering abruptly to a broad-margined petiole.

Nabalus albus, Hook. High land east of Red River prairie, Aug. 24, '73, in flower.

Nabalus, Sp. I. Kootanie Pass, Aug. 15, '74, in flower.

Nardosmia sagitlata, Pursh. Dufferin (low damp thicket). In full bloom in the first week of May, '74. Seed nearly ripe, June 4, '73. Flower with an odour like that of Cratexgus, white, tinged with purple.

Picratenia (Actinella) Richardsoni, Hook. 'T'raders' Road (dry hills) June 18, '74. White Mud River, July 4, '74. Both in flower. 
Rudbeckin 'aciniata, L. Rosean River, Aug. 22, '73. Turtle Mountain (thicket) July 23, '73. Both in flower.

Rudbeckia fulgida, Ait. Dufferin, June 30, '73, in flower.

Senecio luygens, Rich. Var. I'urryi, Watson. Prairie near Turtle Mountain, June 2,74 , in flower.

Senerio resedifolius, Lessing. Rocky Mountains, (6,500 feet), August 18, '74, in flower.

Senecio Fremontii, T. and G. Rocky Mountains, (6,500 feet), August 18, '74, in flower.

Senecio triunguluris, Hook. Rocky Mountains. Border of Mountain stream, (6,000 feet), August 17, '74, in flower.

Senecio canus, Hook. White Mud River, (dry bank,) July 4, '74, in flower.

Senecio aureus, L. Dufferin, (open prairie,) June 13, '73. South Fork Belly R. August 25, '74. Kootanie Pass, Aug. 14, '74, all in flower. Common everywhere in many varietal forms.

Solidago lanceolata, Ait. Lake of the Woods, August 18, 173, in flower.

Solidngo temuifoliu, Pursh. Turtle Mountain, (open prairie,) August 23, '73. Wood Mountain, (shore of saline lake,) July 20, '74. First branch Milk River, August 5, 74, all in flower. Represents Solidago lanceolata on the dry open plains. Stems often many together from a woody caudex ; rarely attaining a height greater than 8 inches. S. tenuifolia var. B. Hook.

Solidago rigida, L. Turtle Mountain, (open prairie,) August 11, 'T3. Fork Milk R., September 11, '74, both in flower.

Solidago virga-aurea, L. Turtle Mountain, Aug. 21, '74, in flower.

Solidayo virgu-aurea, L. var. Alpina Bigel. Rocky Mountains, ( 7,000 feet,) Aug. $18, ' 74$, in flower.

Solidngo Canadensis, L. Turtle Mountain, August 5, '73. N(ar E. Fork Milk R., September 11, 74. First Branch Milk R., August 6, '74, all in flower.

Solidago serotina, Ait. Lake of the Woods, July 30, '73, in flower.

Solidago gigantea, Ait. Three Buttes, July 28, '74. Near Second Branch Milk River, Sept. 1, '74. Both in flower.

Solidago Missouriensis, Nutt. Turtle Mountain (open prairie), July 23, '73, in flower.

Solidago stricta. Foot Hills of Rocky Mountains, Aug. 26, '74, in flower.

Solidago nemoralis, Ait. Wood End (open prairie), July 14, '74, not yet in flower. Three Buttes, July 25, '74, in flower.

Stephanomeria minor, Nutt. Var. South of Wood Mountain (dry clay bank), June 29, '74, in flower. Heads 5 flowered. Ligulate flowers pink-purple. Pappus of about 23 plumose setæo.

Turaxacum dens-leonis, Duf. Dufferin, June 6, '73, in flower.

Yanthium strumarium, L. Lake of the Woods, Aug. 10, '73, in flower.

Yanthium echinatum, Murr. Banks of the Red River. Aluundant.

LOBELACEA.

Loblelin Kalmii, L. Height of land muskeg betwoen Lake of Woods and Red River, Aug. 23, '73, in flower.

Lobelia spicata, Lam. Turtle Mountain (low, open prairie). July 26, '73, in flower.

CAMPANULACEN.

Campanula rotundifulia, L. Red River prairie, June 18, '73, in flower. Abundant.

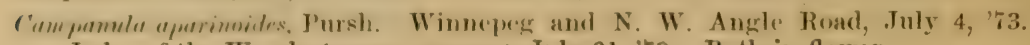
Lake of the Woods (grassy swamp), July 21, '73. Both in flower. 
ERICACEN.

Andromeda polifolia, L. Lake of the Woods (submerged bog). Height of land muskeg between Lake of Woods and Red River, Aug. 22, '73, in flower.

Arctostaphylos uvia-ursi, Spring. Lake of the Woods, July 22, '73, berry ripe. Pemlina Mountain, May 23, '74, in flower. Short Creek (dry banks) June $10, ' 74$, in flower.

Cassandra calyculata, L. Lake of the Woods (submerged bog,) Aug. 12, '73, past flowering.

Gaultheria procumbeus, L. Lake of the Woods.

Ledum latifolium, Ait. Winnipeg and N. W. Angle Road, July 5, '73, past flowering.

Menziesia glanduliflora, Hook. Rocky Mountains (7,000 feet), Aug. 18, '74, in flower. Growing in matted clumps in little meadows frequented by mountain sheep.

- Menziesia Grahamii, Hook. Rocky Mountains, Camp Akamina, (6,500 feet), Aug. 18,74 , in flower.

Moneses uniflora, L. Winnipeg and N. W. Angle Road, July 5, '73, in flower. Thick wood.

Pyrola elliptica, Nutt. Lake of the Woods, July 25, '73, in flower. Woods east of Red River Valley. Turtle Mountain (thicket), July 27, '73, in flower.

Pyrola secunda, L. Lake of the Woods, July 9, '73, in flower. Winnipeg and N. W. Angle Road, July 4, '73, in flower. Kootanie Pass (thick woods), Aug. 16,74 , in flower.

Pyrola rotundifolia, L. Var. incarnata, Fisch. Near Wood Mountain (wooded ravine), July 7 , in flower.

Pyrola asarifolia, Mx. Winnipeg and N. W. Angle Road, July 4, '73.

Vaccinium myrtilloides, Mx. Kootanie Pass (hill sides), Aug. 16, '74, with ripe fruit. Leaves do not show any pubescence.

\section{MONOTROPEA.}

Monotropa uniflora, L. Lake of the Woods (thick wood), Aug. 1, '73, in flower.

\section{PLANTAGINACEA.}

Plantago Major, L. Red River.

Plantago eriopoda, Torr. Near Badger Creek (dry, open prairie), May 30, '74, in flower.

Plantago Patagonica. Var. gnaphaloides, Gray. Near Wood Mountain (dry hill sides, June $30,{ }^{\prime} 74$. This plant was first met with at the place above mentioned, but occurred in great abundance westward to beyond the Three Buttes, growing among the short grass of the dry plains. Large specimens measure 4 inches. The forty-ninth parallel is probably not its northern limit in the western interior region. Known in Texas, California, and Western Wisconsin (Watson). Also common on the barren plains of the Columbia (Douglas), which Hooker believes to be about its northern limit on the west coast.

Plantago Biglorii, Gray. Traders' Road (dried swamp, clayey soil), June 14, '74, with ripe seed, $1 \frac{3}{4}$ inches high. Known from Benica, California (Biglow), and in Salt Lake Valley, Utah (Watson).

Plantago, Sp. I. eriopoda, smooth var.

Plantago, Sp. II. eriopoda?

\section{PRIMLLACEN.}

Amlrosere orridentalis, Pursh. Foot Pembina Mountain (open prairic), May 22, '74, in flower; not exceeding 2 inches. 
Androsace septentrionalis, I. Winnipeg and N. W: Angle Road, July 3, '73, past flowering. Near Badger C'reck (prairie), May 18, '74. Prairie near Turtle Mountain, June 1, '74. Both in flower.

Dodecantheon integrifolium, Mx. Near Turtle Mountain (open prairie), June 1, '74. N. Antler Creek (open prairie), June 6, '74. Both in flower. Also westward to the Rocky Mountains.

Glaux maritima, L. Red River prairie, damp places in marshes, June 5, 20, '73, in flower. Near Wood Mountain (borders of streams), June 30, '74, in flower

Lysimachia ciliatu, L. Red River prairie, June 28 and July 2, '73, in flower. Turtle Mountain, July 15, in flower. Also Lake of the Woods.

Numbergiu thyrsifoliu, Manch. Red River prairie (marsh), June 19, ' 73 . Lake of the Woods, July. Both in flower.

Trientalis Americana, Pursh. Lake of the Woods, July 12, '73, past flowering.

LFNTIBLLACA:

Utricularia vulgaris, L. Lake of the Woods, July 8, '73. Swamp west of the White Mud River, July 12, '74. Both in flower.

\section{OROBANCHACE.}

Orobanche, Sp. I. Wood End (open prairie), June 30, '74, in flower.

\section{SCROPHULARIACEA.}

Castilleia coccinen, Spring. Yellow variety. Rising ground east of Red River, June 20, '73, in flower. Red variety on Rainy River. Lake of the Woods.

Castilleia sessiliflora, Ph. First crossing Souris River, (dry hill sides) June 3, '74, in flower.

Castilleia pallida, Kunth. Red and white rar. Foot-hills of Rocky Mountains, August 8, '74, in flower, abundant. Also found in the mountains between 6,000 and 7,000 feet.

Chelone glabra, L. Lake of the Woods, (swamp), July 31, :73, in flower.

Gerardia purpurea, L. Lake of the Woods, August 18, '73, in flower.

Gratiola Virginiana, L. Red River (open swamp), July 28, '73, still in flower.

Gratiola Virginiana, var. Dufferin. June 12, '73, in flower.

Mimulus ringens, L. South Antler Creek, July 31, '73, in flower.

Mimulus Lewisii, Pursh. Kootanie Pass (border of stream), August 16, '74, in flower. Observed growing in mossy places bordering streams, to 6,000 feet in the mountains, but no where very abundant. The recent plant has a musky odour.

Mimulus luteus, L. West Butte (border of stream), July 29, '74, in flower. Also observed near Second Branch Milk River, growing in the water of a spring at $46^{\circ} \mathrm{F}$.

Melampyrum Americanum, Mx. Lake of the Woods, July 8, '73, in flower.

Pedicularis Cunadensis, L. Rising ground cast of Red River Prairie, June 19, 'r3, in flower.

Pedicularis bracteosa, Benth. South Fork Belly River (dense wood), August 13, '74, in flower.

Pedicularis Sp. I. Rocky Mountains, (1,500 feet) Angust 18, '74, in flower.

Pentatemon pubescens, Soland. Lake of the Woods, July 22, '73, in flower; rare. Rising ground, east of Red River Prairie, June 20, '73, in flower. Near Wood Mountain, (open prairie) June 29, '74, in flower.

Pentstemon glaucus, Grah. Souris River, June 8, '74, in flower. 
Pentstemon Menzieseii, Hook. Rocky Mountains, (6,000 feet) August 16, '74, in Hower. Fomm alumdantly in one locality, growing among broken stone, on an exposed ridge.

Pentstemon confertus, Dougl. Kootanie Pass., August 16, '74, in flower

Pentstemon procerus, Dougl. Traders' Road, June 14, '74, in flower, P. confertus var., carruleo-purpureus, Grey, but apparently quite distinct from that species.

Pentstemon acuminatus, Dougl. Near Short Creek, (dry banks) June 10, '74, in flower. A variety with lower cauline leaves, broad, obcordate at the extremity, with a minute tooth between the lobes. Upper cauline leaves amplexicaul, cordate, obtuse, with a minute accumination. Flowers 8 lines, bright blue.

Pentstemon dasyphyllus, Sp. I. Kootanie Pass, August 16, '74, last blossoms.

Rhinanthus Crista-galli. Foot Hills of Rocky Mountains, August 26, 74, still in flower. Also on the western side of the watershed in the Kootanie Pass.

Veronica Americana, Schwein. Near Wood Mountain (swamp), July 4, '74, in flower.

Veronica Alpina, L. Rocky Mountains (6,500 feet), August 18, '74, in flower.

Veronica peregrina, L. Red River lopen swamp), June 28, '73, with ripe secd. Near Short Creek (open prairie swamp), June 10, '74 in flower.

VERBENACEA.

Verbena hastata, L. Lake of the Woods, July 25, '73, in flower.

LABIATæ.

Brunclla vulgaris, L. South Fork Belly River, August 25, '74, in flower. Waterton Lake, August 14, '74, in flower.

Galeopsis tetrahit, L. Turtle Mountain (thicket), July 25, '73, in flower.

Lycopu.s sinuatus, Benth. Lake of the Woods, July 18, '73.

Iygcopm: Virginicus, L. Lake of the Woods, July 8, August 7, '73 in flower. West Butte, Aug. 2, '74.

Lophnthus anisatus, Benth. Winnipeg and N. W. Angle Road, July 3, '73. Lake of the Woods, July 18, '73. Turtle Mountain, July 15, '73. All in flower.

Mentha Canadensis, L. 'Turtle Mountain, July 25, '73, in flower.

Monarda fistulosa, L. Turtle Mountain (open prairie), July 19, '73, in flower. West Butte, July 26, '74, in flower.

Physostegia Virginiana, Benth. Turtle Mountain (swampy glades), August 11, '73, in fluwer.

Stachys palustris, L. Turtle Mountain, July 15, '73. Near Wood Mountain, July 7, '74. Both in flower.

Stachys aspera, Mx. Winnipeg and N. W. Angle Road, July 2, '73, in flower. Dufferin, September 3, '73, still in flower.

Scutellaria galericulata, L. Winnipeg and N. W. Angle Road, July 3, '73, in flower.

\section{BORRAGINACEN.}

Eritrichum glomeratum, D. C. Hill of the Murdered Scout, and westward, on dry. open prairie, June 9 , '74, in flower.

Eritrichum, Sp. I. Near Short Creek (open prairie), June 10, '74, in flower.

Echinospermum floribuntum, Lehm. Red River, June 29, '73, in flower. TurtleMountain thicket, July 15, '73, still in flow'r. Wood Mountain (thicket), June 24, '74, in flower.

Echinospermum Lappula, Lehm. Red River (open prairie), June 28, July 3, '73, in flower. Abundant. Wood End, June 11,'74, in flower. 
Echinospermum patulum, Lehm. Red River (open prairie), June 28, July 3, '73, still in flower. Abundant. Wood End, June 11, '74, in flower.

Lithospermum canescens, Lehm. Red River (open prairie), June 3, '73, in flower; June 21, '73, still in flower. Pembina Mountain, May 27, '74, first blossoms. Abundant.

Lithospermum longiflorum, Spring. Souris Valley, June 3, '`3, in flower. Not abundant.

Mertensia paniculata, Don. North Antler Creek, June 6, '74, in flower. Abundant. Myosotis alpestris, Schmidt. Rocky Mountains (7,000), August 18, '74, in flower.

Onasmodium Virginicum, Alph, D. C. Turtle Mountain (thicket), July 23, '73, in flower.

\section{POLEMONIACE $A$.}

Gilia minima, Gr. Near Wood Mountain, July 5, '74, in flower.

Phlx canescens, T. J. G. Long River (open prairie), May 29, '74, almost past flowering.

Phlx pilosa, R. Red River prairie, June 29, '73. Traders' Road, June 21, '74, both in flower.

\section{CONTOLTULACEA.}

Calystegia sepium, Br. Lake of the Woods, July 8, '73. Turtle Mountain, July 13, '75. Traders' Road, July 18, '74. Near Wood Mountain, June 30, '74, all in flower. On the third prairie steppe it onty appears along the borders of streams in sheltered positions.

Calystegia spithamæus, Pursh. Red River prairie. Bare.

Cuscuta Gronovii, Willd. Roseau River, August 25, '73, seed formed.

\section{SOLANACE,A.}

Physalis viscosa, L. Winnipeg and N. W. Angle Road, July 4, '73, in flower.

Solanum triflorum, Nutt. var. B. Minor, Hook. South of Wood Mountain, July 2,74 , in flower. Not uncommon over a great part of the second and third prairie steppes. Growing almost always in disturbed earth near the burrows of badgers and gophers. (As noted also by Drummond, Fl. Br. Am., p. 90.$)$

Solanum triflorum, var. First crossing Souris River (low ground), June 3, '74, in flower. Stems smooth; petioles of the leaves ciliate; the leaves themselves sparingly hairy on the veins below. Above with close, short pubescence; Calyx foliaceous, lobes oblong autu, cxcecding the petals, which are lavender or pale purple.

\section{GENTIANACE.E.}

Gentiana crinita, Frolich. Roseau River, August 26, '73; (banks of stream), in flower.

Gentiana dentosa, L. South Fork Belly River, (low ground and thicket), August 15,74 , in flower.

Gentiana Andrewsii, Griseb. Dufferin, September 1, '73, in flower.

Gentiana puberula, Mx. Prairie west of Red River, September, '73, in flower.

Gentiana Menziesii, Griseh. Rocky Mountains. Camp Akamina, (6,000 feet), August 18, '74, in flower.

Gentiana aruta, Mx. 'Turtle Mountain, iopen prairiel, August 12, '73, in flower. Near White Mud Rivor, lopen prairie), July 11, '74, in flower. South Fork Belly liver, August 15, '74, in flower. Kootanie Pass, August 14, '74, in fower. 
Gentiann, Sp. I. Near White Mud River, (valley), September 15,'74. Also probably the same species west Souris, (open prairic), not common, August 11, '73, in flower, and in the same vicinity still flowering first week September.

Gentiana, Sp. II. South Fork Belly River, (thicket), August 15, '74, in flower.

Halonia deflexa, Griseb. Lake of the Woods, July 21, '73, in flower.

\section{APOCYNACEA.}

Apocynum andros:mifolium, L. Dufferin (thicket), June 29, '73, in flower.

Apocynum cannabinum, L. var. glaberrinum, D. C. Near Wood Mountain (border of stream), July 2,174 , in flower.

\section{ASCLEPIADACEE.}

Asclepias incarnata, L. Lake of the Woods, July 18, '73, in flower.

Asclepias variegata, L. var. minor, Hook. Red River (open prairie), June 20, '73, in flower.

Asclepias ovalifolia, D. C. Pembina Mountain (open prairie), July 4, '73, in flower. Asclepias viridiflora, Ell. Wood End, July 1, '74, in flower.

Asclepias speciasa, Torr. Near Wood Mountain (border of stream), July 5, '74, in flower.

\section{ARISTOLOCHIACEÆ.}

Asarum canadense, L. Pembina Mountain (thicket), May 22, '74, in flower.

\section{NYCTAGINACEA.}

Oxybaphus nyctagineus, Sweet. Lake of the Woods (sandy ridges of southern shore), July 11, '73, in flower, but with ripe seed. Wood End, June 30, '74, in flower.

\section{CHENOPODIACE .}

Blitum capitatum, L. Winnipeg and N. W. Angle Road, July 4, '72, in flower.

Blitum 1.onus Henricus, Reichenb. Lake of the Woods, August 3, '73, with ripe serd.

Chenopodium album, L. Lake of the Woods, August 3, '73, in flower. Lake of the Woods, mouth of Reed River. Lake of the Woods, August 6, '73, in flower. Milk River, (dry clay flat.) Near Wood Mountain, June 30, '74, in flower. Wood End, July 14, '74, first blossoms. South of Wood Mountain (clay bottomed valley) June 27, '74, in flower. White Mud River, clayey, subsaline soil, July 11, '74, not yet in flower. 345 mile Point, and growing abundantly in saline soil, from the Souris River westward. Second branch Milk River, (dry clay bank) September 1, '74, with ripe seed. Border of Saline Lake. Near Wood Mountain, bank of saline pool. South of Wood Mountain, (clay bottomed valley) June 27, '74, in flower. South of Wood Mountain, (open prairie) June 30, '74, with ripe seed.

Sarcobatus vermiculatus, Torr. Porcupine Creek and westward, but not to the Rocky Mountains. Near Wood Mountain, June 27, '74, in flower. Grows in dry, clay-bottomed valleys, with saline soil, and is probably near its northern limit on Lat. $49^{\circ}$. Is the "grease wood" of western parlance, though I believe Obione canescens is also sometimes so called.

Salicornia herbacea, L. Fringing saline pools and lakes wherever they occur, but specially abundant in the broken country of the Missouri Coteau.

\section{AMARANTACEA.}

Amarantus retroflexus, L. Lake of the Woods, August 2, '73, with ripe seed. PARONYCHIE $\AA$.

Paronychia sessiliflora, Nutt. White Mud River (dry bank), July 4, 74, in flower. 360 Mile Point, September, '73, past flowering. 
POLYGONACE .

Friogonum crassiffolium, Benth. Wood End, (gravelly hill), June 24, '74, in flower.

Eriogonum, Sp. II. Trader's Road, (dry rocky hill), June 17, '74, first blossoms.

Eriogonum, Sp. III. South of Wond Mountain, (dry, clay-bottomed Valley), June 27 , '74, in flower.

Eriogomum, Sp. IV. Great Valley, (dry clay banks), September, '73, in flower.

Eriogonum, Sp. V. Rocky Mountains, (6,000 feet), August 16, '74, in flower.

Oxyra digynu, Campd. liocky Mountains, (6,500 feet), Aug. 18, '74, past flowering.

Polygonum amphibium, L. var. terrestre. Lake of the Woods, July 21, '73, in flower. Traders' Road, July 15, '74, in flower. Var. aquaticum. Winnipeg and N. W. Angle Rd., July 5, '73, in flower.

Polygonum hydropiperoides, Mx. Lake of the Wocds, July 10, '73, in flower.

Polygonum Pennsylvanicum, L. Lake of the Woods, July 8, '73, in flower.

Polygonum dumetorum, L. Winnipeg and N. W. Angle Road, July 3, '73. Turtle Mountain, July 25, both in flower.

Polygonum cilinode, Mx. Winnipeg and N. W. Angle Rd., July 5, '73, with ripe seed.

Polygonum tenue, Mx. Lake of the Woods, July 23, ' 73 , in flower. Foot Hills of the Rocky Mountains, (damp meadow) August 7, '"4, in flower.

Polygonum aviculare, L. Near Wood Mountain, (clay bank) July 2, '74, in flower.

Polygonum ariculare, L., var. erectum, Roth. West Butte, (coulée) July 25, '74, in flower.

Rumex salicifolius, Weinm. Red River, June 28, '73, in flower. South of Wood Mountain, June 27, '74, seed formed.

Rumex venosus, Pursh. South of Wood Mountrain, (bank of stream) June 27, '74, with ripe seed.

Rumex, Sp. I. Rocky Mountains, (6,500 feet) August 18, '74.

\section{ELEAGNACEA.}

Elragnus argentea, Pursh. Dufferin, June 13, '73, in flower. Second crossing Suuris River, June 8, '74, in flower. South Fork Belly River, August 15, berry fully formed. Extends on the forty-ninth parallel, from the extreme eastern edge of the prairie to the base of the Rocky Mountains It is not common on the Red River Prairie, but frequent on the higher level prairie to the east, and abundant westward, especially on the second prairie level, forming scattered clumps, where no other shrubs are seen. The plant on the plains rarely attains a height of over two to three feet, but near the mountains is a large bush, extremely fragrant.

Shepherdia argentea, Nutt. White Mud River, July 4, '74, berries half grown. Not observed east of Wood Mountain.

Shepherdia Canadensis, Nutt. Kootanie Pass. August 14, '74, berries ripe.

SANTALACEX.

Comandra umbellata, Nutt. Dufferin (open prairie), June 5 , '73, in flower. Abundant Garry and N. W. Angle Road, July 3, '73, past flowering.

Comandra pallida, D. C. Prairie near Turtle Mountain, June 1, '74, first blossoms. The first species seems to pass into this form westward.

EUPHORBIACEA.

Euphorlin gl!ntosperma, Englm. South of Wood Mountain (dry clay bank), July $2, ' 74$, in flower. 
URTICACEA.

Humulus lupulus, L. Lake of the Woods. Dufferin. Turtle Mountain, July 5, ' 73 , in flower.

Laportea Canadensis, Gaudich. Roseau River (woods).

Ulmus Americana, L. Dufferin, May 8, '74, in flower.

Urtica gracilis, Ait. Turtle Mountain, July 15, '73, in flower. Wood Mountain (thicket), June 23,74 , in flower.

\section{CUPULIFERA.}

Corylus Americana, Walt. Dufferin, May 8, '74, in flower.

Quercus macrocarpa, Mx. Var. Turtle Mountain, June 1, '74, in flower. This is the common oak in the Red River country, and attains a good size along the streams and in sheltered localities. The fruit, however, is much smaller than typical macrocarpa. Acorn 9 lines long by 6 lines broad; cup 7 to 8 lines broad, 5 lines deep. This is probably the species which Bourgeau referred to Q. obtusiloba, Mx. (Palliser Expl. B. N. Am.,) but which Gray, in an appendix to the report, calls $Q$. macrocarpa.

\section{SALICACEA}

Populus tremuloides, Mx Dufferin, May 8, '74, in flower. The most abundant poplar in the eastern prairie region, attaining along the Red River generally a height of 30 to 40 feet.

Populus monilifera, Ait. South Fork Belly River and St. Mary River, attaining a large size.

Populus balsamifera, L. var. candicans, Ait. Milk River, growing along the border of the stream.

Salix nigra, Marshall. Dufferin, June 10, '73, past flowering. Second crossing Souris River, June 8, '74, in flower. Turtle Mountain.

Salix, Sp. II. Dufferin, June 6, '73, in flower.

Salix, Sp. III. Dufferin, June 4, '74, past flowering.

Salix, Sp IV. Dufferin, May 8, '74, in flower.

Salix, Sp. V. Dufferin, May $8,{ }^{\prime} 74$, in flower.

Salix, Sp. VI. Dufferin, May 8, '74, in flower.

Salix, Sp VII. Dufferin, May $8,{ }^{\prime} 74$, in flower.

Salix, Sp. VIII. Dufferin, May 8, '74, in flower.

Salix, Sp. IX. Dufferin, May 8, '74, in flower.

Salix, Sp. X Dufferin, May 8, '74, in flower.

Salix, Sp. XI. Rocky Mountains (6,500 feet), August 18, '74, with ripe seed.

CONIFERE.

Alies Douglassi, Lind. Rocky Mountains, near Waterton Lake, east slope, not attaining a large size.

Abies Englemani, a tree of large growth probably this species, forming dense groves in retired vallies at a height of 6,000 to 7,000 feet in the Rocky Mountains.

Abies Alba, Michx. Lake of the Woods.

Abies nigra, Poir. Lake of the Woods.

Abies balsamea, Marshall. Lake of the Woods.

Larix Americana, Michx. Lake of the Woods.

Pinus Banksiana, Lambert. Winnipeg and N. W. Angle Road and Lake of the Woods. 
Pinus Resinosa, Ait. Lake of the Woods.

Thuja occidentalis, L. Lake of the Woods, Roseau River, \&c.

Juniperus Virginiana, L var. procumbeus, Hook. Lake of the Woods.

Pinus contorta, Dougl. var. latifolia, Eng. Kootanie Pass. Very abundant.

\section{ARACEE.}

Acorus Calamus, L. Lake of the Woods.

Arisæma triphyllum, Torr. Dufferin, July 6, '73, in flower.

Calla palustris, L. Winnipeg and N. W. Angle Road, July 5, '73, in flower.

TYPHACEAS.

Sparganium eurycarpum, Eng. Lake of the Woods, August 5, '73, in fruit.

Sparganium natans, L. Lake of the Woods, August 1, '73, in flower.

Typha latifolia, L. Lake of the Woods.

\section{LEMNACRAR.}

Lemna trisulca, L. Small lakes. Red River prairie. Lake of the Woods.

Lemna minor, L. Common in the same localities.

\section{NAIADACEN.}

Potamogeton pusillus, L. Lake of the Woods, July 8, '73, in flower.

Potamogeton natans, L. Lake of the Woods, August 1, '73, in flower.

Potamogeton perfoliatus, L. Lake of the Woods, July 8, '73, in flower.

\section{ALISMACEA.}

Alisma plantago, L. Winnipeg and N. W. Angle Road, July 4, '73. 'Turtle Mountain, July 25, '73, both in flower.

Sagittaria variabilis, Eng. Lake of the Woods, July 30, '73. S. Antler Creek, July 31, '73. Wood End, July 13, '74. All in flower.

Triglochin maritimum, L. Near Wood Mountain, border of saline pool, July 9, '74, in flower.

Triglochin palustre, L. Var, elatum, Nutt. Winnipeg and N. W. Angle Road.

ORCHID $\triangle$ CE

Calopogon pulchellus, Brown. Winnipeg and N. W. Angle Road, July 5, '73, in flower.

Cypripedium pubescens, L. Dufferin, June 13, '73, in flower.

Platanthera hyperborea, Lindl. Lake of the Woods, thicket, July 8, '73, in flower.

Platanthera psycodes, Gray. Lake of the Woods (grassy swamps), July 20, '73, in flower.

Platanthera bracteata, Torr. Eastern border of Red River prairie, June 20, '73, in flower. Pembina Mountain, May 27, '74, first blossoms.

Spiranthes cernua, Richard. Lake of the Woods, July $20, ' 73$, in flower.

\section{AMARYLLIDACEAE.}

Hypoxis crecta, L. Dufferin (damp meadow), June 13, '73, first flowers. North Antler Creek (open prairie), June 6, '74, first flowers.

IRID ACE E.

Iris versicolor, L. Winnipeg and $\mathrm{N}$. W. Angle Road, July 3, '73, in flower.

Sisyrinchium mucronatum, Mx. Red River prairie, June '73. First crossing Souris River, June 3, ' 74 , in flower. 
LILIACESE.

Allium cernun, Roth. Lake of the Woods, July 6, 'i3, in flower. West Butte, July $26, \cdots 4$, in flower.

Allium reticulatum, Frazer. Near Badger Creek, dry hill sides, May 30, 'i4, in flower.

Allium, Sp. I. South Fork Belly River, August 13, '74, in flower

Lilium Philadelphicum, L Red River, June 21, '73, in flower. Abundant.

Lilium Phaladelphicum, L. var. Near Turtle Mountain, (open prairie), July 15, '73, in flower. Probably an albino, petals pale yellow, not spotted; more narrowly lanceolate, and with longer claws. Rare.

Polygonatum giganteum, Dietrich. Dufferin, (thicket), June 22, '73, in flower.

Smilacina stellata, Desf. Dufferin, (thicket), June 2, '73, in flower. Pembina Mountain, (thicket), May 27, '74, first blossoms.

Smilacina bifolia, Ker. Dufferin, June 7, '73, in flower.

\section{MELAYTHACEA.}

Tofieldia glutinosa, Willd. Rocky Mountains, 16,000 feet, August 17,'74, past flowering.

Veratrum album, var. Eschoitzii, Gray. Foot Hills Rocky Mountains, August 7, '74, still in flower.

Xerophyllum tenar, Pursh. Rocky Mountains, 16,000 feet 1 , still in flower. Abundant and past flowering at this date in the lower vallies. The leaves forming a coarse matted soil in some upland meadows.

Zygadenus glaucus, Nutt. Near Turtle Mountain, (open prairie), June 10, '73, in flower.

\section{EQUISETACEA.}

Equisetum arvense, L. Dufferin, June 10, '73. Late specimens springing up on banks emerging from flood.

Equisetum limosum, L. Lake of the Woods.

Equisetum lrevigatum, Brown. Red River.

Equisetum hyemale, L. Souris River.

\section{FLICES.}

Aspidium Lonchitis, Swartz. Rocky Mountains (6,500 feet), August 8, '74. Spores not ripe.

Aspidium spinulosum, Willd. Lake of the Woods.

Botrychium Virginicum, L. Woods on Roseau River.

Botrychium lunarioides, Swartz. Lake of the Woods at mouth of Rainy River, July 19, '73, spores not ripe.

Cystopteris bulbifera, Bernh. Lake of the Woods.

Cystopteris fragilis, Bernh. Near Short Creek. Rocky Mountains $(6,500$ feet.)

Ophioglossum vulgatum, L. Lake of the Woods at mouth of Rainy River, July 19, '73, spores not ripe.

Onoclea sensibilis, L. Lake of the Woods, July 30, '73, spores not ripe.

Polypodium Dryopteris, L. Winnipeg and N. W. Angle Road.

Polypodium vulgare, L. Lake of the Woods, July 6, '73, spores not ripe,

Woodsia ilvensis, $\mathrm{R}$. Br, Lake of the Woods. 
LYCOPODIAEN.

Lycopolium complanalum, L. Lake of the Woods.

Lycopodium lucidulum, Mx. Lake of the Woods.

Seluyinella rupestrin, L. Lake of the Woods also westward, growing among stunted grass on exposed hillsides, on the third prairie steppe.

Juncacex, Cyperncece and Graminece, determined by Professor John Macoun. JCXCACE.X.

Junceus alpinus, rar. insignis, Fries. Lake of the Woods, (boggy shore) Garry and North-west Angle Road.

Junceus acuminatus, Michx. First branch Milk River, (river margin.)

Junceus xiphioides, E. Mayer. Var montanus, Engl. South Fork Belly River.

Junceus Balthicus, Willd. Dufferin and Red River country generally, (damp, open prairie.) North Antler Creek and prairie generally, (da mp ground.)

Junceus Balthicus, var. montanus, Engl. Lake of the Woods.

Junceus Nodosus, L? Garry and N. W. Angle Road.

Ilniceus Mertensianus, Boug. Rocky Mountains. Camp Akamina, 6,000 feet, (wet ground) August 17, '74, in flower. Kootanie Pass, (border of stream) August 17 , past flowering.

Luzula parviflora, var. melanocarpa, Desr. Kocky Mountains. Camp Akamina.

CYPERACEA.

Carex aperta, Boott. North Antler Creek, (low ground), June 6, '74, in flower.

Carex lanuginosa, Michx. Dufferin, June 7, '73, in flower.

Carex longirostris, Torr. Souris River, (valley, damp ground), June 3, '74, past flowering.

Carex riparia, Curtis. Lake of the Woods, (sandy swamp), July 9, '73, past flowering.

Carex polytrichoides, Muhl. Winnipeg and N. W. Angle Road, (thick wood).

Carex scirpoidea, Michx. Between Badger Creek and Turtle Mountain, (swamp).

Carex supina, Wahl. Red River, (open prairie swampl, June 19, ' 73 , past owering.

Carex atrata, L. Rocky Mountains, Camp Akamina, (damp wood), August 17, '74, in flower.

Carex festira, Dewey. White Mud River, (open prairie swamp), July 10, '74, past flowering.

Carex aurea, Nutt. Lake of the Woods, (thicket), July 8, '73, seed nearly ripe. Rocky Mountains, Kootanie Pass, (border of stream).

C'arex straminea, Wahl. Dufierin, damp prairiel, June 7, '73, flow uring. Winnipeg and N. W. Angle Road, July 4, '73. Turtle Mountain, (low open prairie), July $26,{ }^{\prime} 7$.

Carex Richardsoni, R. Br. Souris Valley.

Carex alopecoidea, Tucker. Turtle Mountain, (low, open prairie.)

Carex pseudo-cyperus, L. Lake of the Woods, (marsh.)

Carex lupulina? Muhl. Winnipeg to N. W. Angle Road.

Carex rigidu, Good. Rocky Mountains, (summits) August 17, '74, in flower. 
Carex Douglassii, Hook. Red River, (open prairie) May 20, '74, in flower; also, other specimens, probably belonging to this species, June 3 and 5 , '73. This is the first Carex to appear in flower, and occurs very abundantly all over the prairie of the Red River.

Carex marcida, Boott. Red River, (open prairie swamp) June 20, '73, past flowering; other specimens, probably this species, in flower, June 3.

Carex ampulacea, or atriculata. Red River, (prairie) June 20, '73, in flower. Similar Carex, immature, Souris Valley, June 3, '74.

Carex stricta? Lam. Red River, June 28, '73, in flower.

Carex rosea, Schk. Red River, (swamp.)

Carex siccata, Dew.

Carex stenophylla, Wahl.

Eliocharis palustris, R. Br. Dufferin (damp, open prairie). Souris River (open prairie).

Eliocharis acicularis, R. Br. Red River (open prairie swamp). Lake of the Woods (boggy shore).

Eriophorum latifolium. Between Badger Creek and Turtle Mountain (swamp), May 31,74 , in flower.

Eriophorum polystachyum, L. Winnipeg and N. W. Angle Road.

Scirpus maritimus, L. Saline Lake, near Turtle Mountain, September, '73, in flower.

Scirpus eriophorum, Michx. Winnipeg and N. W. Angle Road (swamp). Lake of the Woods (in water).

Scirpus validus, Vahl. Winnipeg and N. W. Angle Road. Traders' Road.

GRAMINE $\cong$.

Agrostis acabra, Willd. Lake of the Woods. July, '73, immature.

Alopecumes alpinus, Smith. Garry and N. W. Angle Road (damp ground), July 3 , 73 , in flower.

Andropogon fucatus, Muhl. Turtle Mountain (open prairie), August 11, '73, in flower. Lake of the Woods (diy rocky soil), July 20, '73, in flower. South Antler Creek, August 1, ':3, in flower.

Andropogon scoparius, Michx. Souris River (dry bank), August 24, '74, seed shed. Avena striatu, Michx. Winnipeg and N. W. Angle Road (dry sandy soil), July 4, '73, seed formed

Beckmannia cruciformis, Hart. West Fork Milk River, July 18, '74, past flowering

Boutelona oligosturhyu, Turr 'Turtle Mountain and westward to St Mary's River. Common everywhere on the dry plains, forming a elose, short sod where other grasses hardly grow.

Bromus ciliatus, L. Lake of the Woods South Branch Belly River (flat), August 13 , '74, seed formed.

Catabrosa aquatica, Beaur. Near Woody Mountain, July 7, '74, in flower.

Dauthonia spicuta, Besur. Lake of the Woods (dry rocky soil), July 25, seed perfected.

Elymus Canadensis, L. Wood End (clay bank), July 13, '73, in flower. Turtle Mountain (thicket), July 25, '73, in flower.

Elymus C'anadensis, var. glaucifolius. Lake of the Woods (sandy shore;, July 7, '73, in flower.

Elymus Virginicus, L Roseau River, (river banks).

Ericoma cuspidata, Nutt. White Mud River, (dry bank), July 4, '74, seed perfected. 
Festuea ovina, L. Red River, (open prairie).

Festuca borealis? Mert. Lake of the Woods, (in water), July 20,'73, seed perfected.

Glyceria nervata? Trin. Winnipeg and N.W. Angle Road, July 4, '73, past flowering. Dufferin, (open prairie)

Ifierochloa borealis, Roem \& Schultes. Red River, (open prairie, Foot Pembina Mountain, May 22, '74, in flower. Dufferin, (open prairie), June 3, '73, in flower.

Hordeum jubatum, L Red River Prairie generally.

Koeleria cristata, Pers. Dufferin, June 25, '73, in flower. Traders' Road, June 19, '74, in flower.

Lepturus paniculatus, Nutt. Near Wood Mountain, ( barren prairie).

Panicum pauciflorum, Ell. Red River, (swampy prairie), June 21, '73, in flower.

Phaleris arundinacea, L. Red River, (open prairie), June 19, '73, immature. Lake of the Woods, (shore), July 9, '73, seed mature.

Phragmites communis, Trin. Roseau grass. Lake of the Woods, Roseau Lake, \&c. Very common. Borders of pools, Red River prairie. Also on the Souris River.

Phleum alpinum, L. Rocky Mountains (6,000 feet), Aug. 18, '74, in flower.

Poa pratensis, L. Dufferin (open prairie), June 10, '73, immature.

Poa alpina, L. Rocky Mountains (6,000 feet).

Poa cosia, Smith. Var. strictior. Red River. Near Woody Mountain (open prairie).

Poa flexuosa,"Muhl? Red River (open prairie), June 20, '73, in flower.

Spartina gracilis, Roth. Near Wood Mountain (bank of stream), June 30, '74, in flower.

Spartina cynosuroides, Willd. East Souris (low ground), 2 to 4 feet, July 30, '73, in flower. Winnipeg and N. W. Angle Road, July 3, '73.

Stipa spartina, Trin. Pembina Mountain (open prairie), June 30, '73, seed perfected. Garry and N. W. Angle Road (prairie), July 3, '73, seed perfected.

Stipa viridula, Trin. White Mud River (bottom land), July 3, '74, seed perfected. Wood End, July 30, '74 seed perfected.

Triticum repens, L. Var. Lake of the Woods (sandy shore).

Triticum strigosum, Stend. Wood End (bank), July 30, '74, in flower. Near Wood Mountain (clayey valley), June 27, '74, in flower.

Zrizania aquatica, L. Lake of the Woods (in water), August 18, '73, in flower.

Trisetum? Red River. (Open prairie.)

Festuca? Red River. (Open prairie.)

E. Fork Milk River. (valley of creek.)

Rocky Mountains. 6,000 feet.

- Nr. Wood Mountain. (Edge of saline pool.)

Mosses, Lichens, \&c., determined by George Barnston, Esq.

suscr.

Funaria hygrometrica, Hedw. Dufferin.

Bryum cernuum, Hedw. Rising ground east of Red River prairie

Bryum cernuum, Hedw? Lake of the Woods. 
Dicranum undulatum, Turner. Lake of the Woods.

Polytrichum commune, L. Lake of the Woods.

Polytrichum piliferum, Schreber. Winnipeg and N. W. Angle Road. Lake of the Woods.

Ceratodon purpureus, Brid. Lake of the Woods.

Neckera pennata, Hedw. Lake of the Woods.

Pylassa intricata, Br. Eur. Lake of the Woods.

Climacium Americanum, Brid. Lake of the Woods.

Mnium spinulosum, Br. Eur. (broad leaved variety). Lake of the Woods.

Mnium rostratum Schwæg ? Lake of the Woods.

Mnium affine, Bland. Lake of the Woods.

Hypnum serpens L ? (a variety with short capsules). Lake of the Woods.

HEPATIC $A$.

Marchantia polymorpha, L. Winnipeg and N. W. Angle Road.

\section{LICHENES.}

Umbilicaria Dillenii. Lake of the Woods.

Madotheca platyphylla. Lake of the Woods.

Peltigera aphthosa, Hoffm. Lake of the Woods.

Platysma? Lake of the Woods.

Cladocera cristatella, Tuck. Lake of the Woods.

Cladocera gracilis, Fr. Lake of the Woods.

Cladocera furcata, Hoffm? Lake of the Woods.

Cladocera rangiferina, Hoffm? Lake of the Woods. 



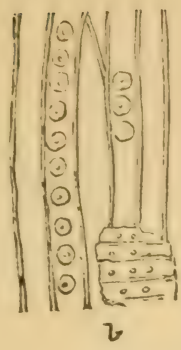

Figure 1.
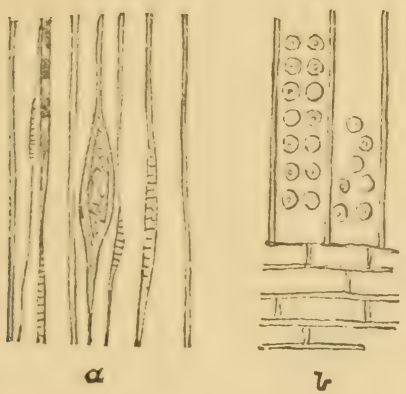

Figure 3.
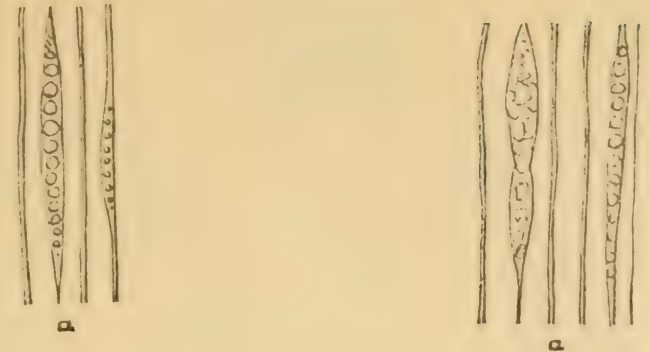

Figure 2.

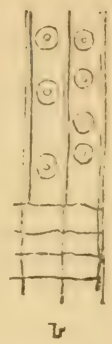

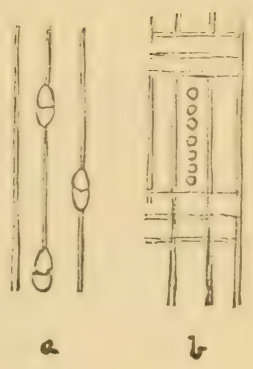

Figure 4 .

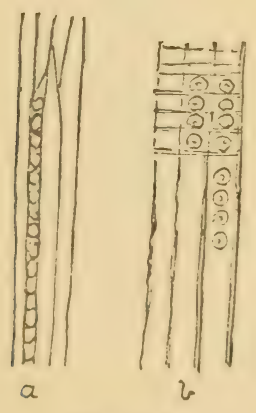

Figure 5.

MICHOSCOPIC STRECTURE OF WOODS-LIGNITE TERTIARY.

(a), Tangential Sections. (b), Raclial Sections. 



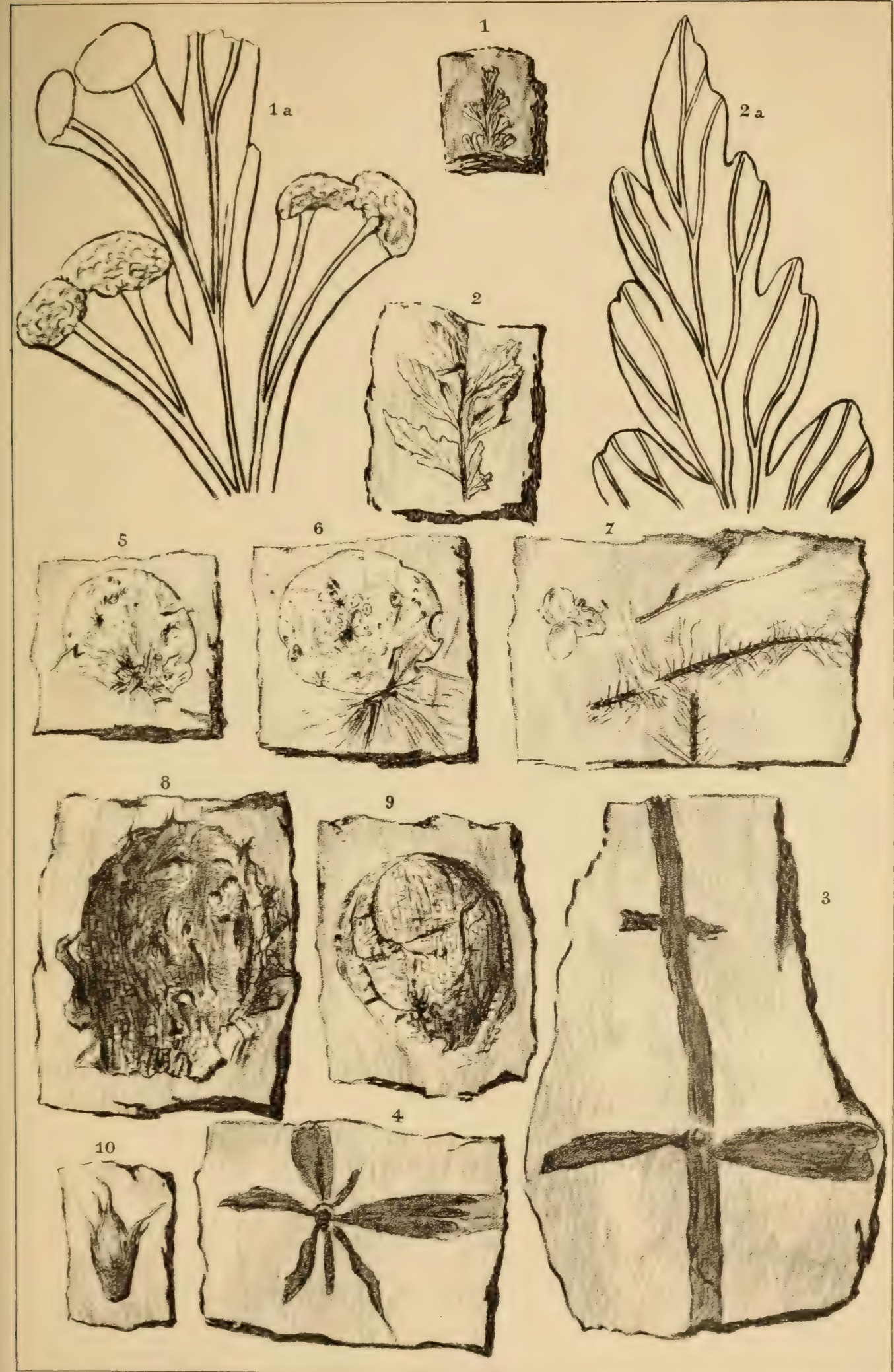





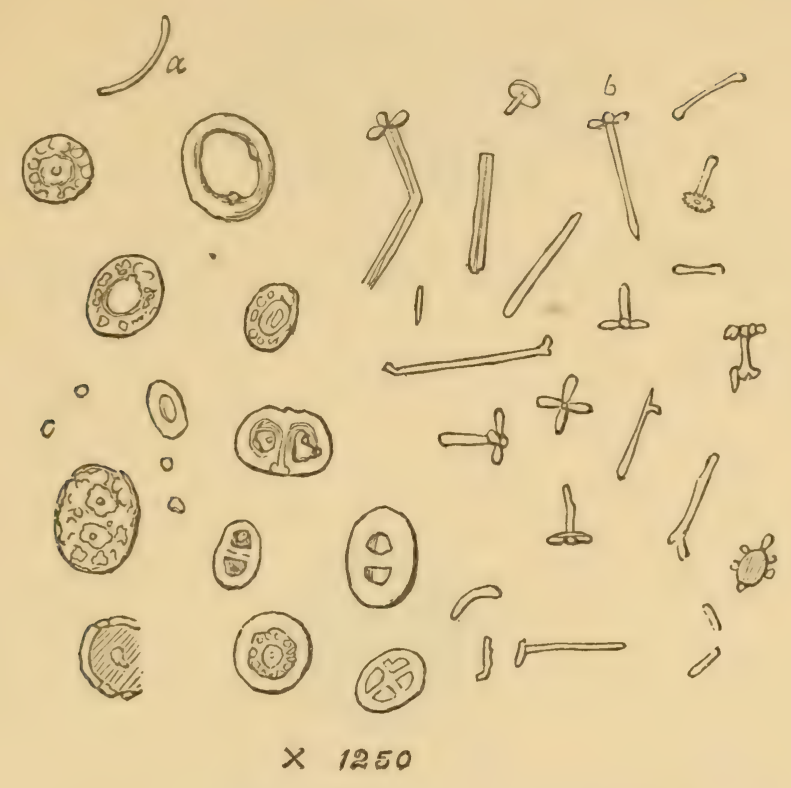

Figure 1.- Tarious forms of Coccoliths $(a)$ and Rhabdoliths (b) from the Cretaceous of Boyne River, Man., (\$ 182.)
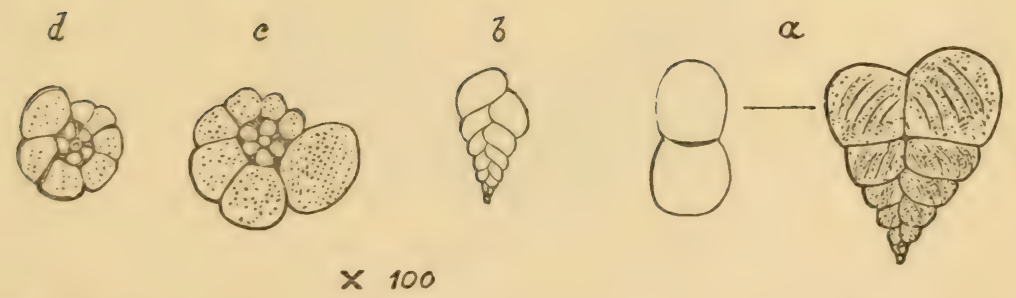

* Figure 2.-Faraminifera from the Cretaceous of Poyne River, Mian. ( $\S 180$ ) a. Textularia globulesa, Ehr. b. Textularia I ygura, D'Crb. c. Flanorbulina ariminensis D'Orb. 



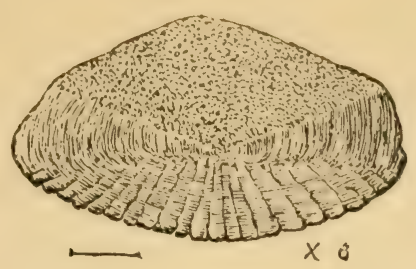

Figure 1-Pembina Escarpment and West Butte. (\$187-310.)

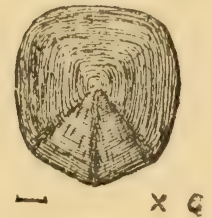

Figure 2-Pembina River. (§ 190.)

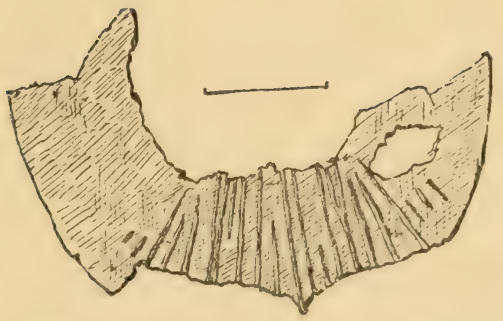

Figure 3-Pembina River. (§ 190.)

FISH SCALES FroM THE PEMBINA MOUNTAIN GROUP AND CRETACEOUS No. 4. 



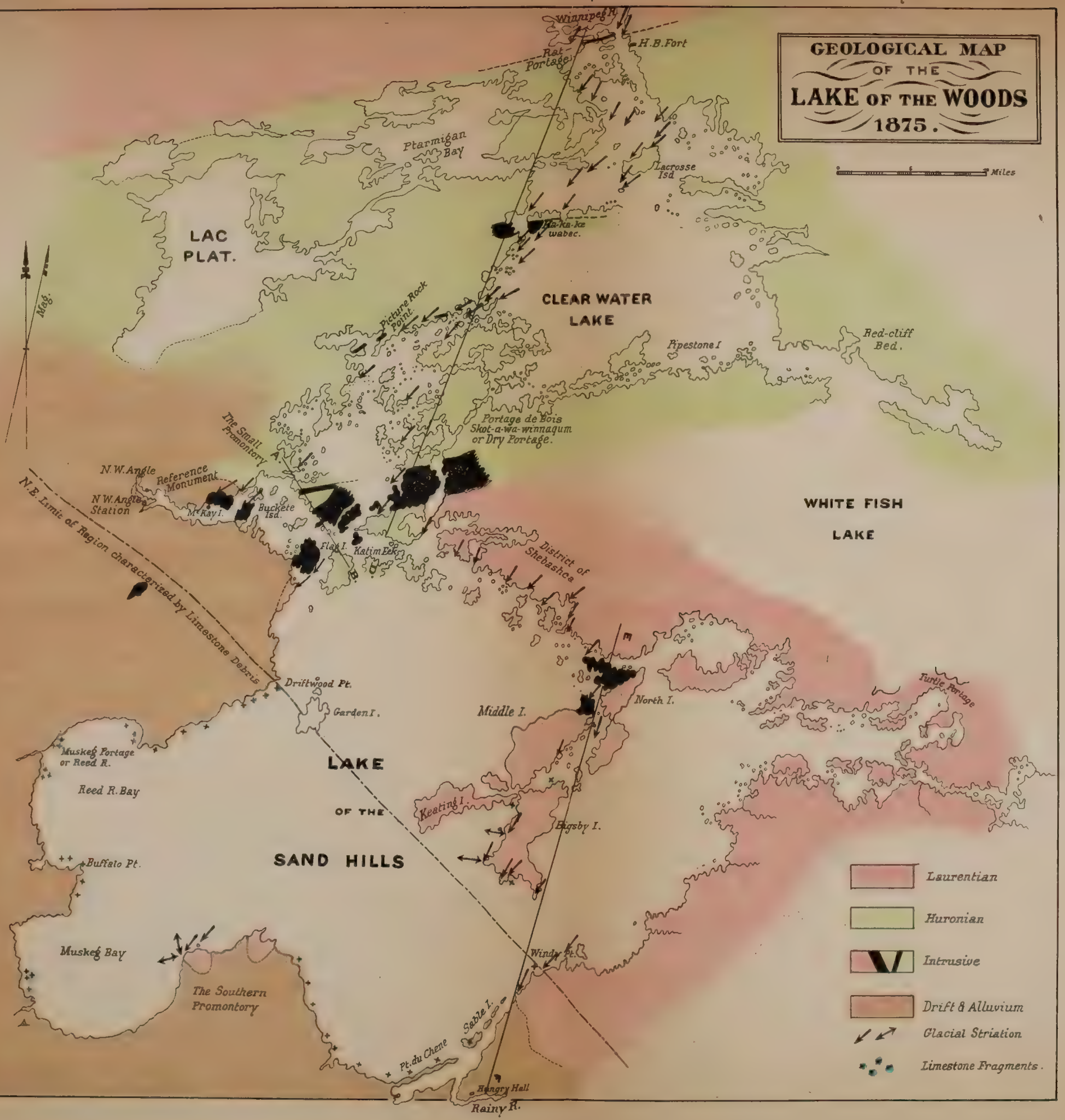






\section{N D E X.}

Age of the Buttes .................. 127

Age of the Lignite formation

Agriculture, basis of prosperity of the North-

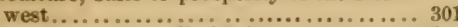

Agriculture, western limit of ................ 283

Akamina, Camp...................... 6

Alkali, 80 called, analysis of.. .......... 293

Allen, J. A , on combustion of Lignites ....... 167

Alluvium of river vallies................

Alluvium of river vallies.................... 252

Alluvium of the Red River Valley, fresh-water

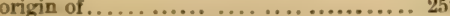

Altered Huronian rocks, area of ............ 30

Alternative channels ................... 265

Analysis of ironstones.................. 181

Analysis of Saline matter from lake.......... 293

Analysis of Lignites. ................. 169

Analysis, ultimate, of Lignites..................... 177

Anticlinal, probable, S. of Ka-ka-ke-wabec. .. 40

Area, total of prairie in British America...... 10

Area of second prairie level............... 5

Area of first prairie level .................

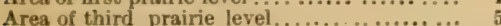

Area of plains in British America............

Artesian boring at Fargo ................ 250

Artesian boring at Winnipeg.............. 250

Badger Creek, drift deposits of . . . 20

Bad Lands, Lignite Tertiary of .................. 154

Bad Lands, mode of formation of ............ 103

Bad Lands South of Wood Mt., Sections in.... 10

Bear's Paw Mountains, the distant view of.... 113

Bear Lake R, Cretaceous beds at........... 18

Belly River, coal from.............. 179

Belly River, Lignite from ................... 179

Belly River. South Fork of ................. 135

Bell, Prof, referred to.................. 21

Bell, Prof, on height Laurentian Watershed.. 216

Bell, Prof, on conformity Laurentian and $\mathrm{Hu}$ -

ronian................................

Bell, Prof, on Eastern limit of Lignite Ter-

Belt, Mr, on glaciation of Siberia.............. 261

Bibliography, geological of interior B. $\mathbf{N}$. America.................... 20

Bir Cut Am Creek, Cretaceous No............ ${ }^{20}$

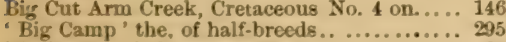

Bigsby, Dr. J. J., referred to .................. 20

Bigsby Island, rocks of ......

Birds, arrival of, at Dufferin, 1874 ........... 280

Birch Creek, rocks near................. 24

Bitter Creek beds, disputed age of the ....... 193

Bitumen and Mineral oil, in Devonian........ 14

"Black Slate," equivalent of on Nackenzie $\mathbf{R}$ 14

Blackiston, Lieut, cn heights of terraces..... 258

Blackiston, Lieut, referred to ........ 56

Black Hills, Carboniferous Limestone of .... 73

Boulders, distribution of in Lake of the Woods resion .......................... 208

Boulder-covered region................... 226

Boulder-clay, on Lake of the Woods........ 209

Boundary Mountain. rocks of the........... 65

Boundary Monument, rocks near the........ 64

Boundary Line, the course of, in the Rocky

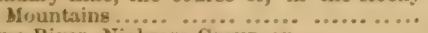

Boyne River, Niobrara Group on ........... 78

Brauches of the Milk River.............. 130
PAGR

Branches of Milk River, Lignite Tertiary of.. 155 Bucketé Island, granite of ................ 33 Buffalo, old paths of .................... 288

Buffalo, probable extinction of the........... 296

Buffalo, present eastern limit of the........ 294

Buffalo grass, eastern limit of ................ 292

Buttes, the distant view of............... 113

Buttes, the description of . ............ 123

Buttes, dykes near ...................... 124

Buttes, eruptive rocks of ................... 125

Buttes, age of the...................... 127

Buttes, how represented on Dr. Hayden's

maps ................................. 1

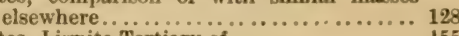
Buttes, Lignite Tertiary of . . . . . . . . . . . . . . 155 Buttes, country surrounding the........... 296 Cactus Plain, based on Cretaceous No 4,... 144 Calf Mountain, probable cause of ......... 81

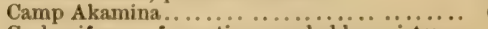
Carboniferous formation, probable existence

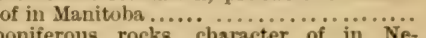

Carboniferous rock8, character or, in Ne-

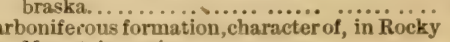
Mountain region....................... Carboniferous Limestone of Rocky Mountains. Carboniferous, rocks of in Montana, sc..... 79 Carleton House, advance of spring at ........ 282 Caribou Muskeg, rocks near............. 24 Cattle, wild, living out through the winter... 303 Chief Mountain, structure of ............. 66 Chief Mountain Lake or Waterton Lake, rocks in the vicinity of $\ldots \ldots \ldots \ldots \ldots \ldots \ldots \ldots, 57$

Chief Mountain Lake, former glacier of ....... 243

Cirques in the Rocky Mountains... ......... 245

Clay-shaie of Pembina Mountain group, character of

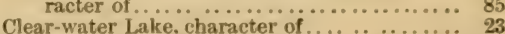

Climate of Eastem base of Rocky Mountains...

Climate of third Prairie Steppe............ 299

Climate of the Red River Valley............. 279

Clinker, from Lignite, occurrence of........ 165

Coals, analysis of by Prof. Haanel.... . . . 178

Coal, bituminovs, on St. Mary River.... . . . 132

Coal of St. Mary R, importance of ............ 178

Coal, rumours of its occurrence at Pembina Mountain.

Coccolith of Niobrara group............ 80

Cole's Falls, Cretaceous beds at ............ 17

Combustinn of Lignites, whether sponta-

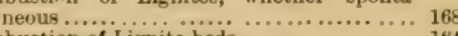

Combustion of Lignite beds .................. 164

Conclusions, general, on the Lake of the Woods................................. Hurunian...................... 29 Conglomerates, incipient, in the Lignite Tertiary

Conglomerate, greenstone.................. 130....

Conglomerate, slate................ 51

Conglomerates, Huronian, origin of the....... 52

Coniferous timber, western limit of ......... 276

Cope, Prof., on the age of the Lignite formation

Cope, Prof, identification of fossile by ....... 105

Cone, Prof, on Vertebrate Fossils........... 333 
Copper ore, occurrence of, on Lake of Woods.. 5 Cormorant, brecding place of the ......... 2 Cotesu, approach to the .............. 228 Coteau, appearance of the ................. 228 Coteau, breadth of the, on lat. $49^{\circ} \ldots . . . \ldots .228$ Cotenu des Prairies. ... .................... 235

Coteau, disused stream valleys of the.. . . . 230

Coteau, formation of, by floating ice.......... 237 Coteau, height of ................... 256

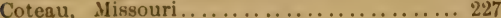

Cotenu, un the Traders' Road ............... 230

Coteau, suppusitions to account for ........... 236

Coteau, southern continuation of the....... 234

Coteau, northern extonsion of the ........ 233

Couleses, formation of ...........268

Country, oomparative aspect of Lsurentian and Huronian ..................... 46

Country of the Third Prairio Steppe........ 293

Country of the Second Prairie Steppe........ 287

Cretacoous beds at Bear Lake River......... 18

Cretaceous beds north of $N$. Srskatchewan

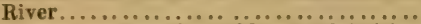

Cretaceuus, comparative table of subdivision

Cretacoous formation, its distribution.......... 16

Creta coous formation, thickness of, on Upper Missouri. .

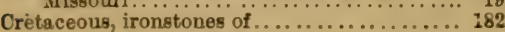

Cretaceous, junction of, with Lignite forma. tion.

Cretaceous, limit of eatern edge of .....

Cretaceous No. 4, at West Butte............ 128

Cretacenus No 5, at West Butte.............. 126

Cretaceous No, 5, Bad Lands Sections ........ 106

Cretaceous No. 5, general distribution of .... 147

Cretaceous, possible occurrence of lignites in.. 185

Cretaceous rocks, by whom examin. d....... 17

Cretaceous rocks, conditions of deposit of .... 159

Cretaceous, subsidenoe and elevation during the....................................

Cretaceous, subdivisions, general distribution

Cretaceous south of $\ddot{\text { Wood }}$ Mountain, dip of beds.................................. 110

Cretaceous, western border of .......... 17

Cretaceous, Uper Mssouri, section of the... 18

Cypress Hills, watershed in............

Cypress Hills, marine Tertiary beds st....... 157

Daily meteorological cycle ......... 292

Dekota group, general oppearance and distribution of

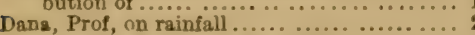

Dawson, Dr. J. W. on Fossil Plants......... 32

Dawson Roßd, country near the.......... 272

Denudation, post-tertiary............... 253

Denudation, carried on by streams.......... 268

Desert character of country overlying Cretataceous No 4

Desert, Amerioan, northern extension of the..

Desiccation of the plains, facts tending to show.

Devonian and Carboniforous of Rocky Moun. tains

Devonian, bitumen and mineral oil in........

Denudation, aetion of on third prairie level.

Devonian, as a salt-bearing formation.......

Devonian, exploration of in Manitoba desir able.

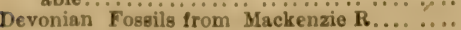

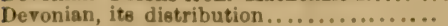

Devonian of Manitoba Lake ................ 1

Devonian of Maokenzie R ................. 12

Diorite, intruave, in Kootanie Pass............ 61

Dirt Hills, Lignites from .................... 178

Division $\boldsymbol{\alpha}$ of Lignite Tertiary .... . . . . . . 104

Division $\beta$ of Lignite Tertiary.............. 104

Division $\gamma$ of Lignite Tertiary ............. 104

Diviston $\delta$ of Lignite Tertlary.
Division B., of Dr. Hectors' Section........ PAGR

Division C., of Dr. Hectors' Section......... I47

Dog Portage, terraces at................ 256 Dolomites of Series A in Rocky Mountains... 57 Drainage, primary systems of ............ 9 Drift deposits, uniform coating of ......... 18 Drift depusits of Turtle Mountain.......... 223 Drift, course of the ..................... 257 Drift covered region...................... 84 Drift, general composition of ................246 Drift, Laurentian, its western limit ......... 243 Drift, numerical examination of constituents

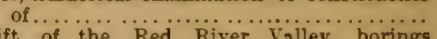
through .... Red River Talley. borings 250 Drift Plateau, S. W. of Lake of the Woods..... 212 Drift Plateau, S. W, of Lake of the Woods.... 212
Drift, Red, N. W. limit of .............. 213 Drift, Sections of on Roseau R ............. 21 Drift, the Quartzite .................... 231 Dykes, complicated intersection of ............ ${ }_{25}$ Dykes observed in Lake of the Woods region. 58 Dykes near the Buttes...................... 124

East Butte, sections north of ........... 122 Fast Butte, the...................... 124 East Fork of Milk River, drift deposits of .... 239 East Fork of Kuotanie Pass.............. 61 East Fork of Milk River, Cretaceous fossils at 114 Edmonton, advance of spring at.......... 283 Edmonton, coal from................. 178 Elevation after blacial subsidenoe......... 258 Elevation of Rocky Mountains, period of ..... 75 Elevations, correlation of ................. 256

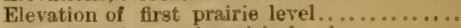
Elevation of second prairie level............ Elevation of third prairie level ............... Elliott, Mr. R. S., on amelioration of climate

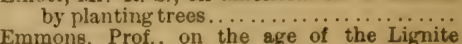
formation ...................... 198 Eocene age of Lignite formation............... 201 Escarnments of the prairie steppes.......... 3 Fargo, artesian boring at.............. 250 Fault in Lignite Tertiary, Porcupine Creek... 90 Fauna, foraminiferal of Niobrara group..... 78 Ferro-calcite, occurrence of in cretaceous shales..........................

Fertile Belt, simultaneous advance of spring

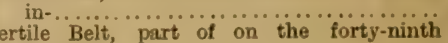
parallel... ........................ 298

File Hills. . . . . . . . . . . . 224

Fires, forest, in Turtle Mountain............. 289

Fires, prairie, necessity of prevention of .... 323

First Branch Milk River, exposures near.... 130

First prairie level.....................

Flag Island, granite of . .............. 39

Flag Island, Huronian on .............. 31

Flexures affecting the Laurentian and

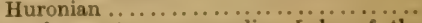

Flora of country surrounding Lake of the Woods............................ 271

Foraminiferal fauna of the Niobrara group.. 79

Forest, scheme for the culture and preservation of ............................... 321

Forest, destruction of, causing deoreased rain fall

Forest of Pembina Mountain ......

Forest area of Turtle Mountain............ 289

Fork, east of Kootaine Pas8............... 61

Fork, west of Kootanie Pass.............. 63

Forty-ninth parallel, cretaceous rocks of the, compared with other sections......... 1

Fort Benton Group, generaI arrangement and distribution of................. 139 Fort Pierre Group at West Butte.............. 126

Fort Pierre Group, conditions of deposit of, 160 Fort Pierre Group at White Mud River...... I09 Fort Pterre Group, weathering of, at White Mud River..

Fort Pierre Group, probable representative of in Pembins Mountain...............

\section{0}


Fort Pierre Group, general appearance and distribution of................... 142 Fort Pierre Group, bad effeet of, on appearance of country ...................... 14

Fort Pierre Group south of Wood Mountain.. 107 Fort shaw, mean temperature of ......... 300 Fort Lnion Group, western representatives

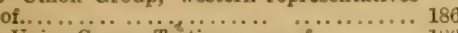
Fort Union Group, Tertiary age of .......... 186 Fussil plants of Liguite Tertiary ........... 327

Fossil vertebrates...................... 333 Fossils, Devonian, from Mackenzio River.... 13

Fossils from first branch Milk River....... 130

Fossils from Milk River.................. 118

Fossils from sections nurth of East Butte... . 122

Fossils from second branch Milk River...... 131

Fossils from West Butte............... 128

Fossils, mode of preservation of, in Cretaceous

Fossils of Cretaceous No. 4 , south of Wood

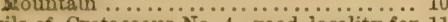

Fossils of Cretaceous No. 4, good locality for 11 Fossils, referred to Jurassic from Mackenzie River

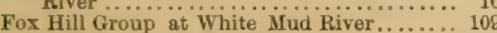

Fox Hill Group at West Butte........... 126

Fox Hill Group, general distribution of ...... 147

Fox Hill Group, smultaniety of deposit of .... 196

Fox Hill Group in Bad Lands sections........ 106

Fox Hill Group, Tertiary facies of molluso. from........................... 201

Fox Hill Group, character of ............ 147

Fox Hill Group, conditions of deposit of ...... 161

Fox Hill Group, general uccurence of ........ 194

Frencluman's Creek, or White Mud Kiver,

Fryer, Mr., on influence of forests on rain fall..

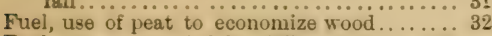

Fuels, areas occupied by different classes of, in the West........................ 180

Fuels, value of lignites as.............. 176

Gallatin R., Montana, Section on.......... 72

Gonesee and Hamilton epochs, equivalents of, on the Mackenzio $\mathrm{R}$.

General section in the Rocky Mountains.

General conclusions, Lake of the Woods....

Geologr, general outline of .

Geolugical bibliugraphy of interior $\mathrm{B}$. N. America.

Geological explorers, former of the Lake of the lioucts.

Glacial periud, introduction of............... 25

Glacial phenomena..................... 203

Glacial phenomena, general features of $\mathrm{E}$. of Red $\mathbf{R}$.

Glacial striæ of Lake of the Woods region....

Glacial subwergence................. 255

Glacial submergence, difticulties of theory... 260

Glacial action in the Rocky Jountains....... 243

Glacier, confluent, on the Laurentian axis.... 216

Glacier, furmer, of Watertun Lake......... 243

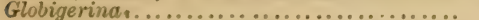

Gneissic rucks, absence of, in liucky Jluuntains, on 49th parallel.................. Gold, rumours of its occurrence at Pembina

Graculus dilophus (Corworant) breeding place of the .............................

Granite, intrusive, of the North-west Augle, pribable course of the

Grauite, intrusive of X. Island.

Granitic rucks, absence of, in Kocky Jountains ou 1'jth parallel

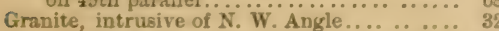

Gru-s, burning of reprehensible, on the plains 324 Grasshopper. (See lucust.)

Great Dry Coulée, a disused River Valley .... 204

Great Dry Coulee, the................ 117

Great Roseau Swamp................. 276

Great Valley, Analysis of Lignites from....... 171

Great Valley, fussils from the shales........ 95
PAGK

93

Great Valley, analyses of ironstone from ........ 181 Greenstune comblomerate.............. 51 Grit, Magnesian, of Series C................ 60 Groo, Mir. B., on lireat Salt Lake.......... 318 Huanel, Prof., analyses of lignites by....... 178 Halt-breeds, big camp of, the............ 295 Hamilton and Genesee epochs, equivalents of, on the Mackenzie River............. 14

Harrington, Dr. B. J., analyses of lignites by 179 Hayden and Meek, section of Cretaceous on Upper Missouri by ................ 18 Hayden, Dr.. on the age of the Lignite forma-

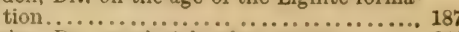

Hayden, Dr., on glacial submergence......... 258

Hayden, Dr., on amelioration of climate by planting trees..................... 318

Hayden, Dr., on southern extension of the Coteau...........................236

Hayden, Dr., section in Uinta Range by....... 73

Hay swamps, promiscuous burning of, reprehensible.......................... 324

Hector, Dr., referred to ..................... 20

Hector, Dr., on sources of rivers in Rocky Mountains.

Hector, Dr., on structure of Rocky Moun-

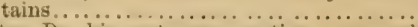

Hector, Dr., his cretaceous section compared with others..................... 151

Hectur, Dr., on valleys without outlet...... 234 Hector, Dr., on northern extension of the

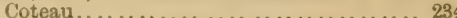

fector, Dr., on Turtle Mountain............... 228

Hector, Dr., on heights of terraces.......... 250 Hector, Dr., his lccalitics for marine 'Tertiary 157 Heer, Prof., referred to............... 21 Height of Land Muskeg.............. 274 Hills and ponds, second prairie steppe...... 222 Hind, Prof., on limestones of Lake Wimipey 12 Hind, Prof, on carboniferous of Manitoba 15 Hind, Prof. Hy., referred to ..............

Hind, Prof., localities in which he found Cretaceous No. 4.................... 148

Hind, Prof., localities in which he found Cre-

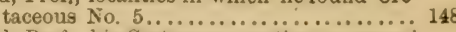

Hind, Prof., his Cretaceous section compared with others

Hind Yrue on terraces at Wour Portare......

Hind, Prof., on change of course in rivers.. 269 Huffman, C., Analyses of lignites by ....... 179 Hungry Hall, positiou of ................ 23

Huronian rocks, altered area of ............. 30

Huronian rucks, isulated area of .......... 34

Huronian rocks, from N. W. Angle to Ka-ka-ke-wabec

Huronian rocks, from the $\mathrm{Ka}$-ka-ke-wabec to Rat Portage.

Hurupian ald Laureutian, junction of the, at Rat Portage.

Huronian and Laurentian, diverse effect of, on country

Hurunian, distribution of the on the Lake of the Woods...

Huronian and Laurentian, flexure of the, on the Lake of the Woods

Huruniau, litholugy of the Lak of $\ldots \ldots . . . .4$

Huronian and Laurentian, Lake of the Woods, general setfuence.

Huronian of Lake of the Woods and elsewhere, conplarisun.

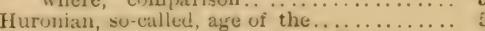

Huronian englumerates, origin of the.........

Hurentim, metamoryhism of ............ 53

Hurunian, pussible vecurrence of, in Rocky Mountains ...

Indian devices on La Füüre Percée.............

Insects, list of ..........................

Interior cuntineritial basin ...................... 10

Intrusive mass of Ka-ka-ke-wabec .......... 40

Irunstone, poor, of Pembina Mountain...... 81

Ironstome, poor, of Pembina River......... 83

Iroustones, analyses of ................ 181 
Ironstones of the Iignite Tertiary.... PAGR

Iromstmes of (retacentis

Irrigation, limited applicahility of ..........

Isvister, Mr., referred to.............. 20

Isolated ares of Hurmuian Rucky........... 34

Judith River beds, currelation of, with beds in the line ....................... 15

Junction of the Laurentian and Huronian at

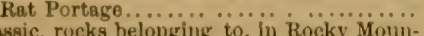
tain region........................

Juragsic, possible occurrence of, on Mackenze

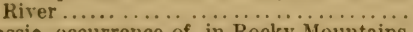

Jurassic, occurrence of in Rocky Mountains..

Ka-ka-ke-wabec, intrusive mass of ...........

Keating, Prof referred to.

King, Clarence, on the age of the Lignite formation.

Kingston Prof on raile

Kirby and Spence Mt., Kootanie Pass........ 63

Kersanton, at the Buttes................ 124

Kootanie Pass, rocks of ................. 60

Kootanie Pass, Watershed in the......... 62

Lacrosse Island, rocks of $\ldots \ldots \ldots \ldots \ldots \ldots \ldots .42$

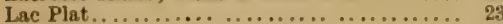

Lake of the Sand-hills................ 23

Lake of the Woods, position of .......... 22

Lake of the Woods, geology of ............. 22

Lake of the Woods, water supply of . . . . . . 22

Lake of the Woods, greorraphy of........... 22

Lake of the Woods, discharge of .......... 23

Lake of the Woods, northern part of........ es

Lake of the Wonds, outlets of the ......... 44

Lake of the Woods, general conclusions on geology of the.

Lake of the Woods, rlacial phenome......... 47

Lake of the Wuods, depth of . . . . . . . . . . 2e4

Lake of the Woods, comnection of basin of, with the rocks..................

Lake of the Woods, character of northern and southern parts.

Lake of the Woods, general direction of glacial

Lake of the Woods, nature of outfail of ....... 20

Lake of the Wood; Upper Silurian Lime-

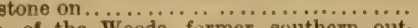

Lake of the Woods, former southern outlet of ........... $\because$ imber of country sur.

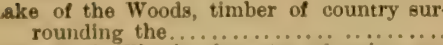

ake of the Woods, character of region sur-

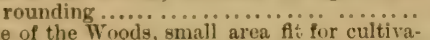

Lake of the Woods, small area flt for cultiva-

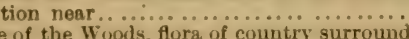

Ing the Woods, flora of country surround-

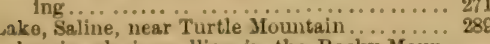

Lakes in glacier vallie in the Rocky Moun-

Lakes, Winnipeg group, area covered by..... 245

Laurentian axis, its general course........ 1

Laurentian axis, its nature.

Laurentian, most western rocks of near Lake of the Woods ......................

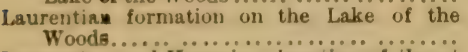

Isurentian and Huronian, junction of the at Rat Portare

Laurentian and Huronian, diverse effect of, on country.

Laurentian, distribution of the, on the Lake of the Woods.

Laurentian and Huronian, flexure of the, on the Lake of the Woods

Laurentiau, flexures affecting the, in Hastings County

Lanrentian, flexures affecting the, on the Ottawa.

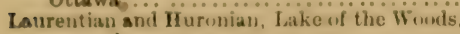
seneral seyucuce.

Isurentian watersbed, slope of

Laureutian drift, its western linit
Lesquereux, Frof., on the age of the Lignite furuation....................... 191

Lesquereux, Prof., on Tertiary age of certain

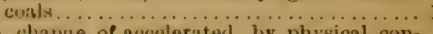

Lifo, change of accelerated, by physical conditions.

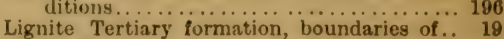
Lignite Tertiary, bections on Souris River.. 86 Lignite Tertiary of Souris Valley, molluses of 91 Lignite Tertiary, exposure of on 'Tradery' Road.......................... 9 Lignite bed, eighteen-foot......................... 98 Lignite, combustion of, in Bad Lands scetions 106

Lignite Tertiary, nearest the mountains.... 134

Lignite on south fork of Belly River......... 185

Lignite Tertiary formation, arrangement and extent of .....................................

Lignite, probability of discovery of, in Dakota Group .................................. 139

Lignite from Fort Francis, Rainy River....... 139

Lignite Tertiary formation, general arrangement and distribution............ 152

Lignite Tertiary, different horizons of ...... 152

Lignite Tertiary, enstem boundary of...... 163

Lignite-bearing formation, eastern limit of

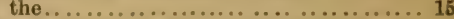

Lignite Tertiary, beds of, below Roche Percée saudstone........................ 154

Lignite Tertiary, possible northern extensions

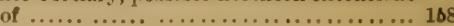

Lignite Tertiary, ironstones of ............... 181

Liguite formation, age of the ............. 183

Iignite formation, unity of the ............... 185

Lignite formation, junction of, with Cretaceous........................... 19

Lignite formation, Eocene age of............ 201

Lignite Tertiary, condtions of deposit of .... 163

Limnite, occurrence of, in drift.......... 240

Lign!tes, combustion of, on Mackenxie River, \&c........................ 167 Iignites, combustion of, whether spontaneous ......................... 168

Lignites, sreas destroyed by combustion..... 169

Lignites, analyses of . . . . . . . . . . . . . . . 169

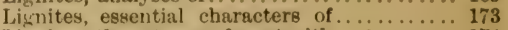

Lignites, three types of, met with ............ 174

Lignites, variable water content of ........... 175

Lignites, their value as fuels............... 176

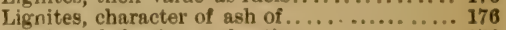

Lignites, behavior on heating....................

Lignites, ultimate analyses of .......... 177

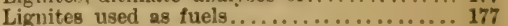

Lignites from Saskatchewan River.......... 179

Lignites from Dirt Hills ................. 179

Lignites, analyses of, by Dr. Harrington..... 179

Lignites, analyses of, by Mr. Hoffmann...... 179

Lignites, regions occupied by different classes

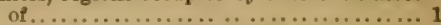

Lignites, occurrence and mode of formation of ................................ 164

Lignites, conibustion of ..................... 164

Lignites, \&c., area occupied by................ 180

Lignites, possible oceurrence of, in Cretaceous 185

Limestone, Jower Silurian, at the Stone Fort 11

Limestone, reported existence of, near Rainy

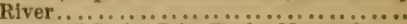

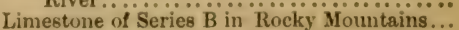

Limestene, great, of Series D, Rocky Mountrins

Limestone of Series D. Mt. Yarrell................

Limestene, Carboniferous, of Rneky Moun-

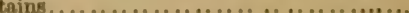

Limestone of Niobrara Group on Boyne River

Limestone debris on the Lake of the Woods...

Limestone drift, orgin of ............... 210

limestone debris, north-eastern limit of...... 210

limestone, reported occurrence of, in Turtle Mountain

Limestune drift the ................. 223

Limestumes, Carboniferous and Silurian, of Moutana.

Lithology of Huronian, Lake of Woods....... 
Line, the Boundary, course of, in the Rocky' Mountains.......................... Huronian, Lake of Woods.............

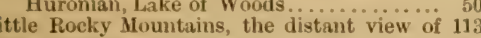
Little Touchwood Hills................. 22. Locust, inroads of the .................. 304

Locust, eggrs and young of the........... 305

Locust, migration of the ............... 306

Locust, years of inroads of, in Manitoba...... 307

Locust, parasites of the ................... 307

Locusts, precautions against the ............. 308

Locusts, means of attacking the .......... 309

Locust plague, amelioration of, by planting trees............................. 310

Locusts, home of the .......................... 304

Logan, Sir W. E., on flexures affecting Laurentian rocks......................

Logan, Sir W. E., on height Laurentian watershed ...................... 216

Long River, sections of Pembina Mountain Group in ......................... 8

Long River, drift deposits of ............... 220

Lower Silurian, deposits of ................ 11

Lower Silurian, series in Minnesota, \&c...... 12

Mackenzie, area drained by, south of lat. $54^{\circ}$. 10

MIcKay's Island, granite of ................. 32

Magnesian grit of Series C............... 60

Mlanitoba, imroads of Locusts in ................ 307

Margin of third prairie steppe............227

Markets, distance from, deterrent to settlement.............................. 303

Marrens, Lacs des.

Marsh, Prof., on the age of the Lignite formation .......................... 193

Material of the Cretaceous deposits........... 162

Meek and Hayden, section of Cretaceous on Upper Missouri, by .................

Meek, Prof,, list of Devonian fossils from Mackenzie River, by .................. 13

Meek, Prof. F. B., referred to.................. 21

Meek, Prof,, on the age of the Lignite formation

Metamorphism of H...................... 18

Meteorological eycle, daily................... 292

Methy Portage, height of ....................... 256

Middle Island, rocks of ....................... 27

Milk River, valley of ..................... 117

Milk River, sections in valley of ............... 118

Milk River, fossils from rocks of ............. 119

Milk River, crossing place of the............ 121

Milk River, branches of .................. 130

Milk River, Lignite Tertiary of ............... 155

Mineral oil and bitumen, in Devonian........ 14

Minue Wakair ......................... 236

Minnesota............................... 139

Missouri Coteau........................... 227

Missouri River, area drained by, in British America.........................

Mississippi, sources of .......................... 213

Mollusea collected, list of ................ 347

Molluses from Lignite Tertiary of Souris Valley.

Molluses, frosh-water, evidence of, with regard to age of Lignite formation

Molluses, marine, evidence of, with regard to age of Lignite formation .................

Molybdenite, vecurrence of ..................... 36

Montagnes du Foin de Senteur, description of 123

Monument, Boundary, on the watershed..... 65

Moose Mt......................... 29

Moraine mounds in the Rocky Mountains...... 245

Jount Wilson, structure of ...............59-60

Movements giving rise to structure of Lake of Woods rocks.................

Mrud-lumps, formation of, in Bad Lands........ 104

Muskeg.............................

Muskeg Portage Swamps.

Nebraska, typical Cretaceous section, in compared with B. N. A. sections

Newberry, Prof. on temperature of Liimite Tertiary period........................
Newberry, Prof., on the age of the Lignite PAG formation

Neutral ground of Indians . . . . . . . . . . 297

Niobrara Group, general appearance and distribution of ..................... 141

Niobrara Group in Pembina Escarpment....... 78

Niobrara Group, fossils of .............. 79

Niobrara period, depth of submergence during ..................... 159

Nodules, large, in Pembina Mountain shales 81

North East Roseau River................. 275

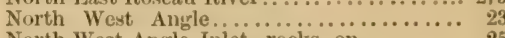

North West Angle Inlet, rocks on.......... 2

North Island, rocks of . . . . . . . . . . . . . 28

North Pembina River, analyses of Lignite from .............................. drift . examination of constituents of

res on Lake of the Woods .............. 54

Ostrea, occurrence of, in drift............... 239

Outfall of Lake of the Woods................ 207

Outlets of the Lake of the Woods............. 44

Owen, Dr, referred to ..................11-21

Pa-ga-ta-wa-minis, or Lacrosse Island, rocks

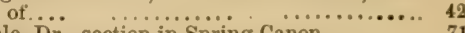

Peale, Dr., section in Spring Canon............ 71

Peat, use of, to economize wood............. 323

Pembina Escarpment, rocks of............. 78

Pembina Mountain Group............... . 81

Pembina Mountain at intersection with

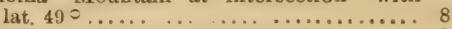

Pembina River valley, exposures in.......... 82 Pembina Mountaiu Group, thickness exposed in Pembina River Valley..............

Pembina Mountain Group, exposures in Long River Valley .................... 84

Pembina Mountain clay-shales, character of.. 8

Pembina River, drift deposits of ........... 21

Pembina Escarpment, drift deposits of....... 219

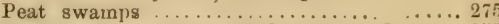

Pembina Mountain, wooded country of...... 287 Pembina River, country near the .......... 287 Permian and Triassic of the interior continental region ................... 15

Physical geography, general outline of..... 1

Picture Rock Point, rocks of ............ 39

Pine timber on the Roseau River ........... 277

Pipe-Stone Pass, rocks of .. ............ 70

Plains, area of, in British America............ 1

Plains, area of the treeless. ............... 318

Plains, cultivation of trees on ............. 319

Plains, facts tending to show gradual dessication of $\ldots \ldots \ldots, \ldots \ldots \ldots, \ldots, \ldots, 315$

Planorbutina globulosa........................ 79 Planorbulina farcta....................... 79 Plants, fossil, from Lignite Tertiary of Great Valley.

Plants fossil, from Po..................... 95 Plants, fossil, from Bad Lands section ....... 105 Plants, evidence of, with regard to age of $\mathrm{Lig}$ nite formation ................. 197

Plants collected, list of .................. 351

Plants in flower on second prairie steppe, May, $1874 \ldots . . \ldots \ldots \ldots \ldots \ldots \ldots \ldots . . \ldots 287$ Plateau, outlying, of the Lignite Tertiary... 213 Plateau, drift, southwest of Lake of the

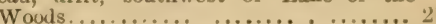

Pluvial period, possible occurrence of...... 26.

Ponds and hills second prairie steppe....... 222

Poreupine Creek, analyses of lignites from... 172 Porcupine Creek, eighteen-foot lignite near.. 98 Porcupine Creek, exposures in. ........... 97 Porcupine Creek, fossil plants from . ....... 100 Post-glacial phenomena............... 26: Pottery, material for manufacture of........ 85 Powder River, Carboniferous limestone on... 72 Prairie, total ares of, in British America...... 10 Prairie, the Red River.................... 277 Prairies, causes assigned for the treelessness

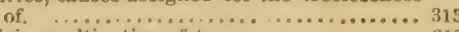

Prairies, unltivation of trees on................ 319

Prairies, question if ever tree-clad............ 311 Prairies, spread of, by fires................ 312 
Prairies, why not reclothed with trees .... PAG Praires, why necessity of prevention of ...... 32s P'rairie fires, necessity of prevention of . River Valley .....................28 Pre-glacial aspect of the country .......... 253 Pyramil ('reek, sections on ............ 95 (.) A puelle, an old river valley ............. 263 Quartzite, an important bed of ... ....... Quartzite, occurrence of.............. 37 Quartzite drift. ....................... 231 Quartzite drift, the............. ... .. 246 Kainfall, never excessive on the plains...... 267 Rainfall of Red River country ........... 28.

Rainfall, least necessary amount of........ 284 Rainfall, spring and summer in the west..... 285 Rainfall, decrease of, on destruction of forest 316 Rainfall, cause of increased, over tree-clad

areas ........................ 317

Rainfall, increased on planting trees... . . . 317

Rainy River, analyses of lignite from ...... 17:

Kat Portage, position of .. $\quad \ldots \ldots \ldots .24$

Rat Portage geoloyy of.............. 44

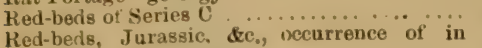

Red-beds, Jurassic, \&c, wecurrence of in Rocky Mountains .............. 74

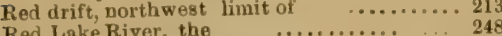

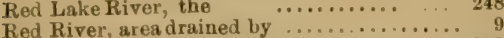

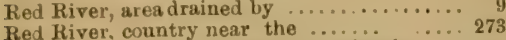

Red River. country nivance of spring in..... $7 \mathrm{y}$

Red River country, arrival of birds in spring 280

Red River country, raintall of............283

Red River country, inroads of locusts in..... 307

Red River prairie

Red River prairie, measure of agricultural capacity of $\ldots$..................... 2

Red River. timber of, destroyed by fire ..... 324

Red River Valley ... ................ 249

Red liver Valley, alluvium of the with the

Red River Valley, connection with the

Red River Valley, formation and former southern outflow of ................254

Rei River Valley, climate of ,..........279

Red River, character of.............. 266

Red River, floods of ... ... . ....... 266

Red River Valley, former communication of, with the Mississippi

Reptiles, fossil, from Bat Lands sections.... 105

Rhabdoliths of Niobrara Group .... .. 80

Rhyolitic trachyte, poiphyry of the Buttes 125

Kicharison, Sir $J$., on Devonian of Mackewzie River

Richardson, sir J., referred to. ..........

Richards,n, Sir $J_{\text {., }}$ on st ucture of Rocky Mountains

Richardson, Sir J, on Methy Portage ...... 69

Riley, Mr., on parasites of the locust ... . ... 307

River Valleys, large................. 262

Kiver valleys, age of................ 253

Rivers, change of cours 3 in ........... 2 .

Riviere des Lacs, course of. .............. 264

Robes, trade in......... ... .... 29

Rocky Mountains, aspect of their eastern front.

Rocky Mountains, age of elevation of.........

Rocky Mountains, break between rocks of, and those of the plains.

Rocky Mountains, cirquics in the

Rountains, comparisos of rocks with those of other localities......................

Rocky Mountaing, eastern front of the .... 6

Rocky Mountains, elevation of 10

Rocky Mountains. general structure of, according to Dr. Hector.

Rocky Mnuntains, glacial action in ........... 213

Rocky Mountains, marine mounds in the.... 2 I5

Rocky Mountaing, timber of the ....... 298

Ruche Percbe.

Rocks, Hurnnisn, from $\ddot{N}$. $\ddot{W}$, augle to $\mathbf{K}_{a-}$ ka-ke-wabee.

Rocks, Hurovian, from Ka-ka-ke-wabec to Rat lortuge.
Roche Miette Mountain, section in PAG

Roseau River, sections of duft on........... 214

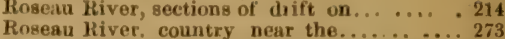

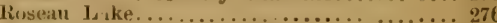

Russell, A. L, referred to ............. 78

Kussell, A, L, liguite received from ........ 139

Saline lake of the ('oteau................ 224 Saline lakes course of. .................. 234

Saline lake near Turtlo Mountain........... 289

Saline matter from lake, analyses of .......... 293

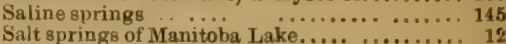

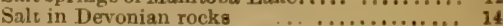

Sanidine-trachyte of the Buttes........... 125

Sand-hill Lake 29

Sandstone, zone of, near the base of the 'Jertiary...

Sandstones, weathered, of $\mathrm{L} \ddot{\mathrm{R}}$ oche Percée Saskatchewan River area drained by .... Saskatchewan Kiver, lignites from ...... 179 St. Mary Kiver, coal on... .............. 132 St Mary River sections on............. 132 st Mary River, analyses of coal from..... 172 -t. Mary River, change of country near...... 298 St. Mary River, Lignite Tertiary of......... 156 sit. Mary River, fossuls from vicinity of. ..... 1 หs Scissors Creek, Iretaceous No. 4 on.......... 14 Scudder on insects collected.............. 34 Second branch Milk River, exposures on ... 131 Second branch Milk River, fossils from ... 131 Second prairie level . ................ Second prairie steppe, edge of, on Saskatche-

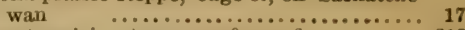
Second prairie steppe. surface of $\ldots \ldots \ldots . .218$ Second prairie steppe, country of the.......287 siecond prairie steppe, drift deposits of . 218 Section, general, in the Rocky Mountains.... 67 Section in Pembina River valley ... ..... 88 Section on the Boundary-line, break in ....... 92 Section, important, near East Fork Milk

River ........................ 114 Selwyu, Mr. A. R. U. referrel to ......... 21 Selwyn, Mr., on height of Laurentian water-

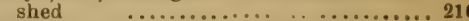

Selenite, its association with plant-beds ....... ${ }_{97}$ Sequence, lithological of Laurentian and Huroniau, Lake of the Woods ....

. eries A of Rocky Mountain beds.... .... 57

Series B of Rocky Mountain beus........... 58

Series $\mathrm{C}$ of Rocky Mountain berls........... 59

Series C, subilivisions of $\ldots \ldots .60$

Series $\mathbf{b}$, great limestone, Rocky Mountains. 62

Series $\mathrm{E}$, contemporaneous trap, Rocky

Mountains.............. Settiement, deterrents to, in the North West $33_{3}$ Settlement, capabilities of the region with

relerrence to ................ ... 269

Shoal lsake, see Lac Plat ................ 23

Short Creek, section on.................... 87 Shumard, Dr., analyses of limestone of Stone

Fort by... ...

silurian, western and northern extension of 19 Slate conglomerate... $\quad \ldots \ldots \ldots \ldots \ldots \ldots . . .51$ slate conglomerate of Series $\mathcal{C}$, Rocky

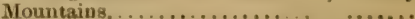

Slope of the interior region of the continent...

Small Promontory, the.............. 3

Suake River, Car boniferous limestone on ... 7

Soil of the second prairie steppe........... 288

Soil of the Red River prairie . .......... 277

Soil, fertility of, due to yellow marl.......... 251

souris Valley, analyses of irolıstone from .... 181

Souris Valley, anslyses of ligıites from..... 10:

Souris River, coututy near . . . . . .... 290

Souris River, Cretaceous No, \& cn......... 146

Souris River Valley, character of.......... 205

Souris River, drift depos ts of ... 2.5

Souris River, Lignite Tertiary rucks on...... 86

Souris River, disused valley of............ 264

Southeru Promontory, the.............. 2t

South East Roseau River................. 275

South Fork of Belly River................. 185

South Kootanie Pass, terraces in............ 244 
PAGE South Saskutchewan, ehange of course of ... 263 Spring, a.tvance of at Eidmonton ... . .... 2x Surius, advance of in Red River country ...279 Spring, advance of at Cumberland House.... 281 Spring, advance of at Carleton House....... 282 Spring Canon, Montana, section in........... 71 Springs, salive...... Springs, temperature of on third steppe...... 299 Stepheusm. Mr., on the age of the Lignite formation .................... 193

Steppes of the prairie, their bounding escarpments.

Stock, wintering of $\ldots \ldots \ldots \ldots \ldots \ldots \ldots, 30$

Stone circles, eastern limit of ............. 290 Stratih visturbed, near Eust Fork of Milk

River......... ........... 114 Striæ, glacial, of Lake of the Woods region... 205 Submergence, glacial, Dr. Hayden on.... 259 submersence, glacial, difficulties of theory 260 submergence, friacial . .............25: submergence, limit of west of Rocky Mountains

Subdivisions of Series C, Knotanie Pass...... ${ }^{259}$

Superficial deposits................... 203

sweet Grass Hulls, description of .......... 123 Sweet Grass Hills, glacial phenomena of. ... 24t

Tempe.ature, mean, of Fort Shaw ........... 300 'Temperature, mean. of Winnipeg .......... 300 Terraces in the south Kootanie Pass... .... 244

Terraces at Dog Portage........... . . 256

Terraces in the Rocky Mountains, heights of. 2:18 Tertiary, Lignite conditions of deposit of. ... 163 Tertiary, Lignite, possible northern extensions of...

Tertiary Plateau, soil and appearance of. .... 293

Testuluria agylutinans.................... 79

T.xtularia gibbosa................., 79

Thickwood Hills............................ 233

Third prairie level.... ... .............

Third prairie steppe, country of the ........ 293

Third prairie steppe, drift deposits of....... 239

Third prairie steppe, margin of .......... 2:7

Third prairie, steppe, climate of ........... 299

Three Buttes, glacial phenomena of ........241

Thomas, Prof., on rainfall of the West...... 285

Thomas, Prof., on susthern extension of the Coteau Timber, question of supply of............... 311

Timber question of supply of........... Wuods.

Timber of the Rocky Mouutains .......... 29.

Timber of the Red liver destroyed by fire.. 324

Touchwood Hills.... 2,

Trachyte-porphyry of the Buttes .......... 125

Traders' Road, Cotean on the ............... 230

Traders' Road, exposures of Liguite Tertiary

Traders' Road, I.ignite Tertiary rocks on, near Wood Mountain.............. 100

Trap, coutemporaneuus, of Kocky Viruntuins 62 Treelessness of prairies, causes assigned for . . 313 Treeless area of the continent..............318

Trees, cause of their effect on rainfall .... . . 317

Trees, cultivation of, in the West ......... 319

Trees, enactmelits encouraging planting of 321

Trees, planting of, incr, asing nainfall . 317

Trees, planting of, necessary in the North West...

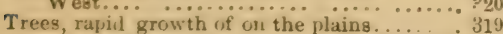

Trees, schieme for the culture and preservation of ..........................

Triassic and Permian of the interior continental region. ...

Triassic, question of existence of in Montan 15

Triassic, occurrence of, in Rocky Mountains...74

Turtle Ifountain, drift depesits of .... 2?

Turtle Mountain, formation of, by floating ice 224

Turtle Miountain, one of a series of drift elevations......... . .

Turtle Mountain, reported occurrence of limestone in........................ 22
Turtle Mountain trees found on PAGF Turtle Mountain, country of $\ldots \ldots \ldots \ldots .289$ Uinta Range, section in the................ 73

Ultimate analyses of lignites $\quad \ldots . \quad \ldots \quad 17 i$

Linconformity between serios C and B of Rocky Mountains.................. 75

Upper Columbia Lake, rocks of... ........... 70 Cpper copper-learing series, rocks resembling, in Rocky Mountaing............

Cpper Silurian limestone on Lake of the Woods......................... 208 Ltall, increased rainfall by planting trees in 317 Vallies, ancient, of the Coteau ............ 230 Valley of the Red River ..................... 248 Vallies, large, of rivers................. 262

Vallies, formation of great alternative .......265

Vennor, $H$. G., on flexures affecting Laurent'an Rocks.

Vertebrates, evidence of, with regard to age of Lignite formation.

Vertehrates of Lignite formation, not all of Cretaceous type................. 200

Vertebrates, from Lignite formation, on lat $490^{\circ}$, learing of, on question of age of the
beds. .

Volcanic origin of Huronian conglomesates, ac. ........................ chronous in America aud Europe

Warren, Major-General G. K., on Minnesota River \&c........................

Watersheds, bounding the interior continental region...........................

Watershed, the southern transverse..............

$w$ atersheds, transverse, of interior continental region.....................

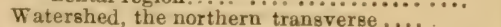

Watershed, the southern transverse, its

cause...
Watershed, the, in the Rocky Mountains.....

Watershed plateau...................... 227

p..... 286

Waterton Lake, former glacier of .......... 57

Wells, deeper and shallower in the Red River Valley

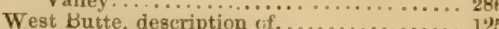

West Butte, sections near.................. 122

West Fork of Kootanie Pass................

West Fork of Milk River................. 117

West Roseau River.......................... 27

White-fish Lake................... 23

White Muil River, or Frenchman's Creek, sections in.... . . . . . . . .... 109

W hite wud Kiver, fossils of No. 4 , at......... 110

White Mud River, weathering of Cretaceous shales at...................... 110

White Mud River, country rear............. 29

W Littlesea, Col, , on red drift.... ..... 213

Wilson Mountain, structure of............. 66

Winchell, Prof. s. H., pre-cretaceous decomposition of granites...... ......... 162

Winchell., Prof., ou polar ice-cap .......... 261

Winchell, Prof, on southern extension of the Cotean........... 2 ......

W invipeg group of lakes, area invered by .

Winnipeg River, beginning of the.......... 44

Winnipeg River, origin of................. 207

Winnipeg, artesian boring at.............. 250

Winnipeg and N. W. Angle Road, country near the ....................... 279

Winnipeg, mean temperature of ........... 300

Wintering of stock................... 302

Wolf Hills...........................

Wood, means to economize use of........ 329

Wood of the Red River.... ........... 278

Word, question of supply of .............. 311

Wood End, sections of drift near.... .... 226

Wood Mountain, watershol near...........

Wood Mountain, Lignite Tertiary near.

YarreIl Yountain; Kontanie Pass............

Yellow marl, fertility of goil based on........ 251 







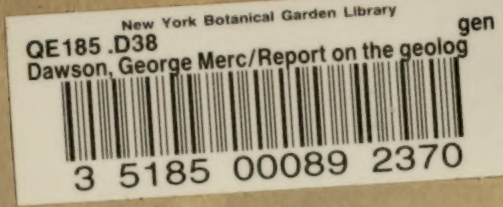


